\title{
Calibã se liberta: 0 setor externo da economia brasileira (1999 a
} 2013)

Tese apresentada ao Programa de Pós-Graduação em História Econômica do Departamento de História da Faculdade de Filosofia, Letras e Ciências Humanas da Universidade de São Paulo para obtenção do título de doutorado.

Orientador: Wilson do Nascimento Barbosa 
Autorizo a reprodução e divulgação total ou parcial deste trabalho, por qualquer meio convencional ou eletrônico, para fins de estudo e pesquisa, desde que citada a fonte.

Catalogação na Publicação

Serviço de Biblioteca e Documentação

Faculdade de Filosofia, Letras e Ciências Humanas da Universidade de São Paulo

Cc COSENZA, Apoena

Calibã se liberta: O setor externo da economia brasileira (1999 a 2013) / Apoena Cosenza ; orientador Wilson Barbosa. - São Paulo, 2017. $305 \mathrm{f}$.

Tese (Doutorado)- Faculdade de Filosofia, Letras e Ciências Humanas da Universidade de São Paulo. Departamento de História. Área de concentração: História Econômica.

1. Setor Externo. 2. Comércio Internacional. 3. História Econômica do Brasil. 4. Macroeconomia. 5. História Contemporânea do Brasil. I. Barbosa, Wilson, orient. 
Resumo: A presente tese possui como questão central: "quais foram os mecanismos que permitiram a recuperação econômica ocorrida no Brasil, entre 2003 e 2010?” A hipótese proposta é que a recuperação aparente da economia local foi resultado da alta dos preços dos bens primários (as chamadas commodities). Para verificação da hipótese, foi analisado o balanço de pagamentos brasileiro, dando-se destaque especial para o balanço comercial. Estudou-se a composição do balanço, e a relação entre o setor externo e alguns dos indicadores macroeconômicos da atividade econômica local. Ainda, verificou-se qual foi a relação entre o desempenho brasileiro no comércio internacional e a distribuição de renda local. Os dados encontrados indicam que tanto a aparente recuperação econômica quanto a distribuição de renda favorável às camadas de menor rendimento se fizeram possíveis graças à alta da demanda chinesa pelas commodities. No entanto, a recuperação econômica não foi acompanhada de investimentos produtivos significativos, o que resultou no não aumento da produtividade local. A tese proposta é que, na ausência de investimentos significativos, os problemas estruturais da economia brasileira, em especial a dependência econômica e a baixa capacidade de acumulação de capital, não foram superados, e até se aprofundaram.

Palavras-chave: Setor Externo; Comércio Internacional; História Econômica do Brasil; Macroeconomia; História Contemporânea do Brasil.

\begin{abstract}
The present thesis has the following central question: "what were the mechanisms that allowed to the economic recovery occurred in Brazil between 2003 and 2010?" The hypothesis proposed is that the recovery of the local economy was a result of the rise of commodities prices. To verify this hypothesis, the brazilian balance of payments was analyzed, with special emphasis on the trade balance. The composition of the balance of payments and the relationship between the external sector and some of the macroeconomic indicators of local economic activity were studied. The relation between the Brazilian performance in international trade and the distribution of local income was also analyzed. The data found indicates that both the economic recovery and the income distribution favorable to lower income population were made possible by the rise in chinese demand for commodities. However, the economic recovery was not followed by significant productive investments, which resulted in no increases in local productivity. The thesis proposed here is that, in the absence of significant investments, the structural problems of brazilian economy, especially the economic dependence and the low capital accumulation capacity, were not overcomen but actually increased.
\end{abstract}

Key words: External Sector; International Trade; Brazil's Economic History; Macroeconomics; Brazil’s Modern History. 


\section{Agradecimentos:}

Agradeço, primeiramente, à CNPq, instituição que, ao conceder a bolsa de doutorado para essa pesquisa, permitiu a minha dedicação exclusiva ao estudo e investigação necessários para produzir a presente tese. Ainda, agradeço ao meu orientador, Wilson do Nascimento Barbosa, por sua paciência de ler e comentar cada linha escrita por mim durante o doutorado. A realização desse doutorado sob orientação de Wilson Barbosa foi uma daquelas experiências que modificam a vida de uma pessoa para o resto dos tempos. Também agradeço aos professores Lincoln Ferreira Secco e José Rodrigues Mao Júnior, pelas sugestões feitas durante a banca de qualificação, que permitiram a melhora do presente trabalho. Agradeço também à Letícia Maria Vieira, minha esposa, por todo seu apoio e carinho, mesmo diante de minhas longas jornadas de estudo, que tomaram parte do tempo que de outra forma teria sido a ela dedicado. Também sou grato aos meus pais, Tibério Canuto de Queiroz Portela e Gilseone Westin Cosenza, por terem sido sempre um exemplo, nunca cessando de estudar e pensar o mundo. Agradeço aos meus queridos amigos, em especial a Igor Grabois, Flávio Petracioli, Flávia Ferrari, Lou Caffagni, e Tania Moreira Perscarini, que aceitaram largas discussões sobre os temas abordados nessa tese; e aos membros do Laboratório de Economia Política e História Econômica (LEPHE) da USP, em especial à Eduardo Januário, Nelson Alves Caetano e Paulo Sérgio Souza Ferreira, pelos anos de trabalho em conjunto, que certamente contribuíram para nossas formações. Agradeço a meu irmão Aitan Canuto Cosenza Portela, por cada crítica e opinião que só a sinceridade de um irmão permite. Por último, dedico essa obra ao meu falecido irmão, Iuri Canuto de Souza Portela, por ter simplesmente sido a pessoa que mais me incentivou e influenciou a ser quem hoje eu sou. 


\begin{tabular}{|c|c|}
\hline \multicolumn{2}{|r|}{ Ficha de Siglas } \\
\hline PIB & Produto Interno Bruto \\
\hline $\mathrm{PIBr}$ & Produto Interno Bruto em reais constantes \\
\hline PIBnd & Produto Interno Bruto em dólares correntes \\
\hline PIBrd & Produto Interno Bruto em dólares constantes \\
\hline RNB & Renda Nacional Bruta \\
\hline G & Gastos do governo \\
\hline $\mathrm{C}$ & Consumo das famílias \\
\hline $\mathrm{Cr}$ & Consumo das famílias em reais constantes \\
\hline$\Delta \mathrm{Cr}$ & Variação do consumo das famílias em reais constantes \\
\hline $\mathrm{I}$ & Investimento \\
\hline Iedr & Investimento estrangeiro direto \\
\hline DvIr & Dívida interna real \\
\hline DvEr & Dívida externa real \\
\hline $\mathrm{S}$ & Poupança \\
\hline $\mathrm{X}$ & Exportação \\
\hline Xnd & Valor total das exportações em dólares correntes \\
\hline $\mathrm{Xr}$ & Valor total das exportações em reais constantes \\
\hline$\Delta \mathrm{Xr}$ & Variação do valor total das exportações em reais constantes \\
\hline Xrd & Valor total das exportações em dólares constantes \\
\hline M & Importação \\
\hline Mnd & Valor total das importações em dólares correntes \\
\hline $\mathrm{Mr}$ & Valor total das importações em reais constantes \\
\hline$\Delta \mathrm{Mr}$ & Variação do valor total das importações em reais constantes \\
\hline Mrd & Valor total das importações em dólares constantes \\
\hline $\mathrm{Y}$ & Renda \\
\hline Yd & Renda disponível total das famílias \\
\hline$\Delta \mathrm{Yd}$ & Variação da renda disponível total das famílias \\
\hline $\mathrm{Yd}_{1}$ & $\begin{array}{l}\text { Renda disponível do 1\% da população com maior } \\
\text { rendimento (primeiro patamar de renda) }\end{array}$ \\
\hline $\mathrm{Yd}_{2}$ & $\begin{array}{l}\text { Renda disponível do 9\% seguintes da população (segundo } \\
\text { patamar de renda) }\end{array}$ \\
\hline $\mathrm{Yd}_{3}$ & Renda disponível do 40\% seguintes da população (terceiro \\
\hline
\end{tabular}




\begin{tabular}{|c|c|}
\hline & patamar de renda) \\
\hline $\mathrm{Yd}_{4}$ & $\begin{array}{l}\text { Renda disponível do 30\% seguintes da população (quarto } \\
\text { patamar de renda) }\end{array}$ \\
\hline $\mathrm{Yd}_{5}$ & $\begin{array}{l}\text { Renda disponível do } 20 \% \text { seguintes da população (quinto } \\
\text { patamar de renda) }\end{array}$ \\
\hline Yw & Renda do trabalho \\
\hline FBCF & Formação Bruta de Capital Fixo \\
\hline FBCFnd & Formação Bruta de Capital Fixo em dólares correntes \\
\hline FBCFr & Formação Bruta de Capital Fixo em reais constantes \\
\hline$\triangle \mathrm{FBCFr}$ & $\begin{array}{c}\text { Variação da Formação Bruta de Capital Fixo em reais } \\
\text { constantes }\end{array}$ \\
\hline FBCFrd & Formação Bruta de Capital Fixo em dólares constantes \\
\hline Id & Investimento doméstico \\
\hline If & Investimento estrangeiro \\
\hline $\mathrm{E}$ & Câmbio real \\
\hline e & Câmbio nominal \\
\hline$i^{*}$ & Inflação externa \\
\hline $\mathrm{i}$ & Inflação interna \\
\hline W ou w & Salários \\
\hline $\mathrm{LC}$ & Capital de longo prazo \\
\hline $\mathrm{T}$ & Tempo \\
\hline $\mathrm{tt}$ & Termos de troca nominais \\
\hline VneFe & Valor nominal exportado do minério de ferro \\
\hline PnFe & Preço nominal do minério de ferro \\
\hline VneSjb & Valor nominal exportado da soja em bruto \\
\hline PnSjb & Preço nominal da soja em bruto \\
\hline VneAc & Valor nominal exportado do açúcar bruto \\
\hline PnAc & Preço nominal do açúcar bruto \\
\hline VneRsj & Valor nominal exportado do resíduo de óleo de soja \\
\hline PnRsj & Preço nominal do resíduo de óleo de soja \\
\hline VreFe & Valor real exportado do minério de ferro \\
\hline PrFe & Preço relativo do minério de ferro \\
\hline VreSjb & Valor real exportado da soja em bruto \\
\hline PrSjb & Preço relativo da soja em bruto \\
\hline VreAc & Valor real exportado do açúcar bruto \\
\hline
\end{tabular}




\begin{tabular}{|c|c|}
\hline PrAc & Preço relativo do açúcar bruto \\
\hline VreRsj & Valor real exportado do resíduo de óleo de soja \\
\hline PrRsj & Preço relativo do resíduo de óleo de soja \\
\hline VniPtr & Valor nominal importado dos óleos brutos de petróleo \\
\hline PnPtr & Preço nominal dos óleos brutos de petróleo \\
\hline VniParp & $\begin{array}{l}\text { Valor nominal importado das partes e peças para veículos } \\
\text { automotores e tratores }\end{array}$ \\
\hline PnParp & $\begin{array}{c}\text { Preço nominal das partes e peças para veículos automotores } \\
\text { e tratores }\end{array}$ \\
\hline VniMdi & $\begin{array}{c}\text { Valor nominal importado de medicamentos para medicina } \\
\text { humana e veterinária }\end{array}$ \\
\hline PnMdi & $\begin{array}{c}\text { Preço nominal de medicamentos para medicina humana e } \\
\text { veterinária }\end{array}$ \\
\hline VniCmb & Valor nominal importado dos óleos combustíveis \\
\hline $\mathrm{PnCmb}$ & Preço nominal dos óleos combustíveis \\
\hline VriPtr & Valor nominal importado dos óleos brutos de petróleo \\
\hline PrPtr & Preço nominal dos óleos brutos de petróleo \\
\hline VriParp & $\begin{array}{l}\text { Valor nominal importado das partes e peças para veículos } \\
\text { automotores e tratores }\end{array}$ \\
\hline PrParp & $\begin{array}{c}\text { Preço real das partes e peças para veículos automotores e } \\
\text { tratores }\end{array}$ \\
\hline VriMdi & $\begin{array}{c}\text { Valor real importado de medicamentos para medicina } \\
\text { humana e veterinária }\end{array}$ \\
\hline PrMdi & $\begin{array}{c}\text { Preço real de medicamentos para medicina humana e } \\
\text { veterinária }\end{array}$ \\
\hline VriCmb & Valor real importado dos óleos combustíveis \\
\hline $\mathrm{PrCmb}$ & Preço real dos óleos combustíveis \\
\hline
\end{tabular}




\section{Sumário}

1 UMA VISÃO SOBRE O COMÉRCIO INTERNACIONAL_...............................................19

1.1 O SETOR EXTERNO E A ECONOMIA ABERTA.........................................................21

1.2 ALGUNS FATORES DE PERTUBAÇÃO DO COMÉRCIO EXTERIOR......................24

1.3 COMPENSAÇÃO DE PAGAMENTO E CRÉDITO.......................................................28

1.4 O CÂMBIO E O COMÉRCIO....................................................................................32

1.5 ASPECTOS DO COMÉRCIO INTERNACIONAL ENTRE MERCADOS

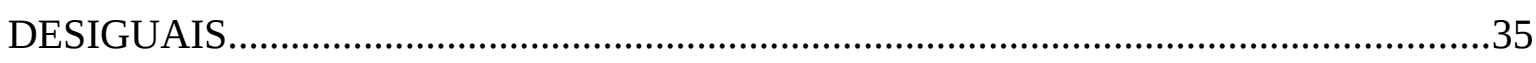

1.6 TROCAS DESIGUAIS E DETERIORAÇÃO DOS TERMOS DE TROCA...................39

1.7 ALGUNS ASPECTOS DO COMÉRCIO DE SERVIÇOS E DE CAPITAL...................43

1.8 O CRESCIMENTO EM ECONOMIAS SUBDESENVOLVIDAS................................46

1.9 UM MODELO DA ECONOMIA BRASILEIRA ENTRE 1999 E 2013.........................53

2 SOBRE O BALANÇO COMERCIAL BRASILEIRO..........................................................58

2.1 ALGUNS EFEITOS MACROECONÔMICOS..........................................................59

2.2 DESEMPENHO DO BALANÇO COMERCIAL E DOS TERMOS DE TROCA........63

2.3 CARACTERÍSTICAS DO COMÉRCIO EXTERIOR BRASILEIRO...........................70

2.3.1 CARACTERÍSTICAS DAS EXPORTAÇÕES BRASILEIRAS..............................71

2.3.2 AS EXPORTAÇÕES BRASILEIRAS E PROBLEMAS ESTRUTURAIS.............74

2.3.3 CARACTERÍSTICAS DAS IMPORTAÇÕES BRASILEIRAS.............................79

2.3.4 AS IMPORTAÇÕES BRASILEIRAS E OS PROBLEMAS ESTRUTURAIS.....83

3 AINDA O BALANÇO COMERCIAL .........................................................................90

3.1 A HIPÓTESE DE DESINDUSTRIALIZAÇÃO..........................................................91

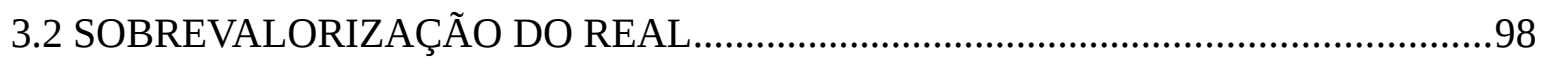

3.3 UMA HISTÓRIA DA POLÍTICA COMERCIAL BRASILEIRA RECENTE.............106 
3.4 O GOVERNO E OS EXPORTADORES-IMPORTADORES 110

3.5 AINDA OS EXPORTADORES-IMPORTADORES. 114

3.6 UM DEBATE SOBRE O COMÉRCIO EXTERIOR BRASILEIRO, DE 1999 A 2013 116

3.7 UMA CARACTERIZAÇÃO SOBRE O PERÍODO. 123

4. APONTAMENTOS SOBRE O BALANÇO DE PAGAMENTOS...................................126

4.1 O BALANÇO DE PAGAMENTOS E AS TRANSAÇÕES CORRENTES.................127

4.2 OS SERVIÇOS NA CONTA DAS TRANSAÇÕES CORRENTES.............................130

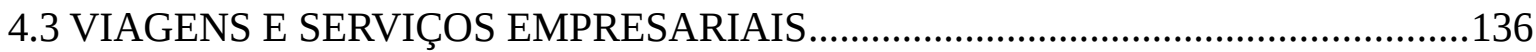

4.4 CONTA DE RENDAS DO BALANÇO DE PAGAMENTOS...................................143

4.5 CONTA FINANCEIRA E INVESTIMENTO DIRETO............................................147

4.6 FLUXO DE INVESTIMENTO E O ESTOQUE DA DÍVIDA...................................155

4.7 INVESTIMENTO E FORMAÇÃO BRUTA DE CAPITAL FIXO..............................158

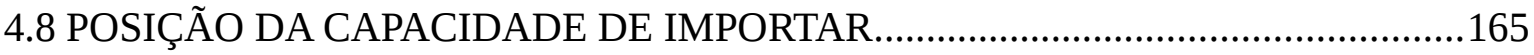

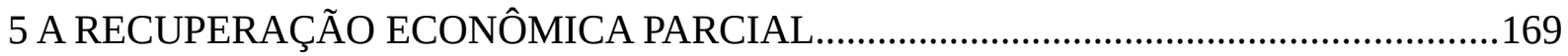

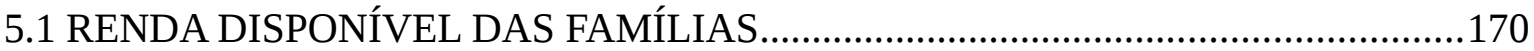

5.2 A RENDA DISPONÍVEL E A REDISTRIBUIÇÃO DE RENDA..............................177

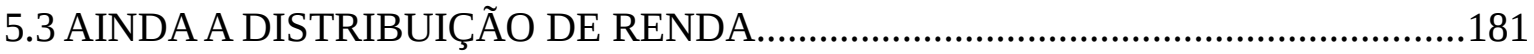

5.4 RENDA DISPONÍVEL DAS CAMADAS E O CONSUMO......................................187

5.5 A ELASTICIDADE MÓVEL DO CONSUMO ..........................................................192

5.6 AS OSCILAÇÕES NO CONSUMO E NA RENDA DAS CAMADAS.....................198

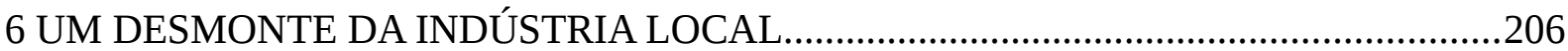

6.1 CARÁTER EXÓGENO DA PROSPERIDADE LOCAL ........................................209

6.2 UMA NÃO RECUPERAÇÃO INDUSTRIAL.......................................................213

6.3 RENDA DISPONÍVEL DAS CAMADAS E A FORMAÇÃO BRUTA DE CAPITAL FIXO. 
6.4 ELASTICIDADE MÓVEL DA FORMAÇÃO BRUTA DE CAPITAL FIXO.............225

6.5 OSCILAÇÕES NA RENDA E NO INVESTIMENTO...........................................231

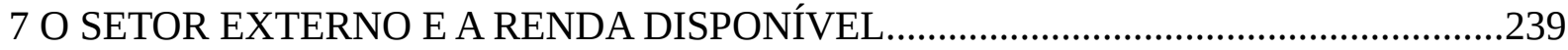

7.1 IMPORTAÇÃO E A RENDA DISPONÍVEL DAS CAMADAS...............................240

7.2 AS IMPORTAÇÕES E OS 90\% DA BASE DA PIRÂMIDE SOCIAL......................246

7.3 AUMENTO DA IMPORTAÇÃO E O DESMONTE DA INDÚSTRIA......................250

7.4 GANHOS NA RENDA DISPONÍVEL E A EXPORTAÇÃO.....................................257

7.5 ELASTICIDADE MÓVEL DOS GANHOS COM A EXPORTAÇÃO......................261

7.6 OSCILAÇÕES NA EXPORTAÇÃO E NA RENDA DAS CAMADAS......................267

7.7 UM MODELO DE CRESCIMENTO DEPENDENTE........................................269

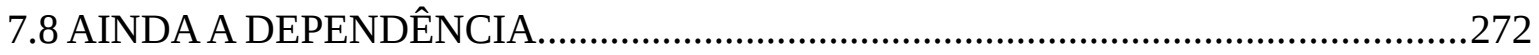

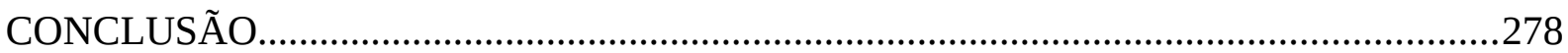

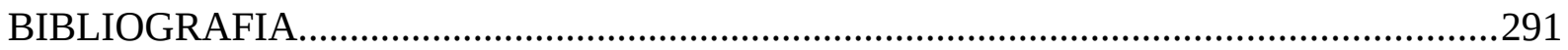

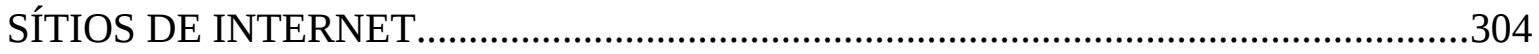




\section{Índice de Tabelas}

Tabela 1.1: Exemplo simplificado de trocas desiguais em comércio internacional. .40

Tabela 2.1 Elasticidade-renda das exportações e o impacto no PIB, 2003 a 2013 (modelos log$\log )$

Tabela 2.2 Elasticidade-renda das importações brasileiras, 1999 a 2013 (modelos log-log)...61

Tabela 2.3 Saldo nominal e real (em reais de 2006) do balanço comercial do Brasil, em milhões de dólares, 1999 a 2013.

Tabela 2.4: Poder de compra das exportações, em bilhões de reais de 2006, 1999 a 2013.....65

Tabela 2.5 Elasticidade-renda das importações e taxas de crescimento da economia brasileira, 2003 a 2013.

Tabela 2.6 Composição da pauta de exportação brasileira por categoria de uso, 1999 a 201372

Tabela 2.7 Cinco principais itens da pauta de exportação brasileira.

Tabela 2.8 Elasticidade-preço dos cinco principais produtos da pauta de exportação brasileira

Tabela 2.9 Elasticidade-renda dos cinco principais itens da pauta de exportação brasileira, 2001 a 2013 (modelo log-log).

Tabela 2.10 Participação (em porcentagem) dos diferentes blocos econômicos no destino das exportações brasileiras, 1999 a 2013.

Tabela 2.11 Composição da pauta de importação brasileira por categoria de uso, 1999 a 2013

Tabela 2.12 Cinco principais itens da pauta de importação brasileira, exportação em milhões de dólares, 1999 a 2013.

Tabela 2.13 Elasticidade-preço dos cinco principais produtos da pauta de importação, 2001 a 2013 (modelos log-log)......

Tabela 2.13 Elasticidade-preço dos cinco principais produtos da pauta de importação, 2001 a 2013 (modelos log-log). 
Tabela 2.14 Participação (em porcentagem) dos diferentes blocos econômicos na origem das importações brasileiras, 1999 a 2013.

Tabela 3.1 Capacidade relativa de abastecimento industrial nacional, 1960 a 2012. .95

Tabela 3.2: Demanda e Oferta de divisas no setor externo brasileiro em bilhões de dólares, 1999 a 2013 100

Tabela 3.3: Câmbio nominal e câmbio real no Brasil, 1999 a 2013. 103

Tabela 4.1a: PIB do Brasil e saldo das transações correntes, 1999 a 2013.

Tabela 4.1b: PIB do Brasil e saldo das transações correntes, 1999 a 2013.

Tabela 4.2a: Saldos da Conta de Serviços da Conta de Transações Correntes do Balanço de Pagamentos, 1999 a 2013.

abela 4.2b (continuação): Saldos da Conta de Serviços da Conta de Transações Correntes do Balanço de Pagamentos, 1999 a 2013. 133

Tabela 4.2c (cont.): Saldos da Conta de Serviços da Conta de Transações Correntes do Balanço de Pagamentos, 1999 a 2013. 135

Tabela 4.3a: Viagens internacionais, valores em bilhões de reais de 2006, 1999 a 2003. 137

Tabela 4.3b (cont.): Viagens internacionais, valores em bilhões de reais de 2006, 1999 a 2003.

Tabela 4.4a: Serviços empresariais, profissionais e técnicos, valores em bilhões de reais de 2006, 1999 a 2013. 140

Tabela 4.4b: Serviços empresariais, profissionais e técnicos, valores em bilhões de reais de 2006, 1999 a 2013.

Tabela 4.5: Conta de Rendas da conta de Transações Correntes do Balanço de Pagamentos, valores em bilhões de reais de 2006, 1999 a 2013.

Tabela 4.6: Conta financeira do Balanço de Pagamentos, valores em bilhões de Reais de 2006, 1999 a 2013

Tabela 4.7a: Conta “Investimento Direto” da “Conta Financeira” do Balanço de Pagamentos, 1999 a 2013 152

Tabela 4.7b (cont.): Conta "Investimento Direto" da "Conta Financeira” do Balanço de 
Pagamentos, 1999 a 2013.

Tabela 4.8: Dívida externa e pública, valores em bilhões de reais de 2006.

Tabela 4.9: Regressões lineares com formação bruta de capital fixo como variável dependente, 2003 a 2013

Tabela 4.10: Elasticidade da Formação Bruta de Capital em relação à fontes de capital, 2003 a 2013

Tabela 4.11: Poder de compra das exportações, em bilhões de reais de 2006, 1999 a 2013. .166

Tabela 4.12: Posição da capacidade de importação em bilhões de reais de 2006, 1999 a 2013

Tabela 5.1: Renda disponível das camadas de renda do Brasil (em bilhões de reais constantes de 2006) - 1999 a 2013

Tabela 5.2: Renda do trabalho, em reais de 2006, explicada pelas exportações e importações do Brasil (1999 a 2013)

Tabela 5.3: Renda disponível total explicada pela renda disponível dos patamares de renda, em reais constantes de 2006 (1999 a 2013)

Tabela 5.4: Valor do consumo real das famílias brasileiras explicado pela renda disponível das camadas de renda - 1999 a 2013.

Tabela 6.1: Participação da Indústria no PIB brasileiro, em porcentagem: 1990 a $2012 . . . . .215$

Tabela 6.2: Capacidade de abastecimento industrial doméstica brasileira por setor, 1990 a 2012

Tabela 6.3: Formação bruta de capital fixo explicado pela renda disponível das camadas de renda.

Tabela 7.1: Importação real brasileira explicada pela renda disponível das camadas de renda

Tabela 7.2: Renda disponível das camadas de renda explicada pelo valor total real das exportações com defasagem de um ano. (2000 a 2013). 258

Tabela 7.3: Renda disponível das camadas de renda explicada pelo valor total real das exportações defasada em um ano e dummy para 2009 a 2013. (2000 a 2013). 260 
Tabela 7.4: Produto Interno Bruto explicado pelo Consumo das famílias e pelas exportações

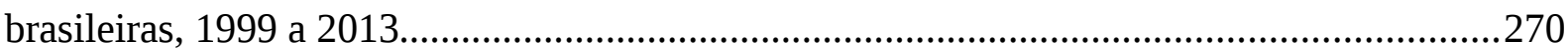

Tabela 7.5: Produto Interno Bruto explicado pelo Consumo das famílias e pelas exportações

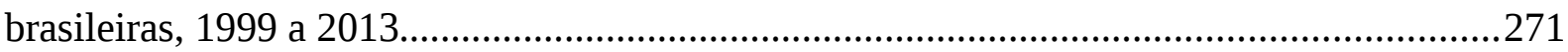

Tabela 7.6: Variação da renda disponível brasileira explicada por distintas variáveis

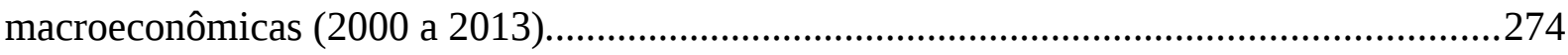




\section{Índice de Gráficos}

Gráfico 2.1: Participação relativa do consumo e da formação bruta de capital fixo em cada novo dólar de importação, 1999 a 2013. 62

Gráfico 2.2 Variação nos termos de troca do comércio exterior brasileiro: 1999 a 2013.........67

Gráfico 2.3: Taxa de crescimento dos termos de troca, 2000 a 2013.....................................68

Gráfico 2.4 Concentração das exportações brasileiras, 1999 a 2013......................................74

Gráfico 2.5 Participação de Bens de Capital e a capacidade brasileira para importar, 1999 a 2013

Gráfico 2.6 Grau de concentração das importações brasileiras, 1999 a 2013.

Gráfico 3.1 Índice da capacidade de abastecimento industrial nacional do Brasil, 1960 a 1989

Gráfico 3.2 Índice da capacidade de abastecimento industrial nacional do Brasil, 1987 a 2012

Gráfico 3.3: Posição relativa do câmbio e da demanda por divisas no Brasil, 1999 a 2013. .101

Gráfico 3.4: Posição relativa do câmbio nominal e do câmbio "de equilíbrio"..... 104

Gráfico 3.5: PIB e Componentes Selecionados (1999 = 100). 105

Gráfico 4.1: Saldo real das Transações Correntes do Brasil, 1999 a $2013 .$. 129

Gráfico 4.2: Déficit de serviços e rendas nas transações correntes, 1999 a 2013. 131

Gráfico 4.3: Déficit das transações correntes de renda, 1999 a 2013. 145

Gráfico 4.4: Saldo real dos investimentos, 1999 a 2013 150

Gráfico 4.5: Entrada e saída de capital pelo investimento estrangeiro direto, 1999 a 2013...156 Gráfico 4.6: Formação bruta de capital fixo explicado pelo investimento estrangeiro direto, 1999 a 2013. .161

Gráfico 4.7: Formação bruta de capital fixo real explicado pela dívida externa real, 2003 a 2013 
Gráfico 4.8: Formação bruta de capital fixo real explicado pela dívida pública interna real, 2003 a 2013

Gráfico 4.9: Posição da capacidade de importação do Brasil, 1999 a 2013. 168

Gráfico 5.1: Renda disponível do primeiro patamar de renda e do quarto e quinto patamar somados, 1999 a 2013

Gráfico 5.2: Renda da metade de cima da pirâmide de renda do Brasil, 1999 a 2013...........173

Gráfico 5.3: Renda média dos assalariados, 1992 a 2013. 174

Gráfico 5.4: Posição relativa da renda do primeiro patamar de renda em relação a oscilação da renda disponível total do Brasil, 1999 a 2013.

Gráfico 5.5: Posição relativa da renda do segundo patamar de renda em relação a oscilação na renda disponível total do Brasil, 1999 a 2013. 183

Gráfico 5.6: Posição relativa da renda disponível do terceiro patamar de renda em relação a oscilação na renda disponível total do Brasil, 1999 a 2013

Gráfico 5.7: Posição da renda disponível do quarto patamar de renda em relação a oscilação da renda disponível total do Brasil, 1999 a 2013.

Gráfico 5.8: Posição relativa da renda do quinto patamar de renda em relação a oscilação da renda disponível total do Brasil, 1999 a 2013. 186

Gráfico 5.9: Participação móvel do primeiro patamar de renda para cada novo real no consumo total das famílias brasileiras, 1999 a 2013.

Gráfico 5.10: Participação móvel do segundo patamar de renda em cada novo real de consumo total das famílias do Brasil, 1999 a 2013.

Gráfico 5.11: Participação móvel do terceiro patamar de renda para cada novo real no consumo total das famílias do Brasil, 1999 a 2012. .194

Gráfico 5.12: Participação do quarto patamar de renda para cada novo real no consumo total das famílias do Brasil, 1999 a 2013. 196

Gráfico 5.13: Participação do quinto patamar de renda para cada novo real no consumo total das famílias do Brasil, 1999 a 2013.

Gráfico 5.14: Posição relativa da renda do primeiro patamar de renda em relação ao consumo 
total das famílias brasileira, 1999 a 2013.

Gráfico 5.15: Posição relativa da renda do segundo patamar em relação ao consumo total das famílias brasileiras, 1999 a 2013

Gráfico 5.16: Posição relativa da renda do terceiro patamar em relação ao consumo total das famílias brasileiras, 1999 a 2013.

Gráfico 5.17: Posição relativa da renda do quarto patamar em relação ao consumo total das famílias do Brasil, 1999 a 2013. 203

Gráfico 5.18: Posição relativa da renda do quinto patamar em relação ao consumo total das famílias brasileiras, 1999 a 2013. 204

Gráfico 6.1: Riqueza relativa das duas camadas do topo em relação as duas camadas da base da pirâmide de renda do Brasil, 1999 a 2013. 210

Gráfico 6.2: Poupança real das famílias, 1999 a 2013. 211

Gráfico 6.3: Gasto real em seguridade social no Brasil, 1999 a 2013. 212

Gráfico 6.4 Capacidade de abastecimento da indústria de transformação brasileira, 2000 a 2012

Gráfico 6.5: Participação móvel do primeiro patamar de renda em cada novo real criado na Formação Bruta de Capital Fixo brasileira, 1999 a 2013. 226

Gráfico 6.6 :Participação móvel do segundo patamar de renda em cada novo real criado na Formação Bruta de Capital Fixo brasileira, 1999 a 2013. .227

Gráfico 6.7: Participação móvel do terceiro patamar de renda em cada novo real criado na Formação de Capital Fixo brasileira, 1999 a 2013 .228

Gráfico 6.8: Participação do quarto patamar de renda em cada novo real criado na Formação Bruta de Capital Fixo brasileira 1999 a 2013. 229

Gráfico 6.9: Participação móvel do quinto patamar de renda em cada novo real criado na Formação Bruta de Capital Fixo brasileira, 1999 a 2013 230

Gráfico 6.10: Capacidade de investimento do primeiro patamar de renda e oscilação na formação bruta de capital fixo do Brasil, 1999 a 2013.

Gráfico 6.11: Capacidade de investimento do segundo patamar de renda e oscilação na 
formação bruta de capital fixo do Brasil, 1999 a 2013.

Gráfico 6.12: Capacidade de investimento do terceiro patamar de renda e oscilação na formação bruta de capital fixo do Brasil, 1999 a 2013.

Gráfico 6.13: Capacidade de investimento do quarto patamar de renda e oscilação na formação bruta de capital fixo do Brasil, 1999 a 2013. 235

Gráfico 6.14: Capacidade de investimento do quinto patamar de renda e oscilação na formação bruta de capital fixo do Brasil, 1999 a 2013. 236

Gráfico 7.1: Participação do primeiro patamar de renda em cada novo real nos gastos de importação do Brasil, 1999 a 2013 .244

Gráfico 7.2: Participação do segundo patamar de renda em cada novo real nos gastos de importação do Brasil, 1999 a 2019 245

Gráfico 7.3: Participação do terceiro patamar de renda em cada novo real nos gastos de importação do Brasil, 1999 a 2013

Gráfico 7.4: Participação do quarto patamar de renda em cada novo real de importação do Brasil, 1999 a 2013.

Gráfico 7.5: Participação do quinto patamar de renda em cada novo real nos gastos de importação do Brasil, 1999 a 2013

Gráfico 7.6: Posição relativa da renda disponível do primeiro patamar de renda em relação ao valor total das importações brasileiras, 1999 a 2013. 252

Gráfico 7.7: Posição relativa da renda disponível do segundo patamar de renda em relação ao valor total das importações brasileiras, 1999 a 2013. .253

Gráfico 7.8: Posição relativa do valor total da renda disponível do terceiro patamar de renda em relação a importações brasileiras, 1999 a 2013 254

Gráfico 7.9: Posição relativa da renda disponível do quarto patamar de renda em relação ao valor total das importações brasileiras, 1999 a 2013. 255

Gráfico 7.10: Posição relativa da renda disponível do quinto patamar de renda em relação ao valor total das importações brasileiras, 1999 a 2013. .256

Gráfico 7.9 Poder de compra das exportações brasileiras, 1999 a 2013. 262 
Gráfico 7.10: Elasticidade móvel da renda disponível brasileira em relação ao valor total das exportações brasileiras, 2000 a 2013.

Gráfico 7.11: Ganhos do primeiro e segundo patamares de renda para cada novo real criado na exportação brasileira, 2000 a 2013.

Gráfico 7.12: Ganhos do terceiro patamar de renda para cada novo real criado na exportação brasileira, 2000 a 2013

Gráfico 7.13: Ganhos do quarto e quinto patamares de renda para cada novo real criado nas exportações brasileiras, 2000 a 2006 266

Gráfico 7.14: Posição relativa da renda dos três primeiros patamares em relação as oscilações no valor total das exportações brasileiras, 1999 a 2013. .268

Gráfico 7.15: Posição relativa do quarto e quinto patamares de renda em relação as oscilações do valor total das exportações brasileiras, 2000 a 2013 .269 


\section{Índice de Modelos}

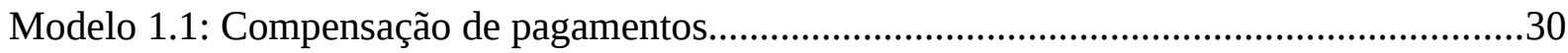

Modelo1.2: Preços internacionais entre mercados desiguais.................................................37

Modelo 1.3: Modelo explicativo para o paradoxo de Leontieff...............................................38

Modelo 1.4: Tendência à deterioração dos termos de troca.....................................................42

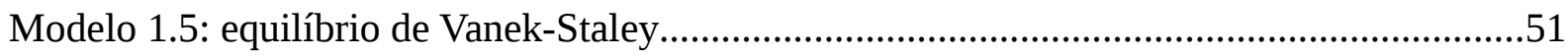

Modelo 1.6Organograma do modelo econômico de dependência brasileiro.............................54

Modelo 1.7: Modelo de equilíbrio Vanek-Staley adaptado.................................................55

Modelo 8.1 - Equilíbrio Vanek-Staley adaptado Situação (a): 1999 a 2000..........................278

Modelo 8.2 - Equilíbrio Vanek-Staley adaptado Situação (b): 2001 - 2003...........................280

Modelo 8.3 - Equilíbrio Vanek-Staley adaptado Situação (c): 2004 - 2007..........................281

Modelo 8.4 - Equilíbrio Vanek-Staley adaptado Situação (d): 2008 - 2011...........................283

Modelo 8.5 - Equilíbrio Vanek-Staley adaptado Situação (e): 2012 em diante.......................285 


\title{
1 UMA VISÃO SOBRE O COMÉRCIO INTERNACIONAL
}

\author{
“CALIBÃ - Já não farei barragem para peixe, \\ nem fogo irei buscar, \\ quando ele me mandar. \\ Não lavo prato nem carrego feixe. \\ Bã, bã bã, Calibã! \\ Outro mestre amanhã! \\ Liberdade! Viva! Liberdade! Liberdade!” \\ SHAKESPEARE, William. A Tempestade, 1623.
}

Sim, amigos! O setor externo da economia brasileira, o Calibã suposto a trabalhar para sempre como "motor do crescimento, cansou-se da "escravidão” e saiu por aí, "trabalhando" em causa própria. A nós, que assistimos estarrecidos o ocorrido, cabe apenas tentar entender o que se passou. Afinal, era ele o nosso vínculo com o “comércio internacional”...

O comércio internacional é considerado uma área de estudo própria. Apesar de emprestar sua metodologia de outras áreas de conhecimento, pela complexidade do assunto, ela foi alavancada, na literatura, a uma área em separado. Os estudos do campo buscam entender as ferramentas que permitem aos países equilibrar seu comércio exterior, os mecanismos que levam a outros a sofrerem perdas, e como o setor externo de uma economia influencia o desempenho econômico local. Para o caso brasileiro, o estudo do setor externo é fundamental para entender o desempenho momentaneamente favorável da economia local, entre 1999 e 2013. No período, o Brasil passou por crises (1999 - 2002), por uma recuperação momentânea (2003 a 2008), com uma nova fase de crises (2009 - 2010), seguida de nova recuperação de fôlego curto (2010 - 2013). Este desempenho pode ser descrito por um modelo de “pare e siga” (“Stop \& Go”), típico de países dependentes da exportação de bens primários.

Apesar do crescimento econômico ter ocorrido junto a uma distribuição de renda parcial, esta apenas ampliou a demanda local, suprida por importações. Não houve novos investimentos na indústria manufatureira local. O resultado é que a recuperação econômica ocorreu com a ampliação da dependência da exportação de bens primários, o que se expressou como redução da participação dos bens manufaturados na pauta de exportação, e sucessivos aumentos na demanda por importação.

A presente pesquisa foi feita com o intuito de responder à questão central: quais foram 
os mecanismos que permitiram a recuperação econômica ocorrida no Brasil, entre 2003 e 2010? Buscava-se com essa questão entender se, passado aqueles anos, o país havia ou não adquirido maior capacidade de crescimento autônomo. A pesquisa foi iniciada antes das crises observadas em 2014, 2015 e 2016. A hipótese, formulada ao início do levantamento dos dados, era que o crescimento econômico brasileiro fora impulsionado pela alta dos preços das commodities. Disso resultava que a recuperação econômica não esteve ligada a novos investimentos produtivos que gerassem aumento da produtividade. Isso significava que o desempenho da economia brasileira dependia principalmente da demanda externa, dita simples, do desempenho da economia chinesa.

Entre 1999 e 2013, a parceria entre a China e os Estados Unidos da América levou a fortes investimentos na China. Aquele país aumentou muito sua capacidade de produção industrial, tornando-se um centro industrial mundial importante. Como resultado, a demanda chinesa por bens primários aumentou. Países fornecedores de matéria-prima e de bens agrícolas tiveram a oportunidade de formar parcerias comerciais favoráveis com a China. O preço dos bens primários aumentou rapidamente, até 2010. Mesmo diante da crise mundial de 2008, a China continuou a crescer aceleradamente, o que manteve em alta a demanda por bens primários. O Brasil foi um dos beneficiados desse processo. Pôde adquirir fortes saldos comerciais, o que impulsionou o crescimento local. No entanto, entre 2011 e 2013, o crescimento da demanda chinesa perdeu ritmo. Em 2013, a China declarou que passaria por uma mudança de modelo econômico. A partir de então, aquele país passou a favorecer um crescimento autocentrado. A consequência foi a imediata redução da demanda chinesa por bens primários. Para o Brasil, isso significou o fim da conjuntura favorável no comércio internacional.

Como não houve investimentos locais suficientes para sustentar um crescimento autocentrado no Brasil, passada a conjuntura favorável, a economia local apresentou dificuldades de crescimento desde 2012. Sem formas de financiar sua demanda por importações, necessárias para sustentar o crescimento econômico, o país viu o nível de sua atividade econômica se reduzir.

Para verificar a tese que o crescimento econômico brasileiro foi fruto do comércio internacional e não resultou em alteração da estrutura dependente do país, é necessário, portanto, investigar o setor externo da economia brasileira. A hipótese é que a economia 
brasileira seja caracterizada pela dependência, sendo necessário buscar a base teórica que permitisse classificar o que é esta dependência, e como operam as assimetrias no comércio internacional.

A presente pesquisa foi dividida em 7 capítulos: o (1) primeiro capítulo é uma introdução que contém uma leitura sobre a teoria do comércio internacional, destacando alguns dos conceitos e princípios mais importantes para uma interpretação estrutural do comércio exterior brasileiro, de 1999 a 2013. Isso significa dar maior enfase para (a) o impacto do comércio internacional na economia interna dos países; (b) destacar algumas características do funcionamento do comércio exterior; e (c) apontar alguns fatores de pertubação e vício no balanço de pagamentos dos países; os dois capítulos seguintes, abordam (2) algumas das características do balanço comercial do Brasil, onde se demonstra aspectos que servem para classificar o país como dependente, e (3) como essas características foram entendidas por autores e agentes que discutiram a economia nacional no período; o (4) quarto capítulo aborda o Balanço de Pagamentos brasileiro, servindo para revelar outros mecanismos de perda de divisas por parte do Brasil no comércio exterior. No capítulo, buscou-se demonstrar como a venda de ativos brasileiros e a dependência das firmas multinacionais impactou a economia brasileira.

No (5) quinto capítulo, caracteriza-se aquilo que denominamos de recuperação parcial da economia brasileira, ocorrida entre 1999 e 2013. Ainda, discute-se a relação da recuperação e a distribuição de renda entre distintas camadas de renda; o (6) sexto capítulo apresenta alguns aspectos da relação entre os investimentos no Brasil e o setor externo da economia, dando destaque ao processo de desmonte da indústria manufatureira local; no (7) sétimo capítulo, realiza-se uma verificação do modelo de crescimento e distribuição de renda do Brasil. Busca-se com isso ressaltar a dependência econômica do Brasil em relação à sua capacidade de importar, sustentada fundamentalmente pelas exportações. Na ausência de capacidade de exportar, o país recorreu à venda de ativos para sustentar seu crescimento.

\subsection{O SETOR EXTERNO E A ECONOMIA ABERTA}

Quando o comércio internacional é analisado pela ótica do impacto que ele exerce na economia de um país específico, diz-se que se está estudando o setor externo daquela economia. Diz-se ainda que está se estudando a referida economia como economia aberta, ou 
seja, que possui relações econômicas com o resto do mundo. ${ }^{1}$

Em geral, as economias podem ter seu desempenho mensurado pelo Produto Interno Bruto (PIB), ou pela Renda Nacional Bruta (RNB)². Tratam-se de variáveis que mensuram o fluxo de produção do país. Ou seja, quanto foi produzido durante determinado período. Em um modelo econômico fechado, tanto o produto nacional ou a renda nacional são iguais a soma dos gastos do governo, do consumo final das famílias, e dos investimentos $(\mathrm{Y}=\mathrm{C}+\mathrm{I}+\mathrm{g})$.

Nesse modelo fechado, os gastos do governo (“G”) são todos os gastos realizados pelo governo, excluindo subsídios e investimento estatal. Em sua maioria inclui programas sociais, programas especiais, e gasto com pessoal. O consumo final das famílias (“C”) inclui todo consumo privado feito pelo setor privado. Ou seja, exclui dele o que é consumo de insumos, partes e peças, etc, que sejam realizados por empresas para fins de criação de um novo produto. Por exemplo, inclui pregos vendidos no atacado ou no varejo para as famílias, mas não incluem as compras de pregos declaradas pelas empresas de montagem de móveis, etc.

Os investimentos (“I”) são a formação bruta de capital fixo. É o investimento final em bens materiais de produção. Inclui máquinas e construção civil. Dessa forma, inclui tratores, bens de capital, estradas, hospitais, casas, etc. Para evitar dupla contagem, os insumos utilizados só entram na conta no ponto final da cadeia de produção. Por exemplo: o minério extraído em uma mineradora, processado na refinaria, transformado em uma siderurgia, e incorporado em uma construção civil é apenas contabilizado na forma do valor da construção civil. Nesse modelo, o investimento é sempre igual à poupança nacional (I=S), visto que o que não é consumo é investimento.

Em um modelo aberto, passa-se a considerar o chamado setor externo. Trata-se do comércio exterior. Quando se fala de PIB, o setor externo em análise inclui apenas as exportações e importações de bens e serviços. Quando se fala de RNB, o setor externo também incorpora as transações de renda de capital (pagamentos de juros e dividendos de investimento). Nos modelos abertos, a renda nacional passa a ser igual à soma dos gastos do governo, do consumo final das famílias, dos investimentos, mais as exportações menos as importações (incluindo pagamento e recebimento de transações de renda). Assim, o modelo é

1 Sobre o tema ler: ACKLEY, Gardner. Teoria Macroeconômica. Vol 1 e 2. São Paulo: Livraria Pioneira Editora,1969.

2 Pela metodologia atualmente adotada pelo IBGE, a diferença entre o PIB e o RNB é que o segundo considera todas as perdas e ganhos das transações correntes do Balanço de Pagamentos, enquanto o PIB apenas considera as perdas e ganhos no comércio exterior. 
simbolizado pela fórmula $\mathrm{Y}=\mathrm{C}+\mathrm{I}+\mathrm{G}+(\mathrm{X}-\mathrm{M})$. Portanto, a renda nacional é igual ao consumo da população, mais investimentos, mais gastos do governo, mais o resultado do setor externo. Kenneth Reinert oferece uma definição sucinta dos componentes da renda, excetuando o consumo:

“O termo capital utilizado aqui não se refere ao capital físico, como máquinas e edifícios. Em vez disso, refere-se a renda não consumida, que está disponível para uso em investimentos. A segunda conta nova é "Governo", e a terceira é "Resto do mundo". A conta Resto do mundo captura as interações da economia mexicana com os outros países do mundo.”3

Para os modelos de economia aberta, as exportações e importações resultam tanto de aspectos nacionais como de aspectos internacionais. Ainda, elas se relacionam diretamente à capacidade de investimento do país. No modelo de economia aberta, a poupança do país passa a ser igual aos investimentos nacionais (Id) mais os investimentos estrangeiros (If). $\mathrm{O}$ investimento estrangeiro, por sua vez, é igual as exportações menos as importações. Isso significa que, ao se importar mais do que se exporta, a poupança total do país se reduz a valor inferior ao investimento do país. O investimento passa a ser financiado, portanto, através da poupança externa (endividamento, por exemplo). ${ }^{4}$

Isso significa dizer que o setor externo da economia de um país descreve-se no Balanço de Pagamentos, que inclui todas as transações entre residentes de um país e os não residentes. Inclui, portanto, investimentos estrangeiros, dívida externa, envio de remessas, serviços prestados ao exterior, ou prestados por não residentes à residentes, etc. ${ }^{5}$

No modelo aberto, deve-se considerar fatores conjunturais e demandas para além do modelo da economia nacional em estudo. Na prática, a importação é fruto de uma demanda interna, mas depende da oferta externa. As exportações são fruto da demanda externa, e dependem da oferta interna ${ }^{6}$.

A importância da oferta e da demanda nacional e internacional, para economias

3 REINERT, Kenneth A. An Introduction To International Economics. New Perspectives on the World Economy. Nova Iorque: Cambridge Press, 2012, pg. 209.

4 Sobre o comércio exterior e a poupança ver: KINDLEBERGER, Charles P. Economia Internacional. São Paulo: Editora Mestre Jou, 1974.pg. 295 - 308

5 Para uma definição de Balança de Pagamentos ver: GÉLÉDAN, Alain \& BRÉMOND, Janine. Dicionário Económico e Social. Lisboa: Livros Horizonte LTDA, 1988. Pg. 209

6 Ver também: BARBOSA, Wilson do Nascimento. Balanço da Economia Brasileira (1940 - 1980). Editora LCTE, SP, 2006. 
abertas, é fator bastante importante. O tamanho da economia nacional em relação à outras economias determina sua dimensão econômica. Essa dimensão influencia o desempenho do país no comércio internacional de duas formas: (1) influencia a importância do comércio exterior na economia interna; e (2) determina a importância do país no comércio internacional. ${ }^{7}$

A dimensão da economia deve, portanto, ser considerada pela ótica (i) interna e (ii) externa. Pela (i) interna, o tamanho da economia é determinado pelo (a) tamanho do seu mercado atual (capacidade imediata de consumir); (b) produtividade local (capacidade de produção per capita); e (c) consequentemente pela renda nacional. Quanto maior for a capacidade nacional de produzir e consumir, o país tenderá a depender menos do comércio internacional, mas quanto maior for a renda local, maior será o mercado do país.

Pela ótica (ii) externa, a dimensão econômica do país será tanto maior quanto (a) maior for a participação do país na produção das mercadorias que exporta; (b) maior for a intensidade de trabalho nos produtos que exporta; e (c) maior for a participação nas importações mundiais. Economias de grande dimensões tem maior influência na determinação dos preços dos itens que exporta e importa. Economias de dimensão menores acabam tendo que exportar e importar a preços já dados pelo mercado.

Considerando essas duas óticas de mensurar a dimensão do comércio exterior de uma nação, pode-se atingir uma primeira consideração. O tamanho do mercado do país indica se a nação é economicamente dependente ou não. Países cuja economia é de pequeno porte tanto pela ótica interna como externa tendem a ser países dependentes, mas apenas o serão se sua capacidade de produção não for capaz de gerar crescimento endógeno.

\subsection{ALGUNS FATORES DE PERTUBAÇÃO DO COMÉRCIO EXTERIOR}

A análise do setor externo de uma economia precisa levar em conta fatores que fogem aos modelos de equilíbrio de comércio exterior. Existem fatores de pertubação da economia que levam a comportamentos erráticos, ou a movimentos tendenciais, contrários ao esperado pelas medidas econômicas tomadas em um país. Ainda, as próprias medidas adotadas são

7 Sobre o papel da dimensão das economias no comércio exterior ver: PALAZZO, José Truda. Balanço de Pagamentos: fatores de pertubação do seu equilibrio e procedimentos para superá-los. Porto Alegre: Tese para concurso de cátedra de "Comércio internacional e câmbios" da Faculdade de Ciências Econômica da Universidade do Rio Grande do Sul, 1954. 
influenciadas por interesses de agentes econômicos, que, se ignorados no momento da análise, tornam incompreensível o sentido geral tomado. Daí a importância da análise históricoeconômica. Alguns dos fatores de pertubação que podem ser destacados são: (a) interesses nacionais e internacionais; (b) interesses de classe; (c) o efeito demonstração; (d) custos de transporte; e (e) existência de economia monopolista. ${ }^{8}$

O comércio internacional é afetado por acontecimentos políticos de diversas ordens. Guerras, bloqueios econômicos, reconstrução após guerra, golpes, revoluções, mudanças de política externa, etc., são alguns dos efeitos que podem fazer oscilar os preços dos bens exportados e importados. Ainda, no século XX, o comércio exterior vinha sendo utilizado como arma na realização da chamada guerra econômica. A política econômica dos países desenvolvidos é pensada de forma a permiti-lhes adquirir riqueza, drenando-as de países menos preparados para se defender de ofensivas econômicas. Um exemplo disso foi o incentivo dado pelo governo norte-estadunidense ao gás de xisto, na década de 2010, que ajudou a derrubar o preço do petróleo. O incentivo resultou em mudança da política de preços do petróleo e de combustíveis, que passou a favorecer os países importadores de petróleo. ${ }^{9}$

Disso resulta que o estudo do comércio internacional passa, também, por buscar identificar possíveis interesses nacionais em jogo. Entre 1999 e 2013, ocorreram: a chamada Guerra ao Terror, a parceria econômica EUA-China, a crise de 2008, a Primavera Árabe, a formação do grupo dos BRICS, e o aumento das hostilidades entre EUA, China, e Rússia. O resultado foi, na primeira metade do período, como expressão do sucesso da parceria dos EUA com a China, a ampliação dos preços das commodities. A partir de 2010, com a chamada “Primavera Árabe” e com o favorecimento da expansão do gás de xisto, ocorreu pressão para queda do preço do petróleo. Em 2013, com a mudança da política econômica chinesa, agora voltada para o crescimento endógeno, houve nova pressão para queda dos preços das commodities, etc.

Além dos interesses nacionais, o comércio exterior de um país sofre influência dos interesses de classes e grupos nele existentes. O comércio internacional pode ser uma fonte de renda. Alterações nas taxas alfandegárias, na política cambial, e nas políticas de insumo afetam a distribuição da renda. No caso do Brasil, pode-se entender que o Real (moeda)

8 Sobre o tema ver: KINDLEBERGER, Charles P. Economia Internacional. São Paulo: Editora Mestre Jou, 1974.

9 Sobre o assunto ver a entrevista de Ildo Sauer, publicado na revista Mouro, número 9, página 29, em janeiro de 2015. 
sobreapreciado fez parte de uma política do governo de buscar agradar aos importadores de bens de consumo. Ainda, o governo utilizou o câmbio e as importações como uma ferramenta de controle da inflação e afago ao investimento externo.

Os ganhos no comércio internacional podem ser utilizados para financiar importação “barata” para distintos grupos de um país. Ragnar Nurkse chamava a atenção para o fato que parcela das elites locais dos países subdesenvolvidos verem no comércio exterior uma ferramenta para realizar seu desejo de consumir, como se fosse parte da elite dos países desenvolvidos $^{10}$. Como a produtividade nos países subdesenvolvidos é menor, isso só é possível através da diminuição da propensão a poupar, e utilizando os ganhos das exportações para financiar um consumo de luxo. A isso, Ragnar Nurkse chamou de efeito demonstração. Esse efeito também afeta outras parcelas da população dos países dependentes, uma vez que as camadas médias, e a população mais pobre, também busca realizar um consumo similar ao da elite local. O resultado é maior propensão a importar no país. Essa maior propensão também afeta o comércio internacional, e somado às disputas de interesse das camadas sociais, pode levar a adoção de políticas econômicas que levam a perdas em médio e longo prazo.

Os países dependentes possuem baixa capacidade de acumulação de capital, e estruturas sociais que fortalecem os mecanismos de escoamento de divisas. Ainda, existem limitações estruturais, e outras naturais, para que esses países consigam superar seus gargalos para o crescimento. No comércio internacional, um dos problemas estruturais são os custos de transporte, conforme destacado por Chales Kindleberger. ${ }^{11} \mathrm{O}$ preço das mercadorias, vendidas no exterior, é acrescido dos custos para transportá-las. Isso pode fazer com que, para vender produtos manufaturados no exterior, os países dependentes precisariam produzir a custos mais baixos (com produtividade maior) do que seus competidores. Em geral, isso só é possível ou (a) com forte desenvolvimento de tecnologia; ou (b) com política de salários desfavorável à população local. Na prática, a existência de custos de transporte favorece que países dependentes, como o Brasil, tenham como principais consumidores de seus produtos industriais os países vizinhos, tendo mercado potencial geograficamente limitado.

10 Sobre o assunto ver: NURKSE, Ragnar. Problema da Formação de Capital em Países Subdesenvolvidos. Rio de Janeiro: Civilização Brasileira, 1957. Ver também PALLOIX, C., AMIN, S., BATTELHEIM, C. \& EMMANUEL, A.. Impersialismo e Comércio Internacional, A Troca Desigual”. São Paulo: Global Editora, 1981.

11 Ver: KINDLEBERGER, Charles P. Economia Internacional. São Paulo: Editora Mestre Jou, 1974. 
No caso do Brasil, isso significa maior possibilidade de exportar bens manufaturados para a América Latina do que para outras regiões. No entanto, para o fazer, precisa enfrentar a produção de firmas multinacionais que se aproveitam de diversas vantagens advindas de sua condição de quase monopolista. Disso resulta que a expectativa que o Brasil venha se tornar um grande produtor manufatureiro é irrealista, ao menos em médio prazo. O problema do comércio internacional é menos o de formular saídas hipotéticas do que o de identificar os gargalos que o tornam desvantajoso para o país. Não se trata apenas de discutir se o câmbio está $10 \%$ acima ou abaixo do câmbio de equilíbrio, ou se eventuais subsídios possibilitariam ou não o setor industrial. Na prática, o sucesso do setor industrial no comércio exterior depende, também, da atuação dos demais países, e das firmas multinacionais (empresas monopolistas).

As firmas multinacionais se aproveitam de algumas vantagens que possuem. A primeira é o volume do capital disponível. Elas podem produzir em larga escala, o que faz com que os custos de produção caiam bastante. Podem também desenvolver tecnologia mais avançada, o que lhes dá vantagem de produtividade. Ainda, desde que os países reconheçam os direitos intelectuais sobre a tecnologia, as firmas multinacionais podem adquirir ganhos extras através da exploração de direitos de patente. Essas características aumentam o chamado custo de entrada de novas empresas competidoras. Empresas locais precisam, primeiro, investir o suficiente para produzir de forma competitiva. Possivelmente, ao utilizar tecnologia estrangeira, precisarão pagar royalties. Ainda, podem ser alvo de política de dumping, realizada por empresas estrangeiras. Firmas monopolistas podem, durante certo período de tempo, vender seus produtos a subpreços, como forma de desorganizar as firmas competidoras de uma economia local. ${ }^{12}$

Os diversos fatores de pertubação atrapalham a formação de ciclos de desenvolvimento local. A capacidade de desenvolvimento também depende do tipo de produto exportado. Produtos de cadeias de produção mais restritas, e de baixa inovação tecnológica tendem a ter menor impacto no crescimento regional, e a ser maior alvo de competição. Talvez haja possibilidade de surgimento de manufaturas locais (complementares), ou de países dependentes passarem a exportar produtos manufaturados. Segundo Raymond Vernon $^{13}$, os produtos manufaturados em geral passam por quatro etapas: (a) surgimento no

12 Sobre o tema ver: HILFERDING, Rudolf. O Capital Financeiro. São Paulo: Nova Cultura, 1985.

13 Ver: VERNON, Raymond. International investment and international trade in the product cycle. The quarterly journal of economics, p. 190-207, 1966. 
país desenvolvedor da nova tecnologia, e produção para consumo local; (b) produção para exportação, e entrada do produto em países importadores; (c) produção local complementar em alguns dos países importadores; e (e) produção para exportação em países que antes eram importadores. No entanto, conforme tese advinda de Schumpeter, isso ocorre em ciclo. Quando o novo produto passa a ser produzido nos países dependentes, é porque já surgiu nova tecnologia nos países desenvolvidos. ${ }^{14}$

Ainda, mesmo que um país subdesenvolvido seja eleito como local de produção de determinados produtos industrializados, quando eles são produzidos por firmas multinacionais, apenas a menor parte do excedente adquirido fica no país produtor. A maior parte dos ganhos se dissipam na forma de remessas de lucro e de pagamentos de royalties e outros serviços prestados pela matrize às filiais. ${ }^{15}$

\subsection{COMPENSAÇÃO DE PAGAMENTO E CRÉDITO}

Um dos primeiros (e principais) aspectos do setor externo das economias é a conta do comércio internacional de bens. Chama-se essa conta de Balança Comercial. Trata-se da relação dos valores exportados e importados por um país. Aparentemente, o comércio internacional é tema simples. Um país exporta parte do que produz e importa parte do que consome. Um país que exporte mais do que importa tem superavit comercial; um que importe mais que exporta possui déficit. Em tese, o superavit ou o déficit influenciam na disponibilidade de divisas internacionais de um país, o que afeta o preço do câmbio (conforme será discutido em seção adiante). Espera-se que os países experimentem oscilações nos seus balanços comerciais que, em médio prazo levem a um ajuste de soma zero: o superavit de um período é compensado com um déficit em um período seguinte. No entanto, isso não ocorre na realidade, conforme argumentado por parte da literatura sobre o tema. ${ }^{16}$

14 Ver: KINDLEBERGER, Charles P. Economia Internacional. São Paulo: Editora Mestre Jou, 1974; BUCKLEY, P. J.; GUARI, P. N. International investment and international trade in the product cycle. The Internationalization of the firm: a reader, p. 14-26, 1999; SCHUMPETER, Joseph A. The analysis of economic change. The Review of Economics and Statistics, v. 17, n. 4, p. 2-10, 1935.

15 Sobre o assunto ver: TIMMER, Marcel P., \& ERUMBAN, Abdul Azeez, et al. Slicing up Global Value Chains. The Journal of Economic Perspectives, Vol 28. No. 2 (Spring 2014), pg $99-118$

16 Sobre o tema ver: KRAEMER, Armando. Taxa de câmbio e balanço de pagamentos. Porto Alegre: Sulina, 1973; KINDLEBERGER, Charles P. Economia Internacional. São Paulo: Editora Mestre Jou, 1974; PALAZZO, José Truda. Balanço de Pagamentos: fatores de pertubação do seu equilíbrio e procedimentos para superá-los. Porto Alegre: Tese para concurso de cátedra de "Comércio internacional e câmbios" da Faculdade de Ciências Econômica da Universidade do Rio Grande do Sul, 1954; SÖDERSTEN, Bo. Economia Internacional. Rio de Janeiro: Interciência, 1979. 
O comércio internacional atual, em um mundo onde as moedas nacionais não possuem mais lastro material, e o câmbio é determinado por bolsas de divisas, depende da existência de sistemas bancários complementares nos países. Um país, que deseje importar bens, precisa exportar para adquirir divisas, com as quais realizará o pagamento dos bens importados. Esse imperativo determinada que as contas externas de um país se compensem em médio prazo. Caso um país não logre exportar o suficiente para pagar suas importações, ele ou (a) terá que diminuir a quantidade importada no período seguinte; ou (b) adquirir divisas com uso de poupança externa (dívida externa ou investimento estrangeiro direto). Em outras palavras, caso o balanço comercial não esteja em equilíbrio, ele precisará ser compensado por outras partes do balanço de pagamentos das contas externas do país.

Historicamente, um instrumento importante para compensação das balanças de pagamento dos países é o sistema de compensação do Fundo Monetário Internacional (FMI). O FMI pode ser entendido como uma cooperativa de crédito, onde a participação de cada membro é determinada por cotas. Quanto maior a cota de cada país, maior a disponibilidade de crédito e maior o poder de voto. Um quarto da cota deve ser pago em Dólar, Yen, Euro, ou Libra Inglesas, ou em direito de saque especial. O restante das cotas pode ser pago em moedas nacionais ${ }^{17}$. O problema é que, na prática, os países que contraem dívidas com o FMI ficam expostos aos interesses dos membros dos fundo com maior poder de voto (i.e. membros com maiores cotas de contribuição para o fundo), conforme bem explicado por Gélédan e Brémond:

Na sua essência, o Fundo funciona como ‘cooperativa de crédito’: os países que queiram pagar os déficits de sua balança de pagamentos apelam ao financiamento do fundo. Convém distinguir o acesso aos recursos do Fundo consoante as quantias pretendidas, sendo as condições tanto mais constrangedoras para o pretendente ao empréstimo quanto mais tiver aumentado o respectivo endividamento (...) Concretamente, o país candidato ao empréstimo fica sob controle do F.M.I., que em geral lhe administra uma verdadeira "purga deflacionista": equilíbrio orçamental, numerosos cortes nas despesas sociais, abrandamento da taxa de crescimento, redução do crescimento da massa salarial e dos rendimentos, eis as consequências usuais dos 'conselhos' do Fundo. As políticas impostas pelo Fundo originaram frequentemente tensões graves, em particular nos P.V.D. (países em

17 Para uma descrição do funcionamento de balanços, ver: REINERT, Kenneth A. An Introduction To International Economics. New Perspectives on the World Economy. Nova Iorque: Cambridge Press, 2012. Pg. 290 


\section{via de desenvolvimento) $^{18}$}

Atualmente, o controle direto realizado pelos governos sobre o setor externo de suas economias é bastante limitado, em países onde o comércio internacional é feito pelo setor privado (como no caso do Brasil). Isso faz com que o chamado equilíbrio do balanço de pagamentos aconteça de forma anárquica, e mesmo desajustada. Em tese, o mercado deveria se auto ajustar através dos chamados mecanismos de ajuste automático. Esses incluem (a) a desvalorização da moeda, que deveria desincentivar importações de um país que esteja importando demais; (b) atração de capital, que um país deficitário deveria realizar, o que deveria permitir a compensação de parte das importações através de investimento estrangeiro, quando houvesse deterioração não errática da moeda; e (c) incentivo à importação por parte de um país que estivesse exportando demais, através da sobrevalorização da moeda. Na prática, no entanto, os mecanismos de ajuste não ocorrem em curto prazo.

Isso porque o balanço comercial funciona através de mecanismos de compensação de pagamentos. Na verdade, apenas uma pequena parte das transações comerciais resultam em transferência material de divisas. O grosso do comércio internacional resulta em compensação contábil entre os bancos (centrais ou nacionais). Isso é feito em certos intervalos de tempo. Ou seja, um déficit de um país não precisa ser compensado no mesmo dia, podendo ser compensado nas semanas seguintes. Isso faz com que as importações e exportações não afetem o preço da moeda no mesmo dia em que elas são realizadas. São os importadores de um país que pagam, em moeda nacional, aos exportadores do próprio país.

Modelo 1.1: Compensação de pagamentos

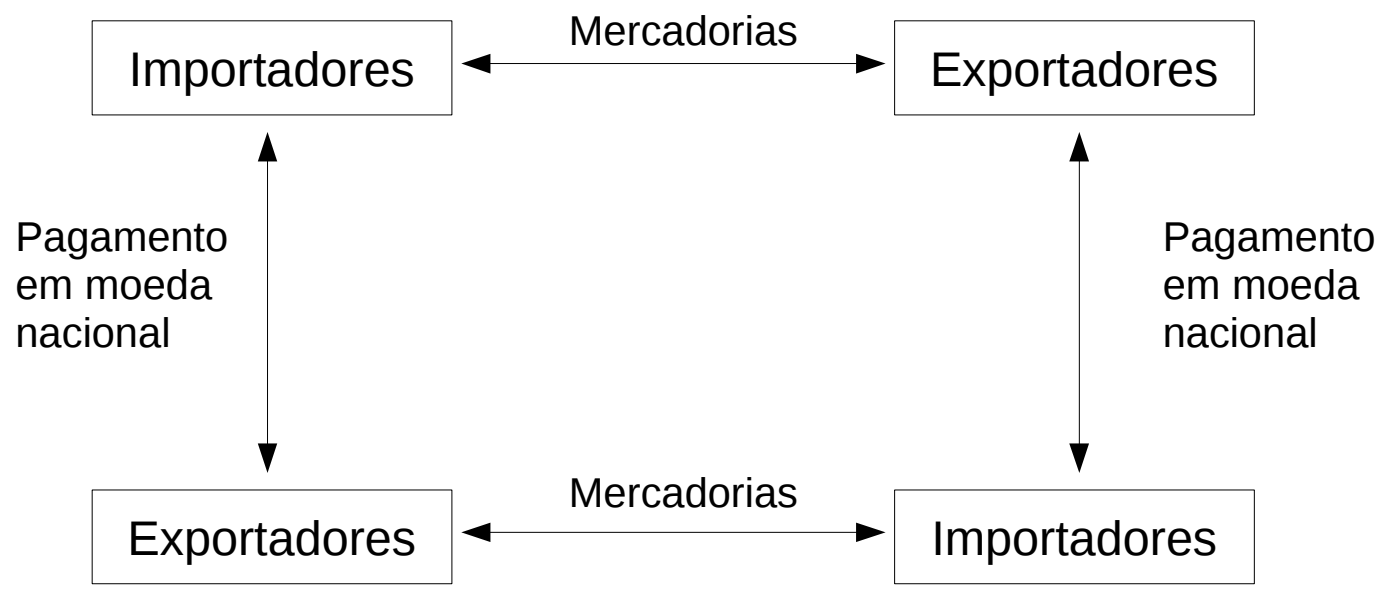

*diagrama do sistema de compensação inspirado em similar descrito por Kindleberger

18 GÉLÉDAN, Alain \& BRÉMOND, Janine. Dicionário das Teorias e Mecanismos Económicos. Lisboa: Livros Horizonte LTDA, 1988. Pg. 397 
A transação em divisas é realizada apenas ao término de certos períodos, determinados em acordos bilaterais entre os países (ou bancos) envolvidos. Esse mecanismo resolve dois problemas: (a) a dificuldade de ter que realizar transação física das divisas adquiridas ou perdidas; e (b) o problema da defasagem entre o momento da compra e o momento da entrega dos produtos.

A existência de bancos intermediários significa que todo comércio internacional é feito, na verdade, através de operações de crédito. Conforme Anders Grath, a forma mais comum de pagamento no comércio internacional é a "conta aberta”, que nada mais é do que um crédito de curto prazo:

A maioria das transações comerciais, particularmente no comércio internacional regional, são baseadas nos chamados termos de pagamento da "conta aberta". Isto significa que o vendedor entrega bens ou serviços ao comprador sem receber dinheiro, uma letra de câmbio ou qualquer outra empresa legalmente vinculativa e executória no momento da entrega, e o comprador deverá pagar de acordo com os termos do contrato de venda e a fatura posterior do vendedor. Portanto, a conta aberta envolve uma forma de crédito curto, mas acordado, concedido ao comprador, na maioria dos casos verificados apenas pela fatura e na data especificada de pagamento, juntamente com cópias do documento de entrega ou entrega relevante, verificando o embarque e data de embarque. ${ }^{19}$

O resultado é que, portanto, o comércio internacional não gera excesso ou falta de divisas em curto prazo nos países. Ainda mais quando são adotados mecanismo de defesa ao exportador (como no caso brasileiro), onde o exportador possui um prazo (que pode variar, atingindo 90 dias de prazo no caso brasileiro) para resgatar o valor adquirido na exportação. Isso permite que o exportador venda, para especulação, seu direito de resgate, acima do câmbio corrente, mas abaixo do câmbio futuro expectado. Há também sistemas de seguro, oferecidos pelos bancos, que protegem o exportador do risco da moeda nacional se valorizar em relação ao câmbio observado no momento da contratação da exportação. ${ }^{20}$

A existência desses mecanismos permite que, ao passo que os exportadores são protegidos, por artifícios contábeis, o câmbio pode ser mantido sobreapreciado, favorecendo

19 GRATH, Anders. International Trade and Finance. Londres e Filadélfia: Kogan Page, 2008. pg. 32

20 Para uma descrição de sistemas de seguro para o comércio internacional, ver: International Credit Insurance \& Surety Association. A Guide to TradeCredit Insurance. Londer: Anthem Press, 2015. Pg. 10. 
as importações ${ }^{21}$. O ajuste automático, em um mundo onde os bancos existem, é improvável, e até desincentivado pelos mecanismos de proteção às partes contratantes.

\subsection{O CÂMBIO E O COMÉRCIO}

Enquanto o comércio afeta o câmbio em médio prazo, o câmbio afeta o comércio desde o curto prazo. Atualmente, o modelo de câmbio adotado pelo Brasil, e por muitos outros países, pode ser chamado de "câmbio viscoso", onde o preço da moeda nacional pode oscilar apenas dentro de um pequena banda. No entanto, ao médio prazo, o câmbio deve seguir determinada tendência de desvalorização ou valorização. Essa tendência pode ser determinada ou (i) pela política econômica do governo; ou (ii) delegada ao mercado, através do sistema de demanda e oferta. No caso brasileiro, a política econômica do governo favoreceu a valorização da moeda nacional, e, portanto, os investidores externos.

Para o estudo do setor externo de uma economia nacional, o câmbio (livre ou viscoso) possui duplo aspecto ${ }^{22}$. Por uma lado, ele é (1) uma mercadoria, cujo preço é resultado da relação entre demanda e oferta de divisas (no caso brasileiro, de dólares); por outro, ele é (2) um instrumento de mediação entre a economia brasileira e as demais economias do restante do mundo. Isso quer dizer que ele é um instrumento de mediação entre os preços internos e os preços externos. Enquanto o primeiro aspecto, de (1) mercadoria é um fator determinante para o preço da moeda nacional, o segundo (2) é fator determinante para se saber se o câmbio está favorecendo as exportações ou importações. ${ }^{23}$

O preço da moeda, como mercadoria, é definido pela demanda e pela oferta de divisas internacionais de um país. Por sua vez, a oferta de divisas é determinada (i) pelo valor total das exportações realizadas; (ii) pelo valor total de crédito contratado no exterior; (iii) pelo valor total dos investimentos estrangeiros realizados no país. A demanda de divisas é resultado: (a) da demanda de importação do país; (b) da oferta de crédito ao exterior oferecida pelo país; e (c) pelo valor total do capital nacional a ser investido no exterior. Ainda, ambas

21 DEARDORFF, Alan V. Terms Of Trade Glossary Of International Economics. Singapura: World Scientific, 2006.

22 Sobre o assunto, ver: Sobre o assunto, ver: BRESSER-PEREIRA, Luiz Carlos. La nueva teoría desarrollista: una síntesis. Economía. UNAM, v. 14, n. 40, p. 48-66, 2017. Pg. 61 - 62.

23 Sobre o assunto ver: KRAEMER, Armando. Taxa de câmbio e balanço de pagamentos. Porto Alegre: Sulina, 1973; e PALAZZO, José Truda. Balanço de Pagamentos: fatores de pertubação do seu equilíbrio e procedimentos para superá-los. Porto Alegre: Tese para concurso de cátedra de "Comércio internacional e câmbios” da Faculdade de Ciências Econômica da Universidade do Rio Grande do Sul, 1954. 
são afetadas pela atividade de especulação. Isso significa que a oferta e a demanda são influenciados pela demanda de bem e serviços e pela oferta de capitais dos países envolvidos no comércio internacional.

Uma ampliação da oferta de divisas causa pressão para queda do preço das divisas (valorização da moeda local), e uma ampliação da demanda causa aumento do preço das mesmas (desvalorização da moeda local). Por outro lado, os novos preços também afetam a oferta e a demanda existente. Assim, caso haja súbito aumento da oferta de divisas, haverá valorização da moeda local, o que causará aumento da demanda de divisas, pressionando novamente o preço das divisas para o alto (causando desvalorização da moeda local). $\mathrm{O}$ tamanho do impacto do novo preço na demanda vai depender da elasticidade da demanda de divisas ao preço da moeda. A elasticidade da demanda e a elasticidade da oferta são distintas, e são determinadas por elementos da economia real.

A elasticidade da oferta de divisas é maior quanto maior for a elasticidade (i) de procura dos artigos exportados; (ii) da oferta dos produtos estrangeiros competidores às exportações nacionais; (iii) da oferta dos produto exportáveis; e (iv) da procura interna de artigos cujo excedente for exportado. A elasticidade da demanda de divisas é maior quanto maior for a elasticidade: (a) da procura interna por produtos importados; (b) da oferta de produtos nacionais competidores; (c) da oferta dos produtos importados; e (d) da procura estrangeira por seus próprios artigos. Em geral, países exportadores de bens primários possuem menor elasticidade da oferta do que da demanda de divisas, em relação ao preço do câmbio.

No caso brasileiro, o câmbio é viscoso. Isso significa que o governo intercede para que o câmbio não se desvalorize (ou valorize) rápido de mais, mas permite que o câmbio siga a tendência determinada pelo mercado ${ }^{24}$. Essa intervenção do Estado se dá através do chamado controle do câmbio. O Banco Central compra ou vende divisas no mercado, em troca de moeda nacional, alterando a demanda e oferta momentânea. Em períodos de alta da oferta, o Banco Central compra dólares, formando um estoque de divisas, a ser usado no futuro. Em períodos de baixa oferta, ou alta da demanda, pode-se vender essas divisas no mercado. Ao atuar dessa forma, o governo permite que o câmbio se distancie, em médio prazo, do chamado

24 Na verdade, o governo é mais propício a aceitar a tendência do mercado quando ela é de apreciação da moeda nacional. Isso porque o governo utiliza o câmbio como ferramenta de controle da inflação. Daí a resistência à desvalorização. 
câmbio de equilíbrio, o que pode ser uma das causas da fragilidade das contas externas do país.

O câmbio de equilíbrio é uma consequência do fato do câmbio ser (2) também uma mediação entre uma economia nacional e as demais economias existentes. O preço da moeda nacional serve como mediador dos preços das mercadorias no mercado local e o preço delas no restante do mundo. Idealmente, produtos idênticos em mercados diferentes deveriam ter o mesmo preço. Por exemplo, caso uma camiseta custe 10 dólares, e o dólar estiver valendo 2 reais, uma camiseta idêntica produzida no Brasil deveria custar 20 reais. No entanto, os preços internos e externos oscilam de forma diferente. Se o Brasil tiver uma inflação anual de 6\%, e os EUA de 1\%, mas o câmbio continuar igual, na verdade a camiseta brasileira se tornará relativamente mais cara. A camiseta passará a custar não 10,1 dólares, mas 21,20 Reais, o que equivaleria a 10,6 dólares. Nessa situação, o Real, na verdade, se apreciou em relação ao dólar. O tamanho da apreciação pode ser calculado através da fórmula para o câmbio real: multiplica-se o câmbio nominal pela divisão da inflação externa dividida pela interna $\left(\mathrm{E}=\mathrm{e}\left(\mathrm{i}^{*} / \mathrm{i}\right)\right)$. No caso, o câmbio real da moeda do Brasil seria de 1,92, e não mais de 2 dólares.

Caso a moeda se haja valorizado em termos relativos, isso significa que os produtos estrangeiros terão se tornado proporcionalmente mais baratos, e os produtos locais proporcionalmente mais caros. O resultado é que haverá tendência das pessoas importarem mais, e das empresas locais exportarem menos. Isso é uma das causas para perda da competitividade do mercado local. Para evitar esse processo, seria necessário que o câmbio se desvalorizasse na mesma medida da distância da inflação interna e externa, o que é o chamado câmbio de equilíbrio.

A perda de competitividade não se dá de forma igual em todos os setores, uma vez que os preços externos também oscilam de forma desigual. É comum que, durante certo período de tempo, o preço externo dos bens primários cresça acima da inflação externa. Isso permite que um país possa ficar com um câmbio real sobrevalorizado, mas que ainda assim permita preços vantajosos para seu principal produto de exportação.

Nesse cenário, o país observará (a) alta da oferta de divisas, potencialmente acima da demanda de divisas; e em seguida (b) pressão para valorização da moeda local, o que aumentará a demanda por divisas. Nessa ocasião, o setor exportador estará financiado uma distribuição de renda favorável aos importadores, e desfavorável aos produtores para o 
mercado local. Esse é um dos processos que permite que um país expresse crescimento econômico, superávit comercial, e desmantelamento de parte da produção local. Passada a fase de alta dos preços, possivelmente o mesmo país observará déficit comercial, pressão para desvalorização da moeda (por conta da alta da demanda em relação a oferta), pressão inflacionária (pelo aumento do preço relativo dos bens importados), e, possivelmente, pressão para queda da renda nacional (por perda de dinamismo econômico).

Observe-se que os mecanismos de ajuste do câmbio como mercadoria são bastante distintos dos efeitos do preço do câmbio para o balanço de pagamentos e para economia local. É perfeitamente possível que, em médio prazo, um câmbio sobrevalorizado seja financiado pelas próprias exportações, ou ainda pelo endividamento ou venda de ativos nacionais. $\mathrm{O}$ aparente equilíbrio entre a oferta e a demanda resultará, nesses casos, em desequilíbrio para economia local. A coincidência entre o preço do câmbio, quando determinado pelo mercado, e o chamado câmbio de equilíbrio é apenas ocasional.

\subsection{ASPECTOS DO COMÉRCIO INTERNACIONAL ENTRE MERCADOS}

\section{DESIGUAIS}

Parte dos desequilíbrios do comércio internacional resultam do fato dos mercados envolvidos no comércio serem desiguais. O debate sobre o impacto da desigualdade dos mercados nas distintas economias pode ser abordado de formas diferentes. Pode-se (a) a tratar (ou descartá-la) como um pressuposto teórico; ou (b) tratá-la como uma característica modificadora do modelo teórico. ${ }^{25}$

Em modelos de vantagens comparativas, a desigualdade de mercado é descartada como parte do pressuposto dos modelos. Para esse modelo, um país sempre se especializará na produção de mercadorias que o país tenha vantagem de produtividade. Enquanto isso, outros países se especializarão em outras mercadorias. Ao realizar comércio internacional, todos os preços tenderão a diminuir, e todos os países passarão a consumir mais do que podiam consumir antes. Esse pressuposto é útil para produzir modelos analíticos. No entanto, é irrealista. Outra alternativa, mais realista, é adotar o pressuposto das vantagens absolutas. Nesse modelo, os países se especializam nos produtos que possam produzir a custos mais

25 Sobre as assimetrias no comércio internacional ver: KINDLEBERGER, Charles P. Economia Internacional. São Paulo: Editora Mestre Jou, 1974; SÖDERSTEN, Bo. Economia Internacional. Rio de Janeiro: Interciência, 1979. 
baixos do que o restante dos países competidores. Nesses casos, haverá tendência de formação de monopólios e oligopólios. Ainda, países de maior produtividade tenderão a atingir enriquecimento relativo. As duas abordagens podem ser descritas em termos similares, e se diferenciarão em dois principais aspectos: a posição dos preços no comércio internacional, e o impacto da disposição dos fatores de produção nas curvas de oportunidade de produção.

O termo oportunidade de produção (ou custo de oportunidade) diz respeito à disposição dos fatores de produção que um dado país possui. É possível - para tratamento teórico - elaborar modelos explicativos usando os fatores (a) trabalho (T); e capital (K). Considerando a existência desses dois fatores, um país possui uma quantidade de capital e outra de trabalho já dadas anteriormente. Com essa disposição, ele pode produzir distintos produtos, mas em combinações finitas. Ele pode, por exemplo, produzir ou 5 mil unidades de tecido; ou 10 mil unidades de trigo; ou 3 mil unidade de tecido e 7 mil unidades de trigo. Quando existe um ponto onde a soma do valor total das produções é maior do que a hipótese de especialização em um ou outro produto, chama-se esse ponto de Ponto Ótimo de produção.

Um dos problemas que se coloca é que (a) a oportunidade de produção é determinada pela disponibilidade de fatores de cada país, o que significa que alguns países podem possuir pontos ótimos de produção que resultam em menor dependência do comércio internacional. Ainda, existe limitação para transição na produção. Parte dos fatores empregados em um tipo de produção não podem ser transferidos para outro tipo. Por exemplo, parte do capital empregado na produção agrícola não pode ser transferida em médio prazo para indústria. Isso gera outro problema para os países envolvidos no comércio exterior: (b) caso o preço de produção de um produto mude com o passar do tempo, um país já especializado em um produto que se tornou menos vantajoso pode não ter condições de mudar sua produção.

Ainda, as curvas de oportunidade precisam suprir as chamadas curvas de satisfação. Isso significa dizer que a produção de um país precisa responder às demandas de consumo de sua população. Tem-se que com o comércio internacional, os países podem atingir níveis superiores para satisfação da demanda de sua população. Isso quer dizer que podem produzir, por exemplo, mais tecido do que precisa e importar mais trigo do que poderiam produzir. No entanto, se os mercados possuem capacidade de produção e de consumo distintos, não existe razão para que os preços internacionais sejam sempre igualmente vantajosos a todos. 
Modelo1.2: Preços internacionais entre mercados desiguais

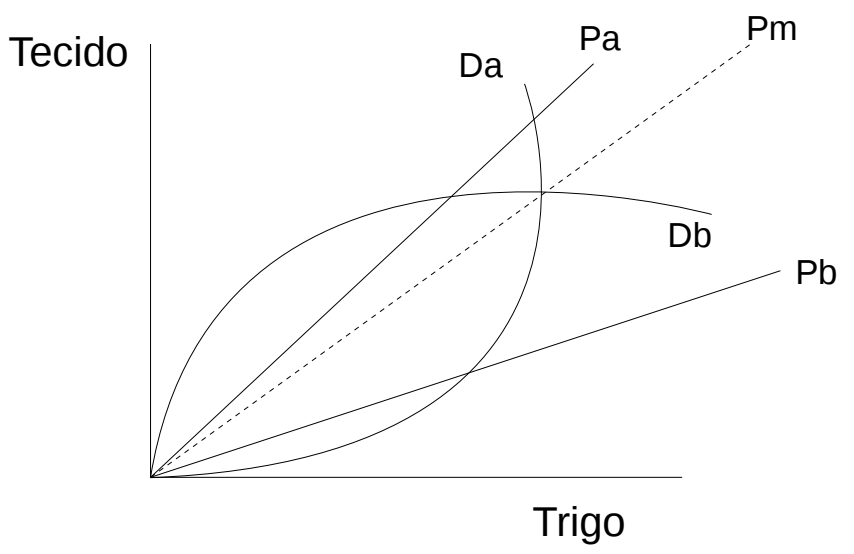

Por exemplo, é perfeitamente possível que um país (país “A”) possua maior produtividade para produtos industriais e agrícolas (produtividade na curva "Pa", do modelo 1.2), e tenha um mercado economicamente mais relevante do que seus parceiros comerciais (curva “Da”). Nesse caso, diz-se que o mercado é determinador de preços. Outro país (país “B”) pode ter baixa produtividade de produtos industriais, mas produtividade competitiva para produtos agrícolas (curva “Pb”), e possui mercado economicamente pouco relevante (curva “Db”). Nessa situação, esse país terá pouca influência individual nos preços internacionais. Nessas condições, ele será tomador de preço. ${ }^{26}$

Nesse modelo, os preços médios tenderão a se dar na curva "Pm”, que se dará mais próxima da curva "Pa” do que da curva “Pb”. Ou seja, os preços serão mais próximos àqueles vantajosos à satisfação da demanda do país de maior mercado. Para parte da literatura, o tamanho do mercado dos distintos países também está ligado à produtividade local. Essa é a visão de Ragnar Nurkse, para quem a capacidade do mercado é determinada pela produtividade do país. Países com baixa produtividade tendem a ter baixa renda per capita.

Conforme Nurkse, a elasticidade da demanda em níveis baixos de renda real tende a ser baixa. Isso cria um ciclo vicioso na determinação do mercado: como o mercado é pequeno, há pouco incentivo para novos investimentos para aumento da produtividade, e como a produtividade é pequena, a renda apresenta crescimento insatisfatório. Isso significa

26 Para uma discussão sobre o tema ver: PALAZZO, José Truda. Balanço de Pagamentos: fatores de pertubação do seu equilíbrio e procedimentos para superá-los. Porto Alegre: Tese para concurso de cátedra de "Comércio internacional e câmbios" da Faculdade de Ciências Econômica da Universidade do Rio Grande do Sul, 1954. 
que países como o Brasil, onde a produtividade é baixa, e a renda nacional resulta em mercado pouco relevante, os preços internacionais são determinados de acordo com as demandas de mercados externos. A consequência desse raciocínio é que países agrícolas pobres exercem papel pequeno no comércio internacional, por sua baixa produtividade e baixo poder de compra. Na prática, é o desenvolvimento que permite melhor inserção no mercado internacional, e não o contrário. ${ }^{27}$

Nessas condições, o debate sobre o comércio internacional não pode ser feito a partir de “preferências de produção”. O problema não é se o país “decidiu” produzir um produto ou outro. Trata-se da disposição dos fatores produtivos e da magnitude do mercado local. A posição do mercado internacional, é, portanto, um assunto diretamente ligado à produtividade e capacidade de acumulação do país em análise. ${ }^{28}$

Modelo 1.3: Modelo explicativo para o paradoxo de Leontieff

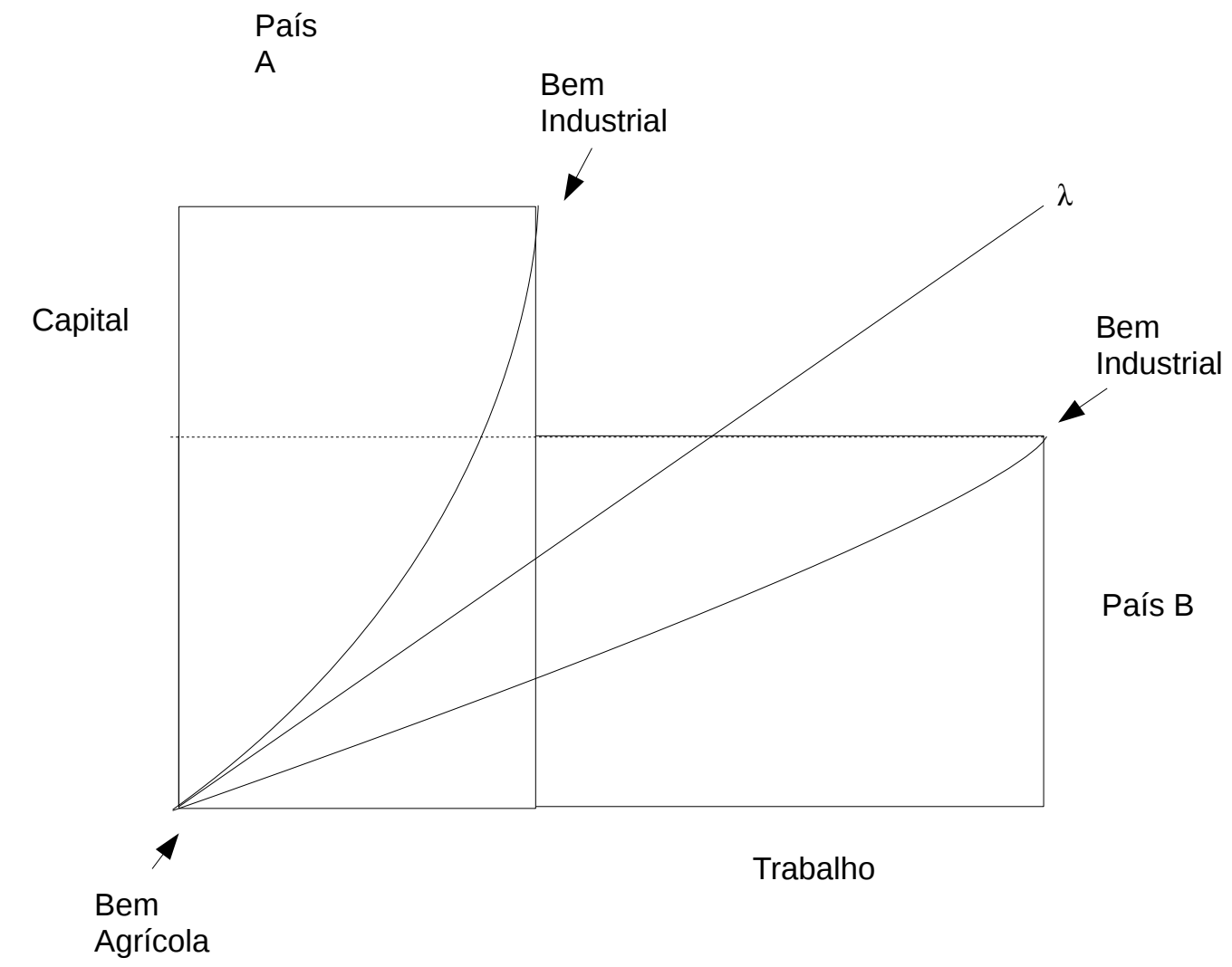

*modelo inspirado em similar disponibilizado por Bo Södersten

27 Sobre o assunto ver: NURKSE, Ragnar. Problema da Formação de Capital em Países Subdesenvolvidos. Rio de Janeiro: Civilização Brasileira, 1957. Pg. 8 - 28.

28 Ver sobre o tema: GÉLÉDAN, Alain \& BRÉMOND, Janine. Dicionário das Teorias e Mecanismos Económicos. Lisboa: Livros Horizonte LTDA, 1988. 425 - 426. 
Como os países possuem dotação de fatores diferentes, adotam métodos de trabalho também diferentes. Um mesmo produto pode ser produzido com métodos trabalho intensivos em um país, e capital intensivos em outro. Isso é o que explica o chamado Paradoxo de Leontieff: situação em que um país intensivo em capital exporta bens agrícolas. ${ }^{29}$

No modelo 1.3, têm-se que os produtos que se encontram abaixo da curva da razão " $\lambda$ " são produtos comparativamente trabalho intensivos. Os produtos localizados acima da curva " $\lambda$ " são comparativamente capital intensivos. No modelo, vê-se que para o país A, os produtos agrícolas são relativamente ricos em capital, em comparação ao país B. O resultado é que os preços dos produtos se tornam bastante distintos. O fato do país "A" ser pobre em trabalho não significa que seus produtos intensivos em trabalho serão mais caros do que se produzidos em países ricos em trabalho. Em outras palavras: a laranja norte-americana pode ser produzida com preço unitário mais barato, mesmo o trabalhador rural norte-americano sendo melhor remunerado.

Nessas condições, um país de baixa acumulação de capital terá que competir a preços que lhe são desvantajosos. A especialização da produção, portanto, mais uma vez não é uma saída necessariamente eficaz para o problema da baixa capacidade produtiva. O que o paradoxo de Leontieff ensina é que o problema do comércio internacional, portanto, não é um problema de custo de oportunidade e de escolha de especialização. O problema é, essencialmente, de produtividade do trabalho.

\subsection{TROCAS DESIGUAIS E DETERIORAÇÃO DOS TERMOS DE TROCA}

A diferença do tamanho dos mercados e da produtividade dos países tem impacto nos preços dos produtos. Como consequência, resulta em ganhos distintos através do comércio para os países envolvidos. Ainda, existe uma tendência histórica para piora dos termos de troca para os países produtores de bens primários. Há duas explicações para isso: uma que é originária do marxismo, e outra que foi primeiro apontada por Raúl Prebisch e outros estruturalistas. Ambas explicações são consistentes, e precisam ser retomadas afim de entender de que forma o comércio internacional se relaciona com o desenvolvimento local.

A nova teoria marxista sobre as trocas internacionais foi elaborada a partir de Arghiri

29 Sobre o assunto ver SÖDERSTEN, Bo. Economia Internacional. Rio de Janeiro: Interciência, 1979. 
Emmanuel (1962) $)^{30}$. Para ele, as economias nacionais que entram em comércio internacional podiam ser tratadas como se fossem parte de um único sistema fechado. As trocas internacionais, portanto, podiam ser analisadas pela ótica das trocas setoriais apresentadas por Marx. Segundo o modelo proposto, a principal razão para desigualdade no comércio internacional é a diferença entre valor de troca e preço da mercadoria. Essa diferença faz com que produtos que precisam de uma quantidade diferente de horas de trabalho para serem produzidos, por conta da quantidade de capital investido e diferença dos salários, resultem em preços iguais. Um produto que deveria ter um valor de troca superior se torna em um produto de preço igual a um que deveria ter valor inferior. A isso se chama subpreço e sobrepreço. A existência de sobrepreços e subpreços faz com que alguns países consigam maior capacidade de acumulação de capital do que outros. ${ }^{31}$

\begin{tabular}{|c|c|c|c|c|c|c|c|c|c|}
\hline (I) & (II) & (III) & (IV) & (V) & (VI) & (VII) & (VIII) & (IX) & (X) \\
\hline País & $\begin{array}{l}\text { Capital } \\
\text { constante } \\
\text { comprometido } \\
(\mathrm{K})\end{array}$ & $\begin{array}{l}\text { Capital } \\
\text { variável } \\
\text { (w) }\end{array}$ & $\begin{array}{l}\text { Mais- } \\
\text { valia } \\
\text { (m) }\end{array}$ & $\begin{array}{l}\text { Valor da } \\
\text { mercadoria } \\
{[\mathrm{V}=} \\
(\mathrm{K}+\mathrm{W}+\mathrm{m})]\end{array}$ & $\begin{array}{l}\text { Custo de } \\
\text { produção } \\
{[\mathrm{R}=} \\
(\mathrm{K}+\mathrm{w})]\end{array}$ & $\begin{array}{l}\text { Taxa de } \\
\text { lucro } \\
{[\mathrm{g}=} \\
\left(\sum \mathrm{m} / \Sigma\right. \\
\mathrm{R})]\end{array}$ & $\begin{array}{l}\text { Lucro } \\
{[1=} \\
(g * R)]\end{array}$ & 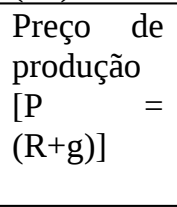 & $\begin{array}{l}\text { Diferença } \\
\text { entre valor } \\
\text { e preço }\end{array}$ \\
\hline $\mathrm{A}$ & 200 & 80 & 20 & 300 & 280 & $25 \%$ & 70 & 350 & +50 \\
\hline B & 100 & 20 & 80 & 200 & 120 & & 30 & 150 & -50 \\
\hline total & 300 & 100 & 100 & 500 & 400 & & 100 & 500 & 0 \\
\hline
\end{tabular}

*dados hipotéticos

Uma forma simplificada de explicar a lógica exposta por Arghiri Emmanuel pode ser verificada no exemplo disposto na tabela 1.1. Na tabela, pode-se ver as contas para o valor e o preço de produção (custo acrescido do lucro) da produção de dois países distintos, descritos na primeira coluna. O país “A” é exportador de bens industrializados, e o país "B” é exportador de produtos primários. Na segunda coluna, vê-se um valor hipotético de capital comprometido na compra de maquinaria e insumos para produção. Observa-se que o país “A” possui maior volume de capital investido, denotando que sua produção é intensiva em capital, Na terceira coluna, verifica-se o total de gasto com salários. Ambas produções possuem, no exemplo hipotético, uma igual quantidade de pessoas empregadas. No entanto, no país “A”,

30 Ver a propósito: BRAUN, Oscar. Comercio internacional e imperialismo. Siglo Veintiuno, 1976; MONZA, Alfredo. Teoría del capital y la distribución. Editorial Tiempo Contemporáneo, 1973. RUBIN, Isaak Illich. A teoria marxista do valor. Brasiliense, 1980; BENETTI, Carlo. La acumulación en los países capitalistas subdesarrollados. FCE, 1976; AMIN, Samir. La ley del valor y el materialismo histórico. FCE, 1981; ROBINSON, Joan; Collected economic papers. Oxford: 1973.

31 Sobre o assunto ver: EMMANUEL, Arghiri. El Intercambio desigual. Ensayo sobre los antagonismos em las relaciones económicas internacionales. Madrid: Ed Siglo ventiuno, 1973 
os salários são cinco vezes superiores aos do país “B”. Como a quantidade de horas trabalhadas em cada país é igual, e o número de pessoas é igual, verifica-se que, na quarta coluna, a quantidade de mais-valia retirada é invertida em relação aos salários: no país "B”, a mais-valia obtida é cinco vezes maior que no país “A”. A soma do capital investido, dos salários pagos, e da mais-valia obtida resulta no valor de troca assinalado na quinta coluna.

Para os marxistas, o valor de troca de uma mercadoria é distinto do preço da mesma, mas a soma do valor de todas as mercadorias é matematicamente igual a soma do preço de todas as mercadorias. Como consequência, a mais-valia é distinta do lucro retirado em cada mercadoria. Para isso, a taxa de lucro média de uma sociedade é igual a soma de toda maisvalia retirada dividida pela soma de todo custo de produção da mesma. As colunas seguintes da tabela 1.1 descrevem essa relação. Na sexta coluna da tabela, vê-se o custo de produção em cada país. O custo de produção é igual ao capital investido mais os salários pagos. Na sétima coluna, vê-se a taxa de lucro média resultante da divisão da soma da mais-valia explorada nos dois países pela soma dos custos de produção. Na oitava coluna verifica-se o lucro obtido em cada país, considerando a taxa de lucro média. Na nona coluna, está o preço de produção das mercadorias, que resulta do custo de produção acrescido do lucro retirado. Na décima, verifica-se a distância do preço de produção e o valor da mercadoria, que expressa a existência de sobrepreço e subpreço. Vê-se que o país “A”, exportador de bens intensivos em capital, foi beneficiado com um sobrepreço, enquanto o país “B”, exportador de bens primários, sofreu subpreço.

O exemplo possui alguns pressupostos que evidentemente não se realizam na realidade. Primeiro, a distância dos salários médios e do capital investido é muito maior na realidade do que no exemplo. Ainda, as indústrias instaladas nos países desenvolvidos costumam ter taxas de lucro superiores às verificadas na produção de bens primários. Na verdade, portanto, o esperado é que os sobrepreços e subpreços expressem distâncias ainda maiores. Mas o exemplo expressa bem o sentido da desigualdade: o país “ $A$ ” recebe, a cada troca, horas de trabalho a mais, gratuitas, sob a forma de mercadoria. O resultado é que consegue acumular maior volume de capital do que o país “B”, aumentando ainda mais a desigualdade dos dois.

Com o passar do tempo, isso leva a uma tendência de deterioração dos termos de troca da pauta dos países produtores de bens primários. Essa tendência é acentuada por conta da 
existência de outros mecanismos de deterioração descritos por Raúl Prebisch. Alguns dos aspectos que levavam a deterioração dos termos de troca, para aquele autor, eram frutos da elasticidade dos produtos das pautas do comércio exterior dos países dependentes. Prebisch ressaltou que esses países exportavam bens primários e importavam bens industrializados. Para os estruturalistas, os bens primários possuem alta elasticidade-preço, e baixa elasticidade-renda ${ }^{32}$. Como consequência, a demanda pelos produtos primários crescia a ritmos inferiores ao crescimento da renda dos seus principais compradores (os países desenvolvidos), ao passo que pequenas variações de preço dos produtos tinham largo impacto no valor total exportado pelos países dependentes. Ao mesmo tempo, cada incremento de renda dos países dependentes demandava um aumento mais do que proporcional do valor importado. Isso fazia com que houvesse tendência à deterioração dos termos de toca dos países dependentes. ${ }^{33}$

Modelo 1.4: Tendência à deterioração dos termos de troca

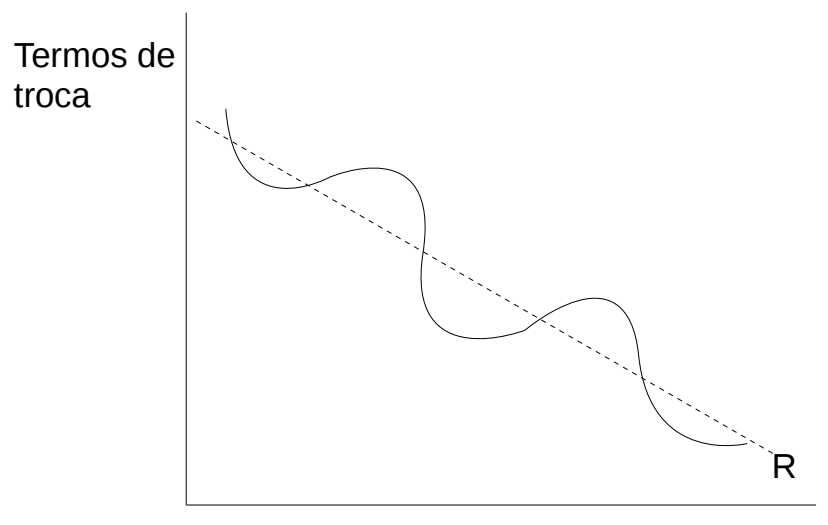

Tempo

Os produtos primários seriam objeto de forte competição na produção. Como resultado, os preços desses produtos tendiam a sofrer quedas periódicas, devido a expansão da produção acima da demanda. Enquanto isso, a produção de produtos industriais seria objeto de baixa competição, o que geraria preços estáveis para esses produtos. No entanto, devido a dinâmica cíclica do crescimento das economias industriais, ocorreria aumentos cíclicos das

32 A elasticidade-preço é a variação do valor vendido de um produto para cada $1 \%$ de variação no preço do produto. A elasticidade-renda é a variação do valor vendido para cada variação de $1 \%$ na renda dos consumidores.

33 Sobre o assunto ver: PREBISCH, Raúl. Dinâmica do desenvolvimento latino-americano. Rio de Janeiro: Editora Fundo de Cultura, 1969. 
demandas por produtos primários. Ainda, eventos conjunturais poderiam ocasionar altas pontuais dos preços desse tipo de bem. O resultado seria que, durante alguns momentos, os preços relativos poderiam se movimentar a favor dos produtos primários. Passada a fase de alta, os preços tenderiam a cair a patamares inferiores ao período anterior, formando uma tendência de deterioração (conforme descrito pela curva "R" no modelo 1.3). Durante o processo de alta dos preços, os países dependentes poderiam ampliar suas importações temporariamente, ampliando também sua taxa de crescimento. Em períodos de queda dos preços, esses países veriam sua capacidade de importar cair, o que geraria queda na taxa de crescimento e substituição de importações parcial (quando a conjuntura assim permitisse).

\subsection{ALGUNS ASPECTOS DO COMÉRCIO DE SERVIÇOS E DE CAPITAL}

O setor externo de uma economia é mais do que o comércio de mercadorias. Inclui o comércio de bens imateriais (serviços) e o comércio de capital. Ainda, se divide em dois grupos de contas: as transações correntes, que inclui toda balança comercial, o comércio de serviços, e as transações de renda; e as contas financeiras e de capital, que inclui os fluxos de capital referentes aos investimentos e empréstimos tomados internacionalmente. Juntas, as contas correntes e as contas financeiras e de capital formam o chamado Balanço de Pagamentos, que, conforme a literatura neoclássica, sempre tende ao equilíbrio. ${ }^{34}$

Parte das contas de serviços podem ser analisadas como se fosse o comércio de um bem material. É o caso das contas de viagens internacionais: quando a moeda local está sobrevalorizada, ficará mais barato fazer turismo no estrangeiro. Isso resulta em perdas de divisas. Quando a moeda local é desvalorizada, o turismo estrangeiro no país é incentivado, resultando em ganhos de divisa. Em termos de perdas e ganhos de divisa, vê-se que o comportamento do item "viagens internacionais” é similar ao comércio de bens materiais. No entanto, tem consequências diferentes. A cadeia de valor do turismo é pequena, e gera pouca distribuição de renda. Na prática, o turismo não costuma ser um motor de crescimento eficaz.

Outras contas de serviço, no entanto, possuem comportamento bastante distinto. As contas de pagamentos de royalties, aluguel de máquinas, serviços de transporte, entre outros,

34 Sobre o balanço de pagamentos ver: KRAEMER, Armando. Taxa de câmbio e balanço de pagamentos. Porto Alegre: Sulina, 1973; e PALAZZO, José Truda. Balanço de Pagamentos: fatores de pertubação do seu equilíbrio e procedimentos para superá-los. Porto Alegre: Tese para concurso de cátedra de "Comércio internacional e câmbios” da Faculdade de Ciências Econômica da Universidade do Rio Grande do Sul, 1954. 
tem pouco a ver com o preço do câmbio. Resultam da estrutura de produção dos países envolvidos. Quando os gastos em royalties e alugueis de máquina são altos, é sinal que parte considerável da produção local no país é feita por firmas multinacionais que possuem matriz sediada no estrangeiro. Já os gastos em transporte indicam a ausência de frota comercial própria do país. ${ }^{35}$

Países dependentes tendem a ser deficitários na conta de serviços. O pagamento pelo direito de uso de tecnologia, da frota comercial alheia, etc. é uma fonte de sangria de divisas adquiridas no comércio de mercadorias. A presença de firmas multinacionais nos países dependentes também resulta em contas de renda deficitárias. Os países dependentes, ao possuir baixa capacidade de acumulação de capital, dependem de investimento ou empréstimo estrangeiro. Daí, precisam pagar juros e enviar remessas de lucro. Como resultado, mesmo quando países dependentes logram exportar grande quantidade de bens primários, e atingem balanços comerciais positivos, podem ter transações correntes bastante negativas.

O déficit das contas de serviço e de rendas são compensados pelas contas financeiras. Têm-se que as contas financeiras e de capital são o espelho da conta de transações correntes. Um país tende a receber investimentos e pegar emprestado volumes de dinheiro suficiente para cobrir o déficit das transações correntes. Caso suas transações correntes sejam positivas, as divisas excedentes podem ser utilizadas para fornecer empréstimos ao exterior ou para realização de investimento no estrangeiro. Disso resulta que as transações correntes e a conta financeira tendem a ser uma o oposto da outra (aproximadamente).

Uma das características dos países dependentes é que possuem contas das transações correntes negativas, e contas financeiras superavitárias. Isso é resultado de sua baixa capacidade de acumulação de capital. A necessidade de divisas e capital podem ser compensados de algumas formas distintas. As contas financeiras podem ser divididas em três grupos relevantes: as contas de empréstimos (dívida externa), seja de curto ou longo prazo; as de investimentos em carteira (investimentos de curto prazo); e as de investimentos estrangeiros diretos (investimentos de médio e longo prazo). Kenneth Reinert oferece uma boa descrição da diferença entre o investimento direto e o investimento em carteira:

Conforme mencionado anteriormente, enquanto a conta corrente

35 Para uma descrição dos itens que compõe a conta de serviços das contas correntes, ver: REINERT, Kenneth A. An Introduction To International Economics. New Perspectives on the World Economy. Nova Iorque: Cambridge Press, 2012. Pg. 100 
registra ganhos e operações de despesas que não envolvem a troca de ativos, a conta capital/financeira tem a característica distintiva de consistentes operações que envolvem troca de ativos. $\mathrm{O}$ tipo de ativos trocados e quem os troca determina o item de capital/conta financeira em que uma transação é registrada. Por exemplo, o item 10 na Tabela 13.2 é o investimento direto, que é apenas o investimento estrangeiro direto (IED) discutido nos capítulos anteriores. Conforme discutimos no Capítulo 1, os ativos envolvidos no investimento direto contêm um elemento de influência gerencial refletido em ações no valor de pelo menos $10 \%$ da empresa em questão. (...)O segundo item de conta de capital é o investimento de carteira. O investimento de carteira inclui títulos do governo de vários vencimentos, ações societárias e títulos corporativos. Ao contrário do investimento direto, o investimento de carteira não envolve um elemento de influência gerencial. ${ }^{36}$

Outra observação importante é que os empréstimos e investimentos de curto prazo não geram capital disponível para ampliação da produtividade do país. Na prática, apenas fornecem as divisas suficientes para pagar os déficits das transações correntes. Por isso, na literatura, esse capital de curto prazo é considerado um fator de instabilidade. Um país que tenha dívida de curto prazo grande deverá pagar juros altos, o que leva a déficits crescentes na conta de rendas. Como o empréstimo não gera acréscimo de produtividade, o novo déficit tenderá a ser compensado com uma ampliação do endividamento, ou redução das importações, no período seguinte.

Já o capital de longo prazo pode resultar em ampliação da capacidade de produção local. O investimento estrangeiro direto, em tese, expressa o investimento realizado por outros países na formação de novas empresas no local. As novas empresas podem gerar ampliação da capacidade produtiva. Mesmo que o investimento seja remunerado com remessas de lucro, a ampliação da produção compensaria os novos gastos. No entanto, é comum que o investimento estrangeiro seja, na verdade, compra de empresas locais por parte de estrangeiros. Nesse caso, a compra não expressa ganho de produtividade para o país, apenas gerando novos gastos na forma de envio de remessas de lucro. Ainda, o investimento estrangeiro direto pode levar ao aumento do gasto com pagamentos de royalties e empréstimos de bens de capital. Nessas condições, os benefícios da venda de ativo local se tornam bastante limitados.

A existência de investimento estrangeiro e dívida externa faz com que o equilíbrio do

36 REINERT, Kenneth A. An Introduction To International Economics. New Perspectives on the World Economy. Nova Iorque: Cambridge Press, 2012. Pg. 215 - 216. 
balanço de pagamentos precise ser lido de forma mais atenta. O fato das contas financeiras compensarem a conta das transações correntes é um dado meramente contábil. Na prática, esse equilíbrio só importa para a análise da oferta e demanda de divisas. Mas no que toca ao equilíbrio do balanço de pagamentos, a análise deve ser outra. Por isso, para os teóricos estruturalistas, e alguns marxistas, a existência ou não de déficit no balanço de pagamentos deve ser observada considerando apenas as contas de transação corrente. ${ }^{37}$

O equilíbrio real do balanço de pagamentos ocorre apenas ocasionalmente, mesmo quando ele observa consistentemente soma zero ao longo do tempo. Isso se deve ao fato do equilíbrio ser uma situação onde: (a) as transações correntes possuem soma zero; e (b) as contas financeiras observem soma zero. Ou seja, está em equilíbrio um país cujas exportações cobrem suas importações, e o país não necessita importar capital, nem exportar. Os países dependentes apenas atingem o equilíbrio contábil devido à venda constantes de seus ativos, e pela aquisição de deveres no exterior. A soma zero contábil na verdade pode expressar perdas contantes e crescentes. No caso do Brasil, por exemplo, a tese aqui adotada é que as exportações crescentes foram utilizadas para financiar as importações também crescentes, e os gastos com serviços e rendas. O resultado foi a constante perda de ativos, em uma economia de baixa produtividade, e ainda dependentes do setor externo como fator determinante do dinamismo interno.

\subsection{O CRESCIMENTO EM ECONOMIAS SUBDESENVOLVIDAS}

O desempenho do setor externo de uma economia está diretamente ligado à produtividade do país. Uma alta produtividade permite que a demanda local seja suprida, em maior medida, por produção local. Ainda, permite que os preços dos produtos exportados tenham maior competitividade, e que haja maior diversidade na pauta de exportação. $O$ resultado é que o comércio exterior, para países de alta produtividade, permite ganhos adicionais. Para os países de baixa produtividade, no entanto, os ganhos no comércio exterior são insuficientes para garantir novos investimentos.

Juan Noyola definiu de forma sucinta como o comércio internacional acaba reforçando

37 Sobre o desequilíbrio do Balanço de Pagamentos ver: PALAZZO, José Truda. Balanço de Pagamentos: fatores de pertubação do seu equilíbrio e procedimentos para superá-los. Porto Alegre: Tese para concurso de cátedra de "Comércio internacional e câmbios" da Faculdade de Ciências Econômica da Universidade do Rio Grande do Sul, 1954; AMIN, Samir. Capitalismo periferico y comercio internacional. Buenos Aires, Ed. Periferia, 1974. 
os entraves econômicos nos países dependentes, ao invés de eliminá-los:

Mas o que é interessante sobre o fenômeno do subdesenvolvimento ou desenvolvimento dependente, que também podemos chamar de "desenvolvimento dependente do imperialismo" - porque ocorre dentro de uma fase do desenvolvimento capitalista geral que é o capitalismo monopolista, que produz o fenômeno do imperialismo tem como característica que o desenvolvimento capitalista está concentrado em alguns setores e retarda o desenvolvimento do resto da economia. Isso é importante e característico. Ou seja, na América Latina, Ásia e África, o desenvolvimento capitalista não só se concentra apenas em alguns setores que trabalham para a economia mundial e não para a economia doméstica, como o próprio desenvolvimento capitalista nesses setores restringe ou impede o desenvolvimento capitalista do resto da economia. ${ }^{38}$

Ou seja, os investimentos realizados nos países dependentes, ou subdesenvolvidos, se concentram nos setores exportadores, que são os de menor produtividade. Ainda, dadas as características dos setores exportadores de baixo valor agregado, a renda se concentra, o que gera aumento da desigualdade interna. O resultado é a manutenção da pequena dimensão do mercado interno. Nas palavras de Alain Gélédan e Janine Brémond:

É assim que, nos países industrializados, o acréscimo da produção induz a subida no nível de vida, a qual, por sua vez, estimula a procura. No Terceiro Mundo, o aumento da produção destinada à exportação pode não ter senão efeitos limitados sobre a economia nacional (fraco apelo à mão-de-obra local devido ao nível tecnológico requerido, decisão de investir os lucros obedecendo a uma lógica mundial, produção não em função do mercado nacional mas sim do mercado mundial). ${ }^{39}$

O raciocínio está de acordo com a visão de Ragnar Nurkse. Este entendia que uma das principais características dos países subdesenvolvidos era sua baixa produtividade, que resultava em baixa acumulação de capital. ${ }^{40}$ Como consequência, havia baixa capacidade de investimento para ampliar a produtividade local. Com baixa produtividade, esses países continuavam a exportar bens primários e importar bens industrializados, o que gerava mais perdas no comércio exterior. Essas perdas eram ainda ampliadas devido ao que denominou

38 NOYOLA, Juan F. La Economía Cubana en los Primeiros Años de la revolución y otros ensayos. Mexico: Siglo Veitiuno. 1978. Pg. 174.

39 GÉLÉDAN, Alain \& BRÉMOND, Janine. Dicionário das Teorias e Mecanismos Económicos. Lisboa: Livros Horizonte LTDA, 1988. Pg. 412.

40 Sobre o assunto ver: NURKSE, Ragnar. Problema da Formação de Capital em Países Subdesenvolvidos. Rio de Janeiro: Civilização Brasileira, 1957. 
efeito demonstração. As elites locais queriam consumir como se fossem parte da elite dos países desenvolvidos. Enquanto isso, a população, em especial a urbana, dos países subdesenvolvidos queriam mimetizar o consumo das elites locais. O resultado era baixa propensão a poupar e alta propensão a importar.

Nessa ótica, que dá ênfase ao problema da produtividade, a dificuldade de crescimento dos países dependentes estava na incapacidade de gerar oferta. Quando havia ampliação da demanda local, como não havia ganhos de produtividade, essa demanda gerava pressão inflacionária. Esta era respondida ou (a) por aumento dos preços locais; ou (b) aumento das importações; ou (c) ambos. Dessa forma, para que houvesse desenvolvimento, era necessário antes que se investisse na indústria (de base) local, afim de gerar ganhos de produtividade futuras. Ragnar Nurkse via duas formas de conseguir os excedentes necessários para esse investimento: (i) extraindo excedente agrícola através da reorganização do campo; ou (ii) usando excedente do comércio exterior, quando houvesse. A segunda opção, para ele, tendia a não funcionar, uma vez que os ganhos das exportações eram em geral utilizados ou (a) para financiar a ampliação do consumo; ou (b) para investir no setor exportador, que possuía baixa produtividade.

Para os países dependentes, conforme aponta Raúl Prebisch, a oportunidade de adquirir ganhos no setor externo de sua economia são limitados ${ }^{41}$. Apenas conjunturalmente havia aumento dos preços dos produtos primários, ao passo que tendencialmente havia queda dos preços relativos dos mesmos. Isso significa que os ganhos duravam pouco tempo, e, em condições naturais, não eram capazes de gerar processo de desenvolvimento. Na verdade, os países dependentes apenas conseguiam crescer se, em médio prazo, os países centrais crescessem ainda mais.

Os países dependentes exportavam bens primários, e importavam bens industrializados. A elasticidade-renda dos bens primários é baixa, e dos bens industrializados é alta. O resultado disso é que para cada crescimento de $1 \%$ na renda dos países desenvolvidos, a demanda pelos bens primários cresce menos de 1\%. Enquanto isso, para cada aumento de $1 \%$ na renda dos países dependentes, a demanda por bens industrializados cresce mais que 1\%. Como consequência, caso tanto os países dependentes quanto os desenvolvidos crescessem ambos 3\% ao ano, a demanda por bens primários aumentaria

41 Sobre o tema ver: PREBISCH, Raúl. Dinâmica do desenvolvimento latino-americano. Rio de Janeiro: Editora Fundo de Cultura, 1969. 
menos que 3\% (por exemplo, 2,4\%); enquanto a demanda por bens industrializados aumentaria mais de 3\% (por exemplo, 3,6\%). No exemplo dado, para que os países dependentes conseguissem crescer consistentemente 3\% ao ano, seria necessário que seus parceiros comerciais crescessem cerca de $3,75 \%$ ao ano.

Alguns dos impactos dessa diferença da elasticidade e da possibilidade de crescimento são que: (a) existe pressão para que os preços dos bens primários caiam, a cada novo ciclo; (b) que a distância econômica entre os países desenvolvidos e os dependentes tenda a aumentar; e (c) a disparidade de produtividade também tende a aumentar. Como consequência, (d) o comércio internacional, sozinho, não gera desenvolvimento automático. As dificuldades econômicas são ainda maiores quando a elite local impõe medidas econômicas (I) importadas de agências internacionais controladas por representantes dos países desenvolvidos; ou (II) copiadas dos países desenvolvidos como se não fosse necessária qualquer adaptação.

Um modelo proposto por Samir Amin ajuda a entender a diferença essencial entre as economias desenvolvidas, denominadas no modelo de autocentradas, e as economias dependentes, ou voltadas para fora. No modelo, as economias são divididas em quatro setores: (i) o exportador; (ii) o de consumo de massa; (iii) o de consumo de luxo; e (iv) o de produção de bens de capital. No modelo, o setor da produção de bens de capital abastece de maquinaria os outros três setores. O consumo de massa e o consumo de luxo podem ser supridos ou por produção local (feita pelo próprio setor) ou por importação. A importação é financiada pelo setor exportador. Samir Amin aponta que os países autocentrados (desenvolvidos) possuem o setor de produção de bens de capital e o de consumo de massa mais pujantes. Na prática, o setor “iv” fornece as máquinas para sua própria expansão, e para expansão do setor “ii”. A produção do setor “ii” é consumida pelo mercado local. Nesse modelo, a renda média da população é suficiente para consumir as mercadorias produzidas no setor de consumo de massa. Dada a distribuição de renda local, e o tamanho da economia, o consumo de luxo tem menor importância para o dinamismo local. Devido ao forte consumo interno e à alta produtividade, o setor exportador também possui baixa importância relativa ${ }^{42}$.

Já nos países dependentes, a produtividade local e a renda média nas mãos dos trabalhadores são baixas. Como consequência, há baixa demanda para consumo de massa, o que faz com que o setor seja pequeno. A baixa produtividade, e a existência de poucas

42 Sobre o tema ver: AMIN, Samir. Capitalismo periferico y comercio internacional. Buenos Aires, Ed. Periferia, 1974 
industrias locais, também resultam da pouca importância do setor de bens de capital (setor “iv”). Dada a concentração de renda, e o baixo nível de renda da maior parte da população, o consumo de luxo tem maior importância. Parte considerável desse tipo de consumo se realiza através da importação. Para financiar a importação, utiliza-se o setor exportador. Dessa forma, os países dependentes tendem a ter o setor (i) exportador e o (iii) de consumo de luxo relativamente mais fortes do que os outros dois setores. Em um trabalho recente, Samir Amin argumentou que os processos de liberalização e privatização reforçaram os oligopólios, e diminuíram a renda das populações locais, resultando em setores de consumo de massa ainda mais reduzidos, nos países dependentes. ${ }^{43}$

François Chesnais chamou a atenção, em sua obra A mundialização do Capital, que a especialização dos países dependentes em mercadorias de baixo valor também é fruto do investimento estrangeiro:

O lugar atualmente ocupado por muitos "países em desenvolvimento" no sistema mundial de intercâmbio não é resultado de uma dotação fatorial natural, que de alguma maneira tenha caído do céu. Em grande número de casos, sua situação de produtor e exportador de uma ou duas matérias-primas básicas, de mineração ou agricultura, frequentemente com demanda cada vez menor pelos países industrializados, é resultado de antigos investimentos diretos, feitos a partir dos anos 1880 por administrações ou empresas estrangeiras. Eram geralmente as do país colonizador ou, quando se tratava de relações semicoloniais, da potência tutelar na "zona de influência” em objeto. ${ }^{44}$

Como havia baixa acumulação de capital local, os países tinham como principal fonte de poupança a externa. Isto é: o investimento realizado pelas metrópoles. Essas, por sua vez, realizavam investimento visando garantir a oferta de matéria-prima para as suas próprias indústrias. Isso resultou no aprofundamento da disparidade de produtividade entre as metrópoles e os países dependentes.

Os autores citados reforçam, portanto, que o problema fundamental do comércio exterior, ligado ao problema do crescimento econômico, está na produtividade local. Charles Kindleberger também ressaltou esse aspecto. Ele buscou, em seus manuais de economia internacional, dar ênfase a modelos representativos para o comércio internacional que

43 Sobre o assunto ver: AMIN, Samir. The Reawakening of the Arab World. Challenge and Change in the Aftermath of the Arab Spring. Nova Iorque: Monthly Review Press, 2016.

44 Ver: CHESNAIS, François. A mundialização do capital. São Paulo: Xamã, 1996. Pg. 47. 
levassem em conta a produtividade local. Um dos modelos com qual trabalhou foi o modelo de equilíbrio de Vanek-Staley. ${ }^{45}$

\section{Modelo 1.5: equilíbrio de Vanek-Staley}

(4)

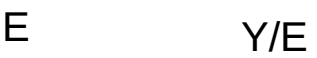

(1)

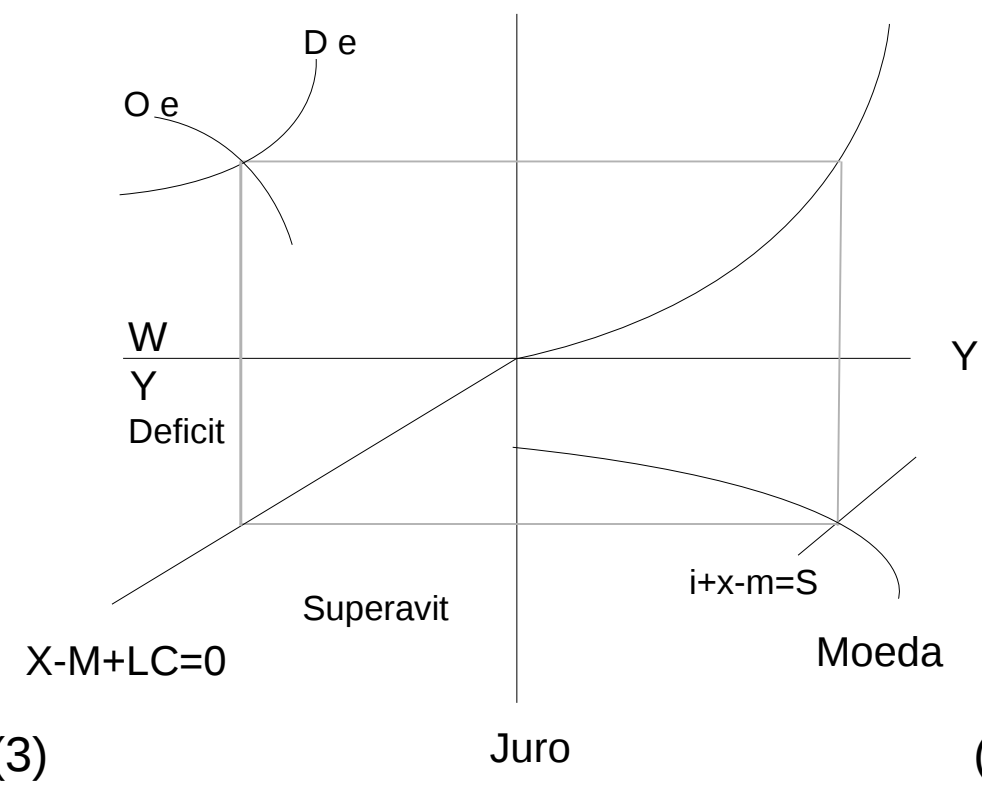

(2)

O modelo acima, similar ao trabalhado por Kindleberger, permite representar a relação entre a produtividade e diferentes componentes da economia nacional e do setor externo. $\mathrm{O}$ modelo possui 4 quadrantes. No (1) primeiro, vê-se a curva de produtividade do país (curva Y/E). Quanto mais inclinado em direção ao eixo das ordenadas (eixo “E”), menor a produtividade do país. Isso significa que precisará de maior disponibilidade de força de trabalho, representada pela letra “E”, para a mesma renda (representada pela letra "Y”). Caso a curva Y/E esteja mais inclinada em direção ao eixo das abscissas, maior será a produtividade. No modelo, vê-se uma curva inclinada na direção da renda, representando um país de alta produtividade.

No (2) segundo quadrante, vê-se a relação entre a renda e juros, e como essas interagem com a oferta de moeda (dinheiro) e com a curva do balanço comercial (curva ixms). Quanto mais a curva da moeda estiver inclinada para o eixo dos juros, maior é o nível

45 Sobre o assunto ver: Sobre as assimetrias no comércio internacional ver: KINDLEBERGER, Charles P. Economia Internacional. São Paulo: Editora Mestre Jou, 1974. 
de inflação observado no país. Já a curva ixms, que expressa a relação entre os investimentos, as exportações, as importações, e a poupança, pode ser insensível ou sensível aos juros. Quanto maior for a capacidade de investimento nativo (poupança nacional) a curva ixms será mais inclinada em direção a renda. No modelo, vê-se uma curva ixms neutra: a poupança nacional pode ser influenciada tanto pelo juros como pela renda nacional. Isso significa que há sensibilidade entre juros e renda. Deve-se atentar que a relação entre juros e renda não é de causa e efeito, mas sim por serem influenciadas por variáveis coincidentes. A poupança, os excedentes comerciais, e a disponibilidade de dinheiro influenciam tanto a um como a outro.

No (3) terceiro quadrante, vê-se a curva de equilíbrio do balanço de pagamentos (curva XMLC=0). Quanto mais inclinado ao eixo dos juros, maior é a importância da aquisição de investimento estrangeiro de longo prazo para o balanço. Quanto mais inclinado em direção ao eixo da renda (eixo Y), maior a importância das transações correntes do balanço de pagamentos. No exemplo, vê-se que a curva é inclinada em direção à renda. Isso significa que há maior margem para superavit do balanço, mesmo sem que o país precise vender ativos nacionais ou adquirir dívida externa.

A produtividade do país e as características do balanço de pagamento influenciam o mercado de trabalho local. Isso está descrito no (4) quarto quadrante. Vê-se que o ponto de equilíbrio da oferta e demanda de emprego (curvas “Oe”, e “De”) está ligado ao nível de renda do país e a produtividade local. O salário médio (eixo “W”), e a quantidade de trabalhadores empregados, influenciam o nível de demanda do país, que impacta no balanço de pagamentos. Em um país em que o balanço de pagamentos tem superavit nas transações correntes, e a produtividade local é alta, há maior margem para que os níveis salariais sejam mais elevados, conforme o modelo.

Evidentemente, o modelo é descritivo. Serve para facilitar a análise teórica sobre as economias existentes. O perfil de países dependentes e países desenvolvidos são diferentes, quando expressos nesse modelo. No entanto, deve-se ter em mente que o equilíbrio é um fenômeno ocasional, e que resulta apenas da soma de sucessivos desequilíbrios. Como ferramenta analítica, o modelo Vanek-Staley permite visualizar a relação entre balanço de pagamentos e a produtividade: em tese, quanto maior a produtividade local, maior será a margem para superavit nas transações correntes, e menor será a dependência de poupança externa. 
O modelo permite formular uma hipótese para descrever o que caracterizou a economia brasileira entre 1999 e 2013. No caso da economia brasileira recente, o superavit do balanço de pagamentos foi (a) fruto da alta dos preços dos bens primários, e (b) do aumento da venda de ativos nacionais, que atraiu investimento de longo prazo. Como o excedente não foi investido em aumento de produtividade, passada a fase de superavit, a economia local voltou à fase de estagnação e contração. Disso resulta a tese que a recuperação econômica local foi caracterizada por um período de alta do comércio exterior, sem que houvesse alteração na estrutura de dependência da economia brasileira.

\subsection{UM MODELO DA ECONOMIA BRASILEIRA ENTRE 1999 E 2013}

A consequência da resposta positiva da hipótese proposta acima é que, ao menos desde o início do século XXI, e possivelmente desde a década de (19)80, a política econômica brasileira esteve a deriva. A fórmula adotada para gerar crescimento foi confiar no "mercado mundial”, seja na forma de importação de capital, seja através das exportações. Quando um falhava, buscava-se fortalecer o outro. Em 1994, com a adoção do chamado "tripé neoliberal”, que era o uso do câmbio e do juros, garantido pelo "superavit primário”, para atingir "metas de inflação”, cristalizou-se a política econômica integralmente voltada para fora. A baixa produtividade, e a queda da capacidade de abastecimento industrial, são frutos dessa estrutura econômica.

Essa estrutura já é conhecida na literatura. Trata-se da reprodução do esquema de dependência econômica. Algumas de suas principais características foi bem descrita por Samir Amin:

Este ponto de vista permite definir o modo capitalista periférico em oposição à sua forma central. (...) A integração implica que o equilíbrio entre o nível de desenvolvimento das forças produtivas e o valor da força de trabalho não se pode ser achado na formação periférica, mas apenas no sistema mundial no qual o último está integrado. Esta falta de correspondência interna entre os dois elementos em questão resulta no círculo vicioso do desenvolvimento periférico: para reproduzir suas próprias condições de existência, a formação periférica ainda deve conter modos de produção précapitalistas ou produzir modos não capitalistas que, sendo dominados, fornecem o modo capitalista com mão de obra barata. ${ }^{46}$

46 AMIN, Samir. Imperialism and Unequal Development. Londres, Nova Iorque: Monthly Review Press, 1977. 
Veja que a principal característica é, portanto, a não correspondência interna entre o nível de desenvolvimento e os salários da população. Trata-se do desequilíbrio do mercado interno, onde o setor dinâmico é o exportador. No entanto, esse se caracteriza por baixos salários, mesmo quando há demanda de altos investimentos (como na extração de petróleo, por exemplo). Isso porque a produtividade média da sociedade é baixa, como resultado da escassez da acumulação de capital. Samir Amin ainda ressalta que a reprodução desse sistema depende, também, da reprodução de relações não capitalistas, sem as quais a reprodução da mão de obra, ao preço desejado, seria impossível. ${ }^{47}$

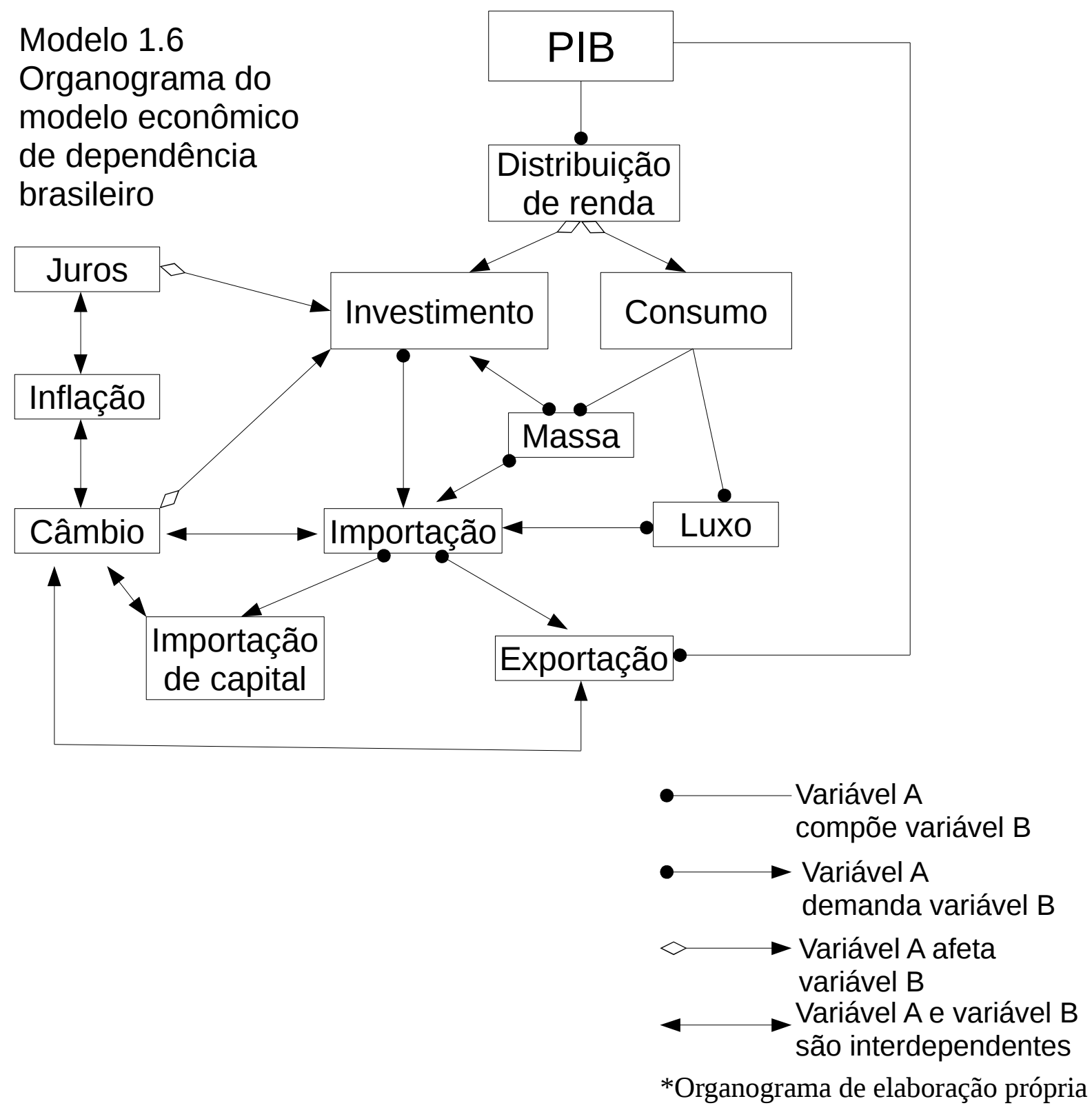

Pg. 218

47 No Brasil, um exemplo desse tipo de relação é o tráfico de drogas, pessoas, etc. 
Pode-se entender que, entre 1999 e 2013, a atividade econômica brasileira funcionou de acordo com o organograma acima. O nível de atividade econômica, descrito pelo PIB, decorreu em dada distribuição de renda. Essa, por sua vez, afetou o investimentos e o consumo (de massa e de luxo) do país. A parcela do consumo de massa foi parcialmente atendida pela produção interna, e parcialmente atendida por importações. No entanto, os investimentos e o consumo de luxo dependeram fortemente das importações. Disso resultou que o crescimento do PIB dependia das importações. Por sua vez, para importar era necessário ter divisas, que ou foram adquiridas pelas exportações, ou foram atendidas pela importação de capital.

Enquanto as exportações afetaram diretamente o nível de atividade econômica, permitindo crescimento momentâneo, ela foi utilizada para compensar a importação de consumo. A larga aquisição de divisas e a política econômica de usar o câmbio para combater a inflação levaram à sobrevalorização do real. Essa sobrevalorização permitiu, no período, reduções periódicas na taxa de juro. Essa redução incentivou novos investimentos, que foram alocados para o setor exportador. Observa-se que nesse modelo, as variáveis cruciais foram as importações, exportações, e a importação de capital, mediadas pela taxa de câmbio.

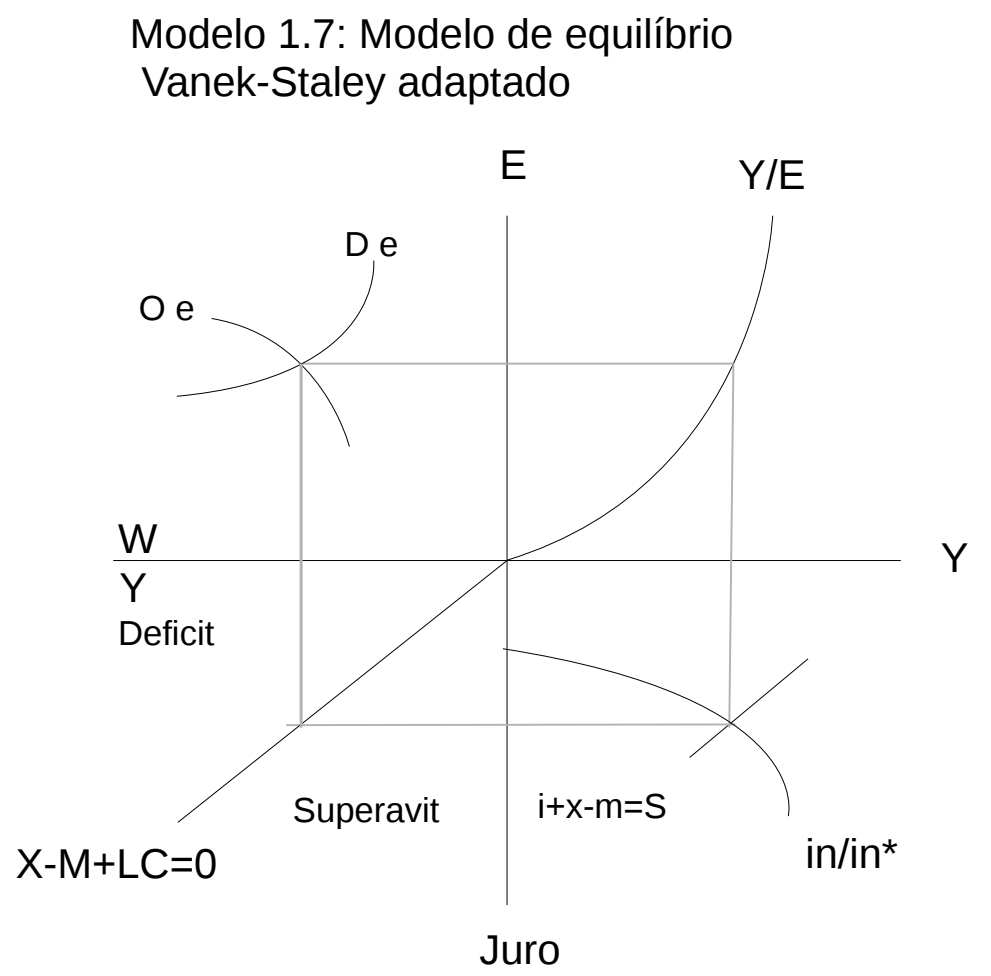

Outra forma de descrever o modelo econômico vigente no Brasil, entre 1999 e 2013, é 
através de uma adaptação do modelo de equilíbrio Vanek-Staley. A adaptação reside em trocar a curva de volume monetário por uma curva da relação entre inflação interna e a inflação externa (curva “In/In*”) ${ }^{48}$. Trata-se de um modelo de equilíbrio de curtíssimo prazo, ou de longo prazo. Os pontos de equilíbrio são, em médio prazo, sempre cruzados, mas raramente a atividade econômica brasileira consegue se estabilizar em pontos de equilíbrio, dada a oscilação dos preços no comércio exterior. Em longo prazo, o equilíbrio é alcançado nos diversos desequilíbrios, gerando o “Stop \& Go” da economia brasileira.

O primeiro quadrante é o "EY”. Ele representa a relação entre a população empregada e a renda, expressando a produtividade brasileira na curva Y/E. Observa-se que a curva da produtividade é mais inclinada na direção da força de trabalho. Isso significa que há, no país, produtividade pequena. Para que ocorra um aumento na renda nacional, é necessário um grande emprego da força de trabalho.

O segundo quadrante é o "YJ”. Representa o impacto do comércio exterior na renda nacional. Ainda, expressa o impacto do juros e da inflação relativa do país no comércio exterior, e, portanto, na renda. No modelo, a inflação e o juro se aceleram a partir do cruzamento com a linha de equilíbrio entre o setor externo e a poupança do país. Isso quer dizer que um crescimento econômico acima do sustentável pelo setor externo (ou pela poupança nacional) gera aumento da taxa de inflação, que tende a ser coberta por juros nominais maiores. Um cenário distinto apenas seria possível caso a curva de inflação mudasse sua inclinação ou posição, como resultado do aumento da demanda e oferta (ou da produtividade) do país, ou por novo ponto de equilíbrio do setor externo da economia.

O terceiro quadrante é o quadrante "JY”, e expressa a relação entre o superavit ou déficit no balanço de pagamentos, o juro realizado no país, e o nível de atividade econômica. No modelo, propõe-se que o equilíbrio do balanço de pagamentos é neutro entre juros e nível de atividade econômica, em longo prazo. Isso significa que o equilíbrio pode resultar tanto de ampliação da atividade econômica (exportação superior a importação) como da política de juros (juros proporcionalmente maiores ao equilíbrio da inflação para atrair investimento estrangeiro). Ou seja, o superavit é neutro entre sua origem nas transações correntes ou na importação de capital de longo prazo.

O quarto quadrante é o “WE”, e expressa a relação entre a população empregada e o

48 Na verdade, falar da relação entre a inflação interna e a inflação externa é a mesma coisa que falar de volume monetário, apenas passando de uma abordagem de valor absoluto para valor relativo. 
nível salarial. Verifica-se as curvas de oferta e demanda de força de trabalho (“Oe” e "De”, respectivamente). A curva “De” é bastante inclinada na direção de salários mais baixos. Isso indica uma forte propensão local a pagar salários mais baixos. A curva “Oe” é neutra, indicando que, embora salários baixos gerem menor oferta de mão de obra, há tendência da população local em aceitar mesmo salários baixos.

Trata-se, portanto, de um país subdesenvolvido, dentro da classificação de Ragnar Nurkse (país com baixa acumulação de capital). É um país dependente, que sofre constrangimento externo, dentro da definição estruturalista-cepalina (um país cujo crescimento econômico depende do crescimento da capacidade de importação). 


\section{SOBRE O BALANÇO COMERCIAL BRASILEIRO}

O balanço comercial (BC) é tido como o principal item do balanço de pagamentos (BP). No caso brasileiro, é nele que se registra a maior parte da entrada de dólares das contas correntes. Ainda, o BC tem suas características determinadas pela capacidade de produção do país e pela demanda externa e interna. Dessa forma, oferece elementos que elucidam as características da própria economia do país em análise.

Entre 1998 e 2013, o Brasil experimentou crises econômicas e a superação parcial delas (1998 - 2003); um crescimento acelerado (2005 - 2007); a resistência a uma crise internacional (2008 - 2009); algum crescimento econômico (2010 - 2011); e o esgotamento daquele crescimento (2012 - 2014). Especialmente entre 2004 e 2008, o comércio exterior apresentou ótimo desempenho em termos de saldo. A partir daí, cresceu mais singelamente e até mesmo diminuiu. Como consequência, o Brasil voltou a experimentar déficit na conta corrente, a partir de 2010.

Uma das principais características do comércio exterior brasileiro foi o ganho de importância da parceria comercial com a China. Também, houve crescimento das exportações de bens primários acima do crescimento da exportação de bens manufaturados. O Brasil se destacou como exportador de commodities em um momento de tendência de crescimento dos preços desse tipo de produto. São mercadorias cuja produção se caracteriza pela baixa produtividade e por não necessitarem de larga cadeia de produção. Como consequência, o aumento da exportação de bens manufaturados não leva, necessariamente, a um aumento da produtividade de país. O comércio exterior, quando marcado pela exportação de bens primários, apenas traz crescimento da renda de um país quando a balança comercial é superavitária. O crescimento se dá sem efeito multiplicador relevante, uma vez que não há ampliação da produtividade local, conforme as proposições teóricas existentes em parte da literatura sobre a economia internacional. ${ }^{49}$

A reflexão sobre o comércio exterior brasileiro e sobre o desempenho econômico do Brasil, entre 1999 e 2013, permite levantar algumas hipóteses a serem melhor investigadas ao

49 Para uma abordagem sobre o investimento e efeito multiplicador ver: ACKLEY, Gardner. Teoria Macroeconômica. vol 1. São Paulo: Livraria Pioneira Editora,1969. Pg. 233 
longo da presente tese. São elas: (a) parte da recuperação recente da econômica brasileira foi fruto do desempenho do comércio exterior brasileiro; (b) esse bom desempenho teve como fonte o crescimento chinês, que por sua vez expressou o sucesso da parceria China-EUA; e (c) a recuperação da economia brasileira não se caracterizou pelo fortalecimento do setor interno, com produção que fosse fortemente voltada ao suprimento do mercado nacional.

\subsection{ALGUNS EFEITOS MACROECONÔMICOS}

Ambos itens “exportação” e “importação” possuem peso relevante na composição do Produto Interno Bruto (PIB) do Brasil. Em 2011, as exportações brasileiras atingiram o valor recorde de 256 bilhões de dólares, e as importações o valor de 226 bilhões de dólares. Embora o saldo houvesse sido de apenas trinta bilhões, a soma dos valores que circularam no comércio exterior brasileiro foi de mais de 482 bilhões, em 2011. Naquele ano, o PIB brasileiro foi de pouco menos que 2 trilhões e meio de dólares. O valor circulado no comércio externo brasileiro correspondeu, portanto, a quase 11,5\% do PIB. Esse valor demonstra que a economia brasileira participa pouco do mercado mundial, mas que esse é bastante importante para o Brasil.

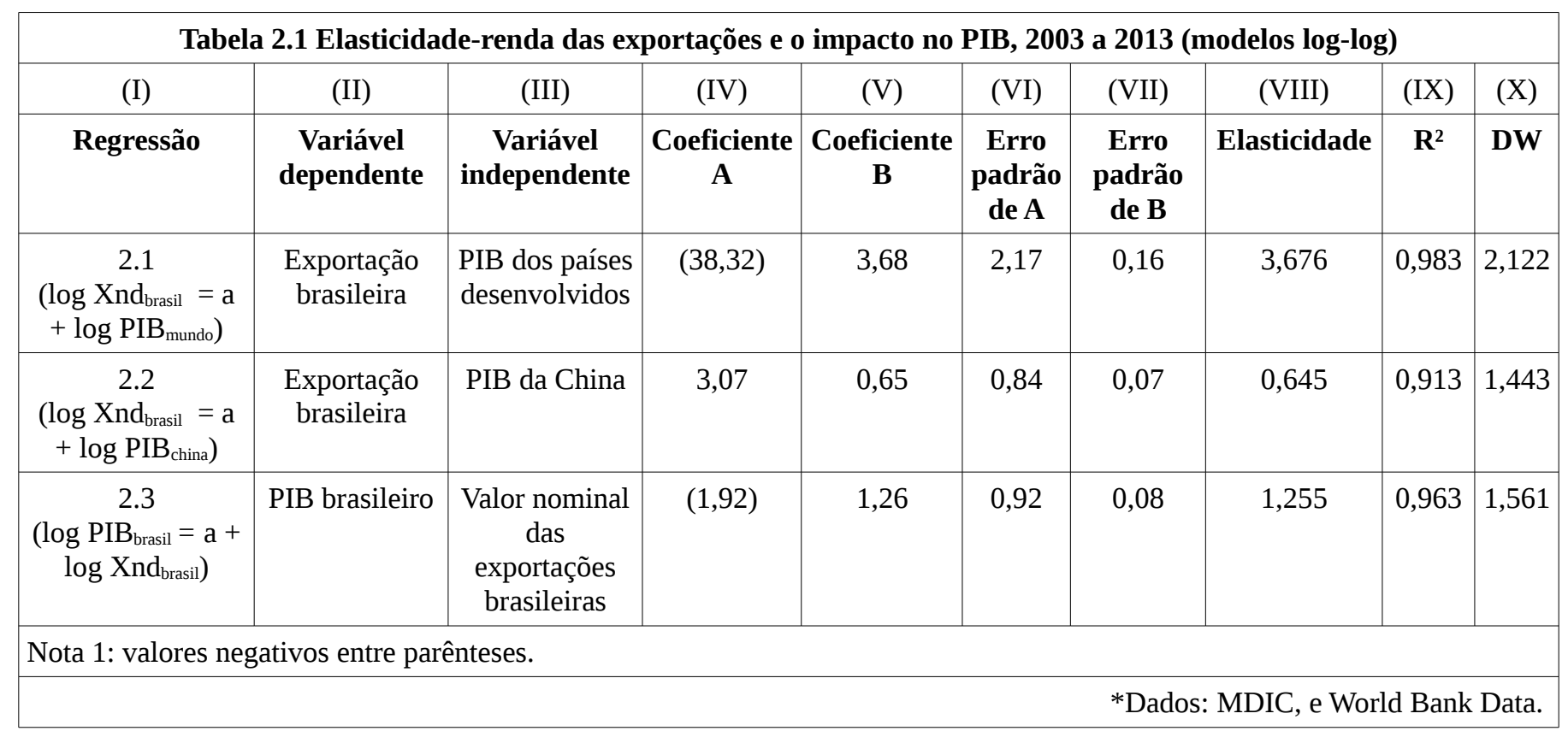

Na tabela 2.1, observa-se os dados para elasticidade-renda das exportações, calculada a partir do (a) PIB dos países desenvolvidos; e (b) do PIB da China. Verifica-se também (c) os dados para elasticidade o PIB brasileiro em relação às exportações. Trata-se dos dados de 
análise de regressão referentes às equações (2.1), (2.2), e (2.3). Revela-se, na tabela 2.1, que o produto interno dos países desenvolvidos e da China influenciam bastante, no período, o desempenho das exportações brasileiras. A elasticidade-renda das exportações do Brasil em relação à renda dos países desenvolvidos é maior (é elástica), enquanto em relação à renda da China tem baixa elasticidade. Isso acontece porque as exportações brasileiras foram, na verdade, mais influenciadas pela economia chinesa. Mesmo as exportações brasileiras sendo pouco elásticas em relação ao seu atual principal parceiro comercial, a alta taxa de crescimento da economia chinesa permitiu que as exportações crescessem acima da taxa de crescimento dos países desenvolvidos. Isso é importante, pois fica clara uma limitação para o crescimento das exportações. A mudança estrutural continuada da economia chinesa teria um impacto relativo bastante superior na balança comercial brasileira.

Essa característica não difere da descrita por pensadores da escola cepalina durante as décadas (19)50 - (19)70: as exportações brasileiras são pouco elásticas em relação à renda de seu principal parceiro. Isso revelaria, para Prebisch ${ }^{50}$, o caráter dependente da economia brasileira. De acordo com Villarreal, essa característica deveria ter sido parcialmente alterada na segunda etapa da substituição de importações. A menos que haja ocorrido um processo desindustrialização, entendida por Prebisch como fruto do avanço do comércio internacional em fase expansiva.

Entre 2003 e 2013, o produto interno bruto brasileiro foi elástico em relação às exportações. Ainda, houve alta correlação entre o dinamismo da economia brasileira e as exportações $^{51}$, quando analisado pelos valores em dólar nominal. A relação entre as exportações e o produto brasileiro serve de indício para duas hipóteses complementares: (a) parte considerável da economia brasileira é pautada pelo dinamismo externo, o que faz com que o sucesso das exportações sirva de incentivo para novos investimentos; e (b) para a realização de investimentos, o Brasil depende de aquisição de divisas, o que é parcialmente suprido pelas exportações.

A elasticidade baixa das exportações e a alta importância delas para o dinamismo do país são indícios da fragilidade e dependência da economia local. Nesse sentido, a recuperação econômica teria sido fruto de uma conjuntura favorável, causada pela alta dos

50 Sobre o tema ver: PREBISCH, Raúl. Dinâmica do desenvolvimento latino-americano. Rio de Janeiro: Editora Fundo de Cultura, 1969.

51 O R² é a medida do quadrado da correlação. 
preços dos produtos de exportação. Trata-se de um aspecto cíclico das economias em desenvolvimento, já estudado por Prebisch.

Ainda, pode-se entender que, embora a China tenha ganhado grande importância para as exportações brasileiras, aquele país tem parte de seu sucesso econômico explicado pela parceria China-EUA. Nesse contexto, a dependência brasileira da economia chinesa para expandir suas exportações continua sendo uma dependência da economia dos países desenvolvidos, em especial da norte-estadunidense.

\begin{tabular}{|c|c|c|c|c|c|c|c|c|c|}
\hline & & & & & & & & & \\
\hline (I) & (II) & (III) & (IV) & (V) & (VI) & (VII) & (VIII) & (IX) & $(\mathrm{X})$ \\
\hline Regressão & $\begin{array}{c}\text { Variável } \\
\text { dependente }\end{array}$ & $\begin{array}{c}\text { Variável } \\
\text { independente }\end{array}$ & $\begin{array}{c}\text { Coeficiente } \\
\text { A }\end{array}$ & $\begin{array}{c}\text { Coeficiente } \\
\text { B }\end{array}$ & $\begin{array}{c}\text { Erro } \\
\text { padrão } \\
\text { de A }\end{array}$ & $\begin{array}{c}\text { Erro } \\
\text { padrão de } \\
\text { B }\end{array}$ & Elasticidade & $\mathbf{R}^{2}$ & DW \\
\hline $\begin{array}{c}2.4 \\
\text { (log Mnd } \\
=\mathrm{a}+\log \\
\text { PIBnd) }\end{array}$ & $\begin{array}{c}\text { Importação } \\
\text { nominal } \\
\text { brasileira }\end{array}$ & $\begin{array}{l}\text { PIB nominal } \\
\text { brasileiro }\end{array}$ & $(1,38)$ & 1,03 & 0,50 & 0,04 & 1,028 & 0,979 & 1,687 \\
\hline $\begin{array}{c}2.5 \\
\text { (log Mnd } \\
=\mathrm{a}+\log \\
\text { FBCFnd) }\end{array}$ & $\begin{array}{c}\text { Importação } \\
\text { nominal } \\
\text { brasileira }\end{array}$ & $\begin{array}{c}\text { Formação bruta } \\
\text { de capital fixo } \\
\text { (FBCF) nominal } \\
\text { brasileiro }\end{array}$ & 0,52 & 0,93 & 0,43 & 0,04 & 0,928 & 0,979 & 0,874 \\
\hline
\end{tabular}

Observando a elasticidade-renda das importações brasileiras, na tabela acima, referente às equações (2.4) e (2.5) da tabela 3.1, verifica-se que elas são elásticas. No entanto, a elasticidade em relação ao PIB é maior do que a elasticidade em relação à formação bruta de capital (FBK). Isso significa que a importação cresceu mais devido ao consumo que ao investimento. Esse dado está de acordo com a tese de Ragnar Nurkse ${ }^{52}$, que apontava como um dos problemas dos países subdesenvolvidos a falta de poupança.

Para ele, esse países sofriam com os efeito demonstração. As camadas abastadas, e mesmo parcela da população trabalhadora, tendiam a querer imitar o consumo que se realizava nos países desenvolvidos. Isso resultava em (a) baixa capacidade de poupança nacional; e (b) aumento das importações de artigos para consumo. Daí a dificuldade daqueles países em superar o subdesenvolvimento. Na prática, o excedente econômico efetivo não se transformou em excedente disponível para o desenvolvimento. ${ }^{53}$

52 Sobre o tema ver: NURKSE, Ragnar. Problema da Formação de Capital em Países Subdesenvolvidos. Rio de Janeiro: Civilização Brasileira, 1957.

53 O excedente efetivo é igual ao custo simples de reprodução de uma sociedade, considerando a reprodução da 
Embora tenha-se que o Brasil seja um país “emergente”, os dados revelam características de um país de economia primário-exportadora, com tendência a importar para consumir. Ainda, trata-se de um tipo de exportação altamente sensível aos preços internacionais, e com baixo impacto na produtividade local, uma vez que não estimulam a formação de uma indústria doméstica ${ }^{54}$. No entanto, deve-se ter em mente que a série analisada para as importações começou em 1999. Isso significa que (a) incluiu-se dois períodos de crise econômica (por não afetar demasiadamente a confiabilidade da regressão para elasticidade-renda das importações); e (b) que não se considerou os efeitos do período de liberalização econômica anterior.

Gráfico 2.1: Participação relativa do consumo e da formação bruta de capital fixo em cada novo dólar de importação, 1999 a 2013

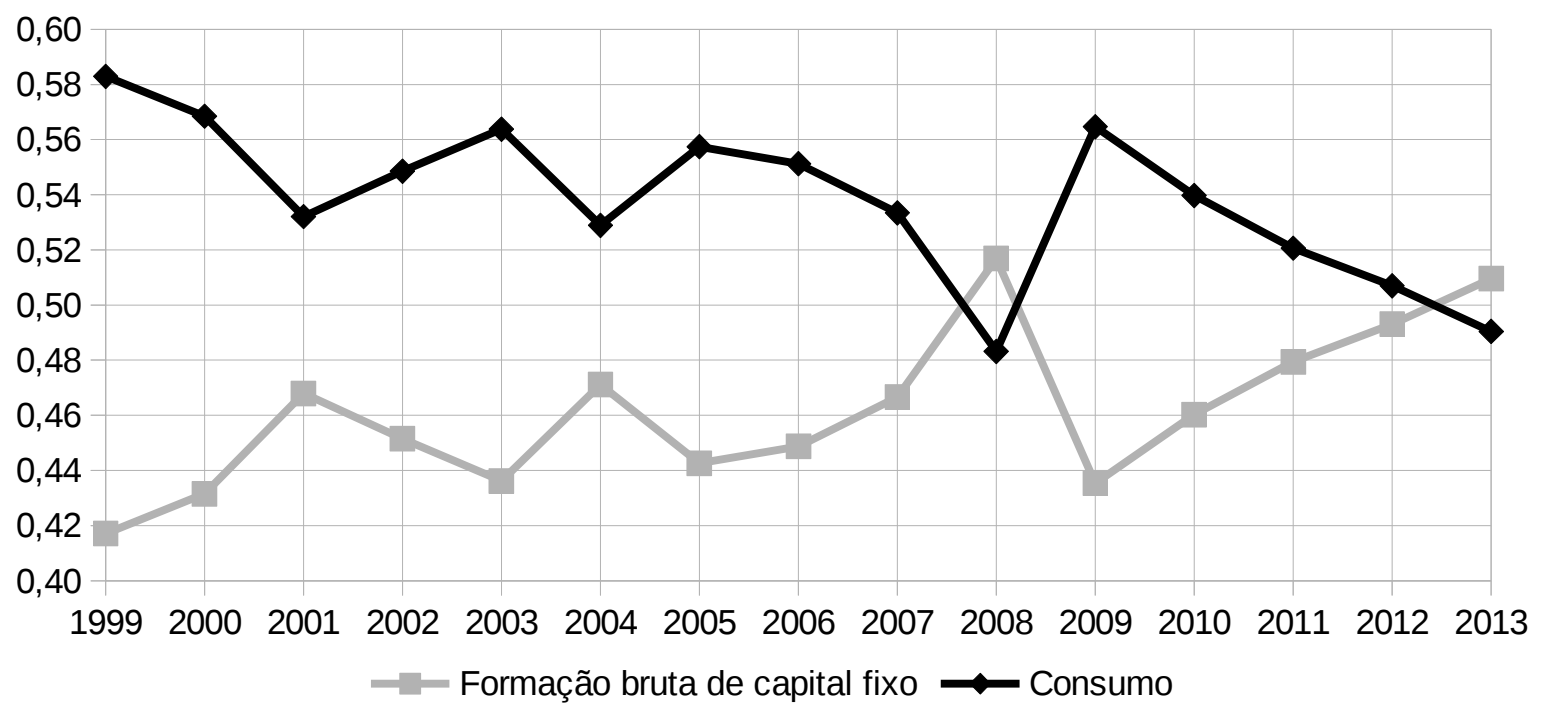

*Dados: MDIC, e World Bank Data.

Com o intuito de adotar uma leitura menos estática, pode-se considerar as elasticidades móveis das importações. No gráfico acima, verifica-se a elasticidade móvel das importações explicadas pelo consumo e pela formação bruta de capital fixo. Elas estão expressas na forma de participação relativa: quanto de cada novo dólar de importação foi direcionado para o consumo e quanto foi direcionado para formação bruta de capital fixo

mão de obra e do aparato social que ela demanda. O excedente disponível para o desenvolvimento é a parcela do excedente que foi gasta com novos investimentos. Para uma discussão sobre o assunto ver: BETTELHEIM, Charles. Planificação e Crescimento acelerado. Rio de Janeiro: Zahar Editores, 1976.

54 Para uma explicação sintética sobre o baixo impacto das exportações de bens primários na produtividade local ver: GÉLÉDAN, Alain \& BRÉMOND, Janine. Dicionário das Teorias e Mecanismos Económicos. Lisboa: Livros Horizonte LTDA, 1988. Pg. 525 - 527 
(FBCF). Observa-se que a participação da formação bruta de capital foi levemente ascendente, no período entre 1999 e 2011. Ela apresentou alta entre 2000 e 2001, oscilou para baixo de 2002 e 2003, e teve uma alta pontual em 2004. A partir daí apresentou alta até 2008. Em 2009, com o impacto da crise econômica internacional, caiu fortemente. A partir de 2010, voltou a crescer. Isso significa que, durante o período analisado, houve aumento do peso da formação bruta de capital (FBK) nas importações brasileiras. Nessa abordagem, a importação de partes e peças a serem montadas no Brasil para suprir o consumo consta como importação para consumo, e não como investimento.

Dessa forma, o quadro que pode ser desenhado pelo analisado até aqui se caracteriza por: (i) impacto das exportações no PIB; (ii) relevância das importações para os investimentos produtivos brasileiros, e principalmente para o consumo das famílias; e (iii) importância do desempenho da China e das economias desenvolvidas para o resultado das exportações brasileiras.

Em outras palavras, observa-se que o Brasil ainda é economicamente dependente, altamente sensível ao desempenho das economias estrangeiras. O (aparente) bom desempenho das exportações brasileiras no período entre 2002 e 2010 não foi convertido em desenvolvimento de dinamismo local independente. Não foi montada uma economia com uma demanda interna forte, suprida pela produção nativa. Se houve investimento na economia nacional, visando a diminuição do grau de dependência efetiva, ainda não logrou êxito.

\subsection{DESEMPENHO DO BALANÇO COMERCIAL E DOS TERMOS DE}

\section{TROCA}

A primeira forma de medir o desempenho do comércio exterior de um país é através do saldo do balanço comercial do mesmo. No entanto, uma primeira discussão é que essa medição deve ser realizada em valores nominais e também reais. Embora o saldo comercial seja relevante em seu valor nominal, é fundamental saber qual foi o ganho na capacidade de compra desse saldo. Isso significa que é necessário deflacionar o dólar através do deflator implícito do mesmo. Assim se obtém os valores constantes, com dado ano como base. 


\begin{tabular}{|c|c|c|c|}
\hline \multicolumn{4}{|c|}{$\begin{array}{l}\text { Tabela 2.3 Saldo nominal e real (em reais de 2006) do balanço comercial do Brasil, em } \\
\text { milhões de dólares, } 1999 \text { a } 2013\end{array}$} \\
\hline (I) & (II) & (III) & (IV) \\
\hline ano & Saldo do BC nominal & $\begin{array}{l}\text { Saldo do BC real (em } \\
\text { reais de 2006) }\end{array}$ & $\begin{array}{l}\text { Variação real no saldo } \\
\text { (em porcentagem) }\end{array}$ \\
\hline 1999 & (1.199) & $(1.420)$ & - \\
\hline 2000 & (698) & (808) & 43,10 \\
\hline 2001 & 2.642 & 2.991 & 470,17 \\
\hline 2002 & 13.130 & 14.639 & 389,43 \\
\hline 2003 & 24.825 & 27.137 & 85,37 \\
\hline 2004 & 33.693 & 35.846 & 32,09 \\
\hline 2005 & 44.757 & 46.132 & 28,69 \\
\hline 2006 & 46.074 & 46.074 & $(0,13)$ \\
\hline 2007 & 40.028 & 38.991 & $(15,37)$ \\
\hline 2008 & 24.746 & 23.641 & $(39,37)$ \\
\hline 2009 & 25.347 & 24.033 & 1,66 \\
\hline 2010 & 20.267 & 18.984 & $(21,01)$ \\
\hline 2011 & 29.796 & 27.346 & 44,05 \\
\hline 2012 & 19.431 & 17.518 & $(35,94)$ \\
\hline 2013 & 2.558 & 2.272 & $(87,03)$ \\
\hline \multicolumn{4}{|c|}{ Nota 1: números negativos entre parênteses } \\
\hline \multicolumn{4}{|c|}{ Dados: MDIC, e USA Bureau of Economic Analysis. } \\
\hline
\end{tabular}

Quando o saldo do BC é analisado em valores reais, ele demonstra crescimento mais acelerado até 2006, em comparação aos valores nominais. A partir daí, apresentou queda mais acentuada. Do ponto de vista do saldo do balanço, o Brasil apresentou bom desempenho nas relações comerciais durante todo o período, com um período excepcional entre 2004 e 2007. Parte do bom desempenho foi sustentado por uma alta de preços das commodities ${ }^{55}$, resultante do aumento da demanda chinesa sobre diversos produtos, entre eles: (a) petróleo e combustíveis; (b) minério de ferro; e (c) soja. O aumento da demanda permitiu o aumento do quantum $^{56}$ exportado de diversos dos então principais produtos de nosso comércio exterior somado à alta do preço.

Para o desempenho do balanço, as oscilações de preço são fundamentais, ao lado das oscilações no quantum exportado e importado. A conjuntura favorável parece ter permitido a melhora do comércio exterior, sem ter sido suficiente para permitir uma reversão da condição brasileira. A pauta de exportação baseada em bens relativamente pouco valorizados, seja por possuírem pouco valor agregado ou por não serem considerados de "alta tecnologia", é

55 Chama-se de commodities os produtos da baixo valor agregado, em geral utilizados como insumo para produtos de maior valor agregado.

56 Quantum de exportação ou de importação é a quantidade comercializada calculada através do peso. 
dependente do desempenho dos países desenvolvidos. Em momentos de crescimento acelerado de algum dos principais parceiros, há possibilidade de crescimento da quantidade e/ou valor das exportações. No momento em que esse crescimento desacelera, as exportações também desaceleram. Enquanto isso, as importações tendem a continuar a crescer enquanto há fortalecimento dos investimentos. No caso brasileiro, as importações vêm crescendo rapidamente desde 2005.

O simples aumento das exportações, seja pelo aumento do quantum ou dos preços, é relevante se comparado com as importações. Nesse sentido, as exportações devem ser medidas também pelo sua capacidade de compra. Para isso, é necessário refletir sobre o desempenho dos termos de troca do país. Para fim desse estudo, utilizaremos o conceito de termo de troca nominal como diferente das relações de trocas reais. O termo de troca nominal é a razão entre o valor exportado e o valor importado. Já as relações de trocas reais pode ser encontrada pelo processo de análise do poder de compra das exportações e da variação no termo de troca a partir da mesma. O procedimento é a base do estudo da posição da capacidade de importação do país ${ }^{57}$.

Tabela 2.4: Poder de compra das exportações, em bilhões de reais de 2006, 1999 a 2013

\begin{tabular}{|c|c|c|c|c|c|c|c|}
\hline (I) & (II) & (III) & (IV) & (V) & (VI) & (VII) & (VIII) \\
\hline Ano & $\begin{array}{c}\text { Importação } \\
\text { total }\end{array}$ & $\begin{array}{c}\text { Exportação } \\
\text { total }\end{array}$ & $\begin{array}{l}\text { Termos de } \\
\text { trocas }\left(\mathrm{tt}_{\mathrm{i}}\right)\end{array}$ & \begin{tabular}{|c} 
Taxa de \\
crescimento dos \\
termos de troca
\end{tabular} & $\begin{array}{c}\text { Termos de } \\
\text { trocas } \\
(2006=100)\end{array}$ & $\begin{array}{c}\text { Poder de } \\
\text { compra das } \\
\text { exportações }\end{array}$ & $\begin{array}{l}\text { Variações } \\
\text { no termo } \\
\text { de troca }\end{array}$ \\
\hline & & & $\begin{array}{l}(4)=((3) / \\
(2)) * 100\end{array}$ & $\begin{array}{c}(5)=\left(t_{t}-t_{i}-1\right) / \\
(t)\end{array}$ & $\begin{array}{c}(6)=(4) / 150,41 ; \\
(2006=100)\end{array}$ & $\begin{array}{c}(7)=((3) * \\
(6)) / 100\end{array}$ & $\begin{array}{l}(8)=(7)- \\
\text { (3) }\end{array}$ \\
\hline 1999 & 163,82 & 159,83 & 97,56 & - & 64,86 & 103,67 & $(56,16)$ \\
\hline 2000 & 175,25 & 173,06 & 98,75 & $1,22 \%$ & 65,65 & 113,62 & $(59,44)$ \\
\hline 2001 & 204,30 & 214,02 & 104,76 & $6,08 \%$ & 69,64 & 149,05 & $(64,97)$ \\
\hline 2002 & 195,33 & 249,62 & 127,79 & $21,99 \%$ & 84,97 & 212,10 & $(37,53)$ \\
\hline 2003 & 184,74 & 279,77 & 151,44 & $18,50 \%$ & 100,68 & 281,68 & 1,91 \\
\hline 2004 & 210,84 & 323,99 & 153,67 & $1,47 \%$ & 102,16 & 331,00 & 7,01 \\
\hline 2005 & 192,20 & 309,16 & 160,85 & $4,68 \%$ & 106,94 & 330,62 & 21,46 \\
\hline 2006 & 202,26 & 304,22 & 150,41 & $(6,49 \%)$ & 100,00 & 304,22 & - \\
\hline 2007 & 226,56 & 301,75 & 133,19 & $(11,45 \%)$ & 88,55 & 267,19 & $(34,56)$ \\
\hline 2008 & 283,81 & 324,36 & 114,29 & $(14,19 \%)$ & 75,98 & 246,46 & $(77,90)$ \\
\hline 2009 & 213,29 & 255,65 & 119,86 & $4,88 \%$ & 79,69 & 203,72 & $(51,93)$ \\
\hline 2010 & 247,61 & 275,24 & 111,16 & $(7,26 \%)$ & 73,90 & 203,40 & $(71,83)$ \\
\hline 2011 & 280,78 & 317,76 & 113,17 & $1,81 \%$ & 75,24 & 239,09 & $(78,68)$ \\
\hline 2012 & 313,16 & 340,43 & 108,71 & $(3,94 \%)$ & 72,27 & 246,04 & $(94,39)$ \\
\hline 2013 & 342,41 & 346,06 & 101,07 & $(7,03 \%)$ & 67,19 & 232,53 & $(113,53)$ \\
\hline
\end{tabular}

Nota 1: Valores negativos em parênteses

Fonte: dados MDIC e USA Bureau of Economic Analysis.

57 A análise da capacidade de importação também foi usada por Celso Furtado, quando ele analisou a formação da indústria brasileira nos anos (19)30. Sobre o assunto ver: CELSO, Furtado. Formação econômica do Brasil. Formação econômica do Brasil. Rio de Janeiro: Fundo de Cultura, 1959. 
Utilizando o termo de troca nominal, observa-se que houve melhora relativa até 2005, observando-se deterioração até $2008^{58}$. A partir de então, o termo de troca manteve-se no mesmo patamar. Somente a partir de 2012 houve novo período de deterioração. Esse processo é condizente com a tese de que a exportação brasileira é dependente dos preços determinados desde fora e que as importações são determinadas pelo impulso de consumo e investimento interno.

Ao observar o poder de compra real das exportações, verifica-se que houve crescimento do mesmo até 2008, apesar de ter passado por uma desaceleração a partir de 2005. Verifica-se, na quinta (V) coluna, que a taxa de crescimento dos termos de troca teve trajetória cadente no período, após apresentar forte alta em 2002 e 2003 . Isso significa que, apesar dos termos de troca terem sofrido deterioração, o crescimento das exportações ainda permitia o crescimento das importações. No entanto, já se verificava um cenário desfavorável para a economia local. A crise de 2008-2009, reverteu o processo de crescimento do poder de compra das exportações, deteriorando mais as relações de troca. Em 2010, o poder de compra das exportações voltou a crescer, atingindo valor recorde em 2011. Nessa perspectiva, até aquele ano, a expansão da exportação continuava a justificar, aparentemente, o otimismo. Para os observadores mais atentos, como Tatiana Lacerda Prazeres, que foi secretária do comércio exterior até outubro de 2013, o otimismo ainda era fundado nos preços altos das commodities, mas já apresentava sinais de limitação devido ao gradual crescimento dos preços das importações.

Ao observar as variações nos termos de troca, a partir da relação entre o poder de compra das exportações e o valor real das exportações em dólares constantes, verifica-se uma deterioração de médio prazo. Apesar da breve estagnação da deterioração, entre 2009 e 2011, a tendência para a perda de vantagem se manteve. Do ponto de vista do comércio exterior brasileiro e seus termos de troca, o período de expansão e melhoria foi curto, durando apenas 5 anos. A crise internacional deu a impressão de que haveria novo ciclo de expansão. Mas o fôlego de uma exportação com base em produtos primários já não acompanhava o crescimento das importações necessárias para o nível de investimento do país.

58 No presente trabalho, utiliza-se a definição de termos de troca em sua forma nominal. Isto é: a relação do valor total das exportações em relação ao valor total das importações. Para uma definição diferente ver: DEARDORFF, Alan V. Terms Of Trade Glossary Of International Economics. Singapura: World Scientific, 2006. pg. 136 e 269. 


\section{Gráfico 2.2 Variação nos termos de troca do comércio exterior brasileiro: 1999 a 2013}

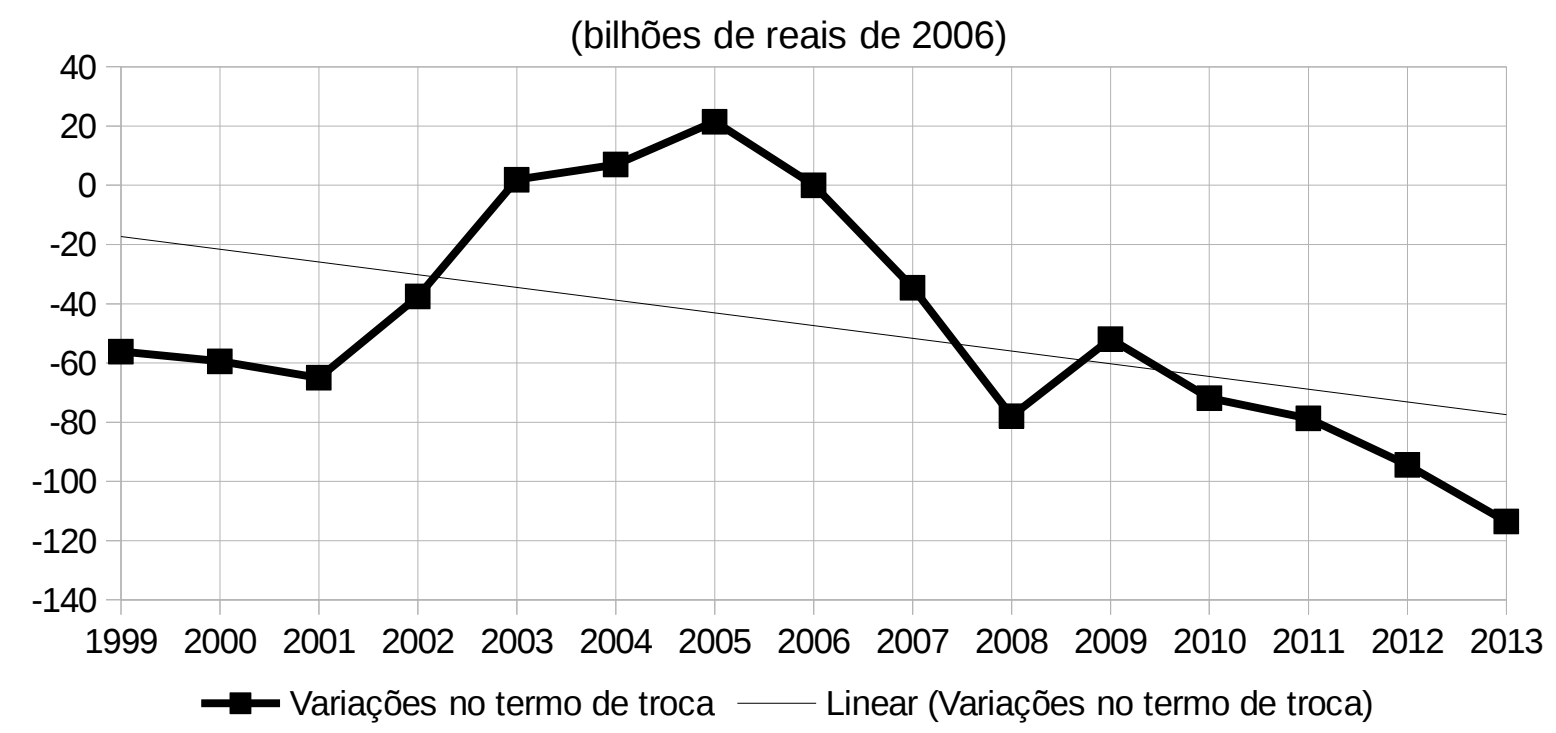

Fonte: dados MDIC e USA Bureau of Economic Analysis.

A deterioração dos termos de troca era um fenômeno previsível. Desde 1948, quando foi produzido um estudo de R. Prebisch sobre o tema, é fato conhecido que o preço dos chamados produtos primários é bastante oscilante. Sabe-se que os produtos agrícolas possuem ciclos de preço mais curtos, enquanto produtos minerais possuem ciclos mais longos (de, por exemplo, 5 anos). A alta do preço impacta na disposição de novos investimentos na produção, o que gera, segundo os estudos em questão, maior oferta e queda nos preços.

A partir de 2005, período que os termos de troca começaram a se deteriorar, a pauta de exportação brasileira começou a sofrer com um processo de reprimarização. No entanto, a deterioração dos termos de troca não se expressa apenas na queda desses preços, mas também no crescimento dos investimentos. O aumento das exportações e as massas de lucro adquiridas tornam vantajosos novos investimentos na produção daqueles produtos, e mesmo de cadeias produtivas complementares.

O aumento da renda do país gera maior demanda interna. Nesse contexto, surge o impulso para uma nova onda de investimentos. A importação de novas máquinas e insumos (mais caros) levam à uma deterioração dos termos e da relação de troca. Na verdade, é pouco realista esperar a melhora constante dos termos de trocas em médio prazo, em especial quando se observa uma pressão estrutural pela reprimarização. 


\section{Gráfico 2.3: Taxa de crescimento dos termos de troca, 2000 a 2013}

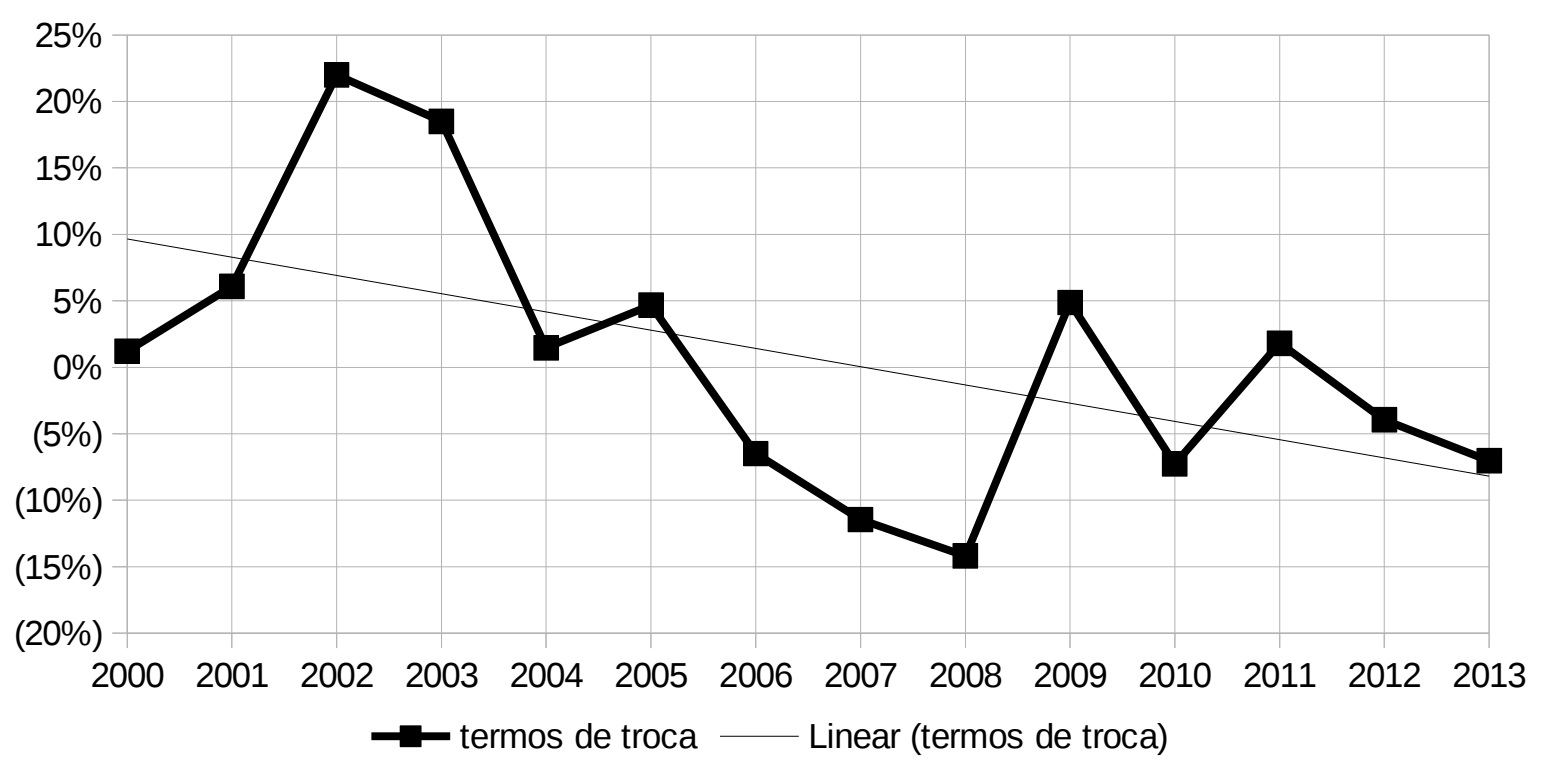

Fonte: dados MDIC e USA Bureau of Economic Analysis. Gráfico de elaboração própria

O gráfico 2.3 traz a taxa de crescimento dos termos de troca do Brasil. Verifica-se que, desde 2002, houve tendência de queda gradual na mesma. A tendência linear observada foi de queda, expressando a deterioração dos termos de troca. Verifica-se uma queda de mais de 25 pontos percentuais entre 2002 e 2013. Esse esgotamento do crescimento dos termos de troca desde cedo foi fruto de um crescimento das importações acima das exportações. Em parte, isso se explica pela valorização do Real frente ao dólar a partir de 2004.

Para Prebisch, um dos problemas estruturais dos países em desenvolvimento seria a força dos ciclos de expansão vinculados à exportação. Para ele, nos ciclos de alta dos preços das exportações, os países dependentes tenderiam a acelerar seu crescimento. No entanto, as importações teriam alta elasticidade em relação ao crescimento real desses países. Como consequência, o dinamismo da economia acabaria impondo uma taxa de crescimento das importações acima da taxa de crescimento das exportações. Isso seria uma das causas para a piora dos termos de troca. Ainda, conforme Prebisch, o crescimento observado em momentos de alta dos preços não gera um crescimento proporcional nos investimentos nos setores não exportadores:

Resumindo o nosso pensamento: A explicação da deterioração está na insuficiência dinâmica do desenvolvimento, que não facilita a absorção da mão-de-bra não requerida pelo lento crescimento da procura e pelo aumento da produtividade nas atividades primárias. 
Estas insuficiência dinâmica impede que os salários destas últimas subam paralelamente ao aumento de produtividade e, na medida em que isso aconteça, a produção primária perde, totalmente ou em parte, o fruto do seu progresso técnico. ${ }^{59}$

Mesmo quando ocorrem investimentos produtivos no setor exportado, os ganhos de produtividade se concentram nele, sem impacto proporcional na renda da população local. Ainda, o setor exportador de bens primários possui baixa demanda de insumos ou bens intermediários locais. Na verdade, parte considerável dos insumos e dos bens de capital utilizados tendem a ser importados. Nesse cenário, o crescimento proporcionado no período de alta das exportações tende a ser compensado por um crescimento mais que proporcional das importações.

No caso brasileiro, para o período de 2003 a 2013, conforme pode-se verificar na tabela 2.5 (referente às contas (2.6), (2.7), (2.8), (2.9), (2.10), e (2.11)), a elasticidade-renda das importações para o crescimento real do PIB foi de 3,869. Isso quer dizer que, para cada ponto percentual a mais na taxa de crescimento do produto interno brasileiro, seria necessário um crescimento de quase 3,9 por cento das importações. A fim de sustentar esse processo, seria necessário que as exportações crescessem em igual ritmo.

Tabela 2.5 Elasticidade-renda das importações e taxas de crescimento da economia brasileira, 2003 a 2013

(A) Elasticidade-renda das importações brasileiras em dólares constantes, com valores do crescimento real do PIB e FBCF, 2003 a 2013 (modelo log-log)

\begin{tabular}{|c|c|c|c|c|c|c|c|c|c|}
\hline (I) & (II) & (III) & (IV) & (V) & (VI) & (VII) & (VIII) & (IX) & (X) \\
\hline Regressão & $\begin{array}{c}\text { Variável } \\
\text { dependente }\end{array}$ & $\begin{array}{c}\text { Variável } \\
\text { independente }\end{array}$ & $\begin{array}{c}\text { Coeficiente } \\
\mathbf{A}\end{array}$ & $\begin{array}{c}\text { Coeficiente } \\
\mathbf{B}\end{array}$ & $\begin{array}{c}\text { Erro } \\
\text { padrão } \\
\text { de A }\end{array}$ & $\begin{array}{c}\text { Erro } \\
\text { padrão de } \\
\mathbf{B}\end{array}$ & Elasticidade & $\mathbf{R}^{2}$ & DW \\
\hline $\begin{array}{c}\mathbf{2 . 6} \\
\text { Mrd = a+ } \\
\text { PIB }\end{array}$ & $\begin{array}{c}\text { Importação } \\
\text { brasileira } \\
\text { em dólares } \\
\text { constantes }\end{array}$ & $\begin{array}{c}\text { Índice do PIB } \\
\text { real brasileiro }\end{array}$ & $(13,23)$ & 3,87 & 0,98 & 0,21 & 3,869 & 0,974 & 2,151 \\
\hline $\begin{array}{c}\mathbf{2 . 7} \\
\text { Mrd = a+ } \\
\text { FBCF }_{\mathrm{r}}\end{array}$ & $\begin{array}{c}\text { Importação } \\
\text { brasileira } \\
\text { em dólares } \\
\text { constantes }\end{array}$ & $\begin{array}{c}\text { Índice da FBCF } \\
\text { real brasileiro }\end{array}$ & $(6,49)$ & 2,40 & 0,92 & 0,19 & 2,399 & 0,945 & 1,008 \\
\hline Nota 1: valores negativos entre parênteses. & & & & & & \\
\hline
\end{tabular}

59 PREBISCH, Raúl. Dinâmica do Desenvolvimento Latino-Americano. Rio de Janeiro: Fundo de Cultura Brasil, 1969. Pg. 98. 
Tabela 2.5 (continuação) Elasticidade-renda das importações e taxas de crescimento da economia brasileira, 2003 a 2013

(B) Taxas de crescimento de componentes da economia brasileira, 2003 a 2013 (modelo log-lin)

\begin{tabular}{|c|c|c|c|c|c|c|c|c|c|}
\hline (I) & (II) & (III) & (IV) & $(\mathrm{V})$ & $(\mathrm{VI})$ & (VII) & (VIII) & $(\mathrm{X})$ & $(\mathrm{XI})$ \\
\hline Regressão & $\begin{array}{c}\text { Variável } \\
\text { dependente }\end{array}$ & $\begin{array}{c}\text { Variável } \\
\text { independente }\end{array}$ & $\begin{array}{c}\text { Coeficiente } \\
\text { A }\end{array}$ & $\begin{array}{c}\text { Coeficiente } \\
\text { B }\end{array}$ & $\begin{array}{c}\text { Taxa de } \\
\text { crescimento }\end{array}$ & $\begin{array}{c}\text { Erro } \\
\text { padrão de } \\
\text { A }\end{array}$ & $\begin{array}{c}\text { Erro } \\
\text { padrão } \\
\text { de B }\end{array}$ & $\mathbf{R}^{2}$ & DW \\
\hline $\begin{array}{c}2.8 \\
\mathrm{PIBr}=\mathrm{a}+ \\
\mathrm{T}_{\mathrm{i}}\end{array}$ & PIB real & Tempo & 4,31 & 0,037 & $3,77 \%$ & 0,02 & 0,002 & 0,978 & $\begin{array}{c}1,44 \\
1\end{array}$ \\
\hline $\begin{array}{c}2.9 \\
\text { FBCFr }=a+ \\
T_{\mathrm{i}}\end{array}$ & FBCF real & Tempo & 4,20 & 0,054 & $5,55 \%$ & 0,09 & 0,009 & 0,805 & $\begin{array}{c}1,58 \\
7\end{array}$ \\
\hline $\begin{array}{c}2.10 \\
\operatorname{Xrd}=\mathrm{a}+\mathrm{T}_{\mathrm{i}}\end{array}$ & Exportações & Tempo & 3,77 & 0,096 & $10,08 \%$ & 0,13 & 0,013 & 0,863 & $\begin{array}{c}1,59 \\
3\end{array}$ \\
\hline $\begin{array}{c}2.11 \\
\operatorname{Mrd}=\mathrm{a}+\mathrm{T}_{\mathrm{i}}\end{array}$ & Importações & Tempo & 3,47 & 0,143 & $15,37 \%$ & 0,14 & 0,014 & 0,922 & $\begin{array}{c}1,86 \\
2\end{array}$ \\
\hline
\end{tabular}

Nota 1: valores negativos entre parênteses.

Nota 2: Exportações e importações em dólares constantes de 2006.

*Dados: MDIC, e World Bank Data.

O PIB brasileiro atingiu a taxa de crescimento médio geométrico de 3,75\% no período. A formação bruta de capital fixo apresentou crescimento mais acelerado, atingindo a taxa de 5,5\% ao ano. A fim de sustentar essas taxas, as importações teriam que crescer entre 14,52 e 13,30 por cento ao ano. Na prática, cresceu 14,82\%, atingindo crescimento acima do expectado. Enquanto isso, as exportações cresceram apenas 10\% ao ano.

Dessa forma, por mais que o crescimento das exportações tenham permitido a recuperação econômica, mesmo durante o ciclo de alta dos preços a economia brasileira já estaria enfrentando redução na capacidade de captação de recursos externos. Daí o desempenho positivo ser apenas aparente, e ser insuficiente para superar o problema estrutural.

\subsection{CARACTERÍSTICAS DO COMÉRCIO EXTERIOR BRASILEIRO}

Nas seções anteriores, foi apresentada uma leitura do desempenho e da importância do comércio exterior brasileiro. Alguns aspectos detectados na pesquisa foram explicados a partir de uma leitura das características gerais do balanço comercial brasileiro. Entre eles, o fato da pauta de exportação ser altamente "primária”, e da pauta de importação ser composta principalmente de bens de capital e insumos para produção. Segundo Celso Furtado, isso 
caracteriza o subdesenvolvimento.

Embora essa primeira observação ajude a leitura dos dados observados até aqui, não basta para entender o processo de fortalecimento e posterior degeneração dos termos de troca. É necessário tratar a composição do BC de forma histórica. A proporção e o peso dos diferentes produtos na pauta de exportação e a de importação não se mantiveram inalteradas durante todo o período. A fim de facilitar a exposição, essa seção será dividida em quatro partes: (i) características das exportações; (ii) as exportações e os problemas estruturais; (iii) características das importações; e (iv) as importações e os problemas estruturais.

\subsubsection{CARACTERÍSTICAS DAS EXPORTAÇÕES BRASILEIRAS}

As exportações brasileiras apresentaram um desempenho excepcional entre 2003 e 2006, do ponto de vista dos termos de troca. A partir de 2006, houve deterioração. Naquele ano também teve início um processo de reprimarização da pauta de exportação. Isso se caracteriza pelo ganho de importância relativa dos bens primários na pauta de exportação em relação aos bens manufaturados e semimanufaturados. Em 2010, os bens ditos primários passaram a ser a maioria dos bens exportados pelo Brasil. O crescimento da exportação de produtos primários não é por si só um dado negativo. Na verdade, poderia ser uma fonte de financiamento importante para futura industrialização, conforme lembram Alain Géledan e Janine Brémond. O problema consiste em que nem o setor extrativo, nem o agrícola, são capazes de gerar, por si só, impulso industrializante. ${ }^{60}$

Parte dessa reprimarização foi causada pelo ganho de importância das matériasprimas, um aumento de 54,7\% para 63,3\% das exportações, entre 2001 e 2011. Um fenômeno também importante foi o aumento das exportações de combustíveis e lubrificantes, com salto de 3,5\% para 10,4\%, entre 2001 e 2011. Também houve uma queda de importância das exportações de bens de capital, expressando queda de 16,1\% para 9,1\%, no mesmo período; e de bens de consumo, duráveis e não duráveis, com quedas respectivas de 6,7\% para 2,9\% e $16,9 \%$ para $12,3 \%$.

60 GÉLÉDAN, Alain \& BRÉMOND, Janine. Dicionário das Teorias e Mecanismos Económicos. Lisboa: Livros Horizonte LTDA, 1988. Pg. 425 - 426 


\begin{tabular}{|l|l|l|l|l|l|}
\hline \multicolumn{5}{|c|}{ Tabela 2.6 Composição da pauta de exportação brasileira por categoria de uso, 1999 a 2013} \\
\hline (I) & (II) & (III) & (IV) & (V) & (VI) \\
\hline Ano & $\begin{array}{l}\text { Bens de } \\
\text { capital }\end{array}$ & $\begin{array}{l}\text { Bens de consumo } \\
\text { não duráveis }\end{array}$ & $\begin{array}{l}\text { Bens de consumo } \\
\text { duráveis }\end{array}$ & $\begin{array}{l}\text { Combustíveis e } \\
\text { lubrificantes }\end{array}$ & $\begin{array}{l}\text { Matérias-primas e produtos } \\
\text { intermediários }\end{array}$ \\
\hline 1999 & 13,95 & 17,35 & 5,59 & 0,79 & 60,61 \\
\hline 2000 & 17,27 & 15,39 & 6,64 & 1,57 & 57,18 \\
\hline 2001 & 16,10 & 16,88 & 6,72 & 3,53 & 54,73 \\
\hline 2002 & 14,16 & 16,97 & 6,43 & 4,79 & 55,91 \\
\hline 2003 & 12,58 & 16,38 & 6,48 & 5,13 & 57,73 \\
\hline 2004 & 15,01 & 16,07 & 6,24 & 4,52 & 56,63 \\
\hline 2005 & 15,24 & 15,86 & 6,11 & 5,92 & 55,04 \\
\hline 2006 & 14,08 & 14,91 & 5,48 & 7,62 & 56,01 \\
\hline 2007 & 14,44 & 15,58 & 4,94 & 8,20 & 54,98 \\
\hline 2008 & 13,51 & 14,76 & 4,19 & 9,33 & 55,78 \\
\hline 2009 & 10,49 & 16,52 & 3,84 & 8,86 & 58,47 \\
\hline 2010 & 9,67 & 14,20 & 3,67 & 9,76 & 60,83 \\
\hline 2011 & 9,13 & 12,32 & 2,88 & 10,36 & 63,33 \\
\hline 2012 & 9,97 & 12,70 & 2,73 & 10,81 & 61,64 \\
\hline 2013 & 11,51 & 13,12 & 3,44 & 7,24 & 62,69 \\
\hline & & & & & \\
\hline
\end{tabular}

Houve largo investimento para que houvesse ganho de competitividade na exportação de combustíveis e lubrificantes, em especial através dos investimentos da Petrobras, e de matérias-primas. Dentre as matérias-primas destacou-se a exportação de minérios, cujo principal empresa é a Vale ${ }^{61}$, e ainda a soja.

Na tabela 2.7, verifica-se o crescimento do valor exportado dos cinco principais produtos da pauta de exportação brasileira. O critério utilizado para destacar esses cinco produtos foi o valor total exportado no período entre 1999 e 2013. Observa-se que esse produtos atingiram alto crescimento no valor exportado, entre 2001 e 2011. O item que observou maior expansão foi a exportação de óleo de petróleo em bruto, atingindo o crescimento total de quase 2,9 mil por cento no período. Os minérios de ferro e seus concentrados atingiram a segunda maior expansão, com mais de 1,3 mil por cento.

61 Trata-se da empresa Vale do Rio Doce, antiga empresa estatal brasileira da área de mineração. Foi fundada em 1942, durante a Segunda Guerra Mundial. Foi tratada como empresa estratégica, até 1997. Naquele ano foi privatizada. Conforme ressalta a Associação de engenheiros da Petrobras (na notícia Desfazendo Mentiras Sobre A Vale Do Rio Doce, de 26/10/2007, disponível no site http://www.aepet.org.br/noticias/pagina/5948, última visualização em 19/09/2017.), a Vale do Rio Doce foi vendida abaixo de seu valor de mercado conforme o cálculo aplicado para empresas de capital aberto; e inferior até mesmo ao valor de seu patrimônio. 


\begin{tabular}{|c|c|c|c|c|c|}
\hline (I) & (II) & (III) & (IV) & (V) & (VI) \\
\hline & $\begin{array}{l}\text { Minérios de ferro e } \\
\text { seus concentrados }\end{array}$ & $\begin{array}{l}\text { Soja mesmo } \\
\text { triturada }\end{array}$ & $\begin{array}{l}\text { Óleos brutos de } \\
\text { petróleo }\end{array}$ & $\begin{array}{l}\text { Açúcar de } \\
\text { cana,em bruto }\end{array}$ & $\begin{array}{l}\text { Farelo e resíduos da } \\
\text { extração de óleo de } \\
\text { soja }\end{array}$ \\
\hline 1999 & 2,746 & 1,593 & 0,000 & 1,162 & 1,504 \\
\hline 2000 & 3,048 & 2,188 & 0,000 & 0,761 & 1,651 \\
\hline 2001 & 2,932 & 2,726 & 0,721 & 1,401 & 2,065 \\
\hline 2002 & 3,049 & 3,032 & 1,691 & 1,111 & 2,199 \\
\hline 2003 & 3,456 & 4,290 & 2,122 & 1,350 & 2,602 \\
\hline 2004 & 4,759 & 5,395 & 2,528 & 1,511 & 3,271 \\
\hline 2005 & 7,297 & 5,345 & 4,164 & 2,382 & 2,865 \\
\hline 2006 & 8,949 & 5,663 & 6,894 & 3,936 & 2,419 \\
\hline 2007 & 10,558 & 6,709 & 8,905 & 3,130 & 2,957 \\
\hline 2008 & 16,539 & 10,952 & 13,556 & 3,650 & 4,364 \\
\hline 2009 & 13,247 & 11,424 & 9,152 & 5,979 & 4,593 \\
\hline 2010 & 28,912 & 11,043 & 16,151 & 9,307 & 4,719 \\
\hline 2011 & 41,817 & 16,327 & 21,603 & 11,549 & 5,698 \\
\hline 2012 & 30,989 & 17,455 & 20,306 & 10,030 & 6,595 \\
\hline 2013 & 32,492 & 22,812 & 12,957 & 9,164 & 6,787 \\
\hline Total & 210,788 & 126,956 & 120,750 & 66,422 & 54,289 \\
\hline \begin{tabular}{|l|} 
Crescimento \\
relativo (2001 \\
- 2011)
\end{tabular} & $1326,46 \%$ & $499,05 \%$ & $2896,83 \%$ & $724,43 \%$ & $175,90 \%$ \\
\hline
\end{tabular}

Apesar da forte expansão dos artigos de monocultura (soja e cana de açúcar), em 2005, as exportações de petróleo e minério de ferro, se somadas, superaram a da soja e do açúcar. Todos os cinco principais itens são considerados artigos de baixo valor agregado. Isso serve para caracterizar o Brasil como país primário-exportador.

Essa trajetória do comércio exterior corrobora a leitura de que o governo e o setor privado investiram mais, pelas condições estruturais, nas: (a) cadeia do petróleo; (b) mineração; e (c) monocultura. Esses três ramos dependem muito da demanda externa (em especial daquela dos países desenvolvidos, inclusive, e principalmente, China). Essa dependência pode ser historicamente amenizada através da ampliação da pauta de exportação, ou acirrada através da concentração. No entanto, a ampliação tende a gerar menor capacidade de exportação e menores taxas de lucro a curto prazo, segundo a teoria cepalina do comércio exterior. 


\section{Gráfico 2.4 Concentração das exportações \\ brasileiras, 1999 a 2013 \\ peso relativo dos cinco principais itens}

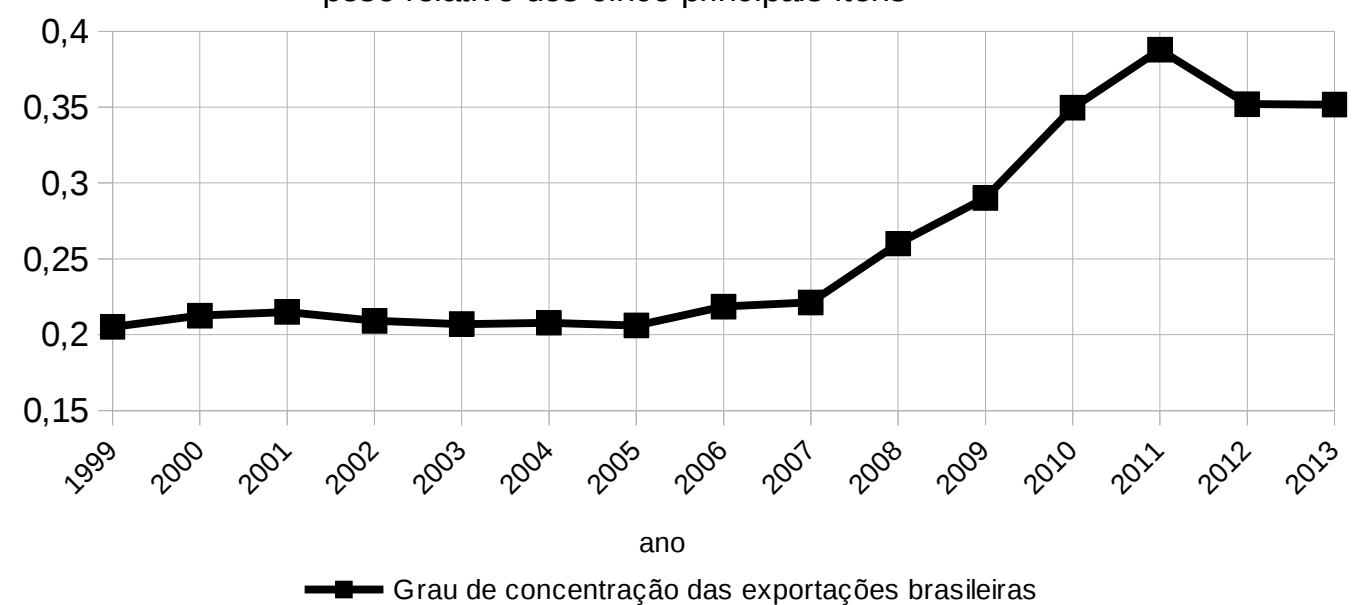

Fonte: dados MDIC. Gráfico de elaboração própria

Para medir o grau de concentração da pauta de exportação pode-se verificar a importância relativa dos cinco principais grupo de produtos exportados. Ao longo de 1999 até 2006, o grau de concentração das exportações brasileiras variou em torno de $20 \%$. A partir de então, cresceu até atingir a marca de 38\%. Isso significa que, durante todo o período estudado, os cinco principais itens representaram, sozinhos, mais de um quinto das exportações brasileiras. Quando se observa o total exportado durante todo o período (de 1999 a 2013), verifica-se que os três primeiros itens (minério de ferro, soja mesmo triturada, e óleos brutos de petróleo) atingiram um valor somado superior à soma dos dez itens seguintes. Nesse contexto, as oscilações de preço dessas poucas mercadorias, em sua maioria de baixo valor agregado, tiveram grande influência no resultado final do balanço comercial.

\subsubsection{AS EXPORTAÇÕES BRASILEIRAS E PROBLEMAS ESTRUTURAIS}

Conforme a teoria proposta por Prebisch, uma das características dos produtos exportados pelos países dependentes é que eles são elásticos em relação aos preços. Isso significa que o valor total das exportações é bastante afetado pelas oscilações dos preços que tendem a ser determinados desde fora ${ }^{62}$.

62 Sobre o assunto ver: PREBISCH, Raúl. Dinâmica do Desenvolvimento Latino-Americano. Rio de Janeiro: Fundo de Cultura Brasil, 1969. 


\begin{tabular}{|c|c|c|c|c|c|c|c|c|c|}
\hline \multicolumn{10}{|c|}{$\begin{array}{l}\text { Tabela 2.8 Elasticidade-preço dos cinco principais produtos da pauta de exportação brasileira, em preços nominais e } \\
\text { preços relativos, } 2001 \text { a } 2013\end{array}$} \\
\hline \multicolumn{10}{|c|}{ (A) Elasticidade-preço nominal, 2001 a 2013} \\
\hline (I) & (II) & (III) & (IV) & $(\mathrm{V})$ & (VI) & (VII) & (VIII) & (IX) & $(\mathrm{X})$ \\
\hline Regressão & $\begin{array}{c}\text { Variável } \\
\text { dependente }\end{array}$ & $\begin{array}{c}\text { Variável } \\
\text { independente }\end{array}$ & $\begin{array}{c}\text { Coeficiente } \\
\text { A }\end{array}$ & $\begin{array}{l}\text { Coeficiente } \\
\text { B }\end{array}$ & $\begin{array}{c}\text { Erro } \\
\text { padrão } \\
\text { de A }\end{array}$ & \begin{tabular}{|c|} 
Erro \\
padrão de \\
B
\end{tabular} & Elasticidade & $\mathbf{R}^{2}$ & DW \\
\hline $\begin{array}{c}2.12 \\
\text { VneFe = a } \\
+ \text { PnFe }\end{array}$ & $\begin{array}{c}\text { Minérios de } \\
\text { ferro } \\
\text { (nominal) }\end{array}$ & $\begin{array}{l}\text { Preço nominal } \\
\text { do minério de } \\
\text { ferro }\end{array}$ & 2,88 & 1,36 & 0,05 & 0,04 & 1,363 & 0,993 & 1,130 \\
\hline $\begin{array}{c}2.13 \\
\text { VneSjb = } \\
a+\text { PnSjb }\end{array}$ & $\begin{array}{c}\text { Soja em } \\
\text { bruto } \\
\text { (nominal) }\end{array}$ & $\begin{array}{c}\text { Preço nominal } \\
\text { da soja em bruto }\end{array}$ & 1,72 & 1,65 & 0,05 & 0,10 & 1,653 & 0,962 & 1,837 \\
\hline $\begin{array}{c}\mathbf{2 . 1 4} \\
\text { VnePtr }= \\
\mathrm{a}+\operatorname{PnPtr}\end{array}$ & $\begin{array}{l}\text { Óleo de } \\
\text { petróleo } \\
\text { bruto } \\
\text { (nominal) }\end{array}$ & $\begin{array}{l}\text { Preço nominal } \\
\text { do óleo de } \\
\text { petróleo bruto }\end{array}$ & 1,58 & 1,70 & 0,07 & 0,12 & 1,700 & 0,947 & 1,545 \\
\hline $\begin{array}{c}2.15 \\
\text { VneAc }= \\
a+\operatorname{PnAc}\end{array}$ & $\begin{array}{l}\text { Açúcar } \\
\text { bruto } \\
\text { (nominal) }\end{array}$ & $\begin{array}{l}\text { Preço nominal } \\
\text { do açúcar bruto }\end{array}$ & 1,56 & 1,79 & 0,06 & 0,10 & 1,794 & 0,970 & 1,273 \\
\hline $\begin{array}{c}2.16 \\
\text { VneRsj = } \\
\mathrm{a}+\text { PnRsj }\end{array}$ & \begin{tabular}{|c|}
$\begin{array}{c}\text { Resíduo de } \\
\text { óleo de soja } \\
\text { (nominal) }\end{array}$ \\
\end{tabular} & $\begin{array}{c}\text { Preço nominal } \\
\text { do resíduo de } \\
\text { óleo de soja }\end{array}$ & 1,15 & 1,06 & 0,04 & 0,06 & 1,060 & 0,965 & 0,933 \\
\hline \multicolumn{10}{|c|}{ (B) Elasticidades-preço relativos, 2001 a 2013} \\
\hline (I) & (II) & (III) & (IV) & $(\mathrm{V})$ & (VI) & (VII) & (VIII) & (IX) & $(\mathrm{X})$ \\
\hline Regressão & $\begin{array}{c}\text { Variável } \\
\text { dependente }\end{array}$ & $\begin{array}{c}\text { Variável } \\
\text { independente }\end{array}$ & $\begin{array}{c}\text { Coeficiente } \\
\text { A }\end{array}$ & $\begin{array}{l}\text { Coeficiente } \\
\text { B }\end{array}$ & $\begin{array}{c}\text { Erro } \\
\text { padrão } \\
\text { de A }\end{array}$ & \begin{tabular}{|c|} 
Erro \\
padrão de \\
B \\
\end{tabular} & Elasticidade & $\mathbf{R}^{2}$ & DW \\
\hline $\begin{array}{c}2.17 \\
\text { VreFe }=\mathrm{a} \\
+\mathrm{PrFe}\end{array}$ & $\begin{array}{l}\text { Minérios de } \\
\text { ferro (real) }\end{array}$ & $\begin{array}{l}\text { Preço relativo } \\
\text { do minério de } \\
\text { ferro }\end{array}$ & 2,94 & 1,41 & 0,06 & 0,04 & 1,405 & 0,989 & 1,112 \\
\hline $\begin{array}{c}\text { 2.18 } \\
\text { VreSjb = a } \\
+ \text { PrSjb }\end{array}$ & $\begin{array}{c}\text { Soja em } \\
\text { bruto (real) }\end{array}$ & $\begin{array}{c}\text { Preço relativo da } \\
\text { soja em bruto }\end{array}$ & 1,78 & 1,78 & 0,07 & 0,14 & 1,775 & 0,936 & 1,715 \\
\hline $\begin{array}{c}2.19 \\
\text { VrePtr }=a \\
+ \text { PrPtr }\end{array}$ & $\begin{array}{c}\text { Óleo de } \\
\text { petróleo } \\
\text { bruto (real) }\end{array}$ & $\begin{array}{l}\text { Preço relativo } \\
\text { do óleo de } \\
\text { petróleo bruto }\end{array}$ & 1,63 & 1,80 & 0,07 & 0,14 & 1,798 & 0,935 & 1,598 \\
\hline $\begin{array}{c}2.20 \\
\text { VreAc }=a \\
+\operatorname{PrAc} \\
\end{array}$ & $\begin{array}{c}\text { Açúcar } \\
\text { bruto (real) }\end{array}$ & $\begin{array}{l}\text { Preço relativo } \\
\text { do açúcar bruto }\end{array}$ & 1,63 & 1,91 & 0,08 & 0,13 & 1,911 & 0,949 & 1,165 \\
\hline $\begin{array}{c}2.21 \\
\text { VreRsj }=\mathrm{a} \\
+ \text { PrRsj }\end{array}$ & $\begin{array}{c}\text { Resíduo de } \\
\text { óleo de soja } \\
\text { (real) }\end{array}$ & $\begin{array}{l}\text { Preço relativo } \\
\text { do resíduo de } \\
\text { óleo de soja }\end{array}$ & 1,16 & 1,07 & 0,04 & 0,08 & 1,071 & 0,948 & 0,930 \\
\hline \multicolumn{10}{|c|}{ Nota 1: Valores negativos entre parênteses } \\
\hline \multicolumn{10}{|c|}{ Nota 2: Variáveis em dólares constantes } \\
\hline \multicolumn{10}{|c|}{ *dados: MDIC e USA Bureau of Economic Analysi } \\
\hline
\end{tabular}


Observa-se, na tabela 2.8, que a exportação dos cinco principais itens da pauta de exportação foram elásticos em relação ao preço, tanto em valores nominais como relativos em dólares constantes. Isso significa que, durante o período, os principais itens da exportação brasileira foram bastante sensíveis às oscilações dos preços. Enquanto os preços oscilaram para cima, isso foi vantajoso ao país.A alta dos preços levou à expansão das exportações, mas também à concentração da pauta exportadora em torno de itens com alta elasticidade-preço. A consequência foi (i) a aquisição de divisas em curto prazo; e (ii) a fragilização potencial do comércio exterior brasileiro.

O problema estrutural permaneceu, apesar da aparente melhora das contas externas. Devido aos largos lucros adquiridos na exportação desses bens, que passaram por alta dos preços, houve ganho de importância dos mesmos. A alta dos lucros atraiu novos investimentos, e resultou na expansão da produção dos mesmos. O problema é que eram de produtos demasiadamente sensíveis aos preços. Logo, o ganho de participação deles na pauta de exportação expôs uma parcela maior da pauta às oscilações dos preços de poucos produtos. A vantagem momentânea não só não reverteu como acirrou a fragilidade do país. Os problemas estruturais, no lugar de serem combatidos, foram fortalecidos.

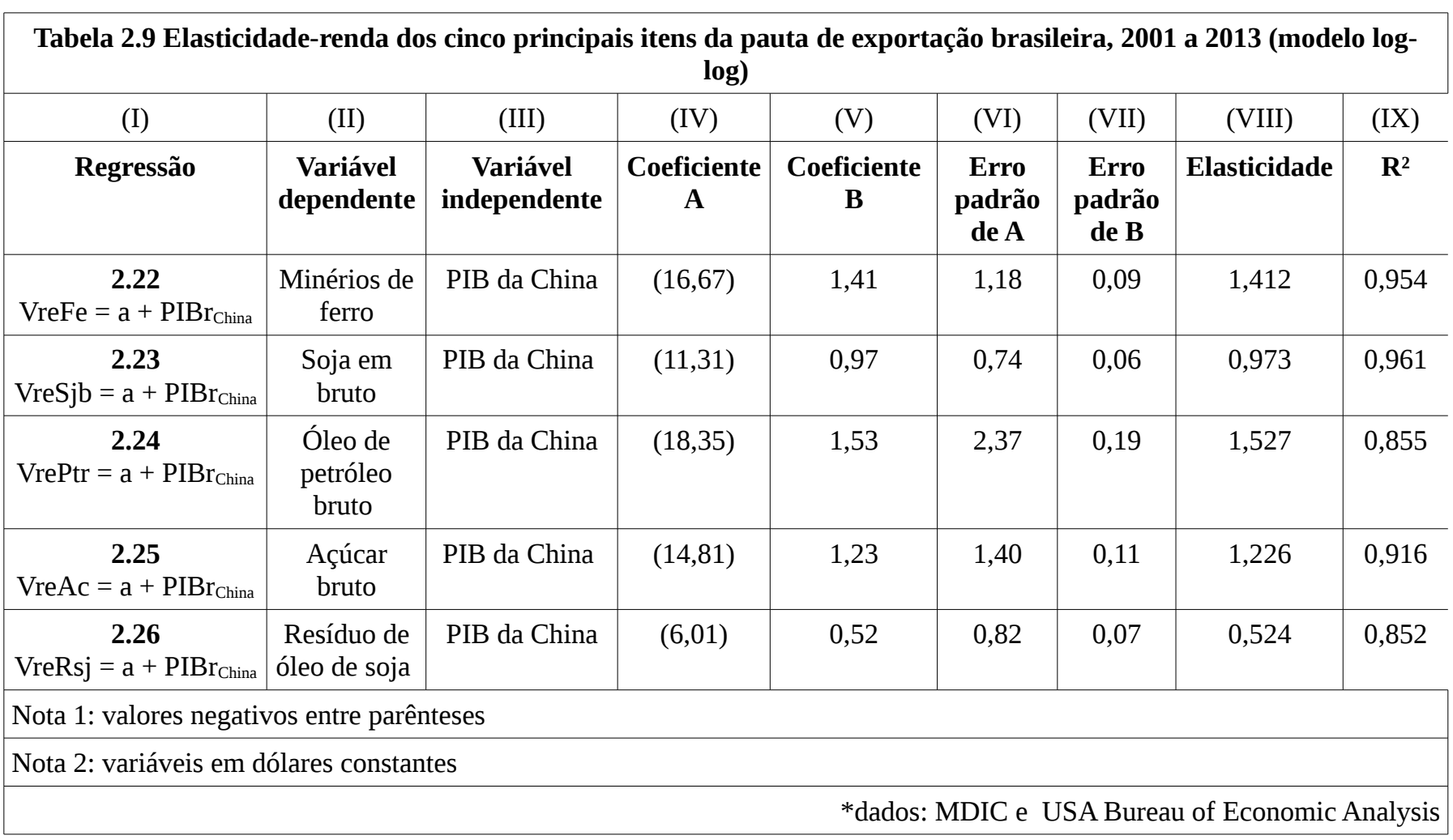


Conforme já apresentado, o sucesso da parceria comercial com a China, permitiu ao Brasil desfrutar de parte do aumento de dinamismo do país asiático. Esse benefício se concentrou em torno dos principais itens da pauta de exportação brasileira, para o período. Isso permitiu que a exportação de minério de ferro, petróleo, soja, e açúcar, aumentasse bastante acima do crescimento do PIB dos países desenvolvidos. O aumento da demanda chinesa permitiu a expansão dos preços e do volume exportado. Note-se que, para esses produtos específicos, a elasticidade renda, representada na tabela 2.9 (referente às regressões 2.22 a 2.26), foi bastante superior àquela encontrada para o conjunto das exportações brasileiras. Esse comportamento ajuda a explicar o impulso para reprimarização da exportação. Não foi algo fruto de uma política de estado, mas sim que aconteceu como resultado da estrutura produtiva brasileira e da conjuntura internacional: havia maior possibilidade de expansão na venda desses produtos do que em outros.

Para alguns, a fase de expansão da economia brasileira, advinda do dinamismo econômico gerado pelo sucesso da parceria China-EUA ${ }^{63}$, não teria se resumido ao aumento de exportações para a China. Na verdade, teria ocorrido aumento da variedade de parceiros comerciais. Em especial, houve diminuição da participação relativa da União Europeia e dos EUA como destino de nossas exportações, entre 1999 e 2013. No entanto, há duas ressalvas a serem feitas: (a) o ganho de importância de novos parceiros teve comportamento diferente a depender do tipo de mercadoria em análise; e (b) as economias dos parceiros comerciais do Brasil continuam dependentes do desempenho dos países desenvolvidos.

Apesar da demanda chinesa por matérias-primas e bens intermediários ter aumentado a partir de 2001, o maior parceiro comercial do Brasil para esse tipo de produto foi a América Latina. Os países membros da ALADI e do Mercosul já eram parceiros importantes, e ganharam ainda mais espaço durante o período analisado. Processo similar ocorreu com as exportações brasileiras de bens de capital. A demanda dos EUA de bens de capital brasileiros apresentou queda relativa entre 1999 e 2013. Enquanto isso, a demanda latino-americana aumentou bastante, saltando de 19,7\% das exportações brasileiras (desse tipo de item) em 2002, para 49,9\%, em 2013.

63 Para uma leitura sobre os principais aspectos da parceria EUA-CHINA durante os anos 2000 e 2010, ver: SCREPANTI, Ernesto. Global Imperialism and the Great Crisis. Nova Iorque: Monthly Review Press, 2014. 
Tabela 2.10 Participação (em porcentagem) dos diferentes blocos econômicos no destino das exportações brasileiras, 1999 a 2013

\begin{tabular}{|c|c|c|c|c|}
\hline (I) & $(\mathrm{II})$ & $(\mathrm{III})$ & $(\mathrm{IV})$ & $(\mathrm{V})$ \\
\hline ano & $\begin{array}{c}\text { Ásia (exclusive oriente } \\
\text { médio) }\end{array}$ & $\begin{array}{c}\text { Estados Unidos (inclusive } \\
\text { porto rico) }\end{array}$ & $\begin{array}{c}\text { ALADI e } \\
\text { Mercosul }\end{array}$ \\
\hline 1999 & 11,93 & 22,53 & 28,52 & 21,96 \\
\hline 2000 & 11,47 & 24,20 & 26,74 & 23,39 \\
\hline 2001 & 11,92 & 24,62 & 25,42 & 20,96 \\
\hline 2002 & 14,55 & 25,69 & 24,97 & 16,32 \\
\hline 2003 & 15,97 & 23,09 & 24,73 & 17,66 \\
\hline 2004 & 15,09 & 19,68 & 25,00 & 20,41 \\
\hline 2005 & 15,67 & 19,20 & 22,35 & 21,48 \\
\hline 2006 & 15,12 & 17,93 & 22,06 & 22,82 \\
\hline 2007 & 15,61 & 15,74 & 25,13 & 22,67 \\
\hline 2008 & 18,91 & 13,94 & 22,40 & 21,76 \\
\hline 2009 & 25,76 & 10,25 & 21,33 & 19,53 \\
\hline 2010 & 27,86 & 9,61 & 20,65 & 20,39 \\
\hline 2011 & 29,94 & 10,10 & 20,10 & 19,38 \\
\hline 2012 & 31,03 & 11,02 & 19,63 & 18,56 \\
\hline 2013 & 32,05 & 10,14 & & Fonte: dados MDIC. \\
\hline
\end{tabular}

A Ásia só foi a principal região destino das exportações brasileiras nos itens "bens de consumo duráveis e não duráveis”, e no item “combustíveis e lubrificantes”. Em ambos os casos a importância relativa dos EUA declinou, no período analisado. Dado o peso individual dos produtos importados pela Ásia, em especial pela China, no conjunto dos produtos, aquela região foi a única a demonstrar ganho de importância relativa de forma quase constante. Os EUA passaram a se tornar um comprador menos importante dos produtos brasileiros a partir de 2001. Os países da América Latina permaneceram praticamente no mesmo nível de importância relativa, apesar deste ter passado por oscilações.

A tese de que houve diminuição da concentração da exportação, entenda-se ampliação da diversidade da parceria comercial sobre o conjunto das exportações, se sustenta pela queda de importância dos EUA e aumento da importância da Ásia. No entanto, quando a análise é feita pelo peso relativo dos grupos econômicos, a desconcentração ocorreu apenas entre 1999 e 2006. A partir daí, houve nova fase de aumento da concentração, em favor da Ásia. Os três principais blocos econômicos parceiros do Brasil (EUA, União Europeia, e América Latina) representavam, em 1999, 73\% das exportações brasileiras. Em 2013, a Ásia, a União Europeia, e América Latina representavam pouco menos de 72,5\%. Isso caracteriza uma mudança na concentração, ao invés de uma diversificação. 


\subsubsection{CARACTERÍSTICAS DAS IMPORTAÇÕES BRASILEIRAS}

A principal mudança nas importações brasileiras, entre 1999 e 2013, foi a diminuição da participação relativa das matérias-primas e bens intermediários, e dos bens de capital, na pauta de importação. Essa queda relativa teve início em 2001, para os bens de capital, e 2003, para as matérias-primas e bens intermediários. Para os bens de capital, houve um pequeno período por recuperação, entre 2008 e 2010. Possivelmente, isso resultou de a demanda de equipamentos ter diminuído menos do que a demanda por insumos. Tal é condizente com o grau de elasticidade-renda ${ }^{64}$ esperado para esses tipos de produto.

\begin{tabular}{|c|c|c|c|c|c|}
\hline \multicolumn{6}{|c|}{ Tabela 2.11 Composição da pauta de importação brasileira por categoria de uso, 1999 a 2013 } \\
\hline (I) & (II) & (III) & (IV) & (V) & (VI) \\
\hline Ano & Bens de capital & $\begin{array}{c}\text { Bens de consumo não } \\
\text { duráveis }\end{array}$ & $\begin{array}{c}\text { Bens de consumo } \\
\text { duráveis }\end{array}$ & $\begin{array}{c}\text { Combustíveis e } \\
\text { lubrificantes }\end{array}$ & $\begin{array}{c}\text { Matérias-primas e } \\
\text { produtos intermediários }\end{array}$ \\
\hline 1999 & 27,54 & 8,47 & 6,44 & 8,64 & 48,91 \\
\hline 2000 & 24,36 & 7,05 & 6,05 & 11,40 & 51,13 \\
\hline 2001 & 26,63 & 6,46 & 6,33 & 11,29 & 49,29 \\
\hline 2002 & 24,54 & 7,20 & 5,31 & 13,30 & 49,65 \\
\hline 2003 & 21,44 & 6,47 & 5,01 & 13,63 & 53,45 \\
\hline 2004 & 19,31 & 5,85 & 5,08 & 16,41 & 53,35 \\
\hline 2005 & 20,92 & 6,19 & 5,34 & 16,21 & 51,34 \\
\hline 2006 & 20,69 & 6,48 & 6,65 & 16,63 & 49,55 \\
\hline 2007 & 20,83 & 6,44 & 6,84 & 16,64 & 49,25 \\
\hline 2008 & 20,74 & 5,67 & 7,34 & 18,17 & 48,08 \\
\hline 2009 & 23,26 & 7,76 & 9,10 & 13,12 & 46,76 \\
\hline 2010 & 22,57 & 7,07 & 10,23 & 13,95 & 46,18 \\
\hline 2011 & 21,17 & 7,07 & 10,65 & 15,99 & 45,12 \\
\hline 2012 & 21,79 & 7,69 & 9,96 & 15,82 & 44,74 \\
\hline 2013 & 21,56 & 7,82 & 9,28 & 16,90 & 44,45 \\
\hline \multicolumn{5}{|r|}{} \\
\hline
\end{tabular}

Como ambos os tipos de item são compostos por mercadorias importantes para o investimento em produção, a mudança do perfil de importações poderia ser fruto de: (a) aumento da capacidade nacional de oferta de meios e insumos para produção; ou (b) degeneração da capacidade relativa de investimento do país. Para o caso das importações de matérias-primas e bens intermediários, a primeira opção parece ser verdadeira. Para os bens de capital, as oscilações nas importações parecem corresponder ao inverso das oscilações na capacidade de importação (que será melhor demonstrada na tabela 4.12). Estas foram negativas até 2003. A partir de então, foram oscilantes com tendência ao crescimento até

64 Medida para a o quanto se aumenta a demanda de importação de um item de acordo com o aumento da renda (PIB) de um país. 
2008.

Isso significa que, quanto maior a capacidade brasileira para importar, menor foi a participação dos bens de capital nas importações brasileiras. Assim, a capacidade de importar não foi utilizada para financiar novos investimentos na capacidade produtiva brasileira. No lugar, foi financiada a importação de bens de consumo duráveis e de combustíveis e lubrificantes. Uma das características negativas detectadas no modelo proposto por Prebisch é justamente que durante a fase de expansão das exportações, não haja investimento adequado na indústria local. O consumo interno, e também os investimentos, mantém sua dependência da oferta externa. Isso faz com que no período seguinte, quando os termos de troca sofrem deterioração, haja desaquecimento da capacidade de crescimento.

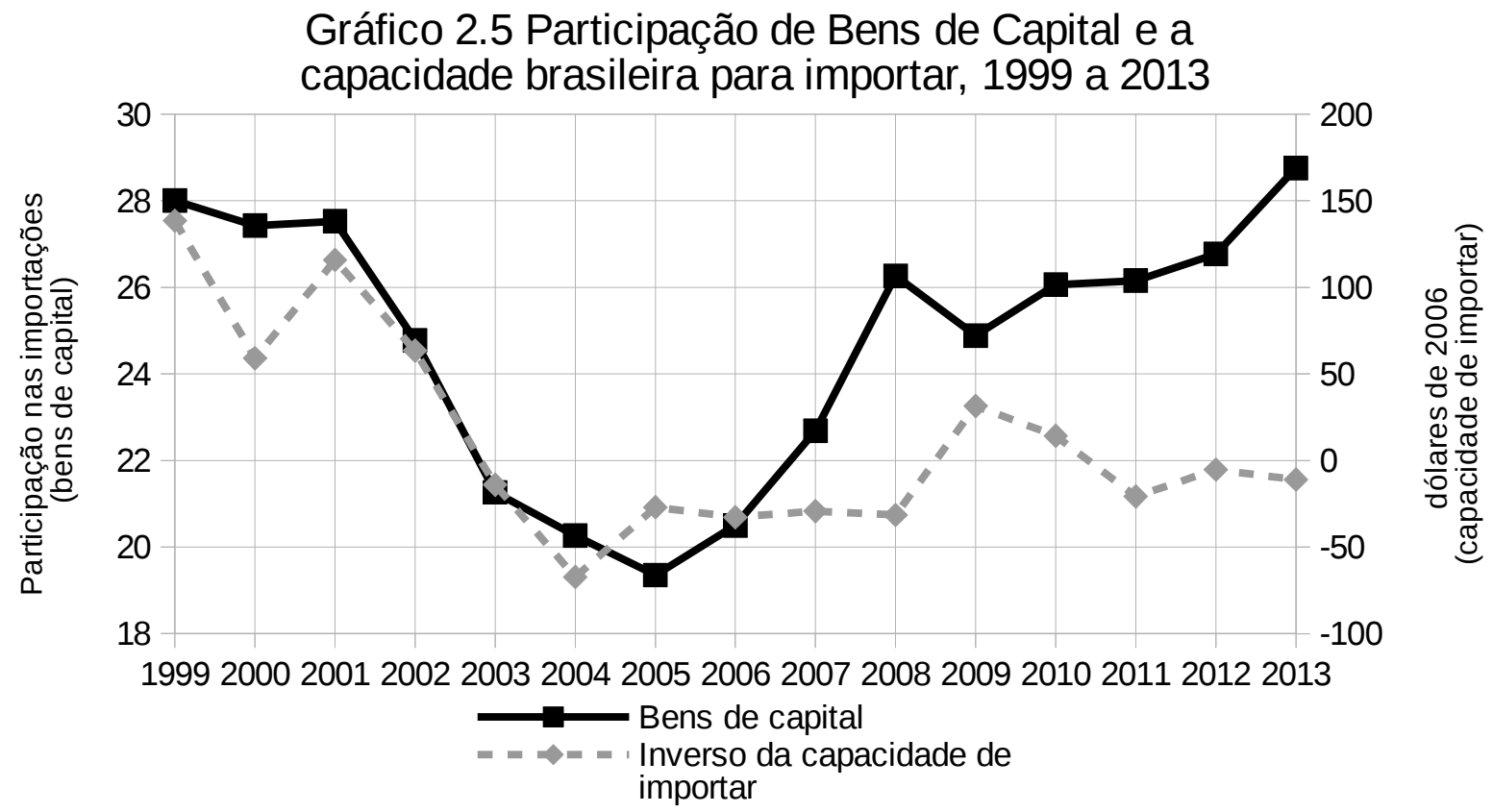

As importações de bens de consumo duráveis e não duráveis aumentaram em relação às demais importações. A demanda brasileira de bens de consumo duráveis importados aumentou a partir de 2003, saltando cerca de 5,5 pontos percentuais em apenas 8 anos. Já a demanda de bens de consumo não duráveis sofreu queda relativa até 2008, aumentando a partir de então. Em 2011, juntos, os bens de consumo totalizaram 18,35\% das importações. Isso é indício de que a demanda por bens de consumo estavam sendo supridas pelas importações, como uma das consequências da perda de produtividade da industria brasileira. Ainda, o real valorizado teria induzido o consumo de bens importados.

A demanda brasileira por combustíveis e lubrificantes apresentou crescimento até 
2008, sofrendo forte queda em 2009, se recuperando lentamente a partir de então. Em 1999, as importações desse tipo de item representavam cerca de 8,6\% da pauta de importação. Em 2013, chegou a representar 16,9\%, havendo atingido quase 18,2\% em 2008. Entre 2002 e 2008, a importação brasileira de combustíveis e lubrificantes foi maior que a similar de bens de consumo. Note-se que esse tipo de produto é ao mesmo tempo insumo para a produção e para o transporte. Como o consumo de veículos só aumentou durante o período analisado, parte do aumento pela demanda de combustível se justifica pelo aumento da demanda de transporte coletivo e individual. Ainda, desde 2006, os preços dos combustíveis deixaram de ser reajustados no mercado interno, o que só pode ser sustentado pelo aumento da importação desse grupo de produtos. Apesar disso, não se deve menosprezar a importância dos combustíveis e lubrificantes para a indústria e para a agropecuária: o Brasil é o maior consumidor mundial de “defensivos” agrícolas ${ }^{65}$, e mecanizou boa parte de sua produção.

Tabela 2.12 Cinco principais itens da pauta de importação brasileira, exportação em milhões de dólares, 1999 a 2013

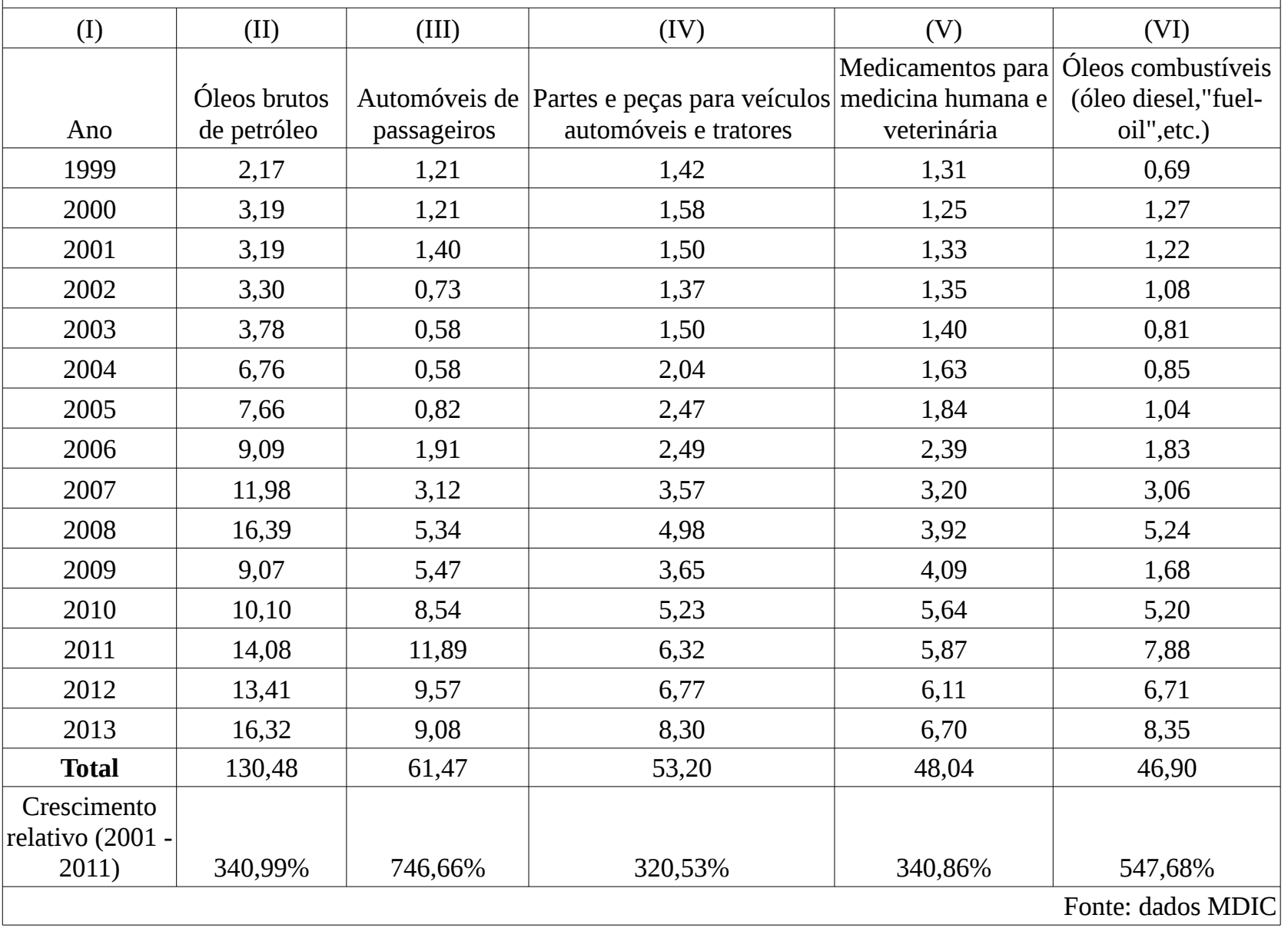

65 Notícia da Agência Câmara, de setembro de 2014. Ver: http://www.perfilnews.com.br/noticias/brasilmundo/brasil-ainda-e-o-maior-consumidor-de-defensivos-agricolas-do-mundo, última visualização em 11/09/2017. 
Os cinco principais produtos da pauta de importação, considerando o valor importado entre 1999 e 2013, foram: (a) óleos brutos de petróleo; (b) automóveis de passageiro; (c) partes e peças para veículos automóveis e tratores; (d) medicamentos para medicina humana e veterinária; e (f) óleos combustíveis. Essa pauta revela um país (i) que supre parte de sua demanda energética por via da importação; (ii) de sistema de transporte dependente do fornecimento externo; e (iii) de alto gasto em farmacêuticos.

A demanda por automóveis importados e por combustível aumentou depois do período auge das relações dos termos de troca brasileiro. No entanto, foram as que apresentaram maior crescimento total. O bom desempenho das exportações serviu de incentivo para novos gastos e investimentos no país, levando à diversificação da pauta de importações. Parte do importado foram bens para consumo. Não se deve descartar, no entanto, o peso dos investimentos produtivos na época. Haja vista que, durante o período, a elasticidade-renda das importações explicadas pelos investimentos em formação de capital foi crescente, conforme já discutido em seção anterior.

Ao comparar os cinco principais itens da pauta de importação com os cinco principais itens da pauta de exportação, pode-se destacar as seguintes características: (1) a pauta de exportação foi mais concentrada do que as pautas de importação; (2) os cinco principais itens da exportação excederam em apenas 118 milhões de dólares os cinco principais itens das importações, valor relativamente baixo para financiar a expansão da economia brasileira; e (3) o país em questão é exportador de bens de baixo valor agregado, e importa para suprir (i) demanda energética; e (ii) demanda por bens de alto valor agregado. Conforme os membros da chamada linha cepalina (Raúl Prebisch, Celso Furtado, René Villarreal, entre outros), essas características já expressam a dependência e fragilidade da economia dos países em desenvolvimento. Nesse sentido, Sarquis Sarquis identificou bem o problema. O sucesso do comércio exterior brasileiro não pode ser apenas o saldo comercial. Deve passar também por uma mudança das características das pautas de exportação e importação:

Ao contrário do Japão, cujo padrão Lawrence e Weistein (2001) caracterizam como import-led growth, o Brasil não logra perseguir permanentemente o canal benigno de crescimento apoiado em importações, devendo ainda capacitar-se em seu desempenho exportador. Não se trata de gerar superávit comercial, mas sim de 
prover as exportações de persistência e estabilidade. Tal desempenho persistente e estável poderia gerar superávit comercial sustentado ou pelo menos assegurar a expansão das importações requeridas para o investimento e crescimento sustentado dentro de faixas de déficits de transações correntes que sejam críveis e financeiramente sustentáveis. Para um país com baixa poupança, ampla desigualdade social e hiatos internos de demanda, a segunda alternativa é mais condizente e provável. $^{66}$

\subsubsection{AS IMPORTAÇÕES BRASILEIRAS E OS PROBLEMAS ESTRUTURAIS}

A tabela abaixo traz alguns resultados da análise de dados referentes às equações (29) à (38) da tabela 3.15. Observa-se que, dos cinco principais itens de importação do Brasil, apenas dois itens apresentaram equações de elasticidade-preço relativo de poder explicativo alto. Foram os itens óleo brutos de petróleo e medicamentos. O primeiro apresentou elasticidade-preço de quase $1 \%$, e o segundo em mais de $2 \%$. Na prática, a existência de $\mathrm{R}^{2}$ inferior, expressa que as importações foram menos explicadas pelas oscilações dos preços do que as exportações. Isso significa que as oscilações e preço no mercado internacional afetaram mais as exportações do Brasil do que as importações. Essa diferença do impacto dos preços, na visão cepalina, é um dos motivos para as fortes oscilações no saldo do balanço comercial dos países de pagamento.

\begin{tabular}{|c|c|c|c|c|c|c|c|c|c|}
\hline \multicolumn{2}{|c|}{ Tabela 2.13 Elasticidade-preço dos cinco principais produtos da pauta de importação, 2001 a 2013 (modelos log-log) } \\
\hline (I) & (II) & (III) & (IV) & (V) & (VI) & (VII) & (VIII) & (IX) & (X) \\
\hline Regressão & $\begin{array}{c}\text { Variável } \\
\text { dependente }\end{array}$ & $\begin{array}{c}\text { Variável } \\
\text { independente }\end{array}$ & $\begin{array}{c}\text { Coeficiente } \\
\text { A }\end{array}$ & $\begin{array}{c}\text { Coeficiente } \\
\text { B }\end{array}$ & $\begin{array}{c}\text { Erro } \\
\text { padrão } \\
\text { de A }\end{array}$ & $\begin{array}{c}\text { Erro } \\
\text { padrão } \\
\text { de B }\end{array}$ & Elasticidade & $\mathbf{R}^{2}$ & DW \\
\hline $\begin{array}{c}\mathbf{2 . 2 7} \\
\text { VniPtr }=\mathrm{a} \\
+ \text { PnPtr }\end{array}$ & $\begin{array}{c}\text { Óleos brutos } \\
\text { de petróleo } \\
\text { (nominal) }\end{array}$ & $\begin{array}{c}\text { Preço nominal dos } \\
\text { óleos brutos de } \\
\text { petróleo }\end{array}$ & 1,26 & 0,99 & 0,03 & 0,06 & 0,988 & 0,961 & 1,678 \\
\hline $\begin{array}{c}\mathbf{2 . 2 8} \\
\text { VniAut }= \\
\text { a + PnAut }\end{array}$ & $\begin{array}{c}\text { Automóveis de } \\
\text { passageiros } \\
\text { (nominal) }\end{array}$ & $\begin{array}{c}\text { Preço nominal dos } \\
\text { automóveis de } \\
\text { passageiros }\end{array}$ & $(6,29)$ & 6,79 & 0,98 & 0,99 & 6,788 & 0,811 & 0,679 \\
\hline $\begin{array}{c}\mathbf{2 . 2 9} \\
\text { VniParp }= \\
\text { a + } \\
\text { PnParp }\end{array}$ & $\begin{array}{c}\text { Partes e peças } \\
\text { para veículos } \\
\text { automóveis e } \\
\text { tratores } \\
\text { (nominal) }\end{array}$ & $\begin{array}{c}\text { Preço nominal de } \\
\text { partes e peças para } \\
\text { veículos } \\
\text { automóveis e } \\
\text { tratores }\end{array}$ & $(2,19)$ & 3,23 & 0,32 & 0,38 & 3,229 & 0,869 & 1,381 \\
\hline
\end{tabular}

66 SARQUIS, Sarquis José Buainain. Comércio Internacional e Crescimento Econômico no Brasil. Brasília: Fundação Alexandre de Gusmão, 2011. Pg. 130 
Tabela 2.13 (continuação) - Elasticidade-preço dos cinco principais produtos da pauta de importação, 2001 a 2013 (modelos log-log)

\begin{tabular}{|c|c|c|c|c|c|c|c|c|c|}
\hline (I) & (II) & (III) & (IV) & $(\mathrm{V})$ & (VI) & (VII) & (VIII) & (IX) & (X) \\
\hline Regressão & $\begin{array}{c}\text { Variável } \\
\text { dependente }\end{array}$ & $\begin{array}{c}\text { Variável } \\
\text { independente }\end{array}$ & $\begin{array}{c}\text { Coeficiente } \\
\text { A }\end{array}$ & $\begin{array}{c}\text { Coeficiente } \\
\text { B }\end{array}$ & $\begin{array}{c}\text { Erro } \\
\text { padrão } \\
\text { de } \mathbf{A}\end{array}$ & $\begin{array}{c}\text { Erro } \\
\text { padrão } \\
\text { de } B\end{array}$ & Elasticidade & $\mathbf{R}^{2}$ & DW \\
\hline $\begin{array}{c}2.30 \\
\text { VniMdi = } \\
\mathrm{a}+\text { PnMdi }\end{array}$ & $\begin{array}{l}\text { Medicamentos } \\
\text { para medicina } \\
\text { humana e } \\
\text { veterinária }\end{array}$ & $\begin{array}{l}\text { Preço nominal dos } \\
\text { medicamentos } \\
\text { para medicina } \\
\text { humana e } \\
\text { veterinária }\end{array}$ & $(3,50)$ & 1,88 & 0,24 & 0,11 & 1,877 & 0,963 & 1,940 \\
\hline $\begin{array}{c}2.31 \\
\text { VniCmb }= \\
\text { a }+ \\
\text { PnCmb }\end{array}$ & $\begin{array}{c}\text { Óleos } \\
\text { combustíveis }\end{array}$ & $\begin{array}{l}\text { Preço nominal dos } \\
\text { óleos combustíveis }\end{array}$ & 0,77 & 1,35 & 0,09 & 0,23 & 1,348 & 0,758 & 0,783 \\
\hline $\begin{array}{l}2.32 \\
\text { VriPtr }=\mathrm{a} \\
+\operatorname{PrPtr}\end{array}$ & $\begin{array}{c}\text { Óleos brutos } \\
\text { de petróleo }\end{array}$ & $\begin{array}{l}\text { Preço relativo dos } \\
\text { óleos brutos de } \\
\text { petróleo }\end{array}$ & 1,26 & 0,99 & 0,03 & 0,07 & 0,988 & 0,949 & 1,675 \\
\hline $\begin{array}{c}2.33 \\
\text { VriAut = a } \\
+ \text { PrAut }\end{array}$ & $\begin{array}{c}\text { Automóveis de } \\
\text { passageiros }\end{array}$ & $\begin{array}{l}\text { Preço relativo dos } \\
\text { automóveis de } \\
\text { passageiros }\end{array}$ & $(10,97)$ & 11,54 & 2,46 & 2,48 & 11,544 & 0,663 & 0,936 \\
\hline $\begin{array}{c}2.34 \\
\text { VriParp }= \\
\mathrm{a}+\text { PrParp }\end{array}$ & $\begin{array}{l}\text { Partes e peças } \\
\text { para veículos } \\
\text { automóveis e } \\
\text { tratores }\end{array}$ & $\begin{array}{l}\text { Preço relativo de } \\
\text { partes e peças para } \\
\text { veículos } \\
\text { automóveis e } \\
\text { tratores }\end{array}$ & $(3,13)$ & 4,35 & 0,74 & 0,88 & 4,352 & 0,688 & 1,113 \\
\hline $\begin{array}{c}2.35 \\
\text { VriMdi = } \\
\mathrm{a}+\text { PnMdi }\end{array}$ & $\begin{array}{l}\text { Medicamentos } \\
\text { para medicina } \\
\text { humana e } \\
\text { veterinária }\end{array}$ & $\begin{array}{l}\text { Preço relativo dos } \\
\text { medicamentos } \\
\text { para medicina } \\
\text { humana e } \\
\text { veterinária }\end{array}$ & $(4,02)$ & 2,13 & 0,35 & 0,17 & 2,126 & 0,937 & 1,877 \\
\hline $\begin{array}{c}2.36 \\
\text { VriCmb }= \\
a+ \\
\text { PrCmb }\end{array}$ & $\begin{array}{c}\text { Óleos } \\
\text { combustíveis }\end{array}$ & $\begin{array}{l}\text { Preço relativo dos } \\
\text { óleos combustíveis }\end{array}$ & $(0,34)$ & 1,26 & 0,12 & 0,20 & 1,259 & 0,788 & 0,932 \\
\hline \multicolumn{10}{|c|}{ Nota 1: valores negativos entre parênteses } \\
\hline \multicolumn{10}{|c|}{ Nota 2: variáveis em dólares constantes de 2006} \\
\hline \multicolumn{10}{|c|}{ *dados: MDIC, WorldBank Data, e USA Bureau of Economic Analysis } \\
\hline
\end{tabular}

De acordo com Raúl Prebisch, esse é um dos problemas críticos para os países em desenvolvimento. Suas pautas de exportação são mais sensíveis às oscilações do mercado internacional do que as importações. Para René Villarreal ${ }^{67}$, isso só deveria ocorrer em países que ainda estivessem em sua primeira etapa de industrialização. Ora, o Brasil já teria passado por essa etapa. O que explicaria é que ele teria experimentado um período de 67 Sobre o tema ver: VILARREAL, René. A contra-revolução monetarista, teoria, política econômica e ideologia do neoliberalismo. Rio de Janeiro: Editora Record,1984. 
desindustrialização em fase anterior da economia. Entre o final da década (19)80, e início da década de 2000, houve sucateamento da indústria e liberalização acelerada. Quando o Brasil passou pelas crises de 1998, 2001 e 2008, a indústria local já estava bastante desgastada.

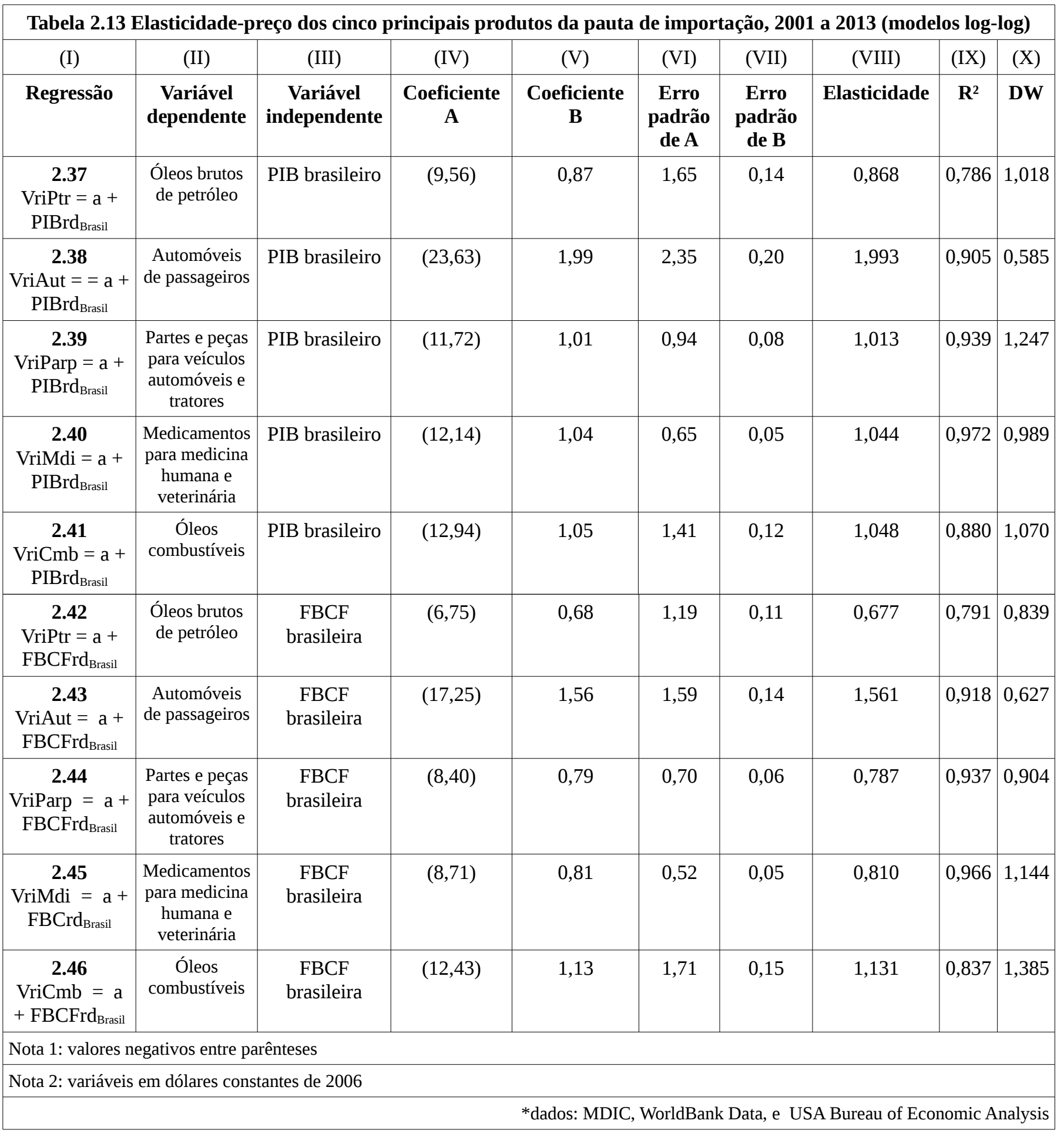

Na tabela 2.13, observa-se alguns dos resultados da análise das equações (2.37) à (2.46), representadas na terceira tabela de equações. Nota-se que quatro dos cinco principais 
itens da pauta de importações se apresentaram elásticos em relação ao crescimento do PIB, em dólares constantes. Esse comportamento está de acordo com a teoria econômica cepalina. No entanto, observou-se elasticidade-renda inferior, quando comparado com o crescimento da formação bruta de capital. Isso indica que as importações foram mais influenciadas pelo consumo do que por investimentos.

Conforme René Villarreal destacou em seus estudos, para os países da América Latina, as políticas desenvolvimentistas de aumento do consumo não eram capazes de gerar crescimento consistente. A tese keynesiana não se aplicaria plenamente às economias em desenvolvimento por conta do alto peso do setor externo. O incremento do consumo não geraria automaticamente incremento dos investimentos, uma vez que eles seriam supridos pela oferta externa. ${ }^{68}$

Como destacado de forma mais direta por Ragnar Nurkse, o incremento do consumo em países dependentes teria dois impactos possíveis (não excludentes): (a) aumento das importações; ou (b) aumento da inflação. O que se observa é que, entre 1999 e 2013, o aumento do PIB esteve atrelado a um maior aumento das importações para consumo. Nesse sentido, houve drenagem da capacidade de poupança nacional. Ainda, nas palavras de Vitor Schincariol:

O próprio fato de o país estar perdendo participação dos bens manufaturados em sua pauta de exportações é um indicativo da perda de dinamismo do setor industrial doméstico, em termos domésticos e internacionais. Seu reverso, na forma de perda da participação da indústria no PIB e câmbio valorizado pelas commodities, foi apresentar uma propensão a importar de quase quinze centavos em bens manufaturados e serviços a cada real adicionado à economia no setor "real". ${ }^{69}$

O saldo da alta das exportações não foi utilizada para uma política de poupança e investimento na economia interna. Daí, resultou-se acirramento do processo de desindustrialização do país. Na prática, o mercado interno também se fragilizou, uma vez que foi fortalecida a demanda por bens acabados e diminuída a demanda por bens intermediários.

68 VILARREAL, René. A contra-revolução monetarista, teoria, política econômica e ideologia do neoliberalismo. Rio de Janeiro: Editora Record,1984. pg. 401 - 470.

69 SCHINCARIOL, V. E. Economia e Política Econômica no Governo Dilma (2011-2014). São Paulo: Selo Tricontinental, 2017. pg. 212 


\section{Gráfico 2.6 Grau de concentração das importações brasileiras, 1999 a 2013}

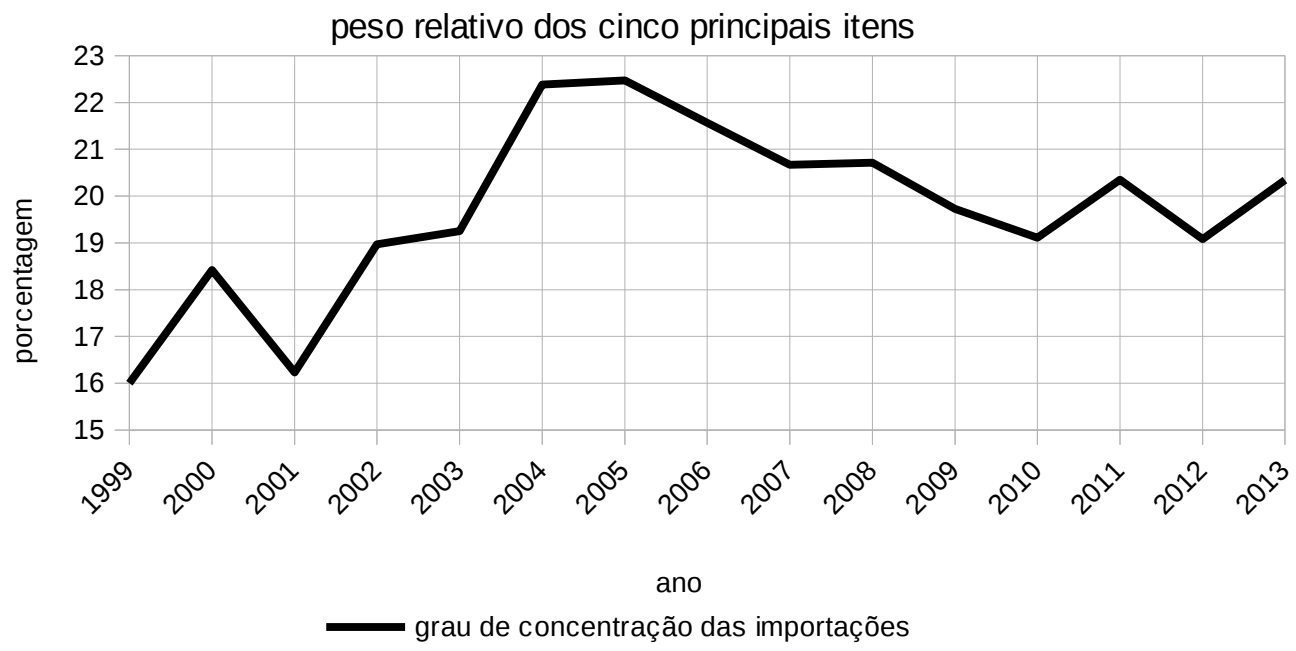

Fonte: dados MDIC

O peso relativo dos cinco produtos mais importantes da pauta de exportação aumentou até 2004, e diminui a partir de então. Para a realização da recuperação econômica houve forte concentração das importações, como parte do aumento da demanda por capacidade energética.

A concentração menor, a partir da recuperação econômica, é um indício do aumento da demanda de insumos diversos e de bens de consumo. Isso foi fruto de um crescimento da renda, da capacidade bruta de investimento e do consumo das famílias. Observa-se que houve tendência de favorecimento pelo suprimento das demandas de bens de consumo, através da oferta externa. Tal certamente expressa imposições vindas dos empréstimos exteriores de recursos e a adoção de esquemas cambiais favoráveis aos importadores.

Também significa que houve perda de competitividade interna da indústria doméstica. Esse processo foi fruto do enfraquecimento relativo das indústrias já existentes e da dificuldade de se montar novas. Também foi relevante o impacto da sobreapreciação do Real, o que incentivou as importações. Isso ajuda a explicar por que, entre 1999 e 2013, houve aumento da demanda por importação na ordem de mais de $400 \%$ dos produtos: veículos e automóveis; circuitos impressos e partes para aparelhos telefônicos; circuitos integrados e microconjuntos eletrônicos; rolamentos e engrenagens; e torneiras e válvulas. Ainda, há que se apontar o aumento da demanda de importação de suéteres e malhas na ordem de 830\%, entre 2000 e 2013. 
Esse processo se deu de forma mais ou menos concomitante ao ganho de competitividade dos produtos chineses. Ao longo do período analisado, a parceria comercial entre o Brasil e a China foi fortalecida também no que toca às importações brasileiras. Os países da Ásia se tornaram os principais fornecedores de bens de consumo e bens de capital para o Brasil em 2005 e 2006, respectivamente. Em 2007, se tornaram principais fornecedores de matérias-primas e bens intermediários. Somente não se tornaram os parceiros comerciais de maior importância no que toca às importações brasileiras de combustíveis e lubrificantes. Para essa última categoria de uso, a África continua a ser o principal fornecedor.

\begin{tabular}{|c|c|c|c|c|}
\hline \multicolumn{5}{|c|}{ Tabela 2.14 Participação (em porcentagem) dos diferentes blocos econômicos na origem das importações } \\
brasileiras, 1999 a 2013
\end{tabular}

Antes, os bens de consumo e bens de capital importados pelo Brasil vinham prioritariamente da Europa. A principal parceria comercial para as importações de matériasprimas e bens intermediários oscilava anualmente entre o ALADI e o Mercosul, e a Europa. Efetivamente, com a transformação da China em potência industrial, ocorreu trocar esse conjunto de parcerias por uma com o país asiático. Embora isso possa ser fruto de um processo para além do controle direto dos envolvidos, coincidiu com a linha defendida por parte da diplomacia brasileira desde $1986 .^{70}$

O aumento da importância da Ásia resultou em aumento do grau de concentração das

70 JAGUARIBE, Helio. Brasil, Mundo e Homem na Atualidade. Brasília: Fundação Alexandre de Gusmão, 2008. pg. 33 a 37. 
origens das importações brasileiras, quando calculadas a partir do peso relativo dos três blocos mais importante em cada ano. Essa medida é importante, pois serve como um dos indicadores de grau de dependência da produção estrangeira. Hipoteticamente, quanto maior for o grau de concentração das importações, mais ela é afetada pelas oscilações de preços dos principais parceiros comerciais.

A partir do final de 2013, a China realizou mudança em sua política de desenvolvimento, focando mais o consumo interno. Como uma das consequências, houve oscilação dos preços chineses para cima. Embora os produtos daquele país continuem sendo mais baratos do que os produtos europeus, a mudança de preço pode ter impacto, em curto e médio prazo, no custo das importações brasileiras. 


\section{AINDA O BALANÇO COMERCIAL}

Neste capítulo, prosseguiremos a análise do balanço comercial e seus efeitos. A leitura do balanço comercial brasileiro realizada nessa pesquisa traz similaridades ao descrito por René Villarreal sobre o México, entre as décadas 1970 e 1980. Para analisar aquele país, a tentativa de superação da crise econômica teria se dado através da exportação do petróleo. Ao não seguir as medidas monetaristas propostas pelo FMI, à época, o México priorizou a produção e exportação de petróleo. Assim, logrou melhorar a balança comercial, e seu balanço de pagamentos. Mas, como um dos efeitos desse processo, o país experimentou uma desindustrialização. A indústria local teria sido parcialmente (ou até completamente) desmontada. Os bens manufaturados, que anteriormente podiam ser produzidos no país, passaram a ser importados. Conforme Villarreal, o governo mexicano buscou uma saída para a crise inflacionária e de balanço de pagamentos que aquele país vivia sem precisar aplicar as medidas monetaristas então recomendadas pelo FMI. Tratava-se de uma saída desesperada que buscava evitar o pior.

Na visão de Prebisch, esse movimento cíclico da industrialização nos países dependentes expressa o movimento do comércio internacional. Quando há retração do mercado mundial, com baixa de preços dos bens primários e alta dos bens industrializados, ocorre, nos países dependentes, impulso industrializante. Quando ocorre ampliação do comércio mundial, com redução dos preços dos bens industrializados e alta dos preços dos bens primários, o impulso desaparece. Para Emmanuel, trata-se de mera regulação da divisão internacional do trabalho.

No Brasil atual, algo similar ocorreu no período em análise. A exportação de bens primários e o fortalecimento da extração de minérios e de petróleos melhorou, temporariamente, a balança comercial. No entanto, o país se tornou mais dependente da importação de bens industriais para consumo, uma vez que houve crescimento da demanda da população acima da capacidade de produção industrial. O governo não soube aproveitar o momento para redirecionar tais estruturas. Ou não pôde. 


\subsection{A HIPÓTESE DE DESINDUSTRIALIZAÇÃO}

Villarreal forneceu uma análise do esgotamento da substituição de importações na América Latina ${ }^{71}$. Para ele, a partir da década de (19)80, os países daquela região mantiveram processos de industrialização. Apesar do processo de endividamento, os países da América Latina continuavam a crescer. A partir daí, observou-se inflação bastante alta, com déficit no balanço de pagamentos, e endividamento acelerado, resultando em baixo crescimento do PIB. A inflação já era endêmica na América Latina desde 1950. No entanto, ela não era considerada um problema, pois as medidas econômicas tomadas não tinham enfoque monetarista. A taxa média de crescimento do déficit das transações correntes foi de 23,3\% anuais, desde a década de (19)70.

Até 1975, observou-se uma trajetória ascendente nas exportações da região, que foi revertida a partir de então. A pauta de serviços não-financeiros já era deficitária, mas atingiu déficit oito vezes superior em 1980 em relação aquele de 1970. Segundo Villarreal, o desequilíbrio externo teria sofrido uma pressão grande na pauta dos serviços financeiros, devido aos pagamentos de juros e lucros sobre o capital estrangeiro. A saída de divisas chegou a atingir o dobro do valor da entrada de investimentos estrangeiros direto, no período.

Para a década de 1980, a expectativa do Fundo Monetário Internacional (FMI) era de que ocorreria aumento do déficit global dos países em desenvolvimento não-exportadores de petróleo. Dessa forma, eles teriam que recorrer ainda mais ao Fundo. A aplicação das receitas do FMI teria gerado melhoras pontuais nos balanços de pagamentos, as custas da saúde econômica local. O déficit no BP seria fruto da insuficiência dos parques industriais dos países, e a receita do FMI teria como principal efeito o agravamento dessa insuficiência, o que geraria pioras de longo prazo.

Ao pedir auxílio ao FMI, um país realizava um saque no fundo, que consistia na compra de divisas usando moedas nacionais. O país comprador de divisas se comprometia a comprar suas moedas de volta. A compra só era autorizada mediante a concordância com um programa de ajuste financeiro, descrito em uma carta de intenções. O FMI permitia que os países superavitários não se ajustassem, mas realizava pressão sobre os deficitários. Desde sua criação, o FMI adotou a tese monetarista para os desequilíbrios externos dos países ${ }^{72}$. A

71 Sobre o assunto, ver: VILARREAL, René. A contra-revolução monetarista, teoria, política econômica e ideologia do neoliberalismo. Rio de Janeiro: Editora Record,1984.

72 Para uma abordagem sobre o papel do FMI na reprodução do sistema desigual na Divisão Internacional do 
consequência dos ajustes nos países deficitários foi bem descrita por Korkut Boratav:

A liberalização da conta de capital nas economias periféricas contribui para o surgimento de novas ligações macroeconômicas. Os governos e o gerenciamento econômico nesses países descobrem que a expansão / contração das economias nacionais se torna cada vez mais dependente dos fluxos de capital não residentes e a contribuição das políticas fiscais e monetárias domésticas torna-se marginal. A política monetária está subordinada aos bancos centrais, que se tornaram cada vez mais autônomos dos governos do terceiro mundo, mas, de fato, passaram sob supervisão do FMI. O objetivo predominante das políticas fiscais tornou-se servir os níveis crescentes de dívida pública e reduzir o risco de inadimplência. Isso foi realizado visando o superávit primário do orçamento público. (...) Nós, portanto, observamos um novo ciclo vicioso de dependência: o crescimento torna-se dependente dos movimentos de capital externos e o último torna-se dependente dos critérios de desempenho do FMI et. al. Como já enfatizamos, esses critérios excluem o governo nacional como agentes ativos na gestão macroeconômica. As classes governamentais se enquadram gradualmente com esta linha de pensamento e as "políticas" nacionais se identificam com os critérios do FMI, porque esta é a única maneira de se"respeitar" nos olhos das finanças internacionais que pode ser adquirida e pode haver estabilidade econômica e "crescimento razoável". ${ }^{73}$

Conforme René Villarreal, o pacote de medidas recomendadas pelo FMI incluíam: (i) contração da demanda agregada, especialmente através da redução dos gastos do governo; (ii) liberalização dos mercados (de juros, câmbio, e preço interno), com controle de salários; e (iii) liberalização do comércio externo. A tese do Fundo era que o desequilíbrio em países em desenvolvimento era fruto do aumento da demanda acima do aumento da oferta, parcialmente causado pela atividade do governo. Essas políticas se traduziam, na prática, em: (a) contração do crédito e aumento do juro; (b) redução do déficit do setor público; e (c) limitação do crédito internacional ao setor público do país, para redução da capacidade de geração de demanda. $^{74}$

Os acordos de estabilização teriam levado a instabilidades regionais. Ao contrário de rever sua política, os EUA e o FMI aprofundaram ainda mais sua crença no mercado e no

Trabalho ver: MAGDOFF, Harry. The Age of Imperialism. The Economics of U.S. Foreign Policy. Nova Iorque e Londres: Monthly Review Press, 1969.

73 BORATAV, Korkut. "Net Resource Transfers And Dependency: Some Recent Changes In The World Economy” in: KÖSE, A. H. \& SENSES, F. et al. Neoliberal Globalization as New Imperialism. Nova Iorque: Nova Science Publishers, Inc., 2007. pg. 11.

74 Ver: VILARREAL, René. A contra-revolução monetarista, teoria, política econômica e ideologia do neoliberalismo. Rio de Janeiro: Editora Record,1984. 
setor privado. As desvalorizações do câmbio favoreciam o dólar; a contração da demanda nos países em desenvolvimento desorganizava suas indústrias. Produzia-se desemprego e baixa produtividade. As políticas monetaristas poderiam trazer benefícios (a quem as aplica) apenas num outro mundo, e não no existente.

O México teria encontrado, segundo Villarreal, uma saída diferente para a crise. A fuga de capitais posterior à desvalorização teria levado o governo a tentar um acordo com o FMI. A ajuda oferecida pelo Fundo era menos de um quarto do valor da dívida externa mexicana. Para efetivar o acordo, o governo mexicano aceitou um programa de ajuste.

Mas, no lugar do plano de liberalização proposto pelo FMI, o México adotou um programa capitaneado pelo Estado. Esse teria sido caracterizado por: (i) objetivar a racionalização do sistema de proteção, visando aumento da competitividade; (ii) afrouxamento do controle dos preços de artigos comercializados; (iii) adoção de um regime cambial de flutuação regulada, com larga atuação de órgãos públicos no controle do câmbio, visando privilegiar a indústria mexicana; (iv) política salarial moderada, casada com programas de fomento ao emprego e distribuição de bens básicos, em acordo com os sindicatos; (v) criação de mecanismos de investimento para os poupadores nacionais, incluindo o título de curto prazo da tesouraria da Federação; (vi) aumento dos gastos públicos em 3 pontos percentuais do PIB, entre 1977 e 1978, com aumento do investimento em formação de capital; e (vii) ampliação do déficit do setor público, com limitação do endividamento externo.

A partir de 1977, o governo mexicano optou pelo aumento dos investimentos na exploração de petróleo. Houve esforço de prospecção, aumentando a reserva comprovada de 6,3 bilhões de barris, em 1975, para 16,6 bilhões, em 1977, e 60,1 bilhões, em 1980. Essa reserva teria servido para recuperar a confiança dos investidores estrangeiros, o que permitiu ao governo adquirir novos empréstimos. Optou-se pelo uso do petróleo como ferramenta de ajuste, e de libertação das condições nocivas do FMI. Isso teria permitido o crescimento acelerado do PIB do país, crescimento do nível de emprego, universalização do ensino básico, e ampliação de programas de seguridade social. Segundo Villarreal, o ajuste econômico também teria sido o que permitiu a reforma política democratizante. No entanto, a estratégia teria permitido apenas êxito temporário.

Em 1980, o país já apresentava sinais de dependência de petróleo. Dois terços da 
exportação de mercadorias tinham origem nos produtos petrolíferos. Metade da receita em divisas vinha do comércio de hidrocarbonetos. A PEMEX se tornou responsável por 25\% da contribuição tributária. Assim, saiu-se da dependência caracterizada pelo déficit do BP para aquela caracterizada pelo comércio externo de um, ou poucos, produtos. Enquanto isso, a produção interna de manufatura teria sido substituída pela importação de manufaturados.

A industrialização se tornou focada no principal produto exportado: o petróleo. Ao final de 1981, houve revisão nos contratos de compra de petróleo mexicano, com retirada parcial de contratos importantes. A redução da entrada de divisas teria levado à redução dos gastos públicos, e a subsequente desvalorização do peso, em 1982. O crescimento acelerado das importações de manufatura, e o aumento gastos nos serviços financeiros superaram o crescimento das exportações de petróleo nos anos seguintes. O valor exportado de petróleo, entre 1977 a 1981, foi de 31 bilhões de dólares, enquanto o serviço da dívida teria atingido a soma de 31 bilhões de dólares.

A história recente da indústria brasileira seguiu outro curso. No entanto, a partir dos dados trabalhados na presente pesquisa, pode-se levantar a hipótese que a partir da década de (19)80, o Brasil entrou em um processo de desindustrialização geral da economia. A partir da década de 2000, o esforço de reconstrução da indústria foi focada em setores de exportação de baixo valor agregado, em especial na indústria extrativa. Devido a má experiência quanto a ingerência do FMI, o Brasil buscou utilizar parte da reserva adquirida no comércio exterior para pagar suas dívidas junto ao fundo ${ }^{75}$. Ainda, o governo passou a acumular divisas com o intuito de (a) controlar o câmbio; e (b) garantir reserva de dólares como indicativo da saúde financeira. Movimento similar foi adotado por outros países, como a Indonésia ${ }^{76}$. Na prática, essa media retirava de circulação dólares que poderiam ser utilizados para financiar o investimento industrial local.

75 O esforço de pagar as dívidas junto ao FMI também foi adotado por outros países da América Latina. Sobre o tema ver: DE LA BARRA, Ximena."The dual debt of Neoliberalism.", in: BUENO, Richard \& LARA, José (orgs). Imperialism, Neoliberalism and Social Struggles in Latin America. Bostom: Brill, 2007. Pg. 74.

76 Sobre o tema ver: PIKETTY, Thomas. Capital in the twenty-first century. Harvard University Press, 2017. Pg. 535. 


\begin{tabular}{|c|c|c|c|c|c|}
\hline \multicolumn{6}{|c|}{ Tabela 3.1 Capacidade relativa de abastecimento industrial nacional, 1960 a 2012} \\
\hline (I) & (II) & (III) & (IV) & (V) & (VI) \\
\hline (A) & (B) & (C) & (D) & $(E)=(C)-(D)$ & (F) \\
\hline Ano & $\begin{array}{l}\text { Produção } \\
\text { industrial }\end{array}$ & $\begin{array}{l}\text { Variação da produção } \\
\text { industrial (em } \\
\text { porcentagem) }\end{array}$ & $\begin{array}{c}\text { Taxa de crescimento da } \\
\text { população (em } \\
\text { porcentagem) }\end{array}$ & $\begin{array}{c}\text { Taxa real de } \\
\text { crescimento da } \\
\text { produção industrial }\end{array}$ & $\begin{array}{c}\text { Índice da } \\
\text { capacidade de } \\
\text { abastecimento } \\
\text { industrial nacional }\end{array}$ \\
\hline 1960 & 8,07 & - & - & - & 33,49 \\
\hline 1961 & 8,84 & 9,58 & 2,90 & 6,68 & 35,72 \\
\hline 1962 & 9,46 & 6,92 & 2,90 & 4,02 & 37,16 \\
\hline 1963 & 9,68 & 2,40 & 2,90 & $(0,51)$ & 36,97 \\
\hline 1964 & 9,86 & 1,89 & 2,90 & $(1,01)$ & 36,60 \\
\hline 1965 & 9,95 & 0,88 & 2,90 & $(2,02)$ & 35,86 \\
\hline 1966 & 10,94 & 9,91 & 2,90 & 7,01 & 38,37 \\
\hline 1967 & 11,16 & 2,07 & 2,90 & $(0,84)$ & 38,05 \\
\hline 1968 & 13,28 & 18,98 & 2,90 & 16,07 & 44,17 \\
\hline 1969 & 14,78 & 11,31 & 2,90 & 8,41 & 47,88 \\
\hline 1970 & 16,94 & 14,59 & 2,51 & 12,07 & 53,66 \\
\hline 1971 & 19,10 & 12,75 & 2,51 & 10,24 & 59,15 \\
\hline 1972 & 21,76 & 13,92 & 2,51 & 11,40 & 65,90 \\
\hline 1973 & 26,32 & 20,93 & 2,51 & 18,41 & 78,03 \\
\hline 1974 & 29,36 & 11,56 & 2,51 & 9,04 & 85,09 \\
\hline 1975 & 30,95 & 5,44 & 2,51 & 2,93 & 87,58 \\
\hline 1976 & 33,91 & 9,54 & 2,51 & 7,02 & 93,73 \\
\hline 1977 & 34,57 & 1,97 & 2,51 & $(0,54)$ & 93,22 \\
\hline 1978 & 37,43 & 8,27 & 2,51 & 5,75 & 98,59 \\
\hline 1979 & 40,44 & 8,04 & 2,51 & 5,52 & 104,03 \\
\hline 1980 & 44,57 & 10,20 & 1,95 & 8,25 & 112,62 \\
\hline 1981 & 42,85 & $(3,87)$ & 1,95 & $(5,81)$ & 106,07 \\
\hline 1982 & 44,65 & 4,22 & 1,95 & 2,27 & 108,49 \\
\hline 1983 & 42,03 & $(5,87)$ & 1,95 & $(7,82)$ & 100,00 \\
\hline 1984 & 46,10 & 9,68 & 1,95 & 7,74 & 107,74 \\
\hline 1985 & 51,64 & 12,01 & 1,95 & 10,06 & 118,58 \\
\hline 1986 & 54,58 & 5,70 & 1,95 & 3,76 & 123,03 \\
\hline 1987 & 56,97 & 4,38 & 1,95 & 2,43 & 126,02 \\
\hline 1988 & 55,96 & $(1,78)$ & 1,95 & $(3,73)$ & 121,32 \\
\hline 1989 & 57,25 & 2,32 & 1,95 & 0,37 & 121,77 \\
\hline 1990 & 45,80 & $(20,01)$ & 1,45 & $(21,45)$ & 95,65 \\
\hline 1991 & 43,27 & $(5,52)$ & 1,45 & $(6,97)$ & 88,98 \\
\hline 1992 & 46,02 & 6,37 & 1,45 & 4,93 & 93,36 \\
\hline 1993 & 51,90 & 12,76 & 1,45 & 11,32 & 103,93 \\
\hline 1994 & 52,84 & 1,83 & 1,45 & 0,38 & 104,32 \\
\hline 1995 & 37,86 & $(28,36)$ & 1,45 & $(29,81)$ & 73,23 \\
\hline 1996 & 36,58 & $(3,37)$ & 1,45 & $(4,82)$ & 69,70 \\
\hline 1997 & 37,97 & 3,80 & 1,45 & 2,35 & 71,34 \\
\hline 1998 & 37,39 & $(1,53)$ & 1,45 & $(2,98)$ & 69,21 \\
\hline 1999 & 37,79 & 1,08 & 1,45 & $(0,36)$ & 68,96 \\
\hline
\end{tabular}




\begin{tabular}{|c|c|c|c|c|c|}
\hline \multicolumn{6}{|c|}{ Tabela 3.1 (continuação) Capacidade relativa de abastecimento industrial nacional, 1960 a 2012} \\
\hline (I) & (II) & (III) & (IV) & (V) & (VI) \\
\hline (A) & (B) & (C) & (D) & $(E)=(C)-(D)$ & (F) \\
\hline Ano & $\begin{array}{l}\text { Produção } \\
\text { industrial }\end{array}$ & $\begin{array}{l}\text { Variação da produção } \\
\text { industrial (em } \\
\text { porcentagem) }\end{array}$ & $\begin{array}{l}\text { Taxa de crescimento da } \\
\text { população (em } \\
\text { porcentagem) }\end{array}$ & $\begin{array}{c}\text { Taxa real de } \\
\text { crescimento da } \\
\text { produção industrial }\end{array}$ & $\begin{array}{c}\text { Índice da } \\
\text { capacidade de } \\
\text { abastecimento } \\
\text { industrial nacional }\end{array}$ \\
\hline 2000 & 42,15 & 11,55 & 1,18 & 10,37 & 76,11 \\
\hline 2001 & 41,47 & $(1,63)$ & 1,18 & $(2,81)$ & 73,97 \\
\hline 2002 & 42,91 & 3,46 & 1,18 & 2,28 & 75,66 \\
\hline 2003 & 44,50 & 3,71 & 1,18 & 2,53 & 77,57 \\
\hline 2004 & 50,93 & 14,44 & 1,18 & 13,26 & 87,86 \\
\hline 2005 & 51,16 & 0,46 & 1,18 & $(0,73)$ & 87,22 \\
\hline 2006 & 52,30 & 2,23 & 1,18 & 1,04 & 88,13 \\
\hline 2007 & 53,56 & 2,42 & 1,18 & 1,23 & 89,21 \\
\hline 2008 & 56,55 & 5,58 & 1,18 & 4,40 & 93,14 \\
\hline 2009 & 54,16 & $(4,23)$ & 1,18 & $(5,41)$ & 88,09 \\
\hline 2010 & 61,04 & 12,71 & 1,18 & 11,53 & 98,25 \\
\hline 2011 & 61,35 & 0,51 & 1,18 & $(0,68)$ & 97,59 \\
\hline 2012 & 59,20 & $(3,50)$ & 1,18 & $(4,69)$ & 93,02 \\
\hline
\end{tabular}

Na tabela acima (3.1), verifica-se o índice da capacidade relativa de abastecimento industrial nacional do país. O índice foi gerado a partir do cálculo do crescimento da indústria, coluna (c), subtraído o crescimento demográfico médio do decênio, coluna (d). Dessa forma, atingiu-se a taxa real de industrialização, coluna (E), que representa o nível de industrialização por habitante. A partir dessa taxa, gerou-se o índice da capacidade de abastecimento industrial nacional, coluna (F). Trata-se de uma mensuração da capacidade de produção industrial em relação a população existente. Esse índice foi transformado em gráficos para melhor análise.

No gráfico 3.1, pode-se observar que a industrialização brasileira manteve-se acelerada durante o final da década de (19)60 e de (19)70. A partir de 1980, ela entrou em desaceleração, passando por baixa entre 1980 e 1984. A partir de 1986, entrou em estagnação. Apesar da crise de baixa industrialização que perdurou de 1980 até 1986, observou-se tendência de crescimento da capacidade de abastecimento industrial nacional. Tratou-se, portanto, de um período de incremento da produção industrial. Mesmo que o modelo de substituição de importações tenha sido abandonado durante a ditadura militar, o progresso industrial continuou, sem que se destruísse a base industrial anterior. 
Gráfico 3.1 Índice da capacidade de abastecimento industrial nacional do Brasil, 1960 a 1989

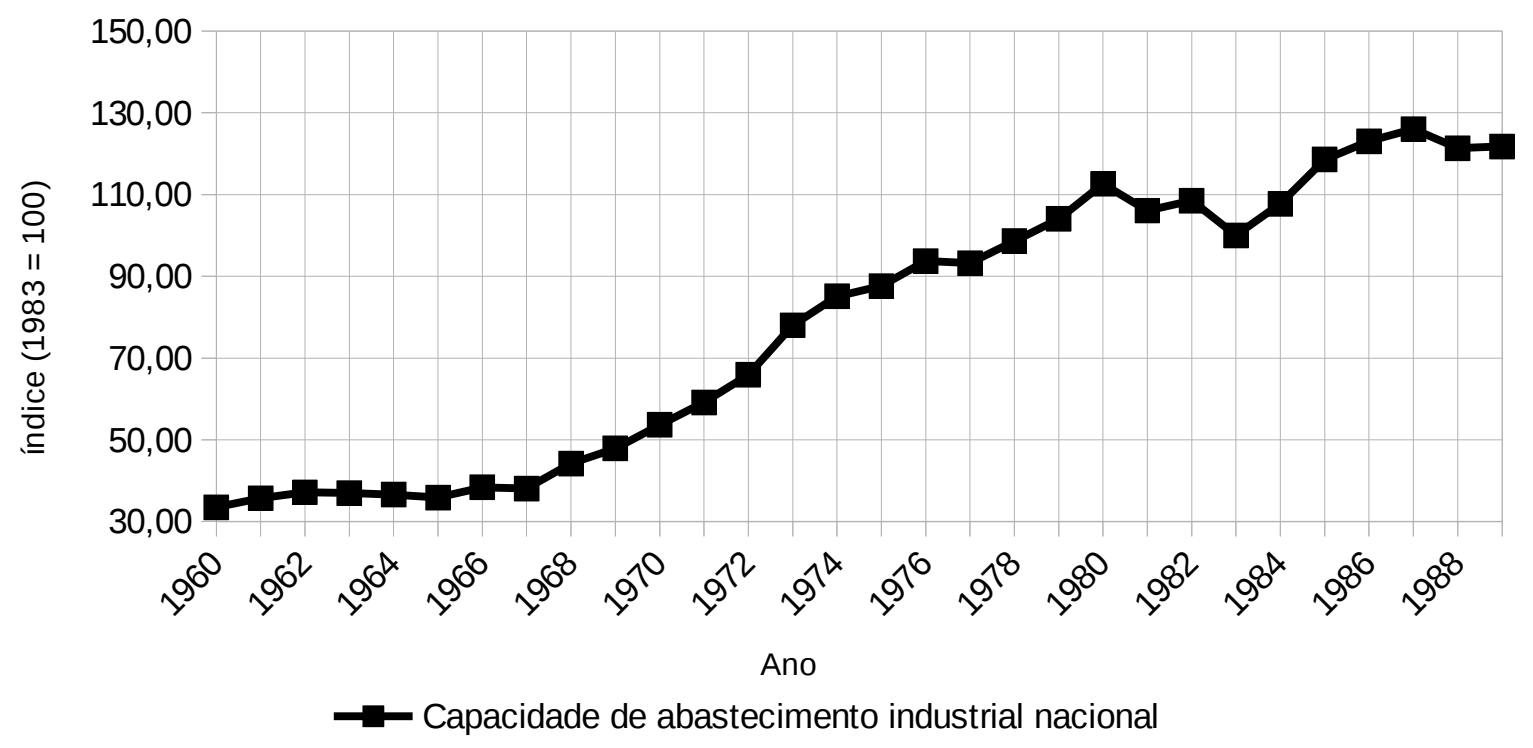

*Fonte: IBGE

O gráfico 3.2 permite uma observação mais detalhada para o período em análise na presente pesquisa. A partir de 1990, ter-se-ia iniciado um rápido processo de desindustrialização do país. Apesar de uma breve retomada da capacidade de abastecimento industrial entre 1992 e 1994 (período da presidência de Itamar Franco), a década de (19)90 foi marcada pela desorganização da indústria brasileira.

\section{Gráfico 3.2 Índice da capacidade de abastecimento industrial nacional do Brasil, 1987 a 2012}

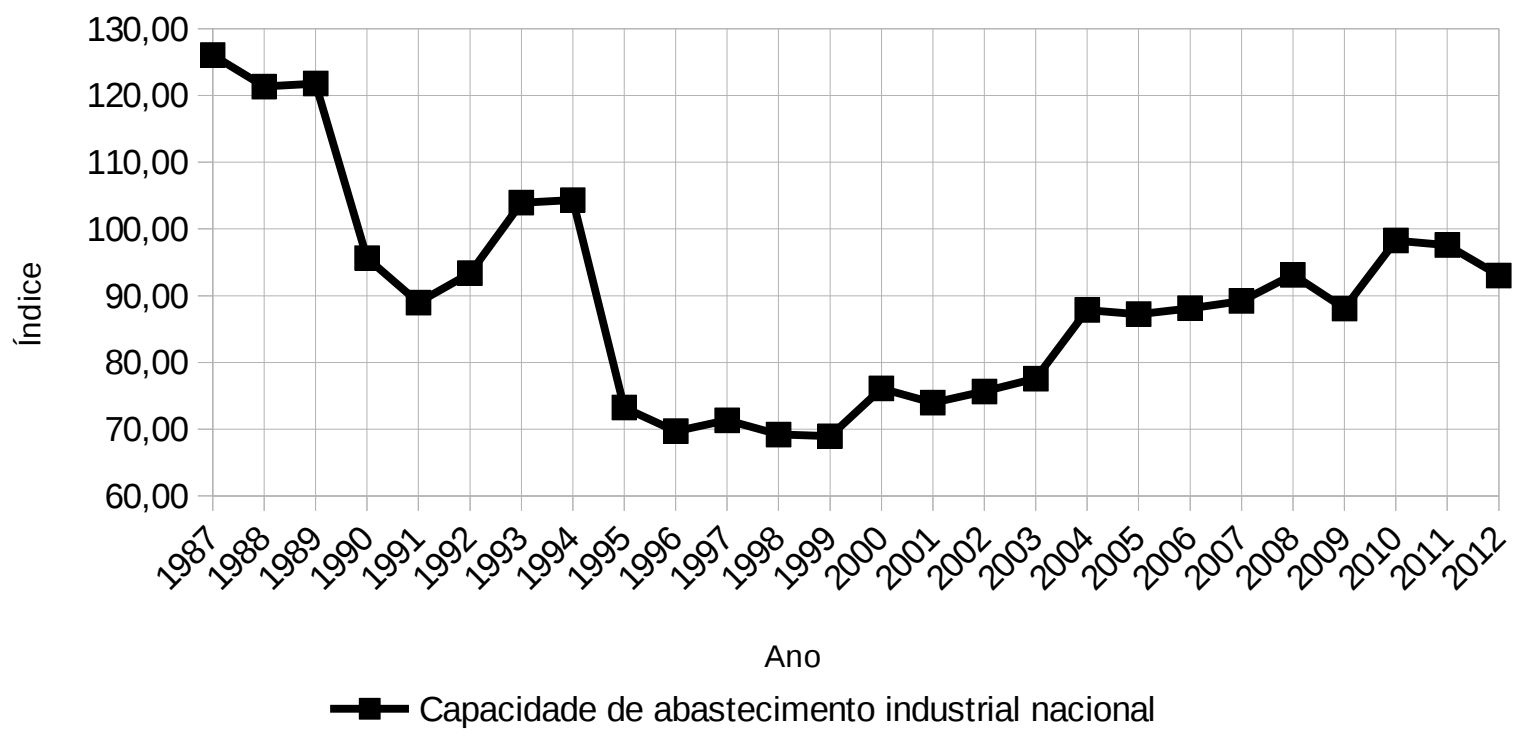


Apenas a partir de 2000 começou um processo de recuperação da capacidade de abastecimento industrial. No entanto, a produção industrial de baixo valor agregado, em especial a extrativa, ganhou maior importância. Conforme já apresentado no capítulo anterior, o Brasil não experimentou, entre 2000 e 2013, um novo processo de desenvolvimento. Ao contrário, fortaleceu-se o caráter de exportador de matéria-prima. A maior produção e exportação de bens agroindustriais (suco de laranja congelada e óleo de soja, por exemplo) não significou verdadeira industrialização manufatureira. Na prática, em 2013, a capacidade de abastecimento industrial nacional brasileira estaria ainda, de acordo com o índice proposto aqui, inferior àquela de 1978.

\subsection{SOBREVALORIZAÇÃO DO REAL}

Para entender o setor externo da economia do Brasil, em especial o problema do Balanço Comercial, é necessário estudar o câmbio dólar-real. Este afeta o setor externo principalmente influenciando as exportações ou importações, e determinando o custo relativo da produção de bens que dependem de insumos importados. A posição do câmbio pode ser analisada por duas vias ${ }^{77}$ : (a) pela demanda por divisas; e (b) pela diferença entre os preços internos e externos ao país.

No Brasil, funciona um sistema de câmbio livre, com intervenção do Estado no mercado de câmbio, quando o governo e o Banco Central consideram necessário. Isso gera um modelo de câmbio semi-livre, ou viscoso. Nesse modelo, o governo deixa o câmbio flutuar dentro de certas bandas não anunciadas previamente. Quando ocorre movimentos muito bruscos, muitas vezes ligados a atividade de especuladores, o governo intervém. Buscase, dessa forma, garantir certa estabilidade no câmbio.

De acordo com Prabhat Patnaik e Vikas Rawal, o modelo é marcado por duplo movimento de perdas para economia local: quando há entrada de capital, o Real (moeda) tende a se valorizar, diminuindo a demanda por produtos locais e aumentando a demanda por

77 Sobre o tema ver: KINDLEBERGER, Charles P. Economia Internacional. São Paulo: Editora Mestre Jou, 1974. Tradução da obra: KINDLEBERGER, Charles P. International Economics. 1968; KRAEMER, Armando. Taxa de câmbio e balanço de pagamentos. Porto Alegre: Sulina, 1973; PALAZZO, José Truda. Balanço de Pagamentos: fatores de pertubação do seu equilíbrio e procedimentos para superá-los. Porto Alegre: Tese para concurso de cátedra de “Comércio internacional e câmbios” da Faculdade de Ciências Econômica da Universidade do Rio Grande do Sul, 1954; SÖDERSTEN, Bo. Economia Internacional. Rio de Janeiro: Interciência, 1979; 
produtos externos, caracterizando perdas para a indústria local. Quando há saída de capital, a depreciação da moeda local traz pressão inflacionária, que no modelo econômico adotado pelo Brasil, entre 1999 e 2013, é respondido com políticas contracionistas por parte do governo. O resultado é a tendência para diminuição do nível da atividade econômica local e aumento do desemprego:

Em uma economia com taxa de câmbio flexível, aberta a fluxos livres de capital, há uma apreciação da taxa de câmbio quando ceteris paribus há ingresso de capital, sob a forma de finanças. Essa valoração tem como efeito reduzir o nível da atividade doméstica e de aumentar o nível de desemprego, deslocando a demanda de produtos domésticos para produtos produzidos no exterior. Quando o capital flui para fora, no entanto, não temos uma inversão exata da história. Não temos, além de um ponto, qualquer aumento no nível de atividade, uma vez que uma depreciação da taxa de câmbio traz pressões inflacionárias, que criam instabilidade econômica e social. Para evitar tal instabilidade, o governo toma medidas antiinflacionárias por meio da redução das despesas públicas e, em geral, desinflando a economia, que novamente afeta negativamente o nível de atividade e o desemprego. ${ }^{78}$

Entre 1999 e 2013, os distintos governos não se propuseram a garantir o chamado “câmbio de equilíbrio”. Não se tentou manter estável o poder de compra do câmbio considerando a inflação interna e a externa. Tão pouco houve liberdade total do câmbio. Quando a oferta de divisas esteve muito alta, a autoridade monetária comprou dólares, impedindo que o câmbio caísse ainda mais. Gerou-se, dessa forma, larga reserva de divisas disponíveis (mas não utilizadas) para o governo controlar o câmbio ou realizar investimentos em um futuro, se assim o desejasse fazer.

No período, o câmbio brasileiro passou primeiro por um período de alta (1999 2003), e por um período de baixa (2004 - 2011), voltando a subir a partir de 2012. Essa trajetória foi resultado da saída das crises econômicas de 1999 e 2001-2002, do bom desempenho do comércio exterior brasileiro, entre 2003 e 2007, e pela capacidade de atrair investimentos (vender ativos) que o Brasil possuiu entre 2006 a 2013.

78 PATNAIK, Prabhat \& RAWAL, Vikas. "The Level Of Activity In An Economy with Free Capital Mobility". in: KÖSE, A. H. \& SENSES, F. et al. Neoliberal Globalization as New Imperialism. Nova Iorque: Nova Science Publishers, Inc., 2007. Pg 22. 


\begin{tabular}{|c|c|c|c|c|c|c|c|}
\hline \multicolumn{2}{|c|}{ Tabela 3.2: Demanda e Oferta de divisas no setor externo brasileiro em bilhões de dólares, 1999 a 2013 } \\
\hline (I) & (II) & (III) & (IV) & (V) & (VI) & (VII) & (VIII) \\
\hline & & & & & & Saldo de divisas \\
\hline & $\begin{array}{c}\text { Demanda } \\
\text { total de } \\
\text { dólares }\end{array}$ & $\begin{array}{c}\text { Oferta total } \\
\text { de dólares }\end{array}$ & (IV+VII) \\
\hline & $\begin{array}{c}\text { conta } \\
\text { financeira e } \\
\text { de capital }\end{array}$ & $\begin{array}{c}\text { Demanda } \\
\text { corrente por }\end{array}$ & (II)+(III) & $\begin{array}{c}\text { Oferta pela } \\
\text { conta } \\
\text { financeira e } \\
\text { de capital }\end{array}$ & $\begin{array}{c}\text { Oorrente de } \\
\text { dólar }\end{array}$ & (V)+(VI) & \\
\hline 1999 & $(15)$ & $(86)$ & $(101)$ & 32 & 61 & 93 & $(8,3)$ \\
\hline 2000 & $(22)$ & $(94)$ & $(116)$ & 41 & 70 & 111 & $(5,0)$ \\
\hline 2001 & $(5)$ & $(96)$ & $(101)$ & 33 & 72 & 105 & 4,3 \\
\hline 2002 & $(11)$ & $(83)$ & $(94)$ & 19 & 76 & 94 & 0,3 \\
\hline 2003 & $(11)$ & $(86)$ & $(96)$ & 15 & 90 & 105 & 8,9 \\
\hline 2004 & $(25)$ & $(104)$ & $(129)$ & 18 & 115 & 134 & 4,5 \\
\hline 2005 & $(32)$ & $(127)$ & $(159)$ & 22 & 141 & 163 & 3,9 \\
\hline 2006 & $(36)$ & $(154)$ & $(191)$ & 52 & 168 & 220 & 29,8 \\
\hline 2007 & $(26)$ & $(199)$ & $(224)$ & 115 & 200 & 315 & 90,6 \\
\hline 2008 & $(26)$ & $(273)$ & $(300)$ & 55 & 245 & 300 & 0,4 \\
\hline 2009 & $(20)$ & $(217)$ & $(237)$ & 90 & 193 & 283 & 45,7 \\
\hline 2010 & $(59)$ & $(291)$ & $(350)$ & 158 & 244 & 402 & 51,6 \\
\hline 2011 & $(39)$ & $(360)$ & $(399)$ & 150 & 308 & 458 & 58,3 \\
\hline 2012 & $(32)$ & $(350)$ & $(383)$ & 104 & 296 & 400 & 17,6 \\
\hline 2013 & $(49)$ & $(376)$ & $(425)$ & 122 & 295 & 416 & $(8,2)$ \\
\hline & & & & & & Fonte: Banco Central do Brasil. \\
\hline
\end{tabular}

Essa trajetória pode ser verificada na tabela 3.2. Nela, observa-se a demanda por divisas (coluna IV) pelas despesas da conta de capital (coluna II), e pelas despesas nas transações correntes (coluna III). Vê-se também a oferta de divisas no balanço de pagamentos (coluna VII), considerando a receita da conta financeira (coluna V) e das transações correntes (coluna VI). Assim, chega-se ao saldo de divisas pelo balanço de pagamentos (coluna VIII).

Através dessa tabela é possível caracterizar quatro períodos: (a) de 1999 a 2002, o Brasil experimentou déficit, ou parcos ganhos, no balanço de pagamentos. Isso foi resultado de uma conta financeira e de capital com baixos saldos, e transações correntes (que inclui o comércio de bens e de serviços, e a conta de rendas correntes) bastante deficitárias; (b) de 2003 a 2006, a demanda resultante da importação e do envio de lucros e pagamentos de juros ao exterior cresceu mais lentamente do que a oferta resultante dos ganhos com exportações. Isso resultou em um superavit relevante no saldo de divisas do Balanço de Pagamentos; (c) de 2007 a 2011, a demanda por divisas nas transações correntes alcançou e superou as ofertas. 
No entanto, os ganhos de divisas com empréstimos no exterior, com investimento estrangeiro direto, e com investimento estrangeiro em carteira superaram a demanda. Disso resultou saldos superiores ao período anterior; e (d) em 2011 e 2013, a capacidade de adquirir divisas no exterior do Brasil diminuiu, o que resultou no déficit de 2013.

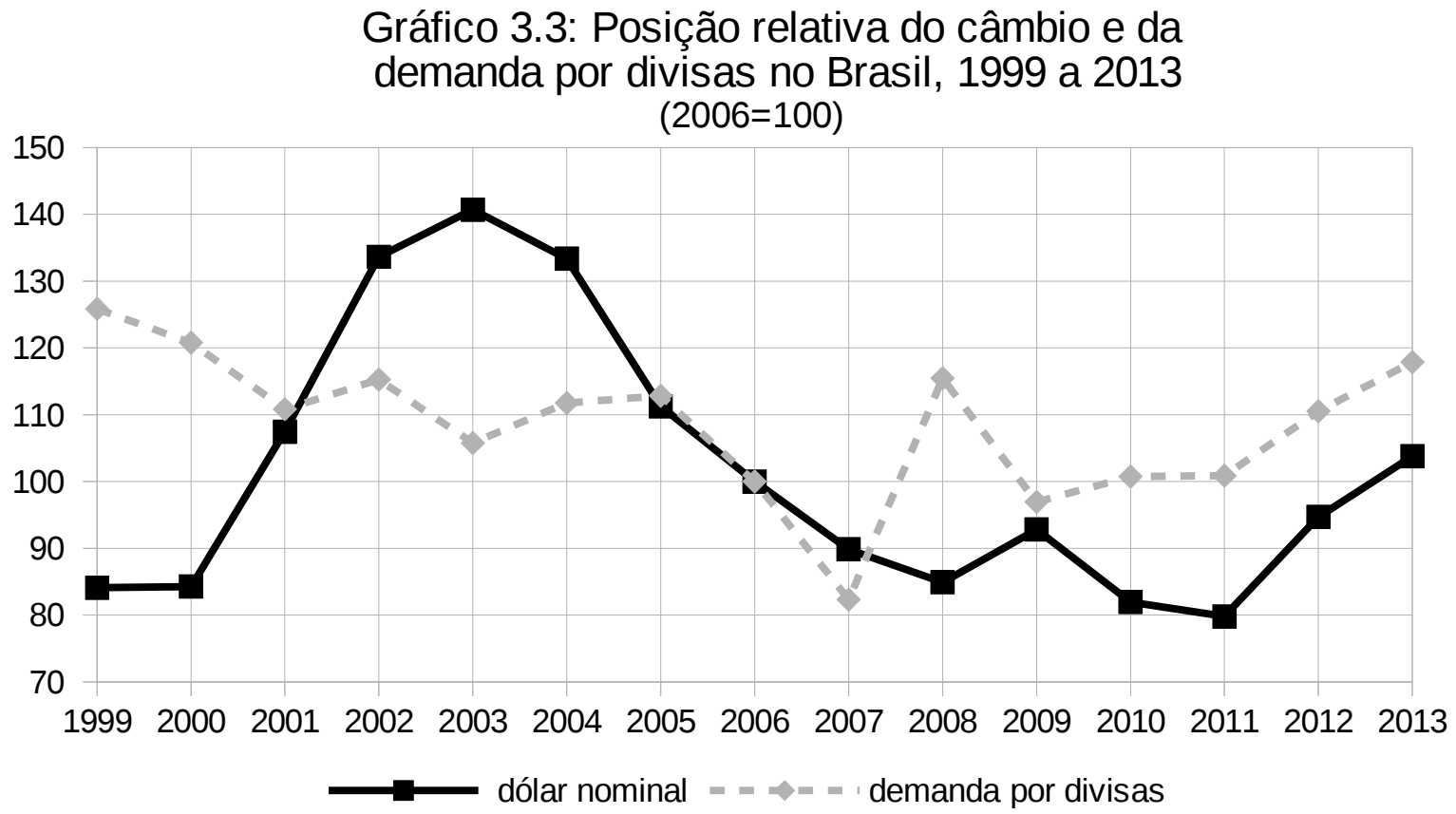

Fonte: Banco Central do Brasil

O gráfico 3.3 traz a posição relativa do câmbio nominal do dólar e a posição relativa do saldo da demanda e da oferta de divisas no Brasil, entre 1999 e 2013. Ambos foram calculados a partir de suas respectivas taxas de crescimento. Descrito dessa forma, pode-se verificar em que momentos o movimento do câmbio correspondeu aos movimentos de oferta e de demanda de divisas. Os momentos em que a posição do dólar aparece acima da posição da demanda por divisas expressa períodos em que o dólar esteve relativamente valorizado: havia oferta de dólares e câmbio caro. Quando a demanda por divisas cresceu acima do preço do dólar significa que houve câmbio barato. Ou seja, o real esteve relativamente valorizado, em relação a demanda.

De 1999 a 2003, o valor do dólar no mercado de câmbio cresceu, enquanto a demanda por divisas caiu. Isso foi fruto do ajuste do câmbio, frente ao real sobrevalorizado da época anterior. Entre 2005 e 2007, o câmbio e a demanda apresentaram movimento cadentes, fazendo coincidir sua posição relativa. Em 2008, ano da crise econômica mundial, houve forte oscilação para cima na demanda por divisas, seguido por uma queda em 2009. Trata-se de um 
comportamento expectado para uma economia com câmbio livre. De 2010 a 2011, houve afastamento do movimento do câmbio e da demanda. De 2012, ambos voltaram a mover-se no mesmo sentido, mas mantendo o câmbio abaixo da demanda. Isso aponta para a sobrevalorização do real, frente a demanda por divisas. Na mesma época, havia excedente no balanço de pagamentos brasileiro, o que significa que a autoridade monetária aumentou o seu estoque de divisas.

Entre 2010 e 2013, a alta oferta de dólares através da conta de capitais; a (a) demanda por dólares para transações correntes acima da oferta das exportações; e (b) a posição do câmbio afastada negativamente em relação a posição da demanda por divisas apontam que a sobrevalorização do real foi financiada através da (c) venda de ativos do país.

A sobrevalorização de uma moeda pode ser definida como a situação onde a taxa de câmbio nominal está se movendo em direção contrária as diferenças entre os preços internos e os preços externos de uma país. Ou seja, a moeda local está se desvalorizando mais lentamente que a indicação da taxa de inflação local. Isso faz com que os preços locais se tornem maiores que os preços externos, conforme bem recorda Donald Coes:

Uma terceira conclusão que se pode tirar da experiência cambial brasileira na última década é que as mudanças na taxa de câmbio real têm efeitos fortes e relativamente rápidos na conta corrente. O uso da taxa de câmbio como ferramenta para a estabilização de preços domésticos no primeiro período de Cardoso produziu uma queda acentuada na balança comercial. De forma reversa, a depreciação real do Real em 1999 resultou em uma reversão da tendência de exportação, tornando este setor um dos de crescimento mais rápido, tanto no segundo governo de Cardoso como no primeiro mandato de Lula. ${ }^{79}$

Na verdade, desde o primeiro mandato de Lula, o câmbio voltou a ser utilizado como instrumento de controle de inflação. Ou seja, houve ausência de uma política econômica que buscasse utilizar os excedentes adquiridos com as exportações para financiar investimentos. Ao contrário, buscou-se atender a demanda interna através das importações, como parte da política de controle da inflação.

79 COES, Donald. "Exchange Rate Policy, Perceptions of Risk, and External Constraints under Lula". In: LOVE, Joseph \& BAER, Werner (orgs). Brazil under Lula Economy, Politics, and Society under the Worker-President. Nova Iorque: Palgrave Macmillan, 2009. pg. 131 


\begin{tabular}{|c|c|c|c|c|}
\hline \multicolumn{5}{|c|}{ Tabela 3.3: Câmbio nominal e câmbio real no Brasil, 1999 a 2013} \\
\hline (I) & (II) & (III) & (IV) & $(\mathrm{V})$ \\
\hline ano & $\begin{array}{c}\text { Câmbio real-dólar } \\
\text { nominal }\end{array}$ & $\begin{array}{c}\text { Índice do deflator } \\
\text { do dólar }\end{array}$ & $\begin{array}{c}\text { Índice do deflator } \\
\text { do PIB } \\
(2006=100)\end{array}$ & Dólar real $=(\mathrm{II} / \mathrm{III}) * \mathrm{IV}$ \\
\hline 1999 & 1,86 & 118 & 179 & 2,81 \\
\hline 2000 & 1,87 & 116 & 168 & 2,71 \\
\hline 2001 & 2,38 & 113 & 155 & 3,25 \\
\hline 2002 & 2,96 & 111 & 140 & 3,71 \\
\hline 2003 & 3,11 & 109 & 123 & 3,50 \\
\hline 2004 & 2,95 & 106 & 114 & 3,16 \\
\hline 2005 & 2,46 & 103 & 106 & 2,54 \\
\hline 2006 & 2,21 & 100 & 100 & 2,21 \\
\hline 2007 & 1,99 & 97 & 94 & 1,93 \\
\hline 2008 & 1,88 & 96 & 87 & 1,72 \\
\hline 2009 & 2,05 & 95 & 81 & 1,76 \\
\hline 2010 & 1,81 & 94 & 75 & 1,46 \\
\hline 2011 & 1,77 & 92 & 70 & 1,35 \\
\hline 2012 & 2,10 & 90 & 67 & 1,56 \\
\hline 2013 & 2,30 & 89 & 62 & 1,61 \\
\hline & & Cálculo r & $\begin{array}{r}\text { Fonte } \\
\text { alizado com } 4 \text { casa }\end{array}$ & $\begin{array}{l}\text { Banco Central do Brasi } \\
\text { decimais e arredondado }\end{array}$ \\
\hline
\end{tabular}

A tabela 3.3 traz o câmbio nominal do dólar, no Brasil (coluna II); o índice do deflator do dólar, que é uma proxy do índice da taxa de inflação dos preços externos (coluna III); o índice do deflator do PIB brasileiro, que pode ser usado como uma proxy do índice dos preços internos do pais (coluna IV); e a taxa de câmbio real (coluna V). Quando a taxa de câmbio real está caindo, ocorre movimento favorável às importações. Quando ela está subindo, então as exportações estão sendo favorecidas.

Observa-se que houve aumento da taxa de câmbio real apenas entre 2000 e 2002. A partir de então, o câmbio real sofreu queda anualmente, até 2011, com uma pequena oscilação para cima, em 2009. Portanto, durante todo período, entre 2002 e 2009, as importações foram favorecidas pelo movimento do câmbio no Brasil.

O gráfico 3.4 traz a posição relativa do câmbio nominal do real para o dólar, e do câmbio de equilíbrio, entre 1999 e 2013. O câmbio de equilíbrio é um valor abstrato que expressa em quanto o câmbio nominal deveria estar para que não houvesse favorecimento nem das exportações nem das importações por conta da diferença dos preços. No gráfico, utilizou-se o câmbio de 2006 como ponto de referência. 


\section{Gráfico 3.4: Posição relativa do câmbio nominal e do câmbio "de equilíbrio"}

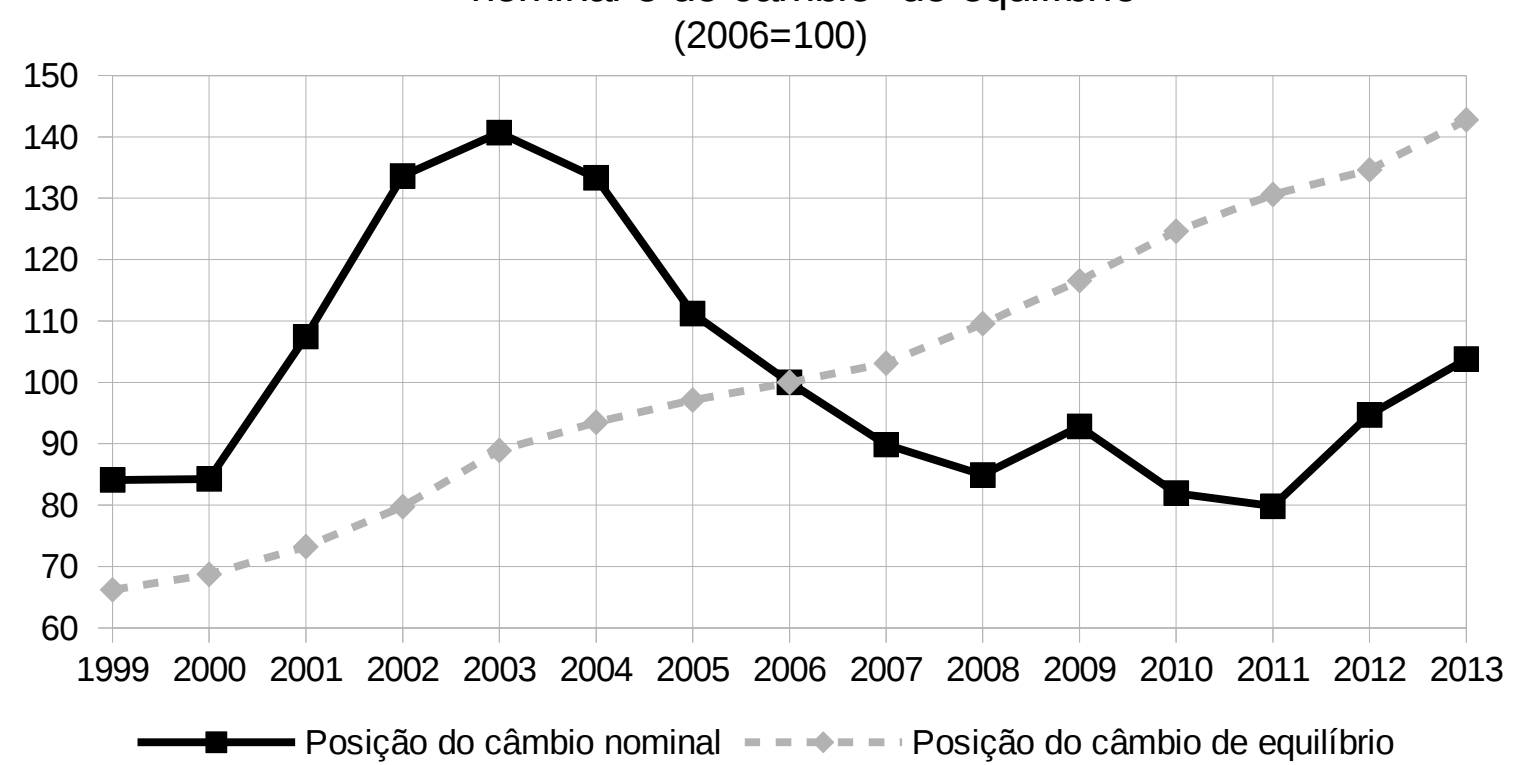

Fonte: Banco Central do Brasil

O que se observa é que, desde 1999 até 2013, o câmbio deveria ter oscilado para cima, a fim de não se incentivar expansão das importações por diferença de preços. Até 2003, o câmbio nominal aumentou bastante a mais do expectado pelo câmbio de equilíbrio. Isso significa que, até aquela data, as exportações brasileiras foram favorecidas. De 2003 a 2011, o câmbio nominal apresentou uma tendência oposta. Caiu rapidamente, cruzando o câmbio de equilíbrio. Nessa época, as importações foram beneficiadas.

Esse movimento de queda do câmbio nominal em um período em que ele deveria estar aumentado, para que se mantivesse o câmbio de equilíbrio, é o que se chama de sobrevalorização do real. A maior parte dessa sobrevalorização ocorreu entre 2004 e 2008, período em que houve superavit nas transações correntes brasileiras. Uma vez que esse superavit se esgotou, o câmbio nominal oscilou no mesmo patamar. No entanto, a inflação interna continuou a empurrar o câmbio real para baixo. Disso resultou novos incentivos para a importação de bens e serviços.

Trata-se de um uso do câmbio como ferramenta de combate à inflação, seguindo as recomendações dos manuais internacionais neoliberais para economias em desenvolvimento. Para os adeptos dessas teorias, o câmbio deve ser mantido valorizado, de forma que o dólar barato "financie" a economia interna, impedindo que a inflação aumente. Em tese, a inflação baixa e o câmbio valorizado deveria atrair investimentos estrangeiros que financiariam o 
câmbio. Na prática, isso só ocorre enquanto houver ativos lucrativos (ou estratégicos) a serem vendidos ao estrangeiro. Ainda, o custo dessa política é a existência do déficit nas transações correntes do balanço de pagamentos, conforme as importações sejam ampliadas acima do crescimento das exportações.

Dércio Garcia Munhoz explicou o impacto negativo dessa política: como há inflação interna no Brasil, e o câmbio estava controlado e valorizado, os produtos brasileiros estavam se tornando relativamente mais caros, e os produtos estrangeiros relativamente mais baratos. Isso fez com que a indústria brasileira perdesse competitividade e se tornasse cada vez mais dependente da importação de partes e peças importadas. Trata-se de um “custo câmbio”, que estava cristalizado a valores de 15 anos atrás, em $2010 .^{80}$

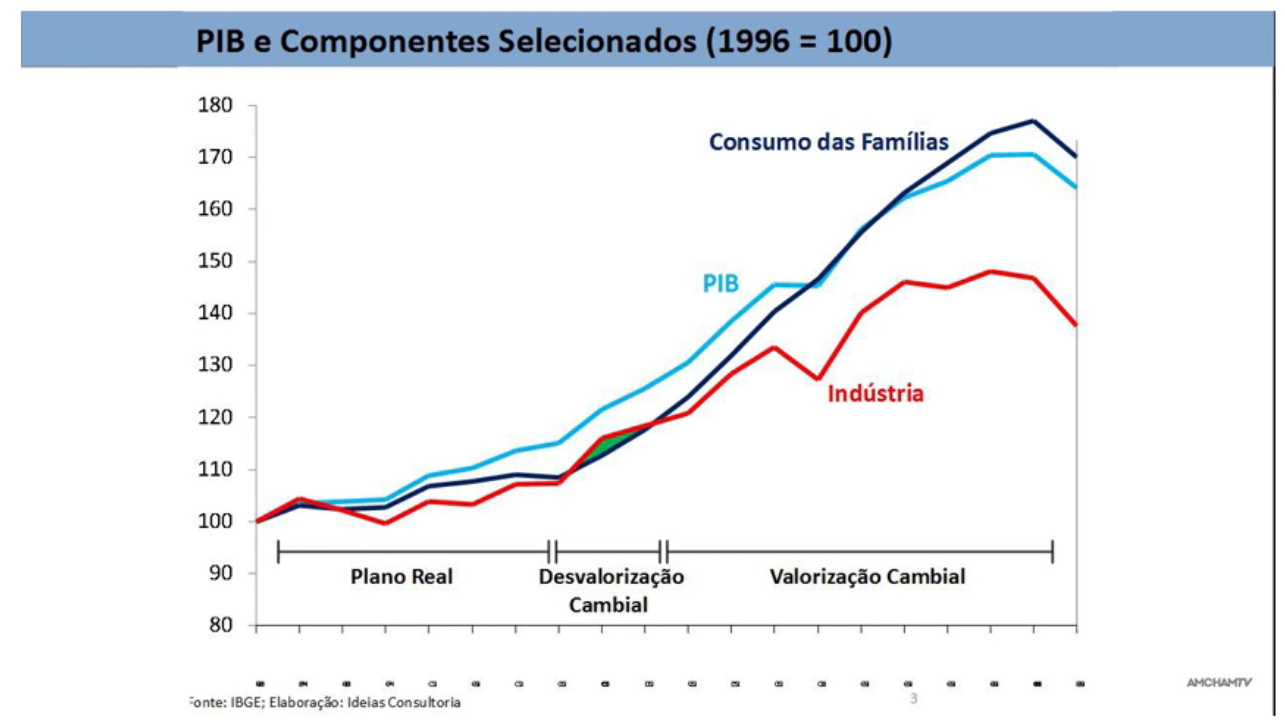

*Fonte: Delfim Netto - Cenário Econômico Nacional e Internacional

Delfim Netto também considera que a política de uso do câmbio para controle da inflação prejudicou a competitividade da indústria localizada no Brasil. Ele justificou seu argumento utilizando um gráfico bastante elucidador, reproduzido acima. Nele, verifica-se que o valor agregado produzido pela indústria apenas esteve acima do consumo das famílias entre 2002 e $2004 .{ }^{81}$

O efeito da perda de competitividade da indústria local só é plenamente percebida pela população local quando as exportações do país caem. Nessas condições, os preços dos 80 Entrevista de Dércio Garcia Munhoz concedida ao Agenda Econômica, programa da Tv Senado, em 15/10/2010.

81 Sobre o tema ver palestra de Delfim Netto: Cenário Econômico Nacional e Internacional (Parte 1), Cerimônia de Posse do Conselho da Amcham 2016. Disponível em: https://www.youtube.com/watch?

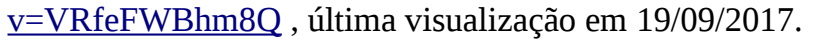


produtos importados tendem a subir, gerando pressão inflacionária. Como a indústria local foi parcialmente abandonada no período anterior, qualquer esforço para substituir os produtos antes supridos pela oferta externa só tem efeito com certo atraso, e em geral esbarra na dificuldade de importar equipamento para expandir a expansão em nível adequado à demanda ${ }^{82}$.

\subsection{UMA HISTÓRIA DA POLÍTICA COMERCIAL BRASILEIRA RECENTE}

Os dados apresentados e interpretados ao longo desse e do capítulo anterior apontam para a confirmação das hipóteses: (a) o comércio exterior foi chave importante na recuperação econômica do Brasil; (b) o desempenho da economia chinesa foi fator de peso no crescimento das exportações brasileiras no período; (c) houve reprimarização da pauta de exportação brasileira, embora não tenha havido queda real nas exportações de produtos industriais; (d) houve perda de competitividade interna na industria doméstica, e uma política cambial ofensiva a ela, acarretando maiores perdas nas importações brasileiras; (e) não houve formação de uma economia local solidamente baseada no suprimento da demanda interna; e (f) nessas condições o país tem continuado dependente das economias desenvolvidas, em especial através da dependência da parceria China-EUA.

Essas características da economia brasileira foram construídas e reafirmadas em um processo histórico à deriva dos projetos brasileiros de consolidação. Isso pode ser detectado através das análises feitas pelo governo, e pelas medidas econômicas tomadas. Através dos relatórios do Banco Central do Brasil, pode-se estudar a formação do novo programa para o comércio exterior brasileiro. ${ }^{83}$

No ano 2000, o Brasil parecia dar sinais de recuperação da crise, havendo superado a crise de 1998. Para isso, as exportações para a China foram consideradas importantes, havendo crescido $40 \%$ somente naquele ano. No entanto, no ano seguinte estourou nova crise, resultante do desempenho ruim da economia internacional e da crise energética no país. Dessa vez, a crise perdurou mais, piorando em 2002.

O governo, ainda no segundo mandato do Presidente Fernando Henrique Cardoso,

82 Sobre o tema ver: MORAN, Cristian. Imports under a Foreign Exchange Constraint. he World Bank Economic Review, Vol. 3, No. 2 (May, 1989), pg. 279-295

83 Sobre o assunto, ver Relatório Anual do Banco do Brasil, edições de 1999 a 2013. 
passou a entender que somente o fortalecimento das exportações poderia melhorar a situação do país. No entanto, ainda não havia um programa claro nesse sentido. Sabia-se que não seria possível desenvolver a exportação sem que a produção se tornasse competitiva. Nesse sentido, optou-se por desonerar os gastos em pesquisa e produção. No ano seguinte, o desempenho do comércio exterior com a China e com a Rússia foram fatores importantes para evitar uma crise ainda maior. Mas, a tradição dessa nova exportação ainda não era forte no Brasil, e precisou ser fomentada através do órgão do governo criado para esse fim: a Agência Promotora de Exportações (Apex). O Brasil também precisou tomar postura mais ativa na Organização Mundial do Comércio (OMC), afim de defender a exportação de produtos agrícolas, que normalmente são alvo de tarifas protecionistas estratégicas nos países desenvolvidos. Mas foram as exportações de ferro que surpreenderam as expectativas e mostraram caminho para o êxito temporário do projeto exportador do Brasil. Devido ao aumento da demanda chinesa, as exportações de ferro bruto se tornaram o principal item, e a China o principal destinatário.

Em 2003, o novo governo (primeiro mandato do Presidente Luís Inácio Lula da Silva) manteve a política de priorização das exportações. Os benefícios aos exportadores foram ampliados. O grosso dos benefícios foram para os grandes exportadores, que receberam, inclusive, 96,9\% dos recursos do BNDES destinados à exportação. No entanto, também foi criado um programa específico para beneficiar os pequenos exportadores. O programa de financiamento aos exportadores foi aperfeiçoado no ano seguinte, diminuindo o montante de recursos destinados ao resgate de juros e aumentando o financiamento direto às exportações. Ainda, o programa de auxílio às importações, que oferecia crédito aos destinatários as exportações brasileiras, também apresentou melhoria. Como resultado das novas políticas e da parceria com a China, entre 2003 e 2004, as exportações brasileiras cresceram muito. Em 2005, esse processo continuou, embora com menor vigor.

Entre 2006 e 2007, o governo (no segundo mandato do Presidente Luís Inácio Lula da Silva) observou a desaceleração da capacidade do país no comércio internacional. Em parte isso foi fruto dos impasses junto as disputas na OMC e no travamento das negociações no Mercosul. Em ambos os casos a dificuldade encontrada foi a resistência à entrada dos produtos brasileiros, embora por motivos opostos. A Europa aumentou o rigoror das medidas protecionistas indiretas, como os critérios sanitários para importação de gado, ao passo que 
exigia a retirada das medidas protecionistas diretas do governo brasileiro.

Tratava-se, segundo o governo, de uma forma de os países desenvolvidos perpetuarem a entrada de seus produtos nos mercados alheios e fechar seus próprios mercados. Enquanto isso, no Mercosul, houve resistência dos países aos produtos brasileiros, pelo medo que houvesse desorganização das produções locais. Por outro lado, os industriais brasileiros resistiram a fazer concessões necessárias, principalmente para a Argentina. Nesse cenário, as negociações com a China apresentaram-se mais frutíferas. Embora as medidas de incentivo a exportação continuassem a ser fortalecidas, o que favorecia as exportações a países mais pobres, a demanda chinesa atraia os principais produtos da pauta de exportação do Brasil. Ao mesmo tempo, ao final daquele ano, estourava a crise econômica dos subprime, nos EUA, diminuindo a chance no crescimento da demanda ocidental de produtos.

No ano de 2008, a crise econômica se generalizou, atingindo a Europa. No cenário de crise, foi feita a escolha, pelo governo, de diminuir o financiamento às exportações, aumentando o financiamento aos produtores exportadores, em especial através dos programas do BNDES. Com a redução do crédito no mercado corrente, ao final do ano, o Banco Nacional de Desenvolvimento Econômico e Social ampliou o crédito máximo oferecido, buscando diminuir o impacto da crise para os exportadores. Em 2009, o cenário permaneceu similar. Diante da oferta de crédito nacional, da diminuição dos incentivos à exportação, e da quebra na demanda internacional, os exportadores voltaram suas atividades para o mercado interno, em parte e temporariamente.

Para evitar que houvesse maiores perdas nas exportações, o governo aprovou uma medida para estender o prazo para contratação de câmbio. Isso permitia aos exportadores jogar de forma mais vantajosa com a especulação cambial. Nesses anos, o investimento local na exploração e refinamento de petróleo foram beneficiados. Tratam-se de investimentos de longo prazo, de que não se espera retorno imediato durante a crise. Por isso, em cenário de baixa da expectativa da realização de boas taxas de lucro, eles se tornaram atraentes.

A partir de 2010, observou-se novo cenário positivo para as exportações brasileiras. Houve recuperação parcial da economia mundial. No entanto, houve desvalorização do dólar frente ao real. As condições internacionais favoráveis ao comércio exterior foram potencializadas pelo governo, que optou por ampliar as linhas de financiamento e de isenção para os exportadores, especialmente para as empresas historicamente exportadoras. O impacto 
positivo das políticas tomadas criou, segundo a leitura do Banco Central, condições para ampliação dos investimentos e do consumo brasileiro. Como resultado, houve aumento das importações acima do das exportações.

Naquele momento, o crescimento das exportações ainda justificava e sustentava a ampliação das importações. Esse cenário perdurou até a metade de 2011, quando o crescimento da economia mundial apresentou sinais de desaquecimento. Em agosto, foi lançado o Plano Brasil Maior (PBM), que visava aumentar a competitividade das exportações brasileiras e da indústria nacional, intentando garantir melhora na balança comercial. Para tal, o PBM incluía novas desonerações sobre a exportação e sobre os investimentos em tecnologia e em compra de bens de capital; e estabelecimento de fontes de novas financiamento, como o Fundo de Financiamento à Exportação. Trata-se de mecanismo de empréstimo para países que desejassem importar mercadorias do Brasil.

Para aumentar a entrada dos produtos brasileiros na América Latina, foram feitas novas concessões no âmbito do Mercosul, permitindo que as negociações avançassem, ao passo que os países passaram a poder aumentar temporariamente as taxas de importação. Apesar de ter havido crescimento pequeno na quantidade de produtos exportados, o cenário mundial ainda foi favorável ao aumento da demanda, resultando em aumento do preço dos produtos brasileiros, em especial o das “commodities”. Essa alta, no entanto, já era percebida como insustentável a médio prazo. Daí a necessidade de uma política que visasse o fortalecimento da competitividade das exportações.

Com o agravamento da crise econômica na Europa, e com o desaquecimento da economia estadunidense, em 2012, os preços das commodities, e sua demanda, entraram em tendência de queda. Como resposta, o governo fortaleceu o Plano Brasil Maior (PBM), realizando novas desonerações. O investimento na marinha mercantil e nos portos brasileiros foi largamente favorecido. A cadeia de produção de automóveis também se beneficiou de novas isenções. Também houve ampliação dos benefícios voltados para a indústria de semicondutores e para o sistema de comunicação e informática. O conceito de empresa exportadora também foi ampliado, aumentando o número de empresas beneficiadas pelos programas de financiamento e desoneração de exportação. Houve até mesmo uma tentativa de desincentivar a entrada de capital de curto prazo e incentivar os investimentos estrangeiros diretos, a partir de março. No entanto, houve forte pressão do mercado para derrubar essas 
medidas tidas como mais radicais, que foram suspensas a partir da metade do ano.

Apesar do esforço de melhoria da competitividade da indústria e dos produtos de exportação do Brasil, houve piora do balanço comercial brasileiro. Em 2013, houve queda no valor de exportação, enquanto se observou crescimento das importações. O Plano Brasil Maior foi mantido, e ainda mais ampliado. O governo entendia, naquele momento, que havia uma recuperação da economia dos países desenvolvidos, que voltava a atrair investimentos, ao passo que as economias emergentes (incluindo a China) observavam desaquecimento. $\mathrm{O}$ resultado foi uma diminuição do fluxo de investimentos estrangeiros para o Brasil e uma queda na demanda de commodities. Nesse sentido, o governo entendia que era necessário fazer um esforço pela ampliação da concessão de crédito e da melhoria das condições para investimento produtivo no Brasil.

\subsection{O GOVERNO E OS EXPORTADORES-IMPORTADORES}

Durante o período de largo crescimento das exportações e do saldo comercial brasileiro, em especial até 2007, houve certa sintonia entre os interesses dos grandes exportadores e o governo. Foram poucos críticos da política de comércio exterior adotada no país. Essa sintonia iria durar ainda alguns anos. Na verdade, diante do bom desempenho da economia brasileira logo após a crise econômica de 2007-09, houve certo frenesi que exaltava a capacidade de crescimento do país.

Ainda em novembro de 2007, Welber Barral, então secretário do comércio exterior do Ministério do Desenvolvimento, Indústria e Comércio Exterior (MDICE), concedeu uma entrevista ao jornal Folha de São Paulo ${ }^{84}$. Naquele momento, o Brasil começava a apresentar esgotamento dos saldos do comércio exterior, caracterizado pela alta das importações bastante acima das exportações. Para ele, a queda nos saldos não era mal sinal. Segundo a visão apresentada na entrevista, o importante era que as exportações continuassem a crescer, o que parecia propício. Em sua visão, a crise internacional não havia afetado negativamente o comércio exterior brasileiro, e isso era resultado da relevância de outros parceiros comerciais, para além dos EUA. Nesse cenário, a principal preocupação do governo era diminuir a burocracia, para permitir que houvesse novos crescimentos nas exportações. A força

84 Disponível no sítio de internet: http://www1.folha.uol.com.br/fsp/dinheiro/fi1811200717.htm, última visualização em 25/03/2015. 
comercial brasileira, era tida, ao menos no discurso, como um processo natural, fruto da realização do potencial do país.

Mais tarde, em 2011, os rumos da exportações já haviam se tornado centro das preocupações da economia brasileira, mesmo aos olhos de representantes do governo. Tatiana Lacerda Prazeres, então secretária do comércio exterior, apresentou um resumo da análise da secretaria, em uma entrevista dada ao programa Pauta Econômica, da TV Senado, em setembro de $2011^{85}$. Para ela, a caracterização do período precedente, durante toda a década de 2000, e especialmente após a crise de 2008, era o ganho de dinamismo da Ásia, em especial da China. Nesse cenário, o Brasil havia encontrado a possibilidade de ampliação e diversificação de seu comércio exterior. Para ela, à época, a pauta de exportação brasileira era competitiva e diversificada, com espaço para crescimento das exportações de manufaturados, inclusive da exportação de aviões.

Os preços internacionais, naquele momento, atraíam exportadores brasileiros, inclusive produtores de etanol, em um momento em que havia falta de etanol no país. Isso apontava para um crescimento pontual do saldo comercial. No entanto, Prazeres explicava na entrevista que estava em andamento um programa que deveria melhorar a qualidade do comércio exterior brasileiro. Este deveria se tornar menos volátil. Durante todo o período anterior (década de 2000), havia sido feito vasto investimento para elevar a competitividade do agronegócio brasileiro, e da indústria extrativa mineral. De forma oficial, ela rechaçava a tese de que havia perda de competitividade da indústria manufatureira brasileira, apresentando uma leitura em que o ganho de importância das “commodities” na pauta de exportação era fruto de uma competitividade maior desse tipo de produto e de alta da demanda pelos mesmos.

Naquele momento, para ela, o real estava adequadamente valorizado, o que permitia maiores investimentos e compra de insumos para produção. Como impacto negativo, havia o crescimento das importações de bens de consumo duráveis, inclusive automóveis. Isso preocupava o governo. O Plano Brasil Maior adotava medidas para garantir inovação na indústria, o que deveria suprir as necessidades para aumentar a competitividade.

Em 2013, Tatiana Lacerda Prazeres, ainda secretária do comércio exterior, voltou ao

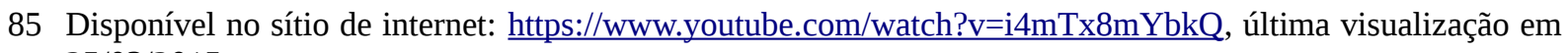
25/03/2015. 
programa Agenda Econômica ${ }^{86}$. Nessa entrevista, Tatiana voltou a apresentar a leitura que a pauta exportadora era diversificada, com bastante importância da exportação de bens manufaturados e semimanufaturados. A alta da demanda das commodities, até 2011, explicava o seu crescimento em valor, bastante acima do crescimento do quantum exportado. Em 2012, houve diminuição no valor das exportações brasileiras, como consequência da queda de preços das “commodities”. Para ela, isso era resultado do crescimento anormal dos preços nos dois anos anteriores, e não de um processo de perda de competitividade dos produtos brasileiros. A tendência era de crescimento das exportações de bens industrializados, mas que o governo podia no máximo realizar incentivos positivos para incentivar a agregação de valor. Não se podia penalizar a exportação de produtos básicos. Apontava, dessa forma, que havia uma escolha por parte dos produtores brasileiros, em exportar os produtos antes de os processar localmente. Ainda, apontava que o agronegócio brasileiro era investidor, e que havia largo investimento brasileiro para que ele fosse referência nessa área.

Na prática, após 2010, o governo havia passado a direcionar o esforço de desenvolvimento para alguns produtos eleitos como mais competitivos para a exportação. Durante esse processo, a indústria extrativa de petróleo foi largamente beneficiada. Os investimentos na expansão dos negócios e na inovação tecnológica renderam à Petrobras um posto de destaque dentre as empresas internacionais de petróleo. Apesar de ter sofrido com a queda dos preços de petróleo, os investimentos para exploração nas reservas petrolíferas da camada pré-sal renderam bons resultados. Em uma apresentação ministrada em junho de 2014 ${ }^{87}$, a então presidente da Petrobras, Graça Foster, explicava que, entre 2010 e 2014, a produção do pré-sal havia crescido dez vezes. Naquele ano, mais da metade da produção de petróleo da empresa havia sido gerada pela exploração do pré-sal. A expectativa era de contínuo crescimento até 2035.

Algo similar ocorreu com o setor da extração de minerais, que foi um dos beneficiados pela política de favorecimento aos exportadores tradicionais. A principal empresa de exploração de minérios do Brasil, a Vale ${ }^{88}$, apresentou bom desempenho entre os anos 2000 e

86 Disponível no sítio de internet https://www.youtube.com/watch?v=EcdNuzGA3dc, última visualização em 25/03/2015.

87 Disponível no sítio de internet: http://www.petrobras.com.br/fatos-e-dados/graca-foster-fala-sobreimportancia-do-pre-sal-em-palestra-no-rio.htm, última visualização, 25/03/2015

88 A Vale, antiga Vale do Rio Doce, foi uma das empresas estatais privatizadas na década de 1990. Foi uma empresa que, no setor privado, já surgiu gigantesca. A privatização da Vale foi um bom negócio para os novos donos, e uma grande perda para o povo brasileiro. Ainda assim, dada sua importância, o governo continua a privilegiá-la, a fim de facilitar sua expansão. Daí que haja, em geral, sintonia entre o presidente 
2013. Em outubro de 2008, diante da crise internacional, o então presidente da empresa, Roger Agnelli, foi entrevistado pela revista Exame $^{89}$. Ele afirmava que a empresa havia apresentado ótimo desempenho econômico no período anterior. A crise econômica havia atingido o mundo em um momento bom para os exportadores de minério que houvessem se preparado para aguentar um pequeno período de quebra. Para ele, a tendência era que a demanda chinesa impulsionasse reajustes para cima no preço do minério de ferro. Em sua visão, o cenário era de oportunidade àqueles que tivessem paciência.

Em 2011, Murilo Ferreira assumiu a presidência da Vale, no lugar de Agnelli. Tratavase do melhor período da história da exportação de minério de ferro, ao menos aos olhos do novo presidente. Em uma entrevista concedida à revista Istoé Dinheiro, em fevereiro de 2015, Murilo analisou a sua gestão até então ${ }^{90}$. Para ele, depois de 2012, os exportadores de “commodities” tiveram que enfrentar uma espécie de ressaca das altas do preço de 2010 e 2011.

Após o largo crescimento das economias e das empresas exportadoras de commodities, com a queda dos preços, elas passaram a ter que mudar sua estratégia. No caso da Vale, isso resultou na necessidade de desinvestimento, mantendo apenas os investimentos mais lucrativos. No entanto, Murilo Ferreira acreditava que o setor extrativo, que o sistema bancário, e o sistema agropecuário do Brasil fossem modernos, e poderiam se adaptar ao novo cenário. Para o então presidente da Vale, portanto, o projeto exportador do Brasil podia ser mantido, se os setores tradicionalmente exportadores se mantivessem atualizados.

Tanto a Petrobras como a Vale são empresas do setor extrativo. Tanto o ramo do petróleo como o dos minérios são considerados favoráveis à conformação de oligopólios. Os oligopólios possuem facilidade de realizar planejamento econômico, aproveitando os momentos de crescimento para gerar excedente a ser queimado em momentos de crise. Nesse sentido, o comportamento da economia brasileira, em especial do setor externo, parece ter sido favorável a esses dois ramos, e em especial a essas duas empresas.

da Vale e o governo brasileiro.

89 Entrevista disponível em: http://exame.abril.com.br/negocios/noticias/vale-se-preparou-inverno-afirmaroger-agnelli-396709, última visualização em 30/03/2015.

90 Entrevista disponível em: http://www.istoedinheiro.com.br/noticias/negocios/20150203/desafios-muriloferreira/228805.shtml, útlima visualização em 30/03/2015. 


\subsection{AINDA OS EXPORTADORES-IMPORTADORES}

Os produtores de automóveis também foram bastante favorecidos pelas políticas do governo durante todo o período. Em 2005, o então presidente da Associação Nacional dos Fabricantes de Automotores (ANFAVEA), Rogélio Golfarb, acreditava que o cenário econômico era positivo para o segmento. Para ele, havia espaço para crescimento das vendas nacionais graças ao crescimento da agropecuária, e para as exportações para mercados vizinhos. ${ }^{91}$

Com o fortalecimento do mercado interno, e com o fortalecimento da capacidade de exportação, os representantes da ANFAVEA continuavam a ter boas expectativas, mesmo diante da crise econômica internacional de 2008. Apesar da queda do crescimento do setor dos automotores, em especial a partir do final do ano, Jackson Schneider, então presidente da ANFAVEA, afirmava que a expectativa era que o impacto da crise não impedisse o bom desempenho das vendas de automóveis. Isso devido a maior parte serem vendas para o mercado interno. Para ele, a maior perda era causada pela dificuldade de os consumidores venderem seus veículos velhos para financiar novas compras. ${ }^{92}$

Em 2010, o mercado de automóveis parecia estar no seu limite. O novo presidente da associação, Cledorvino Belini, expressou, em entrevista concedida ao jornal Valor ${ }^{93}$, que os produtores de automotores tinham dois desafios: (a) enfrentar a competição estrangeira no Brasil; e (b) se tornar competitivos para exportação ao exterior. Para isso, pretendia realizar uma proposta ao governo sugerindo medidas de incentivo para produção nacional de automóveis $^{94}$, e a manutenção de políticas de desincentivo à importação. Ambas as demandas seriam atendidas nos anos que se seguiram. Isso através da redução do IPI e do estabelecimento de taxas maiores para importação de automóveis, como parte do Plano Brasil Maior.

Em 2014, Luiz Moan, o então presidente da ANFAVEA, estava satisfeito com as políticas adotadas pelo governo. Em entrevista à revista Brasil Econômico ${ }^{95}$, afirmou que o

91 Ver entrevista à revista mecânica online:
http://www.mecanicaonline.com.br/2005/04 abril/engenharia/rogelio golfarb.htm, última visualização em 30/03/2015.

92 Ver entrevista à Agência Estado, disponível em: http://www.abril.com.br/noticias/geral/anfavea-industriaautomotiva-tenta-evitar-demissoes-202105.shtml, última visualização em 30/03/2015,

93 Disponível em: http://economia.uol.com.br/ultimas-noticias/valor/2010/04/30/novo-presidente-da-anfaveabelini-pede-choque-de-competitividade.jhtm, última visualização em 30/03/2015.

94 Por produção de automóveis, entenda-se montagem.

95 Disponível em: http://economia.uol.com.br/ultimas-noticias/valor/2010/04/30/novo-presidente-da-anfavea- 
crescimento econômico brasileiro era sustentado pelo consumo interno. As políticas de redução de impostos que haviam sido tomadas no período precedente eram adequadas para garantir o crescimento do setor e aumentar a competitividade dos automóveis produzidos no Brasil. As quedas nas exportações que foram observadas no período podiam ser resolvidas através do fortalecimento de acordos comerciais com países vizinhos, intermediados pelo governo.

No entanto, essa sintonia entre o governo e os produtores tendeu a enfraquecer, quando se analisa o setor agropecuário. Embora tenha havido amplo favorecimento de produtores exportadores, em especial de monoculturas como a da soja e a da cana de açúcar, elas apresentaram maiores dificuldades de conquistar suas demandas, quando apresentadas ao governo.

Glauber Silveira, que era presidente da Aprosoja de Mato Grosso, e posteriormente se tornou presidente da Aprosoja-Brasil, foi entrevistado pelo Canal Rural, em junho de $2008^{96}$. Ele afirmava que o momento era bom para os produtores de soja, mas que havia dificuldades resultantes da falta de infraestrutura para escoamento das mercadorias. Isso acarretava custos mais altos para produção e para a comercialização. Como resultado, a taxa de lucro dos produtores era diminuída. Ao ser questionado se isso impactava na capacidade de produção do Brasil, ele respondeu que não.

Quatro anos depois, em um momento em que os preços das commodities começavam a cair, seu discurso mudou, em um artigo divulgado pela Aprosoja ${ }^{97}$. Para ele, havia falta de investimento, em especial em infraestrutura. Diante dos altos custos, e de preços em queda, a taxa de lucro dos produtores de soja havia declinado. Como resultado, houve declínio da produção. Em 2013, ele voltaria a defender essa tese ${ }^{98}$.

Além da preocupação com a infraestrutura, a Aprosoja, dirigida por Glauber Silveira, se posicionou contrária às políticas do governo que envolviam a preservação ambiental, em especial à do cerrado, e às políticas de demarcação de terras indígenas. Para o presidente daquela associação de produtores, a soja desenvolvia o país. O desmatamento de parte de um

belini-pede-choque-de-competitividade.jhtm, última visualização em 30/03/2015

96 Entrevista disponível no sítio de internet: https://www.youtube.com/watch?v=V9q8Vx9v-yk, última visualização em 30/03/2015

97 Disponível em: http://aprosojabrasil.com.br/2014/clima-e-falta-de-investimento-afetam-desempenho-no-pibaponta-aprosoja-brasil/, última visualização em 30/03/2015.

98 Em artigo disponível em http://aprosojabrasil.com.br/2014/a-batalha-da-producao-brasileira/, última visualização em 30/03/2015. 
sistema ecológico "pobre”"99 era uma consequência aceitável. ${ }^{100}$

A discordância em relação à política econômica do governo também marcou o discurso dos representantes dos produtores de açúcar e de etanol (usineiros), em especial após a queda dos preços das commodities. Entre 2006 e 2012, parecia haver sintonia entre o que governo aplicava e as expectativas dos usineiros, em especial na figura da Associação Biocana $^{101}$. Na época, foram montadas muitas novas usinas. Em 2012, o ritmo de crescimento do setor sucroalcooleiro diminuiu, ao passo que a alta dos preços expressava desgaste.

Diante da queda dos preços, os usineiros passaram a enxergar a política econômica do governo com um olhar mais desconfiado. Leila Alencar Monteiro de Souza, presidente da Biocana, concedeu uma entrevista à revista Canavieiros, da Associação dos Plantadores de Cana do Oeste do Estado de São Paulo, em março de 2015. Nela, pontuava que havia três demandas centrais para o fortalecimento do segmento sucroalcooleiro: (a) aumento do investimento em infraestrutura; (b) maiores incentivos à inovação tecnológica; e (c) revisão da política tributária para favorecimento dos produtores de energia renovável.

O ponto (c) apresentava a maior discordância em relação às políticas do governo, desde 2010. Apesar de ter se aumentado a participação do álcool na gasolina algumas vezes durante no período em análise, o governo priorizou o petróleo como fonte energética, em especial para o transporte. Na prática, o crescimento daquele segmento estaria jogado à própria sorte, dependendo das oscilações dos preços do mercado interno e do mercado exterior. A maior crítica à política econômica do governo era, portanto, a de não eleger o etanol como o carro chefe do desenvolvimento.

\subsection{UM DEBATE SOBRE O COMÉRCIO EXTERIOR BRASILEIRO, DE 1999} A 2013

O debate sobre o significado da recuperação recente do Brasil, e o esgotamento da mesma, teve início logo que ele foi identificado. A sua caracterização e a reflexão de seus

99 Glauber Silveira considerava um dos ecossistemas mais ricos e complexos do mundo, o cerrado, um ecossistema pobre e pouco produtivo.

$100 \mathrm{Em}$ artigo dispónível em http://www.noticiasagricolas.com.br/noticias/agronegocio/136188-produtorbrasileiro-considere-se-culpado--por-glauber-silveira--da-aprosoja-brasil.html\#.VRmo18vETeQ, última visualização em 30/03/2015.

$101 \mathrm{O}$ otimismo da Biocana foi expresso na nota publicada pela então presidente da associação, Leila Alencar Monteiro de Souza, disponível em: http://www.biocana.com.br/index.php/conteudo/visualizar/2011-comsustentabilidade, última visualização em 30/03/2015. 
rumos foi alvo de reflexão de alguns pesquisadores. Alguns deles, Vitor Schincariol, Luiz Eduardo Simões de Souza, Maria de Fátima Silva, Luiz Filgueira, Reinaldo Gonçalves, Luís Antônio Paulino, e Sarquis José Buainain Sarquis, entre outros. As impressões iniciais já apontavam aspectos pertinentes que se confirmaram como entraves para a continuidade da recuperação, mais tarde. Posteriormente, novos estudos iriam identificar outros desafios não superados pelo Brasil, apontando para uma recuperação econômica dependente e limitada.

Em um artigo publicado na Revista de História Econômica e Economia Política (REPHE), em 2007, Vitor Schincariol e Luiz Eduardo apresentavam uma leitura sobre o desempenho da economia brasileira durante o primeiro mandato do presidente Luís Inácio Lula da Silva ${ }^{102}$. Para eles, o que caracterizava a política econômica adotada era a continuidade daquela do segundo mandato do presidente Fernando Henrique Cardoso. Não havia nenhum programa de desenvolvimento industrial, e a dívida externa continuava, àquele momento, a ser um problema grande. A oferta de títulos da dívida com remuneração de juro alto sugava parte do capital disponível para investimento produtivo.

Para eles, o bom desempenho se justificava pela conjuntura internacional favorável. O comércio exterior era uma das causas para superação da crise econômica anterior. Parte dos novos recursos adquiridos foram direcionados para políticas de criação de empregos e transferência de renda. Isso, no entanto, não havia gerado, ainda, uma sociedade voltada ao mercado interno.

Num estudo de maior vulto, Luiz Filgueira e Reinaldo Gonçalves apresentaram uma tese semelhante ${ }^{103}$. Segundo a leitura por eles apresentada, o governo Lula teria se caracterizado pela diminuição da fragilidade externa conjuntural, mas não da estrutural. Essa mudança tornava o Brasil mais resistente à pressões estrangeiras pontuais, em especial à pressões financeiras. No entanto, o país continuava vulnerável às mudanças e às pressões de média e longa duração.

A fragilidade conjuntural havia diminuído devido a força do comércio exterior, em especial das exportações de commodities, impulsionadas pelo crescimento da renda mundial e pelo crescimento acelerado da economia chinesa. No entanto, internamente, a capacidade de

102 SOUZA, Luiz Eduardo Simões de \& SCHINCARIOL, Vitor Eduardo. “O Desenvolvimento Distante - um balanço das políticas do primeiro governo de Lula”. Revista de Economia Política e História Econômica (REPHE). ISSN: 1807 - 2674. Nº 08, Julho de 2007. Pg. 05-32

103 Ver: FILGUEIRAS, Luiz \& GONÇALVES, Reinaldo. A Economia Política do Governo Lula. Rio de Janeiro: Contraponto, 2007. 
exportação brasileira teria crescido como fruto do ganho de produtividade do setor agropecuário e da baixa capacidade de consumo do mercado nacional. Nesse sentido, não ocorrera mudança estrutural na capacidade de produção e nas relações sociais existentes no país.

Como resultado, a exportação de bens primários cresceu mais rapidamente do que a dos bens manufaturados. Dentre os manufaturados, os produtos de baixa intensidade tecnológica também tiveram mais facilidade de experimentar expansão das exportações. A tendência de reprimarização da pauta de exportação só era mascarada pelos bons resultados no saldo comercial. Esses, por sua vez, permitiam financiar a internalização da dívida externa. O resultado foi a diminuição da pressão estrangeira sobre as finanças brasileiras, à custo da fragilização da pauta de exportação.

Esse processo teria como um dos limites a dificuldade de sustentação à médio prazo do modelo econômico adotado. Apesar do esforço do governo para realizar certa distribuição de renda, os gastos com pagamentos da dívida apenas aumentou em relação ao orçamento, entre 2000 e 2006, enquanto os gastos sociais diminuíram em termos proporcionais. As instituições financeiras continuavam a ser privilegiadas em detrimento da formação de uma economia voltada para o suprimento de um mercado interno pujante. Mesmo os programas de investimentos do PAC (Plano de Aceleração do Crescimento), programados para o período de 2007 a 2010, eram marcados por obras voltadas ao escoamento de mercadorias. O modelo exportador seria fortalecido, segundo a leitura dos autores. Na prática, ao invés de haver um programa de desenvolvimento progressista, os projetos de dependência eram privilegiados.

Luís Antônio Paulino corroborou essa leitura, um ano depois ${ }^{104}$. Para ele, a diferença entre a política econômica do governo Lula em relação ao governo FHC era o foco que foi dado às políticas de diminuição do abismo social. Na prática, o que sustentava o bom desempenho econômico do país era o comércio exterior. Para ele, o problema do endividamento público não havia sido superado, embora as exportações tenham servido para financiar uma transferência da dívida externa para dívida interna. Um Estado ainda endividado precisava dedicar parte de seu orçamento para o pagamento de juros. Como foi mantida como política prioritária do governo a “obrigação” do superavit primário e o combate à inflação, havia pouco espaço para um esforço de desenvolvimento independente do país.

104 PAULINO, Luís Antônio. “A Economia Política do Governo Lula da Silva”. Revista de Economia Política e História Econômica (REPHE). ISSN: 1807 - 2674. Nº 15, Dezembro de 2008. Pg. 17-50 
Mais tarde, Luís Eduardo Simões de Souza e Maria de Fátima Silva apesentaram, em $\operatorname{artigo}^{105}$, uma leitura levemente diferente. Embora apontassem que a conjuntura havia se tornado favorável ao comércio exterior brasileiro, acrescentavam que o excedente gerado havia sido empregado para o fortalecimento do mercado interno. Os gastos em distribuição de renda haviam fortalecido a capacidade de consumo das famílias, de 2003 a 2006. A partir daí, os gastos do governo teriam sido fortalecidos especialmente através de investimentos de infraestrutura. Nesse sentido, havia um esforço por parte do governo em transformar a conjuntura favorável em chave para modernização e desenvolvimento do país.

Vitor Eduardo Schincariol desenvolveu um estudo de vulto que resultou em obra lançada em $2012^{106}$. Diante de um momento em que a recuperação econômica do Brasil já mostrava sinais de desgaste, Vitor sintetizou as limitações e dificuldades encontradas. Para ele, o modelo adotado só havia se sustentado graças às exportações de minérios e de soja para China. Como dois dos principais resultados, houve fortalecimento do modelo oligopolista no Brasil, e perda de recursos da reserva mineral do país. Somente os minerais mais importantes para a exportação, em especial o minério de ferro, tiveram suas reservas ampliadas, a partir de programas de exploração e busca por novas jazidas.

Schincariol concluiu que houve as seguintes restrições ao crescimento, para o período de 2000 a 2008: (1) o crescimento foi induzido pelo aumento do setor de serviços e pelas exportações de commodities, e não pela produção manufatureira; (2) o nível de emprego aumentou, mas com grande influência do setor de serviços; (3) o setor industrial do Brasil foi fortemente influenciado pelas decisões dos oligopólios internacionais, o que comprometeria uma política independente para o setor; (4) dada a grande presença de capital estrangeiro no setor, as produções industriais trouxeram retorno diminuto para o país; (5) até a crise financeira, a política monetária conservadora não favoreceu o crescimento dos setores industriais; (6) os investimentos em carteira mais retiraram capital do que colocaram; e (7) o empuxo positivo das exportações teve baixo impacto nas regiões urbanas.

Para ele, a partir de 2008, houve investimentos anticíclicos, em um esforço para diminuir os efeitos da crise internacional. Como consequência, houve possibilidade da

105 SOUZA, Luiz Eduardo Simões de \& PREVIDELLI, Maria de Fátima Silva do Carmo \& DA SILVA NETO, Julio Gomes. "A Economia Brasileira e a Crise Econômica Mundial”.Revista de Economia Política e História Econômica (REPHE). ISSN: 1807 - 2674. № 23, Dezembro de 2010. Pg. 5-25

106 SCHINCARIOL, Vitor Eduardo. Crescimento Econômico no Brasil, 2003-2010. Um balanço da política econômica e do padrão acumulativo. São Paulo: LCTE Editora, 2012. 
continuidade do crescimento econômico, mas com fortalecimento das limitações observadas no período anterior. Nesse sentido, não houve superação do modelo de dependência.

A leitura com que Sarquis José Buainain Sarquis produziu a obra Comércio Internacional e Crescimento Econômico no Brasil ${ }^{107}$, resultado de sua tese para a escola de altos estudos do Rio Branco, foi diferente. Buscou relacionar o crescimento econômico do país com o comércio exterior, revelando alguns aspectos dessa relação. Ao observar a correlação entre crescimento econômico, investimento e importação, caracterizou o crescimento econômico brasileiro como "import-led". O crescimento teria sido induzido por ganhos de produtividade graças às importações.

Para ele, entre 2002 e 2008, o Brasil teria sofrido especialização em bens primários, como fruto de suas relações com a China. No entanto, teria mantido produtividade e competitividade em certos nichos do setor industrial. Apenas as relações econômicas do Brasil com a Ásia seriam caracterizados pelo modelo exportador de bens primários. No entanto, dada a força dessa relação, o país teria se tornado importador líquido de bens industriais.

A tese central de Sarquis é que o problema consistia no não-uso dos ganhos da exportação de bens primários para investimento no setor industrial. Por conta disso, haveria fragilidade do Brasil às futuras oscilações na economia chinesa. Uma vez que a economia brasileira seria guiada pelas importações, as exportações de bens primários não seriam capazes de gerar ganhos de produtividade, caso não resultassem em importação de bens de capital. Ainda, esses bens deveriam ser utilizados para gerar dinamismo nos setores industriais capazes de exportar. Caso a importação se tornasse importação de bens industriais de consumo, o Brasil manteria sua fragilidade.

Dessa forma, ele acreditava que o período entre 2002 e 2008 teria se caracterizado por ganhos momentâneos, mas que portava frutos para fortalecimento das relações Sul-Sul. Esses seriam úteis ao Brasil por serem mais voltadas à exportação de bens industriais. A crise internacional teria revelado a resistência pontual da China, mas não significava que essa não diminuiria a taxa de crescimento em momentos futuros. Quando isso acontecesse, os ganhos das exportações primárias demonstrariam sua fragilidade e momentaneidade. Já os ganhos de produtividade pelas importações e construção de relações comerciais intra-industriais demonstrariam maior resistência de longo termo, embora maior fragilidade momentânea à 107 SARQUIS, Sarquis José Buainain. Comércio Internacional e Crescimento Econômico no Brasil. Brasília: Fundação Alexandre de Gusmão, 2011. 
crise internacional.

Em 2014, Lourdes Casanova e Julian Kassum argumentaram que o crescimento observado pelo Brasil durante a última década se devia em grande parte ao papel da indústria de ferro e outros minerais. Ela ao mesmo tempo permitia ganhos no comércio exterior e mesmo investimento estrangeiro direto. Embora fosse um setor que tivesse um baixo impacto na formação de empregos diretos, quando comparado com a indústria manufatureira, o setor permitiu rápido crescimento econômico do país. Como resultado, o Brasil pode ganhar importância relativa no mundo ${ }^{108}$. Acreditava-se, portanto, que a nova demanda mundial por matérias-primas, bastante influenciada pela demanda chinesa, iria perdurar por mais tempo. Essa relação dúbia quanto ao papel da demanda chinesa para o crescimento econômico foi bem explicado por Marcos Cordeiro, em 2015:

As exportações brasileiras se concentram em alimentos, minérios e matérias-primas, enquanto que as importações são predominantemente de produtos industriais acabados e insumos. Em princípio, a capacidade industrial chinesa pode representar riscos para o Brasil, uma vez que esse novo boom de commodities comandado pela China poderá encerrar o país em um novo ciclo de dependência da produção de matérias-primas, provocando o fenômeno da desindustrialização do país. Por outro lado, se não fosse o superávit comercial obtido com a China o país enfrentaria maiores dificuldades para fechar sua balança de pagamentos desde $2008 .^{109}$

Naquele ano, o limite para o crescimento econômico impulsionado pelas exportações de commodities já estava mais claro. Em 2014, o PIB brasileiro cresceu apenas 0,5\%. Em 2015, chegou a cair 3,77\%. Diante desse desempenho, as análises econômicas sobre o período anterior se tornaram menos otimistas. Em 2016, Bresser Pereira publicou uma análise sobre as políticas econômicas para um novo desenvolvimentismo ${ }^{110}$, onde argumentava que, desde 2003, os ganhos com a exportação das commodities foram utilizados para financiar um aumento do salário mínimo. Isso havia permitido um aumento do consumo das famílias. Mas o governo "cometeu o grave erro de permitir que a taxa de câmbio ficasse dramaticamente sobrevalorizada" $" 111$. O resultado, segundo o autor, foi que a nova demanda foi atendida pelas

108 CASANOVA, Lourdes; KASSUM, Julian. The political economy of an emerging global power: in search of the Brazil dream. Nova Iorque: Palgrave Macmillan, 2014.

109 PIRES, Marcos Cordeiro. “Notas Sobre a Parceria Estratégica Brasil - China”. In SORIA, Adrián Bonilli \& GARCÍA, Paz Milet. FLACSO, 2015. pg. 259

110 BRESSER-PEREIRA, Luiz Carlos. Reflexões sobre o Novo Desenvolvimentismo e o Desenvolvimentismo Clássico. Revista de Economia Política, v. 36, n. 2, p. 143, 2016.

111 BRESSER-PEREIRA, Luiz Carlos. Reflexões sobre o Novo Desenvolvimentismo e o Desenvolvimentismo 
importações, ao invés de fomentar a indústria local.

Em 2017, outros autores corroboraram essa leitura. Foi o caso de Martins Neto e Antonio Soares, que, em um artigo, argumentaram que o boom das commodities havia escondido as fraquezas estruturais do Brasil. Durante o período (2002 - 2012), houve, segundo os autores, esforço para diminuição da desigualdade de rendimentos dos distintos setores da população. Esse esforço resultou na diminuição do índice de Gini (que mede a desigualdade econômica existente no país) de 58,7 para 52,6. Ainda, a demanda asiática por commodities permitiu que o Brasil crescesse e gerasse renda, criando a falsa sensação de sucesso econômico. Mas quando aquela demanda desacelerou, a economia brasileira também sofreu revés. ${ }^{12}$

Também em 2017, Vitor Schincariol fez diagnóstico bastante preciso sobre os fatores que levaram ao esgotamento econômico no Brasil, a partir dos primeiros anos de (20)10 ${ }^{113}$. Ele ressaltou os seguintes pontos: (i) esgotamento cíclico dos investimentos; (ii) queda nos saldos comerciais a partir de 2009; (iii) queda da participação da indústria na economia; (iv) deterioração das expectativas de mercado; (v) uma política econômica nociva ao investimento local; e (vi) conturbação política. Ainda, argumentou que não houve verdadeiro esforço contracíclico por parte do governo para reverter esse esgotamento. Ao contrário, o esforço se concentrou apenas entre 2011 e 2013. Em 2014, período em que o esgotamento econômico se manifestou, o governo adotou políticas restricionistas.

Vitor argumentou que primeiro governo Dilma entendia que o crescimento econômico anterior havia se caracterizado pela ampliação da demanda agregada. Esse ciclo havia chegado no seu limite, uma vez que a demanda não estava mais puxando o crescimento dos investimentos. Parte disso teria sido consequência do alastramento da crise mundial para os países emergentes. Nesse cenário, propôs medidas de desoneração, redução dos juros, e outros incentivos para o investimento do setor privado, que não atingiram o efeito desejado.

Portanto, a literatura recente sobre a economia brasileira de 1999 até 2013 (algumas já abordando também o período posterior) caracteriza o esgotamento do crescimento no final do período como uma consequência da diminuição da demanda das commodities. Essas eram a

Clássico. Revista de Economia Política, v. 36, n. 2, p. 143, 2016. Pg. 242.

112 NETO, Martins; SOARES, Antonio. Income distribution and external constraint: Brazil in the commodities boom. Nova Economia, v. 27, n. 1, p. 7-35, 2017.

113 Trata-se da obra: SCHINCARIOL, V. E. Economia e Política Econômica no Governo Dilma (2011-2014). São Paulo: Selo Tricontinental, 2017. 
principal fonte de financiamento para as importações, das quais o Brasil depende para poder crescer. Como não houve, no período anterior, uma política de fortalecimento da indústria local, o impacto das oscilações de preços dos principais produtos exportados pelo país teve alto impacto na capacidade local de crescimento.

\subsection{UMA CARACTERIZAÇÃO SOBRE O PERÍODO}

Nas últimas seções,até aqui, realizou-se estudo sobre os aspectos gerais e da importância do comércio exterior brasileiro. Considerou-se as políticas econômicas adotadas pelo governo; refletiu-se sobre o desempenho dos principais produtos da pauta de exportação e importação; investigou-se a leitura realizada pelos representantes das principais empresas e associações de produtores, que mais tiraram vantagens do comércio exterior; e retomou-se o debate já realizado por outros autores sobre o comércio exterior recente no Brasil.

Após cumpridas essas etapas de estudo, é possível realizar uma leitura sobre o rumo tomado pela economia brasileira, na ótica do comércio exterior, sem, ainda, considerar os efeitos das contas de serviço e renda da balança do Balanço de Pagamentos. Buscou-se, sobre o comércio exterior, trabalhar as seguintes hipóteses: (a) parte da recuperação recente da econômica brasileira resultou do desempenho do comércio exterior brasileiro; (b) esse bom desempenho foi fruto do crescimento chinês, que por sua vez expressou o sucesso da parceria China-EUA; (c) a recuperação da economia brasileira não se caracterizou pelo fortalecimento do setor interno, com produção fortemente voltada ao suprimento do mercado nacional; e (d) esse processo favoreceu mais a alguns setores da sociedade do que outros.

O que se observa é que o Brasil continua exposto às mesmas fragilidades estruturais características de um país dependente. Não houve qualquer alteração significativa na posição do Brasil na Divisão Internacional do Trabalho. Do ponto de vista do papel do comércio exterior e de suas características, continuamos a ser um país fornecedor de mercadorias de baixo valor agregado, vendidas à preços determinados pelos países desenvolvidos e seus parceiros privilegiados. Na prática, o período analisado demonstrou características de acirramento da desindustrialização.

Na posição de país dependente, o Brasil continuou fornecedor de commodities e de mercadorias manufaturadas para um mercado local. Essa posição é frágil, e está exposta às 
alterações das políticas econômicas de nossos principais parceiros comerciais (i.e. parceria China-EUA). Enquanto as políticas chinesas e estadunidenses apontaram para um ciclo de crescimento acelerado da indústria da China, houve alta da demanda pelas commodities. Isso resultou um cenário vantajoso para o Brasil. Mas a vantagem foi apenas temporária.

O governo optou por um projeto de desenvolvimento que passava pelo fortalecimento dos setores tradicionalmente exportadores. Foi escolhido um modelo de aceleração da economia pela exportação competitiva. Embora o excedente tenha permitido a realização de políticas de transferência de renda, ela só é possível enquanto esse excedente se mantém. Como o projeto adotado não passa pelo fortalecimento consistente da produção manufatureira para o mercado interno, em um momento de crise o mercado interno vê-se sacrificado.

A exportação competitiva gera dinamismo, mas com vantagem para os oligopólios e para os produtores tradicionalmente exportadores. Em especial, a política adotada favoreceu o desenvolvimento de: (a) indústria extrativa de petróleo e de minerais; (b) indústria automobilística para mercado interno e mercado local; e (c) agropecuária exportadora. Do ponto de vista da produção material, o governo se focou no fortalecimento dos produtores desses segmentos citados. Isso significou tecer acordos e construir políticas justificadas pelos interesses deles. Estrategicamente, a produção de petróleo e extração de minerais foram eleitos como os potencialmente mais capazes de gerar desenvolvimento.

Nesse sentido, a partir de 2008, a Petrobras (estatal) e a Vale (privada) foram escolhidas como aliadas prioritárias. Através das políticas de fortalecimento da produção da indústria extrativa, buscou-se gerar dinamismo para indústria de transformação que contribuísse para a cadeia produtiva e de consumo, em especial a siderurgia, a automotiva, e a indústria naval. Para isso, parte do excedente foi sacrificado, em especial através da participação da Petrobras na política de rebaixamento do preço do petróleo. Em verdade, o complexo Petrobras-Eletrobrás foi utilizado para beneficiar produtores, em especial os grandes exportadores. Um dos maiores privilegiados foi o setor extrativo mineral e a siderurgia ${ }^{114}$.

Esse sacrifício significou queda na taxa de lucro em curto prazo, em troca de um aumento da massa de lucro de longo prazo. Embora os acionistas das grandes empresas (em especial Petrobras e Vale) possam se sentir lesados por essa política, para os técnicos e para a 114 Sobre o assunto ver a entrevista de Ildo Sauer, publicado na revista Mouro, número 9, página 29, em janeiro de 2015. 
presidência das empresas a troca era vantajosa. A capacidade de planejamento aliada às vantagens adquiridas pela política econômica do governo permite que as empresas se preparem para garantir seu crescimento, e sua influência, no futuro próximo.

Trata-se do desenvolvimento de um Brasil oligopolista, dependente, e exportador, cujo excedente pôde ser utilizado apenas marginalmente para diminuir o grau de miséria típica de países dominados pelo oligopólio. Trata-se de uma característica estrutural ainda não superada. O Brasil ainda é um país com baixa poupança nacional, dependente do capital externo. A baixa complexidade industrial do país mantém a demanda interna tão baixa quanto a oferta. A busca pela compensação da falta de poupança pela exportação apenas conseguiu aquilo que Ragnar Nurkse já apontava: aumentou a demanda por bens de consumo estrangeiros, sem trazer grandes ganhos na produtividade. O resultado foi, primeiro, o aumento das importações, e, depois, desequilíbrio macroeconômico e maior inflação. 


\section{APONTAMENTOS SOBRE O BALANÇO DE PAGAMENTOS}

O Balanço de Pagamentos mensura o fluxo do setor externo da economia de um país. Até 2015, o Banco Central do Brasil registrava o Balanço de Pagamentos do país pela metodologia BPM5, conforme recomendação do FMI. A partir daquele ano, passou a adotar o modelo BPM6, e recalculou os valores, disponibilizando na nova contabilidade retrospectivamente até 2010. Para nosso estudo, utilizamos os dados conforme o modelo BPM5.

O Balanço de Pagamentos é dividido em duas partes: (a) Transações Correntes e (b) Conta Financeira. A primeira (a) é considerado um indicador da saúde do setor externo pelas diversas vertentes do estudo do comércio internacional. Ela inclui o comércio exterior de bens, os serviços contratados no e pelo exterior, e o envio e recebimento de renda de investimentos internacionais. A segunda (b), da Conta Financeira, é mais polêmica. Inclui as contas de capital, investimento direto e financeiro. Os pensadores estruturalistas apontam que países dependentes costumam ter transações correntes negativas e contas de capital positivas. Isso expressa a relação onde a metrópole está constantemente comprando ativos no país, e recebendo os lucros de suas compras. ${ }^{115}$

No presente capítulo buscaremos demonstrar as características do Balanço de Pagamentos brasileiro. Apesar dos saldos comerciais, as transações corrente tiveram apenas um pequeno período de saldo. O déficit do restante do período foi acompanhado pelo grande saldo da conta financeira. O país continuou a ser caracterizado pela dependência da poupança externa. Apesar de não ter se seguido as privatizações, e ter mesmo diminuído a dívida externa, o Brasil observou grande investimento estrangeiro direto. Tratou-se da venda de ativos do país. No agronegócio, na indústria, e no comércio o capital estrangeiro, e o capital nacional disfarçado de estrangeiro, encontraram terreno fértil. O que aparece como saldo na conta financeira do Balanço de Pagamentos expressa o aumento da dependência externa brasileira.

115 Para uma descrição sintética sobre o Balanço de Pagamentos ver: REINERT, Kenneth A. An Introduction To International Economics. New Perspectives on the World Economy. Nova Iorque: Cambridge Press, 2012. pg. 215. 


\subsection{O BALANÇO DE PAGAMENTOS E AS TRANSAÇÕES CORRENTES}

O estudo do setor externo da economia é relevante perante o impacto do comércio internacional na economia doméstica de cada país. Para esse capítulo, afim de realizar uma análise do Balanço de Pagamentos optou-se por transformar as variáveis para Reais constantes (de 2006). Essa abordagem, portanto, enfatiza o papel estrutural que o Balanço de Pagamentos teve na atividade econômica interna do Brasil.

\begin{tabular}{|c|c|c|c|c|c|}
\hline \multicolumn{6}{|c|}{ Tabela 4.1a: PIB do Brasil e saldo das transações correntes, 1999 a 2013.} \\
\hline (1) & (2) & (3) & (4) & (5) & (6) \\
\hline Ano & $\begin{array}{c}\text { PIB nominal do Brasil em } \\
\text { bilhões de reais }\end{array}$ & $\begin{array}{c}\text { Conversão } \\
\text { nominal do dólar } \\
\text { (média anual) }\end{array}$ & $\begin{array}{l}\text { PIB nominal do } \\
\text { Brasil em bilhões de } \\
\text { dólares correntes }\end{array}$ & $\begin{array}{c}\text { Índice do } \\
\text { deflator do } \\
\text { PIB } \\
(2006=100)\end{array}$ & $\begin{array}{l}\text { PIB real do Brasil } \\
\text { em bilhões de reais } \\
\text { constantes de } 2006 \\
(6)=(2) *(5) / 100\end{array}$ \\
\hline 1999 & 1092,3 & 1,86 & 586,9 & 179 & 1953,69 \\
\hline 2000 & 1202,4 & 1,87 & 644,7 & 168 & 2025,45 \\
\hline 2001 & 1316,3 & 2,38 & 553,6 & 155 & 2034,86 \\
\hline 2002 & 1491,2 & 2,96 & 504,2 & 140 & 2085,19 \\
\hline 2003 & 1720,1 & 3,11 & 552,5 & 123 & 2114,88 \\
\hline 2004 & 1958,7 & 2,95 & 663,8 & 114 & 2229,07 \\
\hline 2005 & 2171,7 & 2,46 & 882,2 & 106 & 2305,3 \\
\hline 2006 & 2409,8 & 2,21 & 1088,9 & 100 & 2409,8 \\
\hline 2007 & 2718 & 1,99 & 1366,8 & 94 & 2567,33 \\
\hline 2008 & 3107,5 & 1,88 & 1653,5 & 87 & 2709,53 \\
\hline 2009 & 3328,2 & 2,05 & 1620,2 & 81 & 2707,26 \\
\hline 2010 & 3886,8 & 1,81 & 2143,1 & 75 & 2921,28 \\
\hline 2011 & 4374,8 & 1,77 & 2476,7 & 70 & 3073,75 \\
\hline 2012 & 4713,1 & 2,1 & 2248,8 & 67 & 3155,88 \\
\hline 2013 & 5157,6 & 2,3 & 2245,7 & 62 & 3208,98 \\
\hline
\end{tabular}

Na tabela 4.1a, observa-se as variáveis utilizadas para transformar as contas do Balanço de pagamento em Reais contantes (de 2006). A variável (2) é o PIB nominal do Brasil, conforme contabilizado pelo IBGE, na metodologia de 2010 e 2014 . A variável (3) é a taxa de conversão do dólar oficial utilizada pelo Banco Mundial. A variável (4) o Produto Interna Bruto brasileiro em dólares nominais, conforme a metodologia do Banco Mundial. O PIB nominal do país é convertido à valores em dólares nominais através da taxa de conversão anual oficial. A variável (5) é um índice do deflator implícito do PIB, disponibilizado pelo IBGE, que resulta da razão entre PIB nominal e PIB real. Ele serve para que seja calculado o valor real das variáveis macroeconômicas descontando a inflação. A variável (6) é o PIB do Brasil em valores constantes de 2006, calculado pelo autor, utilizando os índice do deflator do Produto Interno Bruto. 
(4) é a transformação daquele saldo em bilhões de reais constantes de 2006. A variável (5) é a formação bruta de capital fixo (FBCF) em bilhões de reais nominais, conforme dados do IBGE. A variável (6) é o índice do deflator da Formação Bruta de Capital Fixo, conforme o IBGE. Resulta da divisão da formação bruta de capital fixo real pela nominal. A variável (7) á a FBCF transformada em bilhões de reais de 2006.

É importante notar que entre 1999 e 2013, a Formação Bruta de Capital Fixo real do Brasil cresceu mais do que o PIB do país. Esse crescimento esteve concentrado entre 2003 e 2013. Por outro lado, as transações correntes expressaram movimento oposto. Houve aumento do saldo até 2004, e queda a partir de então.

\section{Gráfico 4.1: Saldo real das Transações Correntes do Brasil, 1999 a 2013}

(bilhões de reais de 2006)

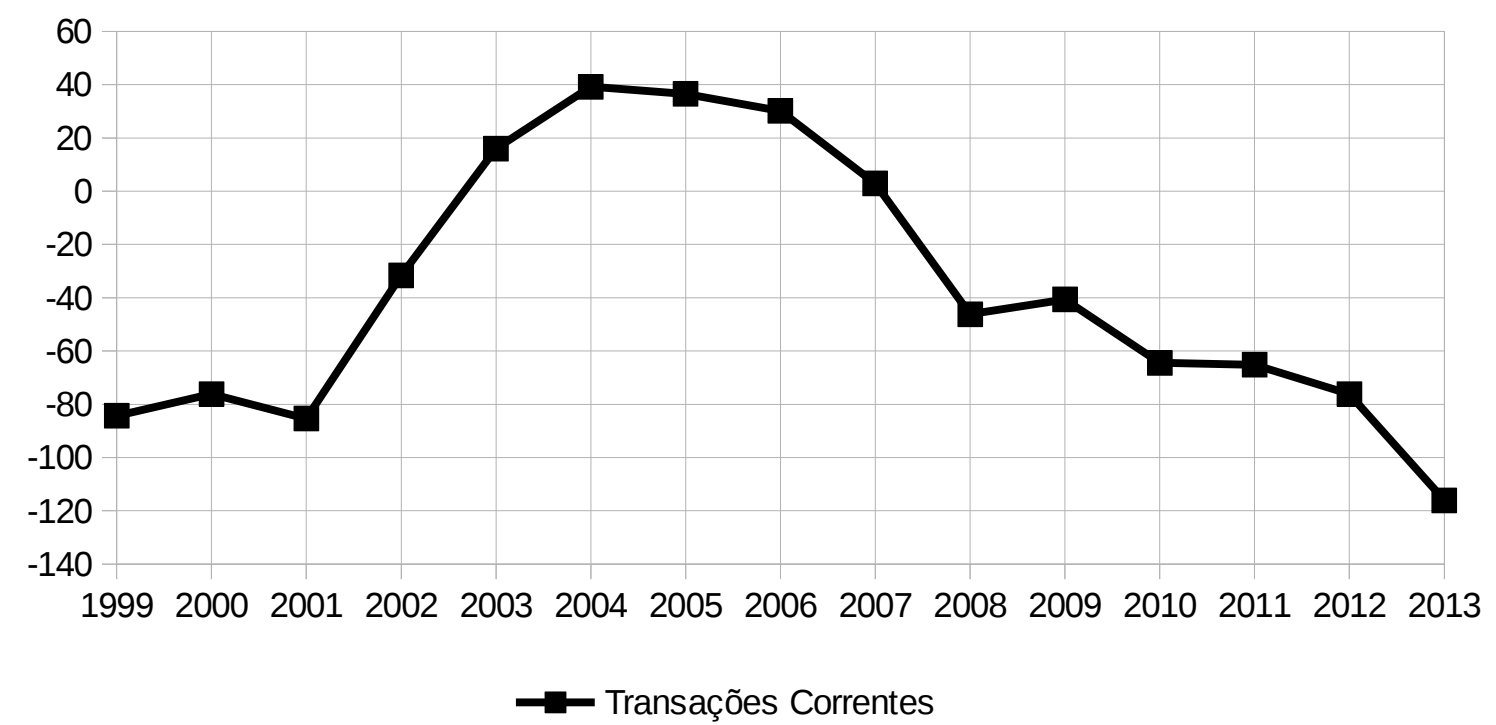

Fonte: Banco Central do Brasil, cálculo próprio

No gráfico 4.1, verifica-se as oscilações do saldo real das transações correntes. Observa-se que até 2001, o saldo foi bastante negativo, atingindo a ordem de -80 bilhões de reais constantes. Entre 2001 e 2004. Nesse período, o Brasil ainda sofria efeito de severas crises (1998, 1999, e 2001). Como consequência, houve forte redução das importações e gastos com serviços contratados no exterior. Como desde 2002 se observou melhoria nas exportações, as transações correntes melhoraram.

Em 2004, a melhoria da economia local já havia "normalizado” o comportamento econômico no Brasil. As importações, os gastos com serviço, e a drenagem de recursos do 
país através do envio de remessas e pagamentos de juros voltaram a crescer. Como o Brasil estava podendo pagar, voltou a perder nas transações correntes. A queda continuou, tendo uma breve pausa em 2009. Naquele ano, a crise econômica mundial havia se expandido na Europa. No entanto, a China, principal parceiro comercial do Brasil, demonstrava bom desempenho. O preço das commodities continuava em alta. Nesse contexto, o aumento do déficit na conta de serviços e na conta de renda foi inferior à melhoria do saldo no comércio exterior. Ainda assim, o Brasil fechou em déficit de 40 bilhões de reais constantes, em 2009. A partir daí, esse déficit voltou a crescer aceleradamente.

Dércio Gárcia Munhoz chamou a atenção que a partir de 2005, os saldos nas exportações brasileiras, e o bom desempenho no Balanço de Pagamentos teve como um de seus impactos pressionar para uma mudança no câmbio em favor da valorização relativa do Real. A consequência desse movimento foi o crescimento das importações no período seguinte. O governo, ao invés de buscar adequar o câmbio para favorecer as exportações, optou por manter o Real valorizado. ${ }^{116}$

\subsection{OS SERVIÇOS NA CONTA DAS TRANSAÇÕES CORRENTES}

Entre 1999 e 2013, durante quase todo o período a conta de serviços foi importante responsável pelo déficit nas transações correntes. Com exceção de 3 grupos de serviços, o Brasil é deficitário em todos demais. Trata-se de um país que abriu mão de sua frota comercial e que depende da tecnologia estrangeira. Para piorar, espelha seu consumo de produtos e serviços no consumo da elite de países desenvolvidos.

Trata-se de efeito também observado em outros países dependentes, conforme Chesnais. Para ele, uma das características da mundialização do capital foi justamente o ganho de importância dos investimentos estrangeiros, e o ganho de importância serviços diversos como ferramenta de transferência de renda internacional. A consequência para os países da periferia econômica mundial (países dependentes) foi, portanto, a drenagem de recursos via serviços e envio de remessas de lucros ${ }^{117}$. Na visão de Sergio Ordoñez, trata-se de um rearranjo da divisão internacional do trabalho que fortalece o caráter hierárquico do mesmo:

116 Entrevista de Dércio Garcia Munhoz ao programa Agenda Econômica, da Tv Senado, em 15/10/2010.

117 Ver: CHESNAIS, François. A mundialização do capital. São Paulo: Xamã, 1996. pg. 60 - 61 
Do demonstrado acima, se deriva uma nova tendência de diferenciação e hierarquia funcional de empresas ao longo da cadeia de valor, resultando em nova divisão interindustrial do trabalho, caracterizada pelos seguintes processos: a) as empresas multinacionais procuram gerar propriedade intelectual e apropriação de receitas tecnológicas pela imposição de padrões tecnológicos em seus ramos de atividade, através da sua especialização em design, marketing e distribuição de marcas; b) por outro lado, eles se separam das operações anteriores, que agora desenvolvem novos estratos de empresas $(\ldots)^{118}$

Conforme a argumentação desses autores, é de se esperar que países dependentes apresentem défice nas contas de serviço. Afinal, as filiais das multinacionais precisam pagar por royalties, serviços administrativos prestados pelas matrizes, serviço de marketing, etc. É nessas condições que parte do saldo adquirido por eventual exportação realizada pelas filiais é perdido sob a forma de serviço e remessas de lucro.

\section{Gráfico 4.2: Déficit de serviços e rendas nas transações correntes, 1999 a 2013}

(em bilhões de reais de 2006)

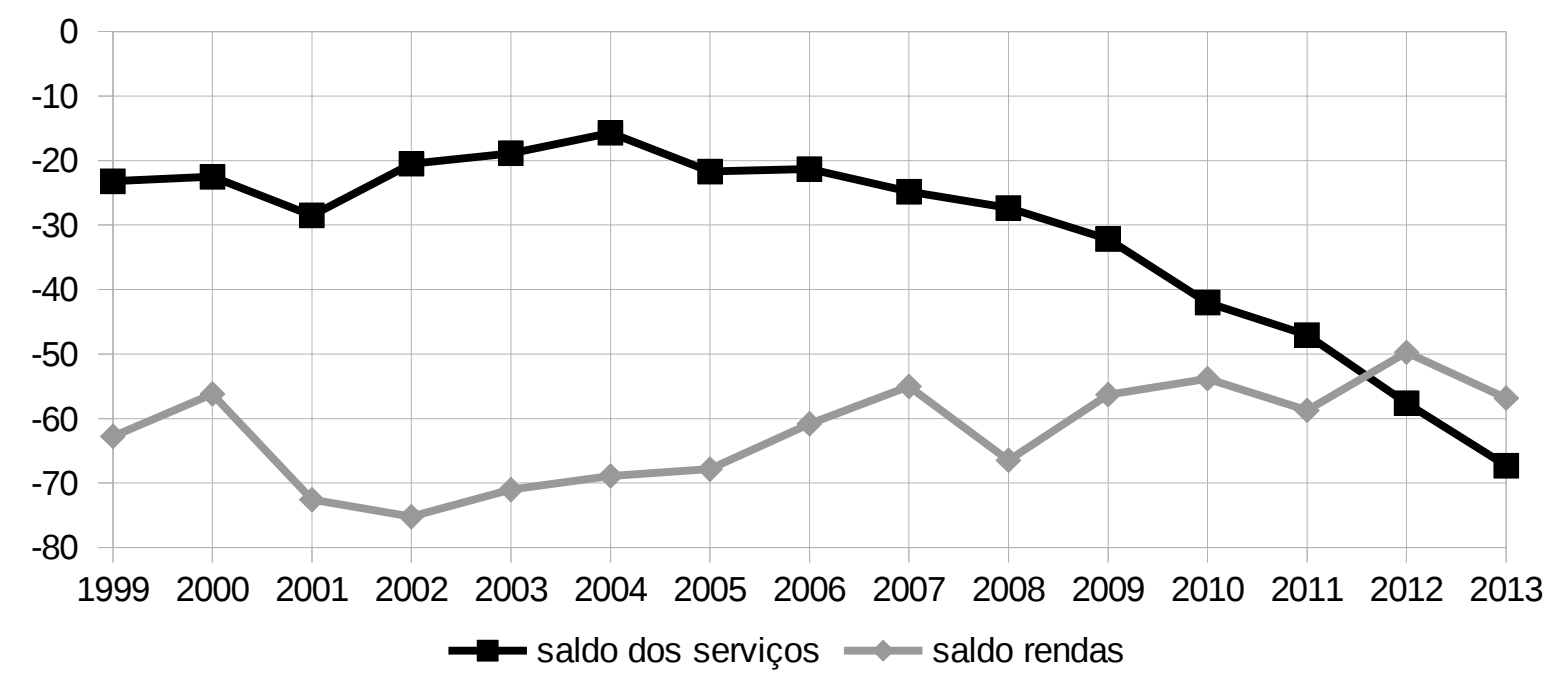

*Fonte: Banco Central do Brasil, cálculo próprio

O gráfico 4.2 nos mostra que, a partir de 2004, o déficit da conta de serviços do Balanço de Pagamentos brasileiro passou a aumentar. No período em que a economia brasileira apresentava bom desempenho de crescimento, parte da riqueza era gasta na contratação de serviços. No mesmo período, as perdas nas contas de renda foram ainda

118 ORDÓÑEZ, Sergio. Capitalismo del conocimiento: ¿México en la integración?. Problemas del Desarrollo, Vol. 37, No. 146 (julio-septiembre 2006), pg.61-62 
maiores, com melhoria a partir de 2005. A partir de 2012, as perdas na conta de serviços se tornou maior do que as perdas na conta de rendas.

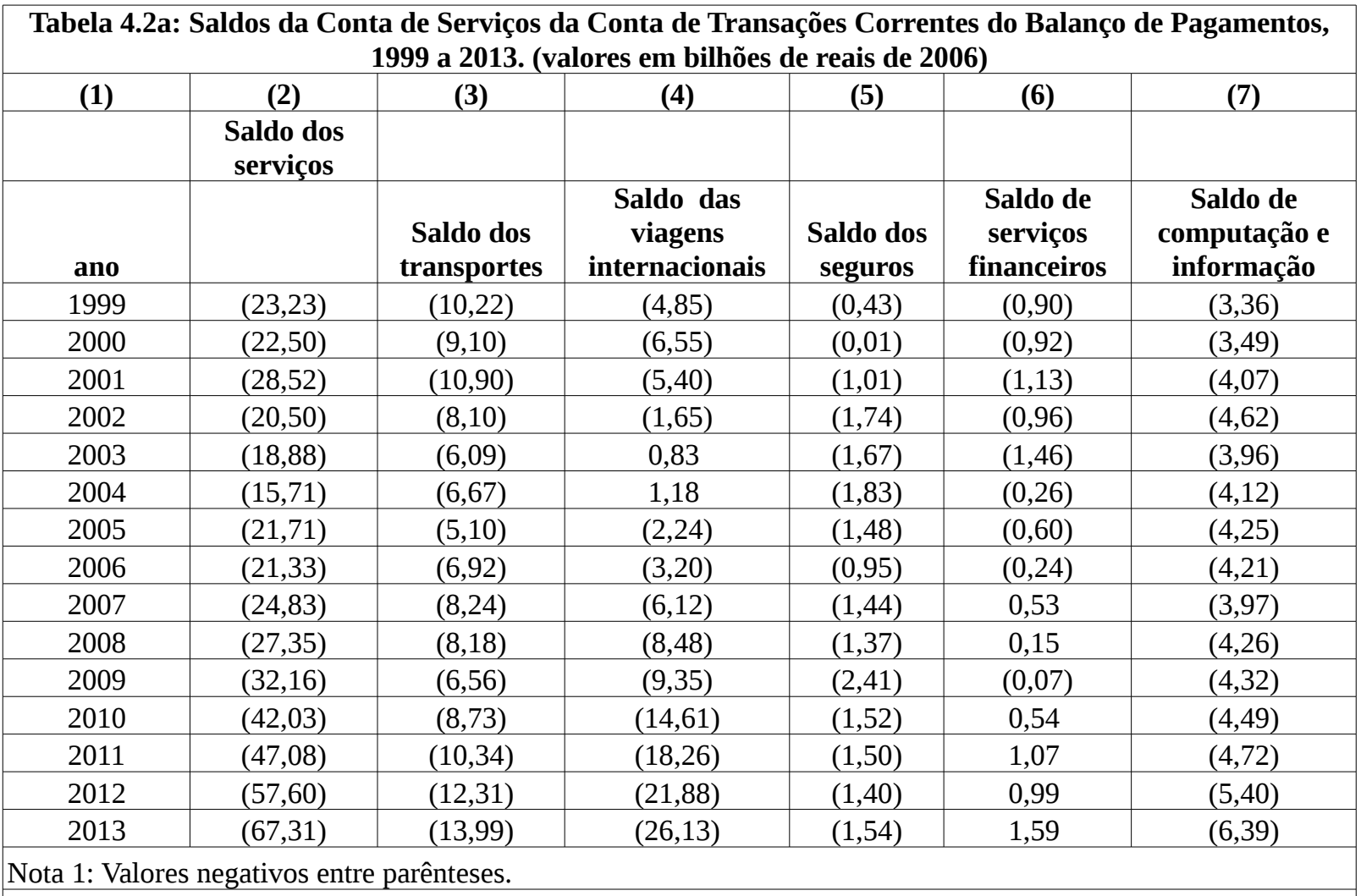

Fonte: Banco Central do Brasil

Na tabela 4.2a, verifica-se alguns dos componentes da conta de serviço das transações correntes, de acordo com a metodologia BPM5. Todos os valores estão em bilhões de reais de 2006. A variável (2), “Saldo dos serviços”, expressa o saldo real da conta serviço. A variável (3), Saldo dos transportes, expressa o saldo real dos serviços de transporte de mercadorias, incluindo transporte aéreo, terrestre, e marítimo. A variável (4), Saldo das viagens internacionais, traz o saldo real das viagens internacionais, incluindo turismo e gastos com cartão de crédito. A variável (5) traz os saldos reais dos gastos com seguros internacionais. A variável (6) representa o saldo real de serviços financeiros, que incluem intermediários financeiros, exceto seguradoras. A variável (7) traz o saldo real dos serviços de computação de dados e informática, inclusive manutenção e consultoria de hardware.

O que se observa é que os gastos com serviços de transporte caíram até 2005. No entanto, mediante a melhoria do comércio exterior, os gastos com esse tipo de serviço voltaram a crescer. Isso demonstra que apesar da alta das demandas por commodities terem gerado a oportunidade do Brasil adquirir divisas, não houve sequer melhoria adequada da 
frota mercantil do país. Parte da resposta do porquê dessa situação está na coluna ao lado (4). De 2005 a 2013, o déficit do Brasil na conta de viagens internacionais aumentou em mais de dez vezes. Note que esse é um gasto que não resulta da atividade de firmas multinacionais.

Tabela 4.2b (continuação): Saldos da Conta de Serviços da Conta de Transações Correntes do Balanço de Pagamentos, 1999 a 2013. (valores em bilhões de reais de 2006)

\begin{tabular}{|c|c|c|c|c|c|}
\hline (1) & (2) & (3) & (4) & (5) & (6) \\
\hline & $\begin{array}{l}\text { Saldo dos } \\
\text { serviços }\end{array}$ & & & & \\
\hline ano & & $\begin{array}{c}\text { Saldo de royalties } \\
\text { e licenças }\end{array}$ & $\begin{array}{c}\text { Saldo dos } \\
\text { alugueis de } \\
\text { equipamento }\end{array}$ & $\begin{array}{l}\text { Saldo dos serviços } \\
\text { governamentais }\end{array}$ & $\begin{array}{c}\text { Saldo das } \\
\text { comunicações }\end{array}$ \\
\hline 1999 & $(23,23)$ & $(3,83)$ & $(1,99)$ & $(1,66)$ & 0,05 \\
\hline 2000 & $(22,50)$ & $(4,05)$ & $(4,12)$ & $(1,73)$ & 0,01 \\
\hline 2001 & $(28,52)$ & $(4,16)$ & $(6,86)$ & $(2,40)$ & 0,11 \\
\hline 2002 & $(20,50)$ & $(4,67)$ & $(6,92)$ & $(1,04)$ & 0,06 \\
\hline 2003 & $(18,88)$ & $(4,29)$ & $(8,85)$ & $(0,58)$ & 0,32 \\
\hline 2004 & $(15,71)$ & $(2,66)$ & $(7,27)$ & $(0,64)$ & 0,58 \\
\hline 2005 & $(21,71)$ & $(3,40)$ & $(10,79)$ & $(1,97)$ & 0,33 \\
\hline 2006 & $(21,33)$ & $(3,35)$ & $(10,81)$ & $(1,00)$ & 0,23 \\
\hline 2007 & $(24,83)$ & $(3,64)$ & $(10,84)$ & $(2,13)$ & 0,34 \\
\hline 2008 & $(27,35)$ & $(3,66)$ & $(12,79)$ & $(1,83)$ & 0,27 \\
\hline 2009 & $(32,16)$ & $(3,47)$ & $(15,69)$ & $(2,37)$ & 0,31 \\
\hline 2010 & $(42,03)$ & $(3,34)$ & $(18,75)$ & $(1,89)$ & 0,22 \\
\hline 2011 & $(47,08)$ & $(3,36)$ & $(20,71)$ & $(1,73)$ & 0,14 \\
\hline 2012 & $(57,60)$ & $(4,43)$ & $(26,30)$ & $(1,98)$ & 0,10 \\
\hline 2013 & $(67,31)$ & $(4,39)$ & $(27,24)$ & $(1,94)$ & 0,03 \\
\hline \multicolumn{6}{|c|}{ Nota 1: Valores negativos entre parênteses. } \\
\hline \multicolumn{6}{|c|}{ Nota 2: a variável (2) é a a variável (2) da tabela 1a } \\
\hline
\end{tabular}

Na tabela 4.2b, verifica-se a continuação da tabela 4.2a. A variável 4.2a, Saldo dos serviços, é a mesma da tabela 4.2a, e serve como valor de referência para comparações entre as demais variáveis, que são suas componentes. A variável (3), saldo de royalties e licenças, inclui os gastos brasileiros com os pagamentos de patentes, royalties em geral, e licenças de uso de tecnologia. A variável (4) representa os gastos de aluguel de equipamentos alugados para usuários residentes no Brasil. A variável (5) é o saldo dos serviços prestados por governos. Dessa forma, inclui serviços prestados pelo governo brasileiro no exterior, e serviços prestados por governos estrangeiros ou instituições internacionais (ONU, FMI, etc.) que tenham sido contratado pelo Brasil, em geral contratado pelo setor público, e que não tenham sido contabilizado em outro tipo de serviço. A variável (6) expressa o saldo das transações que envolvam serviços de comunicação, incluindo as telecomunicações e serviços postais.

Observa-se constância nos déficits reais dos gastos com licenças, e dos serviços 
governamentais; e no saldo dos serviços de comunicação. No entanto, o déficit nos gastos com alugueis de equipamento cresceu mais de 13 vezes e meia, entre 1999 e 2013. No entanto, houve concentração desse aumento nos 4 primeiros anos da série. Entre 2003 e 2013, esse crescimento foi de aproximadamente 3 vezes. O aumento do déficit com alugueis com equipamentos apenas foi inferior ao aumento do déficit com viagens internacionais.

Em parte, isso é efeito (a) da defasagem tecnológica do Brasil perante as economias desenvolvidas; (b) desmonte da indústria de base e de bens de capital; e (c) da transferência da propriedade local da indústria para propriedade estrangeira. As firmas multinacionais que se instalam no Brasil, ou compram companhias locais, tem adotado a estratégia de emprestar equipamentos da matriz para as filiais. Isso permite renda constante para a firma, ao passo que diminui a necessidade de investimento no local. No entanto, aumenta o grau de dependência das filiais e diminui o efeito de transferência de tecnologia.

Para o Brasil, isso significou o fortalecimento de mais um mecanismo de drenagem internacional das riquezas aqui produzidas. Como os alugueis precisam ser pagos todo final de ciclo, ad eternum, a margem de lucro das filiais diminuem, e aumenta a margem de lucro das matrizes. Isso significa, na prática, menor renda nacional.

Ainda, força o balanço de pagamentos para baixo, impondo maior dependência da poupança externa. Ao invés de se gerar capital fixo para o país, gera-se um déficit crescente. A consequência é a perda de divisas adquiridas através comércio exterior. Esse processo deixa claro que o investimento estrangeiro direto não tem "interesse em desenvolver" o país onde investe. Evidentemente, o interesse de quem investe é lucrar. Quem deseja gerar desenvolvimento deve tal fazer em casa. Conforme reitera Ragnar Nurkse, o capital se faz em casa.

A tabela 4.2c é a continuação das duas anteriores. Novamente, a variável (2) é o saldo da conta de serviços, em bilhões de reais constantes de 2006. A variável (3) expressa o saldo dos serviços de construção contratados por residentes para não residentes no país, e viceversa. Inclui contratos de construção de infraestrutura em outros países envolvendo empresas nacionais (Odebrecht, por exemplo). A variável (4) é o saldo dos serviços relacionados ao comércio, excluindo transporte. Inclui serviço de levantamento de informações sobre comércio internacional. A variável (5), saldo de serviços empresariais e profissionais, é uma das mais amplas. Inclui serviços de publicidade, pesquisa e desenvolvimento, consultoria 
jurídica, e outros. A variável (6) saldo de serviços culturais e de recreação inclui dois grupos: (a) serviços culturais audiovisuais (música, cinema, etc); e (b) serviços culturais gerais, como serviços de museu, bibliotecas, esportes, e afins.

\begin{tabular}{|c|c|c|c|c|c|}
\hline \multicolumn{6}{|c|}{$\begin{array}{l}\text { Tabela 4.2c (cont.): Saldos da Conta de Serviços da Conta de Transações Correntes do Balanço de } \\
\text { Pagamentos, } 1999 \text { a 2013. (valores em bilhões de reais de 2006) }\end{array}$} \\
\hline \multirow[t]{3}{*}{ (1) } & (2) & (3) & (4) & (5) & (6) \\
\hline & $\begin{array}{c}\text { Saldo dos } \\
\text { serviços }\end{array}$ & & & & \\
\hline & & Saldo construção & \begin{tabular}{|c} 
Saldo de serviços \\
ligados ao \\
comércio
\end{tabular} & $\begin{array}{c}\text { Saldo de serviços } \\
\text { empresariais e } \\
\text { profissionais }\end{array}$ & $\begin{array}{c}\text { Saldo de serviços } \\
\text { culturais e } \\
\text { recreação }\end{array}$ \\
\hline 1999 & $(23,23)$ & 0,05 & 0,84 & 4,19 & $(1,12)$ \\
\hline 2000 & $(22,50)$ & 0,71 & 0,61 & 7,07 & $(0,94)$ \\
\hline 2001 & $(28,52)$ & 0,06 & $(0,08)$ & 8,45 & $(1,13)$ \\
\hline 2002 & $(20,50)$ & 0,05 & $(0,05)$ & 10,17 & $(1,04)$ \\
\hline 2003 & $(18,88)$ & 0,04 & $(0,35)$ & 8,26 & $(1,08)$ \\
\hline 2004 & $(15,71)$ & 0,00 & $(0,79)$ & 7,99 & $(1,22)$ \\
\hline 2005 & $(21,71)$ & 0,02 & $(0,73)$ & 9,54 & $(1,03)$ \\
\hline 2006 & $(21,33)$ & 0,04 & 0,00 & 10,08 & $(1,00)$ \\
\hline 2007 & $(24,83)$ & 0,02 & 0,03 & 11,70 & $(1,09)$ \\
\hline 2008 & $(27,35)$ & 0,02 & 0,71 & 13,35 & $(1,28)$ \\
\hline 2009 & $(32,16)$ & 0,02 & 1,03 & 12,19 & $(1,47)$ \\
\hline 2010 & $(42,03)$ & 0,03 & 0,34 & 11,47 & $(1,29)$ \\
\hline 2011 & $(47,08)$ & 0,01 & 0,37 & 13,28 & $(1,32)$ \\
\hline 2012 & $(57,60)$ & 0,01 & 0,17 & 16,21 & $(1,39)$ \\
\hline 2013 & $(67,31)$ & 0,02 & 0,45 & 14,53 & $(2,32)$ \\
\hline $\mathrm{a} 1: \mathrm{val}$ & ivos entr & ses. & & & \\
\hline
\end{tabular}

Observa-se que os serviços empresariais e técnicos é o único item da conta de serviços que apresenta saldo considerável. Mais uma vez, isso é resultado do peso das firmas multinacionais no país. Para se instalar, elas se vêm obrigadas a gastar com consultoria jurídica local, com pesquisa de mercado, e com desenvolvimento de pesquisa para adequar seus produtos. Além disso, contratam serviços de administração local. Dessa forma, apesar do saldo nesse item específico, trata-se de mais um sintoma da dependência econômica do país.

Ao contrário do que diz parte dos defensores da tese da "pós-industrialização”, a especialização de parte relevante da mão de obra local em serviços, no Brasil, não gerou fluxo de divisas para o país. Isso porque há grande diferença entre a especialização em serviços de consumo local (serviço pessoal e comércio) e serviços administrativos e de pesquisa. Os primeiros são realizados por trabalhadores mal remunerados, e são consumidos pela população local (em geral pelas classes médias e altas). O segundo são realizados por trabalhadores especializados, contratados por matrizes de firmas multinacionais, e o serviço é 
consumido pelas filiais, localizadas nos países subdesenvolvidos ${ }^{119}$.

\subsection{VIAGENS E SERVIÇOS EMPRESARIAIS}

Dentre os itens da conta de serviços das transações correntes do Balanço de Pagamento, na metodologia BPM5, dois deles se destacam pelos valores dos déficits e saldos, e pelo detalhamento dado no Balanço. O item "viagens internacionais" demonstrou alto crescimento no seu déficit, desde 2005. Em 2013, foi responsável por 38,82\% do déficit da conta de serviços. Foram 28 bilhões de reais constantes em déficit apenas na conta de viagens. Enquanto isso, o item serviços empresariais apareceu como maior responsável pelos saldos na conta de serviços, chegando a atingir, em 2012 o saldo de 16 bilhões de reais constantes (de 2006).

Diante dessas características, é importante observar as oscilações de cada componente desses dois itens. É o comportamento dos componentes que revela o caráter dependente do Brasil, seja quando tem déficit, seja quando tem saldo. Nenhuma das duas variáveis seria capaz, mesmo se ambas tivessem saldo positivo, de gerar desenvolvimento. Turismo não gera desenvolvimento, e consultoria jurídica também não. Isso porque resultam de relações assimétricas entre os países. Renda vinda de fora nem sempre gera independência econômica. Certamente também não impulsiona ciclo de aumento de produtividade, e de consequente melhoria da qualidade de vida.

Pior ainda é quando parcela significativa da renda adquirida é gasta de forma supérflua fora do país. A importação de material de luxo, o turismo, e mesmo os gastos em compra fora do país são formas de consumo que acabam por drenar as divisas adquiridas. São resultado daquilo que Ragnar Nurkse chamou de "efeito demonstração": quando uma população de um país subdesenvolvido imita os padrões de consumo da população (abastada) de países desenvolvidos.

119 Piketty identificou essa diferença ao tratar sobre a diferença entre PIB em dólares e PIB em poder de compra, dando a dica aqui seguida para analisar a especificidade da conta Serviços em países dependentes. Ver: PIKETTY, Thomas. Capital in the twenty-first century. Harvard University Press, 2017. Pg. 66. 


\begin{tabular}{|c|c|c|c|c|c|c|c|c|}
\hline \multicolumn{9}{|c|}{ Tabela 4.3a: Viagens internacionais, valores em bilhões de reais de 2006, 1999 a 2003.} \\
\hline (1) & (2) & (3) & (4) & (5) & (6) & (7) & (8) & (9) \\
\hline & $\begin{array}{c}\text { Viagens } \\
\text { internacionais }\end{array}$ & & & & & & & \\
\hline & & $\begin{array}{c}\text { Viagens } \\
\text { internacionais } \\
\text { (Receita) }\end{array}$ & & & & & & \\
\hline & & $\begin{array}{c}(3)=(4)+(5)+ \\
(6)+(7)+(8)+ \\
(9)\end{array}$ & & & & & & $\begin{array}{l}\text { Com uso de } \\
\text { cartões de } \\
\text { crédito } \\
\text { (Receita) }\end{array}$ \\
\hline ano & & & $\begin{array}{c}\text { Fins educacionais, } \\
\text { culturais ou } \\
\text { esportivos (Receita) }\end{array}$ & $\begin{array}{c}\text { Funcionários } \\
\text { de governo } \\
\text { (Receita) }\end{array}$ & $\begin{array}{l}\text { Negócios } \\
\text { (Receita) }\end{array}$ & $\begin{array}{l}\text { Por motivos } \\
\text { de saúde } \\
\text { (Receita) }\end{array}$ & $\begin{array}{c}\text { Turismo } \\
\text { (Receita) }\end{array}$ & \\
\hline 1999 & $(4,85)$ & 5,42 & 0,11 & 0,00 & 1,78 & 0,05 & 3,48 & 2,92 \\
\hline 2000 & $(6,55)$ & 5,69 & 0,11 & 0,00 & 1,87 & 0,05 & 3,65 & 3,62 \\
\hline 2001 & $(5,40)$ & 6,36 & 0,12 & 0,01 & 2,09 & 0,05 & 4,09 & 3,91 \\
\hline 2002 & $(1,65)$ & 8,26 & 0,16 & 0,10 & 2,62 & 0,07 & 5,31 & 4,13 \\
\hline 2003 & 0,83 & 9,49 & 0,19 & 0,09 & 3,04 & 0,08 & 6,10 & 4,74 \\
\hline 2004 & 1,18 & 10,82 & 0,21 & 0,08 & 3,49 & 0,09 & 6,95 & 5,39 \\
\hline 2005 & $(2,24)$ & 10,09 & 0,16 & 0,07 & 2,77 & 0,04 & 7,05 & 5,49 \\
\hline 2006 & $(3,20)$ & 9,55 & 0,17 & 0,04 & 2,87 & 0,03 & 6,43 & 4,80 \\
\hline 2007 & $(6,12)$ & 9,30 & 0,17 & 0,04 & 2,84 & 0,01 & 6,24 & 4,69 \\
\hline 2008 & $(8,48)$ & 9,48 & 0,17 & 0,04 & 3,01 & 0,01 & 6,25 & 4,59 \\
\hline 2009 & $(9,35)$ & 8,86 & 0,16 & 0,04 & 2,61 & 0,01 & 6,05 & 5,31 \\
\hline 2010 & $(14,61)$ & 7,77 & 0,14 & 0,05 & 2,31 & 0,02 & 5,25 & 5,88 \\
\hline 2011 & $(18,26)$ & 8,14 & 0,18 & 0,03 & 2,90 & 0,01 & 5,01 & 6,13 \\
\hline 2012 & $(21,88)$ & 9,33 & 0,18 & 0,06 & 3,18 & 0,01 & 5,90 & 7,02 \\
\hline 2013 & $(26,13)$ & 9,58 & 0,19 & 0,05 & 3,27 & 0,01 & 6,06 & 7,18 \\
\hline a 1: & es negativ & tre parênteses. & & & & & & \\
\hline
\end{tabular}

Na tabela 4.3a, acima, a variável (2) traz o saldo da conta de viagens internacionais, da conta de serviços das transações correntes, em milhões de reais de 2006. A variável (3) expressa apenas a receita da conta de viagens internacionais, ou seja, aquilo que estrangeiros gastam em viagens para o Brasil. A variável (4) traz os valores da receita de viagens com fins educacionais, culturais, ou esportivas. A variável (5) são as receitas das viagens de funcionários de governo, pagas pelos governos. A seguinte, variável (6), traz a receita de viagens de negócios. A variável (7) expressa a receita de viagens realizadas por estrangeiros para o Brasil por motivos de saúde. A variável (8) é a receita de turismo do Brasil. A variável (9) é o gasto local de estrangeiros não residentes no Brasil com cartão de crédito.

O auge das receitas brasileiras com viagens internacionais foi entre 2004 e 2005, impulsionados principalmente pelos gastos de estrangeiros não residentes no país com turismo e com compras em cartão de crédito no Brasil. Naquele período, a economia brasileira já havia começado a se recuperar. No entanto, o Real ainda não havia sido sobreapreciado. 
Nesse contexto, a viagem turística para o Brasil pôde se tornar mais atrativa.

\begin{tabular}{|c|c|c|c|c|c|c|c|c|}
\hline \multicolumn{9}{|c|}{ Tabela 4.3b (cont.): Viagens internacionais, valores em bilhões de reais de 2006, 1999 a 2003.} \\
\hline (1) & (2) & (3) & (4) & (5) & (6) & (7) & (8) & (9) \\
\hline & $\begin{array}{c}\text { Viagens } \\
\text { internacionais }\end{array}$ & & & & & & & \\
\hline & & $\begin{array}{c}\text { Viagens } \\
\text { internacionais } \\
\text { (Despesa) }\end{array}$ & & & & & & \\
\hline & & $\begin{array}{c}(3)=(4)+(5)+ \\
(6)+(7)+(8)+ \\
(9)\end{array}$ & & & & & & $\begin{array}{l}\text { Com uso de } \\
\text { cartões de } \\
\text { crédito } \\
\text { (despesas) }\end{array}$ \\
\hline ano & & & $\begin{array}{c}\text { Fins } \\
\text { educacionais, } \\
\text { culturais ou } \\
\text { esportivos } \\
\text { (despesas) }\end{array}$ & $\begin{array}{c}\text { Funcionários } \\
\text { de governo } \\
\text { (despesas) }\end{array}$ & $\begin{array}{c}\text { Negócios } \\
\text { (despesas) }\end{array}$ & $\begin{array}{c}\text { Por } \\
\text { motivos de } \\
\text { saúde } \\
\text { (despesas) }\end{array}$ & $\begin{array}{c}\text { Turismo } \\
\text { (despesas) }\end{array}$ & \\
\hline 1999 & $(4,85)$ & $(10,27)$ & $(0,54)$ & $(0,02)$ & $(4,15)$ & $(0,03)$ & $(5,53)$ & $(6,29)$ \\
\hline 2000 & $(6,55)$ & $(12,23)$ & $(0,64)$ & $(0,03)$ & $(4,94)$ & $(0,04)$ & $(6,58)$ & $(6,08)$ \\
\hline 2001 & $(5,40)$ & $(11,76)$ & $(0,61)$ & $(0,05)$ & $(4,73)$ & $(0,04)$ & $(6,33)$ & $(6,07)$ \\
\hline 2002 & $(1,65)$ & $(9,91)$ & $(0,52)$ & $(0,14)$ & $(3,88)$ & $(0,03)$ & $(5,33)$ & $(5,38)$ \\
\hline 2003 & 0,83 & $(8,66)$ & $(0,45)$ & $(0,16)$ & $(3,36)$ & $(0,03)$ & $(4,66)$ & $(4,78)$ \\
\hline 2004 & 1,18 & $(9,64)$ & $(0,50)$ & $(0,16)$ & $(3,76)$ & $(0,03)$ & $(5,19)$ & $(5,35)$ \\
\hline 2005 & $(2,24)$ & $(12,33)$ & $(0,52)$ & $(0,10)$ & $(4,91)$ & $(0,03)$ & $(6,79)$ & $(6,26)$ \\
\hline 2006 & $(3,20)$ & $(12,76)$ & $(0,76)$ & $(0,08)$ & $(4,42)$ & $(0,04)$ & $(7,45)$ & $(6,92)$ \\
\hline 2007 & $(6,12)$ & $(15,42)$ & $(0,90)$ & $(0,08)$ & $(4,46)$ & $(0,04)$ & $(9,94)$ & $(8,84)$ \\
\hline 2008 & $(8,48)$ & $(17,96)$ & $(0,75)$ & $(0,06)$ & $(6,42)$ & $(0,03)$ & $(10,70)$ & $(10,64)$ \\
\hline 2009 & $(9,35)$ & $(18,21)$ & $(0,86)$ & $(0,09)$ & $(4,81)$ & $(0,03)$ & $(12,42)$ & $(11,01)$ \\
\hline 2010 & $(14,61)$ & $(22,38)$ & $(1,10)$ & $(0,09)$ & $(5,59)$ & $(0,02)$ & $(15,58)$ & $(13,86)$ \\
\hline 2011 & $(18,26)$ & $(26,39)$ & $(1,32)$ & $(0,05)$ & $(6,46)$ & $(0,03)$ & $(18,54)$ & $(15,72)$ \\
\hline 2012 & $(21,88)$ & $(31,20)$ & $(1,29)$ & $(0,11)$ & $(7,20)$ & $(0,03)$ & $(22,57)$ & $(17,28)$ \\
\hline 2013 & $(26,13)$ & $(35,71)$ & $(1,47)$ & $(0,07)$ & $(8,29)$ & $(0,04)$ & $(25,83)$ & $(17,69)$ \\
\hline
\end{tabular}

Fonte: Banco Central do Brasil

A tabela 4.3b, continuação da anterior, traz valores das despesas brasileiras em viagens internacionais no Balanço de Pagamentos, na metodologia BPM5. A variável (2) da tabela 4.3b é a variável (2) da tabela 4.3a. As demais variáveis da 3b são as contas de despesas dos mesmos itens da tabela 3a, em bilhões de reais constantes de 2006.

Essa tabela nos revela dois aspectos dos gastos brasileiros com viagens internacionais. O primeiro (a) é que, a partir de 2007, houve tendência de aumento dos gastos brasileiros com viagens de negócios. Entre 2007 e 2013, houve esforço de expansão dos negócios brasileiros no exterior, inclusive com aumento de investimento brasileiro no exterior, como será demonstrado mais adiante. Ainda, como o período era considerado à época como um momento bom do mercado brasileiro, muitas empresas estrangeiras fizeram investimento no 
Brasil. Parte do investimento passava pela viagem de brasileiros para o exterior para treinamento, realização de acordos, etc.

Outro aspecto que se observa é que (b), a partir de 2005 houve crescimento acelerado dos gastos reais dos brasileiros com turismo e compras no exterior. De 2004 a 2013, os gastos brasileiros em turismo cresceu quase cinco vezes, e os gastos com cartão cresceram mais de três vezes. A melhoria da economia brasileira abriu espaço para que as famílias aumentassem seu consumo. Parte da população, em geral de renda mais alta, optou por realizar seu consumo no exterior. Trata-se de típico exemplo do efeito demonstração. Ao invés de consumir bens locais, e realizar turismo nacional, o brasileiro optou por gastar em outros países. A consequência é que esses gastos geram demanda no exterior, e estimulam outras economias, que não a brasileira.

A explicação do porquê se deu essa "opção" é evidentemente estrutural. Como país dependente, a elite do Brasil reconhece o padrão de consumo exterior, e a cultura exterior, como superior à local. A busca pela identidade com a metrópole passa pelo consumo dos bens e culturas de lá. O resultado é que o Turismo e os gastos em cartão de crédito no exterior foram, sozinhos, responsáveis por mais de 26\% do déficit das transações correntes, em 2013. Naturalmente, essa situação só pode ser sustentada enquanto haja largo saldo comercial, que no caso era sustentado pela alta da demanda por commodities.

Na tabela 4.4a e 4.4b, observa-se a conta de serviços empresariais, profissionais e técnicos, em bilhões de reais constantes de 2006. Na tabela 4.4a, a variável (2) é o saldo real da conta. A variável (3) é a receita real da conta em questão, excluindo as despesas. A variável (4) são as receitas brasileiras reais com serviços empresariais de encomenda postal. Nesse item não está incluso o serviço postal estatal. Na variável (5), verifica-se a receita real dos serviços jurídicos, de auditoria, contabilidade, consultoria tributária, e de educação. A variável (6) traz a receita real com passes de atletas. A seguinte, variável (7), expressa a receita real de serviços de publicidade e participação de feiras e exposição. A variável (8) é a receita com serviços de engenharia, arquitetura, pesquisa e desenvolvimento, e assistência técnica. A variável (9) traz a receita real dos serviços administrativos e outros técnicos e profissionais. 


\begin{tabular}{|c|c|c|c|c|c|c|c|c|}
\hline \multicolumn{9}{|c|}{ Tabela 4.4a: Serviços empresariais, profissionais e técnicos, valores em bilhões de reais de 2006, 1999 a 2013.} \\
\hline (1) & (2) & (3) & (4) & (5) & (6) & (7) & (8) & (9) \\
\hline & $\begin{array}{c}\text { Serviços } \\
\text { empresariais, } \\
\text { profissionais } \\
\text { e técnicos }\end{array}$ & & & & & & & \\
\hline & & $\begin{array}{c}\text { Empresariais, } \\
\text { profissionais e } \\
\text { técnicos } \\
\text { (Receita) }\end{array}$ & & & & & & \\
\hline ano & & & $\begin{array}{c}\text { Encomendas } \\
\text { postais } \\
\text { (Receita) }\end{array}$ & $\begin{array}{l}\text { Serviços } \\
\text { jurídicos, de } \\
\text { auditoria, } \\
\text { contabilidade, } \\
\text { consultoria } \\
\text { tributária e de } \\
\text { educação } \\
\text { (Receita) }\end{array}$ & $\begin{array}{c}\text { Passe de } \\
\text { atleta } \\
\text { profissional } \\
\text { (Receita) }\end{array}$ & $\begin{array}{c}\text { Publicidade e } \\
\text { participação } \\
\text { em feiras e } \\
\text { exposições } \\
\text { (Receita) }\end{array}$ & $\begin{array}{c}\text { Serviços de } \\
\text { engenharia, } \\
\text { arquitetura, } \\
\text { P\&D e } \\
\text { assistência } \\
\text { técnica } \\
\text { (Receita) }\end{array}$ & $\begin{array}{c}\text { Serviços } \\
\text { administrativos } \\
\text { e outros técnicos } \\
\text { e profissionais } \\
\text { (Receita) }\end{array}$ \\
\hline 1999 & 4,19 & 9,22 & 0,00 & 0,16 & 0,31 & 0,47 & 3,74 & 4,55 \\
\hline 2000 & 7,07 & 12,22 & 0,00 & 0,18 & 0,41 & 0,55 & 6,15 & 4,93 \\
\hline 2001 & 8,45 & 14,41 & 0,00 & 0,19 & 0,47 & 0,59 & 6,81 & 6,35 \\
\hline 2002 & 10,17 & 15,91 & 0,00 & 0,24 & 0,28 & 0,50 & 7,99 & 6,90 \\
\hline 2003 & 8,26 & 14,24 & 0,01 & 0,16 & 0,28 & 0,40 & 7,34 & 6,04 \\
\hline 2004 & 7,99 & 15,16 & 0,01 & 0,23 & 0,34 & 0,38 & 8,52 & 5,69 \\
\hline 2005 & 9,54 & 15,78 & 0,01 & 1,19 & 0,41 & 0,35 & 8,84 & 4,98 \\
\hline 2006 & 10,08 & 16,65 & 0,01 & 3,18 & 0,29 & 0,38 & 8,24 & 4,55 \\
\hline 2007 & 11,70 & 18,93 & 0,01 & 3,55 & 0,41 & 0,42 & 9,12 & 5,42 \\
\hline 2008 & 13,35 & 21,16 & 0,00 & 4,40 & 0,39 & 0,55 & 9,45 & 6,39 \\
\hline 2009 & 12,19 & 20,68 & 0,00 & 3,82 & 0,30 & 0,58 & 9,71 & 6,27 \\
\hline 2010 & 11,47 & 19,94 & 0,01 & 3,90 & 0,32 & 0,52 & 8,03 & 7,18 \\
\hline 2011 & 13,28 & 22,77 & 0,00 & 3,89 & 0,30 & 0,74 & 9,58 & 8,27 \\
\hline 2012 & 16,21 & 28,16 & 0,00 & 4,72 & 0,25 & 0,98 & 12,97 & 9,23 \\
\hline 2013 & 14,53 & 27,01 & 0,00 & 4,50 & 0,44 & 1,15 & 12,14 & 8,77 \\
\hline
\end{tabular}

Conforme já apontado, a conta de serviços empresariais, nas transações correntes, apresenta saldo real positivo para o Brasil. No entanto, ao verificar os componentes dessa conta fica claro porque esse saldo expressa mais uma relação de dependência da economia brasileira do que de desenvolvimento. Há três componentes que geram alto valor de receita: (a) serviços jurídicos, de contabilidade e educação; (b) serviços de engenharia, pesquisa e desenvolvimento, e assistência técnica; e (c) serviços administrativos e outros técnicos e profissionais.

O primeiro, serviços jurídicos, passou a apresentar maior volume de receita a partir de 
2005. Os outros dois apresentaram receita alta, com tendência de crescimento, desde 2000. As três receitas são consequência da instalação de firmas multinacionais no país. Para se instalar, precisam contratar serviço jurídico e de contabilidade; serviços de engenharia e arquitetura para montar suas filiais; de pesquisa e desenvolvimento para adequar seus produtos ao mercado brasileiro ${ }^{120}$; e precisam contratar técnicos para auxiliar nos serviços de escritório. Como há preferência pela terceirização e subcontratação, as firmas multinacionais realizam uma operação entre a empresa estrangeira (ela mesma) com seus contratados locais, resultando nesse alto volume de receita. Ou seja, a receita é fruto da entrada comercial de empresas estrangeira no país.

Christian Palloix, na década de (19)70 observou bem como as firmas multinacionais se tornaram um mecanismo de transferência de renda internacional. Desde o final da segunda guerra mundial, a exportação de capital havia deixado de ser a principal forma de transferência de renda, sendo substituída pelas trocas desiguais. No entanto, com o fortalecimento das firmas multinacionais, a exportação de capital voltou a ter importância. Evidentemente, a entrada das firmas em um país gera uma renda momentânea, fruto de (a) investimento de capital; e (b) acionamento da economia pela simples entrada da firma. É evidente que o investimento estrangeiro direto tende a gerar algum tipo de ganho local, ainda que apenas de curto prazo ${ }^{121}$.

Parte desse saldo é perdido quando as empresas estrangeiras aqui instaladas enviam suas remessas de lucro para seus países de origem. No Brasil, não há programa de transferência de tecnologia que permita que a instalação de firmas multinacionais resulte em ganho geral de produtividade no país. O que o país ganhou se resumiu ao saldo de 14,53 bilhões de reais constantes, em 2013. Valor relativamente pequeno perante as remessas de lucro que essas multinacionais enviam para o exterior. As perdas se tornam ainda maiores se somadas aos gastos com empréstimos de equipamento e pagamentos de royalties, outras duas fontes de renda importantes para as matrizes das firmas multinacionais.

120 Sobre o investimento em "pesquisa e desenvolvimento" voltados a adaptação de produtos para o mercado local, ver: GUSTAFSSON, Peter \& SEGERSTROM, Paul S. North-South Trade With Multinational Firms And Increasing Product Variety. International Economic Review, Vol. 52, No. 4 (November 2011), pg. 11231155

121 Sobre o assunto, ver: Christian Palloix. As firmas multinacionais e o processo de internacionalização. Lisboa: Editorial estampa, 1974. 


\begin{tabular}{|c|c|c|c|c|c|c|c|c|}
\hline \multicolumn{9}{|c|}{ Tabela 4.4b: Serviços empresariais, profissionais e técnicos, valores em bilhões de reais de 2006, 1999 a 2013} \\
\hline (1) & (2) & (3) & (4) & (5) & (6) & (7) & (8) & (9) \\
\hline & $\begin{array}{c}\text { Serviços } \\
\text { empresariais, } \\
\text { profissionais e } \\
\text { técnicos }\end{array}$ & & & & & & & \\
\hline & & \begin{tabular}{|c} 
Empresariais, \\
profissionais \\
e técnicos \\
(Despesas)
\end{tabular} & & & & & & \\
\hline ano & & & $\begin{array}{c}\text { Encomendas } \\
\text { postais } \\
\text { (Despesas) }\end{array}$ & \begin{tabular}{|} 
Serviços \\
jurídicos, de \\
auditoria, \\
contabilidade, \\
consultoria \\
tributária e de \\
educação \\
(Despesas)
\end{tabular} & \begin{tabular}{|c|}
$\begin{array}{c}\text { Passe de } \\
\text { atleta } \\
\text { profissional } \\
\text { (Despesas) }\end{array}$ \\
\end{tabular} & $\begin{array}{c}\text { Publicidade e } \\
\text { participação } \\
\text { em feiras e } \\
\text { exposições } \\
\text { (Despesas) }\end{array}$ & $\begin{array}{c}\text { Serviços de } \\
\text { engenharia, } \\
\text { arquitetura, } \\
\text { P\&D e } \\
\text { assistência } \\
\text { técnica } \\
\text { (Despesas) }\end{array}$ & $\begin{array}{c}\text { Serviços } \\
\text { administrativos } \\
\text { e outros técnicos } \\
\text { e profissionais } \\
\text { (Despesas) }\end{array}$ \\
\hline 1999 & 4,19 & $(5,03)$ & $(0,03)$ & $(0,05)$ & $(0,11)$ & $(0,22)$ & $(3,10)$ & $(1,53)$ \\
\hline 2000 & 7,07 & $(5,14)$ & $(0,08)$ & $(0,04)$ & $(0,07)$ & $(0,42)$ & $(3,29)$ & $(1,24)$ \\
\hline 2001 & 8,45 & $(5,96)$ & $(0,11)$ & $(0,07)$ & $(0,02)$ & $(0,37)$ & $(3,99)$ & $(1,39)$ \\
\hline 2002 & 10,17 & $(5,74)$ & $(0,13)$ & $(0,06)$ & $(0,02)$ & $(0,28)$ & $(4,16)$ & $(1,10)$ \\
\hline 2003 & 8,26 & $(5,98)$ & $(0,11)$ & $(0,14)$ & $(0,02)$ & $(0,54)$ & $(4,08)$ & $(1,09)$ \\
\hline 2004 & 7,99 & $(7,17)$ & $(0,11)$ & $(0,02)$ & $(0,01)$ & $(0,66)$ & $(5,24)$ & $(1,13)$ \\
\hline 2005 & 9,54 & $(6,24)$ & $(0,10)$ & $(0,38)$ & $(0,02)$ & $(0,27)$ & $(4,48)$ & $(0,99)$ \\
\hline 2006 & 10,08 & $(6,57)$ & $(0,09)$ & $(0,89)$ & $(0,03)$ & $(0,32)$ & $(4,17)$ & $(1,07)$ \\
\hline 2007 & 11,70 & $(7,22)$ & $(0,07)$ & $(0,88)$ & $(0,03)$ & $(0,33)$ & $(4,73)$ & $(1,19)$ \\
\hline 2008 & 13,35 & $(7,81)$ & $(0,02)$ & $(0,85)$ & $(0,07)$ & $(0,48)$ & $(4,79)$ & $(1,60)$ \\
\hline 2009 & 12,19 & $(8,48)$ & $(0,04)$ & $(1,08)$ & $(0,03)$ & $(0,48)$ & $(5,38)$ & $(1,48)$ \\
\hline 2010 & 11,47 & $(8,47)$ & $(0,09)$ & $(0,91)$ & $(0,04)$ & $(0,71)$ & $(5,27)$ & $(1,45)$ \\
\hline 2011 & 13,28 & $(9,49)$ & $(0,12)$ & $(1,18)$ & $(0,07)$ & $(0,94)$ & $(5,61)$ & $(1,58)$ \\
\hline 2012 & 16,21 & $(11,95)$ & $(0,09)$ & $(1,38)$ & $(0,09)$ & $(1,29)$ & $(6,63)$ & $(2,47)$ \\
\hline 2013 & 14,53 & $(12,48)$ & $(0,12)$ & $(1,46)$ & $(0,09)$ & $(1,42)$ & $(7,00)$ & $(2,38)$ \\
\hline
\end{tabular}

Fonte: Banco Central do Brasil

A tabela 4.4b é o espelho da tabela 4.4a. A variável (2) é, mais uma vez, o saldo real da conta de serviços empresariais. Todas as demais variáveis são a conta de despesas para os mesmos itens representados na tabela 4a. As despesas com serviços empresariais tem um componente predominante: a variável (8), despesas com serviço de engenharia, arquitetura, pesquisa e desenvolvimento, e assistência técnica. Até 2005, quase a totalidade das despesas da conta se resumiam à esse item. No caso brasileiro, esse gasto resultava da contratação de empresas estrangeiras para realizar as pesquisas e desenvolvimento para as empresas brasileiras. A partir de 2006, firmas brasileiras passaram a investir mais no exterior. Daí passou a aumentar as despesas em outros itens da conta de serviços empresariais. 


\subsection{CONTA DE RENDAS DO BALANÇO DE PAGAMENTOS.}

Nas transações correntes do Balanço de Pagamentos, na metodologia BPM5, uma das contas é a de "rendas". Trata-se do resultado dos envios e recebimentos de remessas de lucros de empresas estrangeiras e empresas brasileiras instaladas no exterior, dos dividendos de investimentos em carteira, e da renda resultante do pagamento e recebimento de juros de empréstimos realizado. Ainda, conta com os envios e recebimento de salário e ordenados de trabalhadores que estejam no exterior.

Na literatura, essa é uma conta considerada importante. Ela é um indicativo do impacto do endividamento e da entrada de empresas estrangeiras na saúde econômica do país. Para os estruturalistas, como Villarreal, rumo a uma análise mais precisa deveria se considerar também o impacto das amortizações. No entanto, na metodologia adotada pelo Banco Central do Brasil, as amortizações fazem parte da conta financeira.

Tabela 4.5: Conta de Rendas da conta de Transações Correntes do Balanço de Pagamentos, valores em bilhões de reais de 2006, 1999 a 2013

\begin{tabular}{|c|c|c|c|c|c|}
\hline (1) & (2) & (3) & (4) & (5) & (6) \\
\hline & saldo de rendas & & & & \\
\hline ano & $\begin{array}{c}(2)=(3)+(4)+(5)+ \\
(6)\end{array}$ & salários e ordenados & \begin{tabular}{|c} 
renda de \\
investimento direto
\end{tabular} & $\begin{array}{c}\text { renda de } \\
\text { investimento em } \\
\text { carteira }\end{array}$ & renda de juros \\
\hline 1999 & $(62,75)$ & 0,47 & $(12,20)$ & $(25,67)$ & $(25,36)$ \\
\hline 2000 & $(56,19)$ & 0,25 & $(10,18)$ & $(26,85)$ & $(19,42)$ \\
\hline 2001 & $(72,57)$ & 0,35 & $(17,05)$ & $(35,36)$ & $(20,51)$ \\
\hline 2002 & $(75,23)$ & 0,42 & $(20,61)$ & $(34,67)$ & $(20,37)$ \\
\hline 2003 & $(71,02)$ & 0,42 & $(19,51)$ & $(33,47)$ & $(18,45)$ \\
\hline 2004 & $(68,91)$ & 0,61 & $(19,44)$ & $(34,98)$ & $(15,10)$ \\
\hline 2005 & $(67,86)$ & 0,56 & $(26,92)$ & $(30,78)$ & $(10,72)$ \\
\hline 2006 & $(60,81)$ & 0,39 & $(28,39)$ & $(24,41)$ & $(8,42)$ \\
\hline 2007 & $(55,02)$ & 0,84 & $(32,85)$ & $(13,27)$ & $(9,74)$ \\
\hline 2008 & $(66,47)$ & 0,89 & $(43,88)$ & $(13,17)$ & $(10,31)$ \\
\hline 2009 & $(56,28)$ & 1,01 & $(32,99)$ & $(15,39)$ & $(8,91)$ \\
\hline 2010 & $(53,83)$ & 0,68 & $(34,77)$ & $(13,58)$ & $(6,16)$ \\
\hline 2011 & $(58,73)$ & 0,70 & $(36,77)$ & $(15,10)$ & $(7,56)$ \\
\hline 2012 & $(49,75)$ & 0,72 & $(28,01)$ & $(13,91)$ & $(8,54)$ \\
\hline 2013 & $(56,84)$ & 0,73 & $(32,22)$ & $(15,72)$ & $(9,63)$ \\
\hline
\end{tabular}

Na tabela 4.5, acima, há os valores do saldo real, em bilhões de reais de 2006, da conta de rendas das transações correntes do Brasil. A variável (2) é o saldo real, somado todos os componentes. A variável (3) é o saldo real dos salários e ordenados de trabalhadores brasileiros residentes em outros países, mas que enviam contribuições para familiares ou 
conhecidos no Brasil. A variável (4) é o saldo real dos envios e recebimento de remessas de lucro, fruto de investimento direto. Na metodologia BPM5, é considerado investimento direto qualquer aquisição de participação de capital em companhias, empresas, e indústria. Tanto a criação de filiais de uma multinacional como a aquisição de ações de uma empresa brasileira são considerados investimento estrangeiro direto. A variável (6) traz o saldo real das remessas de dividendo de investimentos em carteira. Inclui os investimentos de curto prazo. A variável (7) é o saldo real dos pagamentos e recebimentos de juros de empréstimos realizados. Não inclui amortização.

Entre 1999 e 2002, o déficit real da conta de renda aumentou. A partir de então, passou a diminuir, com oscilações pontuais. Entre 2002 e 2013, houve queda de mais de 32\% no déficit real nessa conta. Dentre seus componentes, o déficit de renda de investimento direto apresentou crescimento desde 1999, com oscilações. Como resultado, entre 2002 e 2013, o déficit no item aumentou em mais de 56\%.

Enquanto isso, o déficit de renda de investimento em carteira apresentou queda, a partir de 2001, o que resultou redução de mais de 120\%, entre 2002 e 2013. Houve movimento similar no saldo real da renda de juros: entre 2002 e 2013, houve redução de mais de 111\%. Essa redução nos déficits de investimento em carteira e de renda de juros foi fruto do pagamento de parte da dívida externa brasileira. Durante o governo de Luís Inácio Lula da Silva, o governo adotou como parte de sua estratégia utilizar as divisas adquiridas no comércio exterior para pagar parte da dívida externa. Para financiar tal movimento, houve aumento da dívida interna.

No entanto, o impacto na redução da fragilidade externa foi bastante inferior. Na ausência de capital nacional, com o Real sobrevalorizado, e com políticas favoráveis ao oligopólio, o Brasil atraiu investimento estrangeiro direto. Isso teve como consequência o aumento no déficit na conta de envio e recebimento de remessas desse tipo de investimento. Wilson do Nascimento Barbosa realizou uma caracterização sobre o investimento estrangeiro direto no Brasil. Apesar de tratar a década de (19)90, a caracterização aponta bem o problema de "investimento direto" que seja mera aquisição de empresas locais:

Em resultado, deu-se nova onda de internacionalização, verificando-se que grande parte dos recursos que entraram no país, durante o período 1994 - 2000, se dedicaram à compra e desnacionalização de indústrias já estabelecidas. Houve uma internacionalização que gerou 
pagamentos de royalties, desde salsichas, fogões, até equipamentos eletrônicos. Interessante é notar que em raros casos houve introdução de novas tecnologias. As compras tiveram por objetivo apossar-se simplesmente de capacidade produtiva e mercados a baixos preços, para promover remessas permanentes de lucros e "direitos sobre patentes”. Será que não se sabia aqui produzir salsichas? Ou fogões? Indústrias como a Dako, Metal Leve, Cofap, etc, desapareceram enquanto entidades do mercado interno, transformando-se em plataformas de montagem de componentes importados, para o mercado local ou para o famigerado Mercosul. Enquanto isso, o governo continuava brincando que era competente. ${ }^{122}$

Note que o investimento estrangeiro direto não significou transferência direta, ao passo que aumentou a sangria de divisas para o exterior. O Brasil teve que arcar com o aumento dos gastos resultantes da entrada de empresas estrangeiras no mercado local, sem adquirir o ganho esperado.

Gráfico 4.3: Déficit das transações correntes de renda, 1999 a 2013 (participação no défice)

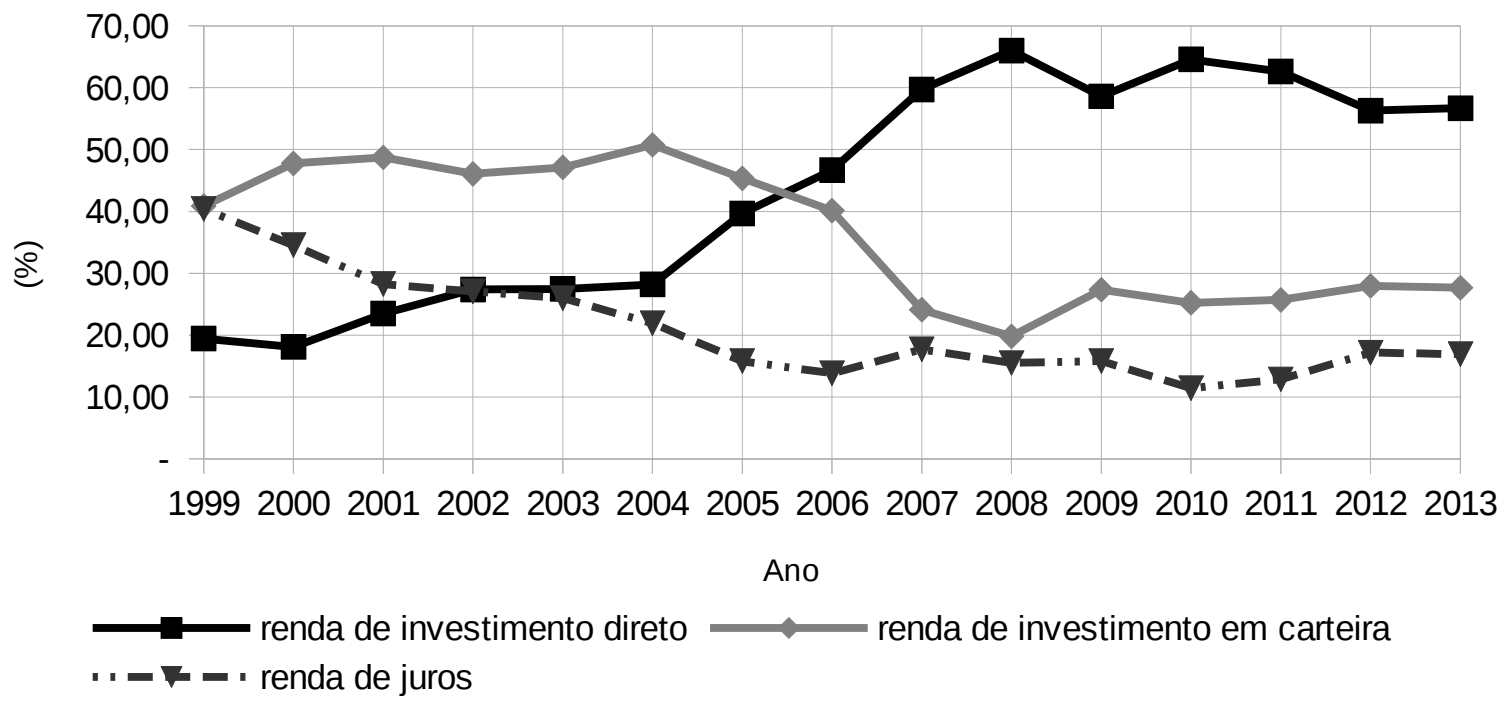

*Fonte: Banco Central do Brasil. Elaboração própria

O gráfico 4.3 permite verificar o movimento relativo dos principais componentes do saldo das transações correntes de renda, entre 1999 e 2013. Observa-se que, desde 2002, o déficit com renda de investimento direto se tornou maior do que o déficit de renda de juros. A partir de 2006, o déficit em renda de investimento direto se tornou superior ao déficit em renda de investimento em carteira. A partir de 2007, a renda de investimento direto se tornou 
responsável por mais de 50\% do déficit. Atingindo mais de 65\% da participação em 2008.

Apresentados dessa forma os dados permitem chegar a dois apontamentos pertinentes: (a) a redução no déficit da conta de rendas significou a diminuição do peso relativo de uma das formas de drenagem dos recursos da economia brasileira; e (b) a diminuição do peso relativo ao envio de dividendos resultantes do investimentos estrangeiros em carteira e dos juros resultantes de empréstimos significou menor vulnerabilidade ao movimento do capital de curto prazo. Na prática, no período, o Brasil diminuiu sua fragilidade perante ataques especulativos (ataques financeiros). Em contrapartida, aumentou seus gastos com envio de remessas de lucro.

A mudança de perfil do investimento estrangeiro (do investimento em portfólio para o investimento direto) refletiu (i) a mudança na política de juros do governo; (ii) maior estabilidade (temporária) nas economia brasileira. Também (iii) se explica por uma política cambial favorável ao capital estrangeiro: o câmbio não acompanhou a inflação. Isso significa que o capital estrangeiro apenas de adentrar e completar um ciclo na economia local podia apresentar ganhos nominais ${ }^{123}$. Evidentemente, isso só pode ser sustentado graças a aquisição de divisas via comércio exterior. Ainda, note que os principais exportadores brasileiros são companhias de capital aberto. Ou seja, também recebem investimento estrangeiro e enviam remessas de lucro ${ }^{124}$.

A recuperação econômica do Brasil, portanto, também favorece ao capital internacionalizado. Que o crescimento das exportações brasileiras tenham favorecido investidores estrangeiros é um fato que fica, diante dos dados, evidente. Que os ganhos brasileiros tenham vazado para o exterior não é novidade na literatura. Como disse Christian Palloix:

Na verdade, a internacionalização do lucro capitalista é tão evidente que não há qualquer vantagem em nos demorarmos muito nesse assunto: é sabido que o lucro das filiais das firmas U.S. no exterior é

123 Quando o câmbio se desloca aquém da inflação, o investidor estrangeiro amplia sua margem de lucro. Por exemplo, se investir mil dólares a 2,00 reais, com uma taxa de lucro de $10 \%$, espera-se retirar, ao final do ano, 1,1 mil dólares. Mas, caso a inflação seja de 6\%, e o investimento rodar o circuito econômico completo durante um ano e apresentar a margem de lucro real de $10 \%$ no final do período os 2 mil reais se tornarão 2,33. Em termos reais, o poder de compra dos novos 2,33 continuará a ser equivalente aos 2,20 do ano anterior. Mas, como o dólar se manteve estável no ano, os 2,33 agora compram 1,16 mil dólares. Note que a taxa de lucro saltou de $10 \%$ para $16 \%$, por puro efeito aritmético.

124 Sobre o assunto ver: CHESNAIS, François. Finance Capital Today: Corporations and Banks in the Lasting Global Slump. Boston: Brill, 2016. Pg 117 e 153. 
superior ao lucro destas firmas quando operam no interior dos E.U.A ${ }^{125}$

\subsection{CONTA FINANCEIRA E INVESTIMENTO DIRETO}

A segunda parte do Balanço de pagamentos é a Conta Financeira. Ela inclui a Conta de Capital, e a Conta Financeira. Pela metodologia BPM5, indicada pelo FMI e adotada pelo Banco Central do Brasil, a conta de capital inclui apenas as transferências unilaterais de capital. Os investimentos, sejam diretos ou investimentos em carteira, constam na conta financeira.

Têm-se que a conta financeira costuma ser o espelho das transações correntes: quando uma é positiva, a outra é negativa. Para Prebisch, Celso Furtado, Villarreal e outros pensadores estruturalistas, é traço dos países dependentes terem transações correntes negativas e contas financeiras positivas. Isso é o resultado de um processo retroalimentar. Como há transações correntes negativas, há demanda por capital estrangeiro, para compensar o déficit. A entrada de capital, seja como investimento direto, seja como empréstimo estrangeiro, pressiona no momento seguinte as transações correntes para o déficit. Esse processo tende a se repetir, enquanto o país não desenvolva uma indústria local e consiga reduzir o déficit nas transações correntes.

Por outro lado, o investimento demanda poupança. Como a produtividade local é baixa, devido ao abandono da indústria, parte do investimento realizado conta com poupança externa. Nas últimas décadas, tomou-se preferência pela poupança externa sob a forma de investimento estrangeiro direto, ao invés do endividamento. Parcialmente, a nova preferência resultou de (a) experiência traumática com o excesso de endividamento (em especial junto ao FMI) e o aumento da fragilidade das economia locais, durante os anos (19)70 e (19)90.

Os investimentos estrangeiros diretos também cresceram como parte da abertura da economia local às firmas multinacionais. Ainda, as medidas tomadas para expandir o acesso ao investimento estrangeiro, em especial a manipulação cambial, afim de garantir maiores ganhos para o investidor estrangeiro, tenderam a impactar negativamente na disponibilidade de poupança interna. Um dos resultados foi ainda maior dependência dos investimentos

125 Christian Palloix. As firmas multinacionais e o processo de internacionalização. Lisboa: Editorial Estampa, 1974. Pg 211 
estrangeiros. ${ }^{126}$

Tabela 4.6: Conta financeira do Balanço de Pagamentos, valores em bilhões de Reais de 2006, 1999 a 2013.

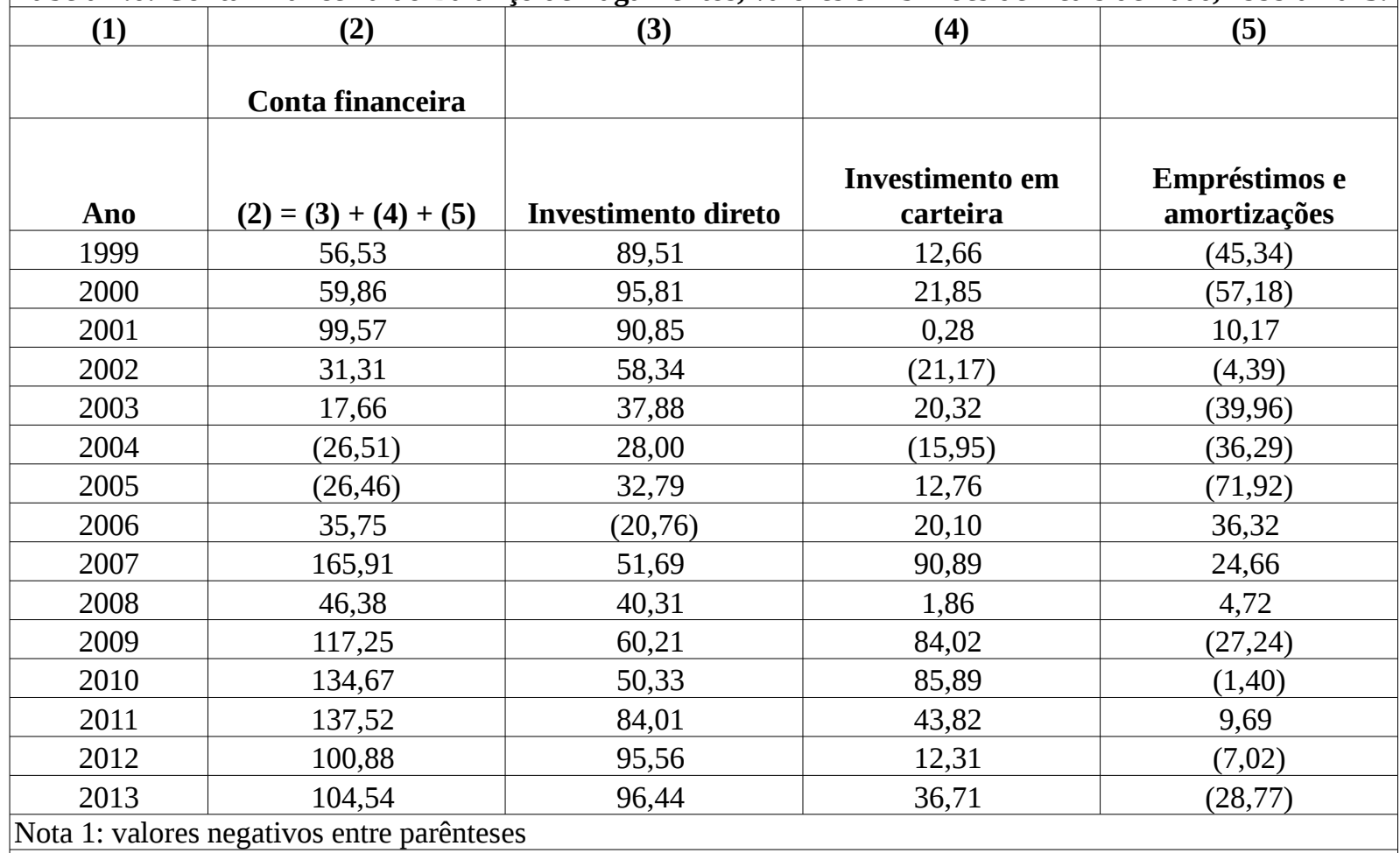

Fonte: Banco Central do Brasil.

A tabela 4.6 traz os saldos reais, em bilhões de Reais de 2006, da conta financeira e seus componentes. A variável (2) é o saldo real da conta financeira, somado todos seus componentes. A variável (3) é o saldo real dos investimentos diretos, considerando os investimentos brasileiros diretos no exterior (saída), e os investimentos estrangeiros diretos (IED) no Brasil (entrada). A variável (4) representa o saldo real dos investimentos em carteira, considerando os investimentos brasileiros em carteira no exterior, e os investimentos estrangeiros em carteira no Brasil. A variável (5) traz o saldo real dos empréstimos ofertados e tomados, e as amortizações pagas e recebidas.

A conta financeira apresentou queda no saldo até 2005. Em 2004 e 2005, houve déficit na conta. Nesses anos, as transações correntes estavam no auge de seu saldo. O comportamento, portanto, é condizente com o esperado na literatura. A partir de 2006, voltou a ocorrer saldo na conta financeira, com tendência de crescimento. O auge do saldo real foi em 2007. A crise econômica internacional, de 2008, desaqueceu os investimentos estrangeiros

126 Para uma discussão sobre o papel das firmas multinacionais como fonte de poupança externa, ver: VANOVIĆ, Igor. Impact Of Foreign Direct Investment (FDI) On Domestic Investment In Republic Of Croatia. Review Of Innovation And Competitiveness, vol 1, issue 1, 2015. 
no mundo inteiro. A partir de 2008, o saldo os investimentos no Brasil voltou a crescer, atingindo novo cume em 2011. Naquele ano, apesar dos déficits reais das transações correntes já serem grandes, havia expectativa internacional no bom desempenho da economia brasileira. A entrada de investimento estrangeiro no Brasil alimentava o discurso que o país ia bem, e que atraía investidores de todas as partes. Os preços das commodities ainda estavam no alto.

A diferença entre 2007 e 2011, quanto aos saldos de investimento, é que em 2007 o saldo resultou majoritariamente de um alto investimento estrangeiro em carteira. Já em 2011, o saldo resultou de alto investimento estrangeiro direto. Durante o período analisado (1999 a 2013), o investimento em carteira oscilou muito, o que é tipico de investimento de curto prazo. Já os investimento direto teve comportamento mais consistente. Até 2006, ocorreu redução no saldo do investimento estrangeiro direto.

A partir de então voltou a crescer. Outra característica importante é que no saldo dos empréstimos e amortizações o Brasil foi deficitário. Isso foi consequência da política de pagamento das dívidas e resistência à contratação de novos compromissos no exterior. Embora, formalmente, a diminuição do endividamento haja diminuído a fragilidade externa, isso resulta parcialmente do fato dessa não contabilizar a venda de ativos como ampliação da fragilidade. A redução do endividamento é apenas uma das medidas possíveis para diminuir a fragilidade da economia local frente a ataques especulativos (ou crises financeiras internacionais). Ataques especulativos também são capazes de gerar queda na entrada de investimento estrangeiro. Podem também gerar fuga de capital, na forma de desinvestimento. O problema central, portanto, não é apenas qual é o tipo de poupança externa ao qual se recorre. É, também, porque se depende de poupança externa, e quais as políticas econômicas (incluindo em especial a política cambial) que serão adotadas para alterar uma situação indesejada ${ }^{127}$.

127A título de exemplo, um dos motivos apontados para a rápida recuperação da Islândia na crise financeira de 2008 - 2009 foi o fato do país possuir uma moeda própria e ter se negado a seguir as indicações do FMI. Sobre o assunto, ver: WALBERG, Eric. Postmodern Imperialism Geopolitics And The Great Games. Atlanta: Clarity Press, 2011. Pg. 111. 
Gráfico 4.4: Saldo real dos investimentos, 1999 a 2013

(Participação no saldo da conta financeira)

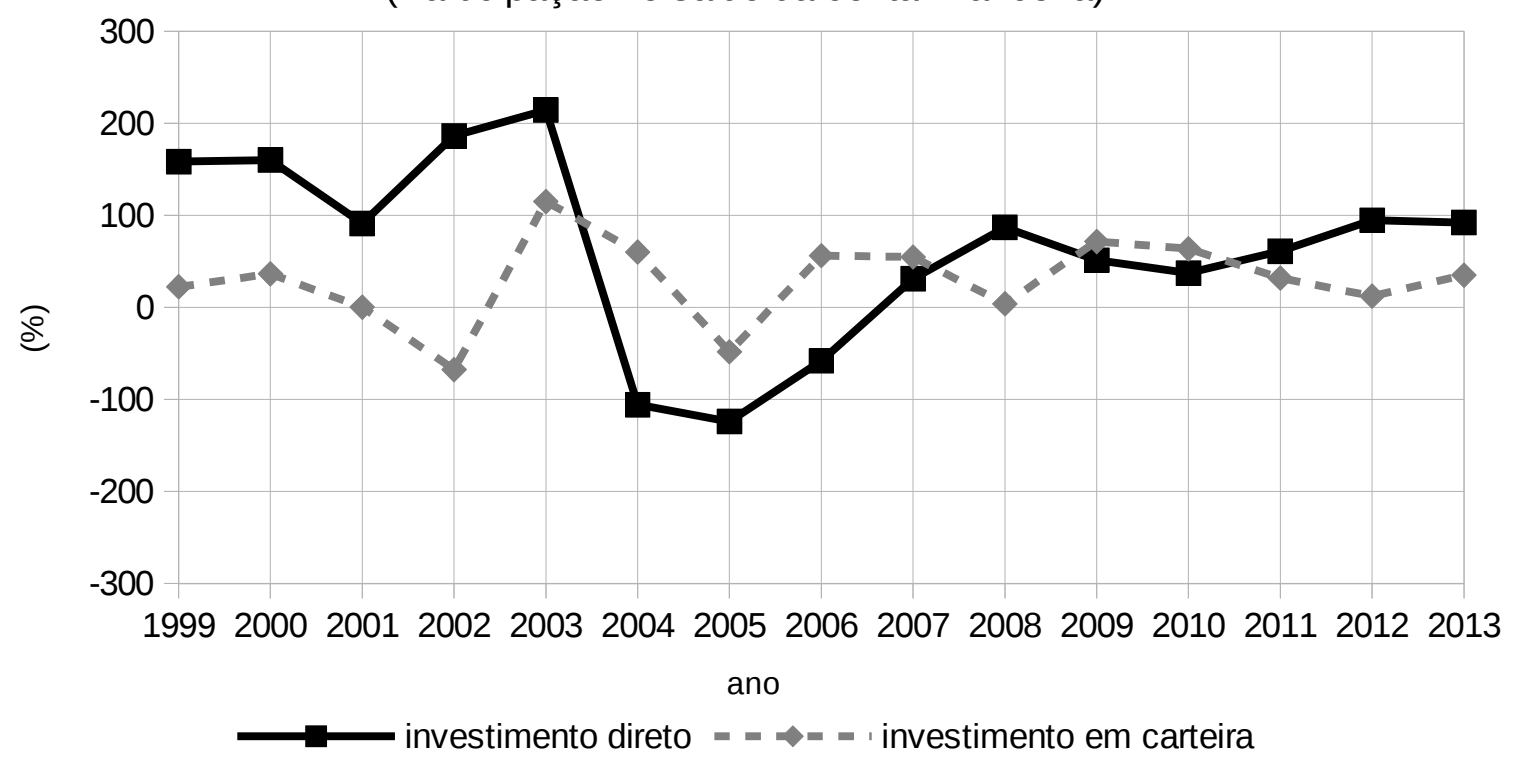

*Fonte: Banco Central do Brasil.

O gráfico 4.4, acima, expressa o movimento relativo do investimento direto e do investimento em carteira para o saldo real da conta financeira do Balanço de Pagamentos. Observa-se que entre 1999 e 2002, período em que o Brasil passava por crises, a participação do investimento em carteira no saldo de investimentos foi muito baixo, e até negativo em 2002. De 2004 a 2006, esse tipo de investimento ganhou maior importância. Só em 2007, o investimento direto voltou a se igualar, e até a ultrapassar, a importância relativa do investimento em carteira. A partir daquele ano, a composição dos investimentos se tornou bastante estável, com maior resiliência e tendência de crescimento à favor do investimento direto.

Esse perfil não é ruim. A oportunidade dada ao Brasil pela demanda chinesa afetou positivamente o comportamento dos investidores internacionais. O Brasil atraiu capital sem se tornar vulnerável à ataques especulativos e grandes retiradas de capital, durante os anos em análise. Isso foi consequência do interesse de agentes estrangeiros em adquirir empresas e negócios no país. Evidentemente, trata-se de uma situação melhor do que a exposição anterior ao mercado financeiro. No entanto, não significa independência econômica. O aumento do investimento estrangeiro direto significa, também, a perda de capacidade decisória, por conta da venda de ativos brasileiros.

Na prática, o que ocorreu foi o interesse daqueles agentes em participar, a longo prazo, 
na drenagem de riqueza produzida no Brasil. Mas essa riqueza era produzida ligada ao comércio de commodities. Não houve fortalecimento da produção industrial local, nem formação de um mercado complexo e autossustentado. A produtividade média do Brasil continuou baixa. Com a diminuição da demanda chinesa, a partir do final de 2012, a economia brasileira experimentou o peso de ter que pagar as remessas de lucro sem ter divisas suficientes vindas do comércio exterior para as sustentar.

O governo brasileiro acreditou que a atração de investidores significaria o alavancamento da produtividade local. Acreditava-se que a entrada de firmas multinacionais traria maior produtividade, ao passo que o endividamento apenas expunha o Brasil a pressões externas. No entanto, parte da literatura atual sobre as firmas multinacionais e os investimentos diretos vem demonstrando que elas nem sempre geram crescimento econômico onde se instalam. Para parte da literatura sobre o tema, a contribuição do investimento estrangeiro ao desenvolvimento local depende da (a) realização de transferência de tecnologia; ou (b) elevação do nível salarial local ${ }^{128}$.

As firmas multinacionais não investem para desenvolver o país, investem para adquirir lucros. Na ausência de uma política econômica voltada ao desenvolvimento local, o investimento estrangeiro tende a apenas reproduzir a relação de dependência econômica do país onde instalam suas filiais em relação ao país da matriz. Para o países dependentes, como o Brasil, o investimento estrangeiro tende a se concentrar nos setores exportadores e importadores, visando (a) explorar os baixos custos da mão de obra local para competir no mercado internacional; e (b) adquirir lucro ao vender produtos importados, drenando parte da renda dos consumidores locais ${ }^{129}$.

O aumento dos envios de remessa de lucro, dos gastos em royalties, do pagamento de empréstimos de equipamento (leasings), apontam para ausência de transferência de tecnologia. O investimento estrangeiro, sozinho, não foi capaz de aumentar a complexidade da economia local ${ }^{130}$. Aponta, na verdade, para o movimento inverso: é o crescimento

128 Sobre o assunto, ver: GLASS, Amy Jocelyn \& SAGGI, Kamal. Multinational Firms and Technology Transfer. The Scandinavian Journal of Economics, Vol. 104, No. 4 (Dec., 2002), pg. 495-513

129 Sobre o papel das firmas estrangeiras no setor exportador e importador dos países dependentes, ver: BALDWIN, Robert. Desarrollo económico. Un análisis introductorio. Buenos Aires: Amorrortu editores, 1970 .

130 Para uma análise da importância do investimento estrangeiro gerar aumento da complexidade da economia local para servir como impulsionador de crescimento, ver: OCAMPO, José Antonio; VOS, Rob (Ed.). Uneven economic development. Nova Iorque: United Nations Publications, 2008. 
econômico local que atraiu investimento estrangeiro ${ }^{131}$.

\begin{tabular}{|c|c|c|c|c|c|c|}
\hline (1) & (2) & (3) & (4) & (5) & (6) & (7) \\
\hline & $\begin{array}{l}\text { Investimento } \\
\text { Direto }\end{array}$ & & & & & \\
\hline & & $\begin{array}{c}\text { Investimento } \\
\text { brasileiro direto }\end{array}$ & & & & \\
\hline & & & $\begin{array}{c}\text { Investimento } \\
\text { brasileiro direto } \\
\text { (crédito) }\end{array}$ & $\begin{array}{l}\text { Investimento } \\
\text { brasileiro direto } \\
\text { (débito) }\end{array}$ & & \\
\hline ano & & $(3)=(4)+(5)$ & & & $\begin{array}{c}\text { Investimento } \\
\text { brasileiro direto } \\
\text { (Participação no } \\
\text { capital) }\end{array}$ & $\begin{array}{c}\text { Investimento } \\
\text { brasileiro direto } \\
\text { (empréstimo } \\
\text { intercompanhia) }\end{array}$ \\
\hline 1999 & 89,51 & $(5,63)$ & 2,37 & $(8,00)$ & $(3,70)$ & $(1,93)$ \\
\hline 2000 & 95,81 & $(7,17)$ & 2,99 & $(10,16)$ & $(5,51)$ & $(1,66)$ \\
\hline 2001 & 90,85 & 8,30 & 18,77 & $(10,47)$ & 6,44 & 1,86 \\
\hline 2002 & 58,34 & $(10,26)$ & 2,42 & $(12,68)$ & $(9,93)$ & $(0,33)$ \\
\hline 2003 & 37,88 & $(0,95)$ & 6,65 & $(7,60)$ & $(0,24)$ & $(0,72)$ \\
\hline 2004 & 28,00 & $(32,93)$ & 4,32 & $(37,26)$ & $(22,30)$ & $(10,63)$ \\
\hline 2005 & 32,79 & $(6,58)$ & 3,96 & $(10,54)$ & $(7,04)$ & 0,46 \\
\hline 2006 & $(20,76)$ & $(62,41)$ & 2,50 & $(64,91)$ & $(51,81)$ & $(10,60)$ \\
\hline 2007 & 51,69 & $(13,27)$ & 42,26 & $(55,53)$ & $(18,95)$ & 5,68 \\
\hline 2008 & 40,31 & $(33,52)$ & 22,34 & $(55,86)$ & $(22,71)$ & $(10,81)$ \\
\hline 2009 & 60,21 & 16,85 & 42,20 & $(25,35)$ & $(7,59)$ & 24,45 \\
\hline 2010 & 50,33 & $(15,80)$ & 31,87 & $(47,66)$ & $(36,51)$ & 20,71 \\
\hline 2011 & 84,01 & 1,28 & 34,48 & $(33,20)$ & $(24,24)$ & 25,52 \\
\hline 2012 & 95,56 & 3,96 & 29,06 & $(25,10)$ & $(10,60)$ & 14,56 \\
\hline 2013 & 96,44 & 4,99 & 39,50 & $(34,51)$ & $(21,09)$ & 26,09 \\
\hline \multicolumn{7}{|c|}{ Nota 1: valores negativos entre parênteses. } \\
\hline
\end{tabular}

A tabela 4.7 traz os créditos e débitos reais do item "investimento direto" da conta financeira, do balanço de pagamentos, em bilhões de Reais constantes de 2006. Elas está dividida em duas partes: tabela 4.7a. E tabela 4.7b. Na tabela 4.7a, a variável (2) é o saldo dos investimentos diretos, incluindo o investimento direto brasileiro no exterior, e o investimento estrangeiro direto no Brasil. A variável (3) é o saldo real do investimento direto brasileiro no exterior. A variável (4) é o crédito na conta de investimento direto brasileiro. Ou seja, representa as entradas de capital no Brasil como resultado de investimento brasileiro no exterior. Trata-se do resultado de desinvestimentos e empréstimos feito por empresas brasileiras fora do país para empresas brasileiras que estejam dentro do Brasil.

131 Para um estudo sobre a relação de investimento estrangeiro e crescimento econômico ver: CARKOVIC, Maria \& LEVINE, Ross. "Does Foreign Direct Investment Accelerate Economic Growth?” In: MORAN, Theodore H. \& GRAHAM, Edward M. \& BLOMSTRÖM, Magnus (Ed). Does Foreign Direct Investment Promote Development? Washington: Institute for International Economics, 2005. 
A variável (5) é o débito real dos investimentos brasileiros diretos. Inclui investimentos feitos em aquisição de capital no exterior, e empréstimos de empresas brasileiras realizados à empresas no exterior. A variável (6) é o saldo dos investimentos brasileiros direto em participação de capital. A variável (7) é o saldo dos empréstimos feitos entre empresas brasileiras no exterior e empresas brasileiras localizadas no Brasil. As variáveis (6) e (7) fazem parte das variáveis (5) e (6).

Observa-se que houve aumento do investimento brasileiro direto no exterior, com oscilações, no período analisado. Entre 2006 e 2007, houve uma mudança no perfil desse tipo de investimento brasileiro. Até então, os investimentos feitos fora do Brasil oscilavam bastante e havia pouco desinvestimento. A partir de então, os investidores brasileiros adotaram perfil mais ofensivo. Houve largos investimentos, mas também grande volume de venda brasileira de participação de capital em empresas no exterior. Ainda, as empresas brasileiras, ou de participação de capital estrangeiro, situadas fora do Brasil passaram a emprestar maior volume de capital para empresas brasileiras situadas no Brasil.

Pode-se dizer que, a partir de 2006, o Brasil se tornou menos irrelevante no mercado mundial de capitais. Se tornou não só destino de investimentos como um investidor de alguma relevância. Empresas como a VALE e Petrobras, ao lado da Gerdau e Odebrech, foram importantes nesse processo $^{132}$. Na época, falava-se do surgimento de multinacionais brasileiras. Se o Brasil era, até então, um país favorável ao oligopólio estrangeiro, também se tornou propício para o oligopólio nacional. No entanto, muito dessa expansão estava fundada na alta da demanda por commodities. E na desnacionalização das empresas, o que resultou na ampliação do envio de remessas de lucro e pagamento de dividendos. Trata-se de outra face da dependência: as grandes firmas locais (incluindo os oligopólios) possuem capital desnacionalizado. A desnacionalização do capital de empresas locais resulta de (a) compra de ações das empresas por investidores estrangeiros; e (b) compra de ações por offshores de investidores locais. Nesse segundo caso, o capital local é transferido para o exterior, e retorna sob a forma de "investimento estrangeiro".

132 Sobre o assunto ver: CHESNAIS, François. Finance Capital Today: Corporations and Banks in the Lasting Global Slump. Boston: Brill, 2016. Pg. 153. 


\begin{tabular}{|c|c|c|c|c|c|c|}
\hline \multicolumn{6}{|c|}{ Tabela 4.7b (cont.): Conta “Investimento Direto" da “Conta Financeira” do Balanço de Pagamentos, 1999 a 2013.} \\
Valores em bilhões de reais de 2006 \\
\hline
\end{tabular}

A tabela 4.7b, acima, é a continuação da tabela 4.7a. A variável (2) da tabela 4.7b é a variável (2) da tabela 4.7a. A variável (3) é o saldo do investimento estrangeiro direto no Brasil. A variável (4) é a entrada de investimento estrangeiro direto, e a variável (5) a saída de IED. A variável (6) é o saldo do IED na forma de aquisição de participação de capital. A variável (7) é o saldo dos empréstimos feitos entre empresas estrangeiras no exterior e empresas estrangeiras localizadas no Brasil.

Observa-se que o investimento estrangeiro direto no Brasil apresentou tendência cadente de 1999 a 2006. A partir de então, voltou a crescer. Entre os anos de 2008 e 2011, houve maior venda de participação de capital estrangeiro nas empresas localizadas no Brasil. Isso foi fruto (a) da crise econômica internacional, de 2008; e (b) excedente econômico no Brasil, fruto do boom nos preços das commodities.

Desde 2007, houve aumento dos empréstimos realizados entre empresas estrangeiras e 
empresas estrangeiras localizadas no Brasil. Isso foi fruto da busca do oligopólio internacional em aumentar sua entrada no mercado brasileiro, sem precisar assumir novos compromissos de longo prazo.

\subsection{FLUXO DE INVESTIMENTO E O ESTOQUE DA DÍVIDA}

A análise do investimento estrangeiro direto no Brasil permite detectar o caráter da recuperação recente da economia brasileira. Tratou-se de uma recuperação pautada pela alta da demanda de bens primários, que permitiu ganhos temporários para o Brasil. O modelo já havia sido descrito por Prebisch, e não é coisa nova. Os ganhos pontuais foram utilizados para aumentar o consumo local, inclusive com alta nas importações. Mas também serviram para fortalecer o sentido oligopolista da economia brasileira.

A recuperação da economia do país não foi apenas boa para seus residentes. Investidores estrangeiros puderam ganhar muito com o crescimento econômico local. Embora tenha se esboçado a formação de multinacionais brasileiras, o ciclo expansivo das mesmas durou pouco. Tão logo os preços das commodities caiu, o ciclo se encerrou, em especial a partir de 2014. Deve-se destacar que o encerramento do ciclo também levou à queda dos preços das ações das empresas locais (em especial as empresas já desnacionalizadas). Durante períodos de crise econômica, conforme destacado por Hilferding, há tendência de concentração de capital ${ }^{133}$.

Assim como a política anterior, de endividamento para financiamento do crescimento $^{134}$, a política de investimento estrangeiro também levou a ampliação estrutural do déficit. Isso porque os gastos causados pelos investimentos estrangeiros só tendem a crescer. Enquanto isso, a quantidade de ativos que podem ser vendidos ao exterior é finita, o que causa quedas esporádicas no investimento estrangeiro.

133 Sobre o assunto, ver: HILFERDING, Rudolf. O Capital Financeiro. São Paulo: Nova Cultura, 1985. Pg. 272.

134 Para um estudo sobre a política de endividamento e impacto dela na economia brasileira, ver: BARBOSA, Wilson do Nascimento. Políticas Econômicas do Governo e Estagnação: Duas Décadas Perdidas (19812000). DH - FFLCH - USP, 2004. 


\section{Gráfico 4.5: Entrada e saída de capital pelo investimento estrangeiro direto, 1999 a 2013}

(em bilhões de reais de 2006)

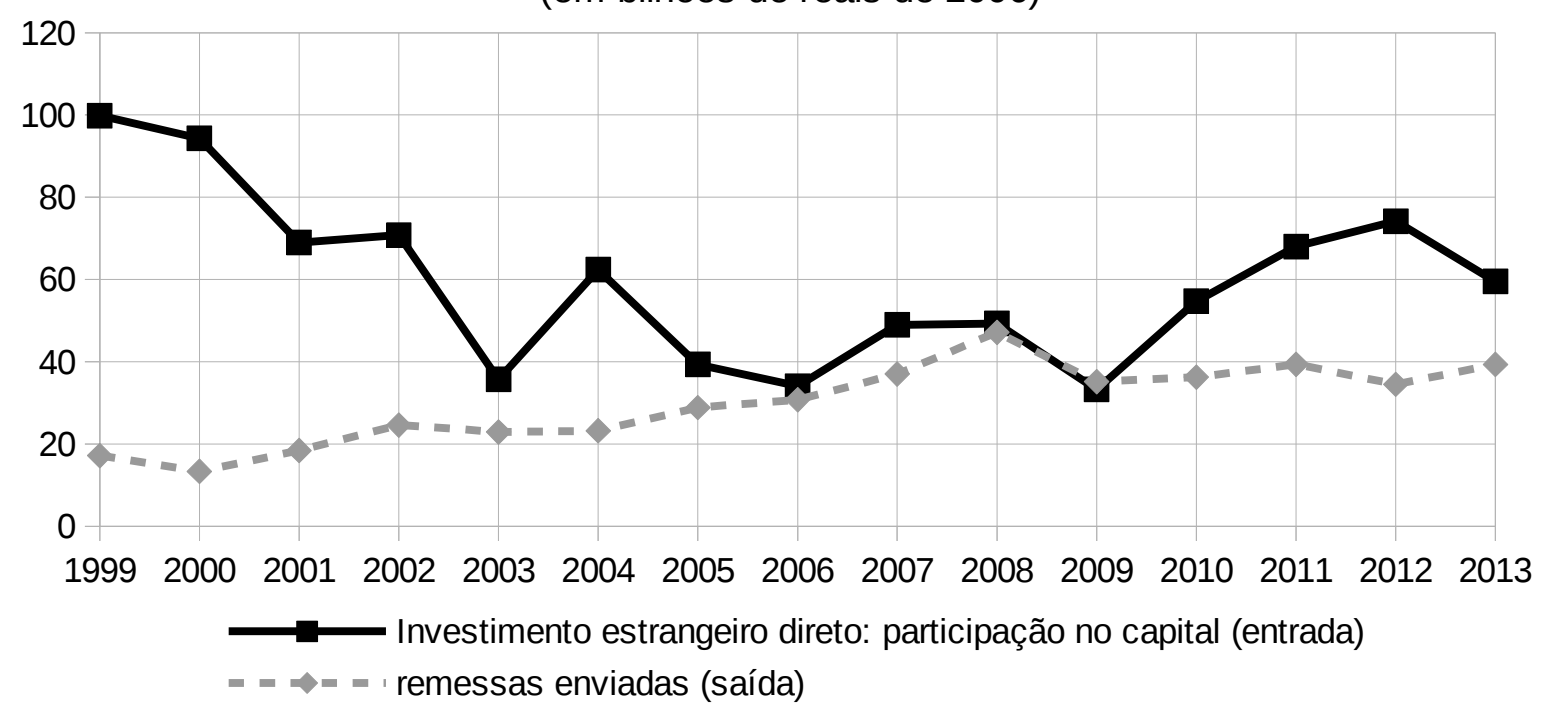

O gráfico 4.5 traz a representação da entrada de investimento estrangeiro direto em participação de capital, em bilhões de reais de 2006; e o envio de remessas de lucro, em bilhões de reais de 2006. O que se observa é que a partir de 2005, o investimento estrangeiro em participação de capital passou a se aproximar do valor enviado para o exterior na forma de remessas de lucro. Isso significa que o Brasil ganhou, naquele momento, pouca ou quase nenhuma divisa com os novos investimentos.

Só a partir de 2010 os investimentos estrangeiros voltaram a atingir valores bastante acima do envio das remessas. Nesse período, as transações correntes do Brasil já apresentavam déficit pesado. Naquele ano, as transações correntes atingiram cerca de 60 bilhões de Reais correntes negativos. A entrada de investimento estrangeiro em conta de capital foi de pouco menos de 55 bilhões de Reais constantes de 2006. A entrada de investimento foi uma resposta a (i) permanência da alta demanda por exportados brasileiros (bens primários); e (ii) demanda brasileira por capital externo.

Caso se some as perdas com remessas de lucro ao exterior, ao saldo dos pagamentos de royalties e pagamentos de empréstimos de equipamento, as perdas geradas pela dependência brasileira do investimento estrangeiro ultrapassaram, em 2010, o valor de 56 bilhões reais constantes de 2006. Ou seja, as perdas causadas pela atividade das firmas multinacionais ultrapassaram os investimentos realizados por elas. 


\begin{tabular}{|c|c|c|c|}
\hline \multicolumn{4}{|c|}{ Tabela 4.8: Dívida externa e pública, valores em bilhões de reais de 2006 } \\
\hline $\mathbf{( 1 )}$ & $\mathbf{( 2 )}$ & $\mathbf{( 3 )}$ & $\mathbf{( 4 )}$ \\
\hline Ano & Dívida pública líquida & Dívida externa & Dívida pública interna \\
\hline 1999 & 923,97 & 803,86 & 760,09 \\
\hline 2000 & 948,67 & 741,93 & 816,07 \\
\hline 2001 & $1.047,22$ & 830,98 & 853,74 \\
\hline 2002 & $1.247,73$ & 941,60 & 923,67 \\
\hline 2003 & $1.146,09$ & 901,18 & 912,82 \\
\hline 2004 & $1.118,13$ & 739,43 & 943,75 \\
\hline 2005 & $1.104,01$ & 491,24 & $1.031,93$ \\
\hline 2006 & $1.120,05$ & 441,22 & $1.147,87$ \\
\hline 2007 & $1.144,58$ & 451,73 & $1.331,94$ \\
\hline 2008 & $1.018,61$ & 430,82 & $1.308,48$ \\
\hline 2009 & $1.108,48$ & 463,80 & $1.346,44$ \\
\hline 2010 & $1.109,20$ & 479,74 & $1.379,54$ \\
\hline 2011 & $1.059,92$ & 501,54 & $1.438,25$ \\
\hline 2012 & $1.037,93$ & 618,33 & $1.452,70$ \\
\hline 2013 & $1.011,89$ & 689,86 & $1.456,55$ \\
\hline \multicolumn{3}{|c|}{} \\
\hline
\end{tabular}

A tabela 4.8 traz a dívida pública líquida (variável 2), que é a dívida bruta menos a reserva de divisas do país, a dívida externa brasileira (variável 3), e a dívida interna brasileira (variável 4), todas em bilhões de reais constantes de 2006. A Dívida Líquida é contabilizada considerando o saldo entre haveres e deveres. A dívida externa é apenas o que o Brasil deve ao estrangeiro (deveres), e a dívida interna contém apenas aquilo que o setor público deve internamente. Durante o período de recuperação econômica do Brasil, iniciados em 2002, foi adotada a estratégia de redução da dívida externa. Tratava-se da busca por diminuição da fragilidade externa da economia nacional. Isso se expressa na redução da dívida externa brasileira para menos da metade, entre 2002 e 2008. A partir daí, a demanda por capital no país pressionou para que o endividamento externo voltasse a crescer. Em 2010, a dívida externa voltou a aumentar aceleradamente.

Segundo autores de textos da época, como Luiz Filgueiras ${ }^{135}$, ocorria, desde 2003, uma política de internalização da dívida brasileira. Essa internalização se expressa pelo aumento nominal da dívida pública brasileira. No entanto, quando analisado em valores reais, observase constância no estoque da dívida pública líquida, com tendência de queda, desde 2002. Ainda, desde 2003, ocorreu aumento do estoque da dívida pública interna brasileira. Observando o comportamento da dívida pública, pode-se apontar que (a) o comércio exterior brasileiro, em seu ciclo de alta, gerou oferta de capital para o mercado local; e (b) o governo 135 FILGUEIRAS, Luiz \& GONÇALVES, Reinaldo. A Economia Política do Governo Lula. Rio de Janeiro: Contraponto, 2007. 
pode operar sem precisar realizar expansão de sua dívida líquida e mesmo diminuir a dívida externa.

Esse movimento aparentava ser sadio para a economia brasileira. Mas só foi possível devido à baixa taxa de investimento local. Na prática, esgotado o ciclo de alta das exportações brasileiras, na ausência de capital interno previamente investido, a demanda pelo capital internacional voltou. Dada a visão negativa da população brasileira sobre o endividamento, essa demanda precisou ser suprida pelo incentivo ao investimento estrangeiro direto.

\subsection{INVESTIMENTO E FORMAÇÃO BRUTA DE CAPITAL FIXO}

Em um país dependente, a economia local costuma ter pouco capital disponível. Daí a necessidade de recorrer a mecanismos para suprir essa demanda. Os dados já levantados nesse capítulo permite abordar alguns desses mecanismos. O primeiro é (a) atração de investimento estrangeiro; o segundo é (b) endividamento externo; e o terceiro é (c) incentivo estatal, financiado pelo sistema tributário e endividamento público.

Durante as décadas de (19)80 e (19)90, o Brasil destruiu a capacidade estatal de investir. Desmantelou estatais, e adotou a regra de superavit primário ${ }^{136}$, que estabelece que o governo não pode gastar mais do que ganha. Na prática, houve estrangulamento da capacidade pública de investir ${ }^{137}$. A desculpa dada para sustentar as reformas era que o déficit das contas do governo levavam a pressões inflacionárias e diminuíam a capacidade do governo de atuar na economia. No entanto, como ressaltou Geraldo Biasoto Jr.:

O superávit primário recorde do primeiro trimestre de 2003 foi insuficiente para pagar dois terços dos juros nominais, situando-se em 2,03\% do PIB, contra 3,19 do PIB dos custos financeiros. Ao mesmo tempo, a dívida líquida experimentou contração de 3,92\% do PIB. Retirados os efeitos da variação do PIB, os fatores que condicionaram essa evolução foram basicamente os ajuste dos saldos externos. A variação da dívida interna, derivada das posições em moeda estrangeira, foi de $1,42 \%$ do PIB. Ao mesmo tempo ajuste da dívida

136 Esta regra foi imposta pelo FMI ao governo FHC, como contraparte para o empréstimo de 60 bilhões, para desafogar o país na crise de 1998. Ela prejudica o interesse nacional. Ver a propósito OLIVEIRA, Fabricio Augusto de. “A Lógica das Reformas: A Evolução do Sistema Tributário (1966-2002)”. In: ALVES PINTO, Marcio Percival \& BIASOTO JR, Geraldo. (orgs) Politica Fiscal e Desenvolvimento no Brasil. Campinas: Editora Unicamp, 2006.

137 Para uma discussão sobre o assunto, ver: CASAGRANDE, Elton Eustaquio \& GARCIA, Renato Vaz. Fiscal policy contradiction: a perspective on Brazil and Mexico. Investigación Económica, Vol. 70, No. 277 (julio-septiembre de 2011), pg. 127 - 152 
externa pública foi de 2,58\% do PIB. Vale dizer que todo o draconiano esforço da política fiscal não serviu nem para dar conta de juros internos, mas a variação cambial foi capaz de produzir uma expressiva retração da dívida líquida do setor público. ${ }^{138}$

As reformas fiscais foram, portanto, pensadas para agradar o mercado financeiro, mas atrapalham o desenvolvimento local. Sintomaticamente, desde o final da década de (19)80, o investimento público em bens de capital não é mais uma variável analisada e disponibilizada em isolado no sistema de contas do IBGE. Não houve, em todo período analisado, esforço do governo de atuar diretamente na formação bruta de capital fixo. Deixou-se a hipótese de um projeto para o investimento nas mãos da iniciativa privada.

Tabela 4.9: Regressões lineares com formação bruta de capital fixo como variável dependente, 2003 a 2013.

\begin{tabular}{|c|c|c|c|c|c|c|c|c|c|}
\hline (1) & (2) & (3) & (4) & (5) & (6) & (7) & (8) & (9) & (10) \\
\hline Regressão & $\begin{array}{c}\text { Primeira } \\
\text { variável } \\
\text { independente }\end{array}$ & $\begin{array}{c}\text { Segunda } \\
\text { variável } \\
\text { independente }\end{array}$ & $\begin{array}{c}\text { Coeficiente } \\
\text { A } \\
\text { (constante) }\end{array}$ & $\begin{array}{c}\text { Coeficiente B } \\
\text { (primeira } \\
\text { independente) }\end{array}$ & $\begin{array}{c}\text { Coeficiente C } \\
\text { (segunda } \\
\text { independente) }\end{array}$ & $\begin{array}{c}\text { Erro } \\
\text { Padrão de } \\
\text { B }\end{array}$ & $\begin{array}{c}\text { Erro } \\
\text { Padrão de } \\
\text { C }\end{array}$ & $\mathbf{R}^{2}$ & DW \\
\hline $\begin{array}{l}(4.1) \\
\text { FBCFr }=\mathrm{a} \\
+\mathrm{IEDr}\end{array}$ & $\begin{array}{l}\text { Investimento } \\
\text { estrangeiro } \\
\text { direto } \\
\end{array}$ & - & 214,32 & 4,66 & - & 1,02 & - & 0,73 & 1,33 \\
\hline $\begin{array}{l}(4.2) \\
\text { FBCFr = a } \\
+ \text { DvEr }\end{array}$ & Dívida externa & - & 611,68 & $(0,18)$ & - & 0,25 & - & 0,04 & 0,15 \\
\hline $\begin{array}{l}(4.3) \\
\text { FBCFr }=\mathrm{a} \\
+ \text { DvIr }\end{array}$ & Dívida interna & - & $(164,64)$ & 0,54 & - & 0,07 & - & 0,85 & 0,87 \\
\hline
\end{tabular}

Nota 1: Valores negativos entre parênteses

Nota 2: coluna (9) representa o $\mathrm{R}^{2}$, que é o quadrado da correlação.

Nota 3: coluna (10) representa o Durbin-Watson.

A tabela 4.9 traz resultados de algumas regressões lineares usadas para calcular o impacto das oscilações do investimento estrangeiro direto, da dívida pública, e da dívida externa, sobre as oscilações da formação bruta de capital fixo real (FBCF), entre 2003 e 2013. Na primeira coluna da tabela, está assinalado o número da regressão. Na segunda coluna, está o nome da variável independente da regressão. Na terceira, está o nome da segunda variável independente, quando usada. Na quarta, está o coeficiente “a”, que representa a constante

138 BIASOTO JR., Geraldo. “A Polêmica sobre o Déficit Público e a Sustentabilidade da Política Fiscal”. In: ALVES PINTO, Marcio Percival \& BIASOTO JR, Geraldo. (orgs) Politica Fiscal e Desenvolvimento no Brasil. Campinas: Editora Unicamp, 2006. pg. 419. 
encontrada na regressão. Na quinta, verifica-se o coeficiente “b”, que é a medida do impacto da variável independente sobre a dependente. No caso, lê-se que para cada um real aumentado na variável independente, aumentou-se valor igual ao coeficiente "b” na formação bruta de capital fixo. A sexta coluna traz o coeficiente “c”, que é referente à segunda variável dependente. A coluna 7 e 8 contém os valores dos erros padrões. Tem-se que valores de erro padrão superiores à metade do coeficiente a qual diz respeito significa que a variável dependente não é significativa. A nona coluna traz o R-quadrado da regressão, que é uma medida do poder explicativo dela. A décima coluna assinala o Durbin-Watson, que é uma medida de confiabilidade da regressão. Caso o Durbin-Watson seja inferior ao R-quadrado diz-se que a regressão é espúria.

O que se vê com a tabela 4.9 é que a dívida externa foi capaz de explica apenas em 4\% as oscilações na formação bruta de capital fixo (regressão 4.2). Isso é consequência da política de redução do endividamento externo, que fez com que as duas variáveis tomassem caminhos diferentes. Também se verifica que o investimento estrangeiro direto influenciou bastante a formação bruta de capital fixo: 73\% das oscilações do FBCF podem ser explicados pelas oscilações no IED real, conforme regressão 4.1. A variável que foi mais capaz de explicar a formação bruta de capital fixo foi o endividamento interno (regressão 4.3). Cerca de 85\% das oscilações do FBCF puderam ser explicados pelas oscilações na dívida pública.

Optou-se por produzir um modelo para verificar se o investimento estrangeiro e a dívida externa explicariam, juntas, uma parcela maior das oscilações do FBCF. Buscou-se com isso tentar assinalar o impacto das oscilações de oferta de capital externo para a formação de capital fixo brasileiro. Conforme pode-se ver nos resultados da regressão 4.4, não houve ganho significativo de poder explicativo.

Uma leitura que se pode fazer da análise das regressões 4.1 à 4.4, é: diante da baixa capacidade de poupança interna local, havia duas alternativas para o financiamento dos novos investimentos: (a) atrair investimento estrangeiro, dependendo, portanto, da poupança externa; ou (b) recorrer ao governo, que ainda podia financiar a iniciativa privada através de programas de subsídio ao investimento (como a oferta de crédito via BNDES). 


\section{Gráfico 4.6: Formação bruta de capital fixo explicado pelo investimento estrangeiro direto, 1999 a 2013}

(bilhões de reais de 2006)

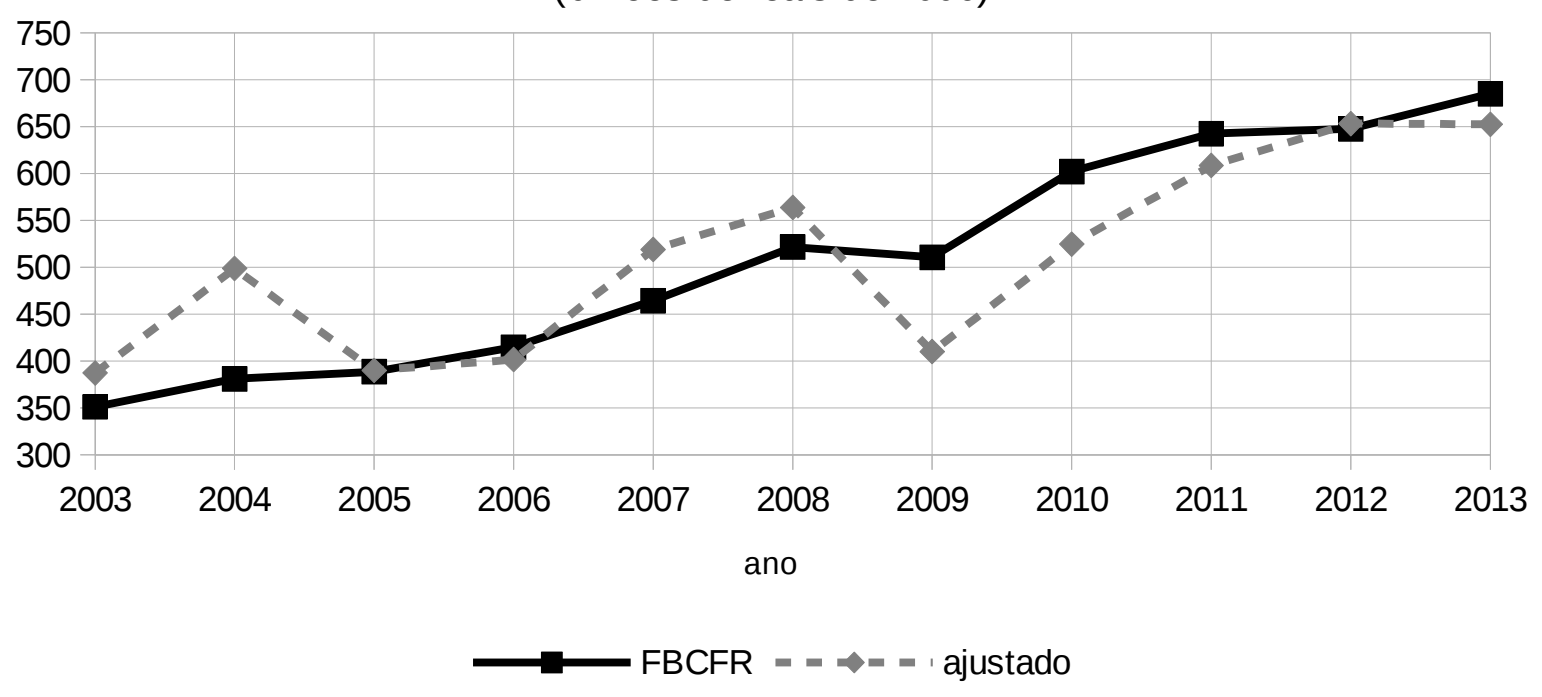

O gráfico 4.6 traz os valores da formação bruta de capital fixo do Brasil (FBCFR), em bilhões de reais constantes, e do valor esperado (ajustado) para ela de acordo com as oscilações no investimento estrangeiro direto. Entre 2003 e 2008, a formação bruta de capital fixo esteve aquém do esperado dado o grau de investimento estrangeiro direto, com exceção dos anos de 2005 e 2006. A partir de 2009, o FBCFR passou a crescer mais do que o esperado mediante o investimento estrangeiro.

É significativo que, caso a economia brasileira fosse mais sensível ao investimento estrangeiro, com a crise de 2009 o país teria experimentado uma crise maior no investimento de sua economia real. A afirmação que, entre 2003 e 2013, o Brasil ganhou maior resiliência tem base empírica. No entanto, é importante saber que a resistência tinha base nas exportações, conforme já apontado em capítulos anteriores. Na prática, a novidade observada para o período entre 1999 e 2013, em relação ao período anterior (década de 1990), foi apenas a chamada internalização da dívida pública. Ou seja, como parte da estratégia de diminuição da fragilidade externa, apostou-se em (a) substituir o endividamento pelo investimento estrangeiro como principal ferramenta de poupança externa; e (b) pagamento da dívida externa em parte financiado por um endividamento interno.

O problema essencial do período exterior, portanto, não foi superado. O uso do câmbio como ferramenta de controle inflacionário apenas permitia crescimento em períodos de alta disponibilidade de capital externo. Parte da crise do final da década de (19)90, e início 
daquela de 2000, se explica, portanto, pelo crescente déficit nas transações correntes ${ }^{139}$. A recuperação parcial da economia brasileira, observada a partir de 2003, esteve fundada na (i) solução temporária do déficit no balanço comercial, resultante da alta da demanda por produtos primários; e (ii) oferta de poupança externa (agora sob a forma de investimento estrangeiro), que acompanhou o aumento da expectativa de lucro das empresas brasileiras, em especial aquelas ligadas ao setor exportador-importador.

\section{Gráfico 4.7: Formação bruta de capital fixo real explicado pela dívida externa real, 2003 a 2013}

(em bilhões de reais de 2006)
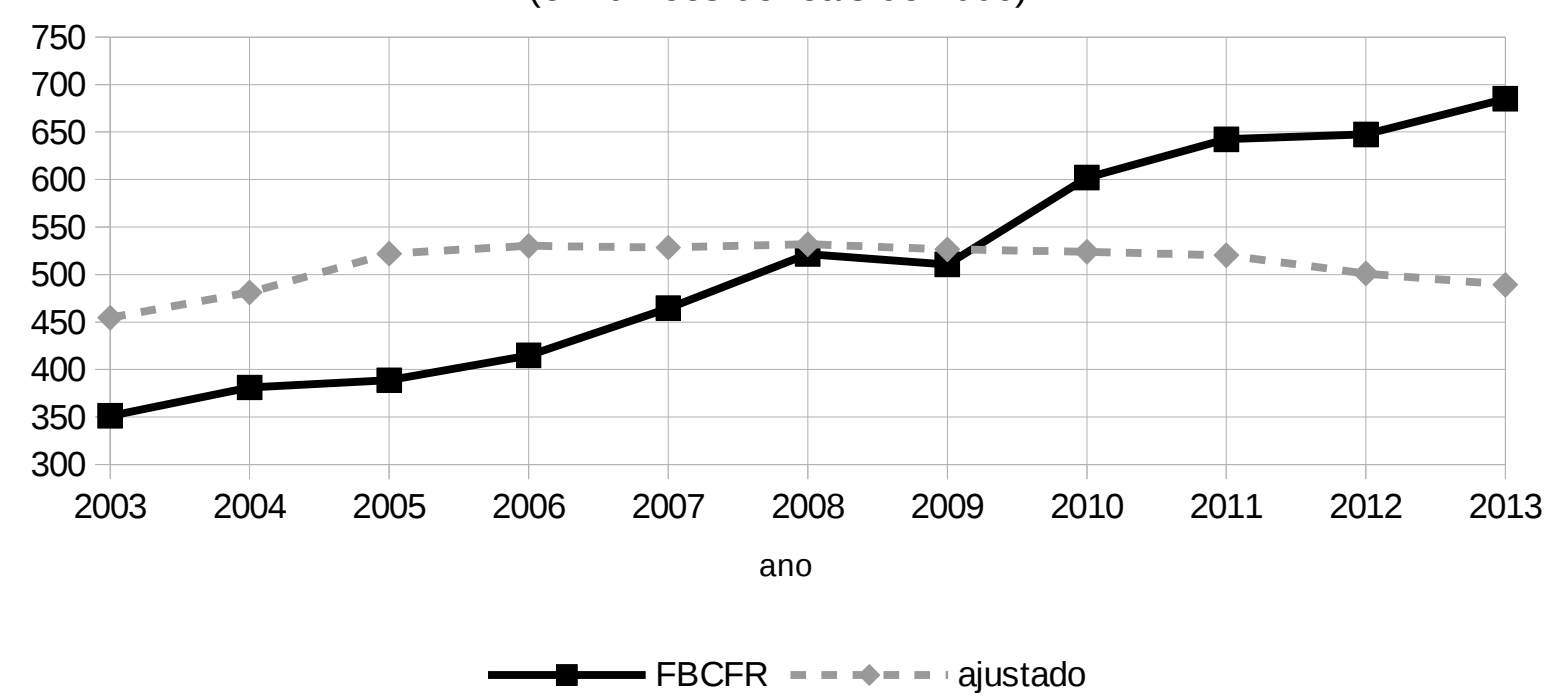

O gráfico 4.7 traz a representação dos valores da formação bruta de capital fixo real, e dos valores esperados mediante as oscilações no estoque da dívida externa brasileira. O gráfico permite notar que de 2003 a 2009, a trajetória das duas variáveis foram bastante distintas. Mas, a partir de 2010, com o aumento do endividamento, houve afastamento das oscilações. Isso significa que enquanto o saldo do comércio exterior impulsionou a economia brasileira, a hipótese do endividamento externo para investimento em capital fixo pode ser afastada.

Esse comportamento descreve algo esperado para um país dependente, conforme a teoria de Prebisch. Em momento de alta econômica pode-se pagar as dívidas e expandir o consumo. Caso o excedente não tenha sido usado para preparar a economia para o ciclo

139 Sobre o assunto, ver: FRITZ, Barbara. Tentativas de estabilização e crescimento por via da divida externa: a economia brasileira de quatro décadas. Iberoamericana (2001-), Nueva época, Año 4, No. 14 (Junio de 2004), pg. 127-142 
seguinte, a alta anterior de importações e novo nível da demanda interna levam à pressão para o endividamento externo.

\section{Gráfico 4.8: Formação bruta de capital fixo real explicado pela dívida pública interna real, 2003 a 2013}

(bilhões de reais de 2006)

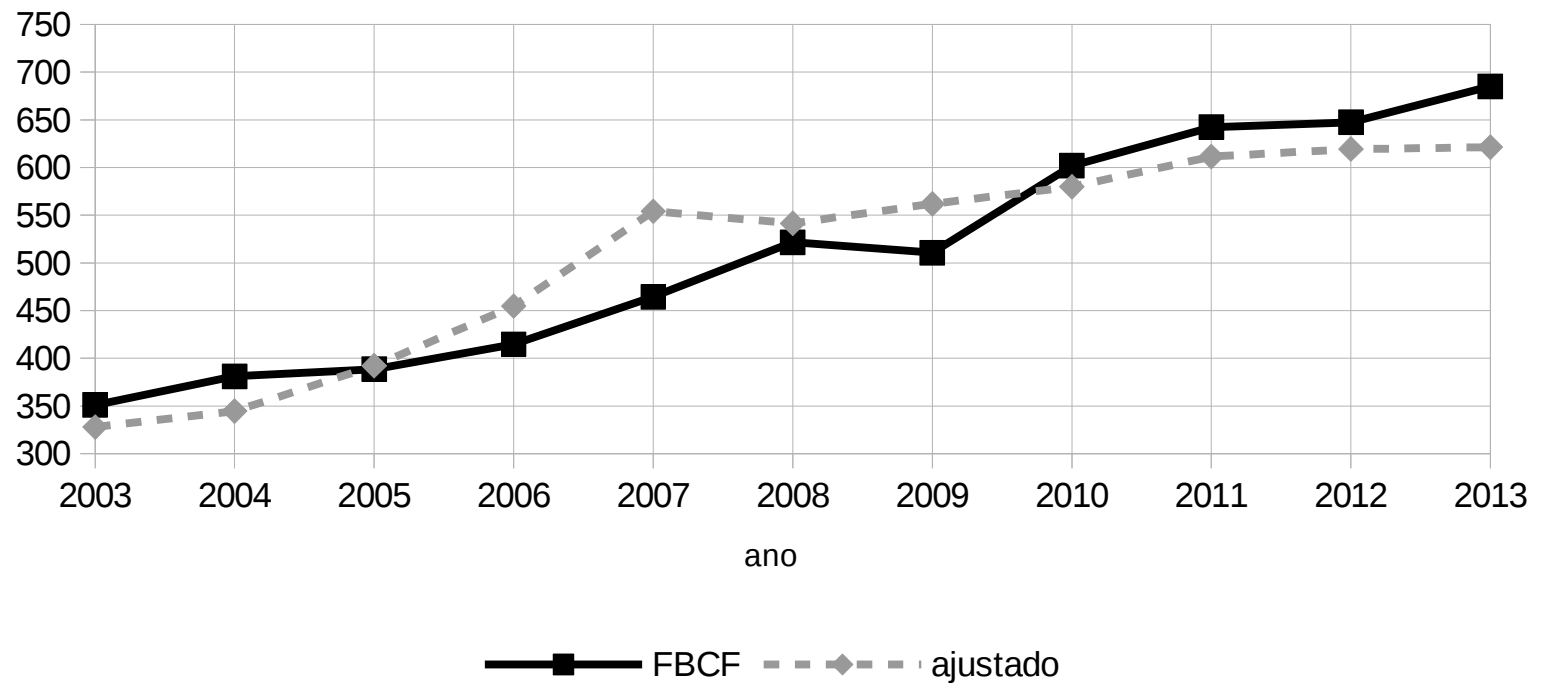

O gráfico 4.8 contém a representação dos valores da formação bruta de capital fixo real e dos valores esperados para FBCF, dado os valores da dívida pública líquida real. Observa-se quase coincidência entre os valores observados e os esperados. Em 2008, ano da crise econômica internacional, houve quase coincidência entre os dois valores. Isso foi resultado de uma contração maior no endividamento público, e pelo fato da crise só ter impactado na formação bruta de capital, no Brasil, em 2009.

No Brasil, entre 2003 e 2013, os investimentos privados continuaram a ser bastante influenciados pelos projetos do governo, e pela disponibilidade de incentivos governamentais. Esses, por sua vez, eram parcialmente fundados no endividamento do Estado. O endividamento público é, também, uma forma de transferência de renda do Estado para o setor privado que o financia. As taxas de juros remuneradas aos portadores de títulos da dívida pública gera uma sangria na capacidade de investimento público.

A tabela 4.10 traz os resultados de regressões de modelo log-log (logarítmicas), que expressam a relação entre a formação bruta de capital fixo real e variáveis dependentes, afim de revelar a elasticidade média da FBCF em relação às demais variáveis. Na primeira coluna, está o número da regressão. Na segunda coluna, está assinalada a variável independente em 
análise. Na terceira coluna, verifica-se a elasticidade da FBCF em relação à variável independente. Lê-se que para cada 1\% a mais na variável independente, a formação bruta de capital fixo real aumentou em porcentagem igual à elasticidade assinalada. Na quarta coluna, está o erro padrão da elasticidade. Erro padrão superior à metade da elasticidade assinala que o valor encontrado para ela não é significativo. Na quinta coluna está o R-quadrado, e na sexta o Durbin-Watson para as regressões correspondentes.

\begin{tabular}{|c|c|c|c|c|c|}
\hline (1) & (2) & (3) & (4) & (5) & (6) \\
\hline Regressão & Variável independente & Elasticidade & Erro padrão & $\mathbf{R}^{2}$ & DW \\
\hline $\begin{array}{c}(4.5) \\
\log \mathrm{FBCFr}=\mathrm{a}+\log \text { IEDr }\end{array}$ & Investimento estrangeiro direto & 0,59 & 0,13 & 0,68 & 1,32 \\
\hline $\begin{array}{c}(4.6) \\
\log \mathrm{FBCFr}=\mathrm{a}+\log \mathrm{DvEr}\end{array}$ & Dívida externa & $(0,22)$ & 0,31 & 0,05 & 0,14 \\
\hline $\begin{array}{c}(4.7) \\
\log \mathrm{FBCFr}=\mathrm{a}+\log \text { DvIr }\end{array}$ & Dívida interna & 1,27 & 0,16 & 0,87 & 0,90 \\
\hline \multicolumn{6}{|c|}{ Nota 1: coluna (2) representa a elasticidade encontrada em modelo log-log. } \\
\hline Nota 2: coluna (4) representa & o R², que é o quadrado da correla & ão, encontrad & m modelo lc & & \\
\hline
\end{tabular}

O que se verifica é que a formação bruta de capital fixo foi inelástica em relação ao investimento estrangeiro direto (elasticidade 0,59), e elástica em relação à dívida interna (elasticidade 1,27). O poder explicativo de ambas as regressões (regressão 5 e 7, respectivamente) foram relevantes. No entanto, a regressão 6, que é o modelo log-log com a FBCF como variável dependente e a dívida externa como independente, revelou uma relação não significativa entre as duas. Ou seja, se confirma que, graças à política de redução da dívida externa, o caminho tomado entre as duas variáveis foi consideravelmente distinto.

Isso significa dizer que, apesar da dependência brasileira da poupança externa, os investimentos brasileiros continuam a ser mais guiados pelos incentivos do governo, financiados em parte pelo endividamento público. Ao abrir mão de parte da capacidade estatal de investir e movimentar a economia, em prol de aumento da confiança de investidores estrangeiros, o Brasil se afastou da possibilidade de construir uma sociedade industrial. Apesar da recuperação econômica da época, a desindustrialização ocorrida nas décadas anteriores é um mal estrutural. Não foi e não podia ser resolvido apenas pela alta dos preços dos bens primários exportados pelo Brasil. Tão pouco poderia ser resolvido exclusivamente por investimento estrangeiro no país. 


\subsection{POSIÇÃO DA CAPACIDADE DE IMPORTAR}

O Brasil experimentou oportunidade de recuperar sua economia. No entanto, como país dependente, enfrentou características estruturais que o jogaram de volta para a estagnação econômica, passado o período de alta do comércio exterior. Trata-se de comportamento perfeitamente esperado e explicado pela teoria estruturalista. Na ausência de um esforço ativo pela industrialização e desenvolvimento local, o comportamento da economia brasileira só podia se comportar de acordo com os estímulos cíclicos. Conforme John Smith, parte das economias dependentes se beneficiara, nos anos 2000, de um ciclo ascendente dos preços das commodities:

Os primeiros anos do novo milênio também viram o início do "super ciclo" de commodities, uma década de preços mundiais crescentes de petróleo e de metais, alimentos e outras commodities primárias, revertendo parcialmente sua longa tendência descendente. $\mathrm{O}$ superciclo foi impulsionado pela insaciável demanda chinesa de matérias-primas e foi prolongado por vários anos além da crise de 2007-2008 por esforços de seus líderes para resgatar a economia chinesa de seus mandíbulas - um enorme programa de investimento em infra-estrutura financiado por endividamento, equivalente a 34\% do PIB, fez a China usar mais concreto em 2011 e 2012 do que os Estados Unidos em todo o século XX (Swanson 2016). ${ }^{140}$

O setor externo da economia brasileira, entre 1999 e 2013, foi marcado pela alta da demanda por bens primários, iniciada em 2002 e encerrada em 2012, fruto, em grande parte, desse crescimento da demanda chinesa. Durante o período, observou-se o crescimento inicial, o auge, e o esgotamento do dinamismo no Brasil. Isso fica ainda mais claro quando se analisa o setor externo a partir da teoria do poder de compra das exportações.

Na tabela 4.11, verifica-se o poder de compra das exportações brasileiras, em bilhões de reais de 2006. A variável (2) é o valor total das importações, e a (3) das exportações. A variável (4) é o termo de troca, resultante da divisão da variável (2) pela (3). A variável (5) é o termo de troca assinalado na forma de índice, com base em 2006. A variável (6) é o poder de compra das exportações, que resulta da multiplicação do valor real das exportações pelo termo de troca. A variável (7) é a variação no termo de troca, resultante da subtração do valor total das exportação do poder de compra das exportações.

140 SMITH, John. The Global South in the Global Crisis. Jornal of Labor and Society, 2017. Pg. 16 - 17 


\begin{tabular}{|c|c|c|c|c|c|c|}
\hline \multicolumn{7}{|c|}{ Tabela 4.11: Poder de compra das exportações, em bilhões de reais de 2006, 1999 a 2013} \\
\hline (1) & (2) & (3) & (4) & (5) & (6) & (7) \\
\hline Ano & $\begin{array}{c}\text { Importação } \\
\text { total }\end{array}$ & $\begin{array}{c}\text { Exportação } \\
\text { total }\end{array}$ & $\begin{array}{c}\text { Termos de } \\
\text { trocas }\end{array}$ & $\begin{array}{c}\text { Termos de trocas } \\
\quad(2006=1)\end{array}$ & $\begin{array}{c}\text { Poder de compra das } \\
\text { exportações }\end{array}$ & $\begin{array}{c}\text { Variações no } \\
\text { termo de troca }\end{array}$ \\
\hline & & & $\begin{array}{l}(4)=((3) / \\
(2)) * 100\end{array}$ & $\begin{array}{l}(5)=(4) / 150 ; \\
(2006=100)\end{array}$ & $(6)=((3) *(5)) / 100$ & $(7)=(6)-(3)$ \\
\hline 1999 & 163,82 & 159,83 & 098 & 64,86 & 103,67 & $(56,16)$ \\
\hline 2000 & 175,25 & 173,06 & 099 & 65,65 & 113,62 & $(59,44)$ \\
\hline 2001 & 204,30 & 214,02 & 105 & 69,64 & 149,05 & $(64,97)$ \\
\hline \begin{tabular}{|l|}
2002 \\
\end{tabular} & 195,33 & 249,62 & 128 & 84,97 & 212,10 & $(37,53)$ \\
\hline 2003 & 184,74 & 279,77 & 151 & 100,68 & 281,68 & 1,91 \\
\hline 2004 & 210,84 & 323,99 & 154 & 102,16 & 331,00 & 7,01 \\
\hline 2005 & 192,20 & 309,16 & 161 & 106,94 & 330,62 & 21,46 \\
\hline 2006 & 202,26 & 304,22 & 150 & 100,00 & 304,22 & - \\
\hline 2007 & 226,56 & 301,75 & 133 & 88,55 & 267,19 & $(34,56)$ \\
\hline 2008 & 283,81 & 324,36 & 114 & 75,98 & 246,46 & $(77,90)$ \\
\hline 2009 & 213,29 & 255,65 & 120 & 79,69 & 203,72 & $(51,93)$ \\
\hline \begin{tabular}{|l|}
2010 \\
\end{tabular} & 247,61 & 275,24 & 111 & 73,90 & 203,40 & $(71,83)$ \\
\hline 2011 & 280,78 & 317,76 & 113 & 75,24 & 239,09 & $(78,68)$ \\
\hline 2012 & 313,16 & 340,43 & 109 & 72,27 & 246,04 & $(94,39)$ \\
\hline 2013 & 342,41 & 346,06 & 101 & 67,19 & 232,53 & $(113,53)$ \\
\hline
\end{tabular}

Observa-se claramente que, de 1999 a 2005, houve tendência de melhoria no termo de troca. A partir daí, observou-se acelerada deterioração nos termos de troca do Brasil. Isso significa que a alta dos preços das commodities permitiu expansão das exportações acima da velocidade de expansão das importações. Em 2006, o cenário se inverteu. Esse crescimento das importações além das exportações permitiu uma taxa de crescimento do PIB maior. No entanto, teve como contrapartida a maior dependência da poupança externa. No caso, essa poupança externa foi adquirida através da venda de ativos.

Parte dos investidores estavam fugindo das baixas taxas de lucro observadas na Europa e nos EUA. Esses investimentos se dirigiram tanto aos setores diretamente ligados as exportações como aos setores de serviços. A área de telecomunicações, de comércio, de educação, entre outras, eram terreno fértil para que investidores estrangeiros realizassem taxas de lucro bastante acima das observadas nos setores similares de suas próprias economias ${ }^{141}$. Na prática, parte do aumento das importações era financiado por investimentos em setores de serviço de baixa produtividade.

141 Para uma discussão sobre a relação entre as privatizações nos setores de serviço e a ampliação das taxas de lucro de grandes investidores, ver: HARVEY, David. The New Imperialism. Oxford: Oxford University Press, 2003. 


\begin{tabular}{|c|c|c|c|c|c|c|c|}
\hline \multicolumn{8}{|c|}{ Tabela 4.12: Posição da capacidade de importação em bilhões de reais de 2006, 1999 a 2013} \\
\hline (1) & (2) & (3) & (4) & (5) & (6) & (7) & (8) \\
\hline ano & $\begin{array}{c}\text { Poder de } \\
\text { compra das } \\
\text { exportações }\end{array}$ & $\begin{array}{c}\text { Recebimento de } \\
\text { remessas }\end{array}$ & $\begin{array}{c}\text { Capacidade } \\
\text { domestica de } \\
\text { pagamento no } \\
\text { exterior }\end{array}$ & $\begin{array}{c}\text { Envio de } \\
\text { remessas } \\
\text { (incluso } \\
\text { amortização de } \\
\text { dividas) }\end{array}$ & $\begin{array}{c}\text { Capacidade } \\
\text { doméstica de } \\
\text { importar }\end{array}$ & $\begin{array}{c}\text { Valor das } \\
\text { importações }\end{array}$ & $\begin{array}{l}\text { Posição da } \\
\text { capacidade de } \\
\text { importação }\end{array}$ \\
\hline & & & $(4)=(2)+(3)$ & & $(6)=(4)-(5)$ & & $(8)=(6)-(7)$ \\
\hline 1999 & 103,67 & 13,10 & 116,77 & $(103,00)$ & 13,77 & 163,82 & $(150,05)$ \\
\hline 2000 & 113,62 & 11,38 & 124,99 & $(85,36)$ & 39,64 & 175,25 & $(135,62)$ \\
\hline 2001 & 149,05 & 12,05 & 161,10 & $(94,97)$ & 66,14 & 204,30 & $(138,17)$ \\
\hline 2002 & 212,10 & 13,63 & 225,72 & $(99,83)$ & 125,89 & 195,33 & $(69,43)$ \\
\hline 2003 & 281,68 & 12,78 & 294,46 & $(91,33)$ & 203,13 & 184,74 & 18,39 \\
\hline 2004 & 331,00 & 10,74 & 341,74 & $(87,57)$ & 254,18 & 210,84 & 43,34 \\
\hline 2005 & 330,62 & 8,35 & 338,96 & $(80,60)$ & 258,37 & 192,20 & 66,16 \\
\hline 2006 & 304,22 & 14,30 & 318,52 & $(78,77)$ & 239,75 & 202,26 & 37,49 \\
\hline 2007 & 267,19 & 21,59 & 288,78 & $(79,39)$ & 209,39 & 226,56 & $(17,18)$ \\
\hline 2008 & 246,46 & 20,50 & 266,96 & $(89,81)$ & 177,15 & 283,81 & $(106,66)$ \\
\hline 2009 & 203,72 & 14,75 & 218,46 & $(77,36)$ & 141,10 & 213,29 & $(72,19)$ \\
\hline 2010 & 203,40 & 10,09 & 213,50 & $(67,47)$ & 146,03 & 247,61 & $(101,58)$ \\
\hline 2011 & 239,09 & 13,35 & 252,43 & $(75,49)$ & 176,94 & 280,78 & $(103,84)$ \\
\hline 2012 & 246,04 & 15,28 & 261,32 & $(67,43)$ & 193,89 & 313,16 & $(119,27)$ \\
\hline 2013 & 232,53 & 14,39 & 246,92 & $(73,36)$ & 173,56 & 342,41 & $(168,85)$ \\
\hline
\end{tabular}

A tabela 4.12 traz a posição da capacidade de importação, calculada a partir do poder de compra das exportações, em bilhões de reais de 2006. A variável (2) da tabela 4.12 é a variável (2) da tabela 4.11. A variável (3) expressa o valor real do recebimento brasileiro de remessas. A variável (4) é a capacidade doméstica de pagamento no exterior, que resulta da soma do valor real das exportações à soma do valor real das remessas recebidas do exterior. A variável (5) é o valor real do envio de remessas, incluindo amortização de dívidas. A subtração da variável (5) da variável (4) resulta na variável (6), que é a capacidade doméstica de importar. A variável (7) é o valor total real das importações. Ao subtrair a variável (7) da variável (6), atinge-se a posição da capacidade de importação, que é a variável (8).

O gráfico 4.9 traz a representação do valor real da posição da capacidade de importação do Brasil, entre 1999 e 2013 (variável 8 da tabela 12). Verifica-se que houve melhoria da posição da capacidade importação do Brasil até 2006, e queda a partir de então. Entre 2004 e 2007, o Brasil experimentou um período em que o setor externo brasileiro manteve-se estável, e positivo. Em 2008, ano da crise econômica internacional, a situação passou a se deteriorar, com melhoria pontual em 2010. 
Gráfico 4.9: Posição da capacidade de importação do Brasil, 1999 a 2013

(em bilhões de reais de 2006)

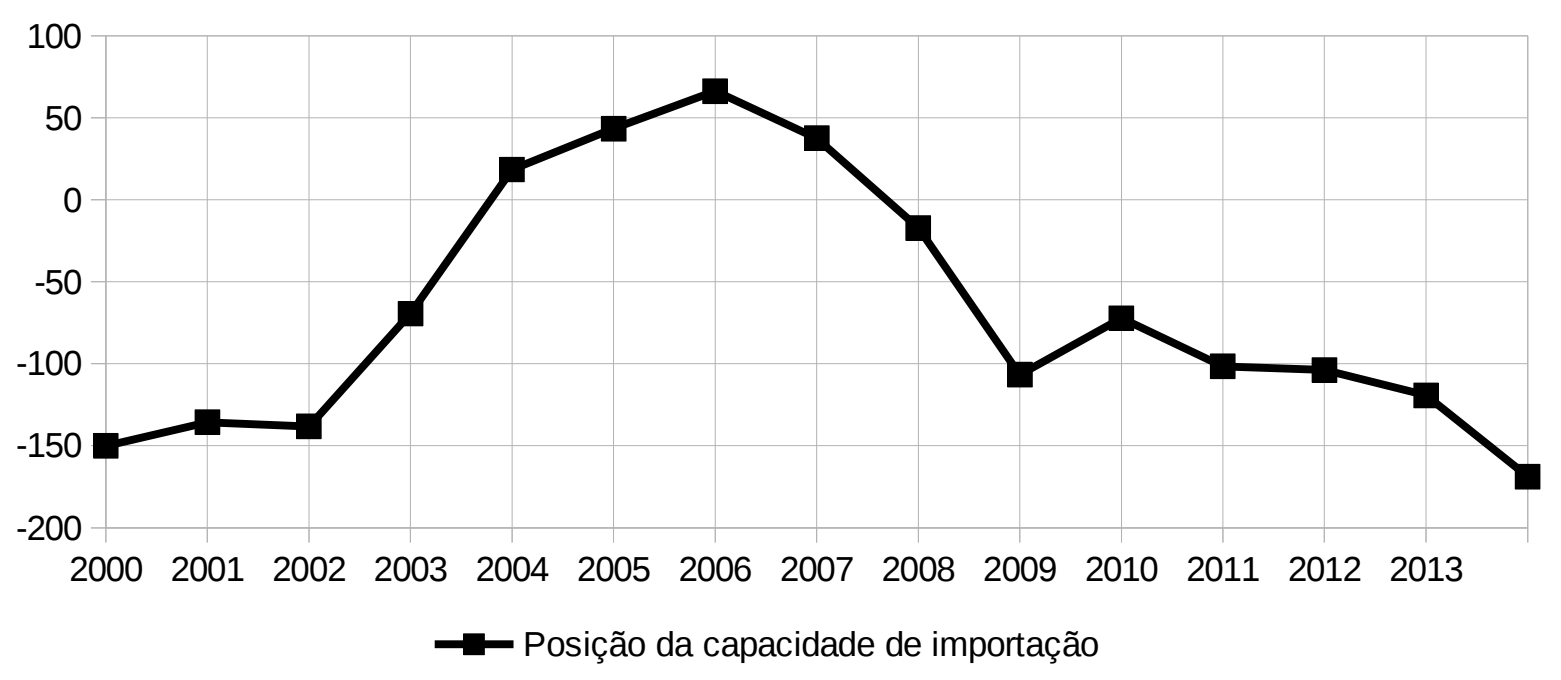

O que se observa é que, apesar do discurso corrente, na época, que o Brasil resistiu a crise econômica internacional, e que se consolidou no país uma estrutura econômica interna saudável, o setor externo brasileira assumiu perfil que não podia se sustentar a longo prazo. A oportunidade que veio do crescimento da economia chinesa ficou para trás. A alternativa foi sustentar as perdas do setor externo através da atração de capital. Isso significava por o país a venda. Em novembro de 2009, uma revista americana lançou uma edição com a capa que trazia a inscrição: "Brazil takes off" 142. Se naquele ano o Brasil decolava era apenas como boa oportunidade para o capital estrangeiro se instalar e drenar o que pudesse antes que o momento positivo terminasse de esgotar. Mas a economia brasileira já havia reafirmado à posição de qual jamais saíra: a de país dependente.

142 Tradução: “O Brasil decolou”. 


\section{A RECUPERAÇÃO ECONÔMICA PARCIAL}

A recuperação econômica brasileira não se resumiu apenas ao crescimento do Produto Interno Bruto, entre 1999 e 2013. Houve recuperação parcial da indústria local, embora em ritmo desacelerado, e diminuição da concentração de renda. A miséria foi parcialmente reduzida. A fome endêmica praticamente desapareceu. A recuperação econômica parece ter sido também uma recuperação social parcial do país.

O comércio exterior foi impulsionador desse processo. O excedente adquirido com as exportações serviram para viabilizar certa transferência de renda favorável às camadas de renda mais baixa. Efetivamente, sem que a estrutura oligopolista e latifundiária do país fosse rompida, o Brasil encaixou-se em um modelo econômico onde parte do consumo da população foi financiado pelos ganhos na exportação. Isso permitiu que as camadas de menor renda ganhassem maior importância na vida econômica local. Esse processo pode ser verificado através da análise da renda disponível das famílias brasileiras, que expressa a renda que cada família possui à sua disposição para realizar consumo ou investimento ${ }^{143}$. O IBGE assim defini a renda disponível das famílias:

A principal fonte de rendimento das famílias é o recebimento de salários e outras remunerações por trabalharem em empresas ou no governo, mas as famílias também têm rendimento de produção própria. Autônomos, empresas não constituídas (sem registro no Cadastro Nacional da Pessoa Jurídica - CNPJ) e agricultores (agricultura familiar) são responsáveis por parte da produção própria das famílias.

Além de gerarem renda diretamente e receberem por sua participação na produção de empresas e governo, as famílias recebem (e fazem) outras transferências de recursos. Contabilizando a renda recebida e todas essas transferências, é possível calcular a renda disponível das famílias, isto é: a renda que elas têm para consumir e poupar. ${ }^{144}$

A renda disponível, portanto, permite calcular o impacto do rendimento das diferentes camadas de renda na realização de consumo e investimentos no país. Esse impacto pode ser calculado através da propensão marginal a consumir, que varia conforme oscila a renda.

143 Para uma discussão sobre formas de cálculo da renda disponível das famílias ver: ACKLEY,Gardner. Teoria Macroeconômica. vol 1. São Paulo: Livraria Pioneira Editora,1969. Pg. 45.

144 IBGE. Sistema de Contas Nacionais - Brasil. Ano de Referência 2010. $3^{\text {a }}$ edição. Rio de Janeiro, IBGE, 2016. Pg. $97-98$. 
Ainda, a propensão a consumir pode ser desdobrada no seu oposto: a propensão marginal a poupar. Uma explicação sintética sobre o tema pode ser encontrado em Dicionário Econômico e Social de Géledan e Brémond:

A propensão a consumir mede a fração do rendimento que o indivíduo consagra ao consumo. Se um indivíduo ganha 5000F e despende 4000F, a propensão média a consumir é: $\frac{\text { Despesas } x 100}{\text { rendimento }} \quad$ ou seja: $\quad \frac{4000 F}{5000} \times 100=80 \%$

Quando, porém, o rendimento muda, a fração despendida varia. Para medir esta variação, define-se a propensão marginal a consumir:

$$
\text { Propensão marginal a consumir }=\frac{\text { Variação das despesas }}{\text { variação do rendimento }} \cdot{ }^{145}
$$

Além da propensão marginal a consumir, de cada camada de renda, é possível calcular o impacto das oscilações da renda no investimento, e nas importações (propensão marginal a importar). Ainda, pode-se verificar o ganho marginal de renda com as exportações realizadas pelo país. Por isso, para realizar uma análise do impacto do comércio exterior na atividade econômica brasileira, a renda disponível das camadas de renda foi examinada para verificar (a) a diminuição parcial da concentração de renda; (b) a ligação entre a renda das camadas e o consumo das famílias; (c) a ligação com a formação bruta de capital fixo; (d) ligação com as importações; e (d) a relação entre renda disponível das camadas e o valor total das exportações.

\subsection{RENDA DISPONÍVEL DAS FAMÍLIAS}

A renda disponível das famílias pode ser organizada por camadas de renda. Isso facilita verificar as mudanças na distribuição de renda do país ao longo dos anos. De 1999 a 2013, ocorreu no Brasil uma mudança significativa: houve redução da miséria e da pobreza. Isso foi resultado de um crescimento da renda média das famílias mais pobres maior do que o crescimento da renda média das famílias mais ricas.

A princípio, a redistribuição de renda poderia ter se originado pelo (a) aumento da poupança nacional, que teria permitido o ganho de complexidade na economia local. Se esse fosse o caso, além da redistribuição de renda, teria ocorrido desenvolvimento econômico 
local; ou (b) poderia ter origem em políticas de redistribuição de renda por parte do governo como elemento de uma política de desenvolvimento; ou (c) poderia ter sido um subproduto de um período de prosperidade local, potencializado por políticas governamentais não hostis à população.

\begin{tabular}{|c|c|c|c|c|c|c|}
\hline (1) & (2) & (3) & (4) & (5) & (6) & (7) \\
\hline & $\begin{array}{l}\text { Renda disponível } \\
\text { do primeiro } \\
\text { patamar de renda } \\
(\mathbf{1} \% \text { do topo }) \\
\end{array}$ & $\begin{array}{l}\text { Renda disponível } \\
\text { do segundo } \\
\text { patamar de renda } \\
(9 \% \text { seguintes })\end{array}$ & $\begin{array}{l}\text { Renda disponível } \\
\text { do terceiro } \\
\text { patamar de renda } \\
\text { (40\% seguintes) }\end{array}$ & $\begin{array}{c}\text { Renda disponível } \\
\text { do quarto patamar } \\
\text { de renda ( } 30 \% \\
\text { seguintes) }\end{array}$ & $\begin{array}{l}\text { Renda disponível } \\
\text { do quinto } \\
\text { patamar de } \\
\text { renda (20\% da } \\
\text { base) }\end{array}$ & $\begin{array}{c}\text { Total da } \\
\text { renda } \\
\text { disponível } \\
\text { das } \\
\text { famílias } \\
\end{array}$ \\
\hline Ano & $\left(Y_{d_{1}}\right)$ & $\left(\mathbf{Y d}_{2}\right)$ & $\left(\mathbf{Y d}_{3}\right)$ & $\left(\mathbf{Y d}_{4}\right)$ & $\left(\mathbf{Y d} \mathbf{d}_{5}\right)$ & (Yd) \\
\hline (i) 1999 & 225,3 & 579,1 & 681,4 & 175,0 & 41,0 & 1701,9 \\
\hline (ii) 2000 & 242,3 & 603,4 & 714,3 & 183,5 & 42,3 & 1785,8 \\
\hline (iii) 2001 & 252,8 & 609,9 & 726,7 & 186,8 & 42,4 & 1818,6 \\
\hline (iv) 2002 & 246,6 & 617,5 & 734,9 & 192,0 & 46,3 & 1837,3 \\
\hline (v) 2003 & 253,7 & 642,4 & 787,1 & 207,3 & 49,1 & 1939,6 \\
\hline (vi) 2004 & 267,8 & 667,4 & 842,6 & 228,6 & 56,7 & 2063,1 \\
\hline (vii) 2005 & 280,6 & 698,6 & 877,4 & 242,4 & 61,1 & 2160,1 \\
\hline (viii) 2006 & 296,3 & 742,0 & 946,7 & 267,5 & 67,8 & 2320,3 \\
\hline (ix) 2007 & 313,1 & 784,4 & 1036,9 & 296,1 & 72,3 & 2502,8 \\
\hline (x) 2008 & 325,2 & 830,2 & 1117,3 & 328,2 & 82,4 & 2683,3 \\
\hline (xi) 2009 & 333,7 & 844,9 & 1151,6 & 342,2 & 85,2 & 2757,6 \\
\hline (xii)2010 & 373,5 & 950,1 & 1312,2 & 396,8 & 98,6 & 3131,2 \\
\hline (xiii) 2011 & 389,0 & 993,9 & 1390,5 & 428,0 & 106,2 & 3307,6 \\
\hline (xiv) 2012 & 425,0 & 990,5 & 1409,5 & 441,2 & 112,2 & 3378,4 \\
\hline (xv) 2013 & 409,5 & 1039,8 & 1466,1 & 459,8 & 113,0 & 3488,3 \\
\hline \begin{tabular}{|l|} 
(xvi) Média em \\
relação ao total
\end{tabular} & $12,57 \%$ & $31,44 \%$ & $41,21 \%$ & $11,87 \%$ & $2,92 \%$ & $100 \%$ \\
\hline \begin{tabular}{|c|} 
(xvii) \\
$\begin{array}{c}\text { Crescimento no } \\
\text { período }\end{array}$ \\
\end{tabular} & $81,76 \%$ & $79,55 \%$ & $115,16 \%$ & $162,74 \%$ & $175,61 \%$ & $104,97 \%$ \\
\hline
\end{tabular}

Na tabela 5.1 observa-se a renda disponível das camadas de renda do Brasil. A primeira coluna (1) traz o ano referente. A segunda (2) traz a renda disponível real do primeiro patamar de renda do país, que é o patamar do $1 \%$ do topo da pirâmide de renda. A terceira (3) traz a renda disponível do segundo patamar de renda, contendo os $9 \%$ seguinte da pirâmide. A quarta (4) traz a renda disponível do terceiro patamar, que contêm os $40 \%$ seguintes.

A quinta coluna (5) apresenta a renda disponível do quarto patamar de renda, que é dos 30\% seguintes na pirâmide (na verdade, aqui já começa a faixa dos mais pobres, aqueles que possuíram renda mensal de cerca de 444 reais per capita, em reais de 2006). A sexta (6) traz o quinto patamar de renda, que são os $20 \%$ da base da pirâmide de renda (aqueles que precisaram passar o mês com cerca de 157 reais constantes per capita, em média, no período). 
A sétima (7) é o total da renda disponível das famílias brasileiras. Na linha (xvi), observa-se a média da renda das famílias de cada camada em relação ao total da renda disponível das famílias. Na linha (xvii) verifica-se o crescimento total da renda de cada camada, entre 1999 e 2013.

Para o período entre 1999 e 2013, observa-se que os 1\% do topo da pirâmide de renda representaram, em média $12,57 \%$ da renda disponível das famílias, enquanto os $20 \%$ da base representaram em média apenas 2,92\%. Trata-se de considerável grau de concentração. Sozinhos, os $9 \%$ do segundo patamar representaram, no período, cerca de 31,44\% da renda disponível das famílias. Enquanto isso, a metade de baixo da pirâmide (quarto e quinto patamares) foram responsável por apenas 14,78\%. Evidentemente, é um país de alta concentração de renda. No entanto, nota-se que a taxa de crescimento da renda disponível da metade de baixo da pirâmide foi mais do que o dobro da do topo. As camadas que apresentaram maior crescimento de renda foram, respectivamente o quinto e o quarto patamar.

\section{Gráfico 5.1: Renda disponível do primeiro patamar de renda e do quarto e quinto patamar somados, 1999 a 2013}

(bilhões de reais de 2006)

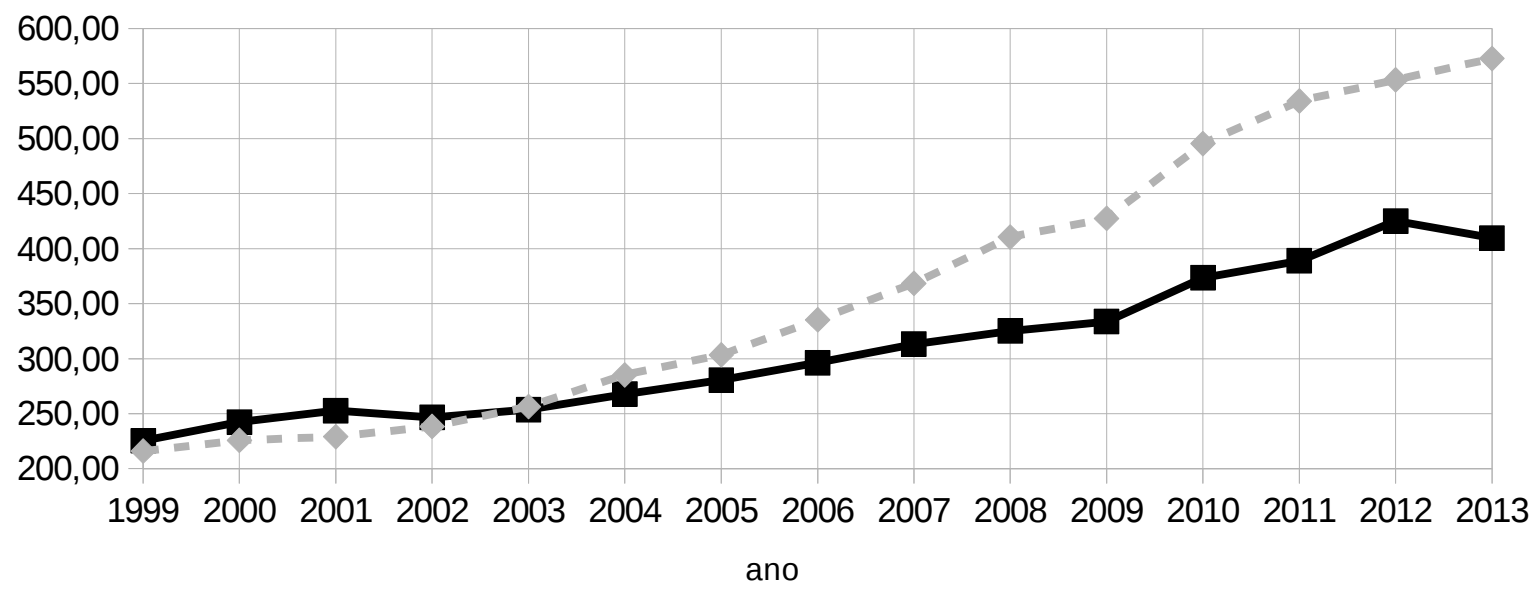

Renda do primeito patamar $=-b=-$ renda do quarto e quinto patamares

Fonte: IBGE e IPEA.

O gráfico 5.1 permite verificar parte do efeito da desconcentração de renda. No gráfico, está a representação do crescimento da renda disponível dos 1\% do topo da pirâmide de renda (em preto) e dos $50 \%$ da base, que incluem o quarto e quinto patamar de renda (em cinza). Até 2003, a renda disponível dos $1 \%$ do topo foi superior ou igual ao total da renda disponível dos 50\% da base. A partir de 2004, a renda total dos 50\% da base passou a crescer 
mais rapidamente. Em 2011, já representavam quase 1,4 vezes a renda dos 1\% do topo. Evidentemente, ter que somar a renda da metade da base para que se possa atingir valor comparável ao dos $1 \%$ do topo demonstra o tamanho da concentração de renda que ainda existia. Inegavelmente, no entanto, ela diminui no período observado.

A recuperação econômica do Brasil, neste período, parece ter favorecido a base da pirâmide, ainda que os 1\% da camada do topo em momento algum, com exceção de 2013, tenha sofrido quebra na renda disponível. O esforço de transferência de renda, ainda que não se tenha sacudido a estrutura oligopolista e latifundiária do Brasil, teve impacto na composição de renda.

\section{Gráfico 5.2: Renda da metade de cima da pirâmide de renda do Brasil, 1999 a 2013}

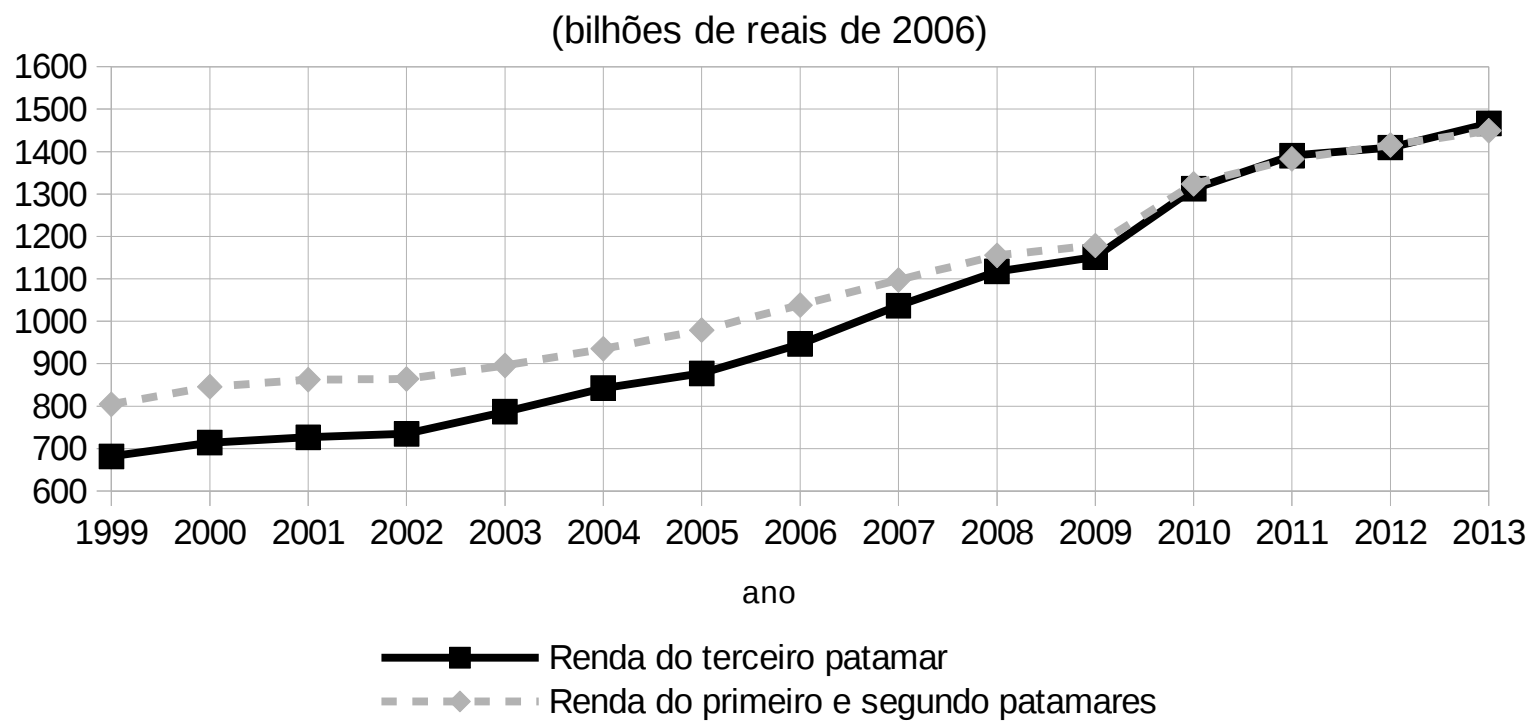

Fonte: IBGE e IPEA

A redução na concentração de renda também afetou a distribuição de riqueza da metade do topo da pirâmide de renda do Brasil. O gráfico 5.2 traz a representação da renda disponível da soma do primeiro e segundo patamar de segmentos de renda (em cinza) e do terceiro patamar (em preto). No início do período a renda dos $10 \%$ do topo da pirâmide superava em cerca de 0,5 vezes a renda somada dos $40 \%$ seguintes. A partir de 2003, essa diferença começou a diminuir lentamente. Em 2009, finalmente os dois segmentos se igualaram.

Na literatura, esse fenômeno ficou conhecido como crescimento das camadas médias. Mais pessoas estiveram, no período, ganhando melhor, o que fez com que a renda média do 
terceiro patamar de renda aumentasse lentamente. O resultado foi que, embora individualmente os membros das camadas médias continuassem ganhando bem menos do que os $10 \%$ do topo, a renda aumentou e o segmento “melhorou de vida”.

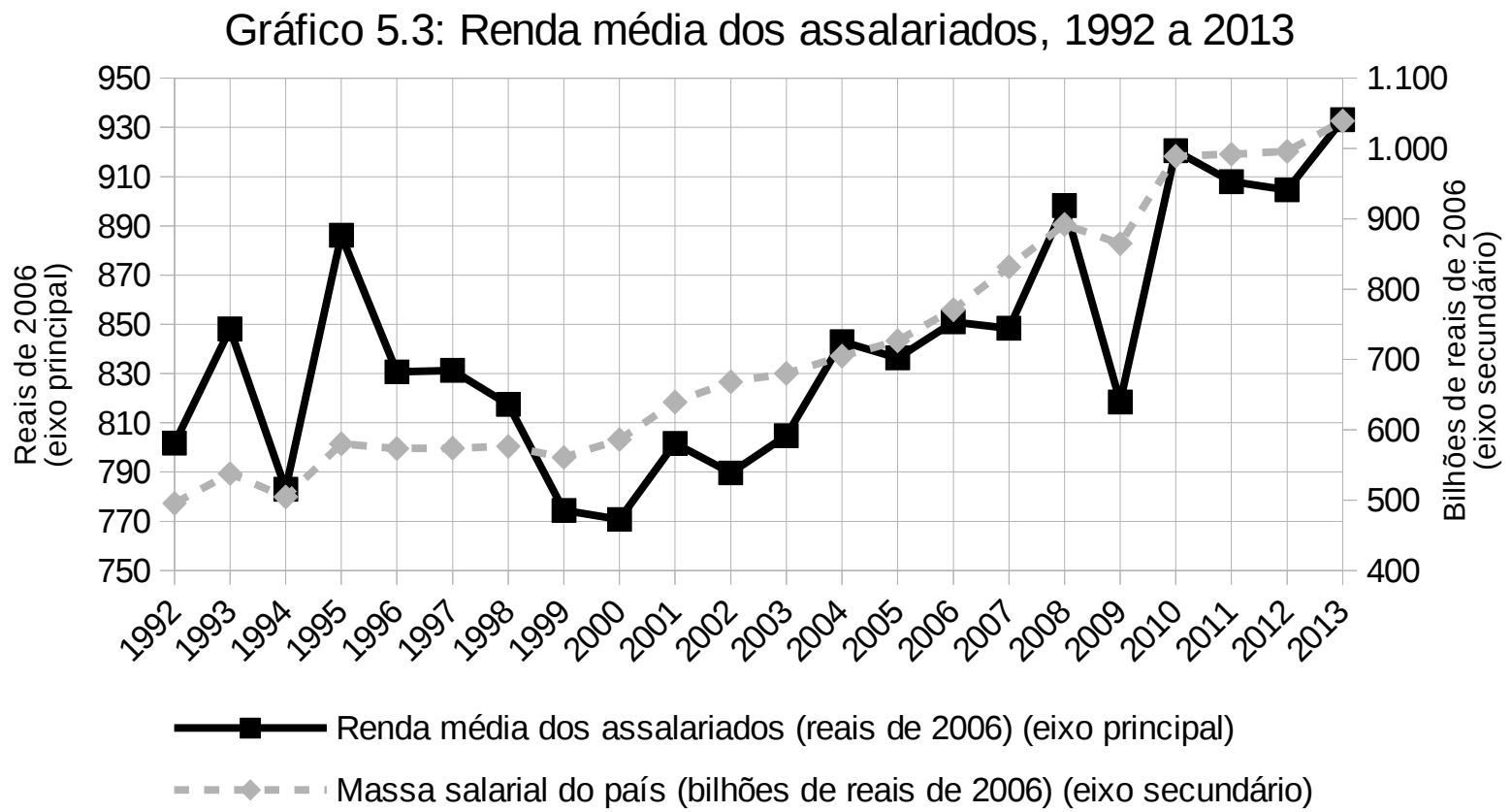

Fonte: IBGE, IPEA, cálculo próprio

Parte da redução da concentração de renda se explica pelo aumento da renda do trabalho, ocorrido a partir de 2001. No gráfico 5.3, verifica-se que, no período entre 1995 e 2000, a renda média adquirida pelos trabalhadores assalariados apresentou perda real. Isso ocorreu a despeito da propaganda do governo e da mídia local. Ambos afirmavam que os juros altos e a estabilidade da moeda garantiam maior poder de compra para a população. Em 2000, a renda dos assalariados atingiu seu patamar mais baixo. Entre 2001 e 2003, houve recuperação parcial da renda, no entanto, ela manteve-se a baixo da observada em 1998. A partir de 2001, o salário médio real voltou a crescer, acelerando sua recuperação em 2004. Apesar da queda pontual de 2009, resultante do impacto da crise de 2008, a renda dos assalariados só apresentou esgotamento em sua recuperação a partir de 2011. A chamada renda do trabalho ou massa salarial do país, representada no eixo secundário do gráfico acima, observou trajetória similar. Manteve-se estagnada de 1994 até 2001. A partir de então, iniciou processo de crescimento, e entrou em nova fase de oscilação para baixo em 2011.

O aumento da renda dos assalariados pode ser explicado por alguns fatores: (a) a ampliação dos ganhos no setor externo da economia resultou em aumento da renda disponível 
do país. Como a produtividade não aumentou no período, ela foi compensada pelo aumento mais que proporcional na contratação de força de trabalho. Como resultado, houve pressão para ampliação dos salários. Ainda (b) o governo realizou uma política de aumento do salário mínimo, que serve como ponto de referência para o estabelecimento das políticas de salário do setor privado. Por último (c) os programas sociais do governo podem ter permitido que parcelas dos trabalhadores que anteriormente aceitavam condições precárias de trabalho tenham passado a exigir salários no mínimo superiores ao rendimento adquirido nos programas sociais.

Não se deve atribuir peso muito grande a esse último fator, uma vez que os programas de assistência do governo pagavam bastante abaixo do salário médio do período anterior. O programa Bolsa Família, em 2003, por exemplo, permitia às famílias com renda mensal de até $\mathrm{R} \$ 120$ per capita adquirir um benefício de $\mathrm{R} \$ 30$ por criança ou adolescente, com limite de 5 benefícios (totalizando $\mathrm{R} \$ 150$ ). Os reajustes nesses valores andaram lentamente. Em 2016, o valor do benefício era de apenas R \$39 por criança ou adolescente. Na prática, os programas de assistência foram importantes para diminuir a fome endêmica no país, mas tiveram pouco impacto na redistribuição de renda.

\begin{tabular}{|c|c|c|c|c|c|c|c|}
\hline \multicolumn{6}{|c|}{ Tabela 5.2: Renda do trabalho, em reais de 2006, explicada pelas exportações e importações do Brasil (1999 a } \\
\hline (I) & (II) & (III) & (IV) & (V) & (VI) & (VII) & (VIII) \\
\hline Regressão & $\begin{array}{c}\text { Variável } \\
\text { independente }\end{array}$ & $\begin{array}{c}\text { Coeficiente } \\
\text { A }\end{array}$ & Coeficiente B & Erro de A & Erro de B & $\mathbf{R}^{2}$ & DW \\
\hline $\begin{array}{c}5.1 \\
\mathrm{Y}_{\mathrm{w}}=\mathrm{a}+\mathrm{Xr}\end{array}$ & $\begin{array}{c}\text { Valor } \\
\text { exportado } \\
\text { (reais de 2006) }\end{array}$ & 225815 & 2,05 & 145261 & 0,51 & 0,552 & 0,312 \\
\hline $\begin{array}{c}5.2 \\
\mathrm{Y}_{\mathrm{w}}=\mathrm{a}+\mathrm{Mr}\end{array}$ & $\begin{array}{c}\text { Valor } \\
\text { importado } \\
\text { (reais de 2006) }\end{array}$ & 174922 & 2,71 & 84995,3 & 0,36 & 0,812 & 0,980 \\
\hline $\begin{array}{c}\text { Valor } \\
\text { exportado } \\
\text { (dólares de } \\
2006)\end{array}$ & 457113 & 2,49 & 24570,3 & 0,16 & 0,946 & 1,546 \\
$\mathrm{Y}_{\mathrm{w}}=\mathrm{a}+\mathrm{Xdr}$ & & & & & \\
\hline
\end{tabular}

É possível verificar a importância do setor externo na renda do trabalho através de uma série de regressões. Na tabela acima, verifica-se três regressões referentes ao período de 1999 a 2013: a renda do trabalho explicada pelo valor exportado em reais constantes de 2006; a renda do trabalho explicada pelo valor importado, também em reais de 2006; e por último, vê-se a renda do trabalho, em reais constantes, explicada pelo valor exportado em dólares constantes de 2006. Verifica-se que as importações possuem forte poder explicativo em 
relação à renda do trabalho, com baixa espuriedade ( $\mathrm{R}^{2}$ de 0,81 , e Durbin Watson de 0,98). Já a regressão considerando as exportações em reais constantes teve alta espuriedade, e poder de explicação inferior ( $\mathrm{R}^{2}$ de 0,55 , e Durbin Watson de 0,31 ). No entanto, quando se verifica uma regressão similar, mas com a renda do trabalho em reais constantes de 2006, e as exportações em dólares constantes de 2006, o poder explicativo se torna alto e a espuriedade desaparece.

A baixa capacidade de explicação das exportações, em reais constantes, se dá pelo fato do câmbio ter sido usado como ferramenta de regulação da inflação. O governo manteve o real sobrevalorizado, tornando as importações mais baratas para o país (prejudicando a indústria local no processo). Isso fez com que o câmbio se comportasse de forma contrária ao poder de compra da moeda local. O resultado é que as exportações, quando calculadas aos preços em moeda nacional, apresentou comportamento errático. No entanto, o uso do câmbio como ferramenta de controle da inflação só foi possível pela alta das exportações no período. Uma forma de se manter a moeda local sobrevalorizada é através da forte oferta de divisas. Por isso, expecta-se que os ganhos de dólares no comércio internacional por parte do Brasil seja um fator relevante para explicar o desempenho da economia local.

Desde a adoção do plano Real, o câmbio passou a ser utilizado, principalmente, como ferramenta de controle da inflação. O câmbio sobrevalorizado facilitava a importação de bens de consumo, dando vasão à pressão inflacionária. Como resultado, o consumo das famílias pôde crescer acima do crescimento da oferta interna de bens. No entanto, isso apenas foi possível devido a disponibilidade de dólares para esse fim. Na década de (19)90, a aquisição de dólares foi feita através da privatização e venda de ativos brasileiros, e pelo endividamento externo. As divisas adquiridas dessa forma não resultavam na criação de novos empregos, ou na melhoria da renda local. Ainda, o governo local praticou política de arroxo salarial, o que levou à distribuição de renda favorável às camadas de maiores rendimentos. Esse modelo entrou em crise em 1998, forçando uma alta cambial, a partir de 1999. A desvalorização do Real favoreceu as exportações. Esse processo coincidiu com a alta da demanda chinesa. A expansão das exportações permitiu aquisição de renda no exterior e criação de novos postos de trabalho no país. A melhoria conjuntural dos termos de troca diminuiu as perdas relativas do Brasil, permitindo uma maior taxa de crescimento local. Isso ocorre, em parte, porque as perdas de excedente por parte dos países dependentes se explica, em parte, por trocas desiguais, conforme ressaltado por Korkut Boratav: 
A exploração relacionada com o comércio ocorre através das relações de distribuição entre os produtores diretos na periferia versus o capital comercial nas metrópoles e seus representantes de fato na periferia. $\mathrm{O}$ quadro conceitual para uma análise dessas linhas é menos complicado para o comércio de produtos primários exportados pela periferia. Os agentes relevantes dentro do processo de distribuição são (a) produtores diretos, capital mercantil e o estado da economia periférica; e (b) capital transnacional, comercial e estado das metrópoles. A proporção de valor agregado acumulada por (b) sobre (a) representa a taxa de exploração da economia periférica pelas metrópoles através do comércio. ${ }^{146}$

Portanto, evidentemente, quanto melhor remunerados o produtos de exportação, menor será a drenagem de recursos locais. Disso resulta que a alta da demanda por bens primários, ocasionada pelo crescimento chinês, possibilitou ganho de rendimentos locais. O que não estava dado, no entanto, era como seria a distribuição dessa nova renda.

A partir de 2003, o novo governo optou por (a) valorizar o Real, e (b) realizar uma política de aumento do salário mínimo. Como a demanda chinesa continuava a crescer, foi possível sustentar a política de controle da inflação através do câmbio, aumento da renda do trabalho, e facilitação das importações para suprir a nova demanda interna. Na época, houve forte expansão dos postos de trabalho no chamado setor terciário (setor dos serviços). A nova demanda por força de trabalho também pressionou os salários para cima. O aumento do salário médio e a criação de novos postos de trabalho, sustentados pelo setor externo, foram os mecanismos pelo quais foi possível a distribuição de renda favorável às camadas de menor rendimento, sem que a política econômica do governo passasse por mudanças sensíveis. ${ }^{147}$

\subsection{A RENDA DISPONÍVEL E A REDISTRIBUIÇÃO DE RENDA}

Uma outra forma de abordar o tema da redistribuição de renda no Brasil, entre 1999 e 2013, é através da verificação econométrica da relação entre a renda disponível total do Brasil e a renda disponível de cada patamar de segmento de renda. Uma verificação como a renda disponível brasileira oscilou conforme oscilou cada camada. Na prática, verifica-se o grau de

146 BORATAV, Korkut. "Net Resource Transfers And Dependency: Some Recent Changes In The World Economy” in: KÖSE, A. H. \& SENSES, F. et al. Neoliberal Globalization as New Imperialism. Nova Iorque: Nova Science Publishers, Inc., 2007. Pg. 2

147 Para uma explicação entre as oscilações de demandas por produtos exportáveis, o nível de emprego, e o salário médio local, ver: EMMANUEL, Arghiri. Unequal Exchange. A Study of the Imperialism of Trade. Nova Iorque e Londres: Monthly Review Press, 1972. Pg. 67. 
participação de cada segmento na geração e na distribuição de riqueza do país.

Ao adotar essa abordagem, busca-se responder a seguinte questão: "qual foi a relação entre os ganhos de renda de cada camada e o ganho de renda no país?”. Ao responder essa pergunta, pode-se verificar se as camadas de baixo da pirâmide de renda participaram significantemente como detentores de renda, ou se houve monopólio das camadas de cima na participação. Caso as camadas de baixo tivessem participação significativa, poderia se falar de uma economia de massas, ou de consumo. Conforme Arghiri Emmanuel, uma remuneração alta dos trabalhadores é um dos requisitos para diminuição das perdas no comércio internacional desigual, haja visto que parte das trocas desiguais estão fundadas na baixa remuneração dos trabalhadores dos países subdesenvolvidos ${ }^{148}$.

A ausência da participação das camadas de renda baixa pode, em contrapartida, ser um sintoma de uma economia dependente. Em um modelo de sistema periférico, conforme Samir Amin, uma das diferenças entre um sistema autocentrado e um sistema periférico (e portanto dependente, é quais setores da economia são priorizados. Amin propôs seu modelo considerando a existência dos quatro setores: (I) exportação; (II) consumo de massas; (III) consumo de luxo; e (IV) bens de capital. Para Samir, uma economia autocentrada priorizava o setores II e IV, enquanto uma economia dependente priorizava os setores I e III. Uma das consequências da priorização da exportação e do consumo em luxo seria a alta concentração de renda e baixa participação das camadas de rendimentos menores na geração de riqueza através de seus rendimentos. ${ }^{149}$

Trata-se de uma sistematização da proposição anterior de Prebisch, que entendia que um dos gargalos das economias dependentes era a permanência de organizações sociais pretéritas e alta concentração de renda. A existência de aristocracia local e fortes oligopólios, e de parcela da população não inserida no consumo (em especial a população rural), dificultava o desenvolvimento local.

148 Sobre o tema, ver: EMMANUEL, Arghiri. Unequal Exchange. A Study of the Imperialism of Trade. Nova Iorque e Londres: Monthly Review Press, 1972. Pg. 174.

149 Sobre o tema, ver: AMIN, Samir. Capitalismo periferico y comercio internacional. Buenos Aires, Ed. Periferia, 1974. 
Tabela 5.3: Renda disponível total explicada pela renda disponível dos patamares de renda, em reais constantes de 2006 (1999 a 2013)

\begin{tabular}{|c|c|c|c|c|c|c|c|c|}
\hline (1) & (2) & (3) & (4) & (5) & (6) & (7) & (8) & (9) \\
\hline $\begin{array}{l}\text { Número da } \\
\text { regressão }\end{array}$ & $\begin{array}{c}\text { Variável } \\
\text { independente }\end{array}$ & Coeficiente A & Coeficiente B & $\begin{array}{c}\text { Erro } \\
\text { Padrão } \\
\text { de } \mathbf{A}\end{array}$ & $\begin{array}{c}\text { Erro } \\
\text { Padrão de } \\
\text { B }\end{array}$ & $\begin{array}{l}\text { Elasticidade } \\
\text { de } B\end{array}$ & $\mathbf{R}^{2}$ & DW \\
\hline $\begin{array}{c}5.4 \\
\mathrm{Yd}=\mathrm{a}+\mathrm{Yd}_{1}\end{array}$ & $\begin{array}{l}\text { Renda disponível do } \\
\text { primeiro patamar }\end{array}$ & $(518,84)$ & 9,64 & 98,11 & 0,31 & 1,22 & 0,9866 & 2,254 \\
\hline $\begin{array}{c}5.5 \\
\mathrm{Yd}=\mathrm{a}+\mathrm{Yd}_{2}\end{array}$ & $\begin{array}{l}\text { Renda disponível do } \\
\text { segundo patamar }\end{array}$ & $(585,71)$ & 3,94 & 29,70 & 0,04 & 1,24 & 0,9988 & 2,731 \\
\hline $\begin{array}{c}5.6 \\
\mathrm{Yd}=\mathrm{a}+\mathrm{Yd}_{3}\end{array}$ & $\begin{array}{l}\text { Renda disponível do } \\
\text { terceiro patamar }\end{array}$ & 163,74 & 2,27 & 10,98 & 0,01 & 0,93 & 0,9997 & 1,555 \\
\hline $\begin{array}{c}5.7 \\
\mathrm{Yd}=\mathrm{a}+\mathrm{Yd}_{4}\end{array}$ & $\begin{array}{l}\text { Renda disponível do } \\
\text { quarto patamar }\end{array}$ & 647,00 & 6,21 & 11,37 & 0,04 & 0,73 & 0,9995 & 1,469 \\
\hline $\begin{array}{c}5.8 \\
\mathrm{Yd}=\mathrm{a}+\mathrm{Yd}_{5}\end{array}$ & $\begin{array}{l}\text { Renda disponível do } \\
\text { quinto patamar }\end{array}$ & 742,92 & 23,90 & 29,56 & 0,39 & 0,68 & 0,9966 & 2,065 \\
\hline
\end{tabular}

A tabela 5.3 contém dados sobre cinco regressões feitas com a renda disponível total do Brasil como variável dependente, e com as distintas camadas de renda como variáveis independentes, para o período entre 1999 e 2013. A primeira coluna traz o número de referência da regressão. A segunda traz o nome da variável independente utilizada. A coluna (3) traz o coeficiente "a”, que é a constante encontrada na regressão. A coluna (4) contém os coeficientes “b”, que expressam quantos reais constantes de 2006 cresceu a renda disponível total brasileira para cada real constante a mais na renda do patamar de renda utilizado com variável independente. As colunas (5) e (6) trazem o erro padrão para os coeficientes "a” e “b”, respectivamente. A coluna (7) contém a elasticidade do coeficiente "B” para as diferentes regressões. A elasticidade expressa em quantos por cento aumenta a renda disponível total para um aumento de um por cento na renda disponível do patamar de renda utilizada como variável independente. A coluna (8) traz o R-quadrado da regressão, que expressa o poder explicativo da mesma. A coluna (9) traz o valor do Durbin-Watson. Considera-se que regressões com Durbin-Watson abaixo do valor respectivo do R-quadrado são espúrias.

Todas as regressões dispostas na tabela 5.3 tiveram R-quadrado próximo a 1. Ou seja, mais de 98\% das vezes que se projetou a variação de renda disponível total por qualquer uma das rendas disponíveis dos patamares de renda, atingiu-se o valor esperado dentro da margem de erro. Note-se que a elasticidade encontrada para o primeiro e o segundo patamar de renda foi bastante alta, atingindo mais de 1,2. 
A elasticidade encontrada para cada camada pode ser utilizada para se atingir uma hipótese de modelo de distribuição da renda no país. Isso pode ser feito através da soma de todas as elasticidades, equalizando o total a um. Assim, chega-se a uma leitura de quantos centavos cada patamar de segmento de renda ficou para cada real gerado na renda disponível total. O primeiro patamar, dos 1\% do topo da pirâmide de renda, ficou com 25 centavos, para cada real criado. O segundo patamar, dos 9\% seguintes, ficou com 26 centavos. O terceiro patamar ficou com 19 centavos, o quarto patamar ficou com 15 centavos. O quinto patamar ficou com 14 centavos.

A concentração de renda e o modelo social brasileiro, entre 1999 e 2013, se expressam nessa relação. O primeiro e segundo patamar de renda foram protagonistas na economia brasileira. Apesar da distribuição de renda ter ocorrido em favor das camadas de baixo da pirâmide, o modelo de organização do mercado brasileiro continuou sendo oligopolista. O sistema de tributação continuou a favorecer aqueles que possuíam rendimentos mais altos.

Embora a camada média de renda, que se encontra no terceiro patamar de renda, tenha apresentado relação elástica entre sua renda disponível e a renda disponível total brasileira, o desempenho econômico dela foi um subproduto. Ela ficou com menos de cerca de 19 centavos para cada real criado, o que se aproxima da quinta parte da riqueza do país. Note-se que essa camada aglutina $40 \%$ da população. Tendeu a estar bem enquanto a economia ia bem. Daí a relação direta entre sua renda e a renda disponível total.

Já para a metade de baixo da pirâmide de renda, considerando tanto o quarto como o quinto patamares de renda, a relação encontrada foi inelástica. Isso significa que o ganho de renda para essas camadas se expressou menos do que proporcionalmente na renda disponível total brasileira. Entre 1999 e 2013, embora o consumo tenha sido bastante incentivado, a sociedade brasileira ainda não havia se tornado uma sociedade de consumo de massa. A população, desprovida de habitação, com deficiência alimentícia, com o aumento de sua renda pode apenas consumir o básico. O consumo realizado por esses patamares de renda conferiu maior resiliência à economia brasileira no momento de crise, mas foi incapaz de sustentar um mercado interno suficientemente grande e complexo. 


\subsection{AINDA A DISTRIBUIÇÃO DE RENDA}

Entre 1999 e 2013, o Brasil continuou sendo um país de baixa produtividade, que passou pela dissolução parcial de sua indústria, e com uma população de renda demasiadamente baixa. Melhorar a renda dos patamares de baixo os inseriu no mundo do consumo. Conferiu até certa dignidade a quem antes não tinha nada. Mas não gerou desenvolvimento local suficiente para romper a estrutura social oligopolista, e dependente, do Brasil.

O modelo econômico local se comportou de forma similar àquele analisado por Prebisch. A camada de cima da pirâmide social deteve grande parcela da renda disponível brasileira. Essa camada foi privilegiada pelo Estado e pela organização social vigente no país. Em momentos de crise pôde resistir de forma mais eficiente. Em momentos de prosperidade, continuou ganhando.

A prosperidade das camadas de menor renda foi apenas um resíduo do crescimento econômico impulsionado pelo excedente do comércio exterior. Prebisch apontava que em momentos de prosperidade local, as condições de vida da população melhorava. Mas tão logo houvesse deterioração dos termos de troca, a prosperidade cessava, e as condições de vida pioravam. Como ressaltou Esteban Pérez Caldentey, ao analisar o desempenho dos países na América Latina, na década de 2000:

Consequentemente, a política interna dos países da periferia é largamente delimitada e permanentemente restrita por condições externas. É nesse sentido que os esforços de crescimento dessas economias enfrentam uma restrição externa. Mais especificamente, os países enfrentam uma restrição externa quando seu desempenho (atual e esperado) nos mercados externos e a resposta dos mercados financeiros a esse desempenho (atual e esperado) delimitam e restringem seu espaço para implementar políticas internas, incluindo política, fiscal, taxa de câmbio e política monetária. ${ }^{150}$

Ou seja, as políticas econômicas dos países da América Latina, incluindo o Brasil, não superaram o problema da restrição externa. Continuaram a ter seu crescimento econômico, e sua distribuição de renda, limitados pela sua capacidade de importação ${ }^{151}$. O crescimento

150 CALDENTEY, Esteban Pérez. "Una coyuntura propicia para reflexionar sobre los espacios para el debate y el diálogo entre el (neo)estructuralismo y las corrientes heterodoxas”. In: BÁRCENA, Alicia \& PRADO, Antonio (orgs.). Neoestructuralismo y corrientes heterodoxas en América Latina y el Caribe a inicios del siglo XXI. Chile: CEPAL, 2005. Pg. 61.

151 Sobre o papel dos preços das commodities no crescimento econômico de países da América Latina, ver 
observado, e eventuais melhorias nas condições de vida da população local, foram fruto do aumento dos preços dos produtos de exportação local.

Gráfico 5.4: Posição relativa da renda do primeiro patamar de renda em relação a oscilação da renda disponível total do Brasil, 1999 a 2013

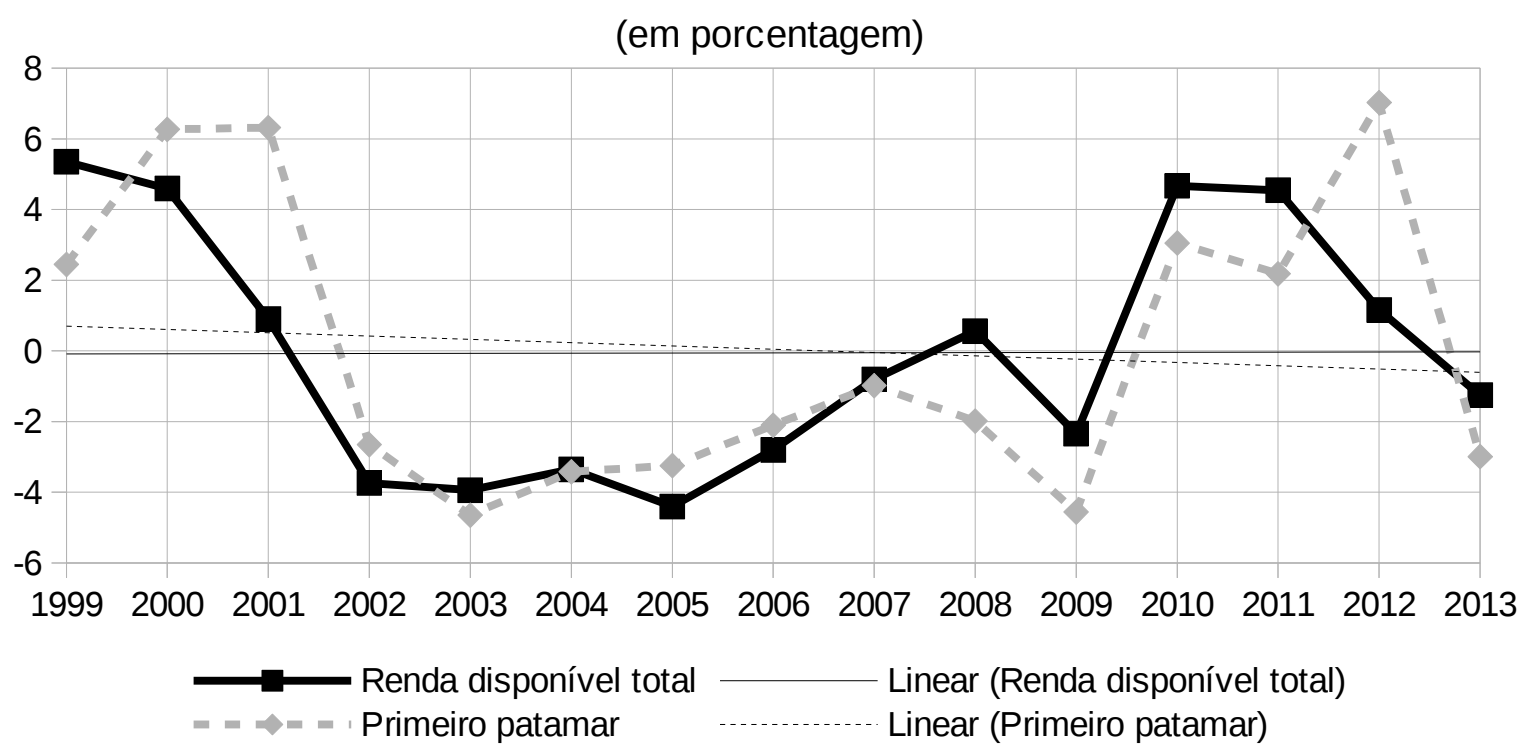

Fonte: IBGE e IPEA

O gráfico 5.4 traz as oscilações da renda disponível do primeiro patamar de renda relacionado as oscilações na renda disponível total do Brasil, entre 1999 e 2013. Os valores acima de zero expressam que os valores observados da renda disponível estiveram acima dos valores esperados, o que significa um período de maior crescimento.

O perfil oscilatório do primeiro patamar de renda (os $1 \%$ do topo da pirâmide) apresenta perfil cíclico de cerca de cinco anos. A cada cinco anos, aproximadamente, a linha do perfil oscilatório da renda disponível do primeiro patamar cruzou a linha da renda disponível total do Brasil. Observa-se que, na crise de 2000 e 2001, enquanto a renda disponível do Brasil sofria aperto, a renda do primeiro patamar sofreu menos que o restante do país, mantendo sua renda acima do esperado pelo desempenho da renda disponível total. Enquanto a economia do Brasil estava em crise, os 1\% do topo continuaram a expandir seus rendimentos. Somente em 2002 a crise atingiu aquele patamar de renda. O mesmo ocorreu em 2012: enquanto os demais patamares de renda da metade de cima da pirâmide de renda passavam por desaceleração no crescimento dos rendimentos, os $1 \%$ do topo deu um salto nos seus ganhos.

também: OCAMPO, José Antonio; VOS, Rob (Ed.). Uneven economic development. Nova Iorque: United Nations Publications, 2008. 
Na prática, o único período onde o rendimento do primeiro patamar apresentou defasagem considerável e consistente em relação ao crescimento da renda disponível total do Brasil foi entre 2008 e 2011. A crise mundial de 2008 e as políticas de distribuição de renda e incentivo ao consumo favoreceram mais as demais camadas da pirâmide. Entre 1999 e 2013, a renda do primeiro patamar de renda apresentou perfil oscilatório de tendência negativa. Isso quer dizer que começou com crescimento médio acima do esperado, e terminou com crescimento médio abaixo do esperado, em relação à renda disponível total.

\section{Gráfico 5.5: Posição relativa da renda do segundo patamar de renda em relação a oscilação na renda disponível total do Brasil, 1999 a 2013} (em porcentagem)

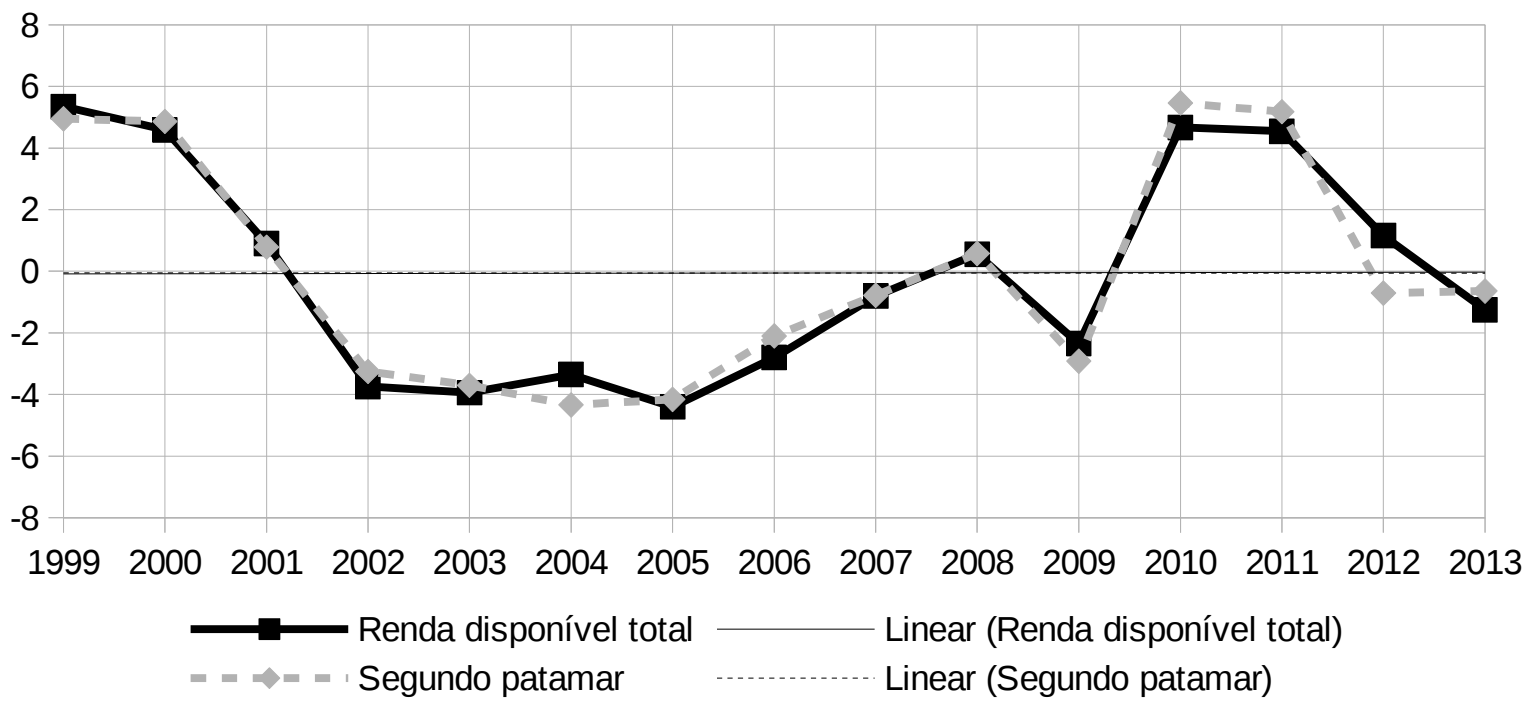

Fonte: IBGE e IPEA

O segundo patamar de renda apresentou perfil cíclico de três anos, caracterizado pelo cruzamento entre a renda disponível do segundo patamar e a renda disponível total. Trata-se de um ciclo de ajuste de renda de curto prazo. Na prática demorou apenas um ano de defasagem, em média, até que se fizesse um reajuste a favor do movimento da renda disponível total. Mas, a política de redistribuição de renda e incentivo ao consumo adotadas pelo governo brasileiro após 2008 impactaram em favor da expansão da renda disponível dos $9 \%$ seguintes ao $1 \%$ do topo da renda. Na prática, a renda disponível dos $10 \%$ do topo desconcentrou a favor dos 9\% "menos favorecidos" entre os "mais favorecidos".

O desempenho do segundo patamar foi mais rente ao desempenho da renda disponível total do Brasil. Esse patamar apresentou renda mais dependente das oscilações na atividade econômica brasileira. No entanto, em períodos de maior oscilação da renda disponível total, e 
a partir de 2010, houve afastamento entre o desempenho do segundo patamar de renda e o desempenho da renda disponível do país.

Gráfico 5.6: Posição relativa da renda disponível do terceiro patamar de renda em relação a oscilação na renda disponível total do Brasil, 1999 a 2013

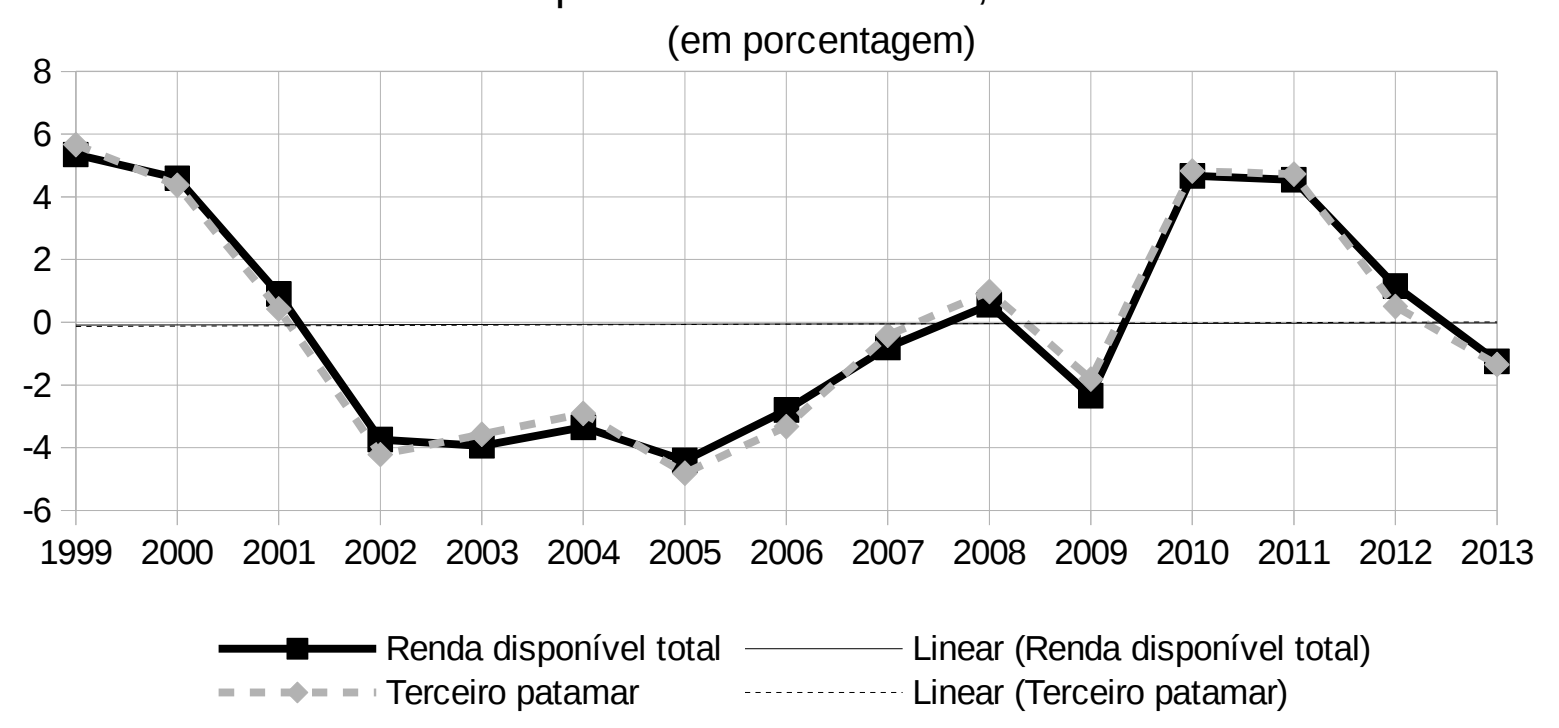

Fonte: IBGE e IPEA

O perfil do terceiro patamar, representado no gráfico 5.6, apresentou ciclo de 4 anos entre pontos altos e baixos em relação a renda disponível total. Mas o ciclo se manteve bastante próximo ao movimento esperado. Isso resultou da baixa oscilação da renda dos $40 \%$ seguintes aos $10 \%$ do topo, em relação ao esperado pela renda disponível total do país. Essa camada não foi especialmente prejudicada ou favorecida pela política ou estrutura local. Mas sua parcela da distribuição de renda esteve sempre garantida.

Observa-se que a linha de tendência das oscilações da renda disponível total e a linha de tendência das oscilações da renda disponível do terceiro patamar são quase completamente coincidentes. Para essa camada de renda, denominada “camada média”, na literatura, possuiu seu desempenho praticamente determinado pelo nível de atividade econômica brasileira, entre 1999 e 2013. Isso significa que, na prática, ela foi a verdadeira “base” da economia brasileira.

O gráfico 5.7 traz o perfil oscilatório da renda disponível do quarto patamar de renda em relação ao perfil da renda disponível total brasileira, entre 1999 e 2013. Os valores positivos apontam crescimento da renda acima do esperado para renda disponível total do Brasil. A posição da renda do quarto patamar de renda está disposta em relação a renda disponível total. 


\section{Gráfico 5.7: Posição da renda disponível do quarto patamar de renda em relação a oscilação da renda disponível total do Brasil, 1999 a 2013}

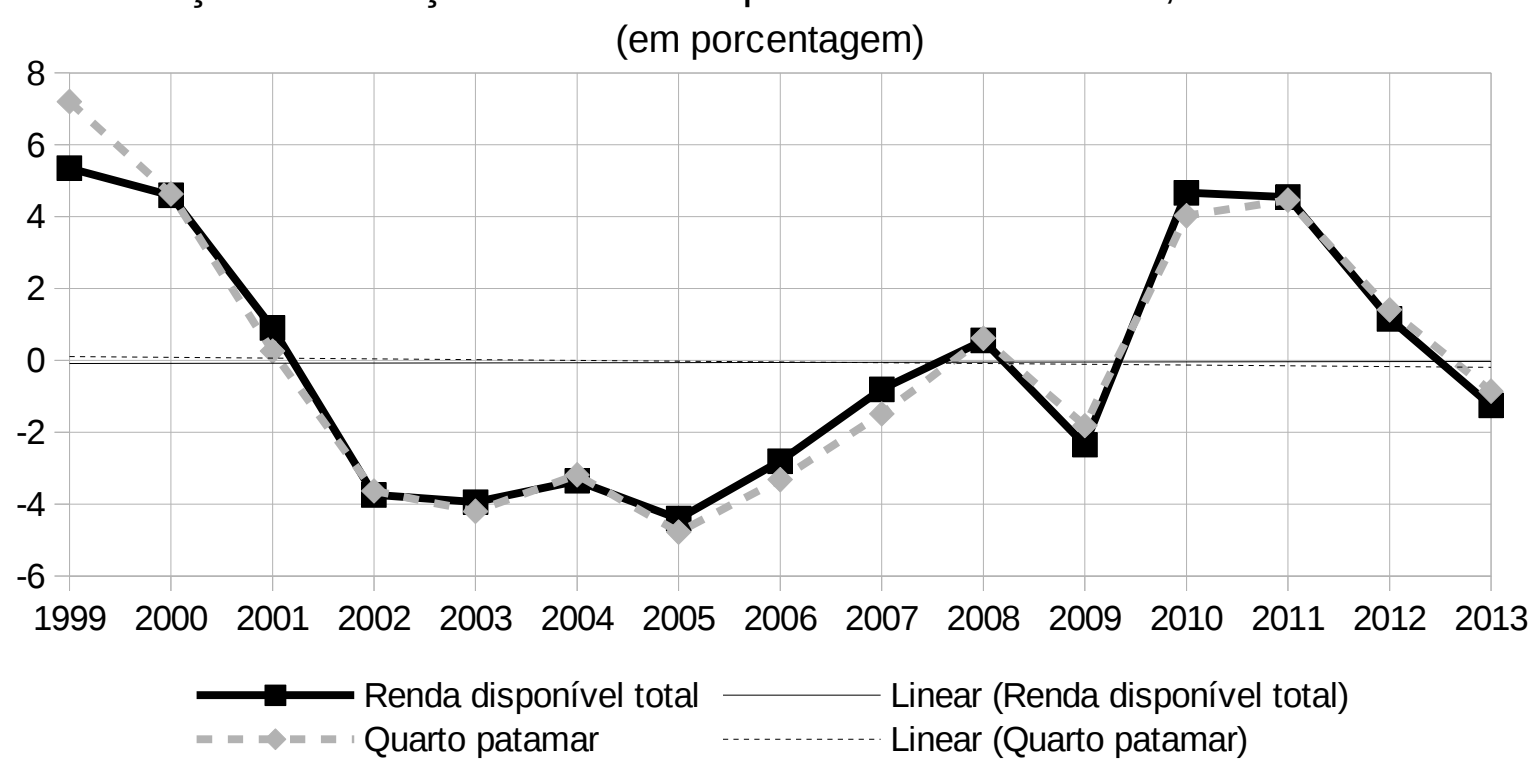

Fonte: IBGE e IPEA

O quarto patamar de renda apresentou oscilações suaves, sinalizando que o desempenho da renda disponível desse patamar e o da renda disponível total do Brasil apresentaram movimentos bastante similares. Entre 1999 e 2001, a renda disponível do quarto patamar sofreu arroxo, saindo de um ponto de cerca de dois pontos percentuais acima do desempenho da renda disponível total, para a posição de um ponto abaixo. A partir de então, as oscilações entre os pontos altos e baixo se mantiveram a menos de dois pontos percentuais. Para essa camada, os momentos de crise significaram perda de renda. Ainda, as chamadas políticas anticíclicas ${ }^{152}$ adotadas a partir de 2010 tiveram como resultado a melhoria da renda dos $30 \%$ seguintes à metade de cima da pirâmide de renda.

O quarto patamar de renda possuiu tendência negativa para suas oscilações em relação a oscilação da renda disponível total. Isso significa que apresentou oscilações mais fortes para baixo do que para cima, a partir da segunda metade. Entre 2006 e 2010, enquanto houve um período de prosperidade local, a renda disponível dessa camada apresentou crescimento abaixo do esperado.

152 Uma política anticíclica visa diminuir os impactos negativos das oscilações cíclicas do nível de atividade econômica. Para esse fim, o Estado deve atuar tanto no período de sobreaquecimento quanto no período de arrefecimento. Sobre o tema, ver: GÉLÉDAN, Alain \& BRÉMOND, Janine. Dicionário das Teorias e Mecanismos Económicos. Lisboa: Livros Horizonte LTDA, 1988. Pg. 284 - 285. 
Gráfico 5.8: Posição relativa da renda do quinto patamar de renda em relaçao a oscilação da renda disponível total do Brasil, 1999 a 2013 (em porcentagem)

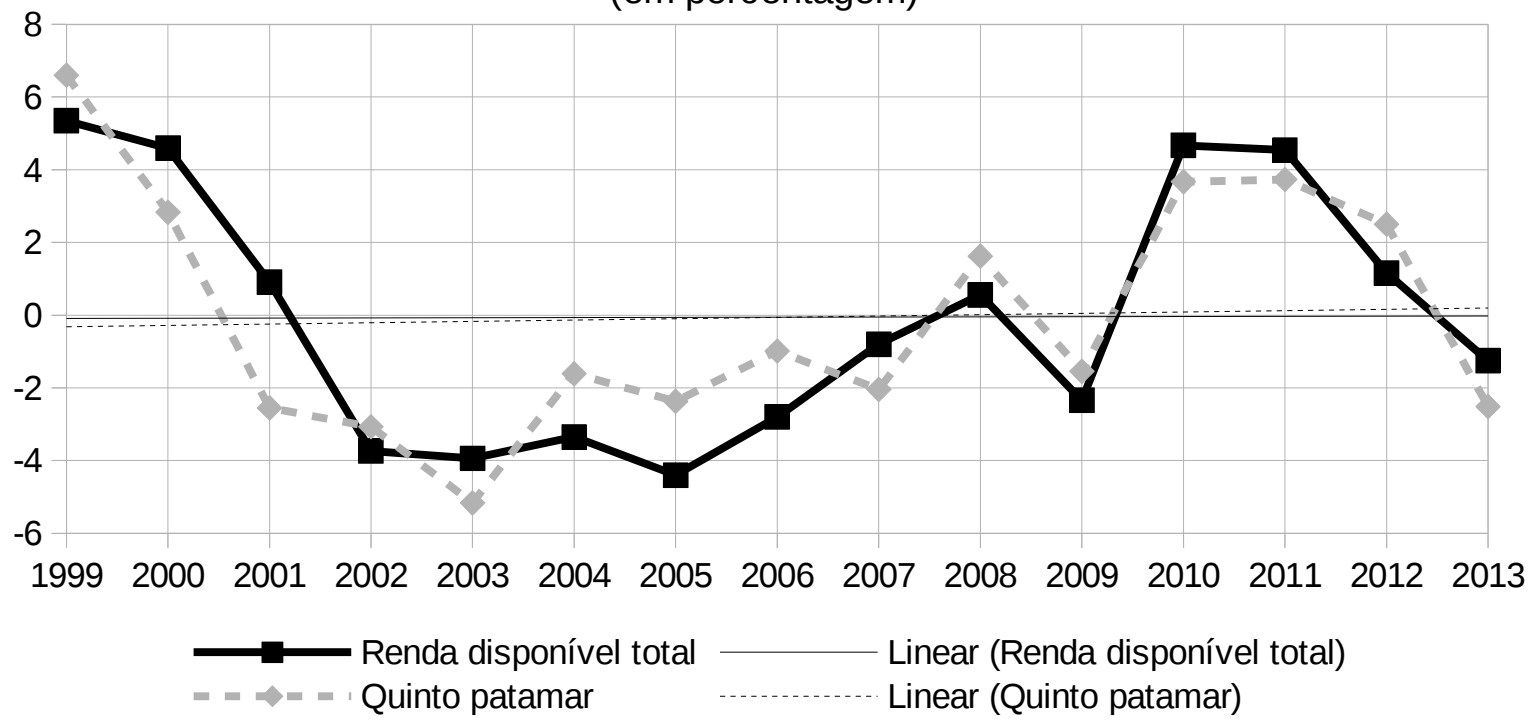

Fonte: IBGE e IPEA

Enquanto isso, o quinto patamar, que inclui os $20 \%$ da base da pirâmide de renda, possuiu perfil oscilatório menos estável, especialmente até 2007. Para essa camada, o entrecho de 1999 a 2013 se dividiu em três períodos diferentes. De 1999 a 2001, a renda dessa camada foi comprimida de forma mais severa do que o do total da renda disponível do país. As crises econômicas daquele período pesaram mais sobre os possuidores de menores rendimentos. De 2002 a 2006, os ganhos adquiridos no comércio exterior favoreceram o rendimento dessas camadas, o que explica que a renda disponível total do Brasil esteve abaixo do esperado, quando considerados os ganhos do quinto patamar de renda. De 2003 a 2006, os programas sociais do governo, somados à melhoria econômica do país, e ao aumento do salário dos trabalhadores, levou à melhoria de condições da população. Foi um período em que a miséria extrema diminuiu.

De 2007 a 2013, o perfil apresentou oscilação de cerca de 1 pontos em relação ao desempenho da renda disponível total do Brasil. Isso significa que, nesse período, a renda dos $20 \%$ da base da pirâmide de renda estabilizou sua relação com o restante da renda disponível do país. Ou seja, parou de crescer mais aceleradamente, mas também não sofreu perdas relativas frente a outras camadas.

Em parte, ao se atingir certa desconcentração de renda, as mudanças sociais do país diminuíram o ritmo. A crise econômica mundial de 2008 teve seu peso na limitação da 
continuidade da redistribuição de renda a favor dos mais pobres. No entanto, esse limite seria atingido em algum momento. Como a mudança se sustentava apenas no sucesso do comércio exterior e no incentivo do consumo, ao atingir-se um novo patamar de distribuição de renda, na ausência de novas políticas econômicas, ela tenderia a se estagnar. Foi isso que aconteceu a partir de 2008.

\subsection{RENDA DISPONÍVEL DAS CAMADAS E O CONSUMO}

A renda disponível das distintas camadas de renda da população é um fator que, conforme a literatura, influencia o consumo das famílias de um país. Cada camada possui uma distinta propensão marginal a consumir, que pode ser mensurada pela elasticidade entre o consumo das famílias e a renda da camada.

Na prática, a propensão marginal a consumir serve como uma medida para o nível de inserção na vida econômica nacional da camada. Quanto maior for a propensão a consumir, maior é o peso que a camada possui no consumo doméstico. Nesse sentido, para países dependentes, onde o efeito de comparação exerce pressão sobre o consumo da população, e as camadas mais pobres tem renda tão comprimida que mal conseguem se alimentar adequadamente, é de se esperar que o impacto a renda das camadas do topo da pirâmide de renda influa mais no consumo nacional do que a renda das camadas de baixo é capaz de fazer.

Isso pode acontecer apesar das camadas de baixo possuírem propensão marginal a consumir, em relação a sua renda, maior do que a das camadas do topo. Na teoria keynesiana, a constatação do impacto da renda das camadas no consumo nacional é relevante para formulação de políticas públicas. Caso as camadas do topo sejam as maiores responsáveis pelo consumo, o incremento da renda doméstica tenderá, em tese, ao incremento do consumo de luxo. Em médio prazo, se não houver redistribuição de renda, gerar-se-á um incremento de renda doméstica abaixo do multiplicador de investimento ${ }^{153}$. O multiplicador foi assim definido por Keynes:

Esta quantidade é de importância considerável, porque nos diz como o próximo incremento de produção terá que ser dividido entre consumo e investimento. Para $\Delta \mathrm{Y}_{\mathrm{w}}=\Delta \mathrm{C}_{\mathrm{w}}+\Delta \mathrm{I}_{\mathrm{w}}$, onde $\Delta \mathrm{C}_{\mathrm{w}}$ e $\Delta \mathrm{I}_{\mathrm{w}}$ são os incrementos de consumo e investimento; portanto $\Delta \mathrm{Y}_{\mathrm{w}}=\mathrm{k} \Delta \mathrm{I}_{\mathrm{w}}$, onde 1

153 Sobre o assunto, ver: RUGGLES, Richard \& RUGGLES, Nancy D. Contabilidade Nacional e Análise Macroeconômica. Lisboa: Livraria Sá da Costa editora, 1962. 
- 1/k é igual à propensão marginal a consumir.

Vamos chamar $\mathrm{k}$ do multiplicador de investimentos. Isso nos diz que, quando houver um incremento no investimento agregado, a receita aumentará em um montante que seja $\mathrm{k}$ vezes o incremento de investimento. ${ }^{154}$

Caso o aumento de renda doméstica em um país de renda concentrada seja acompanhado de uma redistribuição de renda favorável aos mais pobres, haverá aumento da propensão marginal a consumir do país. Isso leva, em tese, a um aumento do efeito multiplicador do investimento, que é a proporção que o consumo aumenta a cada novo investimento. Como a relação entre investimento e consumo é fixa a curto prazo, um aumento no investimento leva a um aumento do consumo em razão proporcional. Ou seja: a redistribuição de renda a favor das camadas de menor renda tende a aumentar a propensão ao consumo nacional, haja vista que a propensão marginal a consumir dos mais pobres tende a ser mais alta. Nessas condições, um novo investimento tenderá a causar maior incremento de renda, dado o efeito multiplicador do investimento e sua relação proporcional à propensão marginal a consumir. ${ }^{155}$

Deve-se destacar que, em um país dependente, existe o perigo do aumento de renda causar parcos novos investimentos, se o consumo for sempre ampliado através da importação, e se os investimentos forem muito dependentes de insumos e bens de capitais importados. Nesses casos, mesmo o multiplicador de investimento será inferior ao que deveria ser, devido a sangria de recursos para o exterior.

Em uma sociedade de consumo de massa, espera-se que um aumento de renda das camadas de baixo da pirâmide tenha alto impacto no aumento do consumo nacional. Isso ocorreria devido a alta propensão marginal a consumir dessas camadas, e de sua grande participação no consumo. Em uma sociedade dependente, onde parcela grande do consumo é de luxo, um aumento dos rendimentos das camadas de baixo pode gerar aumento pouco proporcional no consumo total do país. Isso por que as camadas de baixo da pirâmide social teriam pouca participação no consumo doméstico.

154 KEYNES, John Maynard. The General Theory Of Employment, Interest And Money. Nova Iorque: Cambridge University Press, 2013 (publicação : 1936). Pg. 115

155 Sobre o assunto, ver também: DILLARD, Dudley. La Teoria Economica de John Maynard Keynes. Teoria de una Economia Monetaria. Madrid: Aguilar, 1971. Pg. 88. 


\begin{tabular}{|c|c|c|c|c|c|c|c|c|}
\hline (1) & (2) & (3) & (4) & (5) & (6) & (7) & (8) & (9) \\
\hline Regressão & $\begin{array}{c}\text { Variável } \\
\text { independente }\end{array}$ & Coeficiente A & Coeficiente B & $\begin{array}{c}\text { Erro } \\
\text { Padrão A }\end{array}$ & $\begin{array}{c}\text { Erro } \\
\text { Padrão B }\end{array}$ & $\begin{array}{c}\text { Elasticidade } \\
\text { de B }\end{array}$ & $\mathbf{R}^{2}$ & DW \\
\hline $\begin{array}{c}5.9 \\
\mathrm{Cr}=\mathrm{a}+ \\
\mathrm{Yd}_{1}\end{array}$ & $\begin{array}{l}\text { Renda disponível } \\
\text { do primeiro } \\
\text { patamar de renda }\end{array}$ & 155,78 & 4,49 & 53,89 & 0,17 & 0,90 & 0,982 & 1,926 \\
\hline $\begin{array}{c}\mathbf{5 . 1 0} \\
\mathrm{Cr}=\mathrm{a}+ \\
\mathrm{Yd}_{2}\end{array}$ & $\begin{array}{l}\text { Renda disponível } \\
\text { do segundo } \\
\text { patamar de renda }\end{array}$ & 127,08 & 1,83 & 39,89 & 0,05 & 0,91 & 0,990 & 1,569 \\
\hline $\begin{array}{c}\mathbf{5 . 1 1} \\
\mathrm{Cr}=\mathrm{a}+ \\
\mathrm{Yd}_{3}\end{array}$ & $\begin{array}{l}\text { Renda disponível } \\
\text { do terceiro } \\
\text { patamar de renda }\end{array}$ & 475,48 & 1,05 & 27,82 & 0,03 & 0,68 & 0,992 & 1,256 \\
\hline $\begin{array}{c}5.12 \\
\mathrm{Cr}=\mathrm{a}+ \\
\mathrm{Yd}_{4}\end{array}$ & $\begin{array}{l}\text { Renda disponível } \\
\text { do quarto patamar } \\
\text { de renda }\end{array}$ & 699,39 & 2,90 & 18,83 & 0,06 & 0,53 & 0,994 & 1,226 \\
\hline $\begin{array}{c}\mathbf{5 . 1 3} \\
\mathrm{Cr}=\mathrm{a}+ \\
\mathrm{Yd}_{5}\end{array}$ & $\begin{array}{c}\text { Renda disponível } \\
\text { do quinto patamar } \\
\text { de renda }\end{array}$ & 745,52 & 11,12 & 26,13 & 0,34 & 0,49 & 0,988 & 0,928 \\
\hline \multicolumn{9}{|c|}{ Dados: IBGE e IPEA } \\
\hline
\end{tabular}

A tabela 5.4 traz os resultados de regressões lineares com a variável "consumo real total das famílias brasileiras” como variável dependente, e a renda disponível das distintas camadas como variáveis independentes. Cada linha representa o resultado de uma regressão diferente. A primeira coluna (1) assinala o número de referência da regressão. A coluna (2) traz os nome da variável independente utilizado na regressão. A coluna (3) traz o coeficiente “a”, que é a constante encontrada na regressão, de qual a série de dados parte. A coluna (4) traz o coeficiente “b”, que expressa quantos reais constantes de 2006 aumentam no consumo das famílias brasileiras para cada aumento de um real constante na renda disponível da camada em referência. Esse valor, em isolado, não permite uma leitura completa, pois ele pressupõe o aumento proporcional de outras variáveis. A coluna (5) traz o erro padrão da constante. A coluna (6) traz o erro padrão para o coeficiente "b". Considera-se que erros padrão superiores à metade do coeficiente simboliza a não-relevância da variável independente para explicar a variável dependente. A coluna (7) traz a elasticidade do coeficiente "B”, que expressa quantos por cento cresceu o consumo para cada um por cento de crescimento na renda do patamar de segmento de renda em análise. A coluna (8) traz o Rquadrado $\left(\mathrm{R}^{2}\right)$ da regressão, que é a capacidade explicativa da regressão. A coluna (9) contém o Durbin-Watson (DW) da regressão. Valores de DW inferiores ao $\mathrm{R}^{2}$ apontam que a regressão é espúria: dado o impacto de algumas conjunturas, a regressão pode não expressar corretamente os coeficientes. 
O que se observa é que, para o período entre 1999 e 2013, a renda disponível das camadas é capaz de explicar quase a totalidade das oscilações no consumo das famílias, com pequena espuriedade na regressão referente aos $20 \%$ da base. Essa espuriedade é resultado do crescimento acelerado da renda disponível da camada e do alto impacto que ela teve no consumo das famílias. A redução da miséria absoluta impactou no perfil de consumo das famílias mais pobres, e na participação dos mesmos na vida econômica nacional. No entanto, entre 1999 e 2013, o consumo brasileiro continuou sendo mais influenciado pelas oscilações na renda do $1 \%$ do topo da pirâmide e dos $9 \%$ seguintes a eles, no que se refere à mudança qualitativa no consumo.

Para cada um real a mais no consumo brasileiro, 26 centavos vieram do primeiro patamar de renda, e outros 26 centavos do segundo patamar. Juntos, os 10\% do topo foram responsável pela criação de 52 centavos de cada real a mais no consumo. O terceiro patamar foi responsável por 19 centavos de cada real a mais de consumo. O quarto patamar ficou com 15 centavos de cada 1 real de consumo. O quinto patamar consumiu apenas com 14 centavos de cada real consumido. O quarto patamar e o quinto patamar juntos representam $50 \%$ da população, mas foram responsáveis por apenas 29 centavos de cada real de consumo das famílias do Brasil.

O fato do consumo ser mais elástico para a renda dos 10\% do topo da pirâmide renda e menos elástico para o restante da pirâmide é condizente com uma sociedade de renda acumulada. Ainda que somada, a renda dos $90 \%$ de baixo da pirâmide foi pouco significativo para influenciar o nível de consumo do país, sendo responsáveis por apenas 48 centavos de cada novo real consumido.

A distribuição de renda que haja sido realizada no período não modificou a estrutura oligopolista do Brasil ${ }^{156}$, que favoreceu os $10 \%$ da população detentores de maior nível de rendimento. Parte da literatura entende que o monopolismo instalado nos países dependentes, ligado ao comércio de bens primários, faz parte do sistema neocolonial ${ }^{157}$. Esse, conforme

156 Observe-se sempre que se trata de uma estrutura oligopolista reflexa, montada de "fora para dentro" e que prioriza os interesses externos da acumulação capitalista. Ver: MAGDOFF, Harry. Imperialism: from the colonial age to the present. Nova Iorque e Londres: Monthly Review Press, 1978.; DOBB, Maurice. Theories Of Value And Distribution Since Adam Smith. Cambridge: Cambridge University Press, 1973.; DOBB, Maurice. Political Economy and Capitalism. Londres: Routledge, 1937.; BROWN, Michael B. The Economics of Imperialism. Harmondsworth: Penguin Books, 1974.; SWEEZY, Paul. The Theory of Capitalist Development. Londres: Dobson Books, 1942.

157 Ver MAGDOFF, Harry. Imperialism: from the colonial age to the present. Nova Iorque e Londres: Monthly Review Press, 1978. Pg. 110. 
Magdoff, se caracteriza pela manutenção do monopólio dos grandes negócios nas metrópoles, ao passo que se estabelece um oligopólio reflexo nos países dependentes. Assim, o controle sobre as matérias-primas continua sendo mediado pelos interesses das metrópoles ${ }^{158}$. Nos países dependentes, as sociedade se dividem entre um setor capitalista, e outro onde se reproduzem práticas de exploração não capitalistas ${ }^{159}$. Essa divisão permite a existência de largos contingentes de mão de obra excluída do mundo do trabalho, o que pressiona os salários para baixo. Evidentemente, essa estrutura permite taxas de lucro superiores para o setor exportador ${ }^{160}$, onde o capital estrangeiro também participa ${ }^{161}$.

O efeito da desproporção das taxas de lucro nos países dependentes é uma tendência da migração do capital local para o setor exportador, o que retarda o desenvolvimento dos demais setores, daí a dificuldade de formação de uma economia de massa ${ }^{162}$. Parte do aumento de renda resultante do comércio exterior gera um consumo local, que pode ser suprido por firmas estrangeiras instaladas no país. Disso resulta que mesmo a produção para um mercado local é dependente da poupança estrangeira ${ }^{163}$. Conforme ressaltaram Köse e Öncü, esse modelo de dependência leva a formação de uma camada empresarial local fortemente ligada aos interesses estrangeiros ${ }^{164}$.

Entre 1999 e 2013, o Brasil não formou uma sociedade de consumo de massa, onde o consumo da maioria sustenta macroeconomicamente a reprodução da riqueza na sociedade. Ao contrário, manteve-se o perfil de sociedade de consumo mais de luxo, e portanto mais dependente da exportação e da importação para sustentar o modelo de reprodução de riqueza, típica de países dependentes ${ }^{165}$. A dependência econômica tem como algumas de suas características: (i) a baixa produtividade local, que gera um ciclo de baixa capacidade de acumulação de capital ${ }^{166}$; (ii) elevações e quedas cíclicas na renda disponível, como fruto da

158 Ver: MAGDOFF, Harry. Imperialism: from the colonial age to the present. Nova Iorque e Londres: Monthly Review Press, 1978. Pg. 140

159 Ver: DOBB, Maurice. Theories Of Value And Distribution Since Adam Smith. Cambridge: Cambridge University Press, 1973. pg. 269 - 270

160 Ver: DOBB, Maurice. Political Economy and Capitalism. Londres: Routledge, 1937. pg. 244 - 245.

161 Ver: SWEEZY, Paul. The Theory Of Capitalist Development. Londres: Dobson Books, 1942. Pg. 99.

162 Ver: SWEEZY, Paul. The Theory Of Capitalist Development. Londres: Dobson Books, 1942. P. 301.

163 Sobre o assunto, ver: BROWN, Michael B. The Economics of Imperialism. Harmondsworth: Penguin Books, 1974. Pg. 284.

164 Ver: KÖSE, A. H. \& ÖNCÜ, Ahmet. "Imbalances In The World Economy And Congestion In The Periphery”. in: KÖSE, A. H. \& SENSES, F. et al. Neoliberal Globalization as New Imperialism. Nova Iorque: Nova Science Publishers, Inc., 2007. Pg. 56.

165 Ver FURTADO, Celso. O mito do desenvolvimento econômico. Rio de Janeiro: Paz e Terra, 1974.

166 Ver: PREBISCH, Raúl. Dinâmica do Desenvolvimento Latino-Americano. Rio de Janeiro: Fundo de Cultura Brasil, 1969. Pg. 38. 
transferência dos efeitos cíclicos do setor externo para o interno ${ }^{167}$; e (iii) a determinação dos setores dinâmicos da economia, das taxas de investimento, e dos níveis de renda, a partir das demandas externas ${ }^{168}$.

\subsection{A ELASTICIDADE MÓVEL DO CONSUMO}

Uma outra forma de analisar a relação entre o consumo das famílias brasileiras e a renda das camadas é através da elasticidade móvel. Essa forma permite verificar os ganhos e perdas momentâneos de participação das camadas no consumo. A prosperidade local impactou em ganhos distintos para os patamares de segmento de renda. Isso só pode ser verificado com a participação de cada segmento. Esta foi colocada em perspectiva histórica.

A teoria keynesiana chama a atenção para dois fatos: (a) a função consumo depende do patamar de renda em análise; e (b) ela é histórica. Conjunturas distintas tendem a impactar na função consumo global e na de cada patamar de renda. Daí a importância de analisar a elasticidade móvel do consumo das famílias brasileiras.

Gráfico 5.9: Participação móvel do primeiro patamar de renda para cada novo real no consumo total das famílias brasileiras, 1999 a 2013

(em centavos de reais 2006)

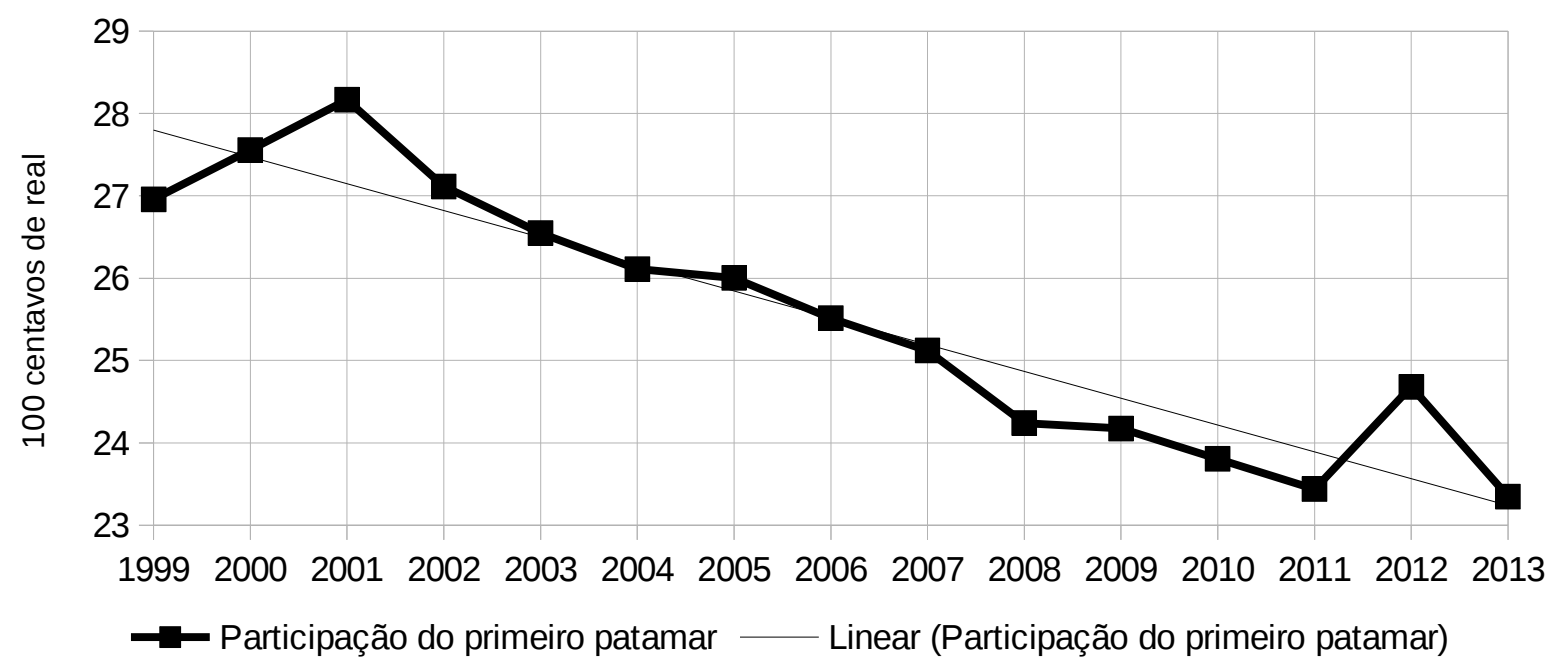

Fonte: IBGE e IPEA

167 Ver: FURTADO, Celso. Formação Econômica do Brasil. São Paulo: Editora Nacional, 1979. Pg. 231 - 232. 168 Ver: NOYOLA, Juan F. La Economía Cubana en los Primeiros Años de la revolución y otros ensayos. Mexico: Siglo Veitiuno. 1978. Pg. 242. 
No gráfico 5.9, há a representação da participação móvel do consumo do primeiro patamar de renda em cada novo real de 2006 no consumo das famílias brasileiras. A linha fina representa a tendência da referida participação. Verifica-se que, entre 1999 e 2001, os 1\% do topo aumentaram sua participação em cada novo real de consumo. A partir de então, apresentou queda de participação. Em 2001, era responsável por 28 centavos de cada novo real de consumo. Em 2013, era responsável por cerca de 23 centavos. Trata-se de uma queda de 5 centavos em cada novo real, em 12 anos. Foi uma perda de 1,55\% ao ano. Observa-se que, em 2012, essa camada aumentou pontualmente sua participação. A cada cinco anos, o consumo dessa camada sofreu pequena oscilação para cima, em relação a tendência de queda.

Apesar da queda ter sido grande, expressa uma estrutura de renda concentrada. Os 1\% do topo da pirâmide de renda foram responsáveis, no auge do período, por $28 \%$ do crescimento do consumo. No seu ponto mais baixo, foi responsável por mais de $23 \%$. A queda expressou uma perda de 18\% em relação a posição inicial, de 2001. Essa camada continuou a realizar seu consumo de luxo. Seu poder de compra, bastante acima do restante da população brasileira, permitiu um modelo de consumo que incluía a compra de bens de luxo de consumo durável importado (como carros).

\section{Gráfico 5.10: Participação móvel do segundo patamar de renda em cada} novo real de consumo total das famílias do Brasil, 1999 a 2013

(em centavos de reais 2006)

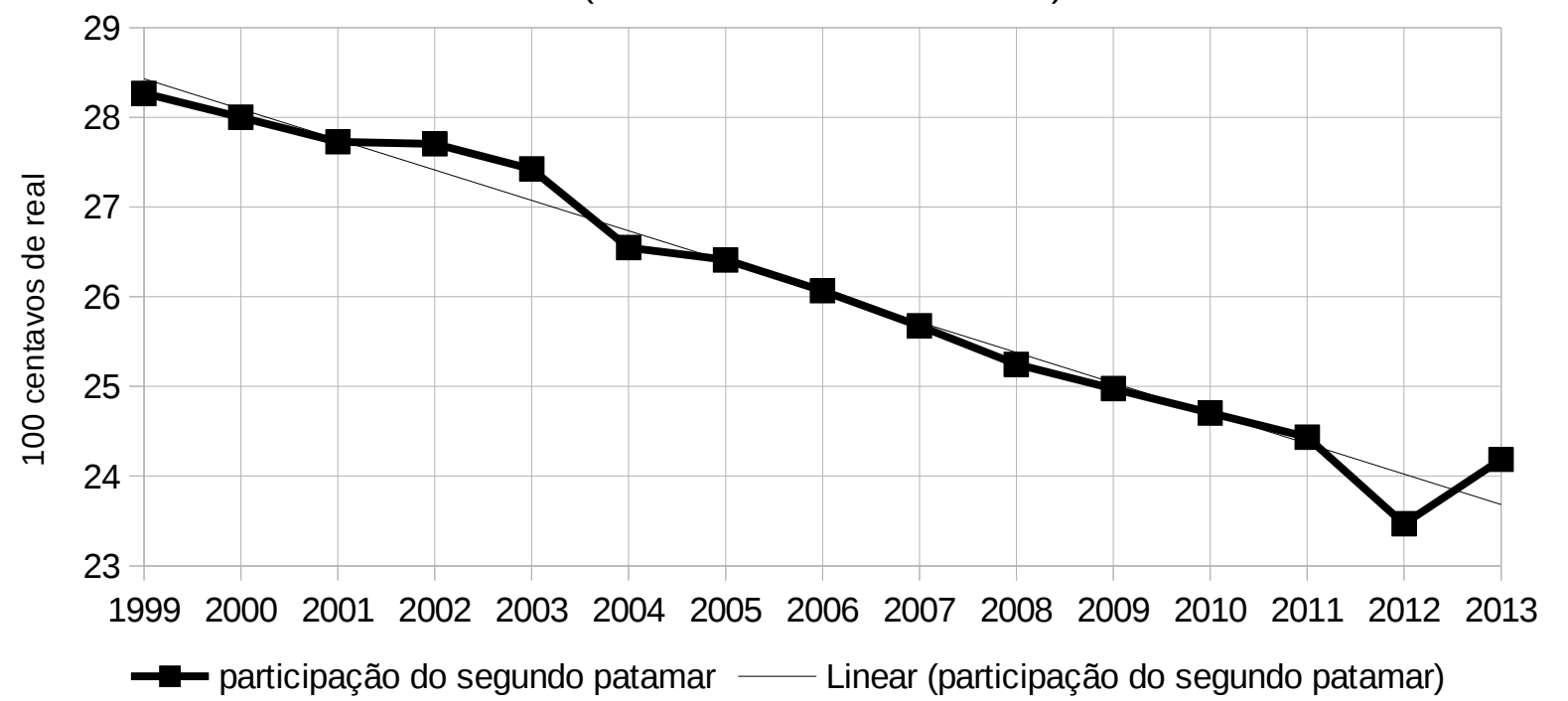

Fonte: IBGE e IPEA 
No gráfico 5.10, verifica-se a representação da participação dos $9 \%$ seguintes ao primeiro patamar de segmento de renda em cada novo real de consumo das famílias brasileiras, e sua linha de tendência. Entre 1999 e 2003, a participação do segundo patamar de renda frente ao consumo caiu aceleradamente, com reversão pontual em 2002. A partir de 2004, a participação desse patamar passou a diminuir com velocidade quase constante. Em 2012, houve uma queda mais acentuada na participação, com recuperação parcial em 2013.

O processo de perda da participação no consumo foi mais estável para o segundo patamar, havendo menos oscilações positivas ou negativas em torno da tendência de perda. Ao contrário do que aconteceu com os $1 \%$ do topo da pirâmide de renda, para os $9 \%$ seguintes, a participação no consumo começou a cair desde 1999. Se considerado o período integral, a queda de ambos os patamares foi de cerca de cinco centavos. No entanto, se considerado apenas o período de 2001 a 2013, a queda do segundo patamar de renda foi de cerca de 4 centavos. Foi uma perda de cerca de 1,13\% ao ano.

Entre 2001 e 2013, tanto o primeiro como o segundo patamar de renda aumentaram seu consumo bruto, mas houve queda relativa em relação ao consumo total do Brasil. Essa perda na participação fica mais significativa quando considerado os dois patamares do topo em conjunto. Em 2001, os 10\% do topo da pirâmide eram responsáveis por 56 centavos de cada novo real de consumo criado no Brasil. Em 2013, se tornaram responsáveis por apenas 48 centavos de cada novo real de consumo.

Gráfico 5.11: Participação móvel do terceiro patamar de renda para cada novo real no consumo total das famílias do Brasil, 1999 a 2012

(em centavos de reais 2006)

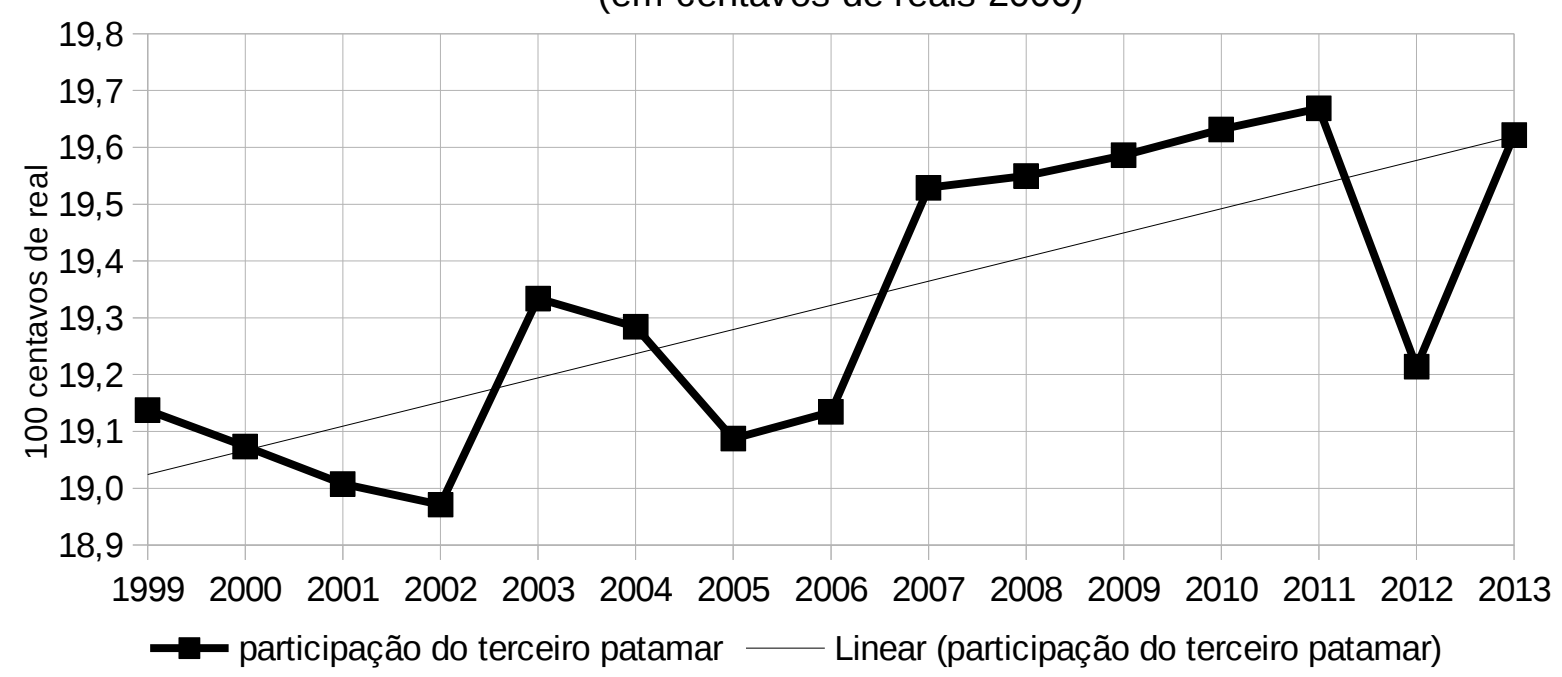

Fonte: IBGE e IPEA 
No gráfico 5.11, observa-se a participação móvel do terceiro patamar de renda (40\% seguintes ao segundo patamar) em cada novo real de consumo das famílias, em reais de 2006 . Observa-se que, em 2003, apresentou recuperação pontual da participação perdida entre 1999 e 2002. Em 2004 e 2005, voltou a perder participação. A partir de 2006, passou a apresentar ganhos relativos, com uma oscilação para baixo em 2012. Durante o período analisado a participação do terceiro patamar esteve bastante abaixo do observado para os 10\% do topo da pirâmide. Apesar de ter apresentado ganhos, entre o seu ponto mais baixo, em 2002, e o ponto mais alto, em 2011, aumentou sua participação em cada novo real de consumo das famílias brasileiras em menos de 1 centavo.

Na prática, essa camada média da população ampliou sua capacidade de consumo na mesma velocidade que houve crescimento da renda nacional. A recuperação econômica e a distribuição de renda não melhoraram a capacidade de consumo dessa grande parte da população. O aumento do consumo realizado por essa camada foi fruto do crescimento da economia local, e não da redistribuição de renda. Por ser um período de prosperidade local, essa camada pode ampliar seu consumo de forma normal, mantendo sua propensão marginal ao consumo em patamar estável e sem alterar sua participação no consumo brasileiro.

A ampliação da capacidade de consumo de ampla parcela da população é um dos pressupostos econômicos para eventual aumento da capacidade de resistência econômica às crises externas. É, também, um dos pressupostos para formação de uma economia de consumo de massas. No entanto, caso o aumento do consumo das chamadas camadas médias seja suprido por importações, e sustentado pelas exportações, pode haver ocorrido apenas uma expansão do mercado de luxo para as camadas médias em período de prosperidade econômica local.

Caso o período de recuperação econômica entre 2003 e 2010 tivesse se sustentado na ampliação do mercado interno e nos efeitos multiplicadores do aumento da renda local, os novos investimentos teriam levado a ampliação da renda das camadas médias. Dentro do modelo econômico keynesiano, espera-se que o os investimentos realizados como parte da ampliação da demanda agregada gere novos investimentos em setores diversificados. Isso leva à ampliação da participação de camadas médias. No que toca a participação do terceiro patamar de renda no consumo brasileiro, isso não ocorreu.

A dificuldade de ampliar o consumo dessas camadas também se explica pelo 
encarecimento dos serviços domésticos e de serviços fora do lar (almoço e jantar fora de casa, custo da educação, etc.). A estrutura social brasileira apresenta uma cisão entre os $50 \%$ de cima da pirâmide social e os 50\% de baixo. Parte do consumo das camadas de cima é o serviço prestado pelas camadas de baixo, que têm sido muito mal remuneradas. Entre 2003 e 2013, houve no Brasil um esforço para diminuição da miséria absoluta. Um dos resultados disso foi o aumento da renda das camadas mais baixas da pirâmide social.

Para as camadas médias, acostumadas a manter empregadas domésticas, porteiros, motoristas, e outros mais serviços pessoais, o consumo se tornou mais caro. Ao mesmo tempo, o real esteve sobrevalorizado. Isso permitiu que essa camada adquirisse maior número de bens importados, inclusive bens de luxo. Houve ampliação da compra de carro importado, de computadores, e roupas "de marca”. O terceiro patamar de renda experimentou efeito contraditório. Por um lado, pode consumir produtos importados similares aos consumidos pelas duas camadas de renda acima, satisfazendo o efeito demonstração. Por outro, diminuiu sua capacidade de manter empregados e serviçais, ao modelo da elite local.

\section{Gráfico 5.12: Participação do quarto patamar de renda para cada novo real no consumo total das famílias do Brasil, 1999 a 2013}

(em centavos de reais 2006)

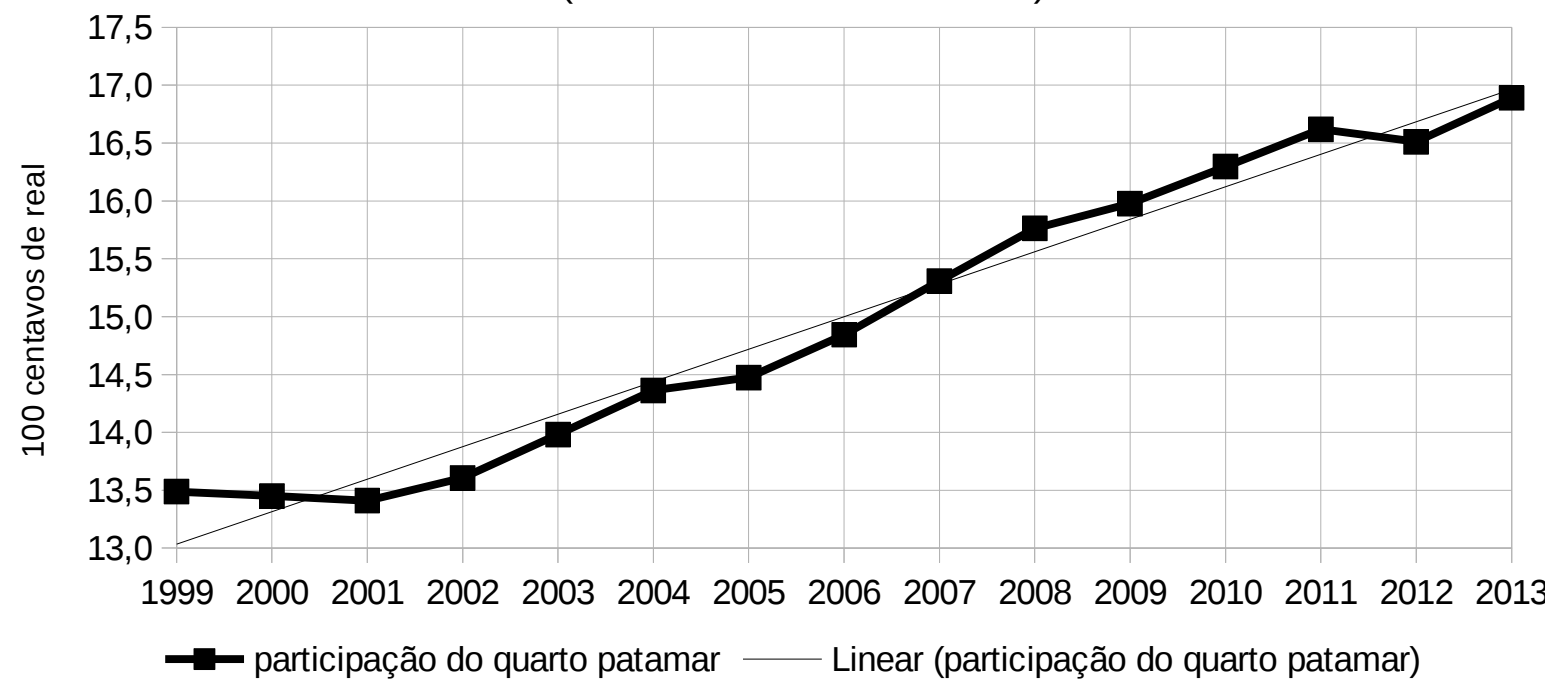

Fonte: IBGE e IPEA

O gráfico 5.12 traz a participação do quarto patamar de renda em cada novo real de consumo das famílias brasileiras, em reais de 2006. Observa-se que, entre 2001 e 2013, esses 30\% apenas sofreram queda na participação em 2005 e 2012. Desde 2003, a participação no consumo desse grupo cresceu aceleradamente. Em 2001, estava em pouco mais de 13 
centavos para cada novo real, e chegou a cerca de 17, em 2013. Tratou-se de uma ampliação de 1,94 por cento ao ano, entre 2001 e 2013.

Esta camada da população, do quarto patamar, tinha, até 2002, pouca relevância no consumo das famílias brasileiras. Apesar de não serem miseráveis, também tinham consumo bastante restrito. Era uma camada que ainda não tinha amplo acesso a eletrodomésticos e bens de consumo em geral. Em 2012, isso já havia mudado. Essa camada ganhou maior acesso a bens de consumo, e se tornou camada relevante para a economia local.

Embora tenha se tornado relevante, a participação máxima atingida foi de cerca de 17 centavos (em 2013). Trata-se de uma participação ainda muito pequena. Ou seja, o aumento da renda dessa camada não gerava aumento suficiente no consumo doméstico. Isso significa que não havia, naquele momento, no Brasil, uma sociedade de consumo de massa.

\section{Gráfico 5.13: Participação do quinto patamar de renda para cada novo real no consumo total das famílias do Brasil, 1999 a 2013}

(em centavos de reais 2006)

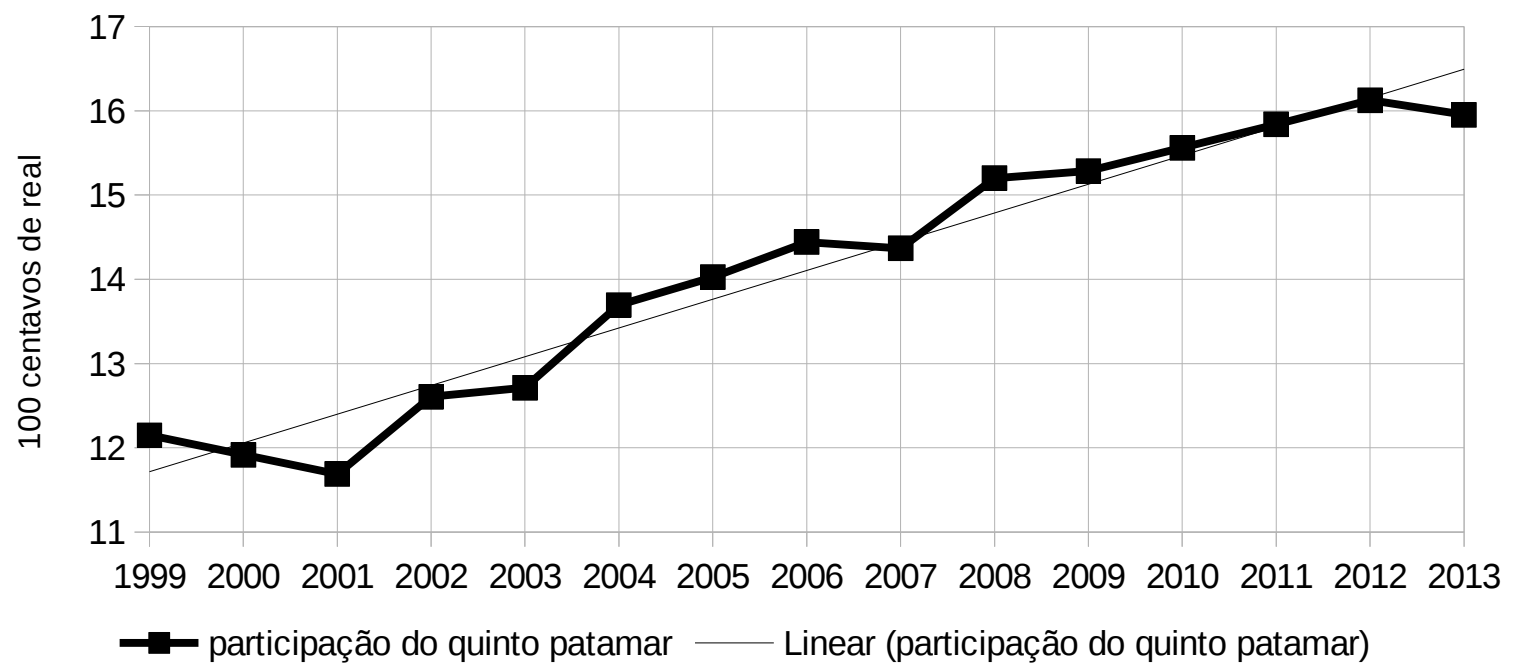

Fonte: IBGE e IPEA

O gráfico 5.13 traz a participação do quinto patamar de renda (os 20\% da base da pirâmide social) em cada novo real de consumo das famílias brasileiras em reais de 2006. Observa-se que, a partir de 2002, a participação aumentou aceleradamente, com quedas pontuais em 2003, 2007, e 2013. Esse patamar partiu de uma participação em cada novo real de consumo de menos de 12 centavos, em 2001. Em 2012, atingiram a participação de cerca de 16 centavos, o que é ainda pequena.

Samir Amin explica que países dependentes e subdesenvolvidos apresentam classes 
que vivem efetivamente em situação pré-capitalista. Na prática, a renda recebida pelo trabalho não é suficiente para sustentar a existência física de seus membros. Isso é possível pois (a) essas classes possuem alguma produção própria para subsistência; (b) possuem redes sociais que as auxiliam na sobrevivência material; (c) conforme os laços pretéritos são rompidos, elas são jogadas para miséria absoluta; e (d) quando não têm “mercado primitivos”, vivem uma ditadura de violência aberta do capital.

Em 2001, os 20\% pertencentes da camada mais baixa de renda do Brasil estavam efetivamente em condição pré-capitalista. Sua renda era absolutamente irrelevante para o consumo nacional. Eles pouco consumiam. A inanição era a marca da miséria. Eram pessoas que não possuíam moradia, e não tinham a certeza de um prato de comida ao dia. Em 2012, a pobreza ainda era grande. No entanto, os $20 \%$ mais pobres passaram a ganhar alguma relevância para o consumo das famílias. Isso foi fruto da diminuição da miséria absoluta, e do desaparecimento, ao menos momentâneo, da fome endêmica no Brasil. Os mais pobres finalmente se tornaram capazes de algum consumo.

O que se observa é que a recuperação econômica brasileira significou trazer os patamares de renda mais baixo do país para a vida econômica como consumidores. Deixaram de ser apenas mão de obra para serem compradores de mercadoria. A redistribuição de renda teve impacto no perfil do mercado consumidor brasileiro. O direito de comprar foi estendido da oligarquia e dos latifundiários para as camadas de baixo, sem que se reduzisse o nível de consumo dos de cima. Tão pouco foi capaz de criar um modelo econômico autocentrado, sustentado pelo consumo de massa doméstico.

\subsection{AS OSCILAÇÕES NO CONSUMO E NA RENDA DAS CAMADAS}

O processo de recuperação econômica brasileira, entre 1999 e 2013, foi marcado por fortes oscilações. O modelo dependente da economia brasileira seguiu o tradicional aspecto de “stop \& go” (pare e siga), que é a existência de breves períodos de crescimento seguidos por breves períodos de estagnação. Conforme ressaltam Alain Gélédan e Janine Brémond, países dependentes, que sofrem de restrições externas (dependem da importação para sustentar o crescimento do nível de atividade econômica), tendem a adotar modelos de pare e siga:

Num país constrangido, qualquer relançamento do consumo ou do 
investimento destinado a estimular o crescimento e o emprego pode traduzir-se num aumento de importações rapidamente insuportável. O acréscimo da produção pode, sem dúvida, ser parcialmente destinado à exportação, mas o que é próprio dos países constrangidos é o fato de encontrarem dificuldades em aumentar as suas exportações tão rapidamente como crescem as suas importações, tanto mais quanto uma fraca taxa de crescimento nos outros países limita as perspectivas de exportação.

Os países constrangidos são frequentemente levados a adotar políticas de 'stop \& go', que fazem suceder tentativas de relançamento a políticas de abrandamento da atividade. ${ }^{169}$

Uma das consequências desse modelo, para o Brasil, foi a predominância dos ciclos curtos na determinação dos investimentos. Isso fez com que a indústria local crescesse de forma pouco articulada ${ }^{170}$. Mas, conforme nota Ocampo, a resposta dada por cada país dependente influencia como o mesmo reagirá ao período de alta e, depois, de baixa dos preços:

O forte impacto dos choques nos mercados globais financeiros e de commodities não significa que os fatores específicos da região e do país não sejam importantes. Existe, no entanto, uma relação estreita entre os fatores e elementos específicos do país, e da região, e a conjuntura específica. Se um país experimenta um crescimento rápido ou não durante períodos de expansão econômica, no mundo em desenvolvimento como um todo, ou se pode mitigar ou evitar um colapso do crescimento durante o ciclo descendente, depende da interação entre as condições domésticas e a maneira pela qual o país é afetado pela dinâmica global ou regional do mercado. ${ }^{171}$

Daí a importância de se entender o impacto que o crescimento econômico, impulsionado pelo setor externo, teve no setor interno. No Brasil, entre 1999 e 2013, um fator relevante foi que o crescimento do consumo e da renda não coincidiram inteiramente. A população aumentou seu consumo apenas quando já havia segurança que a recuperação da renda se manteria por um tempo. No entanto, quando o crescimento da renda começou a minguar, tardou para diminuir o crescimento do consumo em forma proporcional.

O gráfico 5.14 traz as oscilações na renda disponível do primeiro patamar de renda

169 GÉLÉDAN, Alain \& BRÉMOND, Janine. Dicionário das Teorias e Mecanismos Económicos. Lisboa: Livros Horizonte LTDA, 1988. pg. $54-55$.

170 Sobre o tema, ver: RANGEL, Ignacio. Economia: Milagre e Anti-Milagre. Rio de Janeiro: Jorge Zahar, 1985. Pg. 36.

171 OCAMPO, José Antonio; VOS, Rob (Ed.). Uneven economic development. Nova Iorque: United Nations Publications, 2008. Pg. 13 - 14 
distribuído em torno das oscilações do consumo total das famílias brasileiras. Observa-se as linhas de tendência para ambos perfis oscilatórios. Os dados estão descritos em termos de distância relativa, em porcentagem, do valor esperado para o valor observado. Para o consumo, valores positivos assinalam que o crescimento do consumo dos brasileiros foi maior do que o esperado. As oscilações da renda da camada estão distribuídas em torno das oscilações do consumo. Descrito dessa forma, o que se verifica são os ganhos e perdas da capacidade de consumo do primeiro patamar de renda. Assim, para o primeiro patamar, valores acima de zero representam ganho na capacidade de consumo.

\section{Gráfico 5.14: Posição relativa da renda do primeiro patamar de renda em relação ao consumo total das famílias brasileira, 1999 a 2013} (em porcentagem)

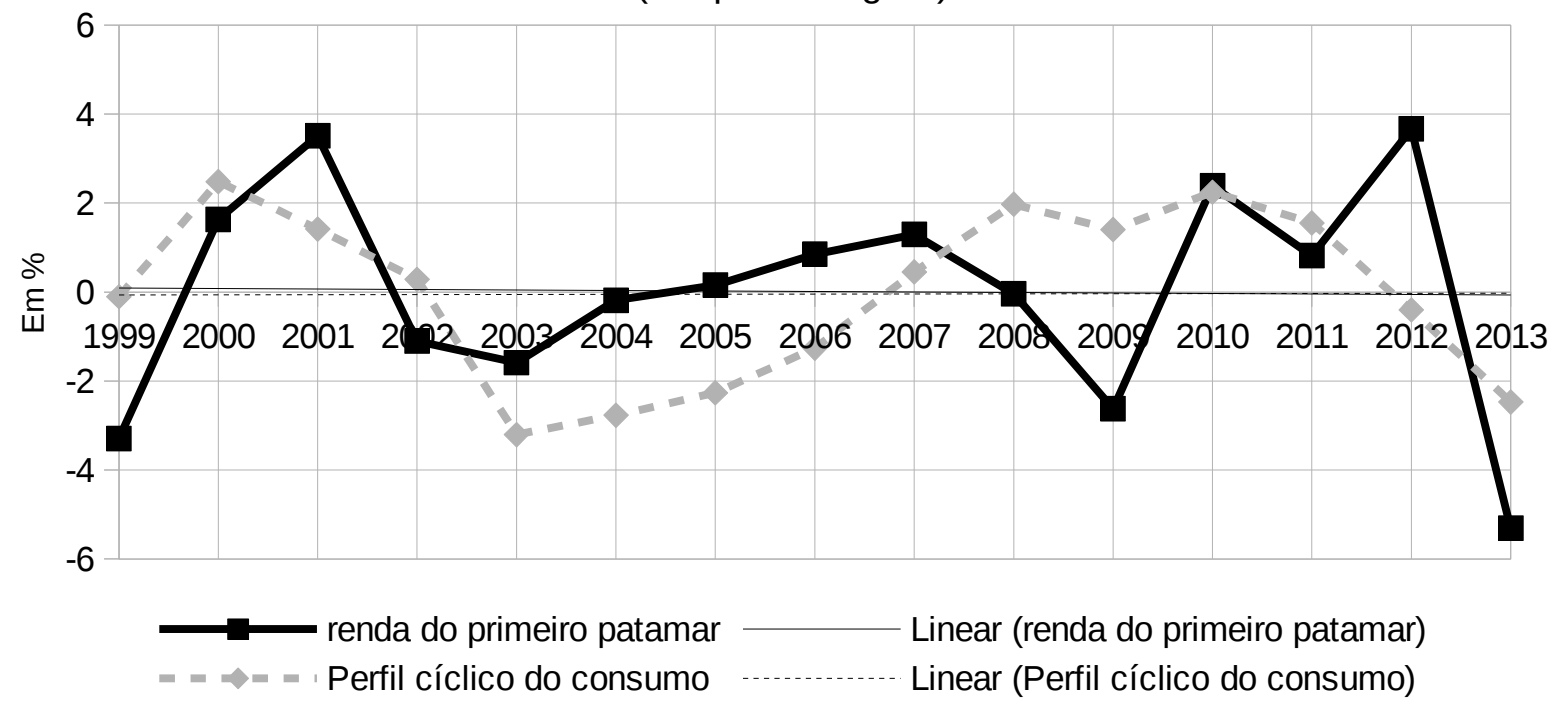

Fonte: IBGE e IPEA

Observa-se que, entre 1999 e 2000, o consumo esteve acima do esperado pela renda disponível do primeiro patamar. Em 2002, o consumo esteve abaixo do esperado perante a renda do primeiro patamar. Isso é fruto da concentração de renda ocorrida no período, que permitiu o crescimento dos rendimentos dos $1 \%$ do topo da pirâmide de renda em um período em que o consumo nacional ainda estava contingenciado devido a crise econômica. Observase que de 2000 a 2003, o consumo das famílias brasileiras passou por um período de crise, enquanto a renda dos $1 \%$ do topo da pirâmide social apenas apresentou perdas em relação ao esperado para o nível de consumo nacional a partir de 2002. Ainda assim, tirando o ano de 2001, a renda do primeiro patamar de renda esteve abaixo do nível de consumo nacional.

A maior oscilação para o primeiro patamar de renda se deu entre 2009 e 2012, quando 
ocorreu oscilação de 6 pontos percentuais. Nos períodos de crise, os 1\% do topo possuíram desempenho de rendimentos melhor do que outras camadas. Enquanto o consumo do país foi comprimido na crise de 2001-2003 e após a crise mundial de 2008, a renda dessa camada cresceu. Isso explica as baixas no perfil oscilatório do consumo em relação a renda do primeiro patamar em 2001 e 2012. Ainda, reforça a leitura que as crises econômicas são favoráveis à concentração de renda, e que pouco prejudica os 1\% do topo da pirâmide de renda. Observa-se, através da linha de tendência da renda do primeiro patamar, que durante o período entre 1999 e 2013, essa camada manteve, em média, sua capacidade de consumo estável.

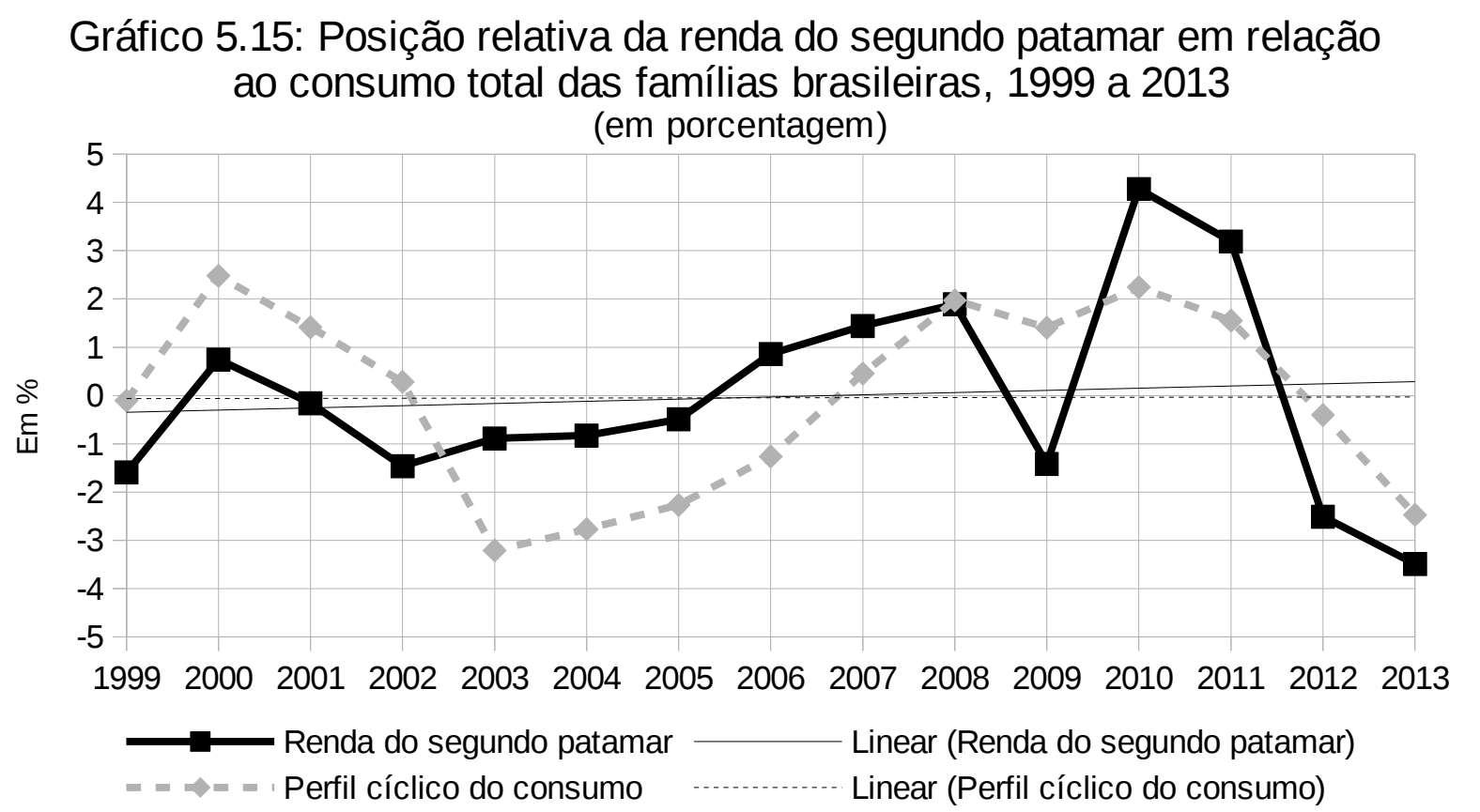

Fonte: IBGE e IPEA

Para o segundo patamar de renda, o nível de consumo esteve acima do desempenho da renda, entre 1999 e 2002. De 2003 a 2006, o cenário se inverteu. O consumo se encontrou abaixo do esperado para a renda disponível daquela camada. Isso significa dizer que o crescimento da renda não impactou imediatamente ou completamente no consumo total do Brasil. Entre 2003 e 2006, o Brasil ainda estava se recuperando da pesada crise anterior.

O uso de parte da renda para realização de investimentos e a desconfiança quanto a aparente prosperidade foram fatores que influenciaram a resistência ao aumento do consumo, nos primeiros anos de recuperação econômica. Ainda, a indústria local havia sido dilapidada no período anterior. Para que o consumo aumentasse era necessário o aumento da oferta de 
produtos, que só ocorreu posteriormente, com o aumento das importações para consumo. A renda do segundo patamar apresentou tendência de oscilar acima do consumo. A partir de 2006, sobrou renda desse patamar, que apresentou ganhos na capacidade de consumo. Entre 1999 e 2013, o segundo patamar de renda apresentou ganhos líquidos na capacidade de consumo.

\section{Gráfico 5.16: Posição relativa da renda do terceiro patamar em relação ao consumo total das famílias brasileiras, 1999 a 2013 (em porcentagem)}

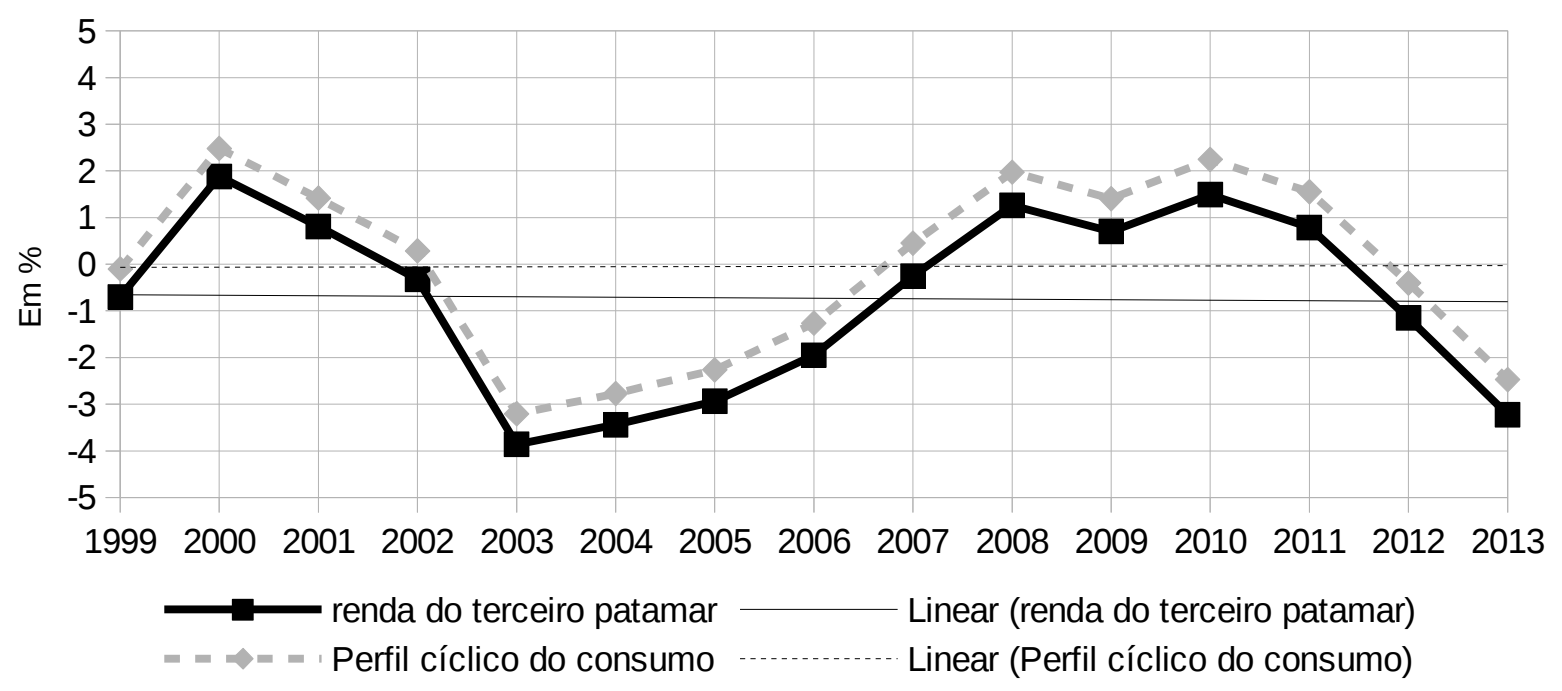

Fonte: IBGE e IPEA

As oscilações da renda disponível do terceiro patamar de renda acompanhou as oscilações no consumo total das famílias brasileiras, sempre se mantendo pouco menos de um ponto percentual abaixo. Isso é resultado de: (a) estabilidade na propensão marginal a consumir das camadas médias da sociedade brasileira; e (b) da ausência de perdas ou ganhos relativos na distribuição de renda nacional.

O desempenho da renda e do consumo dessa camada esteve ligado ao desempenho do dinamismo da economia local. Observa-se que o período de recuperação da economia local foi também o período de recuperação da capacidade de consumo dessa camada. Entre 2003 e 2008, enquanto o bom desempenho no setor externo da economia brasileira haja se mantido, essa camada adquiriu ganhos brutos. Em 2009, entrou em um período de 3 anos de estagnação, entrando em declínio em 2012.

Na verdade, os $40 \%$ seguintes aos $10 \%$ do topo da pirâmide social foram a verdadeira "base” do sistema. O consumo nacional e o consumo dessa camada coincidiram, porque foi a 
renda dessa camada que determinou o consumo das famílias. Trata-se de uma camada numerosa (40\% da população), e com poder de compra relevante. Abaixo dela, os 50\% da base da pirâmide social possuíram pouca inserção no mercado consumidor. Disso resultou que parte considerável do desempenho da atividade econômica do Brasil coincidiu com o desempenho da renda disponível do terceiro patamar de renda.

\section{Gráfico 5.17: Posição relativa da renda do quarto patamar em relação ao consumo total das famílias do Brasil, 1999 a 2013 (em porcentagem)}

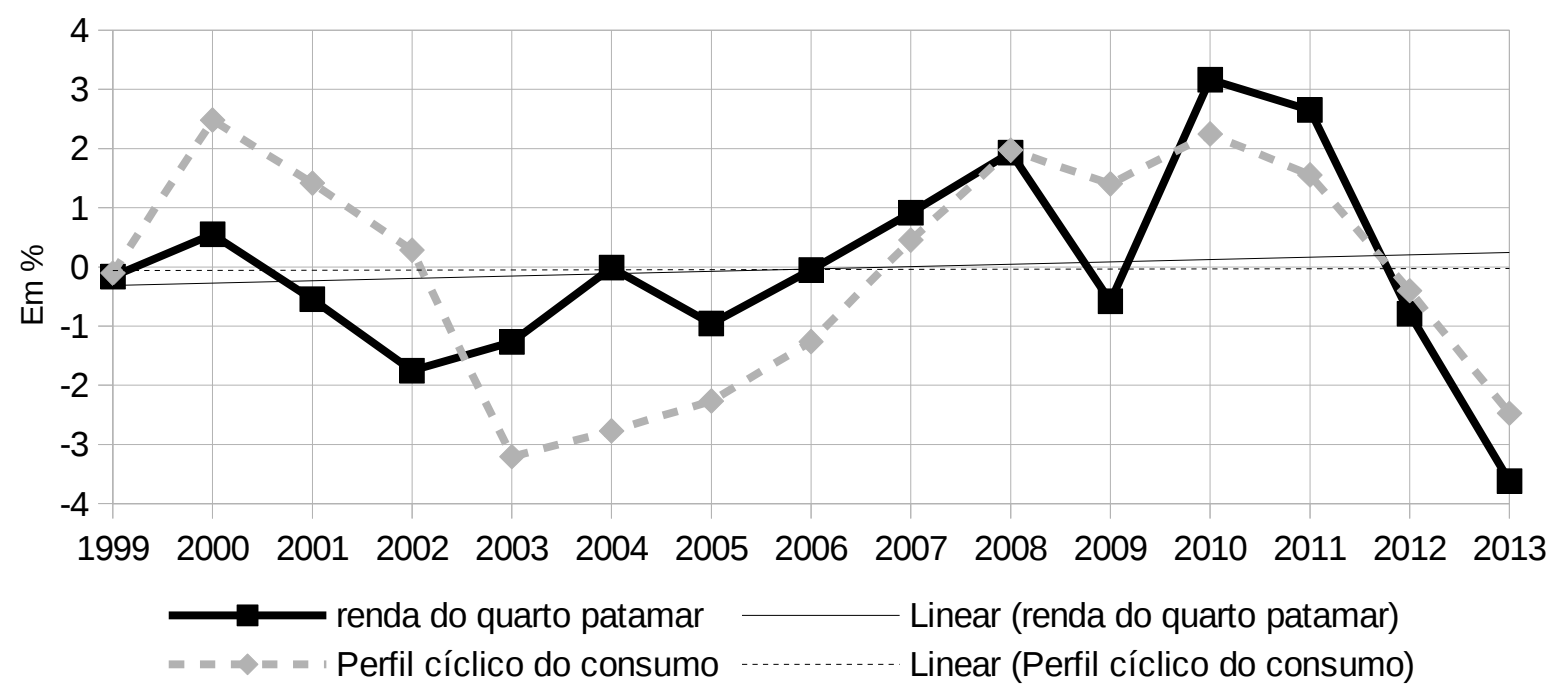

Fonte: IBGE e IPEA

O gráfico 5.17 traz as oscilações da renda disponível do quarto patamar de renda em relação ao perfil oscilatório do consumo, para os anos entre 1999 e 2013. Os valores acima de zero expressam um crescimento do consumo acima do esperado. O gráfico descreve o movimento da capacidade de consumo do quarto patamar de renda. Valores acima de zero para a renda disponível do quarto patamar de renda descrevem ganho na capacidade de consumo daquela camada. De 1999 a 2002, o consumo esteve acima do esperado para a renda do quarto patamar. Em 2002, o consumo sofreu queda relativa considerável, apenas começando a se recuperar em 2004. Nesse período, a renda do quarto patamar de renda apresentou bom desempenho. Mas foi só a partir de 2007 que essa camada apresentou ganho na capacidade de consumo. Entre 1999 e 2013, o quarto patamar apresentou ganho na capacidade de consumo.

A desaceleração do aumento da renda disponível e o incentivo ao consumo como parte da "política anticíclica" do governo levaram a, em momento de crise, o consumo 
continuar crescendo quando a renda já não crescia mais. Diante da crise mundial de 2008, o governo local manteve suas políticas de distribuição de renda, o que facilitou o crédito para os consumidores. Apesar da euforia local com o aparente sucesso da política de incentivo ao consumo, em 2010 já estava claro que o consumo deixaria de crescer se a renda não voltasse a crescer.

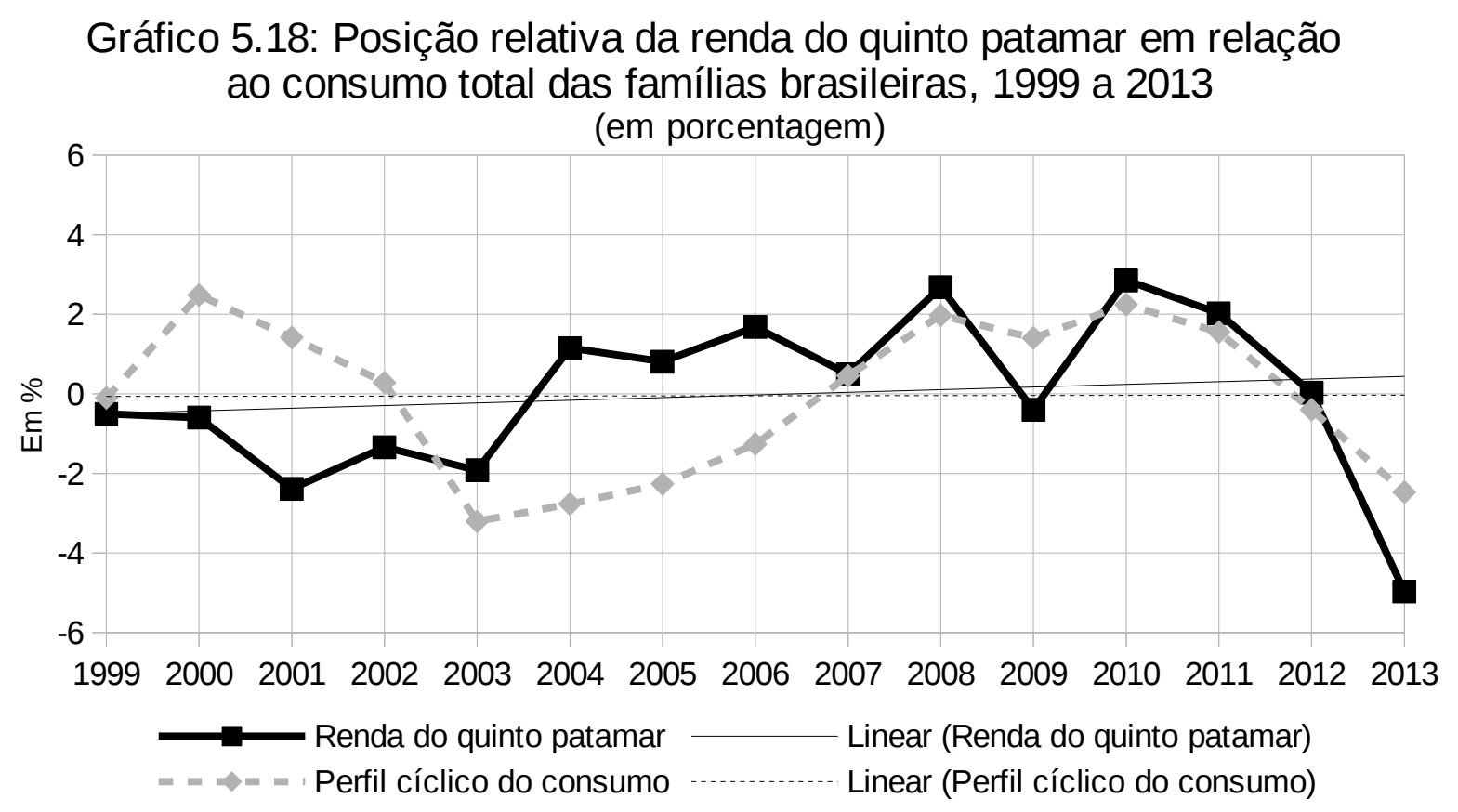

Fonte: IBGE e IPEA

Para os $20 \%$ da base da pirâmide de renda (quinto patamar), a queda relativa entre 2010 e 2013 foi maior, atingindo quase 8 pontos percentuais de queda na capacidade de consumo. Para essa camada, houve ganho na capacidade de consumo desde 2004. Os ganhos de renda dessa camada anteciparam o aumento do consumo nacional. Isso foi fruto da forte recuperação da renda dessa camada. A melhoria da renda dos mais pobres não impactou no aumento imediato do consumo. Em 2009, a crise econômica afetou fortemente a capacidade de consumo do quinto patamar de renda. Mas houve recuperação pontual em 2010.

A resposta dada, entre 2010 e 2012, foi a aprovação de novos pacotes de incentivo econômico. Entre diversos programas (Minha casa, Minha vida; Brasil Maior, etc.), o governo buscou liberar parte da renda retida dos trabalhadores e diminuir os custos da indústria do país, com corte de taxas e impostos. O intuito era, segundo os Boletins do Banco Central do Brasil, fortalecer a indústria local e garantir a expansão de renda e de consumo das distintas camadas de renda. A renda continuou a crescer pouco entre 2012 e 2013, levando o consumo 
crescer acima da renda, pelo endividamento.

No Brasil, a crise econômica de 2008 apresentou problemas distintos daqueles observados em países desenvolvidos. A crise levou a uma desaceleração da economia brasileira em 2009. Mas, em 2010, devido ao desempenho da economia chinesa, houve largo aumento da demanda por soja e minério de ferro. Como resultado, verificou-se ampliação das exportações brasileiras. Parte dessa ampliação foi imediatamente contrastada pelo aumento da importação de bens de consumo. Por exemplo, em 2014, os brasileiros gastaram 25 bilhões de reais em automóveis importados e 21 bilhões em pares de sapatos (entre importados e produzidos no país).

A prosperidade momentânea também permitiu novo impulso para desconcentração de renda. Mas o modelo já estava esgotado, para o Brasil. O aumento do consumo não gerou aumento suficiente do investimento local em produção. Ao contrário, a demanda expandida foi compensada pela expansão da importação de bens de consumo. Quando o então presidente da China, Xi Jinping, anunciou, em 2013, a reforma econômica que levaria a China a importar e exportar menos, a crise econômica já estava a ser instalada no Brasil. 


\section{UM DESMONTE DA INDÚSTRIA LOCAL}

Caso se considere as teorias de Prebisch, de Samir Amin, e de Ragnar Nurkse para analisar a recuperação econômica brasileira, entre 1999 e 2013, a caracterização dos problemas enfrentados no período pode se tornar mais clara. Para Ragnar Nurkse, um dos principais problemas encarados por países subdesenvolvidos tem sido a baixa acumulação de capital. ${ }^{172}$

A falta de investimento desses países era resultado da baixa produtividade local, que gerava baixa capacidade de produção de excedente econômico. Como havia baixo excedente, havia baixa poupança, e portanto pouco investimento. Com baixo investimento, havia baixa acumulação de capital. Por sua vez, com pouca acumulação de capital, havia baixa produtividade local.

A baixa produtividade local tinha como uma de suas consequências a baixa remuneração do trabalho. Isso era fator importante para existência de mercados relativamente pequenos. Com mercados restritos, havia pouco incentivo para novos investimentos privados, haja vista que não haveria demanda suficiente para uma nova oferta de produtos locais. Enquanto isso, o setor exportador não enfrentava dificuldade similar, haja visto que sua produção estava voltada para demanda externa ${ }^{173}$.

Por outro lado, a ampliação do mercado não era, na visão de Nurkse, entre outros, tarefa simples. Dada a baixa produtividade local, a tentativa de ampliação da demanda tendia a atrair investimento para os setores comerciais, mais lucrativos. Caso se adotasse maior abertura comercial internacional, os investimentos estrangeiros tenderiam a ser realizados em setores exportadores, onde haveria demanda suficiente para sustentar os novos investimentos. O problema era que, nesses países, os setores exportadores eram setores de produtividade relativamente pequena.

Caso se considere a tese de Prebisch ${ }^{174}$, o problema do desenvolvimento industrial

172 Sobre o tema ver: NURKSE, Ragnar. Problema da Formação de Capital em Países Subdesenvolvidos. Rio de Janeiro: Civilização Brasileira, 1957.

173 Sobre o assunto, ver também: SANTOS, Milton. O Espaço Dividido: Os Dois Circuitos da Economia Urbana dos Países Subdesenvolvidos. São Paulo: Edusp, 2004.

174 Sobre o tema ver: PREBISCH, Raúl. Dinâmica do desenvolvimento latino-americano. Rio de Janeiro: Editora Fundo de Cultura, 1969. 
ganha nova complexidade. As estruturas sociais locais de países em desenvolvimento representavam gargalos. A propriedade da terra e a concentração de renda eram fatores dificultadores para a aceleração da industrialização local. Ainda, como as relações internacionais tendiam para deterioração dos preços dos produtos primários, exportados por esses países, a industrialização local se dava em ciclos, e com tendência a déficit. Apenas quando havia alta dos preços dos bens primários, havia excedente no comércio exterior favorável a esses países. No entanto, nessa situação, os novos investimentos eram feitos em setores exportadores. Quando os preços voltavam a cair, os países se viam forçados a reduzir sua importação. Contraditoriamente, caso desejassem se industrializar, esses países teriam que ampliar sua importação de bens de capital e insumos.

Esse ciclo vicioso foi descrito por Samir Amin ${ }^{175}$ em um modelo de quatro setores: (i) setor exportador; (ii) consumo de massa; (iii) consumo de luxo; e (iv) produção de bens de capital. Os países dependentes tendiam, para ele, a ter os setores exportadores e de consumo de luxo mais avantajados. Uma das consequências disso é que o crescimento econômico não levava a formação de consumo interno e produção de bens de capital de forma relevante.

Uma das promessas da chamada globalização era que, a partir da liberalização dos mercados, haveria possibilidade de especialização de todas economias do mundo. Isso levaria à formação de um único mercado mundial, onde os países exportariam um conjunto específico de produtos para importar o restante de tudo que consomem. No entanto, a “expansão do mercado mundial” foi assimétrica. As liberalizações significaram maior abertura das economias locais dos países subdesenvolvidos ao capital estrangeiro, fortalecendo o caráter dependente daquelas economias ${ }^{176}$. Isso porque (a) os capitais estrangeiros são sobre-remunerados; (b) aumentou-se a já excessiva elasticidade-renda das importações dos países subdesenvolvidos; e (c) as eventuais melhorias nos preços das exportações são de curta duração, e apresentam tendência declinante ${ }^{177}$.

Entre os anos 1999 e 2013, somou-se à dependência como característica estrutural da economia brasileira, a manutenção da política econômica contrária ao desenvolvimento da

175 Sobre o tema ver: AMIN, Samir. Capitalismo periferico y comercio internacional. Buenos Aires, Ed. Periferia, 1974.

176 Sore o assunto, ver: BELLUZZO, Luiz Gonzaga de Mello; TAVARES, Maria da Conceição. "Desenvolvimento no Brasil: relembrando um velho tema”. In: Políticas para a retomada do crescimento: reflexões de economistas brasileiros. Brasília: IPEA/CEPAL, 2002-p. 149-184, 2002. pg. 6

177 Sobre o assunto, ver também: BARBOSA, Wilson do Nascimento. Crescimento no Brasil e Flutuações no Comércio exterior. Universidade de Lund - Suécia. 1976. Traduzido pelo autor do inglês. Pg. 45 - 46 
indústria local. Em especial, optou-se por manter a taxa de câmbio sobreapreciada, resultando na redução da participação dos produtos manufaturados nas exportações brasileiras ${ }^{178}$. Eleutério Prado chamou a atenção que a sobreapreciação não é fenômeno isolado, e não aconteceu apenas no Brasil. Na verdade, trata-se de uma política econômica voltada a interesses financeiros, pressionada desde fora, e abraçada pelo setor privado brasileiro. Parte do empresariado residente no Brasil também lucrou com o aumento da dependência econômica local ${ }^{179}$.

Pode-se, portanto, afirmar que a manutenção da dependência local também está ligada ao caráter colonial da elite doméstica. Nas palavras de Marcos Cordeiro:

É importante compreender que, do ponto de vista dos países periféricos, as elites locais sempre foram aliadas dos grupos internacionais, como um agente interno que se submete aos ditames de grupos industriais e financeiros. Similar às antigas elites coloniais ao interesses metropolitanos. O papel da elite local na reprodução do sistema capitalista em nível mundial é o de manter baixa a produção das mercadorias necessárias à acumulação de capitais. A introdução de técnicas modernas foi (e é) direcionada para os setores vinculados à exportação de bens primários ou insumos industriais, aquilo que hodiernamente denominamos de commodities. Os ganhos obtidos com a exploração de mão de obra e dos recursos naturais, abundantes nos países periféricos, não se direcionam para a ampliação da capacidade produtiva do país ou ainda para o aumento geral da produtividade da economia. De forma geral, aquilo que Marx chamava de "mais valia" era (e é) consumido para garantir um padrão de vida faustoso e não para ser reinvestido em novas tecnologias ou ainda na capacidade da mão de obra. Nesse sentido, compreender a lógica da acumulação de capital é importante para compreender como este processo é bloqueado na periferia, tanto por interesses avessos à criação de concorrentes no mercado internacional em segmentos de maior valor agregado, como pelos interesses internos que lucram com uma população mal remunerada, mal educada e despolitizada. ${ }^{180}$

O empresariado local, evidentemente, procura (a) altas taxas de lucro para seus investimentos; e (b) sustentar o estilo de vida mimetizado das elites estrangeiras. Enquanto as

178 Ver: BRESSER-PEREIRA, Luiz Carlos. A quase-estagnação brasileira e sua explicação novodesenvolvimentista. Escola de Economia de São Paulo, Getulio Vargas Foundation (Brazil), 2014. Pg. 6.

179 Para uma discussão sobre o tema, ver: PRADO, Eleutério. Das explicações para quase estagnação da economia capitalista no Brasil. Revista de Economia Política, vol 37. n 3 (148), pg. 478 - 503. Julhosetembro/2017. Pg. $494-500$.

180 PIRES, Marcos Cordeiro. "Reflexões Sobre Acumulação de Capitais, Desenvolvimento e Subdesenvolvimento”. In: SOUZA, Luiz Eduardo Simões de (org.). Ideologia e Ciência Econômica: Mais estudos de caso. São Paulo, LCTE, 2017. Pg. 144. 
taxas de lucro do setor exportador, ou do mercado financeiro, são suficientemente grandes, não há porque realizar investimentos com menores taxas de retorno em setores industriais. Em economias de mercado, não há porque esperar que o empresariado de um país esteja interessado no desenvolvimento de longo prazo do mesmo. Mas, hipoteticamente, caso houvesse uma redistribuição de renda local, formando um mercado interno vultoso, e ocorressem investimentos na indústria para consumo (aumentando a produtividade média local), poderia haver aumento da taxa de lucro local. Para isso, seria necessário, antes, neutralizar as restrições externas do país através de uma política cambial hábil, permitindo que houvesse transferência dos ganhos com as exportações para a indústria manufatureira local $^{181}$.

\subsection{CARÁTER EXÓGENO DA PROSPERIDADE LOCAL}

Ao se verificar a desconcentração de renda, que se deu entre 2001 e 2013, uma questão que se levanta é: “teria sido a redução da desigualdade de renda causa ou consequência da prosperidade econômica local existente no período?”. O governo da época afirmava que eram suas políticas públicas que estavam desconcentrando a renda e, como consequência gerando maior dinamismo econômico para o Brasil.

Se esse fosse o caso, poderia se interpretar que, no Brasil, houve aplicação, naquele período, de uma "política keynesiana de incentivo econômico", através da ampliação da demanda agregada da sociedade. Ou seja, o governo estava aumentando a renda da população, o que teria gerado maior consumo. Por sua vez, o aumento do consumo gerava novos incentivos para investimento.

No entanto, para que isso funcionasse seria necessário que a economia brasileira tivesse se comportado com uma economia de tipo "fechada", ou "autocentrada"182. Significaria que a economia brasileira não se comportou como economia dependente. Que a demanda interna foi atendida de acordo com a capacidade produtiva local. Isso não aconteceu.

181 Sobre o assunto, ver: BRESSER-PEREIRA, Luiz Carlos. La nueva teoría desarrollista: una síntesis. Economía. UNAM, v. 14, n. 40, p. 48-66, 2017

182 Sobre o assunto ver: RUGGLES, Richard \& RUGGLES, Nancy D. Contabilidade Nacional e Análise Macroeconômica. Lisboa: Livraria Sá da Costa editora, 1962; e AMIN, Samir. Capitalismo periferico y comercio internacional. Buenos Aires, Ed. Periferia, 1974. 


\section{Gráfico 6.1: Riqueza relativa dos $10 \%$ mais ricos em relação aos $50 \%$ mais pobres \\ (proporção em relação aos 50\% mais pobres)}

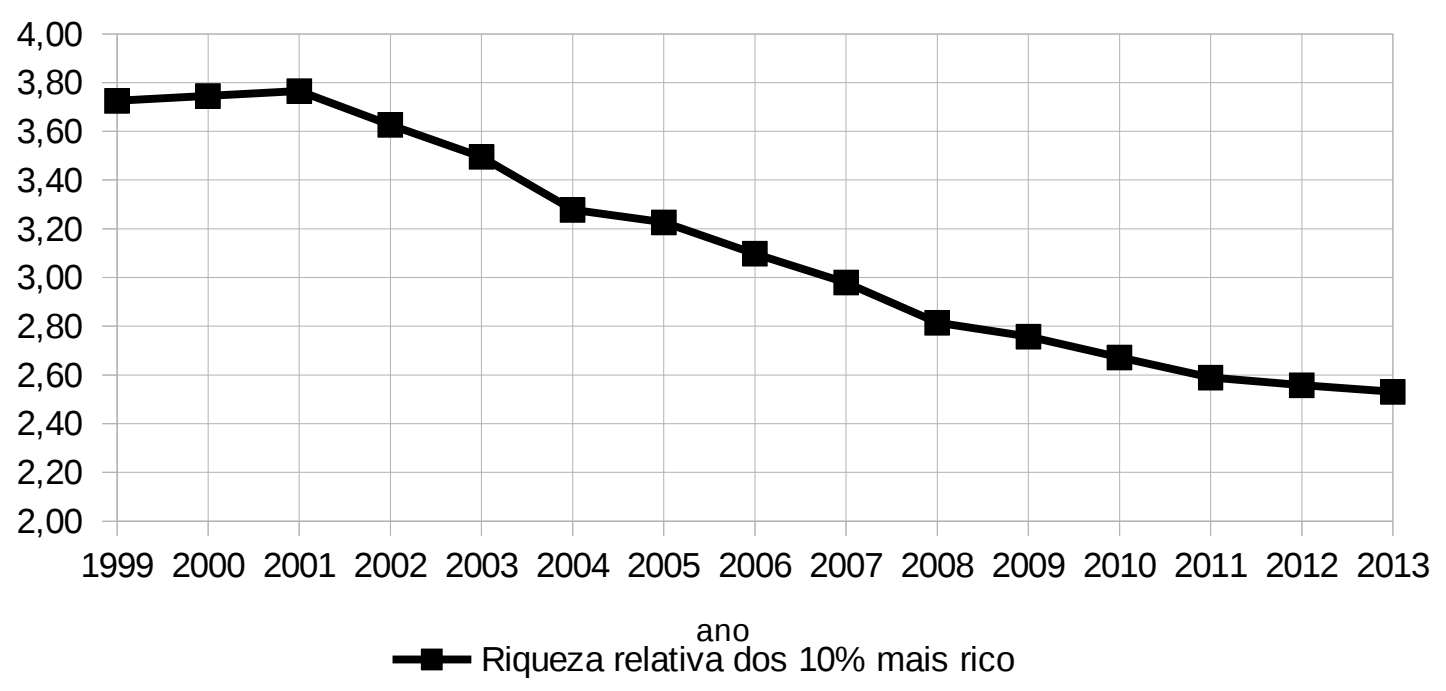

Fonte: IBGE e IPEA.

Desde 2001, após as crises econômica de 1998-1999 e de 2001-2003, começou a se gestar uma mudança no Brasil. Naquela época, do "exportar ou perecer”, a concentração de renda havia chegado a patamares de difícil sustentação. No gráfico 5.4, observa-se a riqueza relativa dos $10 \%$ do topo da pirâmide de renda em comparação aos 50\% da base. Em 2001, auge do abismo social, os mais ricos detinham 3,8 vezes a renda somada dos mais pobres. Em 2003, esse valor já havia caído para cerca de 3,5 vezes. Em 2004, a diminuição da concentração de renda se acelerou, para não mais voltar a crescer, até 2013.

No final do período, o primeiro e segundo patamar de renda haviam reduzido sua riqueza para "apenas" pouco mais de 2,5 vezes a renda do quarto e quinto patamar. Essa redução foi fruto da redução da miséria e da pobreza. Os ricos continuaram muito ricos. Os $10 \%$ do topo da pirâmide detinham mais de 2,5 vezes o montante correspondente à riqueza dos 50\% da base, em 2013, o que não é pouco. Mas é menos do que detinham em 2001. Tratase de um forte processo de redistribuição de renda em favor das camadas de baixo da pirâmide social. No entanto, dado o grau de miséria da população no período anterior, essa redistribuição não significou ainda a formação de uma sociedade de consumo de massa. Tampouco significou a criação de um modelo autocentrado de desenvolvimento.

A redistribuição de renda em favor das camadas de menores rendimentos pode ser explicada por dois fatores. O primeiro é o aumento do salário mínimo e do salário médio dos 
trabalhadores. Também se deve considerar o impacto de programas de redistribuição de renda e de redução da miséria, como o bolsa-família ${ }^{183}$.

\section{Gráfico 6.2: Poupança real das famílias, 1999 a 2013}

(bilhões de reais de 2006)

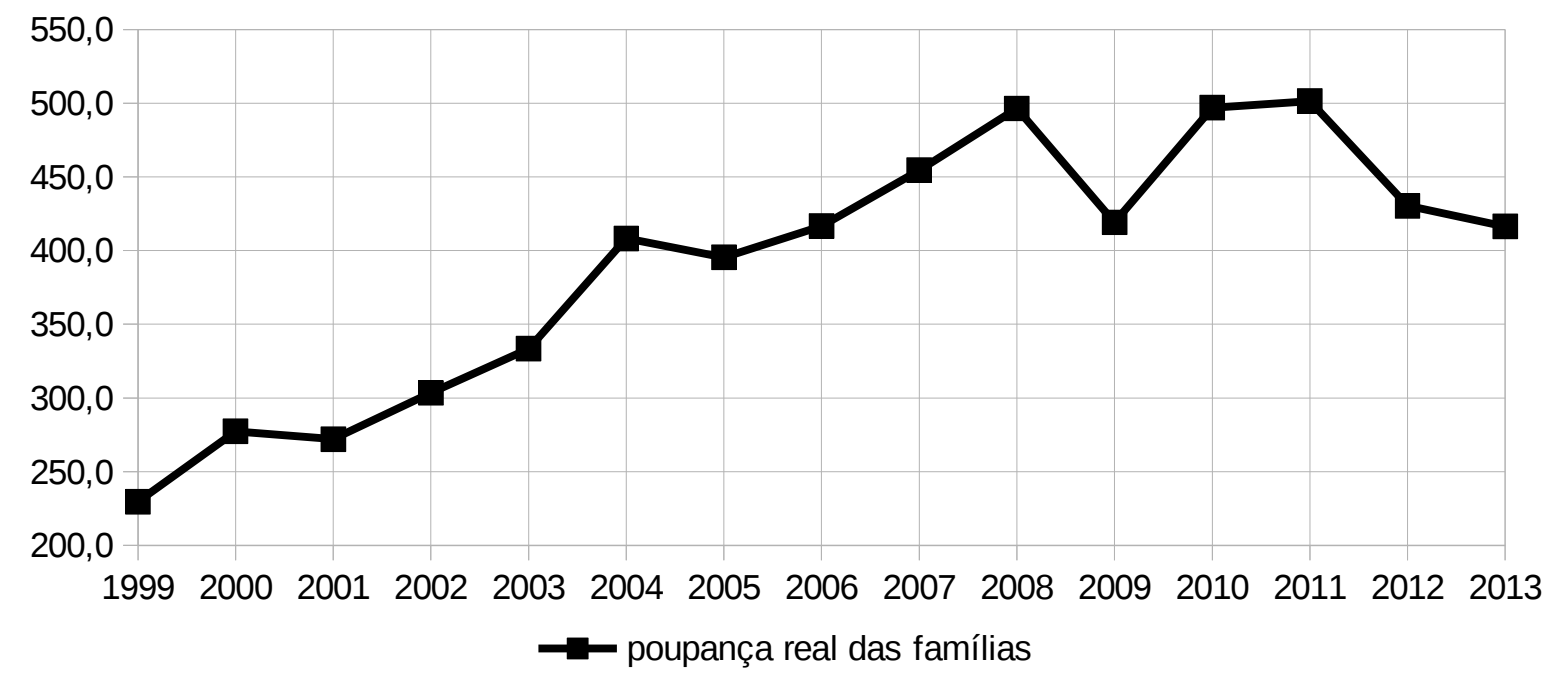

Fonte: IBGE e IPEA

O gráfico 6.2 traz a representação da poupança real das famílias brasileiras, ano a ano, de 1999 a 2013. O gráfico demonstra (a) considerável oscilação no volume da poupança das famílias; (b) quedas no valor real em 2005, 2009, 2012 e 2013. Na prática, as crises influenciaram negativamente a disposição das famílias para poupar. Ainda, observa-se que em 2001, a poupança das famílias era de cerca de 270 bilhões de reais constantes de 2006. Naquele mesmo ano, a renda disponível real total das famílias foi de cerca de 1,8 trilhões de reais. Isso significa que a taxa de poupança das famílias foi de 14,48\%. Em 2008, a poupança atingiu o valor de 500 bilhões de reais constantes, e a renda disponível das famílias 2,7 trilhões, o que significou uma taxa de poupança de 18,48\%. Entre 2003 e 2008, portanto, a prosperidade econômica local, sustentada pela alta dos preços das commodities, permitiu aumento da taxa de poupança. Ou seja, os ganhos da exportações estimularam a demanda local, mas também a poupança.

No entanto, a partir da crise de 2009, a taxa de poupança das famílias passou a diminuir. Em 2013, essa taxa caiu para 15,12\% da renda disponível total das famílias. Trata-se 183 Sobre o assunto, ver: AMANN, Edmund \& BAER, Werner. "The Macroeconomic Record of the Lula Administration, the Roots of Brazil's Inequality, and Attempts to Overcome Them”. In: LOVE, Joseph \& BAER, Werner (orgs). Brazil under Lula Economy, Politics, and Society under the Worker-President. Nova Iorque: Palgrave Macmillan, 2009. 
de indício que a economia brasileira não melhorou graças à poupança e criação de excedente doméstico. Foi a alta do preço das commodities que criou a possibilidade para o aumento temporário da poupança e para a redistribuição temporária de renda, sem a superação dos entraves estruturais da economia local ${ }^{184}$.

Gráfico 6.3: Gasto real em seguridade social no Brasil, 1999 a 2013

(bilhões de reais constantes de 2006)

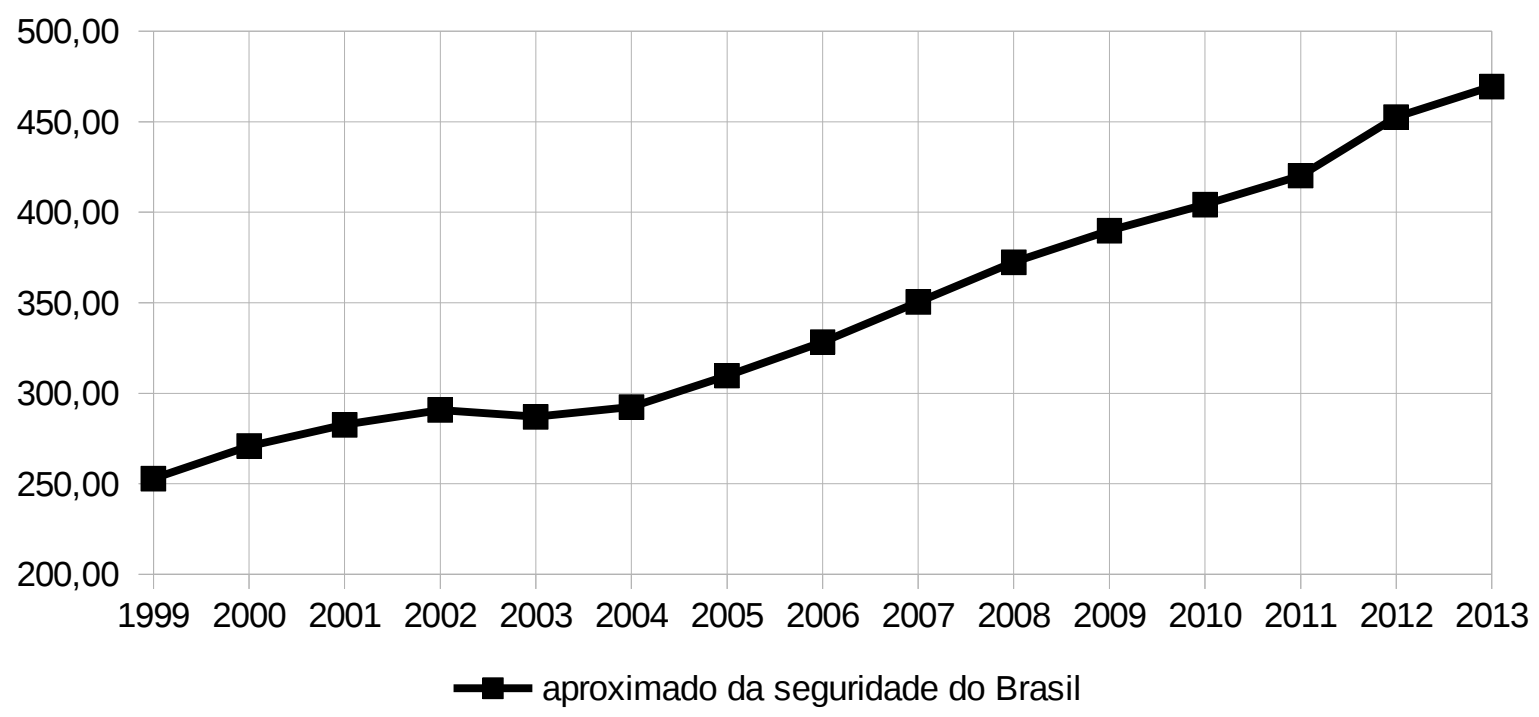

Fonte: IBGE e IPEA

No gráfico 6.3, verifica-se o crescimento dos gastos reais em seguridade social, que incluem o sistema de saúde, de educação, e de assistência social (inclusive bolsa família). Até 2004, o aumento dos gastos foi singelo, observando mesmo queda em 2003. No entanto, a partir de então, observou-se rápido crescimento. É importante destacar que, naquele ano, o abismo social já havia começado a diminuir bastante. Dessa forma, não foi o aumento de gastos na seguridade que permitiu a diminuição da pobreza. Ao contrário, foi a melhoria da renda média dos brasileiros que gerou recursos internos liberados para a seguridade social, financiada pelos impostos internos.

De fato, a redução do abismo social pode ser explicada por dois fatores: (a) a obtenção de divisas através do comércio exterior permitiu melhoria de vida das camadas mais pobres e aumentou a receita nacional, liberando recursos para a seguridade social; e (b) a criação e reorganização de programas sociais, como o "bolsa-família”, impactou na diminuição da

184 Sobre o assunto, ver também: MILANI, Ana Maria Rita. The Reduction of Inequality in Latin America during 2000-2010: A Path to Development?. World Review of Political Economy, Vol. 4, No. 4 (Winter 2013), pg. 437-454. 
miséria. Isso gerou drástica redução na concentração de renda. Note-se que os programas sociais do governo possuíram, no período, volume pouco significante ${ }^{185}$. Por exemplo, em 2014, o bolsa família foi de 25 bilhões de reais. No mesmo ano, os brasileiros gastaram em compra de sapatos cerca de 21 bilhões de reais, e importaram 25 bilhões de reais em automóveis produzidos no exterior ${ }^{186}$.

\subsection{UMA NÃO RECUPERAÇÃO INDUSTRIAL}

Para o caso brasileiro, entre 1999 e 2013, as considerações de Nurkse, Prebisch, e Samir Amin permitem a reflexão sobre o seguinte problema: “o período de prosperidade local impactou acumulo de capital capaz de sustentar o crescimento econômico futuro?”. Responder a essa questão significa dar um passo a mais na caracterização do modelo econômico vigente no Brasil, naquele período. Essa reflexão passa por mensurar o acúmulo de capital e a produtividade local.

Uma das formas de mensurar a produtividade de um país é através da capacidade de abastecimento industrial doméstico, já discutido na seção 4.1, do capítulo 4. Na tabela 4.1, foi apresentada uma estimativa da capacidade de abastecimento industrial doméstico, considerando a taxa de crescimento da população brasileira e a taxa de crescimento da indústria.

No entanto, o problema formulado agora exige abordagem mais detalhada. As teses dos autores citados, como Samir Amin, Ragnar Nurkse, Raúl Prebisch, consideram que a indústria relevante para a ampliação da produtividade local é a indústria de transformação. Ainda, dada a diferença que fazem entre setor industrial e setor exportador, no caso brasileiro a indústria extrativa faz parte, na verdade,2 do setor exportador. A importância da indústria de transformação (ou indústria manufatureira) também foi ressaltada por José Ocampo:

$185 \mathrm{O}$ programa bolsa-família também foi utilizado como instrumento para cadastramento da população. É possível argumentar que seu impacto não se resumiu ao valor distribuído. Segundo essa leitura, o programa teria dado condições para o melhor conhecimento sobre as condições de vida da população brasileira. Para uma discussão sobre o tema, ver: SOARES, Fabio Veras. Brazil's Bolsa Família: A Review. Economic and Political Weekly, Vol. 46, No. 21 (MAY 21-27, 2011), pg. 55-60

186 Os programas de distribuição de renda tiveram pouco impacto na demanda agregada. No entanto, forneceu para uma parte da população a possibilidade de alimentação mínima, ainda que insuficiente para garantir as necessidade nutricionais. Sobre o assunto, ver: SOARES, Fábio Veras. Evaluating The Impact Of Brazil's Bolsa Família: Cash Transfer Programs in Comparative Perspective. Latin American Research Review, Vol. 45, No. 2 (2010), pg. 173-190 
Os países mais bem sucedidos são caracterizados por um crescimento de produtividade mais rápido (figura 11.8). Em todos estes casos, o desenvolvimento industrial tem sido um dos principais impulsionadores do crescimento geral da produtividade do trabalho. A realocação do trabalho entre os setores amplamente definidos, que mede o grau em que a mobilidade dos trabalhadores voltada para setores de maior produtividade contribui para o crescimento geral da produtividade, tem sido importante em alguns casos (particularmente no Sudeste Asiático), mas bastante modesto em outros. Isso reflete o fato de que, em muitos países de crescimento lento, a realocação do trabalho tem sido dominada por problemas de emprego nas áreas urbanas. Nesses países, o dinamismo insuficiente dos setores industriais e serviços modernos induziu trabalhadores ao emprego do setor informal, abrandando o crescimento da produtividade, particularmente no setor de serviços. ${ }^{187}$

No Brasil, assim como em outros países da América Latina, o crescimento econômico impulsionado pela alta dos preços das commodities, não foi capaz de gerar aumento no setor industrial manufatureiro. Parte do crescimento econômico foi drenado por setores de serviço de baixa produtividade. A expectativa de que investimento estrangeiro direto de firmas multinacionais levasse a um aumento da produtividade ${ }^{188}$ não se confirmou. Assim como em outros países subdesenvolvidos, o crescimento do investimento estrangeiro esteve associado a redução do investimento doméstico em setores de maior produtividade ${ }^{189}$.

Para uma análise mais detalhada do desempenho da indústria brasileira, entre 1999 e 2013, o desempenho da indústria pode ser fragmentado pelos distintos setores: (a) indústria extrativa; (b) indústria de transformação; e (c) outras indústrias (inclusive construção civil).

A tabela 6.1 traz a participação dos setores da indústria em relação ao PIB brasileiro, entre 1990 e 2012. A coluna (1) traz o ano de referência. A coluna (2) traz a participação total da indústria brasileira no PIB do país. A coluna (3) traz a participação da indústria extrativa. A coluna (4) traz a participação da indústria de transformação. A coluna (5) traz a participação dos demais setores, incluindo a indústria de construção civil, que é o principal ramo das

187 OCAMPO, José Antonio; VOS, Rob (Ed.). Uneven economic development. Nova Iorque: United Nations Publications, 2008. Pg. 51.

188 Sobre o assunto, ver: GÖRG, Holger \& STROBL, Eric. "Foreign Direct Investment and Local Economic Development: Beyond Productivity Spillovers” In: MORAN, Theodore H. \& GRAHAM, Edward M. \& BLOMSTRÖM, Magnus (Ed). Does Foreign Direct Investment Promote Development? Washington: Institute for International Economics, 2005.

189 Para uma discussão sobre possíveis impactos negativos do investimento estrangeiro direto, ver também: IVANOVIĆ, Igor. Impact Of Foreign Direct Investment (FDI) On Domestic Investment In Republic Of Croatia. Review Of Innovation And Competitiveness, vol 1, issue 1, 2015. 
indústrias restantes.

\begin{tabular}{|c|c|c|c|c|}
\hline (1) & (2) & (3) & (4) & (5) \\
\hline Ano & Indústria (total) & Indústria extrativa & Indústria de transformação & Outros (construção) \\
\hline 1990 & 38,7 & 1,71 & 26,54 & 10,45 \\
\hline 1991 & 36,2 & 1,63 & 24,86 & 9,71 \\
\hline 1992 & 38,7 & 1,61 & 26,43 & 10,66 \\
\hline 1993 & 41,6 & 1,17 & 29,06 & 11,37 \\
\hline 1994 & 40 & 1,03 & 26,79 & 12,18 \\
\hline 1995 & 27 & 0,82 & 18,62 & 7,56 \\
\hline 1996 & 25,3 & 0,91 & 16,8 & 7,59 \\
\hline 1997 & 25,4 & 0,83 & 16,67 & 7,9 \\
\hline 1998 & 24,9 & 0,73 & 15,72 & 8,45 \\
\hline 1999 & 24,8 & 0,98 & 16,12 & 7,7 \\
\hline 2000 & 26,5 & 1,59 & 17,22 & 7,69 \\
\hline 2001 & 26,3 & 1,47 & 17,13 & 7,7 \\
\hline 2002 & 26,2 & 1,6 & 16,85 & 7,75 \\
\hline 2003 & 27 & 1,72 & 18,02 & 7,26 \\
\hline 2004 & 28,7 & 1,92 & 19,22 & 7,56 \\
\hline 2005 & 28,6 & 2,46 & 18,09 & 8,05 \\
\hline 2006 & 27,8 & 2,89 & 17,37 & 7,54 \\
\hline 2007 & 27,1 & 2,35 & 17,03 & 7,72 \\
\hline 2008 & 27,4 & 3,24 & 16,63 & 7,53 \\
\hline 2009 & 25,7 & 1,83 & 16,65 & 7,22 \\
\hline 2010 & 27,4 & 2,97 & 16,23 & 8,2 \\
\hline 2011 & 27,2 & 4,08 & 14,6 & 8,52 \\
\hline 2012 & 25,4 & 4,27 & 12,95 & 8,18 \\
\hline
\end{tabular}

Fontes: IBGE e IPEA

Observa-se que a indústria sofreu uma grande queda na participação do PIB entre 1994 e 1995. No anos seguintes, até 1999, a indústria continuou a minguar em relação ao restante do Produto Interno Bruto brasileiro. De 2000 a 2004, a indústria voltou a ganhar importância relativa para a atividade econômica brasileira, voltando a declinar a partir de 2006, até 2012.

Quando se observa exclusivamente a indústria de transformação, que era a maior parte 
do setor industrial, observa-se que a queda sofrida do primeiro período (1994 até 1999) e a recuperação do segundo período (2000 a 2004) observaram processo similar ao restante da indústria. No entanto, a queda no terceiro período foi mais acentuada para a indústria de transformação, em especial no terceiro período (2005 a 2012), levando a, em 2012, atingir a participação de apenas 12,95\% do PIB brasileiro. Trata-se do valor mais baixo de todo período analisado. Ao mesmo tempo, observa-se que a participação do setor extrativo cresceu desde 1999, e a participação da indústria de construção civil e demais ramos oscilou entre os 7 e 8 por cento do PIB.

Descrito dessa forma, verifica-se que, se o período entre 1994 e 1999 foi de perda da participação da indústria na atividade econômica, o período de 2000 a 2012 foi de recuperação parcial e momentânea. No entanto, essa recuperação se deu mais forte para indústria extrativa. Essa forma de analisar já fortalece a hipótese que a prosperidade local nem gerou aumento da acumulação de capital, nem foi resultado de aumento da capacidade produtiva. No entanto, como os dados são relativos ao PIB, seria possível argumentar que o ganho da produtividade e o aumento da complexidade econômica, devido a política de incentivo ao consumo, é que causaram essas mudanças. Ainda, alternativamente seria possível argumentar que, entre 1999 e 2012, teria ocorrido perda da capacidade industrial em todos os setores. Mas não foi nenhum dos dois o que aconteceu.

A tabela 6.2 traz a capacidade de abastecimento industrial doméstico do Brasil, entre 1990 e 2012, organizada entre os três setores da indústria. A coluna (1) traz o ano de referência, para as linhas (i) a (xxiii). A coluna (2) contém a capacidade de abastecimento industrial doméstico total da indústria, onde o valor 100 é igual à capacidade de abastecimento industrial doméstico de 1983. A coluna (3) traz a capacidade de abastecimento da indústria extrativa, que é a participação em valores absolutos da indústria de extração na capacidade de abastecimento doméstica. A coluna (4) dispõe a capacidade de abastecimento da indústria de transformação, que é a participação, em valores absolutos, da indústria de transformação na capacidade de abastecimento doméstica. Na coluna (5), verifica-se a capacidade de abastecimento dos demais tipos de indústria, em especial da indústria de construção civil. 


\begin{tabular}{|c|c|c|c|c|}
\hline \multicolumn{5}{|c|}{ Tabela 6.2: Capacidade de abastecimento industrial doméstica brasileira por setor, 1990 a 2012.} \\
\hline$(1)$ & $(2)$ & (3) & (4) & (5) \\
\hline Ano & $\begin{array}{l}\text { Capacidade de } \\
\text { abastecimento } \\
\text { industrial } \\
\text { doméstica (1983 } \\
=100)\end{array}$ & $\begin{array}{c}\text { Capacidade de } \\
\text { abastecimento da } \\
\text { indústria } \\
\text { extrativa }\end{array}$ & $\begin{array}{l}\text { Capacidade de } \\
\text { abastecimento da } \\
\text { indústria de } \\
\text { transformação }\end{array}$ & $\begin{array}{c}\text { Capacidade de } \\
\text { abastecimento outros } \\
\text { tipos de indústria }\end{array}$ \\
\hline (i) 1990 & 95,65 & 4,23 & 65,59 & 25,83 \\
\hline (ii) 1991 & 88,98 & 4,01 & 61,11 & 23,87 \\
\hline (iii) 1992 & 93,36 & 3,88 & 63,76 & 25,72 \\
\hline (iv) 1993 & 103,93 & 2,92 & 72,60 & 28,40 \\
\hline (v) 1994 & 104,32 & 2,69 & 69,87 & 31,77 \\
\hline (vi) 1995 & 73,23 & 2,22 & 50,50 & 20,50 \\
\hline (vii) 1996 & 69,70 & 2,51 & 46,28 & 20,91 \\
\hline (viii) 1997 & 71,34 & 2,33 & 46,82 & 22,19 \\
\hline (ix) 1998 & 69,21 & 2,03 & 43,70 & 23,49 \\
\hline (x) 1999 & 68,96 & 2,72 & 44,82 & 21,41 \\
\hline (xi) 2000 & 76,11 & 4,57 & 49,46 & 22,09 \\
\hline (xii) 2001 & 73,97 & 4,13 & 48,18 & 21,66 \\
\hline (xiii) 2002 & 75,66 & 4,62 & 48,66 & 22,38 \\
\hline (xiv) 2003 & 77,57 & 4,94 & 51,77 & 20,86 \\
\hline (xv) 2004 & 87,86 & 5,88 & 58,84 & 23,14 \\
\hline (xvi) 2005 & 87,22 & 7,50 & 55,17 & 24,55 \\
\hline (xvii) 2006 & 88,13 & 9,16 & 55,06 & 23,90 \\
\hline (xviii) 2007 & 89,21 & 7,74 & 56,06 & 25,41 \\
\hline (xix) 2008 & 93,14 & 11,01 & 56,53 & 25,60 \\
\hline (xx) 2009 & 88,09 & 6,27 & 57,07 & 24,75 \\
\hline (xxi) 2010 & 98,25 & 10,65 & 58,20 & 29,40 \\
\hline (xxii) 2011 & 97,59 & 14,64 & 52,38 & 30,57 \\
\hline (xxiii) 2012 & 93,02 & 15,64 & 47,42 & 29,96 \\
\hline (xxiv) Taxa de crescimento anual total & $(0,13)$ & 6,13 & $(1,46)$ & 0,68 \\
\hline$(\mathrm{xxv})$ Crescimento total $(\%)$ & $(2,75)$ & 270,00 & $(27,70)$ & 15,99 \\
\hline (xxvi) Taxa de crescimento : 1990 a 2001 & $(2,31)$ & $(0,20)$ & $(2,77)$ & $(1,59)$ \\
\hline (xxvii) Crescimento: 1990 a 2001 & $(22,66)$ & $(2,17)$ & $(26,55)$ & $(16,15)$ \\
\hline (xxviii) Taxa de crescimento : 2001 a 2012 & 2,10 & 12,86 & $(0,14)$ & 2,99 \\
\hline (xxix) Crescimento: 2001 a 2012 & 25,75 & 278,21 & $(1,57)$ & 38,32 \\
\hline
\end{tabular}

Nota 1: valores negativos entre parênteses.

Fonte: IBGE e IPEA

A linha (xxiv) contém a taxa de crescimento anual da capacidade de abastecimento de cada setor, para o período entre 1990 e 2012. A linha (xxv) traz o crescimento total observado da capacidade de abastecimento para cada um dos setores analisados, entre 1990 e 2012. A linha (xxvi) traz a taxa de crescimento anual da capacidade de abastecimento da primeira 
metade do período da tabela (1990 a 2001), e a linha (xxvii) traz o crescimento total para o mesmo período. A linha (xxviii) contém a taxa de crescimento anual da capacidade de abastecimento para segunda metade do período da tabela (2001 a 2012), e a linha (xxix) dispõe o crescimento total para o mesmo período.

Quando verificado o período completo, entre 1990 e 2012, observa-se que a capacidade de abastecimento doméstico sofreu uma queda de 2,75 por cento. Ela foi resultado do crescimento de 270 por cento da capacidade de abastecimento da indústria extrativa, do crescimento de 15,99 por cento da indústria de construção e demais, e da queda de 27,70 por cento na capacidade de abastecimento da indústria de transformação. No entanto, pode-se verificar que, entre 1990 e 2001, a capacidade de abastecimento da indústria sofreu uma queda de 22,66 por cento. Todos os setores sofreram queda na capacidade de abastecimento, embora o setor extrativo, que já tinha capacidade pequena, sofreu menos. O processo de desindustrialização (e desnacionalização da indústria) durante os anos (19)90 foi um dos resultados da política cambial da época, como destacou Wilson Barbosa:

A âncora cambial, verdadeiro "chiclete" nas mãos do governo, devia ser esticada para sempre. No lugar do país produzir as riquezas industriais e com elas comprar os dólares que necessitava para pagar o serviço da dívida e expandir a produção, ele se dedicava a obtê-los hoje, fornecer-lhes juros exorbitantes no circuito do "parquinho" financeiro local e devolvê-los mais gordos depois de amanhã. Uma taxa de juros alta devia ser mantida para remunerar o smart capital, embora a mesma desestimulasse a economia efetiva local. Quanto mais se desnacionalizava a indústria local, tanto mais se aproximava pela redução do potencial de compra externo - o estrangulamento cambial. No entanto, os bonecos de engonço do Palácio do Planalto continuavam a imitar os ministros das metrópoles e a falar de âncora cambial, indução dos juros e outras maravilhas que no Terceiro Mundo só funcionam com o sinal trocado. ${ }^{190}$

A manutenção do controle da inflação através do câmbio manteve a tendência de degradação da indústria manufatureira local. O período de crescimento da renda disponível local apenas gerou uma reversão temporária, e insuficiente, na desindustrialização local. Entre 2001 e 2012, a capacidade de abastecimento industrial doméstico cresceu em 25,75 por cento. Embora tenha representado um crescimento pequeno frente a capacidade existente em 1990, foi uma forte recuperação frente à queda que havia sofrido até 2001. Essa recuperação foi 
fruto de um crescimento de 278,21 por cento na capacidade de abastecimento doméstico da indústria extrativa, e do crescimento de 38,32 por cento na capacidade da indústria de construção e demais.

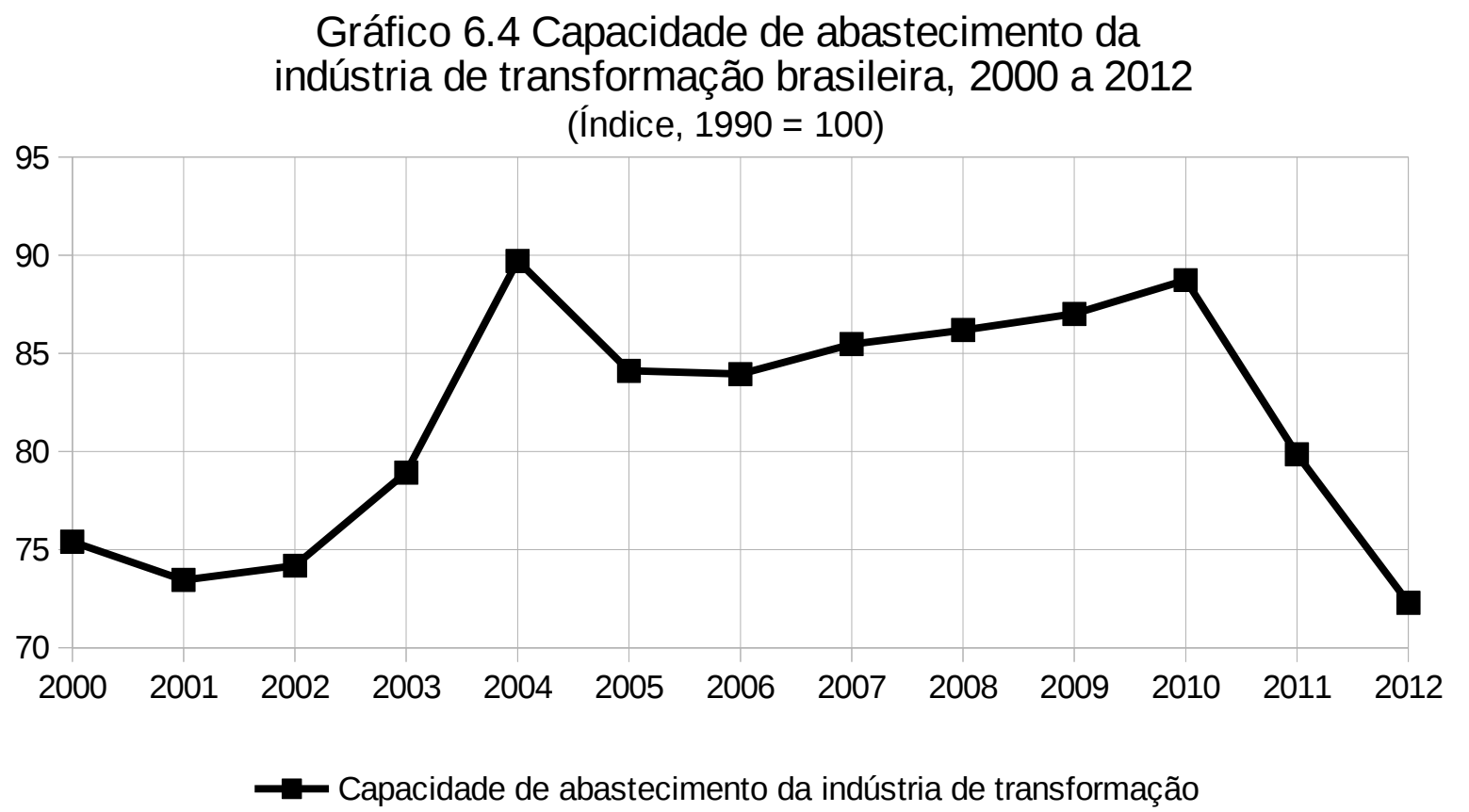

O saldo da capacidade de abastecimento da indústria de transformação, entre 2000 e 2012, foi a redução de 1,57 por cento. Essa queda foi resultado da baixa na indústria de transformação ocorrida em 2011 e 2012, após um período de parcos crescimentos entre 2005 e 2010. Nesse subperíodo, entre 2001 e 2012, só houve considerável crescimento na capacidade de abastecimento industrial da indústria de transformação brasileira entre 2002 e 2004, período em que o real esteve desfavorável às importações.

Deve-se considerar que parte da recuperação da indústria de transformação se deu através da alteração de parte das indústrias manufatureiras em montadoras, que importavam partes e peças de outros países (em especial da China). Ainda, outras se transformaram em espécie de empacotadoras, que importavam os produtos já prontos da China, e apenas a empacotavam aqui, em caixas produzidas localmente, ou também importadas.

Pode-se considerar esses dados como testes da aplicabilidade das teses de Ragnar Nurkse e de Samir Amin à realidade brasileira entre 1999 e 2012. Nesse caso, seriamos obrigados a reconhecer que a recuperação econômica não significou recuperação da capacidade industrial. Não houve acumulação de capital, nem aumento de produtividade para 
a indústria de transformação. Na verdade, o incremento no capital acumulado e na produtividade se deu nos setores exportadores. Isso significa que, de acordo com a teses desses autores, o Brasil poderia ser considerado, no período, subdesenvolvido e economicamente dependente.

\subsection{RENDA DISPONÍVEL DAS CAMAdAS E A FORMAÇÃo BRUTA DE} CAPITAL FIXO

Ainda que a recuperação econômica tenha concentrado os investimentos na indústria extrativa e na indústria de construção, isso impactou na relação entre a renda disponível da população e a taxa de investimento. Na contabilidade social, essa taxa é resultado da formação bruta de capital fixo dividida pelo PIB. Dessa forma, é possível detectar qual foi o resultado da mudança na distribuição de renda no investimento, através da relação entre a renda disponível de cada camada de renda e a formação bruta de capital fixo.

É de se esperar que, conforme diminua a miséria, as camadas da base da pirâmide de renda passem a influenciar também os investimentos internos. Quando a renda da população aumenta, ela causa (a) aumento da demanda local, o que pode favorecer investimentos para criação de oferta de produtos; e (b) gera arrecadação para o governo e participa como contribuinte no sistema de seguridade social.

Ao mesmo tempo, espera-se que os investimentos sejam mais influenciados pela renda das camadas do topo da piramide de renda, devido a menor propensão ao consumo nas camadas mais elevadas de renda. Para os países dependentes, onde há grande concentração de renda, é comum que a influência dos mais ricos nos investimentos seja ainda maior. Isso pois (a) dada a superexploração dos trabalhadores, o investimento estaria ligado a um crescimento de renda mais que proporcional para as camadas do topo, e um crescimento de renda menos que proporcional para as camadas da base; (b) a renda do patamar de baixo é tão reduzida que não há excedente em posse de seus membros, impedindo-os de participar do investimento doméstico; (c) o consumo dessas camadas debaixo não atinge volume suficiente para impulsionar novos investimentos; e (d) parcela significativa do consumo é garantida através das importações, e não por investimento e produção local.

A relação entre a a formação bruta de capital fixo e a renda disponível faz parte do 
estudo da função consumo ${ }^{191}$. A função consumo é a curva que prevê o nível de consumo para cada camada de renda, e pode ser traduzida em uma função consumo de um país. Essa função expressará a relação entre a renda disponível de um país, o consumo, e a poupança (Renda disponível $=$ consumo + poupança). Como macroeconomicamente a poupança de um país é sempre igual ao investimento, a formação bruta de capital fixo pode substituir a poupança, na fórmula.

O nível de investimento de um país pode ser utilizado para encontrar o multiplicador do investimento, que é a proporção em que a renda disponível deve crescer para um dado investimento novo. Ou seja, é a elasticidade da renda em relação ao investimento. Quanto maior for a participação do consumo na renda disponível nacional, maior tenderá a ser o efeito multiplicador. Políticas e conjunturas econômicas que geram investimento redistribuidor de renda tendem, na teoria, a gerar ampliação da renda disponível, ao passo que gera aumento da propensão marginal a consumir da sociedade. Ou seja: o investimento gera emprego e aumento da renda dos mais pobres, que passam a consumir mais, o que gera maior incremento de renda. Esse é o chamado efeito acelerador ${ }^{192}$. Richard Ruggles e Nancy Ruggles chamaram a atenção para o fato do efeito acelerador depender das características do ramo em qual foi feito investimento:

A taxa de aceleração: $O$ volume das despesas induzidas em bens de investimento que resultará de uma dada variação no volume das despesas dos consumidores diferirá, consideravelmente, não só entre indústrias diferentes, mas também para as mesmas indústrias em circunstâncias diversas. A procura induzida resultante de um acréscimo das despesas dos consumidores para produtos de algumas indústrias pode ser desprezível; isto seria especialmente válido naquelas indústrias que reagem a um acréscimo de despesas, fazendo subir os preços e não aumentando a produção. Mesmo nas indústrias que de facto aumentam a produção, existe, todavia, um certo número de factores que podem servir para manter relativamente baixa a expansão das despesas de investimento: (1) A indústria pode laborar abaixo de sua capacidade, podendo dar-se um considerável aumento da produção antes de ser necessário um acréscimo de capacidade. Um acréscimo das despesas dos consumidores numa tal indústria, pode não originar despesas de investimento. (2) Pode tratar-se de uma

191 Sobre o assunto, ver: DILLARD, Dudley. La Teoria Economica de John Maynard Keynes. Teoria de una Economia Monetaria. Madrid: Aguilar, 1971; e RUGGLES, Richard \& RUGGLES, Nancy D. Contabilidade Nacional e Análise Macroeconômica. Lisboa: Livraria Sá da Costa editora, 1962.

192 Para uma demonstração do efeito multiplicador, ver: ACKLEY, Gardner. Teoria Macroeconômica. vol 2. São Paulo: Livraria Pioneira Editora, 1969. pg. 514 - 515. 
indústria que utilize um reduzido volume de bens de equipamento, de modo que um acréscimo na produção pode conseguir-se recrutando mais trabalho e comprando mais matérias-primas. Isto aplica-se especialmente naquelas indústrias em que a maior parte da sua atividade consiste no trabalho de montagens. (3) A expansão necessária na capacidade transformadora pode ser obtida simplesmente através de novas máquinas que garantem uma maior produtividade, de maneira que o volume das despesas de investimento normalmente exigidas pela necessidade de substituição de equipamento pode, só por si, ser suficiente para, nalguns períodos, satisfazer uma expansão real da indústria. ${ }^{193}$

Isso significa que, em uma sociedade onde a indústria de transformação se caracteriza pela existência de montadoras; e que há grande capacidade ociosa, o efeito acelerador tenderá a ser menor. Isso porque um incremento da renda levará a um aumento do investimento abaixo do multiplicador. Ainda, o efeito acelerador depende da criação de novos postos de trabalho.

Outro problema que o modelo da função consumo pode revelar é que a propensão marginal a investir das camadas de maior renda é maior. Isso significa, por um lado, que o incremento da renda dessas camadas tenderá a gerar maior investimento, e portanto maior crescimento da renda. No entanto, tenderá a gerar redução do multiplicador do investimento. Em médio e longo prazo, portanto, desincentivará novos investimentos.

Em uma sociedade de renda demasiadamente concentrada, e sem estrutura industrial consolidada, o problema do multiplicador se torna mais complexo. Na prática, quase todo investimento de um país dependente está ligado a renda das camadas de maior rendimento. Ainda, o consumo local se caracteriza pelo consumo de luxo. Isso faz com que incremento no nível de renda das camadas de renda mais baixa não gere aumento suficiente no consumo nacional. Soma-se a esses aspectos o fato dos novos investimentos, e mesmo parte do consumo, precisarem ser supridos por importações. Isso gera uma sangria na capacidade de crescimento, que se expressa na forma de um efeito multiplicador do investimento menor. Como parte da demanda criada é suprida por importações, a criação de postos de trabalho para a atender ocorre no exterior.

Um dos sintomas que podem servir para identificar a existência de uma sociedade de renda concentrada, economicamente dependente, e de baixo efeito multiplicador do 
investimento, é através da verificação da relação entre a formação bruta de capital fixo e a renda disponível de cada camada de renda. Caso haja inelasticidade dos investimentos em relação a renda das camadas de renda mais baixa, pode-se sustentar a hipótese que essas camadas não possuem poupança significativa, e seu consumo não é suficiente para a ampliação da demanda, que justifique crescimento dos investimentos.

Uma das formas de superar o baixo multiplicador dos investimentos resultante da concentração de renda é através da realização de investimentos públicos que beneficiem as camadas de menor rendimento. Ainda, pode ocorrer naturalmente melhoria temporária do multiplicador em períodos de prosperidade, quando a renda das camadas de baixo da pirâmide aumenta o suficientemente para que haja aumento do consumo local. Em ambas ocasiões, espera-se que ocorra aumento da elasticidade da formação bruta de capital fixo em relação a renda das camadas de menor rendimento.

\begin{tabular}{|c|c|c|c|c|c|c|c|c|}
\hline \multicolumn{9}{|c|}{ Tabela 6.3: Formação bruta de capital fixo explicado pela renda disponível das camadas de renda } \\
\hline (1) & (2) & (3) & (4) & (5) & (6) & (7) & (8) & (9) \\
\hline $\begin{array}{c}\text { Número da } \\
\text { regressão }\end{array}$ & $\begin{array}{c}\text { Variável } \\
\text { independente }\end{array}$ & Coeficiente A & Coeficiente B & $\begin{array}{c}\text { Erro } \\
\text { Padrão A }\end{array}$ & $\begin{array}{c}\text { Erro } \\
\text { Padrão B }\end{array}$ & $\begin{array}{c}\text { Elasticidade } \\
\text { de B }\end{array}$ & $\mathbf{R}^{2}$ & DW \\
\hline $\begin{array}{c}\mathbf{6 . 1} \\
\text { FBCFr }=a \\
+\mathrm{Yd}_{1}\end{array}$ & $\begin{array}{c}\text { Renda } \\
\text { disponível do } \\
\text { primeiro } \\
\text { patamar de } \\
\text { renda } \\
\end{array}$ & $(95,84)$ & 1,83 & 31,33 & 0,10 & 1,18 & 0,963 & 1,619 \\
\hline $\begin{array}{c}6.2 \\
\mathrm{FBCFr}=\mathrm{a} \\
+\mathrm{Yd}_{2}\end{array}$ & $\begin{array}{c}\text { Renda } \\
\text { disponível do } \\
\text { segundo } \\
\text { patamar de } \\
\text { renda }\end{array}$ & $(108,79)$ & 0,75 & 25,77 & 0,03 & 1,20 & 0,976 & 0,649 \\
\hline $\begin{array}{c}6.3 \\
\text { FBCFr }=\mathrm{a} \\
+\mathrm{Yd}_{3}\end{array}$ & $\begin{array}{c}\text { Renda } \\
\text { disponível do } \\
\text { terceiro } \\
\text { patamar de } \\
\text { renda }\end{array}$ & 34,20 & 0,43 & 19,90 & 0,02 & 0,89 & 0,975 & 0,700 \\
\hline $\begin{array}{c}\mathbf{6 . 4} \\
\mathrm{FBCFr}=\mathrm{a} \\
+\mathrm{Yd}_{3}\end{array}$ & \begin{tabular}{|c|} 
Renda \\
disponível do \\
quarto patamar \\
de renda
\end{tabular} & 125,62 & 1,18 & 15,09 & 0,05 & 0,70 & 0,978 & 0,848 \\
\hline $\begin{array}{c}6.5 \\
\mathrm{FBCFr}=\mathrm{a} \\
+\mathrm{Yd}_{4}\end{array}$ & \begin{tabular}{|c|} 
Renda \\
disponível do \\
quinto patamar \\
de renda \\
\end{tabular} & 145,74 & 4,53 & 18,40 & 0,24 & 0,64 & 0,964 & 0,777 \\
\hline \multicolumn{9}{|c|}{ Nota 1: valores negativos entre parênteses } \\
\hline & & & & & & & IB & e IPEA \\
\hline
\end{tabular}

Na tabela 6.3, verifica-se o resultado de cinco regressões com a formação bruta de capital fixo real (FBCF), em bilhões de reais de 2006, como variável dependente, e com a renda disponível real das camadas de renda como variáveis independentes. Essas regressões 
mensuram o impacto do aumento de renda de cada camada na formação bruta de capital fixo no Brasil. Ou seja, no investimento material do país. Na coluna (1) está o número de referência da regressão. Na coluna (2), verifica-se a variável independente usada na regressão. Na coluna (3), está o coeficiente “a” (constante) encontrado. Na coluna (4), observa-se o coeficiente "b”, que mensura a variação em reais constantes de 2006 para cada aumento de um real constante na renda disponível da camada em análise. Na coluna (5) e (6), observam-se os erros padrões para os coeficientes. Deve-se lembrar que erros padrões iguais ou maiores que a metade do coeficiente apontam para irrelevância estatística do coeficiente em questão. A coluna (7) traz a elasticidade do coeficiente “b”, que expressa o quanto a variável dependente cresceu, em porcentagem, para cada aumento de um por cento na variável independente. A coluna (8) traz o R-quadrado $\left(\mathrm{R}^{2}\right)$ da regressão, que é o poder explicativo encontrado. A coluna (9) traz o Durbin-Watson (DW), que, se menor que o R-quadrado, sinaliza espuriedade da regressão.

A primeira coisa que se observa é que apenas a regressão com a renda dos $1 \%$ do topo (primeiro patamar de renda) não demonstrou espuriedade. Todas as demais apresentaram impacto alto o suficiente na mudança da elasticidade para que gerasse "vício" no coeficiente observado. Esse vício é expressão da queda do FBCF entre 2001 e 2003, período em que a renda disponível das camadas já havia começado a crescer. No entanto, o uso de regressões com variável conjuntural para correção não gerou impacto significativo na elasticidade encontrada.

A alta elasticidade do primeiro e segundo patamares de renda, e baixa elasticidade dos demais expressa valor expectado. O que a elasticidade observada expressa é a seguinte distribuição da origem para cada novo real criado na formação bruta de capital fixo: (i) 26 centavos resultaram da renda do primeiro patamar de renda; (ii) outros 26 centavos foram criados pela renda do segundo patamar; (iii) 19 centavos foram criados pela renda do terceiro patamar; (iv) 15 centavos foram criados pela renda do quarto patamar; e (v) 14 centavos pela renda do quinto patamar.

A formação bruta de capital fixo resulta do investimento. O investimento de uma sociedade é igual a poupança que ela realiza. Na prática, quanto maior a renda de uma pessoa, maior é sua propensão a poupar. Daí resulta que o investimento seja mais elástico a renda das camadas do topo da pirâmide de renda do que às camadas de baixo. Portanto, a elasticidade 
encontrada para o quinto patamar de renda, que inclui os $20 \%$ da base da pirâmide, foi bastante baixo. Isso indica que essa camada, entre 1999 e 2013, participou pouco na poupança da sociedade. Ainda, aponta que o consumo realizado pela base da pirâmide de renda não foi fator suficientemente relevante para impulsionar investimentos. Ou seja, a sociedade brasileira, no período, não se tornou uma sociedade de consumo de massa.

\subsection{ELASTICIDADE MÓVEL DA FORMAÇÃO BRUTA DE CAPITAL FIXO}

A propensão marginal a investir é o quanto se espera de aumento no investimento, para cada novo aumento da renda de uma população, ou de um dado patamar de segmento de renda. Conforme Dillard ${ }^{194}$, a propensão marginal a investir é histórica. Ela é influenciada por (a) patamar da renda, sendo que renda mais alta tende a gerar propensão marginal a investir maior; e (b) pela eficácia marginal do capital, que é a lucratividade prevista de um novo investimento. Têm-se que a eficácia marginal do capital possui tendência declinante, haja vista que cada novo investimento tende a ter lucratividade menor que o anterior, devido ao acúmulo de capital.

No Brasil, entre 1999 e 2013, houve distribuição de renda favorável às camadas de baixo da pirâmide de renda. Ao mesmo tempo, ocorreu (a) aumento dos investimentos no setor extrativo, e estagnação do setor de transformação; (b) queda da taxa de lucro da indústria doméstica, devido ao câmbio valorizado. Como resultado, ocorreu ganho de propensão marginal a investir das camadas debaixo da pirâmide, e queda da propensão marginal a investir das camadas do topo da pirâmide, quando se trata de investimento material.

O investimento provoca aquilo que é denominado "efeito multiplicador”, conforme a literatura keynesiana. O efeito multiplicador é tanto maior quanto maior for a propensão marginal a consumir, e portanto menor for a propensão marginal a poupar. Nesse sentido, espera-se que uma redistribuição de renda favorável às camadas de baixo da pirâmide social, que possui menor propensão marginal a investir, aumente o efeito multiplicador do investimento.

194 Sobre o tema, ver: DILLARD, Dudley. La Teoria Economica de John Maynard Keynes. Teoria de una Economia Monetaria. Madrid: Aguilar, 1971. 
Para que isso ocorra, no entanto, depende do tipo de investimento que é realizado ${ }^{195}$. O efeito multiplicador reverbera nos períodos seguintes. Haverá maior impacto de uma injeção de investimento passado no investimento futuro, caso o investimento tenha sido realizado em cadeias produtivas mais complexas. No caso brasileiro, já se verificou que o investimento ocorreu principalmente na indústria extrativa e na construção civil, que são setores que demandam uma cadeia produtiva de média complexidade. Disso resulta que injeções de investimentos tenham pouco impacto no crescimento de investimentos nos próximos anos.

O gráfico 6.5 apresenta a participação móvel do primeiro patamar de renda na formação bruta de capital fixo real (FBCF) no Brasil, entre 1999 e 2013. Observa-se que de 1999 a 2001, a importância da renda disponível dos 1\% do topo da pirâmide de renda cresceu em relação aos investimentos domésticos. No entanto, a partir daí apresentou trajetória declinante. Houve quedas mais acentuadas em 2004, 2008, e 2011, com uma recuperação pontual em 2012. A participação dessa camada na criação de novos investimentos partiu de 27 centavos, em 1999, para mais de 28 centavos, em 2001. Em 2013, havia caído para pouco mais de 23 centavos.

\section{Gráfico 6.5: Participação móvel do primeiro patamar de renda em cada novo real criado na Formação Bruta de Capital Fixo brasileira, 1999 a 2013}

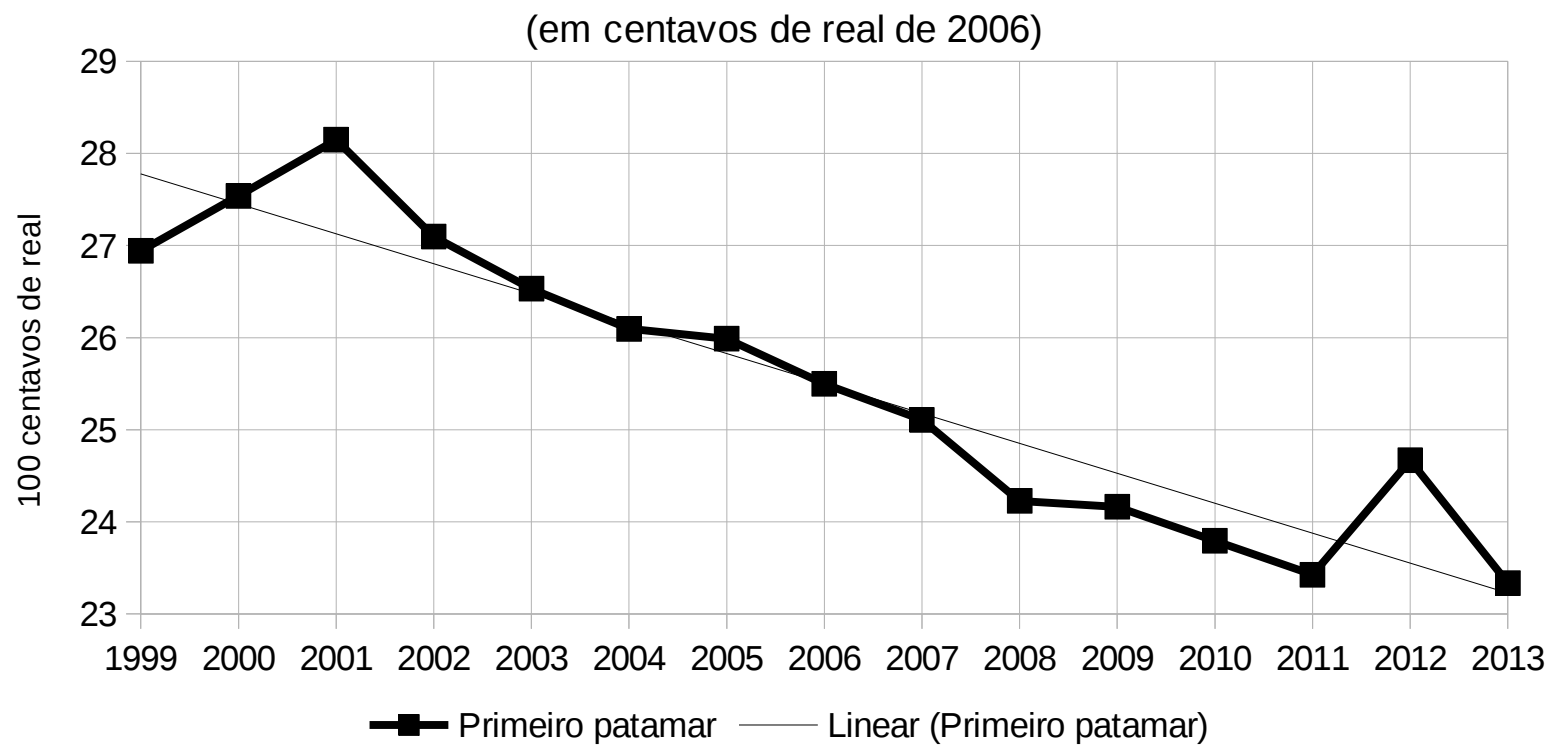

Fonte: IBGE e IPEA

Trata-se de valores altos, que apontam que a formação bruta de capital fixo é elástica,

195 Sobre o assunto, ver: DILLARD, Dudley. La Teoria Economica de John Maynard Keynes. Teoria de una Economia Monetaria. Madrid: Aguilar, 1971; e RUGGLES, Richard \& RUGGLES, Nancy D. Contabilidade Nacional e Análise Macroeconômica. Lisboa: Livraria Sá da Costa editora, 1962. 
e portanto bastante sensível, em relação à renda da camada do topo. No entanto, ao decorrer do entrecho analisado, foi se tornando cada vez menos sensível, apontando para diminuição do protagonismo do topo da pirâmide de renda. A queda, entre 2001 e 2013, foi de mais de 4 centavos. Em porcentagem, essa queda significou uma queda de $17 \%$ no total. Trata-se de uma taxa de perda de $1,27 \%$ ao ano.

O gráfico 6.6 traz a participação relativa do segundo patamar de renda na formação bruta de capital fixo real, entre 1999 e 2013. Observa-se que, após cair aceleradamente até 2001, a participação do segundo patamar na FBCF passou por um período de dois anos de queda menos acelerada. Em 2004, houve uma forte queda na participação, e a partir de 2005 a perda na participação dessa camada caiu em velocidade constante. Em 2012, houve uma nova queda acentuada, com recuperação pontual em 2013. Em 1999, a participação dessa camada era de 28 centavos em cada novo real na formação bruta de capital fixo. Em 2013, havia caído para menos de cerca de 24 centavos. Isso significou uma queda total de 12,75\%.
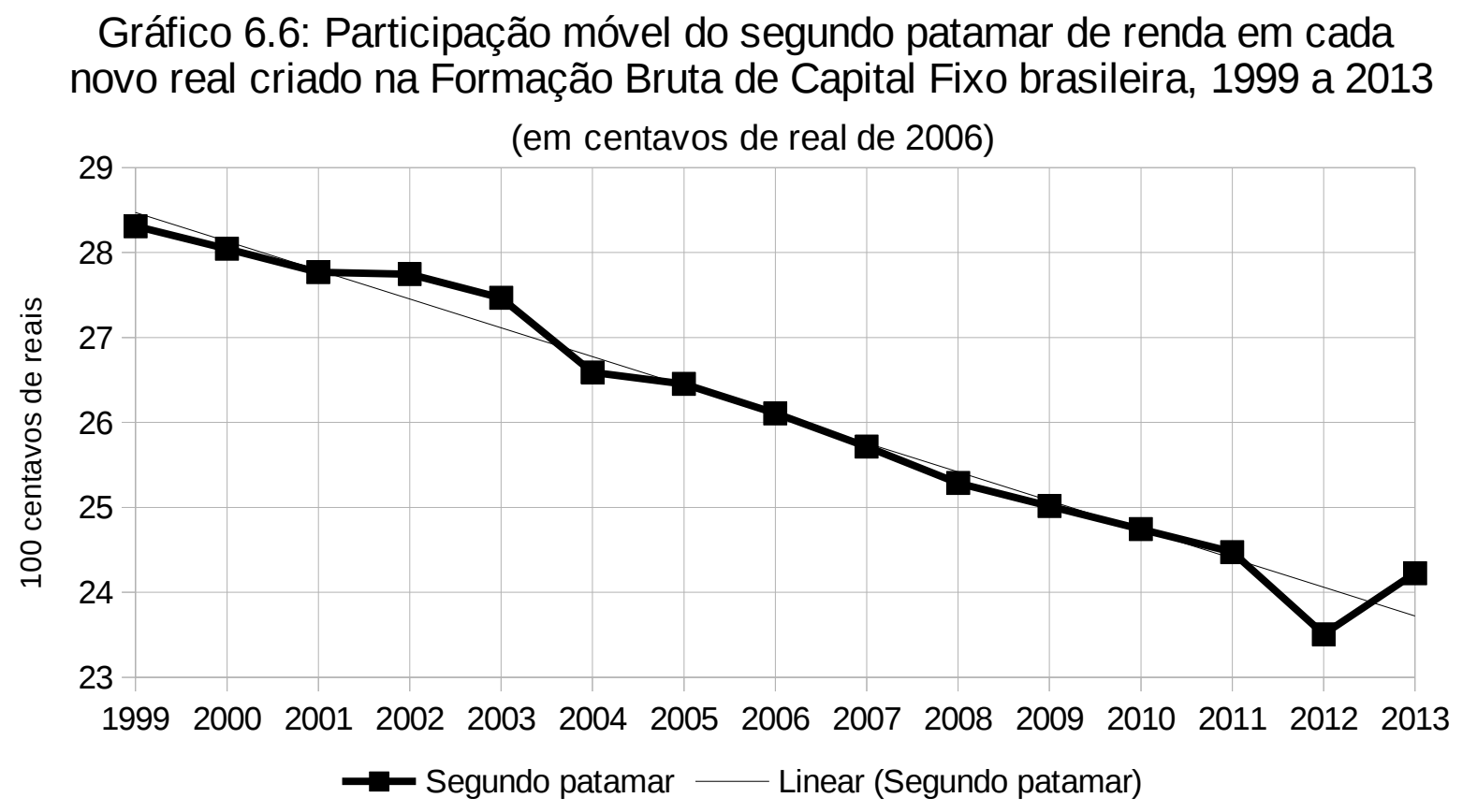

Fonte: IBGE e IPEA

Observa-se que a importância da renda do segundo patamar para a formação bruta de capital fixo caiu no período analisado. Juntos, em 2001, o primeiro e o segundo patamar representavam 56 centavos de cada novo real de investimento. Em 2013, essas duas camadas, que representam os $10 \%$ do topo da pirâmide social, foram responsáveis por 48 centavos de cada novo real de investimento. Trata-se de uma redução de 1,25\% ao ano. Um processo 
como esse, onde parte do protagonismo das camadas do topo é deslocado para outros setores, pode gerar insatisfação de quem estava acostumado com o oligopolismo antes incontestável.

Kalecki ensina que os pobres consomem o que ganham, e os ricos ganham o que consomem. Um dos efeitos que isso gera é que, quanto maior a concentração de renda, maior é a sensibilidade dos investimentos à renda dos mais ricos, e menor em relação à renda dos mais pobres. O aumento da renda das camadas de baixo pode gerar aumento da taxa de crescimento e investimento da sociedade. Mas tem como efeito a redução da ligação entre a renda do topo e os investimentos no país, reduzindo seu protagonismo. Também se expressa como redução da taxa de crescimento (e da taxa de lucros do “setor de ponta”).

Gráfico 6.7: Participação móvel do terceiro patamar de renda em cada novo real criado na Formação de Capital Fixo brasileira, 1999 a 2013 (em centavos de real de 2006)

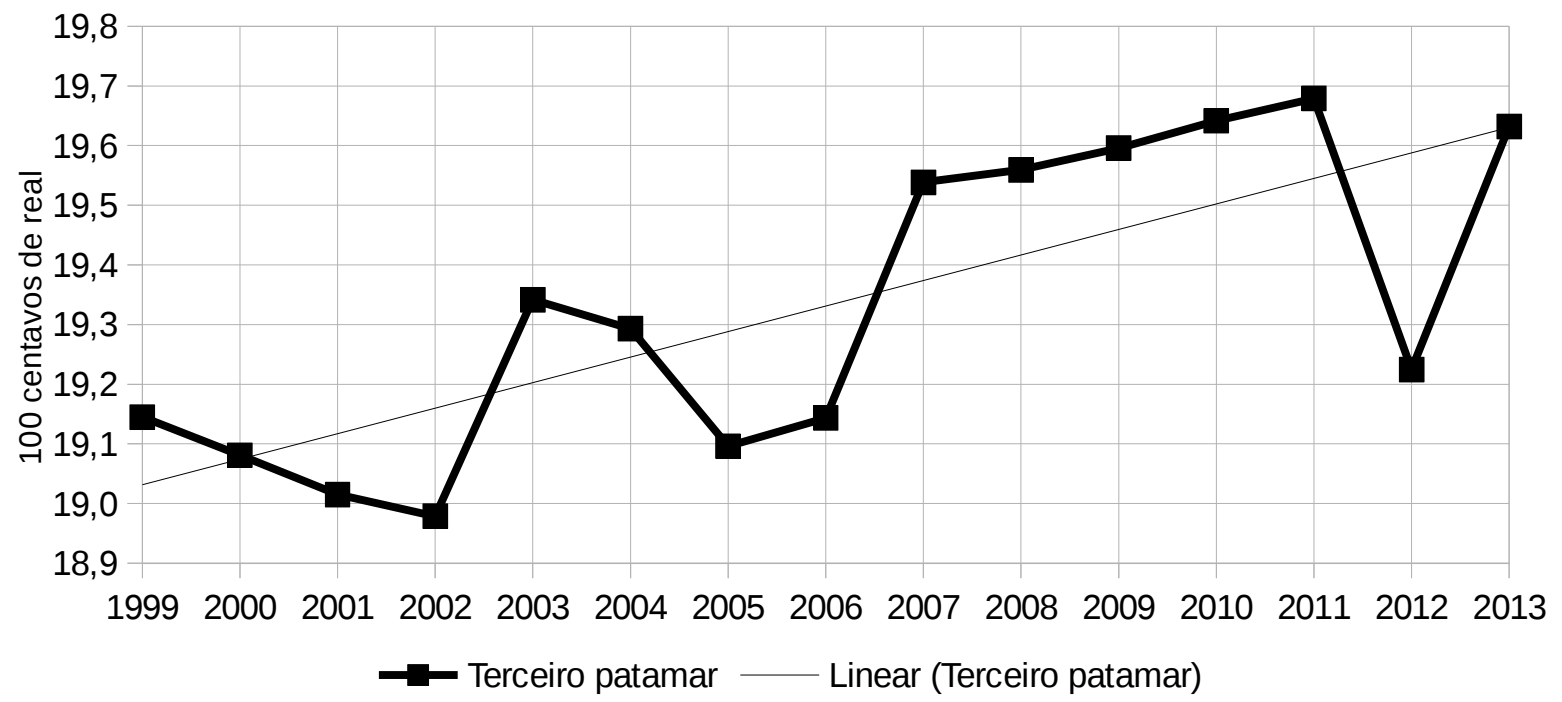

Fonte: IBGE e IPEA

O gráfico 6.7 traz a participação do terceiro patamar (de qual participam os $40 \%$ seguintes ao segundo patamar) de renda em cada novo real na formação bruta de capital fixo real. Observa-se que, de 2002 a 2011, período da melhora da capacidade de importação do Brasil. Essa camada apresentou ganho de importância na formação de capital fixo. Saltou de cerca de 19 centavos em 2001, para cerca de 19,7 centavos, em 2011. Em 2012, apresentou queda mais acentuada, com recuperação em 2013. Entre 2001 e 2013, a participação desse patamar cresceu apenas 3\%, no total. Isso significou um crescimento anual de menos de 0,3\% ao ano.

Para essa camada, enquanto os ganhos no exterior estavam em seu ápice, o 
investimento era possível. Quando o crescimento das exportações começou a fraquejar, houve diminuição no ritmo de crescimento na participação no investimento. Para o terceiro patamar de renda, os ganhos foram momentâneos, e fruto do cenário econômico propício. Ela ganhou enquanto houve alta cíclica dos preços das commodities.

Isso significa dizer que o protagonismo das camadas médias dependeu do desempenho econômico do pais. Sozinha, a renda dessa camada não foi suficiente para impulsionar investimento. No entanto, quanto melhor o país esteve, mais essa camada pode dedicar seus recursos para fins além do consumo. A realização de poupança das camadas médias foi fruto da prosperidade. Novamente, o comportamento estável da participação dessa camada aponta para o fato dela ser a "base” da atividade econômica nacional.

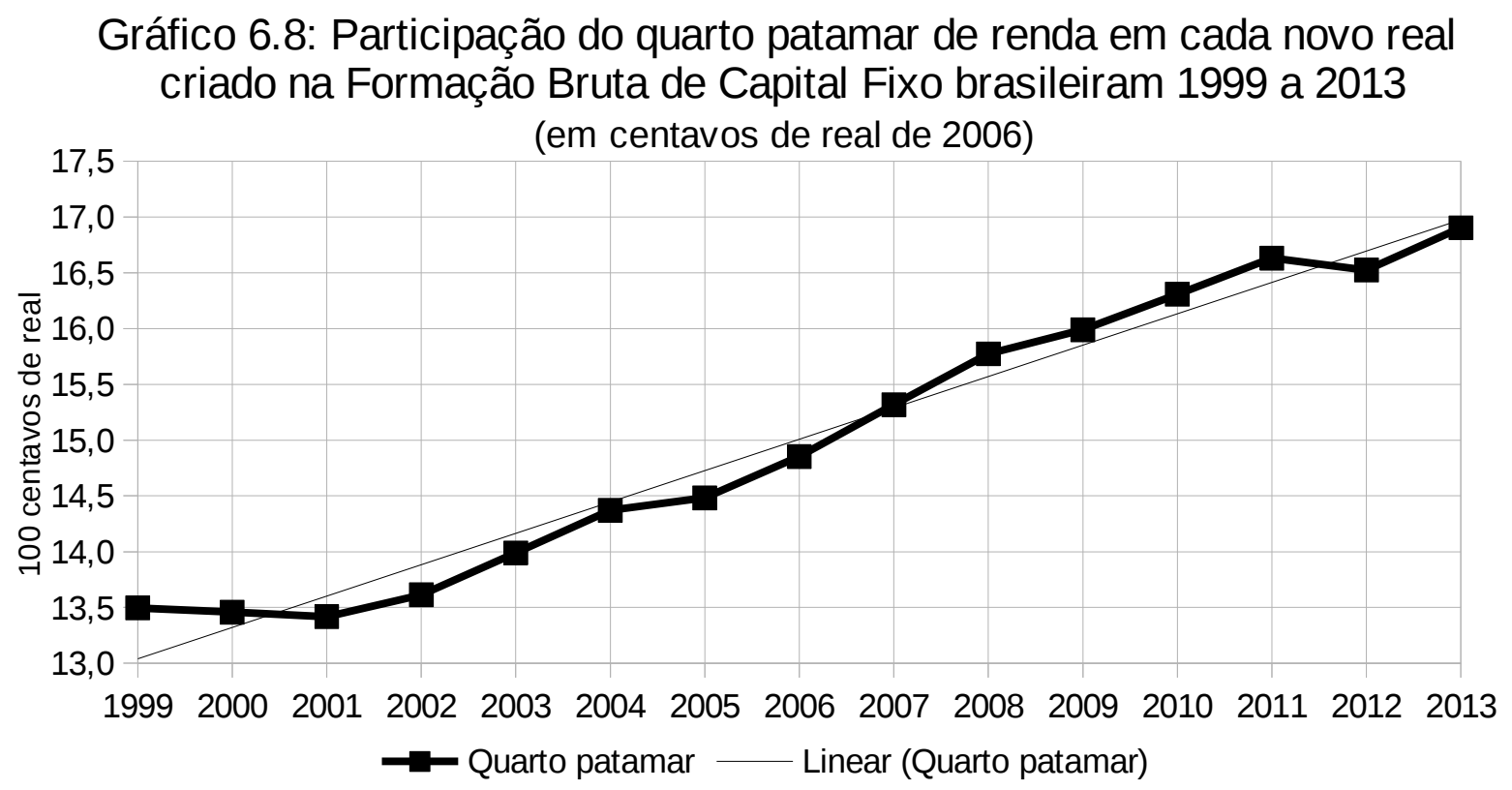

Fonte: IBGE e IPEA

O gráfico 6.8 contém participação relativa do quarto patamar de renda (os 30\% da população seguintes ao terceiro patamar) na formação bruta de capital fixo real. Traz também a linha de tendência linear dessa participação. Essa camada saiu da participação de em torno de 13,5 centavos em cada novo real de investimento e chegou ao patamar de em torno de 17 centavos, no período analisado. Entre 1999 e 2001, observou redução na participação no investimento. De 2003 em diante, apresentou crescimento acelerado, com estagnação em 2005 e queda em 2012. Entre 2001 e 2013, a participação desse setor cresceu 26\%, o que equivale a um crescimento de quase $2 \%$ ao ano.

Do ponto de vista da importância para a formação bruta de capital fixo, somente com a 
melhoria da renda disponível os membros do quarto patamar passaram a conseguir gerar demanda e realizar poupança que impactassem na FBCF. Ainda, ganharam com investimentos direcionados feitos pelo Governo. A distribuição de renda não só permitiu ao quarto patamar consumir como, consequentemente, o transformou em um agente econômico relevante.

Os membros desse patamar deixaram de ser apenas força de trabalho para se tornar consumidores e poupadores. Evidentemente, ainda consumiam e poupavam em níveis bastante inferiores aos membros dos patamares do topo. Ainda viviam na pobreza. Mas se observa que, de 2003 a 2012, ganharam maior relevância para a vida econômica local.

Gráfico 6.9: Participação móvel do quinto patamar de renda em cada novo real criado na Formação Bruta de Capital Fixo brasileira, 1999 a 2013

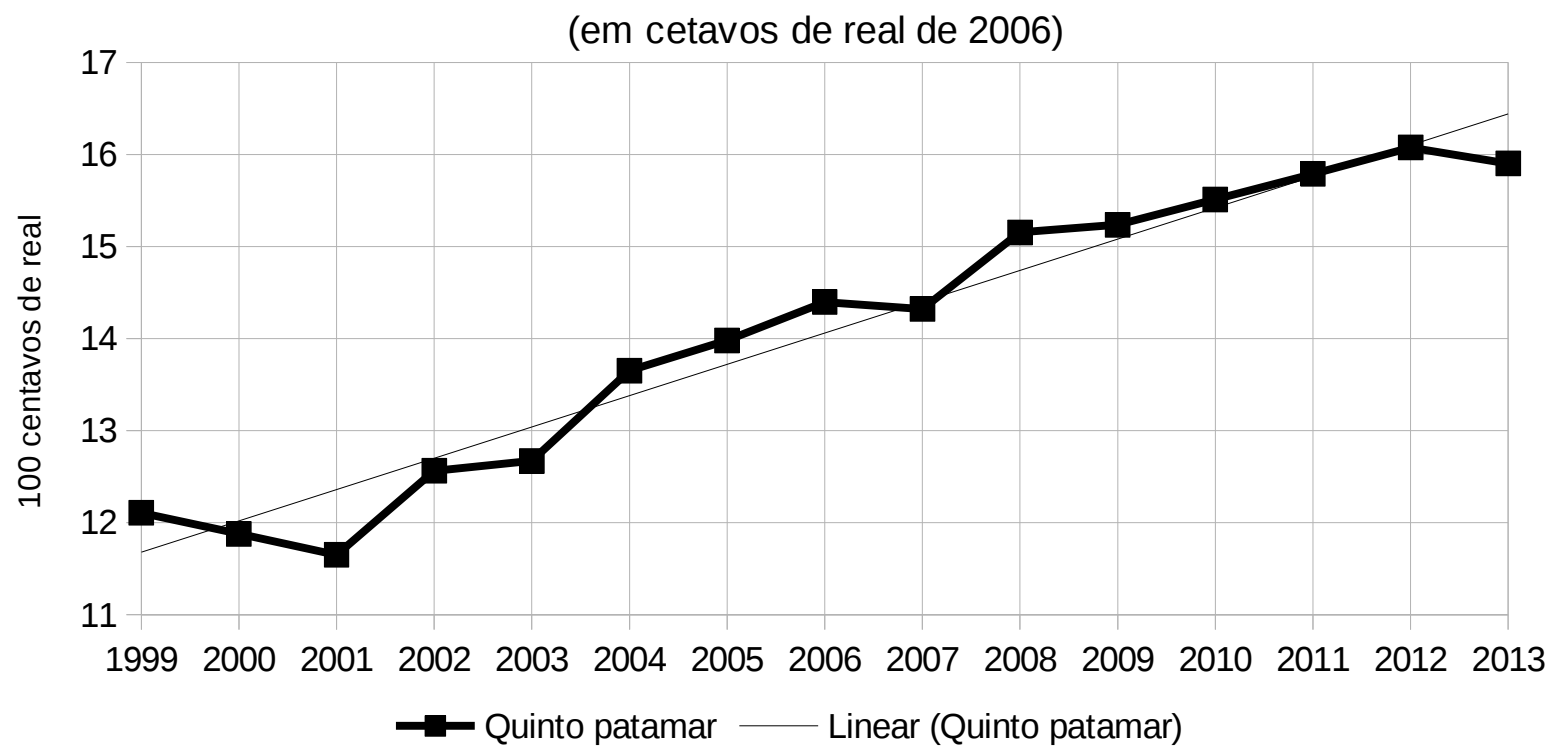

Fonte: IBGE e IPEA

O gráfico 6.9 traz a participação relativa do quinto patamar de renda (20\% da população que está na base da pirâmide de renda) em cada novo real na formação bruta de capital fixo real, entre 1999 e 2013. Observa-se que desde 2002, houve crescimento da participação desse patamar, até 2012. Houve quedas pontuais em 2007 e 2013. Após três anos de queda, em 2001, a participação do quinto patamar era de menos que 12 centavos em cada novo real de investimento. Em 2013, era de quase 16 centavos. Isso significou um crescimento de mais de 2,6\% ao ano, totalizando quase 36,5\% de crescimento, entre 2001 e 2013.

A renda disponível dessa camada da população era tão diminuta que não impactava visivelmente na criação de demanda nem na formação de poupança. Tudo que ganhavam 
gastavam com a sobrevivência. Com a melhoria da economia local, houve ganhos relativos para os $20 \%$ da camada da base da pirâmide de renda. As políticas de transferência de renda permitiram que os ganhos no comércio exterior fossem transformados em maior participação desse camada na vida econômica do país.

O que se aponta é que essa camada passou a participar da formação da poupança doméstica, e ter parte maior de sua renda influenciada pelos investimentos domésticos. Embora a participação ainda fosse baixa em 2013, expressava certa liberdade e ganho de importância dos mais pobres. Para esse processo contribuíram políticas de investimento direcionado do Governo, como o programa Luz para Todos e Minha Casa Minha vida.

\subsection{OSCILAÇÕES NA RENDA E NO INVESTIMENTO}

A relação entre a renda disponível das camadas e a formação bruta de capital fixo também pode ser analisada pela ótica das oscilações. Para isso, utiliza-se o perfil oscilatório alcançado através da regressão linear com a formação bruta de capital fixo como variável dependente, e as rendas das camadas como variável independente. O que se revela com esses perfis oscilatórios são os momentos em que houve alta de investimento, frente a renda existente, ou baixas no investimento. Trata-se de uma forma de medir a capacidade de investimento de cada patamar de renda, entendida como o impacto real do aumento da renda de um segmento no aumento dos investimentos em capital fixo.

Isso significa encontrar diferenças na resposta à crises por parte de cada segmento de renda. Para a história econômica, esse método permite verificar a coincidência das crises internas de um país com crises mundiais, ou com acontecimentos não-mensurados. Permite verificar impacto de políticas econômicas, e mesmo as defasagens nas relações de "incentivo e resposta”. Ou seja, permite verificar se (a) forças exógenas influenciaram os investimentos no Brasil; (b) se o investimento respondeu ao aumento de renda, ou se foi mais influenciado pela perspectiva de lucro; e (c) se as políticas econômicas adotadas impactaram no nível de investimento, para além do nível de renda disponível.

O gráfico 6.10 traz as oscilações da renda disponível do primeiro patamar de renda em torno das oscilações na formação bruta de capital fixo (FBCF), para o período entre 1999 e 2013. Para a FBCF, os valores acima de zero significam que houve investimento acima do 
esperado para o período. Para o primeiro patamar de renda, os valores acima de zero significam que houve ampliação da capacidade de investimento. ${ }^{196}$

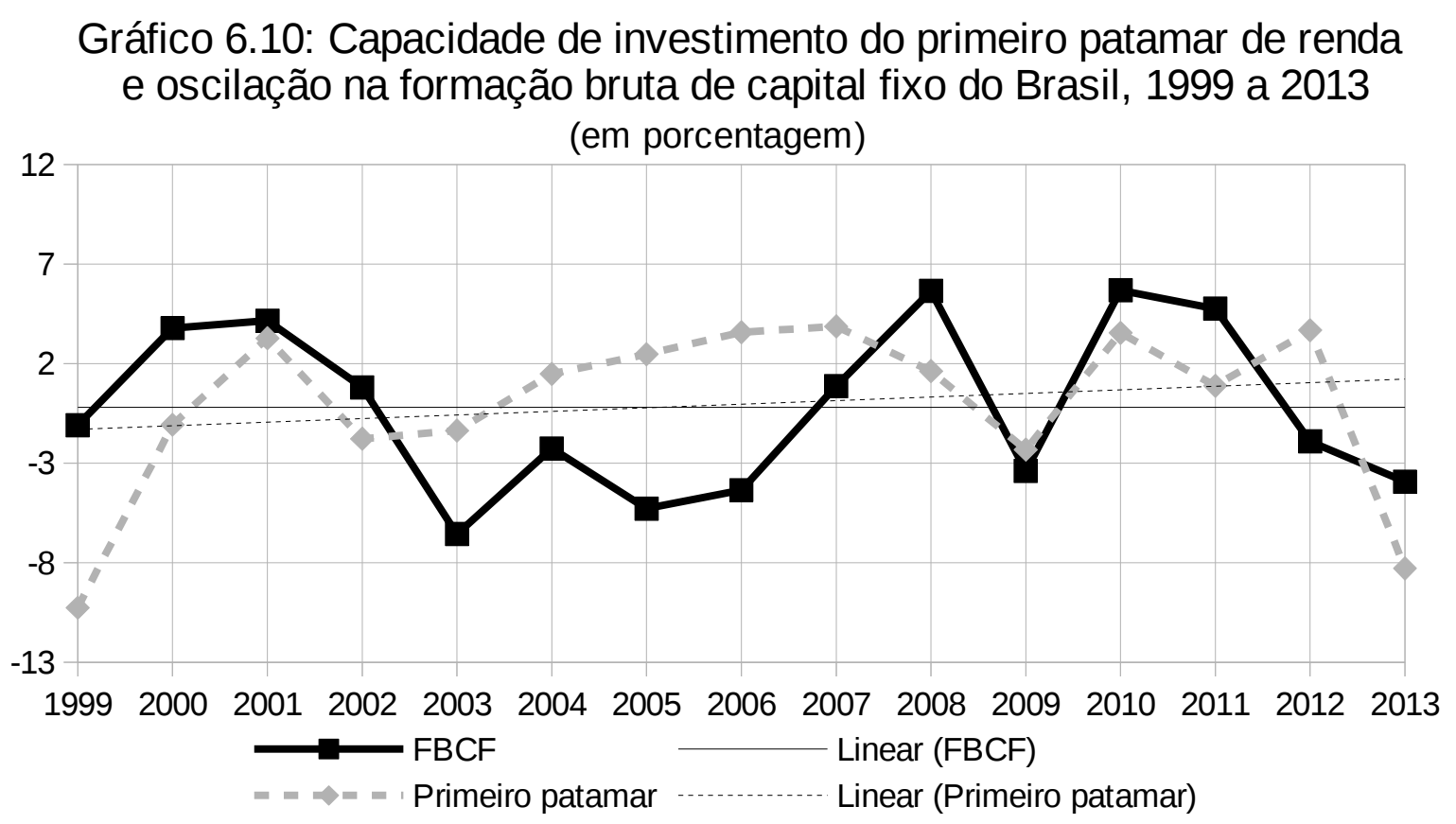

Fonte: IBGE e IPEA

Observa-se que entre 2003 e 2006, houve considerável crise no investimento brasileiro. Apenas entre 2007 e 2008 houve recuperação na formação bruta de capital fixo, em relação à renda disponível. A partir de então, estagnou-se no mesmo patamar, com oscilação em 2009. Em 2012, houve início de nova fase de crise no investimento brasileiro. O primeiro patamar de renda apresentou recuperação e alta na capacidade de investimento, entre 1999 e 2001. Em 2002 e 2003, observou baixa temporária. Mas, entre 2004 e 2012, o primeiro patamar de renda apresentou alta na capacidade de investimento, com queda pontual em 2009. Isso se explica por ser o primeiro patamar de renda o principal responsável pelos investimentos. Ainda, em tempos de crise, essa camada observou menores níveis de perda (ou apenas ausência de aumento de ganho). Como, nos períodos de crise, os investimentos tendem a sofrer redução (bruta ou relativa), diante de perdas menores na renda do primeiro patamar de renda, o que se expressa é um aumento da capacidade de investir.

196 O gráfico foi construído com o perfil oscilatório da formação bruta de capital fixo explicado pelo tempo. Daí que os valores acima de zero expressam desempenho da FBCF acima do esperado. Os valores assinalados para renda disponível do primeiro patamar de renda são a oscilação da renda do primeiro patamar explicado pela formação bruta de capital fixo. Essa oscilação foi plotada em torno das oscilações do FBCF. Disso resulta que o valor esperado para o primeiro patamar é que ele acompanhasse as oscilações do FBCF, que se esperava que ficasse em torno do zero. Ou seja, valores da renda disponível do primeiro patamar acima do zero assinalam que o crescimento de renda foi acima do esperado caso a formação bruta de capital fixo tivesse crescido de forma constante. Isso quer dizer que houve ganho de capacidade de investimento. 
A prosperidade local, iniciada em 2003, se expressou primeiro na renda (e portanto na capacidade de investimento), e só depois nos investimentos realmente realizados. Isso reforça a leitura que o crescimento econômico, no Brasil, entre 1999 e 2013, não foi resultado de investimentos realizados pelo empresariado. Ao contrário, foi o crescimento econômico que impulsionou novos investimentos.

Gráfico 6.11: Capacidade de investimento do segundo patamar de renda e oscilação na formação bruta de capital fixo do Brasil, 1999 a 2013

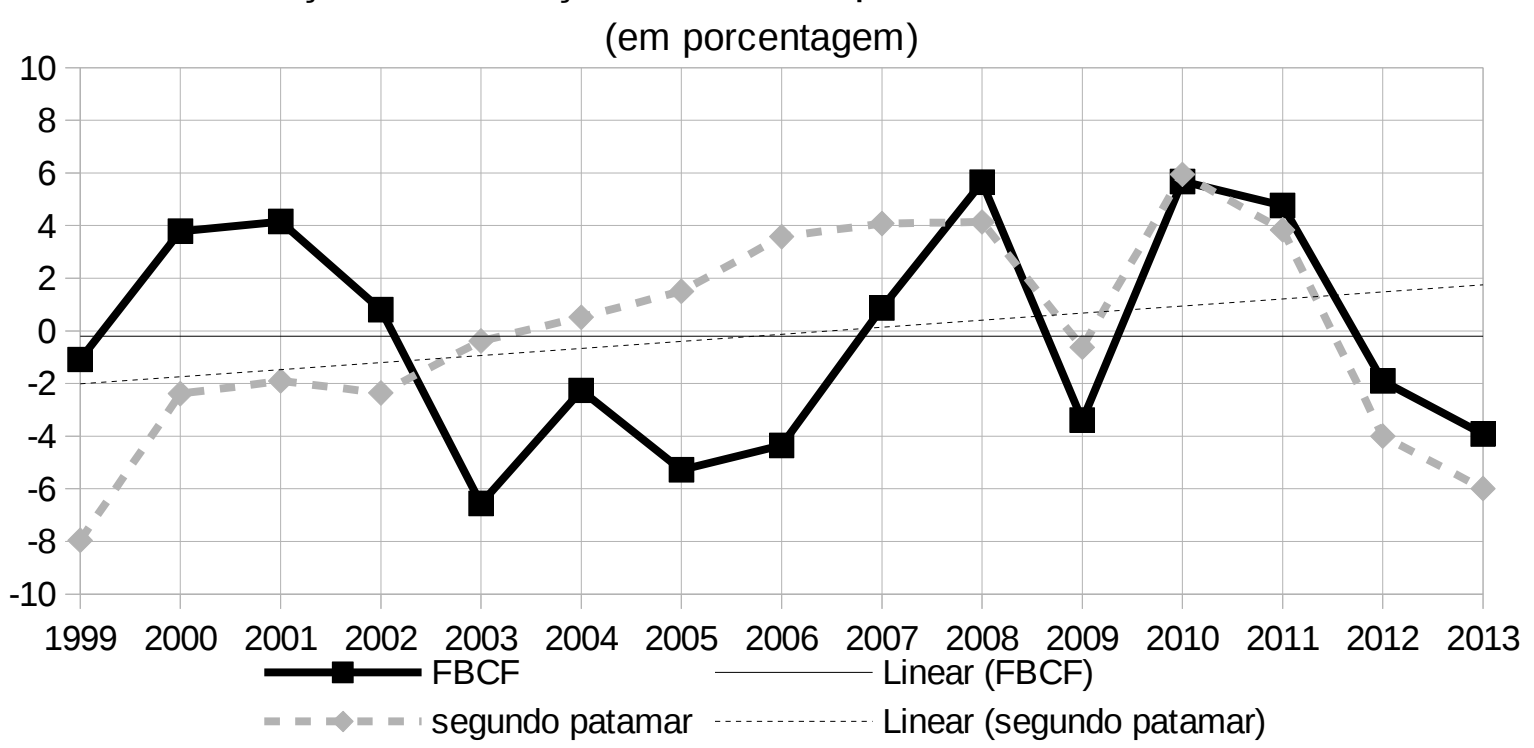

Fonte: IBGE e IPEA

Para o segundo patamar de renda, ocorreu algo similar. No entanto, o aumento na capacidade de investimento foi ainda mais influenciado pela prosperidade local. Tão logo começou a recuperação econômica do pais, essa camada logrou aumentar sua capacidade de investimento. Mas, assim que as exportações brasileiras deixaram de ser capaz de sustentar a alta capacidade de importação, a capacidade de investimento dessa camada também demonstrou desgaste.

Após um crescimento pontual, em 2010, os 9\% seguintes ao 1\% do topo da pirâmide social viram sua capacidade de investir cair. Para essa camada, o período dos "super-preços" das commodities não deu fôlego para um crescimento da renda suficiente para sustentar novos investimentos. Ainda assim, em 2013, observou-se crise menor na capacidade de investimento do que aquela que observou-se em 1999. O saldo do período foi, apesar das crises e da dependência das exportações, ainda positivo. 
Gráfico 6.12: Capacidade de investimento do terceiro patamar de renda e oscilação na formação bruta de capital fixo do Brasil, 1999 a 2013

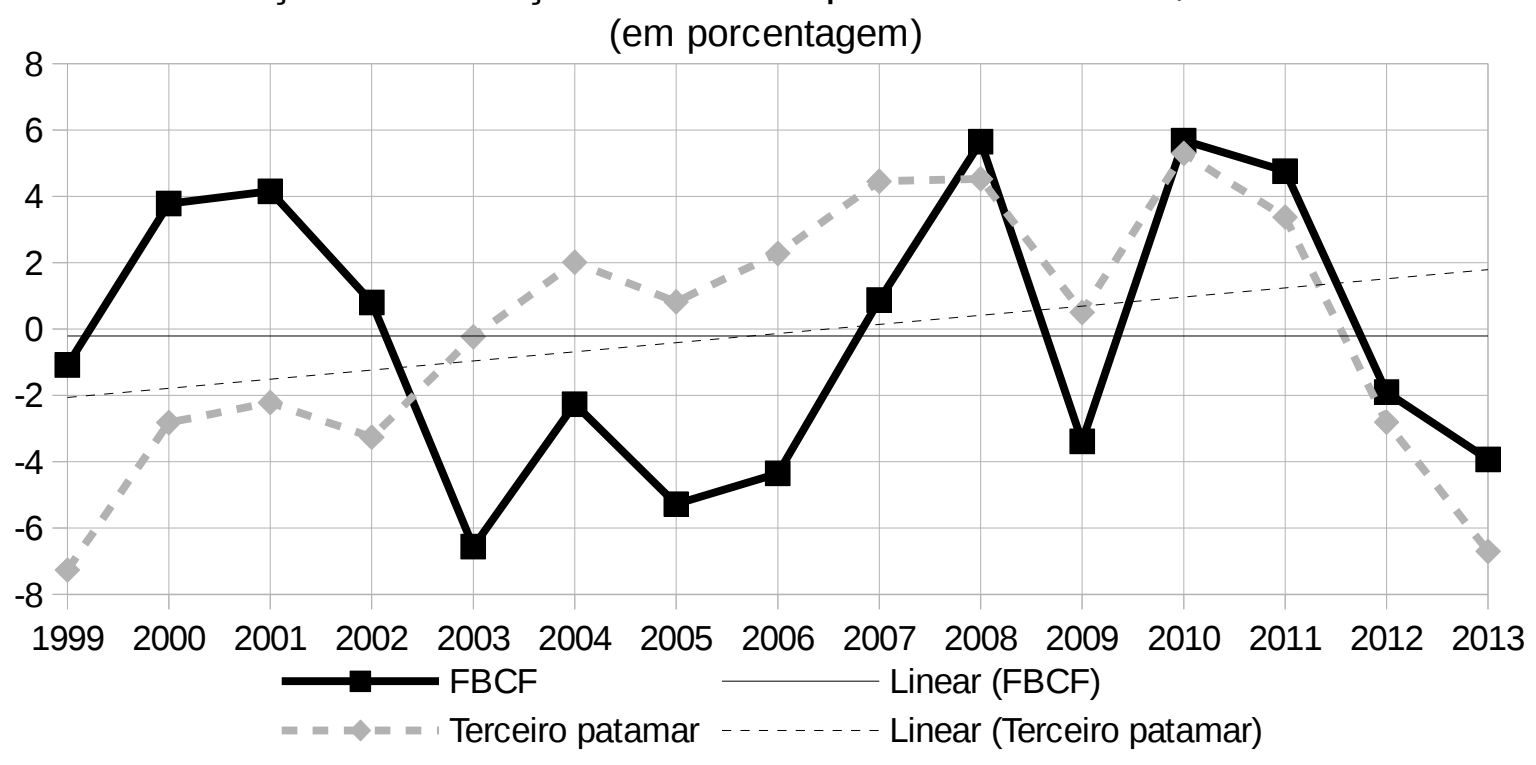

Fonte: IBGE e IPEA

Para o terceiro patamar de renda, que engloba os $40 \%$ seguintes aos $10 \%$ do topo da pirâmide de renda, a trajetória de recuperação e ganho de capacidade de investimento, entre 1999 e 2008, foi ainda mais acentuada. O período de prosperidade local resultou em ganhos para essa camada média da sociedade. Entre 2004 e 2008, viveu-se aparente “era de ouro”, onde as camadas médias puderam ampliar sua capacidade de investimento de forma considerável. Mas, com a crise de 2008-2009, houve sinais de desgaste. Em 2011, iniciou-se acelerado processo de perda na capacidade de investimento do terceiro patamar de renda.

Essa camada média, cujo desempenho do consumo depende do desempenho da atividade econômica de forma direta, demonstrou ter sensibilidade maior no que toca a capacidade de investir. Isso se explica por dois fatores: (a) as camadas médias investem quando sua renda disponível está aumentando. Quando se encontra em períodos de crise, ela se abstém de fazer novos investimentos. Isso é resultado de sua baixa propensão marginal a poupar. Parte considerável dessa camada média é composta de administradores e técnicos de grandes empresas. Assim, sua capacidade de investimento é mais afetada negativamente quando há queda no investimento realmente realizado na produção.

Ainda, (b) é resultado da ausência de uma economia de massa no Brasil. Embora existam em grande volume, os pequenos e médios negócios não são fator determinante no desempenho do nível de investimento do Brasil. Ao contrário, resultam dele. Em momentos 
de prosperidade, cresce o número de estabelecimentos de serviço, consultórios de profissionais livres, etc. Em momentos de crise, esses estabelecimentos param de surgir, e mesmo fecham. Parte relevante desses estabelecimentos são formados para atender a demanda da metade de cima da pirâmide social.

Quando ocorreu a crise de 2008 e 2009, o governo brasileiro realizou “políticas anticíclicas”197, aumentando o crédito e ampliando seus gastos com a população mais pobre. Essas camadas mais pobres, mesmo ampliando sua renda, ainda estava excluída de parte do consumo dos bens e serviços oferecidos pelo terceiro patamar de renda. Daí o baixo impacto das “políticas anticíclicas” na capacidade de investimento do terceiro patamar de renda.

Gráfico 6.13: Capacidade de investimento do quarto patamar de renda e oscilação na formação bruta de capital fixo do Brasil, 1999 a 2013

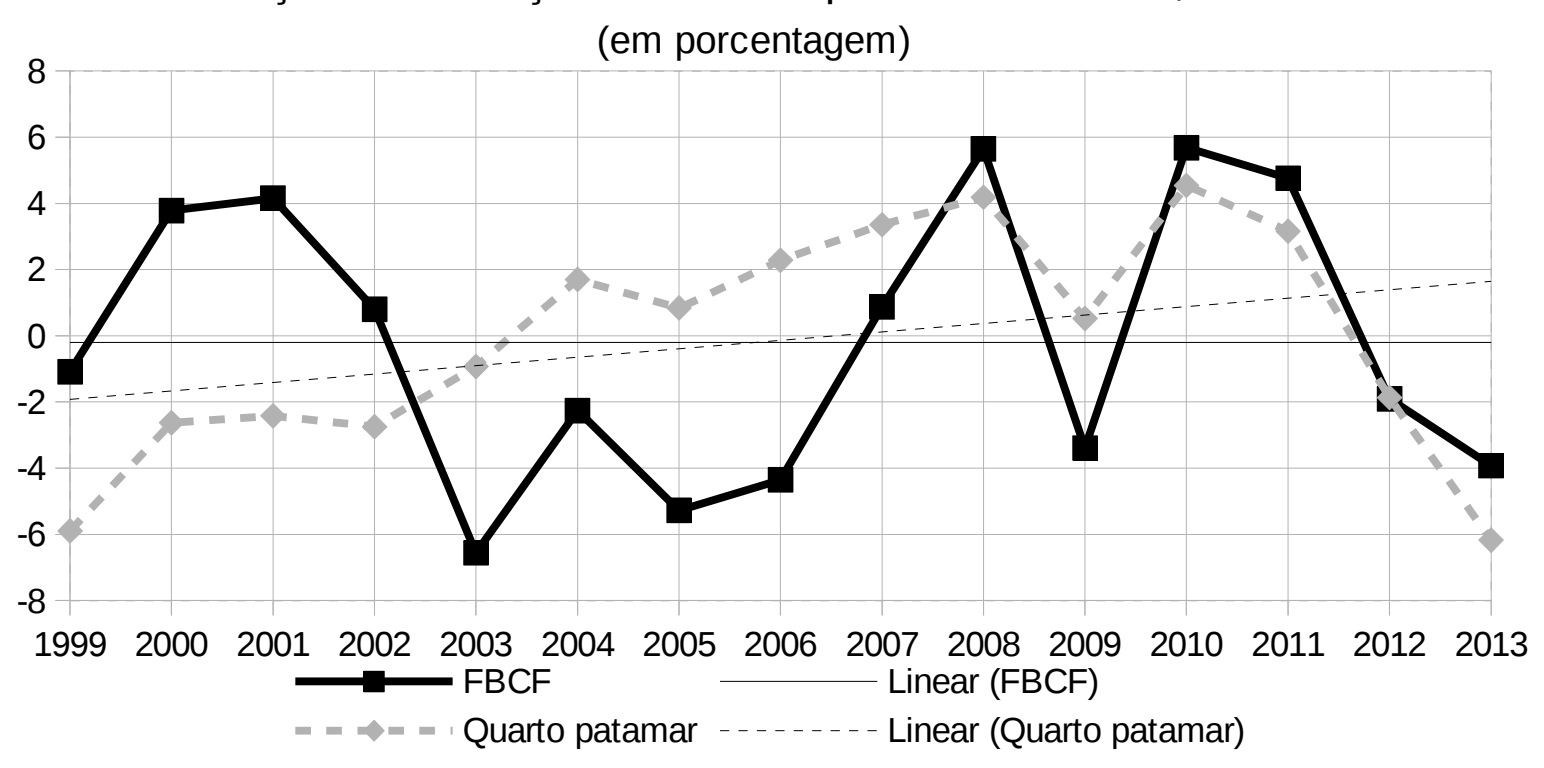

Fonte: IBGE e IPEA

O gráfico 6.13 a capacidade de investimento do quarto patamar de renda e as oscilações na formação bruta de capital fixo, para o período entre 1999 e 2013. Para essa camada, observou-se recuperação e ganho na capacidade de investimento entre 2003 e 2008. Em 2009, com o impacto da crise de 2008-2009, houve rebaixamento nos novos ganhos. Mas só a partir de 2012 observou-se queda na capacidade de investimento.

Para o quarto patamar de renda, que são os $30 \%$ seguintes aos $50 \%$ do topo da pirâmide de renda, a capacidade de investimento tem significado distinto ao que tem para as

197 Em termos rigorosos, mais políticas anticrise do que anticíclicas, ver a propósito: OCAMPO, José Antônio.

"Developing Countries' Anti-Cyclical Policies In A Globalized World". In: XIII Seminario Regional De Politica Fiscal - Compendio De Documentos, CEPAL, 2001. 
camadas de cima. Para essa camada, sua “capacidade de investimento" é a pouca poupança que possa fazer e o impacto que a demanda de consumo pode ter no investimento.

Entre 1999 e 2008, as oscilações nos investimentos e na renda disponível do quarto patamar de renda tiveram pouca relação. Isso foi fruto do crescimento acelerado da renda dessa camada, durante o período de prosperidade, e do baixo impacto que possuíam no investimento local. Somente a partir de 2008, a renda dessa camada e o investimento brasileiro em capital fixo passaram a oscilar de forma mais similar.

Gráfico 6.14: Capacidade de investimento do quinto patamar de renda e oscilação na formação bruta de capital fixo do Brasil, 1999 a 2013

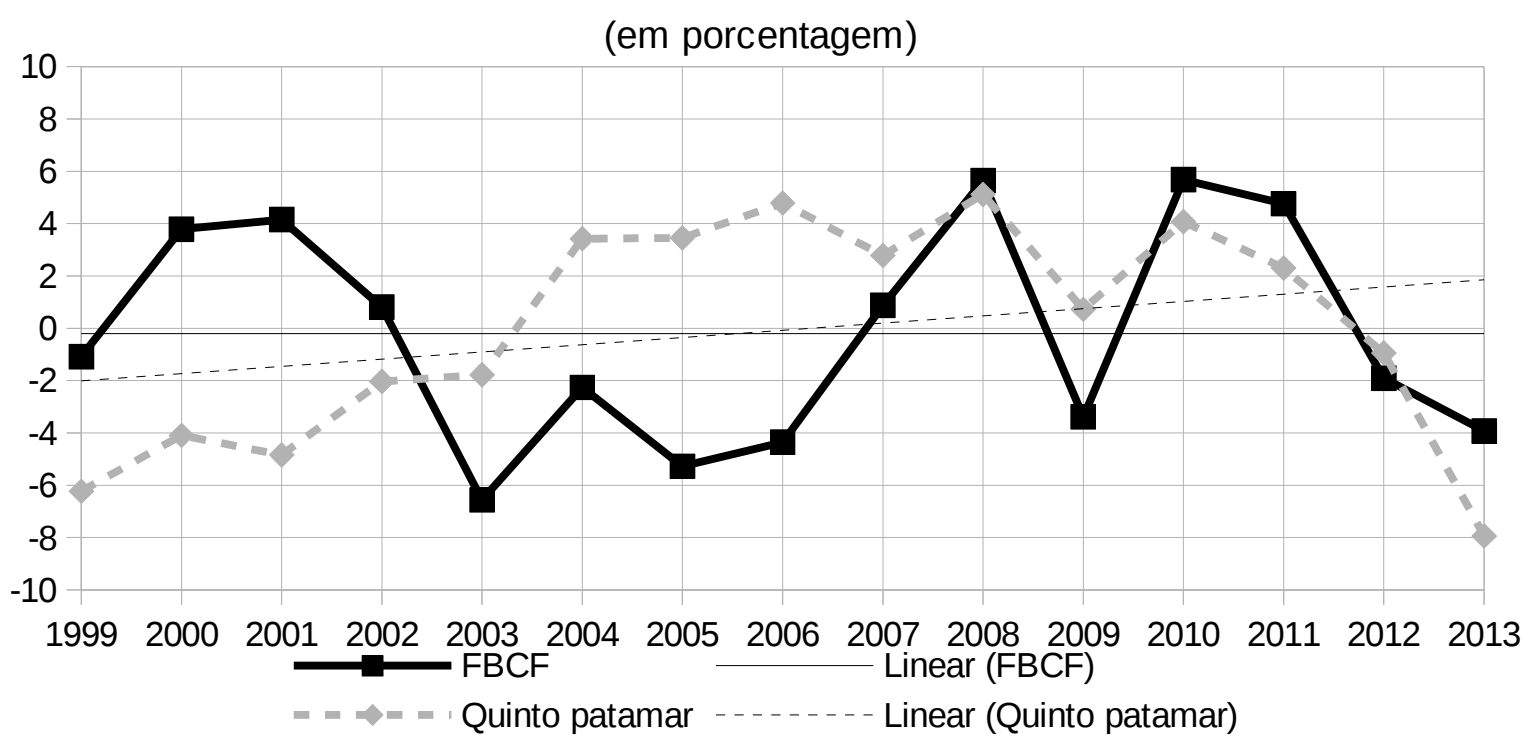

Fonte: IBGE e IPEA

Para o quinto patamar de renda, a recuperação e distanciamento entre seu desempenho de renda e os investimentos brasileiros foi ainda maior, até 2008. Só a partir daí, quando a crise econômica já havia se instalado, é que passou a ocorrer maior coincidência entre as oscilações da renda dos $20 \%$ da base da pirâmide social e a formação bruta de capital fixo.

A crise econômica de 1999 e a de 2000 e 2001 levaram à forte desaceleração econômica, no Brasil. A resposta encontrada foi, como sempre, o “exportar ou perecer”. Para salvar a economia doméstica, diante do mercado consumidor em decréscimo, a saída foi exportar. Em 2002, já estava claro para o Banco Central do Brasil que o comércio exterior estava possibilitando ganho de divisas. A Ásia, em especial a China, já se destacava como forte parceiro econômico para o futuro próximo.

Em 2003, os ganhos do comércio exterior foram utilizados para incentivar o consumo, 
e diminuir a concentração de renda. Acreditava-se que ao impulsionar o consumo, a renda cresceria mais rápido, o que levaria ao aumento também do investimento. Esperava-se que o efeito multiplicador keynesiano se realizasse conforme o previsto na teoria. No entanto, a teoria keynesiana traz diversas ressalvas. O casal Richard e Nancy Ruggles, em seu manual de macroeconomia ${ }^{198}$ lembram que o multiplicador do consumo e do investimento são históricos. Isso significa que podem sofrer alterações drásticas em contextos diferentes. Na prática, ao ampliar o consumo, o multiplicador pode, em dado momento, cair.

No caso brasileiro, como a fonte de renda que permitiu o aumento do consumo não veio da política de investimento do governo ou do setor privado, mas sim da ampliação do comércio exterior. Formou-se sangria de recursos. O sucesso das exportações levou à valorização da moeda nacional. O aumento da renda disponível das camadas levou ao aumento da demanda. Nesse contexto, a forma mais barata de suprir a demanda foi com a ampliação das importações. Para a indústria, saia mais lucrativo importar bens do exterior e apenas ensacá-los localmente.

Esse processo durou até 2006. Em 2007, o Plano de Aceleração do Crescimento (PAC) entrou em vigor. O governo fez grandes investimentos em obras de infraestrutura. Em parte, o programa permitiu que a renda das camadas de baixo da população crescesse mais rapidamente. Parte dos recursos arrecadados foi utilizado para continuar a impulsionar pouco a formação bruta de capital fixo. A crise de 2008, que impactou na economia brasileira em 2009, levou a uma queda pontual nos investimentos, mas em 2010 a política do governo voltou a dar frutos. No entanto, a formação bruta de capital se concentrou no setor da construção civil.

Na verdade, esse crescimento pontual foi resultado do esforço anticíclico chinês, o que permitiu que os preços dos bens primários exportados pelo Brasil continuasse a crescer. Naquele ano, a demanda chinesa por matérias-primas também impactou na indústria doméstica brasileira. A expansão da extração de petróleo, marcada pelos investimentos na exploração da camada pré-sal, e da exportação de minério de ferro levaram a indústria de extração a crescer. Como a taxa de lucro esperada para a Europa e EUA era baixa, houve fluxo de capital para os países dependentes. Houve crescimento do investimento estrangeiro nos setores exportadores e nos setores de serviço. Enquanto isso, a indústria de transformação 
não sofreu renovações.

Desta forma, a recuperação dos investimentos não significou melhoria na produtividade doméstica. Foi, na verdade, resultado da reafirmação do papel do Brasil como exportador de bens primários. As políticas anticrise não significaram recuperação da economia local, mas sim sobrevida do modelo estrutural econômico de dependência. A hipótese de uma política anticíclica havia sido prejudicada pelas reformas do período anterior. Em parte, havia uma forte limitação fiscal para que houvesse verdadeiro esforço anticíclico, uma vez que a crise tende a gerar queda na arrecadação. Apenas era possível ampliar os gastos do governo com despesas de capital de forma consistente ou (a) reduzindo os gastos correntes; ou (b) realizando déficit orçamentário. Ainda, como na período anterior o Estado privatizou as empresas estatais, ficou com pouca margem de manobra, dependendo exclusivamente do orçamento do governo. A adoção do modelo de "responsabilidade fiscal”, e a dependência estrutural da poupança externa tiveram, ambos, efeitos pró-cíclicos ${ }^{199}$. Bastaria que os preços dos produto primários caíssem para que a economia brasileira sofresse forte revés.

199 Para uma discussão sobre o impacto pró-cíclico dos fluxos de capital financeiro, ver: OCAMPO, José Antonio; VOS, Rob (Ed.). Uneven economic development. Nova Iorque: United Nations Publications, 2008. Pg. 119. 


\section{O SETOR EXTERNO E A RENDA DISPONÍVEL}

Em uma entrevista concedida em 15/10/2010 ao programa Agenda Econômica, da TV Senado, o professor Dércio Garcia Munhoz, da Universidade de Brasília, foi questionado quanto ao papel da formação de reservas internacionais para garantir estabilidade econômica para os países, em especial para países em desenvolvimento. A explicação dada por ele foi que existem dois tipos de reservas internacionais: (a) a reserva sadia, adquirida através de uma exportação superior à importação, dentro de certos volumes e limites; e (b) a nociva, adquirida artificialmente através de empréstimos e facilitação de entrada de capital estrangeiro.

A reserva internacional artificialmente construída pode ser parte de um ciclo vicioso. Adquirida para criar garantias aos investidores estrangeiros, como forma de dizer "se quiserem retirar todo seu capital investido, haverá reservas para isso”. No entanto, para garantir essa reserva, aqui faz-se necessário realizar empréstimos e criar condições extraordinárias de investimento. Isso foi feito (i) com a sobrevalorização do investimento, e (ii) com juros demasiadamente altos. Tanto o real sobrevalorizado como os juros altos criavam maior demanda de reserva internacional.

Munhoz explicou que essa forma de "gerar estabilidade" seguiu a fórmula de desregularização do mercado de capitais, da década de 1990. Na prática, ao invés de se criar estabilidade, o modelo espalhou instabilidade por todos os países onde foi aplicada. Para se proteger da instabilidade, os governos atuaram, através de seus bancos centrais, para desvalorizar a capacidade de investimento das moedas locais.

No Brasil, o caminho tomado foi o fortalecimento da autonomia do Banco Central. Por sua vez, o Banco Central brasileiro reforçou a política de garantia da estabilidade através do controle de inflação. Para isso, era instrumento a sobrevalorização do Real, o câmbio, e juros altos. Os saldos das exportações não compensaram suficientemente, durante todo período, os déficits na conta corrente do setor externo brasileiro. A aquisição de divisas foi garantida através da entrada de capital estrangeiro, em especial sob a forma de investimento estrangeiro direto. Esse caminho fortaleceu os mecanismos de estrangulamento da economia brasileira. Por um lado, o Real sobrevalorizado (em cenário de inflação) encarecia os produtos 
brasileiros e barateava os produtos estrangeiros. Como consequência, a indústria brasileira perdeu ainda mais sua capacidade de competição. Por outro lado, os juros altos, a autonomia do Banco Central, e o modelo de políticas econômicas adotado, levou à falta de incentivo e de recursos públicos para garantir investimento na indústria local. O resultado foi o desmantelamento do parque industrial de transformação.

Nessas condições, a recuperação econômica brasileira, da década de 2000, foi caracterizada por um momento de prosperidade no comércio exterior, e a manutenção e fortalecimento de mecanismos de estrangulamento da economia brasileira. No período, o Brasil observou baixos ganhos no acúmulo de capital fixo, e crescimento de mecanismos de perda de recursos.

O modelo de financiamento através do investimento estrangeiro direto gerou grande aumento nas perdas de divisa através do pagamento de dividendos ao exterior. Para sustentar os pagamentos devidos, foi necessário facilitar a entrada de novos capitais estrangeiros. Nas palavras de Munhoz, isso significou vender o Brasil.

O que Munhoz descreveu foi (a) um modelo de dependência da economia brasileira; e (b) uma caracterização do Brasil como país subdesenvolvido. Isso significa que o Brasil (i) possuiu, no período, pouca acumulação de capital e baixa produtividade; (ii) o pouco que produziu pagou ao exterior; e (iii) o mercado interno ficou minguado.

\subsection{IMPORTAÇÃO E A RENDA DISPONÍVEL DAS CAMADAS}

Em países dependentes e subdesenvolvidos, conforme Ragnar Nurkse, o acúmulo de capital fixo é pequeno. Há baixa industrialização e produtividade, que resulta da falta de excedente, embora seja também uma de suas causas. Ainda, o contato comercial e cultural com outros países geram o efeito demonstração: as burguesias locais desejam consumir aquilo que é consumido nas metrópoles. Os pobres locais desejam consumir aquilo que a burguesia consome.

A baixa acumulação de capital fixo gera (a) necessidade de importação de bens de capital e insumos para sustentar a industrialização local; e (b) há pressão para importação conforme haja aumento do nível de consumo doméstico. Nesse sentido, a criação de demanda em países dependentes pode resultar ou (i) em pressão inflacionária; (ii) expansão da 
importação; ou ainda (iii) ambos.

Uma das formas de mensurar a interação entre a renda disponível e a importação é através do cálculo da propensão marginal a importar, que é a parcela da renda que dada camada (ou nação) gasta com a importação. A propensão marginal a importar pode, também ser descrita como quanto o aumento de um real na renda gerará de aumento na importação. Quando se utiliza a renda em valores reais em moeda nacional, e a importação também em valores reais em moeda nacional (portanto levando em consideração o impacto das oscilações do câmbio), a propensão marginal também indica a chamada sangria no efeito multiplicador $^{200}$. A sangria do multiplicador resulta da fuga de recursos que um país sofre quando possui dependência de importação para crescer: ao realizar um incremento de renda, parte da nova demanda agregada é compensada com o aumento da importação. Isso faz com que um aumento no consumo, ou mesmo nos investimentos, tenha um efeito menor para o incremento imediato na renda disponível, pois parte do efeito multiplicador esperado é perdido sob a forma de importação ${ }^{201}$

Conforme Yeong-Her Yeh, quanto maior a propensão marginal a importar, caso a elasticidade-renda das importações for positiva, pior serão os termos de troca do país ${ }^{202}$. Isso significa que, quanto maior a dependência das importações, não só maior serão as perdas de divisas para cada novo Real (no caso do Brasil) criado na economia, maior será a necessidade de expandir a exportação para compensar cada novo Real de importação. É isso que define a chamada "restrição externa” da economia de um país,explicada por Raúl Prebisch da seguinte forma:

O crescimento das exportações estabelece um limite máximo para o ritmo de desenvolvimento de um país periférico. Êste limite é determinado pela intensidade com que aumenta a procura de importações, à medida que cresce a renda por habitante. Um simples exemplo serve para ilustrá-lo. Suponha-se que as exportações primárias cresçam à razão de $2 \%$ ao ano, por habitante. A renda por

200 Para uma discussão sobre as formas de cálculo da propensão marginal a importar, ver: SHINOHARA, Miyohei. The Multiplier and the Marginal Propensity to Import. The American Economic Review, Vol. 47, No. 5 (Sep., 1957), pg. 608-624.

201 Sobre o assunto, ver: RUGGLES, Richard \& RUGGLES, Nancy D. Contabilidade Nacional e Análise Macroeconômica. Lisboa: Livraria Sá da Costa editora, 1962.; DILLARD, Dudley. La Teoria Economica de John Maynard Keynes. Teoria de una Economia Monetaria. Madrid: Aguilar, 1971.;SHINOHARA, Miyohei. The Multiplier and the Marginal Propensity to Import. The American Economic Review, Vol. 47, No. 5 (Sep., 1957), pg. 608-624

202 Ver: YEH, Yeong-Her. On the Consumption Pattern and Terms of Trade. The American Economist, Vol. 12, No. 2 (Fall, 1968), pg. 64-68. 
habitante só poderá crescer com igual intensidade, se a procura de importações também aumentar de $2 \%$, ou seja, se sua elasticidade em relação à renda for de 1 . Mas se o aumento das importações fôr mais intenso, a renda por habitante não poderá crescer espontaneamente com a mesma força que as exportações. Com efeito, se as importações tendessem a crescer em $1,5^{\circ}$ em cada $1 \%$ de incremento da renda por habitante, esta não poderia crescer até $2 \%$, pois em tal caso a procura de importações aumentaria para 3\%, superando assim a taxa de $2 \%$ com que se desenvolvem as es exportações. Evidentemente, não poderia continuar por muito tempo um desequilíbrio exterior dessa natureza. Para que o desenvolvimento se realizasse com equilíbrio exterior, o crescimento da renda por habitante não poderia exceder do limite de 1,33 ao ano, já que essa taxa, dada a elasticidade renda da procura de importações, faria com que estas últimas crescessem em $2 \%$, ou seja, a mesma taxa das exportações. ${ }^{203}$

Tem-se que as camadas de maior rendimento possuem maior propensão marginal a importar, devido (a) ao efeito demonstração, e (b) o maior impacto sobre o investimento (que, nos países dependentes, demandam importação). Dessa forma, a expansão da importação é influenciada pela distribuição de renda no local e pelo grau do efeito demonstração. Tanto as oscilações na renda como novos perfis de consumo das distintas camadas gera oscilações na propensão marginal a importar.

Caso a propensão marginal a importar das camadas de menor rendimento seja menor, um incremento da renda dos mesmos tenderá a gerá maior demanda interna do que um incremento da renda das camadas de maior rendimento o faria. Assim, tenderia a ocorrer uma diminuição da propensão marginal a importar do país. No entanto, o aumento da renda das camadas de baixo da pirâmide de rendimentos pode ser acompanhado da elevação da propensão marginal a importar das mesmas. Disso resultaria que o a sangria externa no efeito multiplicador continuaria similar. Tão pouco haveria tendência de melhora dos termos de troca por migração do consumo de importados para consumo de bens produzidos localmente.

203 PREBISCH, Raúl. Dinâmica do Desenvolvimento Latino-Americano. Rio de Janeiro: Fundo de Cultura Brasil, 1969. Pg. 136 


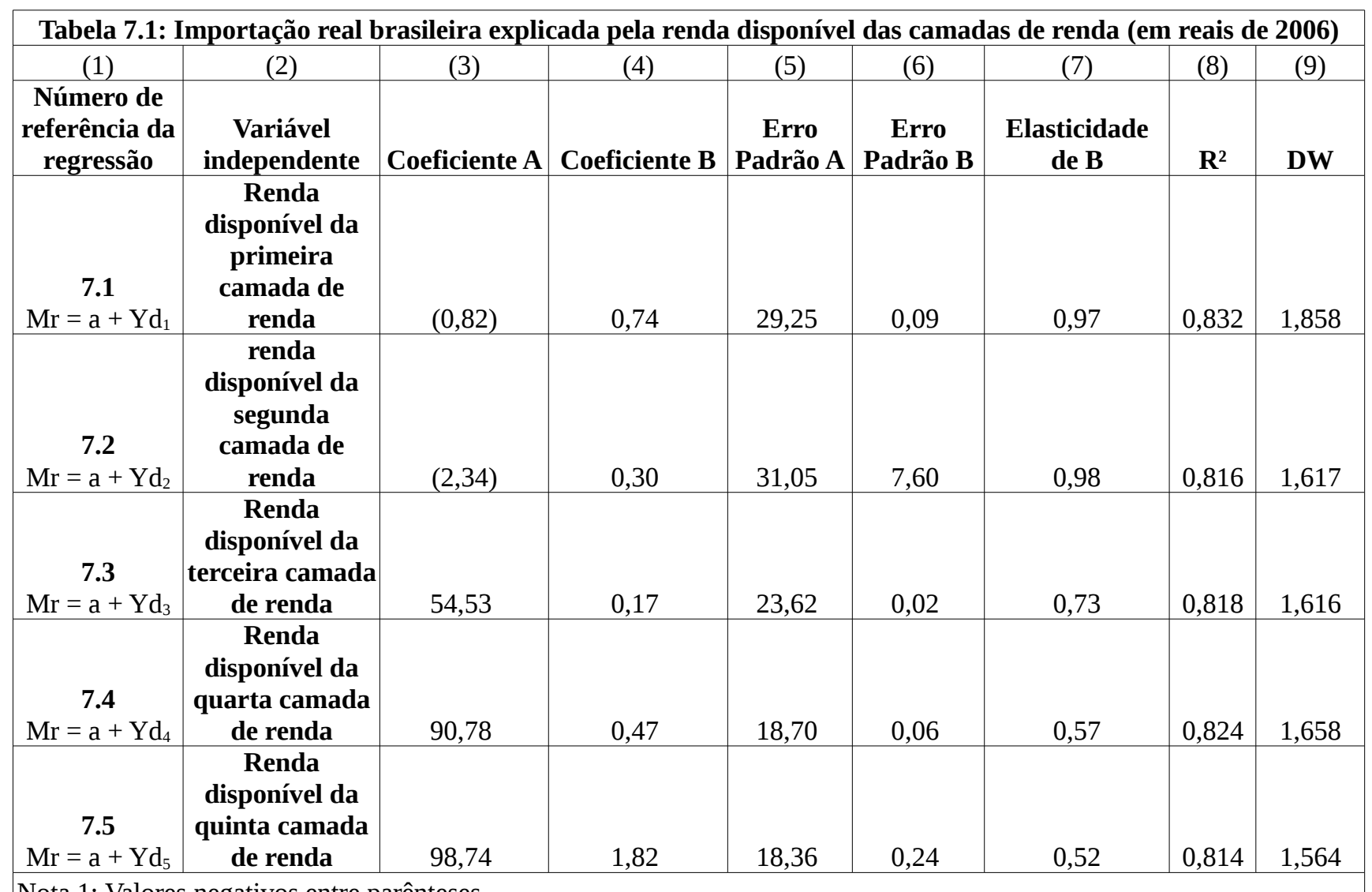

Nota 1: Valores negativos entre parênteses

Fonte: IBGE e IPEA

A tabela 7.1 contém os resultados de cinco regressões com a importação real do Brasil como variável dependente e as camadas de renda como variáveis independentes, ambos em reais constantes de 2006. A coluna (1) traz o número de referência da regressão. A coluna (2) contém o nome da variável independente, expressando qual é a camada de renda cuja renda disponível foi considerada. A coluna (3) traz o coeficiente “a”, que é a constante encontrada. A coluna (4) traz o coeficiente "b”, que expressa quantos reais constantes aumentaram na importação para cada real aumentado na renda disponível da camada em análise. A coluna (5) e (6) contém o erro padrão dos coeficientes. A coluna (7) traz a elasticidade média do coeficiente "b”. A coluna (8) traz o R-quadrado e a coluna (9) contem o Durbin Watson da regressão.

Observa-se um poder explicativo alto (mais de 80\%) para todas as regressões apresentadas na tabela. Nenhuma delas apresentou espuriedade, haja visto que todos os valores de Durbin-Watson estão acima do R-quadrado da regressão respectiva. Ainda, conforme se verifica pelos erros padrões, a renda disponível das distintas camadas de renda possuem relevância estatística para a importação brasileira efetiva, ou real. 
A elasticidade observada expressa a seguinte divisão: para cada real a mais no valor total das importações, 26 centavos foram de responsabilidade do primeiro patamar; 26 centavos do segundo patamar; 19 centavos do terceiro patamar; 15 centavos do quarto patamar; e 14 do quinto patamar. Isso significa dizer que a renda dos $10 \%$ do topo da pirâmide de renda do Brasil determinou, entre 1999 e 2013, a maior parte (52 centavos a cada novo real) das oscilações no valor total importado. Isso se explica por (a) serem a renda dessas camadas também responsáveis pela maior parte da oscilação nos investimentos do pais; e (b) serem também essas camadas as maiores responsáveis pelo consumo de luxo.

A baixa elasticidade encontrada para os quartos e quinto patamares são sintoma que indica que, entre 1999 e 2013, essas camadas foram pouco responsáveis pela importação. Dada a baixa participação dessas camadas no consumo e no investimentos do país, era natural que também tivessem baixa participação nas importações. No período, foram camadas que participaram pouco na vida econômica do país, senão como trabalhadores.

\section{Gráfico 7.1: Participação do primeiro patamar de renda em cada novo real nos gastos de importação do Brasil, 1999 a 2013}

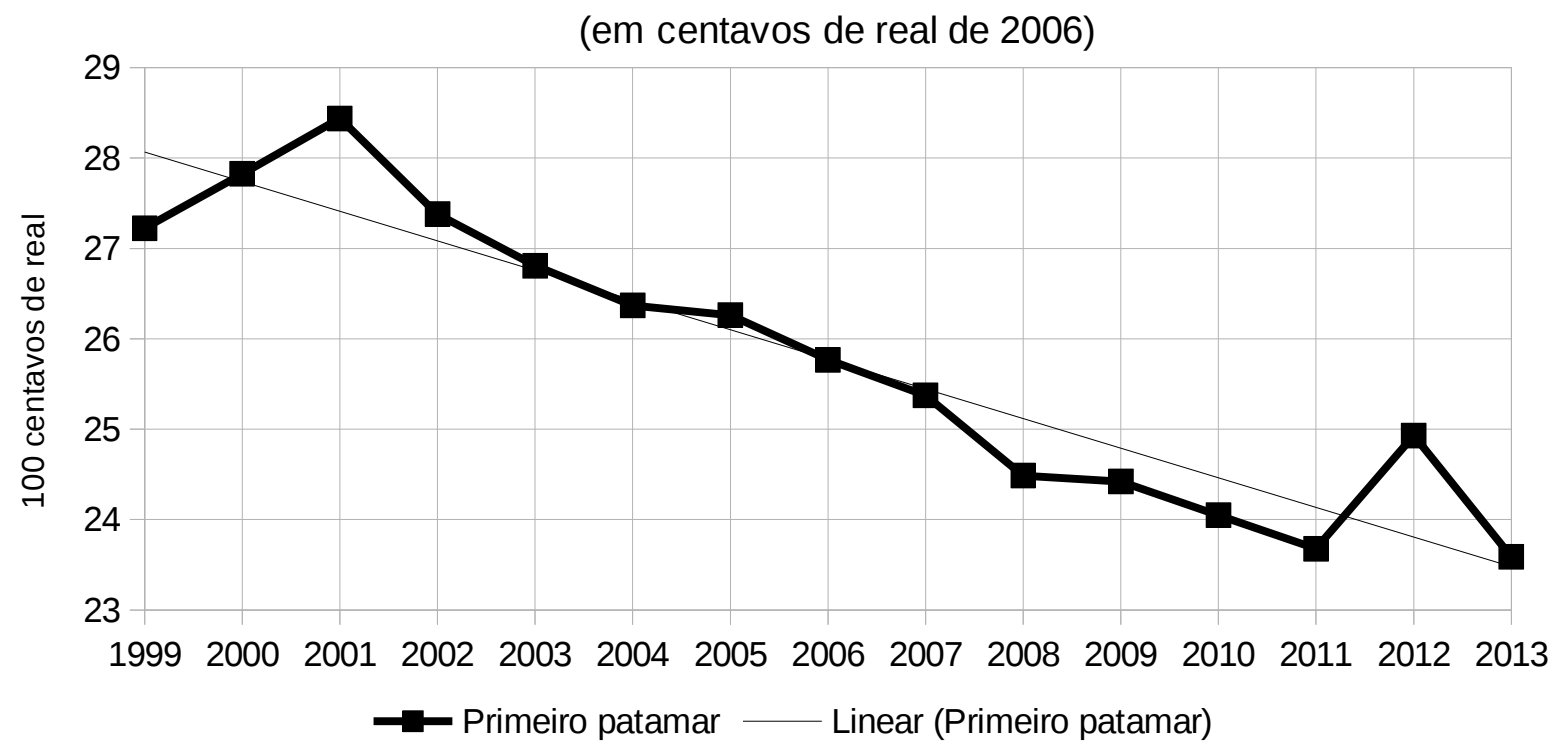

Fonte: IBGE e IPEA

O gráfico 7.1 traz a participação relativa do primeiro patamar de renda (1\% do topo) em cada novo real constante na importação total brasileira, e sua linha de tendência, para os anos de 1999 a 2013. Observa-se que a elasticidade oscilou; a participação cresceu de 1999 a 2001, e então passou a cair com pequenas oscilações. Ainda, apresenta caráter cíclico de cerca de cinco anos. A cada 4 ou 5 anos, a participação dessa camada sofreu oscilações de redução 
pontual na velocidade de queda. Isso ocorreu em 2001, 2005, 2009, 2012-2013. O ponto mais alto de participação foi em 2001, quando o primeiro patamar representou 28,5 centavos em cada real novo de importação. O ponto mais baixo foi em 2011 e 2013, quando representou menos de 24 centavos a cada novo real. Entre 2001 e 2013, a participação do primeiro patamar caiu quase cinco centavos. Isso significou uma queda de $17 \%$, com uma taxa de queda de $1,5 \%$ ao ano.

A participação na importação em relação a renda do primeiro patamar pode ser explicada pela alta relevância da renda dessa camada para a formação bruta de capital, e pelo consumo de luxo. Tanto os investimentos produtivos como o consumo de artigos de luxo, no período, foram marcados pela alta participação das importações. A existência de ciclos de 5 anos para a elasticidade das importações em relação a renda dos $1 \%$ do topo é forte indício que parte da importação causada pela renda dessa camada foi de investimento. Isso porque os investimentos possuem, historicamente, caráter cíclico de cinco anos, denominado "ciclos de semeadura e colheita”. Também a cada 5 anos, parte da população repôs parte de seus bens de luxo, incluindo carros importados.

\section{Gráfico 7.2: Participação do segundo patamar de renda em cada novo real nos gastos de importação do Brasil, 1999 a 2019} (em centavos de real de 2006)

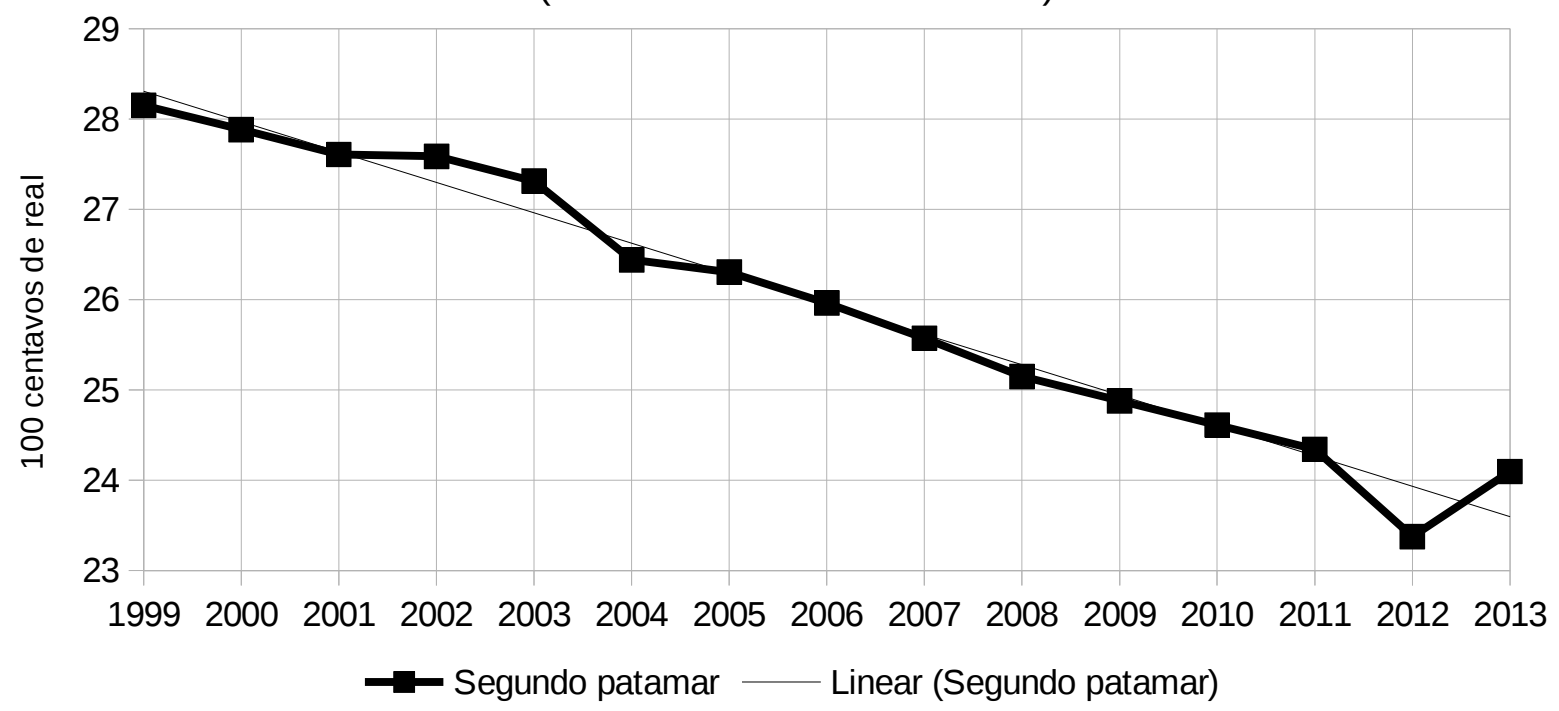

Fonte: IBGE e IPEA

O gráfico 7.2 traz a participação relativa do segundo patamar de renda (9\% seguintes aos $1 \%$ do topo) em cada novo real contantes no valor total das importações do Brasil, e sua linha de tendência. A participação dessa camada caiu desde 1999, mas em velocidade menos 
acelerada do que a do primeiro patamar. Ela observou pequena recuperação em 2002, voltando a cair em 2004. Também está presente o caráter cíclico de cerca de cinco anos. Entre 2001 e 2013, a participação dessa camada caiu cerca de 3,5 centavos. Isso significou uma queda de quase $13 \%$ no total, expressando uma taxa de queda de $1,13 \%$ ao ano.

A existência do perfil cíclico de 4 a 5 anos de duração indica que a ligação entre a renda das camadas do topo (primeira e segunda) é marcada pela lógica de "semeadura e coleta”, típica de investimento. A compra de bens de capital e de produtos intermediários se faz com altos e baixos, que acompanham os ciclos de renovação e manutenção de equipamento. No entanto, mesmo quando tem havido período de baixa, as elasticidades têm sido altas.

Seja quando está-se investindo ou quando está comprando bens de luxo, a renda disponível dos mais ricos influencia bastante o valor total dos produtos importados pelo Brasil. Verifica-se que a concentração de renda tem como um de seus impactos a alta propensão marginal a importar do país, comportamento esperado em um modelo de “dependência das importações”.

\subsection{AS IMPORTAÇÕES E OS 90\% DA BASE DA PIRÂMIDE SOCIAL}

A participação móvel das importações, para os 10\% do topo da pirâmide de renda do Brasil, entre 1999 e 2013, apresentou baixa. O comportamento das importações seguiu o modelo de ciclos de investimento e renovação de bens de consumo duráveis. Mas, para o restante da população brasileira, o período se caracterizou por aumento na participação da importação. Isso se deu por ter ocorrido: (a) ampliação do consumo, sustentado por insumos e bens importados; e (b) efeito demonstração, que levou as camadas de baixo da pirâmide a mimetizar o consumo de luxo dos $10 \%$ do topo.

O gráfico 7.3 contém a representação da participação relativa do terceiro patamar de renda em cada novo real constante no valor total das importações brasileiras, entre 1999 e 2013. Traz também a linha de tendência. Observa-se que os ciclos de 5 a 6 anos estão presentes de forma bem menos acentuada, dada a baixa magnitude das oscilações. Ainda, de 2002 a 2009, houve crescimento do impacto da renda disponível desses 40\% da população sobre as importações. No período, ocorreu a subvalorização do real, o que favoreceu as 
importações. Em 2001, a participação dessa camada estava próxima a 18,9 centavos. Em 2013, foi de mais de 19,6 centavos, o que significa um ganho de 3,29\% em 12 anos. A taxa de crescimento da participação dessa camada nas importações foi de $0,27 \%$ ao ano. Na prática, essa camada manteve estável sua participação na importação brasileira.

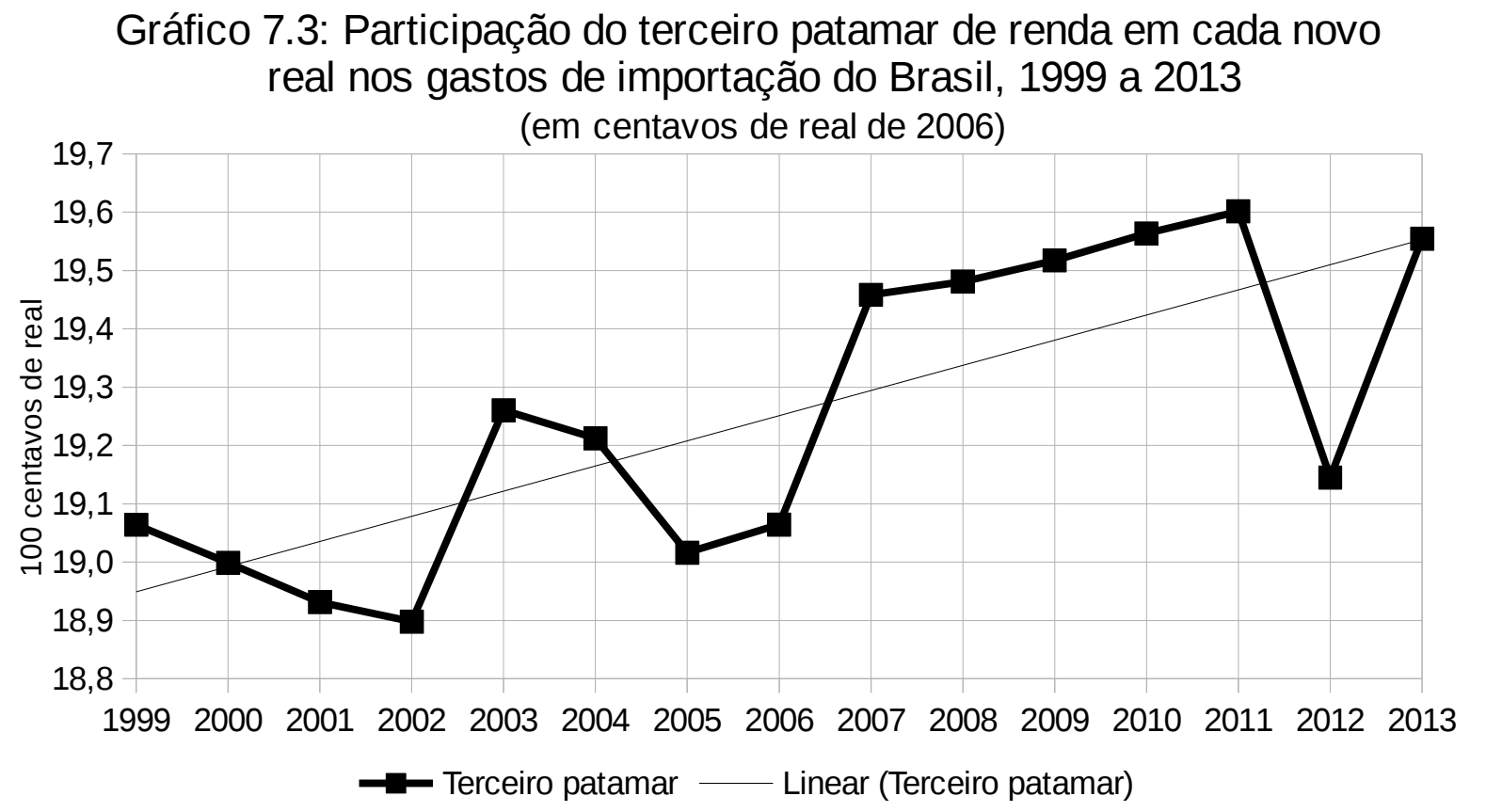

Fonte: IBGE e IPEA

A pouca relevância dos ciclos de 5 a 7 anos revela que para essa camada o dólar barato foi fator que permitiu que a demanda de produtos gerada pelo aumento da renda fosse compensado pela importação. O fato de essa camada ter participado com mais de 18 centavos em cada novo real de importação significa que (a) ela não foi a maior responsável nos gastos de importação, o que se torna evidente ao se observar que parcela significativa das importações são de partes e peças, e de insumos para produção. Como a terceira camada de renda é composta por funcionários e técnicos, e pequenos e médios proprietários de empresas, sua renda tem pouco impacto direto na parcela da importação de insumos.

Mas, essa parcela consome produtos de luxo importados. O aumento desse tipo de consumo oscilou na mesma medida em que ocorreu prosperidade local no país. Isso foi possível devido a alta das exportações, que gerou obtenção de divisas estrangeiras pelo Brasil, financiando o real sobrevalorizado. Esses $40 \%$ da população ganharam durante o período em que as commodities estiveram em alta (2003 a 2011). Esgotado o ciclo favorável aos bens primários no comércio exterior, essa camada média viu a oportunidade de comprar no exterior 
diminuir, o que se expressa na relativa estagnação de sua participação.

Considerando o efeito demonstração, descrito por Ragnar Nurkse, a pequena elevação da participação significou ganho temporário, entre 2003 e 2013, da oportunidade de mimetizar a elite dos países europeus e dos Estados Unidos da América. Como isso estava calcado em um modelo dependente, logo aquela camada foi lentamente afastada do sonho de ser igual à consumidora europeia ou norte estadunidense.

\section{Gŕafico 7.4: Participação do quarto patamar de renda em cada novo real de importação do Brasil, 1999 a 2013}

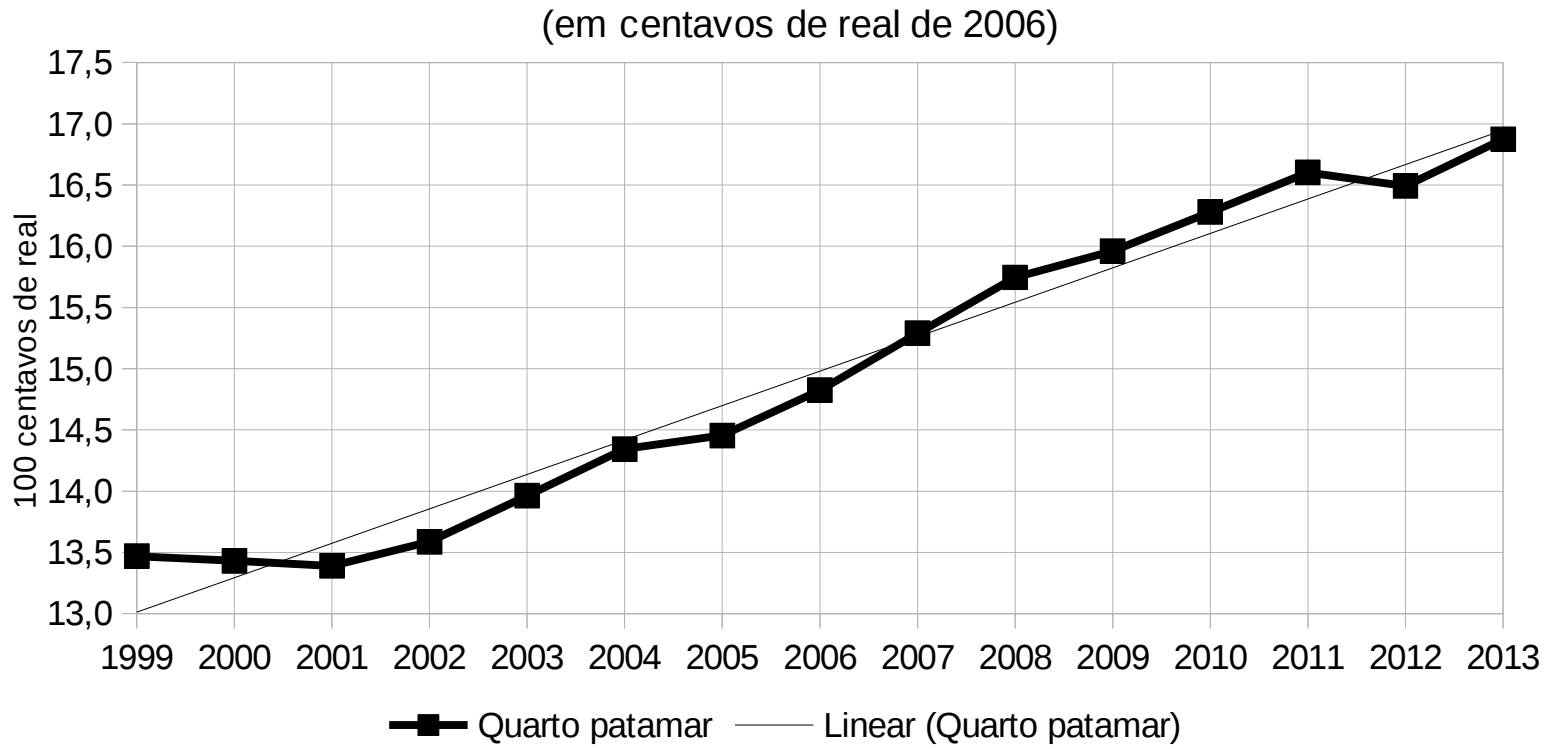

Fonte: IBGE e IPEA

O gráfico 7.4 traz a participação relativa do quarto patamar de renda (este inclui os $30 \%$ seguintes ao terceiro patamar) em cada novo real constante no valor total das importações brasileiras, entre 1999 e 2013. Verifica-se que, de 2001 a 2013, houve queda pontual na participação dessa camada de renda apenas em 2012. Durante todo o restante do período verificou-se crescimento. Em 2001, a participação do quarto patamar estava próxima de 13,5 centavos em cada novo real de importação. Em 2013, chegou a quase 17 centavos. Trata-se de um crescimento de cerca de 3,5 centavos. Isso significou uma alta de $26 \%$, ou $1,95 \%$ ao ano.

O modelo econômico brasileiro foi, entre 1999 e 2013, marcado pela baixa taxa de industrialização. A demanda doméstica pressionou em favor das importações. Conforme as camadas de baixo da pirâmide de renda passaram a ganhar peso na participação da renda disponível total do país, também passaram a impulsionar mais o consumo, e portanto as 
importações. Daí a participação dessa camada ter crescido quase na mesma velocidade na criação de consumo, investimento, e importação.

Gráfico 7.5: Participação do quinto patamar de renda em cada novo real nos gastos de importção do Brasil, 1999 a 2013

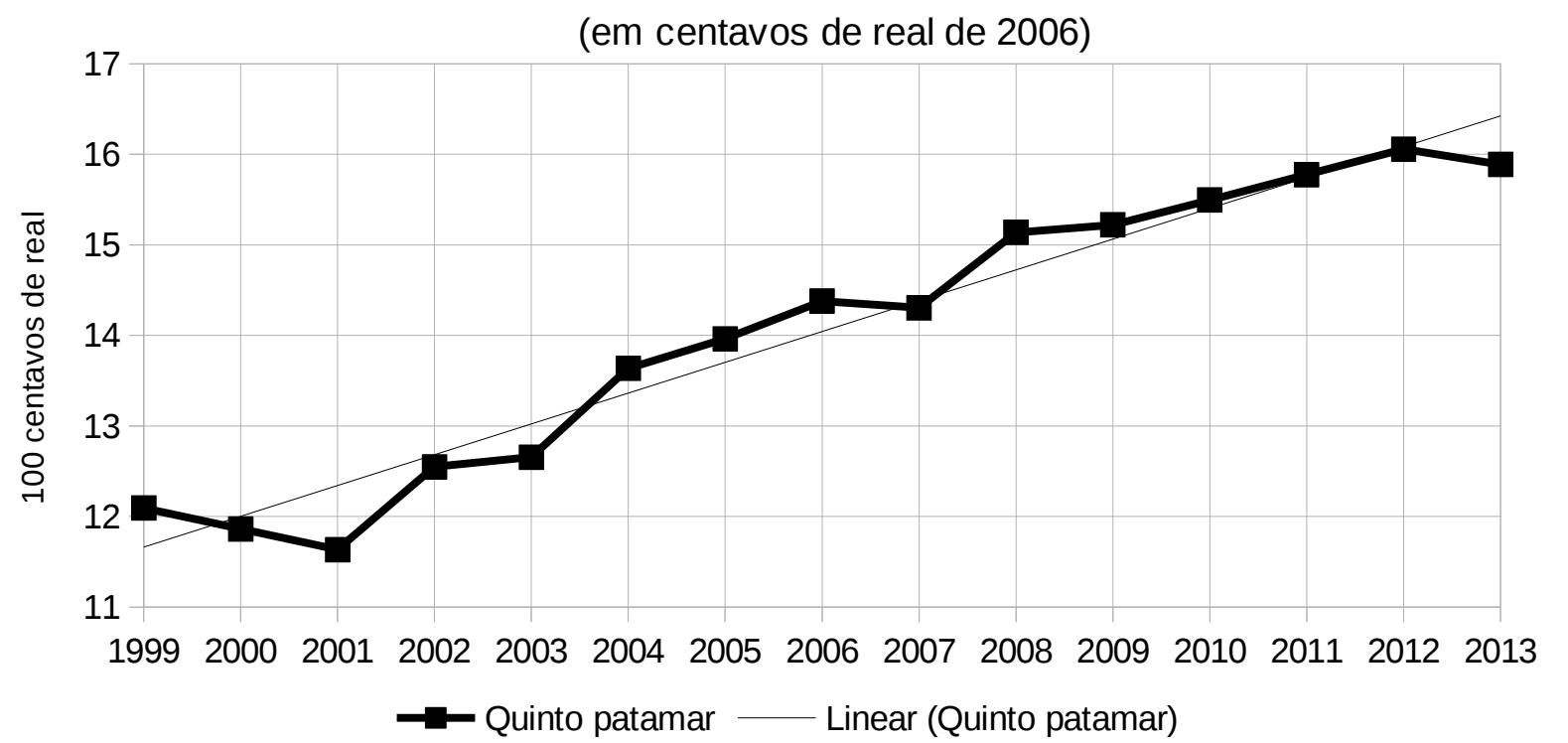

Fonte: IBGE e IPEA

No gráfico 7.5, verifica-se a participação relativa do quinto patamar de renda em cada novo real constante no valor total das importações brasileiras, e sua linha de tendência, entre 1999 e 2013. Essa camada, que engloba os 20\% da base da pirâmide de renda, teve desempenho similar ao quarto patamar. No entanto, partiu da participação de menos de 12 centavos em cada novo real, em 2001, atingindo cerca de quase 16 centavos, em 2013. Foi um crescimento de mais de 4 centavos. Isso significou uma alta de 36,5\%, no total, ou uma taxa de crescimento de 2,63\% ao ano.

No período entre 2001 e 2013, os 20\% da base passaram a influenciar mais a importação de bens. Há que ponderar que parte dos produtos importados são componentes para bens alimentícios. O trigo, por exemplo, é item importante da pauta de importação. Ou seja, o aumento da importação não necessariamente expressa que essa camada compre bens de consumo duráveis importados.

O aumento da participação tanto do quarto como do quinto patamar aponta para três coisas: (a) com o aumento da demanda agregada, sem que tenha acompanhado o aumento da oferta local, parte da demanda foi suprida por importação; (b) as camadas mais pobres sofreram com efeito demonstração, passando a consumir itens importados que as camadas 
mais ricas já consumiam; e (c) com a melhoria de renda, os mais pobres passaram a participar mais da vida econômica local, fazendo com que sua renda disponível também impactasse mais nas importações. Isso inclui o impacto da melhoria da saúde alimentar dos mais pobres, o que gerou aumento da demanda por insumos importados.

\subsection{AUMENTO DA IMPORTAÇÃO E O DESMONTE DA INDÚSTRIA}

O aumento da participação nas importações, sem que tenha ocorrido perdas na importação das camadas do topo, só foi possível devido à expansão do comércio exterior brasileiro. Tanto o aumento da demanda agregada como a satisfação do efeito de comparação exigiram que o Brasil expandisse suas importações. É dizer que a recuperação econômica, de 2003 a 2013, não foi sustentada pela edificação de uma economia doméstica nova. Ao contrário, tratou-se de um episódio calcado na alta cíclica dos preços dos bens primários.

Durante o período em análise, a renda disponível da população cresceu acima da capacidade de abastecimento industrial do país. Os investimentos se destinaram ao setor exportador e ao setor de serviços. Como resultado, houve aumento da participação da importação de produtos acabados no total das importações ${ }^{204}$. Se, hipoteticamente, o aumento da propensão marginal a importar das camadas de menor rendimento pode estar ligado a uma reorganização da matriz insumo-produto do país em favor da indústria manufatureira ${ }^{205}$, no caso brasileiro, fica evidente que isso não ocorreu. Conforme Celso Furtado, um país subdesenvolvido depende de altas taxas de importação para gerar aceleração de seu crescimento econômico. Mas o desenvolvimento desses países ocorre quando o aumento da importação também está ligado a um aumento da importação de bens de capital e insumos ${ }^{206}$.

Penélope Pacheco-Lopez e A. P. Thirlwall também refletiram sobre o fenômeno do aumento da propensão marginal articulado a perda de competitividade das indústrias locais na América Latina. Argumentaram que parte do deslocamento da importação em favor de bens de consumo podem ser explicados pela liberalização das economias locais. Como a liberalização ocorreu de forma brusca, sem que houvesse incentivo para melhoria da indústria

204 Ver tabela 2.11.

205 Sobre o assunto ver: SUNDARARAJAN, V. \& THAKUR, Subhash. Input-Output Approach to Import Demand Functions: Experiments with Korean Data. Staff Papers (International Monetary Fund), Vol. 23, No. 3 (Nov., 1976), pg. 674-698

206 Sobre o tema, ver: FURTADO, Celso. El Desequilibrio Externo En Las Economías Subdesarrolladas. El Trimestre Económico, Vol. 25, No. 98(2) (Abril-Junio de 1958), pg. 232-239 
local, houve desarticulação da indústria então voltada para a demanda interna. Ocorreu, nos países da América Latina (incluindo o Brasil), aumento da demanda de bens industriais importados, acompanhada com a diminuição da exportação de bens manufaturados ${ }^{207}$. Daí a desindustrialização (ou reprimarização) da economia brasileira. A liberalização significou o abandono da hipótese de adoção de uma política econômica pensada para o desenvolvimento. Conforme Géledan e Brémond, só uma política econômica ativa poderia permitir superar as restrições externas:

No que se refere às importações, a competitividade das produções nacionais constitui o travão mais forte ao seu desenvolvimento, mas o evitar 'buracos' no aparelho industrial permite também limitar as importações às matérias-primas, à energia e a alguns produtos semiacabados que não podem ser verdadeiramente produzidos no território nacional em condições satisfatórias.

Reduzir o constrangimento exterior equivale a adotar políticas industriais e comerciais ativas. ${ }^{208}$

Uma vez abandonada a política ativa em favor do desenvolvimento ${ }^{209}$, a economia brasileira rumou para reprimarização. O desmonte da indústria de transformação gerou diminuição da importação de bens de capital, e aumento da importação de bens de consumo. Como consequência, houve redução da importação frente a renda disponível. Portanto, uma forma de verificar o impacto do desmonte da indústria doméstica de transformação é através das oscilações do valor total das importação frente aos valores esperados da renda disponível.

O gráfico 7.6 traz a posição relativa da renda disponível do primeiro patamar de renda (que inclui o 1\% do topo da pirâmide) em relação ao perfil oscilatório do valor total das importações brasileiras, para o período entre 1999 e 2013. Em preto, verifica-se a representação gráfica do valor total das importações. Em cinza, verifica-se as oscilações da renda disponível do primeiro patamar de renda. Valores acima de zero para as importações indicam que houve crescimento das importações acima do esperado. Valores acima de zero para a renda do primeiro patamar de renda significa que houve crescimento acima do

207 Ver: PACHECO-LÓPEZ, Penélope. \& THIRLWALL, A. P. Trade Liberalization, the Income Elasticity of Demand for Imports, and Growth in Latin America. Journal of Post Keynesian Economics, Vol. 29, No. 1 (Autumn, 2006), pg. 41-66

208 GÉLÉDAN, Alain \& BRÉMOND, Janine. Dicionário das Teorias e Mecanismos Económicos. Lisboa: Livros Horizonte LTDA, 1988. Pg. 56.

209 Na verdade, não só se abandou a política econômica ativa para superar as restrições externas, como adotouse políticas que ativamente as aumentaram. Em especial, destaca-se a adoção do uso da taxa de câmbio como mecanismo de controle de inflação. Tal teve impacto nocivo ao incentivar a importação e desincentivar as exportações. 
esperado para a taxa de crescimento de importação do período. Descrito dessa forma, verificase a capacidade de importar primeiro patamar de renda: quando o primeiro patamar esteve acima de zero, houve aumento capacidade de importar. Quando esteve abaixo, ocorreu diminuição.

Gráfico 7.6: Posição relativa da renda disponível do primeiro patamar de renda em relação ao valor total das importações brasileiras, 1999 a 2013

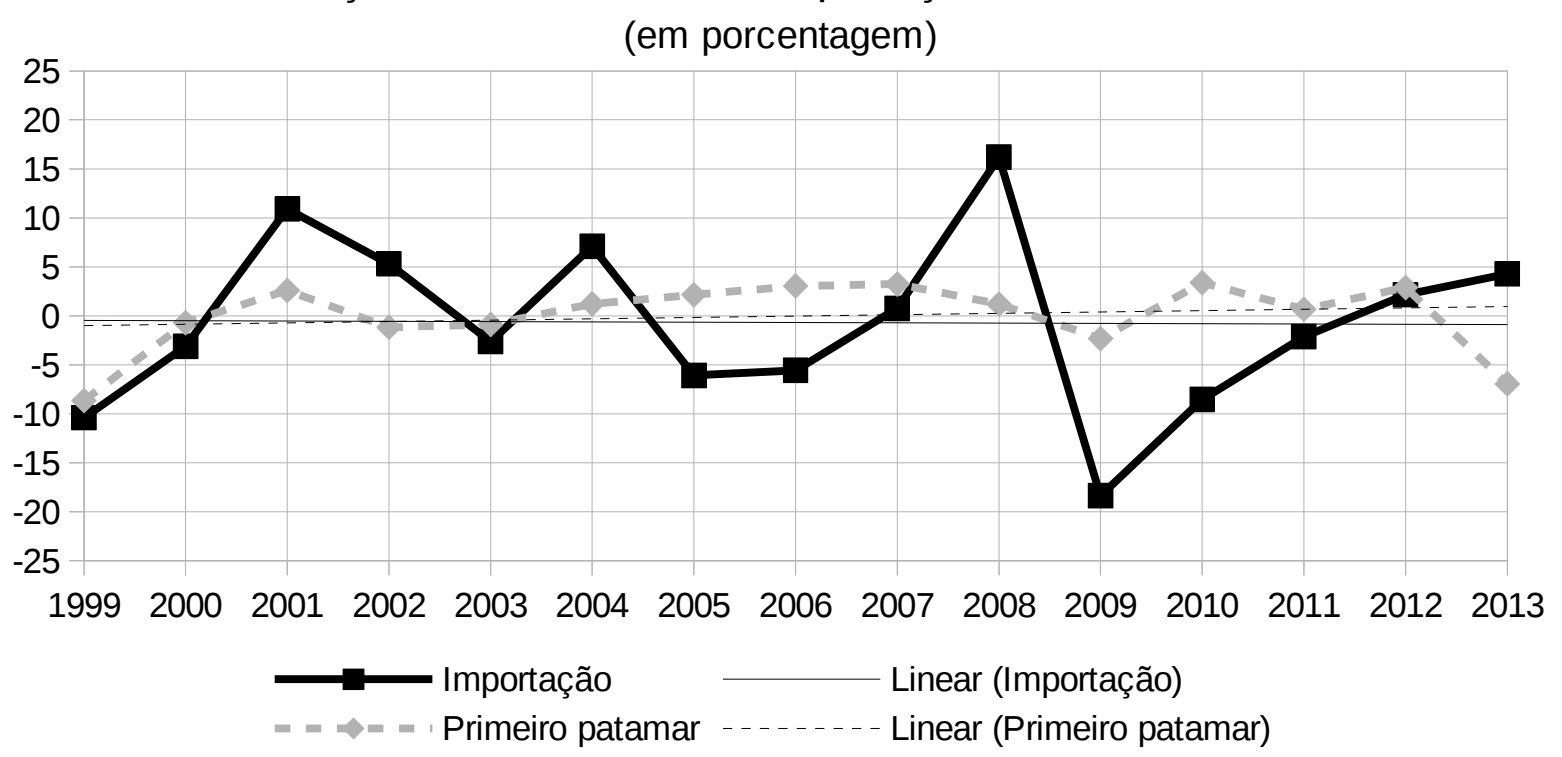

Fonte: IBGE e IPEA

Observa-se que as oscilações nas importações são marcadas por um perfil cíclico, com três ciclos completos (2000-2004; 2004-2008; 2008-2013). Trata-se do ciclo de reposição dos bens de capital e dos bens de consumo duráveis. A capacidade de importar do primeiro patamar de renda observou tendência de crescimento. As oscilações descreveram dois ciclos completos (2001-2007; 2007-2012). Esses perfis coincidem com o movimento da capacidade de importação do Brasil (gráfico 4.9). De 2001 a 2007, houve uma fase de expansão, e de 2008 em diante, uma fase de retração.

No entanto, entre 2010 e 2013, o Brasil observou crise no crescimento. Apesar dos chamados super saldos comerciais, as importações, os gastos em serviço, e despesas com o pagamento de juros e remessas de lucro ao exterior cresceram acima do poder de compra das exportações. O crescimento das importações brasileiras no período foi acompanhado pelo crescimento de capacidade de importar do primeiro patamar de renda, até 2012.

Considerando que, entre 2010 e 2012, houve retração no crescimento dos investimentos no Brasil, o aumento da capacidade de importar do primeiro patamar de renda 
gerou aumento da demanda por bens de consumo importados. Trata-se de mais um fator que aponta que a crise econômica não afetou negativamente os $1 \%$ do topo da pirâmide social como afetou outras camadas. Ao contrário, foi um período que apresentou a possibilidade de recomposição parcial de sua participação na distribuição de renda.

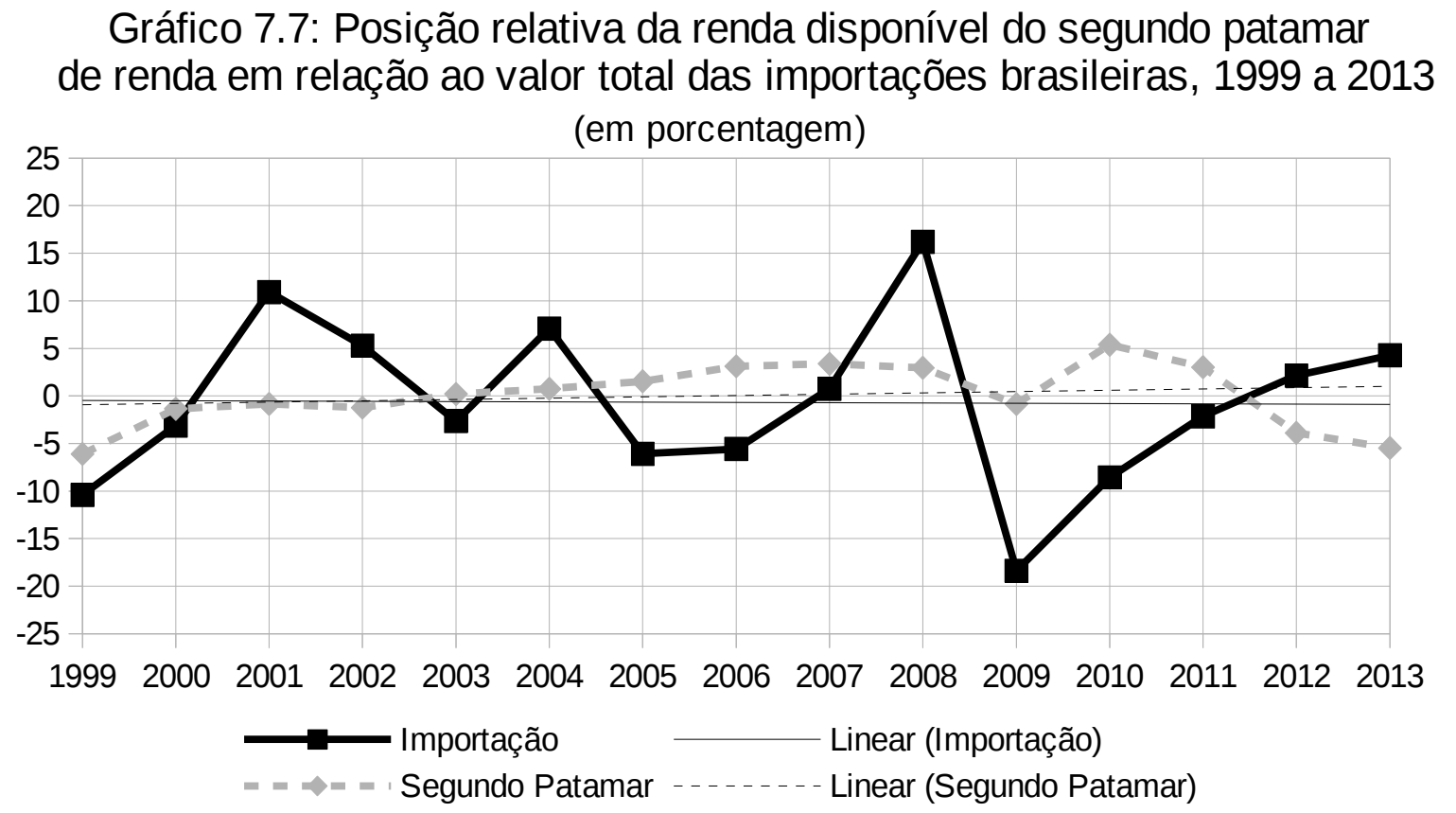

Fonte: IBGE e IPEA

O gráfico 7.7 traz a posição relativa das oscilações na renda disponível do segundo patamar de renda (que inclui os 9\% seguintes ao 1\% do topo da pirâmide de renda) em relação as oscilações no valor total das importações brasileiras, para o período entre 1999 e 2013. As oscilações da renda disponível do segundo patamar expressam as oscilações na capacidade de importar.

Para o segundo patamar, verifica-se dois períodos distintos. Entre 1999 e 2010, houve recuperação, de 1999 a 2002, e aumento da capacidade de importação, de 2003 a 2010, com queda em 2002 e em 2009. O segundo período iniciou-se em 2011, e se caracterizou pela redução na capacidade de importação. Para essa camada, a crise econômica de 2008-2009 afetou pontualmente a demanda por bens importados. No entanto, diante do continuo aumento dos preços das commodities, e da expansão das exportações brasileiras para a Ásia, foi possível financiar o aumento das importações, em 2010 e 2011.

Entre 1999 e 2013, o segundo patamar de renda apresentou ganhos líquidos no poder de compra frente aos produtos de consumo estrangeiros. Isso foi o resultado do aumento das 
exportações brasileiras, da recuperação econômica local, e do real sobrevalorizado. O modelo apresentou esgotamento em 2011.

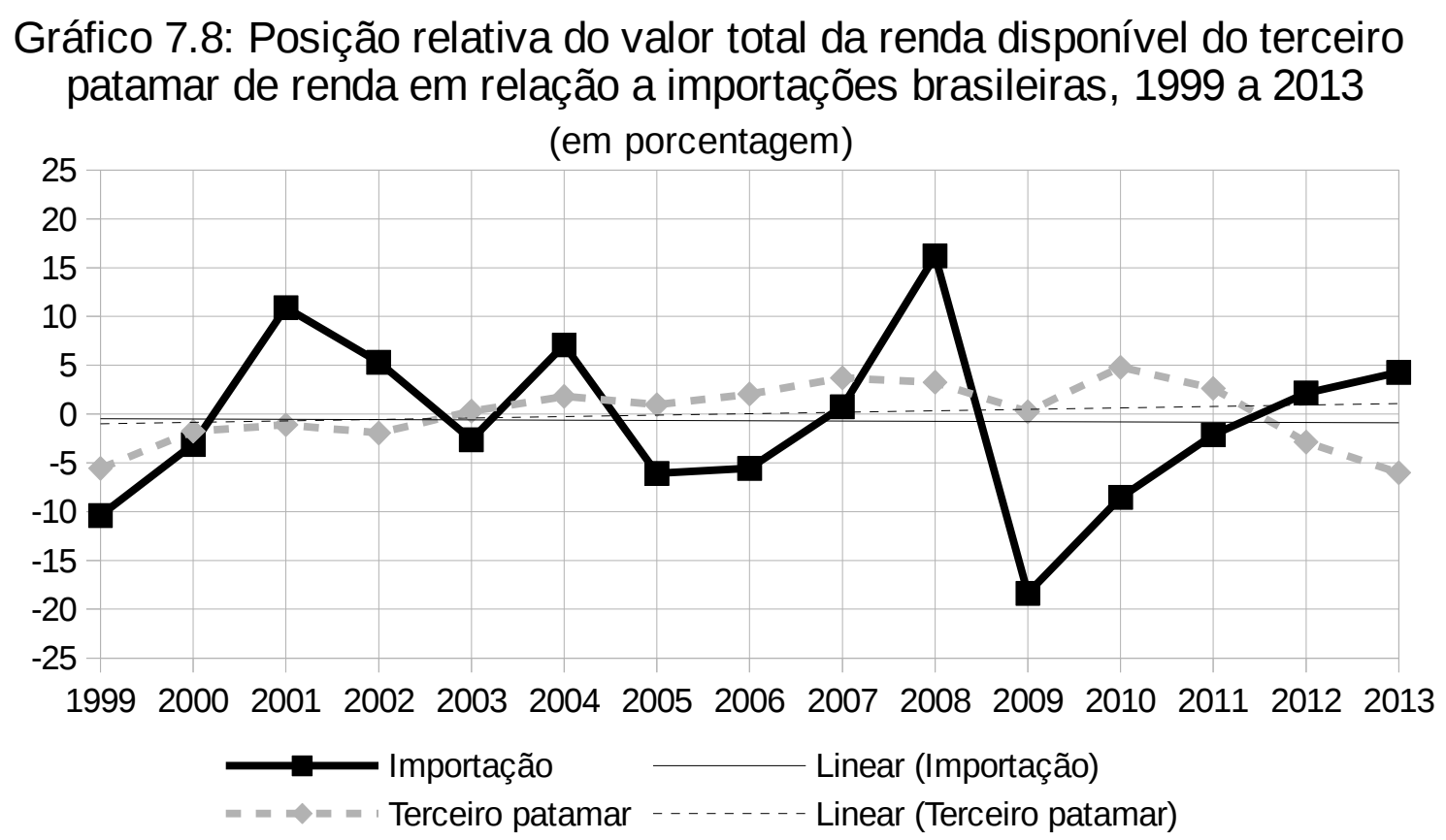

Fonte: IBGE e IPEA

Para o terceiro patamar (que inclui os $40 \%$ seguintes aos $10 \%$ do topo), também houve recuperação e ganho na capacidade de importação, entre 1999 e 2010. Para essa camada, os ganhos foram mais acentuados. Mas a queda na capacidade de importação, que ocorreu entre 2011 e 2013, também o foi. Essa camada atuou, no período, como a verdadeira base do desempenho econômico do país. O nível de consumo do terceiro patamar de renda, que são as “camadas médias” da economia brasileira, coincide com o nível de consumo do país (como indicado no capítulo 5). O ganho da capacidade de importar dessa camada foi fruto, também, do aumento das exportações brasileiras e do real sobrevalorizado.

Reforça-se assim a leitura que o desmonte parcial da indústria de transformação impactou no perfil da importação. Esse foi parte do segredo da "prosperidade local”. Em um momento de alta das exportações, a renda disponível aumentou. Ao mesmo tempo, a indústria doméstica foi parcialmente desmontada, diminuindo a demanda proporcional imediata de importações, graças a redução de demanda por insumos e maquinaria. Nesse cenário, sobrou renda das camadas, e divisas, para sustentar a importação de bens de consumo. As camadas do topo puderam consumir mais produtos em moda quanto ao topo da pirâmide social de países desenvolvidos. 


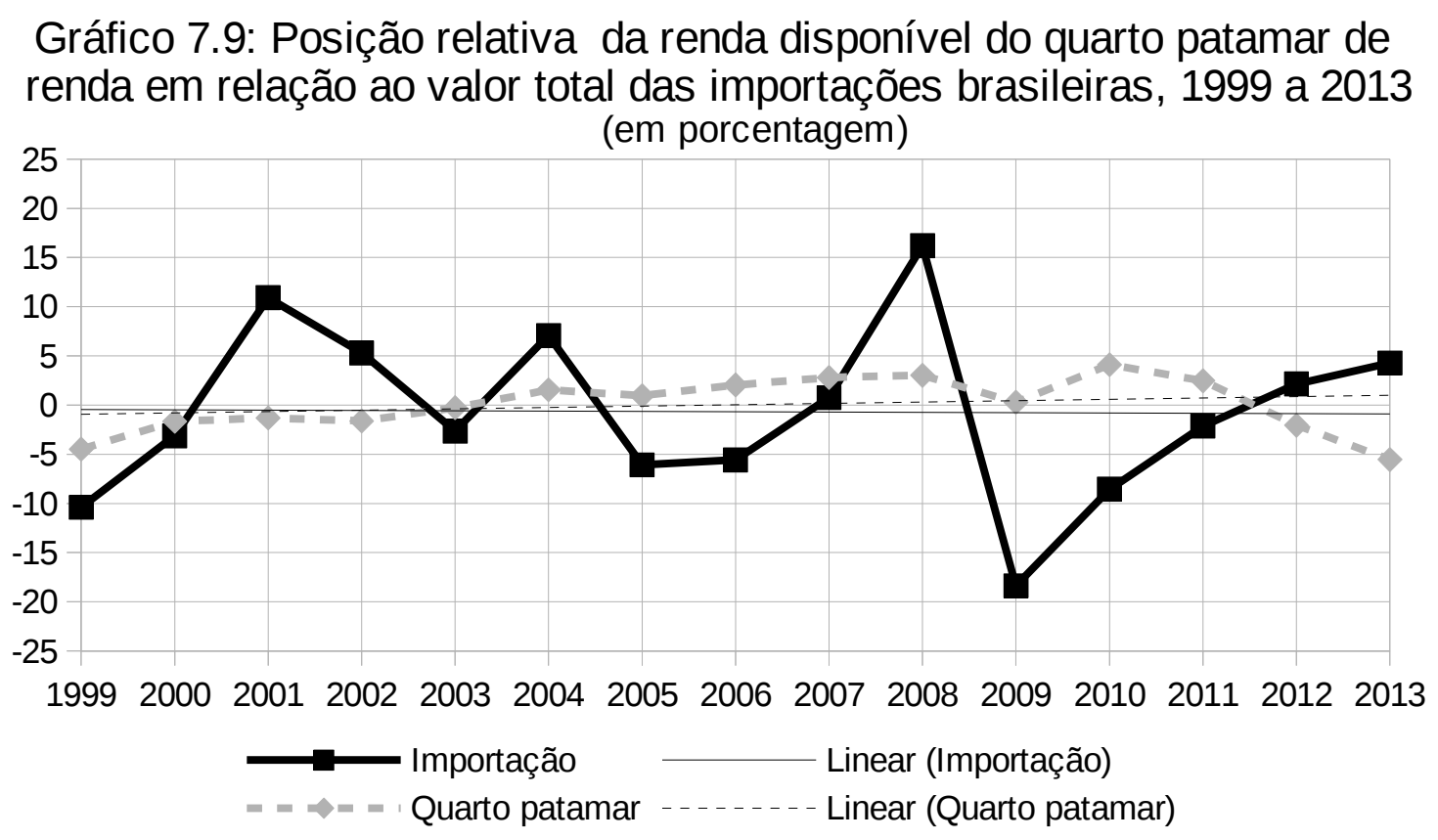

Fonte: IBGE e IPEA

O quarto patamar de renda também expressou trajetória similar: de 1999 a 2002, experimentou perdas decrescentes na capacidade de importação (o que caracteriza recuperação); de 2003 a 2010, apresentou ganhos crescentes; de 2011 a 2013 experimentou redução no crescimento e posterior perdas na capacidade de importar. Para essas camadas, os principais bens importados foram bens de consumo não duráveis. De 2007 em diante, também ocorreu aumento na importação de alguns artigos de consumo de maior complexidade, como celulares.

Para qualquer camada considerada, verifica-se que o perfil cíclico das importações possui tendência declinante, caracterizada por topos e fundos cadentes até 2009; e um perfil oscilatório ascendente para a capacidade de importação das camadas. A existência de ciclo de cinco anos justifica-se pelo peso relativo da importação de bens de capital e partes e peças no total das importações. Como a continuidade da produção doméstica (composta por montadoras de partes importadas) depende da renovação e manutenção periódica da maquinaria usada, é de se esperar a formação de ciclos de média duração na importação. Esse movimento é reforçado pela substituição de bens de consumo durável através da importação a cada ciclo de cinco anos. 
Gráfico 7.10: Posição relativa da renda disponível do quinto patamar de renda em relação ao valor total das importações brasileiras, 1999 a 2013

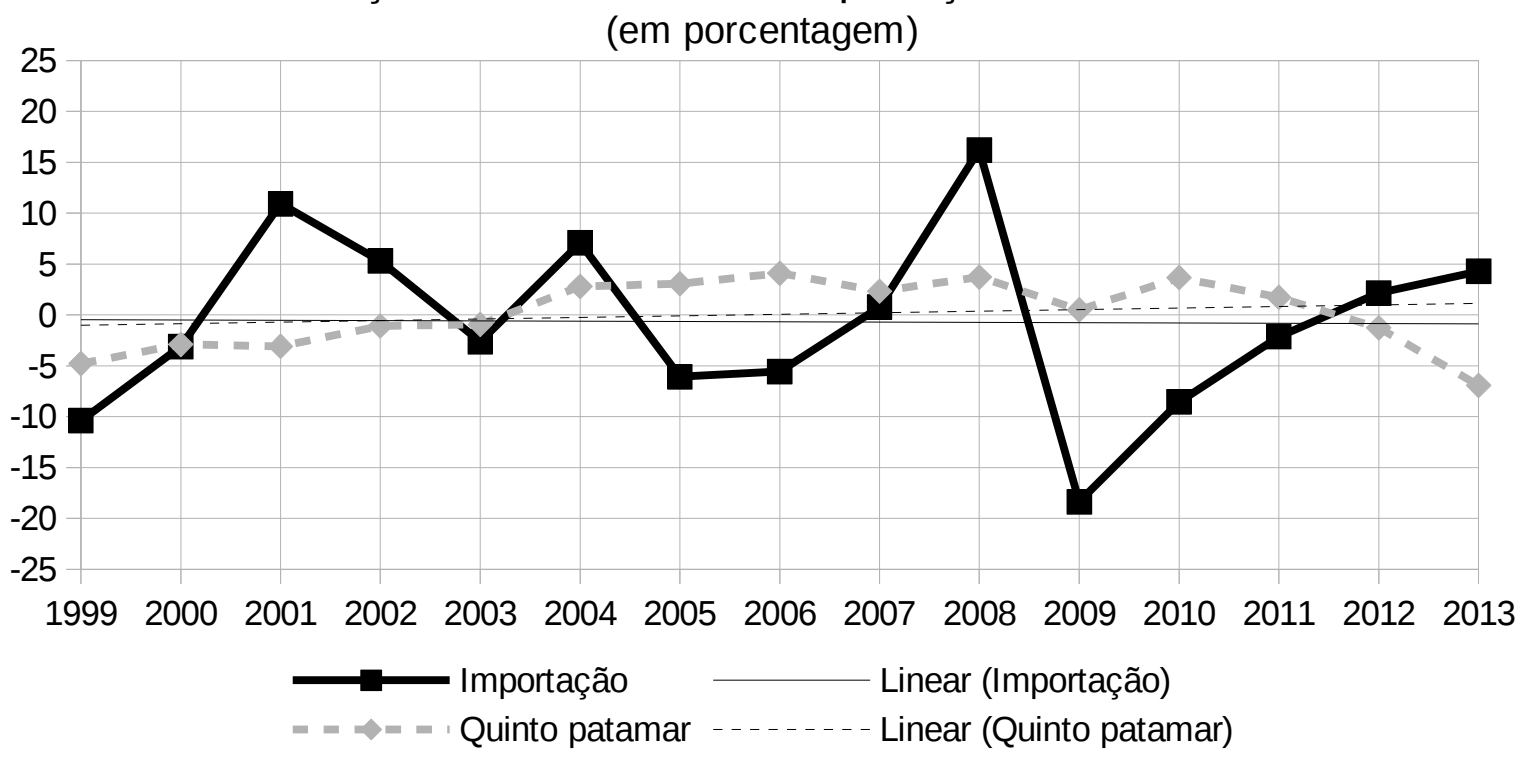

Fonte: IBGE e IPEA

Para o quinto patamar de renda (que inclui os $20 \%$ da base da pirâmide de renda do Brasil), a trajetória foi um pouco diferente, no que toca os ganhos na capacidade de importar. Pata eles, as perdas também foram decrescentes até 2002. Mas os ganhos só começaram em 2004, atingindo seu auge em 2006. A partir de então, os ganhos passaram a perder velocidade, mas se mantiveram até 2011. Em 2012, o quinto patamar apresentou pequenas perdas, só experimentando grande perda na capacidade de importar em 2012.

Essa trajetória é fruto dessa camada ser mais sensível às oscilações no poder de compra das exportações. Assim, o auge de ganhos relativos na capacidade de importação do quinto patamar de renda coincidiu com o auge da posição da capacidade de importar do Brasil. Ainda, foi fruto das políticas de redistribuição de renda dentro do país.

O fato de o ciclo das importações apresentar topos e fundos notáveis expressam que, para o período entre 2001 e 2009, houve tendência de queda relativa nas importações. Por se tratar de um período de prosperidade local, a renda disponível pode crescer rapidamente, demorando para ser adequadamente acompanhada pelas importações. Ainda, o desmonte da indústria doméstica de transformação diminuiu a demanda relativa pela importação de bens de produção.

A elevada magnitude das oscilações nas importações são uma expressão do caráter dependente da economia brasileira no período entre 1999 e 2013. Entre os pontos altos e 
baixos, a oscilação foi sempre maior que 10 pontos percentuais, com exceção da distância entre a baixa de 2003 e a alta de 2004. Tamanha magnitude resulta, entre outros fatores, da baixa complexidade e estabilidade da economia local. Na ausência de complexos produtivos bem integrados, parte considerável da fase de manutenção e investimentos dependeu das importações. Enquanto isso, o real sobrevalorizado e os ganhos com as exportações permitiram a todas as camadas aumentar sua capacidade de importação. Passada essas fases, as importações oscilaram bruscamente para baixo, e a capacidade de importação das famílias brasileiras minguou.

\subsection{GANHOS NA RENDA DISPONÍVEL E A EXPORTAÇÃO}

Em momentos de alta cíclica de preços de bens básicos, os países dependentes conseguem atingir maior taxa de crescimento, e mesmo melhorar, com algum esforço, as condições de vida da população. Para Prebisch, nesses momentos seria importante que o excedente advindo do comércio exterior fosse transformado em investimento. Dessa forma, quando houvesse queda dos preços seria possível manter algum crescimento local.

No caso do Brasil, entre 1999 e 2013, o crescimento foi bastante influenciado pelo preço de exportação da soja, do ferro, e do petróleo. A demanda mundial foi puxada para cima devido ao crescimento acelerado da economia chinesa. O momento favoreceu as exportações brasileiras. O que se demonstrou até aqui é que a prosperidade local foi parcialmente utilizada para gerar dada diminuição da concentração de renda.

No entanto, a ligação entre os ganhos no comércio exterior e a distribuição de renda foram ligados conjunturalmente. A relação entre ambos não aparece automaticamente quando a análise se resume à estatística observacional. Mas, ao se verificar os ganhos das camadas de renda com as exportações, pode-se chegar à real importância do comércio exterior para a redução do abismo social.

Para isso, foi necessário calcular regressões com a exportação como variável dependente e a renda disponível das camadas como variáveis independentes. Em seguida, foram analisadas as elasticidades móveis encontradas no segundo grupo de regressões. A partir delas, pode-se confirmar o que a análise dos demais aspectos da economia brasileira já apontava: foi a prosperidade temporária no comércio exterior que permitiu a distribuição de 
renda e o crescimento econômico local.

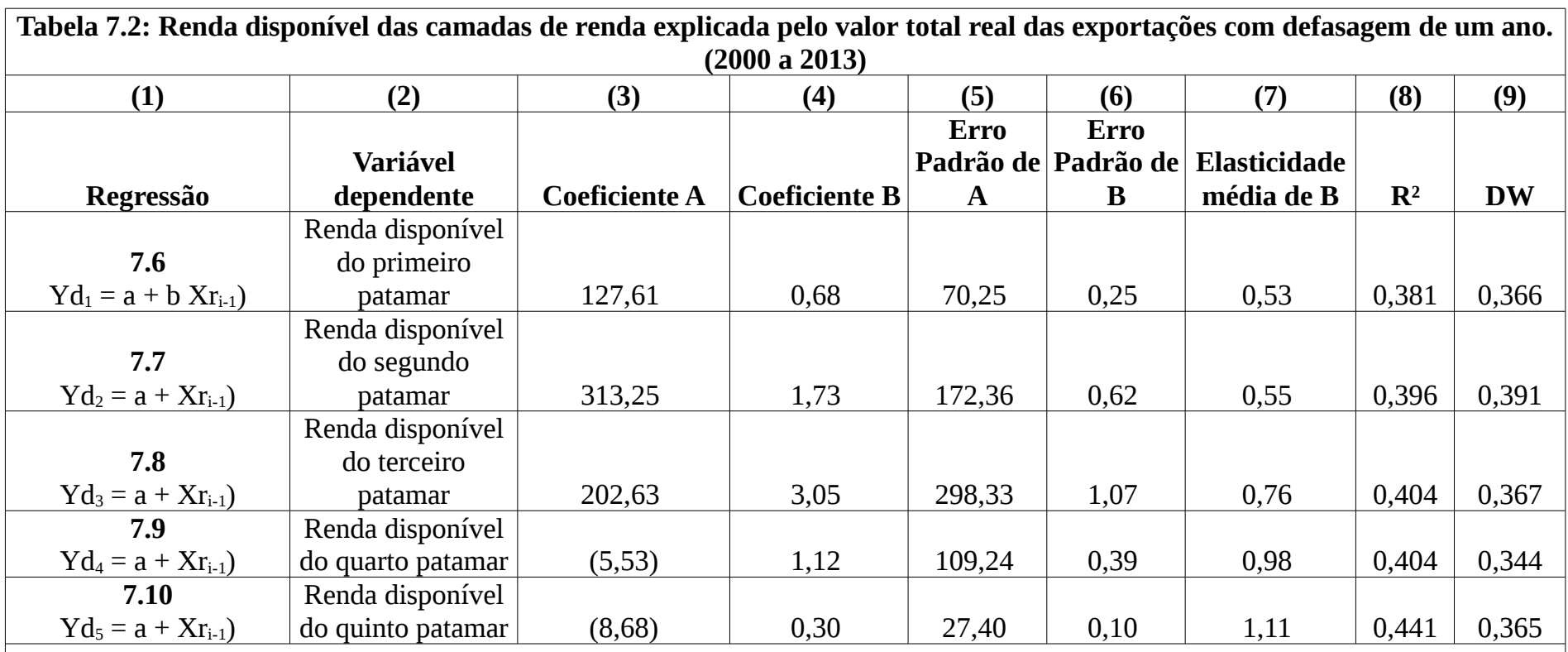

Nota 1: valores negativos entre parênteses.

A tabela 7.2 traz os resultados para cinco regressões com a renda disponível de cada das camadas de renda explicada pelo valor total real das exportações com defasagem de um $a^{210}$. A coluna (1) da tabela traz o número de referência da regressão. A coluna (2) contém o nome da variável dependente, que é a camada de renda a qual diz respeito a regressão. A coluna (3) traz o coeficiente “a”, que é a constante da regressão. A coluna (4) traz o coeficiente "b”, que é quanto um aumento de 1 real de 2006 nas exportações gerou de aumento na renda das camadas. As colunas (5) e (6) trazem os erros padrões dos coeficientes. A coluna (7) traz a elasticidade média do coeficiente “B”, que é expressa o quanto o aumento de um por cento na exportação de um ano gerou de aumento, em porcentagem, na renda disponível do patamar de renda em análise, para o ano seguinte. A coluna (8) traz o Rquadrado $\left(\mathrm{R}^{2}\right)$, que é o poder explicativo da regressão. A coluna (9) contém o Durbin-Watson da regressão. A escolha de realizar essa regressão com defasagem de um ano se deu por fornecer resultados mais confiáveis, com valores melhores do Durbin-Watson, quando comparado com a similar sem defasagem. O impacto das exportações tende a demorar até gerar alteração na renda local, e portanto no nível de consumo local também.

No entanto, verificou-se baixo valor do R-quadrado e do próprio DW. Isso é resultado

210 As regressões realizadas utilizaram a formula $\mathrm{Yd}_{\mathrm{i}}=\mathrm{a}+\mathrm{bX}_{\mathrm{i}-1}$. Ou seja, colocou-se a renda total de cada camada em função do valor total das exportações do ano anterior. Dessa forma, considerou-se que as exportações de um ano tem impacto na renda disponível da população, naquele ano. 
do impacto da crise de 2009. Com a crise, houve desaquecimento do mercado mundial, gerando internalização parcial das economias, e redução dos mercados. Ao verificar os valores estimados pela regressão e os valores observados nos dados originais, pode-se detectar que o fator conjuntural foi uma queda nas exportações em 2009, e que impactou nos anos seguintes. Ou seja, o desaquecimento do mercado mundial, a partir da crise econômica de 2008, afetou a relação entre as exportações e a renda disponível das camadas de renda do Brasil.

Ainda assim, o poder explicativo das regressões se manteve próximo aos $40 \%$, sendo mais baixo para o primeiro patamar de renda, e mais alto para o quinto patamar. Isso significa dizer que a renda dos que tem maior renda foi menos explicada pelas oscilações nas exportações, e a renda da camada de baixo foi melhor explicada pelas exportações. As variações das exportações explicou $13,6 \%$ a mais as variações na renda do quinto patamar do que do primeiro.

A elasticidade média dos patamares do topo da pirâmide de renda, incluindo o primeiro e segundo patamar, foi mais baixa, apontando inelasticidade. Para os patamares da base da pirâmide, incluindo quarto e quinto, ela foi mais alta. Ou seja: a metade de baixo da pirâmide é a camada que tem sua renda melhor determinada pelas variações das exportações. A distribuição de cada novo real gerado pelas exportações foi: 13,6 centavos para o primeiro patamar de renda; 14 centavos para o segundo patamar; 19,2 centavos para o terceiro; 25 centavos para o quarto; e 28,2 para o quinto patamar.

Observou-se um movimento cíclico previsto pelo modelo de Prebisch: quando há expansão do comércio internacional, os países dependentes tendem a abrir mais sua economia. Disso resulta ganho de importância do setor externo. Quando há retração do comércio, esses mesmos países são forçados a realizar internalização parcial de sua economia. Daí resultou historicamente as substituições de importação. No caso em análise, o que ocorreu foi o fortalecimento da indústria extrativa, com enfase no petróleo e minério de ferro, e enfraquecimento da indústria de transformação, mesmo após o desaquecimento no comércio internacional. 


\begin{tabular}{|c|c|c|c|c|c|c|c|c|c|c|}
\hline (1) & (2) & (3) & (4) & (5) & (6) & (7) & (8) & (9) & (10) & (11) \\
\hline Regressão & $\begin{array}{c}\text { Variável } \\
\text { dependente }\end{array}$ & A & B & Dummy & Erro de A & $\begin{array}{c}\text { Erro de } \\
\text { B }\end{array}$ & $\begin{array}{l}\text { Erro da } \\
\text { dummy }\end{array}$ & $\begin{array}{l}\text { Elasticidade } \\
\text { média de B }\end{array}$ & $\mathbf{R}^{2}$ & DW \\
\hline $\begin{array}{c}\mathbf{6 . 1 1} \\
\left(\mathrm{Yd}_{1}=\mathrm{a}+\mathrm{X}_{\mathrm{i}-1}\right. \\
+ \text { Dmy })\end{array}$ & \begin{tabular}{|c|} 
Renda \\
disponível do \\
primeiro \\
patamar
\end{tabular} & 183,59 & 0,36 & 94,57 & 37,47 & 0,14 & 16,19 & 0,30 & 0,849 & 1,992 \\
\hline $\begin{array}{c}\mathbf{6 . 1 2} \\
\left(\mathrm{Yd}_{2}=\mathrm{a}+\mathrm{X}_{\mathrm{i}-1}\right. \\
+ \text { Dmy })\end{array}$ & \begin{tabular}{|c|} 
Renda \\
disponível do \\
segundo \\
patamar \\
\end{tabular} & 451,56 & 0,92 & 233,63 & 89,93 & 0,34 & 38,85 & 0,32 & 0,859 & 2,180 \\
\hline $\begin{array}{c}\mathbf{6 . 1 3} \\
\left(\mathrm{Yd}_{3}=\mathrm{a}+\mathrm{X}_{\mathrm{i}-1}\right. \\
+ \text { Dmy })\end{array}$ & \begin{tabular}{|c|} 
Renda \\
disponível do \\
terceiro \\
patamar
\end{tabular} & 443,37 & 1,64 & 406,67 & 152,72 & 0,58 & 65,97 & 0,46 & 0,866 & 2,144 \\
\hline $\begin{array}{c}\mathbf{6 . 1 4} \\
\left(\mathrm{Yd}_{4}=\mathrm{a}+\mathrm{X}_{\mathrm{i}-1}\right. \\
+ \text { Dmy })\end{array}$ & \begin{tabular}{|c|} 
Renda \\
disponível do \\
quarto \\
patamar
\end{tabular} & 82,97 & 0,60 & 149,49 & 55,16 & 0,21 & 23,83 & 0,61 & 0,870 & 2,116 \\
\hline $\begin{array}{c}\mathbf{6 . 1 5} \\
\left(\mathrm{Yd}_{5}=\mathrm{a}+\mathrm{X}_{\mathrm{i}-1}\right. \\
+ \text { Dmy })\end{array}$ & \begin{tabular}{|c|} 
Renda \\
disponível do \\
quinto \\
patamar
\end{tabular} & 13,45 & 0,17 & 37,38 & 13,99 & 0,05 & 6,05 & 0,73 & 0,875 & 2,215 \\
\hline
\end{tabular}

Fonte: IBGE e IPEA

A tabela 7.3 traz as cinco regressões realizadas com o valor das exportações brasileiras defasado um ano como variável independente, com a renda disponível das camadas de renda como variáveis dependentes, e acréscimo de uma variável de correção conjuntural (dummy). A dummy utilizada foi uma variável com valor zero até 2008, e valor 1 a partir de 2009.

A coluna (1) da tabela traz o número de referência da regressão. A coluna (2) contém o nome da variável dependente, que é a camada de renda a qual diz respeito a regressão. A coluna (3) traz o coeficiente "a”, que é a constante da regressão. A coluna (4) traz o coeficiente "b”, que diz em quanto um aumento de 1 real de 2006 nas exportações gerou de aumento na renda das camadas. A coluna (5) expressa o impacto da dummy, que é em quanto a renda da camada foi acrescida acima do esperado pelas exportações, de 2009 em diante. As colunas (6), (7), e (8) trazem os erros padrões dos coeficientes e da dummy. A coluna (9) possui a elasticidade média do coeficiente "B”. A coluna (10) traz o R-quadrado (R²), que é o poder explicativo da regressão. A coluna (11) contém o Durbin-Watson da regressão. Observa-se que, ao utilizar a dummy, as regressões ganharam poder explicativo e perderam espuriedade. Ou seja, se considerarmos um efeito conjuntural da crise econômica nas exportações, ela (na verdade, a ausência dela) é capaz de explicar o crescimento da renda das 
distintas camadas em relação ao esperado pelas exportações.

Apesar de ganhar maior poder explicativo, regressões que utilizam dummies apenas servem para duas coisas: (a) para calcular a relação a-histórica entre a renda e a exportação, permitindo estipular quanto deveria ter sido a renda de cada camada caso a crise econômica não existisse; e (b) para se averiguar que a espuriedade e baixo poder explicativo de uma regressão de fato é resultado de uma conjuntura específica. No caso, pela crise de 2009. Ou seja, se o modelo original possui baixo poder explicativo é porque existiu um fenômeno histórico que causou mudança significativa de comportamento nas exportações, e portanto na relação entre a exportação e a renda disponível das camadas. Isso está de acordo com o modelo para economias subdesenvolvidas de Prebisch ${ }^{211}$, onde um aumento das exportações leva a longo prazo a um crescimento da renda disponível menos do que proporcional ${ }^{212}$. Ao mesmo tempo, uma queda na renda disponível da população pode levar a um crescimento momentâneo das exportações ${ }^{213}$.

\subsection{ELASTICIDADE MÓVEL DOS GANHOS COM A EXPORTAÇÃO}

Assim como as propensões marginais a investir e a consumir, os ganhos marginais com a exportação também são históricos. São influenciados por diversos fatores. O primeiro deles é pelo grau de dependência econômica do país. Quanto mais dependente o país for do setor exportador, mais elásticos serão os ganhos na renda com a exportação. Outro fator relevante é o grau de concentração da propriedade e da renda. Quanto mais concentrada for a renda, tanto mais os patamares de baixo da pirâmide social serão dependentes do setor externo, caso ele seja um setor de grande importância para economia local.

Outro fator importante é o poder de compra das exportações. O poder de compra das exportações mede o quanto as exportações realizadas cresceram em relação (i) as perdas de divisa causadas pelo pagamento de amortizações, juros, e remessas de lucro ao exterior; e (ii) o volume das importações. Quanto mais as exportações crescerem frente as perdas de divisa,

211 Ver: PREBISCH, Raúl. Dinâmica do Desenvolvimento Latino-Americano. Rio de Janeiro: Fundo de Cultura Brasil, 1969.

212 Ver também: BHALLA, A. S. Uneven Development in the Third World. Londres: Macmillan Press LTD, 1995; CHENA, Pablo Ignacio. Crecimiento restringido por la balanza de pagos en países exportadores de alimentos. Problemas del Desarrollo, Vol. 39, No. 155 (outubro-dezembro 2008), pg. 29-51

213 Para uma dedução matemática dos possíveis impactos das oscilações na renda nas exportações de destintos tipos de países, ver: ZHANG, Wei-Bin. International Trade Theory. Capital, Knowledge, Economic Structure, Money, and Prices over Time. Japan: Springer, 2008. 
espera-se maior capacidade do setor externo em auferir renda para as distintas camadas. Quando os ganhos das exportações são pequenos, frente aos mecanismos de perda de reservas internacionais, mais os ganhos de renda precisarão vir de outra fonte, se existirem. Ainda, quanto maior for o setor externo da economia, frente ao PIB, espera-se maior grau de relação entre os ganhos e perdas de renda das camadas e as exportações.

Gráfico 7.9 Poder de compra das exportações brasileiras, 1999 a 2013

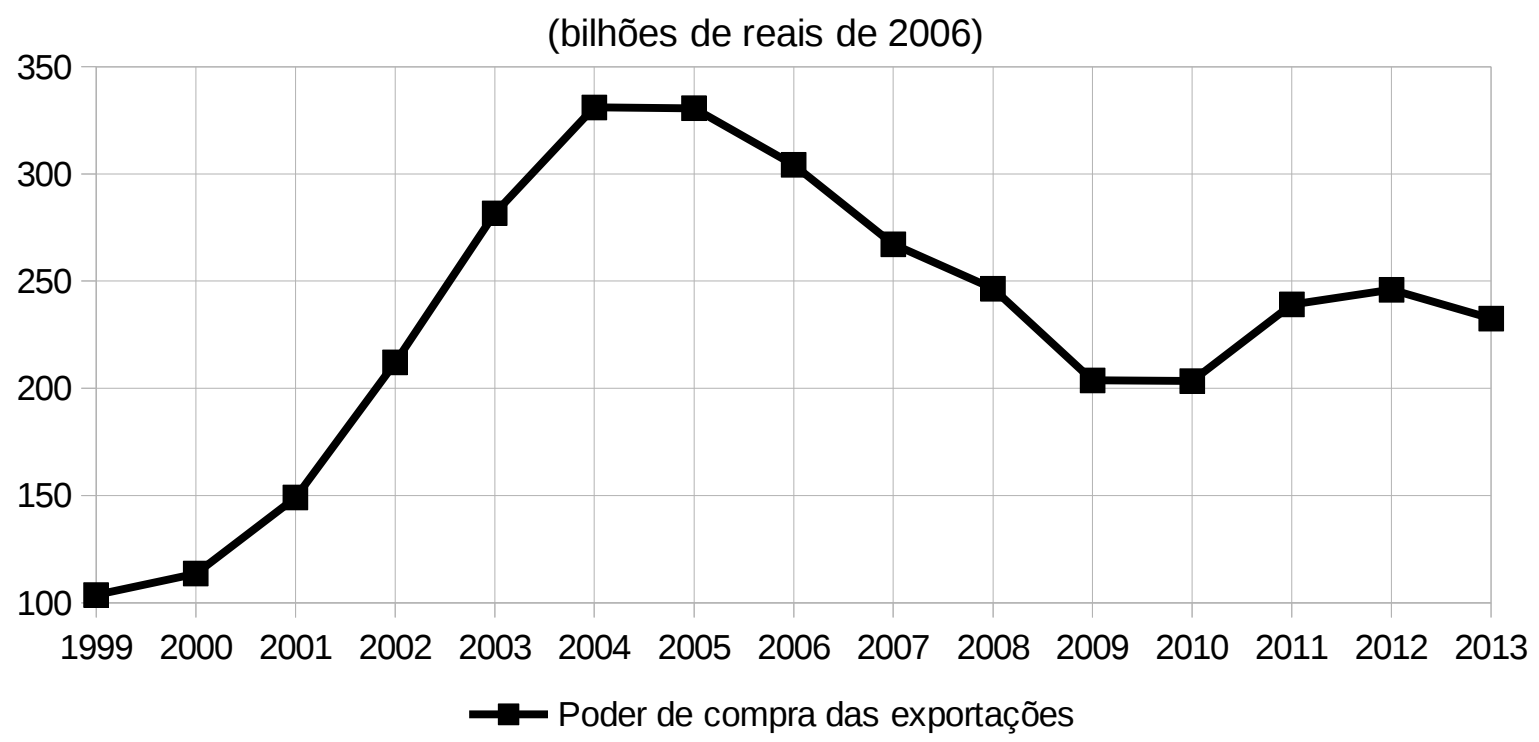

Fonte: MDIC e IBGE

O gráfico 7.9 traz a representação do poder de compra das exportações brasileiras, que pode ser conferido na coluna (VI) da tabela 3.5 (capítulo 3). Trata-se de informação relevante para a análise das exportações brasileiras, visto que considera os termos de troca do balanço comercial. O gráfico revela que houve aumento do poder de compra das exportações até 2004. Em 2005, houve pequena queda. De 2006 a 2009, a queda se acelerou. Em 2010, houve queda pequena no poder de compra das exportações. Em 2011 e 2012 houve recuperação, e nova queda em 2013. Esse perfil deve ser lembrado para que se entenda o movimento da elasticidades da renda disponível perante as exportações.

Para se analisar a elasticidade móvel da renda disponível em relação a exportação, é importante trabalhar com o modelo econômico sem a dummy de conjuntura. Isso porque a dummy aumenta a elasticidade artificialmente. Daí, poderia se criar a impressão que as exportações foram mais importantes do que realmente foram para cada camada. 


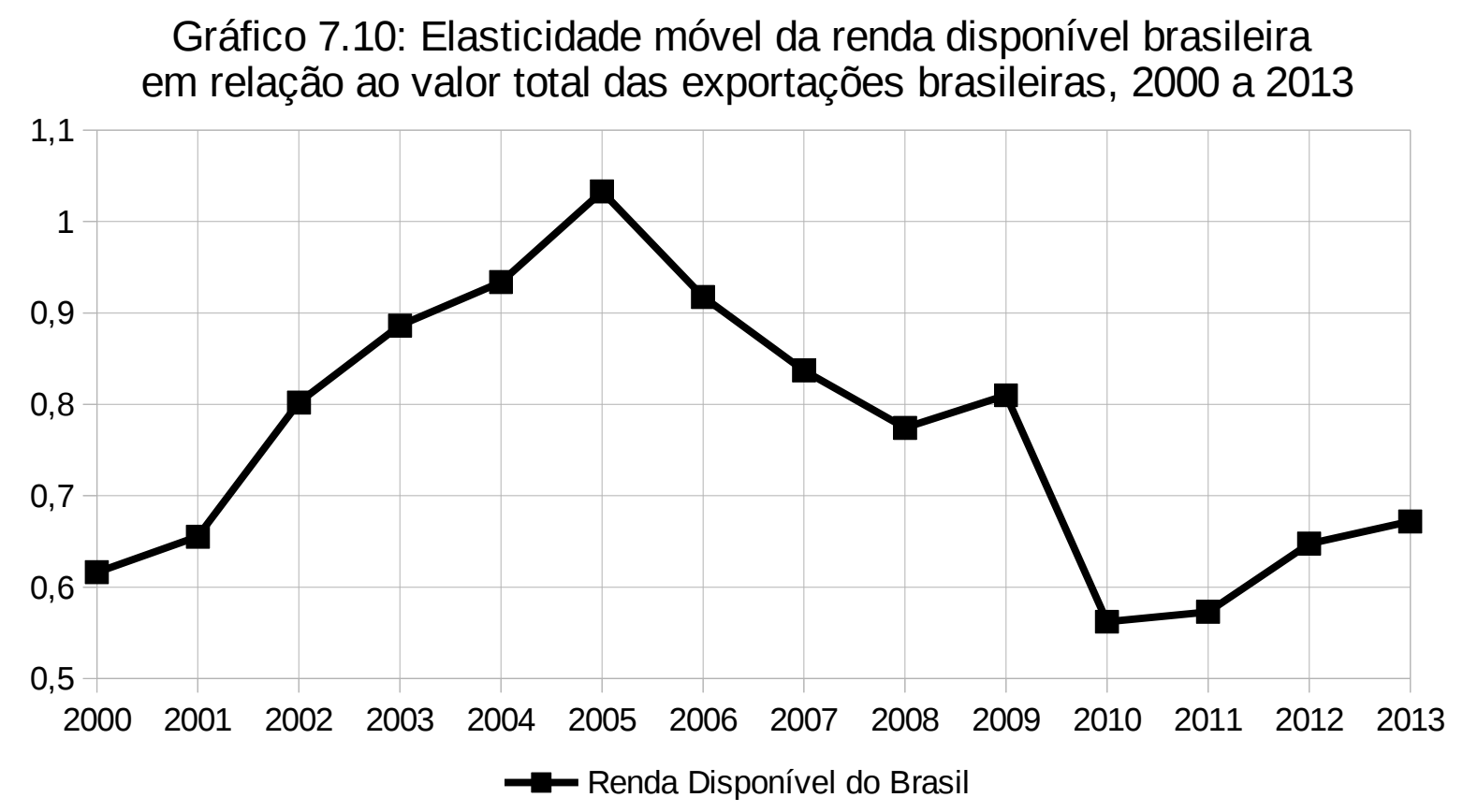

Fonte: IBGE e IPEA

O gráfico 7.10 traz a elasticidade móvel da renda disponível brasileira em relação ao valor total real das exportações brasileiras. Verifica-se perfil similar ao do poder de compra das exportações: crescimento até 2004, queda até 2012, e recuperação a partir de 2011. Isso significa que, quanto maior foi a capacidade das exportações para financiarem as importações brasileiras, maior foi o impacto dela na renda disponível do Brasil. Ainda, observa-se que, com a crise econômica internacional de 2008-2009, a renda disponível brasileira se tornou menos sensível às oscilações nas exportações.

Verifica-se que a elasticidade da renda foi tanto maior quanto maior foi o poder de compra das exportações brasileiras. Isso indica que, apesar das exportações possuírem baixo poder explicativo para a renda disponível do Brasil, e portanto das distintas camadas de renda, elas foram mais importantes para expansão na renda nos momentos em que as exportações tinham maior capacidade de financiar as importações do país.

Mais uma vez, verifica-se indício da possibilidade de aplicar a tese de Prebisch em um modelo para o desempenho da atividade econômica do Brasil, entre 1999 e 2013. Enquanto a economia internacional experimentou um período de expansão, impulsionado pelo sucesso da parceria China-EUA, a atividade econômica do Brasil se tornou mais sensível às oscilações internacionais. Passada a etapa de expansão, houve redução parcial dessa sensibilidade. A dificuldade de continuar a expandir as importações levou à diminuição do impacto das 
exportações na renda nacional.

\section{Gráfico 7.11: Ganhos do primeiro e segundo patamar de renda para cada novo real criado na exportação brasileira, 2000 a 2013}

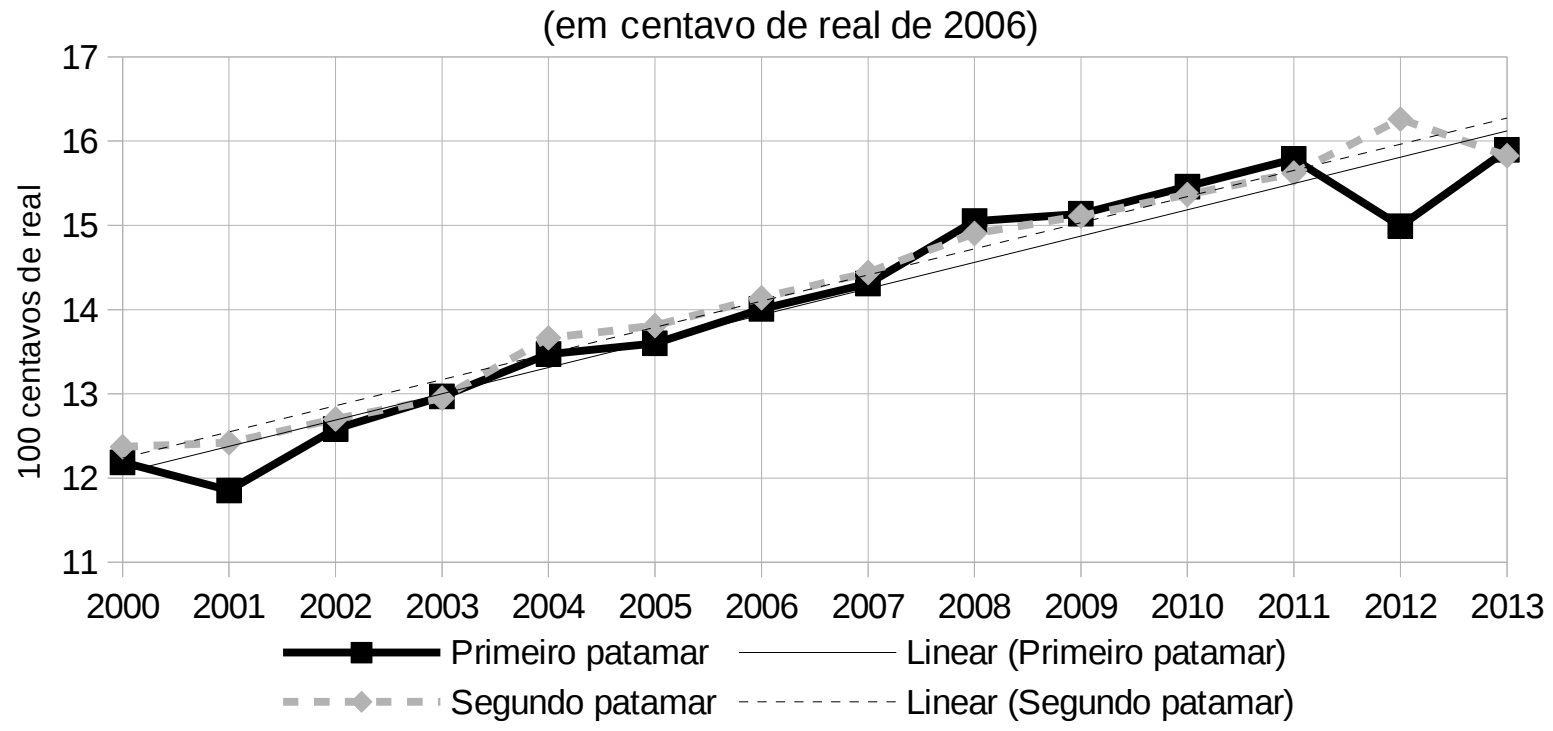

Fonte: IBGE e IPEA

O gráfico 7.11 traz os ganhos do primeiro patamar de renda (que inclui os 1\% do topo da pirâmide de renda), e do segundo patamar (que inclui os 9\% seguintes) para cada novo real constante de 2006 no valor total das exportações brasileiras. Durante todo período, os 1\% do topo e os $9 \%$ seguintes expandiram sua participação nos ganhos com a exportação. No entanto, verifica-se que os novos ganhos de renda do primeiro patamar foi bastante baixo. Em 2001, os 1\% ficava com cerca de 12 centavos de cada novo real criado pela exportação,e os 9\% seguintes ficavam com outros 12. Em 2013, passaram a ganhar cerca de 16 centavos cada.

A baixa participação dessa camada em cada novo real de exportação explica como, durante o período de expansão das exportações essas camadas perderam participação na distribuição da renda disponível no Brasil. A trajetória de ampliação da participação nos ganhos, por parte dos $10 \%$ do topo, é condizente com a mudança na pauta de exportação brasileira. Entre 1999 e 2013, houve ganho relativo das exportações de bens primários, e redução dos bens industriais finais.

Essa mudança de perfil da pauta de exportação teve impacto no potencial das exportações fomentarem novos ganhos de renda no Brasil. A cadeia produtiva de bens primários gerou, no período, menor efeito multiplicador de renda. Daí ocorrer ganho relativo do primeiro patamar de renda com a criação de cada novo real de exportação. 
Importante notar que as exportações explicaram apenas 38\% das oscilações na renda do primeiro patamar, e menos de 39\% das oscilações do segundo patamar. Isso quer dizer que, apesar da baixa participação dessa camada nos ganhos com exportação, ela foi capaz de fazer crescer sua renda por outros meios. Os $10 \%$ do topo são detentores de títulos da dívida pública, acionistas de grandes empresas, e de propriedades urbanas e rurais. A diversificação da origem de renda fornece, à essa camada, maior independência do desempenho de sua renda frente ao comércio exterior brasileiro.

O descolamento da renda das camadas de maior rendimento é condizente com o modelo do países subdesenvolvidos. São países de baixa capacidade de acumulação de capital, cuja o crescimento da renda depende das importações, financiadas pela exportação ou por poupança externa. Como há forte concentração de renda e poder nas mãos de uma elite local, essa busca transferir eventuais perdas de rendimento em momentos de crise para as demais camadas. Daí a relação de dependência dos países subdesenvolvidos também ser denominada de neocolonialismo. ${ }^{214}$

\section{Gráfico 7.12: Ganhos do segundo patamar de renda para cada novo real criado na exportação brasileira, 2000 a 2013 \\ (em centavos de real de 2006)}

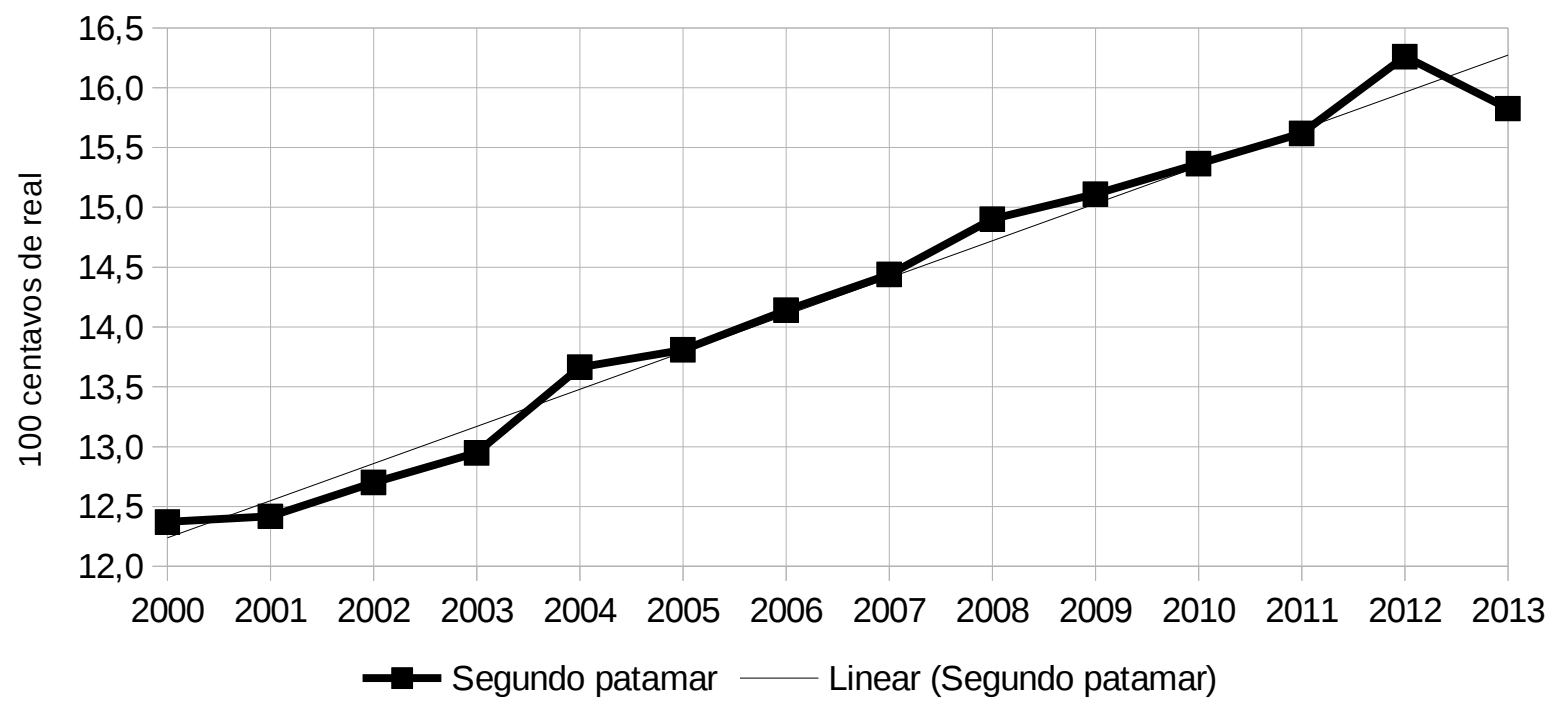

Fonte: IBGE e IPEA

O terceiro patamar de renda, composto pelos 40\% seguintes aos $10 \%$ do topo (camadas médias da sociedade), apresentaram participação relevante nos ganhos com a exportação. Conforme verifica-se no gráfico 7.12, de cada novo real, em 2001, essa camada 
adquiriu pouco mais de 18,5 centavos. Em 2013, passou a representar mais de 19,5 centavos. Trata-se de comportamento quase estável. A renda das camadas médias foi explicado em cerca de $40 \%$ pelas oscilações nas exportações.

Gráfico 7.13: Ganhos do quato patamar de renda para cada novo real criado nas exportações brasileiras, 2000 a 2006

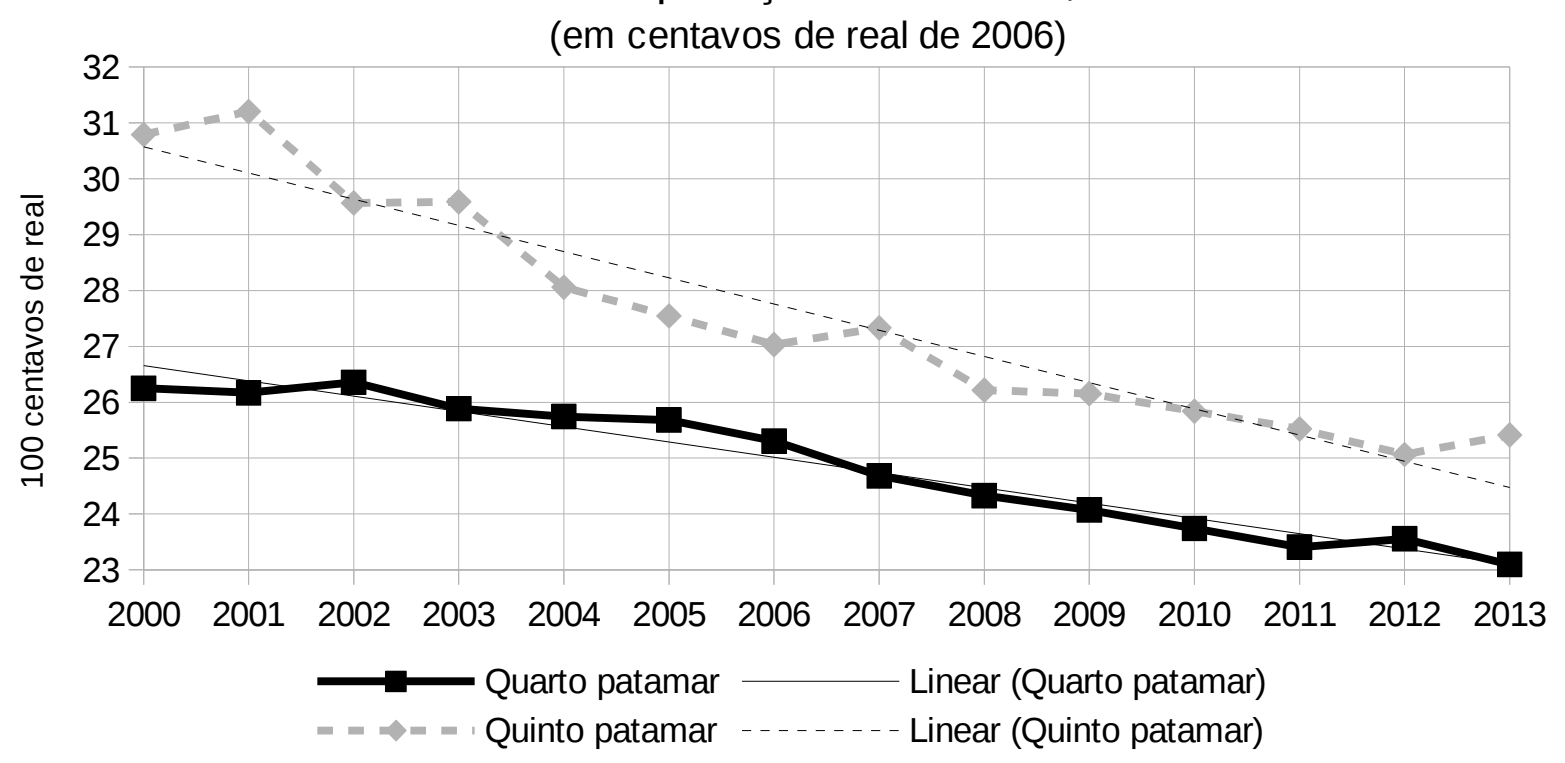

Fonte: IBGE e IPEA

O gráfico 7.13 traz os ganhos do quarto e quinto patamares de renda para cada novo real criado nas exportações brasileiras, entre 2000 e 2013. O quarto patamar teve sua renda explicada em torno de 40\% pelas exportações, e ganhou, em 2001, cerca de 26 centavos para cada novo real criado pela exportação. Em 2013, esse valor havia caído para 23 centavos. O quinto patamar teve sua renda explicada em 44\% pelas exportações. Em 2001, ganhou 31 centavos para cada real criado pela exportação. Em 2013, passou a ganhar cerca de 25,5 centavos em cada novo real.

A expansão das exportações permitiu às camadas da população com menor renda aumentar sua participação na renda disponível brasileira. Foram as exportações que financiaram uma redistribuição de renda ocorrida no período. Mas, conforme os bens primários cresceram mais rapidamente na pauta de exportação, a capacidade de financiar o crescimento da renda das camadas de baixo foi diminuindo.

Trata-se de um modelo onde aqueles que possuem maior renda parecem sempre ganhar. Seus ganhos, embora afetados pelo setor externo, puderam crescer independentemente 
da existência ou não de prosperidade no país. O Brasil, como país dependente, e subdesenvolvido, tem como marca a existência de uma elite que pode lucrar mesmo com a crise ou a miséria do povo.

A elite local se configurou, entre 1999 e 2013, como sócia do capital estrangeiro. Quando as exportações estiveram em alta, puderam ganhar com os lucros do comércio exterior. Quando houve momentos de crise, a existência do real sobrevalorizado facilitou a entrada de capital especulativo, aberto ou disfarçado como investimento direto elevando os juros. Como os rendimentos da camada do topo da pirâmide social brasileira é parcialmente advindo de negócios com o exterior, mesmo nos momentos de crise, puderam ganhar. Ainda, o governo brasileiro, no período, dedicou partes volumosas dos recursos do Estado para pagar dívidas com juros bastante altos. O modelo de controle da inflação adotado foi o de garantir a moeda local sobrevalorizada, e juros altos.

A estrutura econômica brasileira foi configurada de forma que os de menor renda só puderam observar prosperidade em períodos de alta cíclica dos preços das exportações. Tratase de um aspecto de economias dependentes. Para os mais pobres, só houve prosperidade quando o comércio internacional permitiu ganhos excepcionais. Para os mais ricos, houve ganhos em qualquer circunstância.

\subsection{OSCILAÇÕES NA EXPORTAÇÃO E NA RENDA DAS CAMADAS}

O grau de dependência econômica e a capacidade de ganho no comércio internacional também afeta as oscilações nos ganhos da exportação. A distância entre o valor observado e esperado da renda disponível das distintas camadas de renda em relação ao valor total das exportações revela os períodos de crise econômica local. Quando a renda é menor do que o esperado para dado volume de exportação, é sinal que os demais mecanismos econômicos estão sufocados.

Ainda, a observação das oscilações permite verificar que, entre 1999 e 2013, os ganhos com a exportação precederam o crescimento da renda disponível da população. Mais uma vez, reforça-se que a tese de Samir Amin sobre a predominância do setor exportador, se considerado um modelo de quatro setores, pode ser aplicada ao Brasil, para aquele período. 
Gráfico 7.14: Posição relativa da renda dos três primeiros patamares em relação as oscilações no valor total das exportações brasileiras, 1999 a 2013

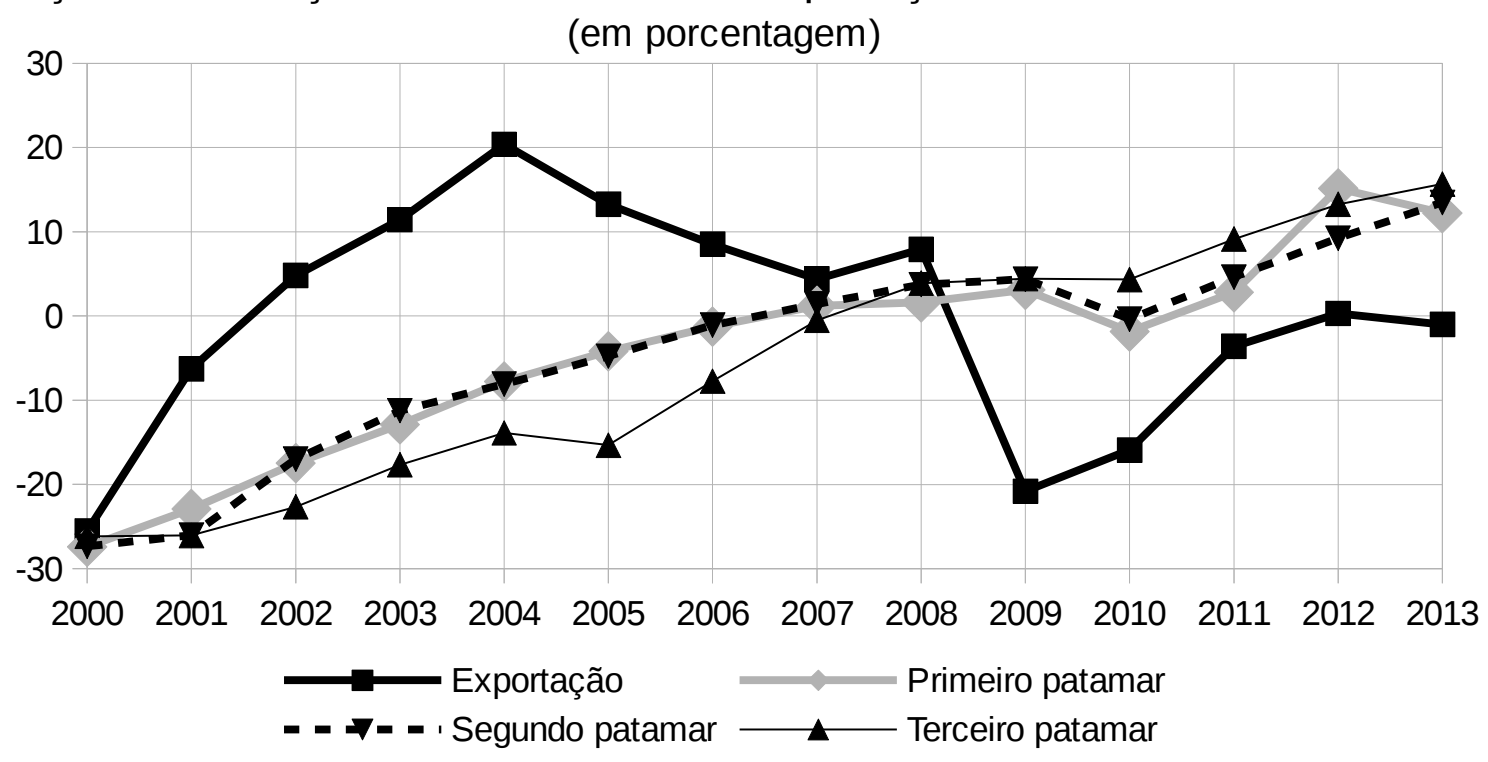

Fonte: IBGE e IPEA

O gráfico 7.14 traz a posição relativa das oscilações na renda disponível dos três primeiros patamares de renda distribuídos em torno das oscilações no valor total das exportações, para o período entre 2000 e 2013. Valores da oscilação na exportação acima das oscilações na renda disponível significaram maior capacidade das exportações financiarem o crescimento da renda do patamar, o que ocorreu de 2000 a 2008. Quando as oscilações na renda se mantiveram acima das oscilações das exportações, houve perda da capacidade de financiamento da expansão da renda, o que ocorreu de 2009 em diante.

De 2000 a 2006, a renda das três camadas de cima da pirâmide de renda esteve em valores abaixo do esperado. A recuperação econômica do Brasil iniciou-se primeiro no setor externo, através da ampliação das exportações e redução temporária das importações, até 2003. A partir de 2006, a renda passou a crescer mais rapidamente do que o esperado pelas exportações. Isso foi consequência da recuperação da economia local através (a) da variação na distribuição de renda; e (b) do incentivo ao consumo.

O gráfico 7.15 traz a posição relativa das oscilações na renda disponível dos dois patamares de baixo da pirâmide de renda distribuído em torno das oscilações no valor total das exportações, para o período entre 2000 e 2013. O gráfico é bastante similar ao verificado para os três patamares de cima da pirâmide de renda. No entanto, a amplitude das oscilações é bastante superior. Isso é resultado da maior fragilidade dos rendimentos da metade mais pobre 
do país.

Gráfico 7.15: Posição relativa do quarto e quinto patamares de renda em relação as oscilações do valor total das exportações brasileiras, 2000 a 2013

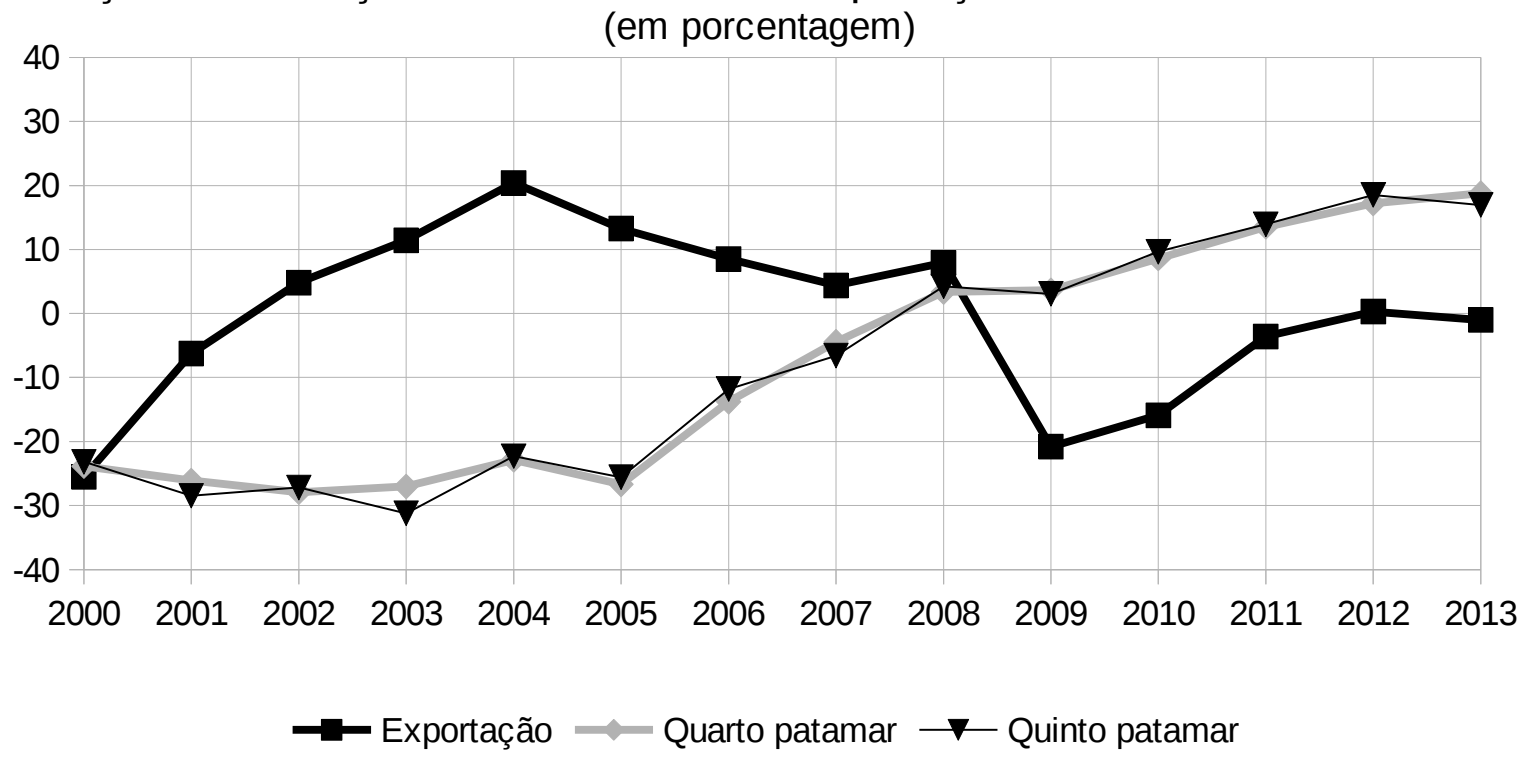

Fonte: IBGE e IPEA

De 2001 a 2007, a capacidade das exportações para financiar o crescimento da renda disponível do quarto e quinto patamares de renda foi bastante alta. Desde 2006, quando houve desaceleração do crescimento das exportações, essa capacidade foi rapidamente diminuindo. Com a crise de 2009, ela se tornou negativa. Graças as políticas anticíclicas adotadas no Brasil, a renda das distintas camadas continuou a crescer. Em 2011, houve recuperação parcial das exportações brasileiras e diminuição no ritmo de crescimento da renda das camadas de baixo da pirâmide social.

A adoção de políticas de distribuição de renda e incentivo ao consumo ocorridas entre 2003 e 2013, permitiu os ganhos adquiridos na exportação serem distribuídos e se multiplicarem na renda disponível dos brasileiros. Concedeu mesmo certa resiliência à crise mundial de 2008-9. No entanto, não rompeu com o modelo econômico anterior. Disso resultou o esgotamento do crescimento da renda nos anos de 2012 e 2013.

\subsection{UM MODELO DE CRESCIMENTO DEPENDENTE}

Entre 1999 e 2013, a estrutura econômica brasileira foi marcada pelo baixo acúmulo de capital fixo e alta dependência do comércio exterior. Os estruturalistas analisaram o 
comportamento cíclico de economias deste tipo, assim como apresentaram a tendência de piora das condições econômicas, conforme houvesse tendência de degeneração dos termos de troca. O modelo de análise proposto por Prebisch, Celso Furtado, Noyola Vasquez, e outros, pode ser aplicada ao caso brasileiro, para aquele período.

Entre 2001 e 2013, o Brasil experimentou crescimento sustentado pela exportação. Os ganhos adquiridos no comércio exterior não foram direcionados para gerar aumento de produtividade. Não houve expansão significativa da base industrial. Isso quer dizer que não ocorreu aumento suficiente do acúmulo de capital fixo. O crescimento econômico foi utilizado para gerar distribuição de renda e aumento do consumo das distintas camadas.

Um olhar desatento poderia concluir que se tratava de um modelo econômico impulsionado pelo consumo. Ou seja, um modelo onde o consumo gerasse demanda agregada, impulsionando o investimento. Isso não aconteceu, e nem poderia acontecer. A adoção de um modelo econômico, sem que ocorressem mudanças estruturais na distribuição das propriedades, não podia ser capaz de superar a estrutura dependente. Disso resultou a distribuição de renda com outro modelo de dependência.

Tabela 7.4: Produto Interno Bruto explicado pelo Consumo das famílias e pelas exportações brasileiras, 1999 a

\begin{tabular}{|c|c|c|c|c|c|c|c|c|}
\hline (1) & (2) & (3) & (4) & (5) & (6) & (7) & (8) & (9) \\
\hline $\begin{array}{l}\text { Número da } \\
\text { regressão }\end{array}$ & $\begin{array}{c}\text { Constante } \\
\text { (coeficiente a) }\end{array}$ & $\begin{array}{c}\text { consumo das } \\
\text { famílias } \\
\text { (coeficiente b) }\end{array}$ & $\begin{array}{c}\text { Exportação } \\
\text { brasileira } \\
\text { (coeficiente c) }\end{array}$ & Erro de a & Erro de b & Erro de c & $\mathbf{R}^{2}$ & DW \\
\hline $\begin{array}{c}6.11 \\
(\mathrm{PIBr}=\mathrm{a}+\mathrm{Cr}+ \\
\mathrm{Xr})\end{array}$ & 142,88 & 1,38 & 0,80 & 41,48 & 0,03 & 0,17 & 0,997 & 1,222 \\
\hline
\end{tabular}

Dados: IBGE

A tabela 7.4 traz os resultados de uma regressão (regressão 7.16) com o Produto Interno Bruto em reais constantes de 2006 explicado pelo consumo real das famílias e pela exportação real brasileira. Na coluna (1), verifica-se o número da regressão. Na coluna (2) verifica-se o valor da constante. Da coluna (3) a (4), observa-se o valor do coeficiente para as variáveis independentes referentes. Da coluna (5) a (7), está o erro padrão dos coeficientes correspondentes. Na coluna (8), verifica-se o R-quadrado, e na (9)o Durbin Watson da regressão.

Essa regressão é um modelo econômico parcial, considerando apenas alguns dos componentes do PIB para explicar o total dele. O que se verifica é que o consumo e a 
exportação foram capazes de, sozinhos, explicar quase a totalidade das oscilações do Produto Interno Bruto do brasil. Trata-se de um poder explicativo de 99,7\%, sem espuriedade.

Como o consumo só pode gerar crescimento se houver oferta que o supra, ele pode gerar (a) aumento da produção local; ou (b) aumento da importação. Está claro que o impacto, no caso brasileiro, entre 1999 e 2013, foi maior para o aumento da importação. Isso significa que o consumo precisou ser sustentado pela exportação: a demanda interna foi parcialmente suprida pela oferta externa (importações).As divisas adquiridas pela exportação foram, em parte, gastas para financiar a importação para consumo, ao invés de permitir expansão dos investimentos de base.

A tabela 7.5 traz o resultado de uma regressão (regressão 7.17) com o Produto Interno Bruto real como variável dependente, e consumo das famílias, exportação brasileira real, a formação bruta de capital fixo real, e as importações brasileiras reais como variáveis independentes. Na coluna (1) está número ; na coluna (2) está o coeficiente da constante; da coluna (3) a (6) estão os coeficientes para as diferentes variáveis independentes; da coluna (7) a (10) estão os erros padrões para os respectivos coeficientes; e na coluna (11) observa-se o Rquadrado da regressão, e na (12) o Durbin-Watson.

\begin{tabular}{|c|c|c|c|c|c|c|c|c|c|c|c|}
\hline (1) & (2) & (3) & (4) & (5) & (6) & (7) & (8) & (9) & (10) & (11) & (12) \\
\hline Regressão & Constante & $\begin{array}{c}\text { Consumo } \\
\text { das famílias } \\
\text { (coeficiente } \\
\text { b) }\end{array}$ & $\begin{array}{c}\text { Exportação } \\
\text { brasileira } \\
\text { (coeficiente } \\
\text { c) }\end{array}$ & $\begin{array}{c}\text { Formação } \\
\text { bruta de } \\
\text { capital fixo } \\
\text { (coeficiente } \\
\text { d) }\end{array}$ & $\begin{array}{c}\text { Importação } \\
\text { brasileira } \\
\text { (coeficiente } \\
\text { e) }\end{array}$ & $\begin{array}{c}\text { Erro } \\
\text { de b }\end{array}$ & $\begin{array}{l}\text { Erro } \\
\text { de c }\end{array}$ & $\begin{array}{l}\text { Erro } \\
\text { de d }\end{array}$ & $\begin{array}{c}\text { Erro } \\
\text { de e }\end{array}$ & $\mathbf{R}^{2}$ & Dw \\
\hline $\begin{array}{c}7.17 \\
(\mathrm{PIBr}=\mathrm{a}+\mathrm{Cr} \\
+\mathrm{Xr}+\mathrm{FBCFr} \\
+\mathrm{Mr})\end{array}$ & 142,88 & 1,38 & 0,8 & 1,23 & $-0,93$ & 0,03 & 0,17 & 0,62 & 0,44 & 0,998 & 1,045 \\
\hline
\end{tabular}

Trata-se de um modelo amplo, que excluiu apenas os gastos do governo ${ }^{215}$. Ao considerar apenas essas quatro variáveis independentes, o modelo econométrico se aproxima de um modelo de quatro setores, de Samir Amin. A regressão atingiu alto poder explicativo (cerca de 99,8\%), sem espuriedade. Ao observar os coeficientes e os erros padrões, verifica-se

215 A escolha de excluir os gastos do governo se deu pelo fato de a inclusão dela gerar uma regressão com excesso de variáveis. Isso resultou em um modelo onde as variáveis independentes perderam sua relevância explicativa, dada o ganho de importância das componentes ocasionais. Os gastos do governo foi a variável com maior erro padrão, que se encontrava acima do aceitável, em um modelo ampliado. Na verdade, boa parte desta variável já se encontra na FBCF e, ao excluí-la, se evita correlação. 
que os erros padrões para a formação bruta de capital e para as importações se aproximaram ou ultrapassaram a metade do valor do coeficiente respectivo.

Isso significa que, em um modelo amplo, enquanto o consumo e as exportações continuaram a ter grande relevância para explicar o PIB, as importações e a formação bruta de capital fixo se apresentaram quase como fatores ocasionais. Ou seja, resultaram do consumo e da exportação, com variações aleatórias ano a ano. Disso pode-se concluir que o modelo econômico que explica o período de 1999 a 2013 é um modelo de dependência. Trata-se da expressão de um país que não pôde superar seu subdesenvolvimento. A melhoria das condições de vida da população local foi episódio que perdurou em um período de prosperidade, sem que se rompesse com a estrutura vigente oligopolista.

Ao final do período, esgotado o ciclo de expansão dos preços dos bens primários, tudo o que sobrou foi a melhoria no consumo dos mais pobres. Sem que tenha ocorrido ampliação dos investimentos produtivos, não houve melhoria na produtividade local. O excedente que vinha das exportações desapareceu. Disso resultou a desintegração, embora com certa lentidão, do componente de crescimento. Cedo ou tarde haveria de chegar a estagnação. Sem o crescimento só restou às distintas camadas e classes da população se digladiarem para ver quem iria perder menos.

\subsection{AINDA A DEPENDÊNCIA}

O modelo proposto por Samir Amin, de que as economias dependentes são melhor explicadas pelo setor exportador e pelo setor de consumo de luxo, aponta para economias em dificuldades. Essas economias crescem mais quando exportam bastante. Ao mesmo tempo, elas bloqueiam o crescimento do mercado interno com seu ajustamentos ${ }^{216}$.

Um modelo econométrico produzido com as taxas de crescimento de variáveis macroeconômicas pode servir para verificar pontos de estrangulamento. Enquanto os modelos com valores brutos, realizados na seção anterior, permitem verificar a influência bruta de uma variável sobre a outra, modelos com a taxa de crescimento permitem verificar a influência das flutuações de uma variável sobre as flutuações de outra.

Para facilitar a compreensão da diferença entre os procedimentos, pode ser útil um

216 Ver: AMIN, Samir. Capitalismo periferico y comercio internacional. Buenos Aires, Ed. Periferia, 1974. 
exemplo: (a) uma fábrica que deseje saber qual é a relação entre o capital investido e a produção gerada, pode utilizar uma regressão com dados em valores brutos. Hipoteticamente, poderá chegar à conclusão que a produção será igual a 100 unidades de tecido mais uma unidade para cada mil reais investidos; (b) se a mesma fábrica deseja saber por exemplo quanto será capaz de aumentar a produção para o ano seguinte ao investir certa quantidade de capital em relação ao ano anterior. Nesse caso, poderá realizar uma regressão com as taxas de crescimento da produção e do capital investido. Hipoteticamente poderá chegar à conclusão que sua produção aumentará $4 \%$ mais 1 ponto percentual para cada aumento de $1 \%$ no capital investido. Isso significa que se investir a mesma quantidade do ano anterior, a sua produção aumentará 4\%. Mas se investir 1\% a menos, o aumento de sua produção cairá para 3\%. Se investir $1 \%$ a mais aumentará sua produção em 5\%.

Para fins de análise, pode-se considerar a importação como uma proxy do "setor de consumo de luxo". Dessa forma, o modelo econômico proposto por Samir Amin pode ser representado por: taxa de crescimento da formação bruta de capital fixo expressando o investimento; o consumo das famílias expressando o consumo de massas; a variação no valor total das exportações representando o setor exportador; e a variação no valor total da importação expressando o consumo de luxo. Assim, gera-se um modelo empírico que pode funcionar como uma espécie de teste de adequação do modelo teórico à realidade observada.

A tabela 7.6 contém dados de regressões com a variação real na renda disponível bruta brasileira explicada pela variação real nos componentes das contas nacionais para o período entre 2000 e 2013. Na primeira coluna está o número de referência da regressão. Na coluna (2) está a variável dependente da regressão. Na coluna (3) verifica-se o coeficiente “a”, que assinala a constante encontrada, em porcentagem. Na coluna (4) verifica-se o coeficiente "b", que assinala quantos pontos percentuais aumentou a taxa de crescimento da renda disponível bruta para cada ponto percentual a mais na taxa de crescimento da variável independente em referência. Nas colunas (5) e (6) encontra-se os erros padrões para o coeficiente “a” e "b”, respectivamente. Na coluna (7) verifica-se o R-quadrado, que expressa o poder explicativo da regressão. Na coluna (8) encontram-se o valor do Durbin-Watson. 


\begin{tabular}{|c|c|c|c|c|c|c|c|}
\hline (1) & (2) & (3) & (4) & (5) & (6) & (7) & (8) \\
\hline $\begin{array}{l}\text { Número da } \\
\text { regressão }\end{array}$ & $\begin{array}{c}\text { Variável } \\
\text { independente }\end{array}$ & Coeficiente A & Coeficiente B & $\begin{array}{c}\text { Erro padrão } \\
\text { de A }\end{array}$ & $\begin{array}{c}\text { Erro padrão de } \\
\text { B }\end{array}$ & $\mathbf{R}^{2}$ & DW \\
\hline $\begin{array}{c}7.18 \\
\Delta \mathrm{Yd}=\mathrm{a}+\Delta \mathrm{Cr}\end{array}$ & Variação do consumo & 1,62 & 0,95 & 1,53 & 0,35 & 0,381 & 2,391 \\
\hline $\begin{array}{c}7.19 \\
\Delta \mathrm{Yd}=\mathrm{a}+ \\
\Delta \mathrm{FBCFr}\end{array}$ & $\begin{array}{l}\text { Variação da formação } \\
\text { bruta de capital fixo }\end{array}$ & 3,11 & 0,43 & 0,66 & 0,08 & 0,686 & 1,895 \\
\hline $\begin{array}{c}7.20 \\
\Delta \mathrm{Yd}=\mathrm{a}+\Delta \mathrm{Xr}\end{array}$ & Variação da exportação & 5,42 & $(0,02)$ & 1,04 & 0,08 & 0,004 & 1,990 \\
\hline $\begin{array}{c}7.21 \\
\Delta \mathrm{Yd}=\mathrm{a}+\Delta \mathrm{Mr}\end{array}$ & Variação da importação & 4,71 & 0,10 & 0,92 & 0,07 & 0,151 & 1,431 \\
\hline $\begin{array}{c}7.22 \\
\Delta \mathrm{Yd}=\mathrm{a}+\Delta \mathrm{Cr}_{\mathrm{i}-1}\end{array}$ & $\begin{array}{l}\text { Variação do consumo } \\
\text { defasada em } 1 \text { ano }\end{array}$ & 4,36 & 0,25 & 2,03 & 0,46 & 0,026 & 2,011 \\
\hline $\begin{array}{c}7.23 \\
\Delta \mathrm{Yd}^{\prime} \mathrm{a}+ \\
\Delta \mathrm{FBCFr}_{\mathrm{i}-1}\end{array}$ & $\begin{array}{l}\text { Variação da formação } \\
\text { bruta de capital fixo } \\
\text { defasada em } 1 \text { ano }\end{array}$ & 5,89 & $(0,11)$ & 1,22 & 0,15 & 0,045 & 1,422 \\
\hline $\begin{array}{c}7.24 \\
\Delta \mathrm{Yd}=\mathrm{a}+\Delta \mathrm{Xr}_{\mathrm{i}-1}\end{array}$ & $\begin{array}{c}\text { Variação da exportação } \\
\text { defasada em } 1 \text { ano }\end{array}$ & 6,96 & $(0,25)$ & 0,60 & 0,05 & 0,716 & 1,251 \\
\hline $\begin{array}{c}7.25 \\
\Delta \mathrm{Yd}=\mathrm{a}+\Delta \mathrm{Mr}_{\mathrm{i}-1}\end{array}$ & $\begin{array}{c}\text { Variação da importação } \\
\text { defasada em } 1 \text { ano }\end{array}$ & 6,49 & $(0,19)$ & 0,67 & 0,05 & 0,610 & 0,779 \\
\hline & & & & & & \multicolumn{2}{|c|}{ Fonte: IBGE } \\
\hline
\end{tabular}

A regressão 7.18 obteve coeficiente “a” de 1,62 e erro padrão de 1,53. Isso significa dizer que a constante de crescimento para a renda disponível real do Brasil está em torno de 0,09\% e 3,15 ao ano. A essa taxa de crescimento soma-se a variação de 0,95 pontos percentuais para cada $1 \%$ na taxa de crescimento do consumo real brasileiro no ano, com erro padrão de 0,35. O R-quadrado aponta que a regressão possui 38,1\% de poder explicativo. Ou seja, mais de um terço das vezes, ao seguir esses valores acerta-se a margem em qual estava a taxa de crescimento da renda disponível brasileira. A relação entre a taxa de crescimento de consumo e a taxa de crescimento da renda foi, entre 2000 e 2013, elástica, mas com forte oscilação.

A regressão 7.22 expressa a relação entre a taxa de crescimento da renda disponível brasileira e a taxa de crescimento do consumo brasileiro no ano anterior. Descrito dessa forma, busca-se responder a questão: "quanto a taxa de crescimento do consumo de um ano afeta a taxa de crescimento da renda disponível no ano seguinte?”. O erro padrão do coeficiente "b" foi suficientemente alto, e o R-quadrado foi suficientemente baixo, para que se possa afirmar que afetou de forma irrelevante e bastante aleatória, entre 2000 e 2013.

A teoria keynesiana afirma que conforme a renda aumenta, a propensão marginal do consumo oscila, alterando o efeito multiplicador de renda. Ainda, fatores externos também 
afetam o multiplicador. O que se observa é que para o Brasil, entre 2000 e 2013, o oscilação da taxa de crescimento do consumo foi um dos fatores explicativos relevantes para explicação da oscilação da taxa de crescimento da renda. No entanto, a relação entre ambos foi fortemente afetada por fatores externos. A principal explicação para isso está na resistência dos brasileiros a passar a consumir menos assim que a renda disponível acelerou, a partir de 2003; e a dificuldade de reduzir o consumo quando a taxa de crescimento da renda já havia caído, a partir de 2011. Ainda, sendo o Brasil um país dependente, e com economia aberta voltada para exportação, a relação entre consumo e renda tendeu a ser instável no período.

A regressão 7.19, da tabela 7.10 expressa o impacto da variação real anual da formação bruta de capital fixo na variação real anual da renda disponível brasileira, entre 2000 e 2013. O coeficiente "a” foi de 3,11, com erro padrão de 0,66. Ou seja, anualmente, a base da taxa de crescimento da formação bruta de capital fixo esteve entre 2,45 e 3,77. O coeficiente "b" foi de 0,43 . com margem de erro de 0,08 . Portanto, para cada ponto percentual da taxa de crescimento da formação bruta de capital fixo no ano, a taxa de crescimento da renda disponível aumentou entre 0,35 e 0,51 pontos percentuais, entre 2000 e 2013 . A regressão possuiu poder explicativo de 68,6\%. Isso significa dizer que, apesar da relação entre a taxa de crescimento da renda disponível real do Brasil e a formação bruta de capital fixa ser inelástica, a regressão expressa valores corretos para mais de dois terços dos anos.

A regressão 7.23 traz a relação entre a variação da renda disponível e a variação da formação bruta de capital fixo do ano anterior. O alto erro padrão do coeficiente "b” e o baixo R-quadrado nos revela que o oscilação na taxa de crescimento da formação bruta de capital fixo em um ano não revela informações sobre a taxa de crescimento da renda disponível bruta do ano seguinte.

A regressão 7.20 foi realizada com a variação real da renda disponível como variável dependente, e a variação real nas exportações brasileiras como variável independente. O coeficiente "a”, que revela o crescimento constante base da regressão para a renda disponível bruta, foi de 5,42\% ao ano, entre 2000 e 2013. O erro padrão foi de 1,04. No entanto, o coeficiente " $\mathrm{b}$ " foi de -0,02 pontos percentuais, com margem de erro de 0,08. O R-quadrado da regressão foi próximo de zero. Isso significa que a taxa de crescimento das exportações de um ano não afeta a taxa de crescimento da renda disponível do país.

A regressão 7.24 traz a relação entre a variação da renda disponível do Brasil e a 
variação do valor total das exportações do ano anterior, para o período entre 2000 e 2013. Proposta dessa forma, visa responder a pergunta: “em que medida a taxa de crescimento do valor real total das exportações de um ano explica a taxa de crescimento da renda disponível bruta real do Brasil para o ano seguinte, entre 2000 e 2013”. A regressão possuiu poder explicativo de 71,6\%. O coeficiente "a” encontrado foi de 6,96, com erro padrão de 0,6. O coeficiente "b” foi de $-0,25$ pontos percentuais com erro padrão de 0,05 . Isso significa que a renda disponível cresceu entre 6,36 e 7,56 por cento ao ano, menos um valor entre 0,20 e 0,30 pontos percentuais por ponto percentual a mais na variação das exportações do ano anterior.

Ou seja, embora a taxa de crescimento da exportação não seja boa explicadora para o crescimento da renda disponível no próprio ano, é bom preditor da taxa de crescimento da renda disponível do ano seguinte. Ainda, verifica-se que quanto maior a taxa de crescimento das exportações do Brasil em um ano, menor foi o a taxa de crescimento da renda disponível do país, entre 2000 e 2013. A explicação para isso pode ser melhor elaborada se o assunto for tratado após a análise da relação entre as importações e a renda disponível do Brasil.

A regressão 7.21 expressa a relação entre a taxa de crescimento da renda disponível brasileira e a taxa de crescimento do valor real importado pelo Brasil no mesmo ano, entre 2000 e 2013. O alto erro padrão do coeficiente "b” e o baixo R-quadrado permite interpretar que a relação entre ambos é de baixa relevância. Ou seja, a taxa de crescimento da renda disponível não é explicada pela taxa de crescimento das importações no mesmo ano.

A regressão 7.25 foi realizada com a taxa de crescimento da renda disponível brasileira como variável dependente, e com a taxa de crescimento do valor real total das importações do ano anterior como variável independente. Foi considerado o período entre 2000 e 2013. A regressão visa responder a pergunta: “qual a relação entre a taxa de crescimento do valor total real das importações de um ano e a taxa de crescimento da renda disponível real do Brasil, entre 2000 e 2013”. O coeficiente "A” obtido foi de 6,49; com erro padrão de 0,67. O coeficiente "B" foi de -0,19; com erro padrão de 0,05. O R-quadrado obtido foi de 0,610. O que significa que, considerando uma taxa de crescimento base da renda disponível real brasileira entre 5,87\% e 7,16\% ao ano, houve redução de algo entre 0,14 e 0,24 pontos percentuais para cada ponto percentual a mais na taxa de crescimento das importações brasileiras no ano anterior. Isso dentro de um grau de certeza de 61\%.

O fato de a taxa de crescimento da exportação e da importação serem bons preditores 
para a taxa de crescimento da renda disponível brasileira do ano seguinte reforça a interpretação que o Brasil teve características de dependência econômica, entre 2000 e 2013. Características essas que fazem parte da organização estrutural do país. As exportações foram importante fonte de renda para o país, e as importações foram utilizados para viabilizar os investimentos e consumo da população local. No entanto, quanto mais a exportação e a importação cresceram, menos a renda disponível brasileira cresceu.

O Brasil, entre 2000 e 2013, continuou a ser um país dependente, com traços de subdesenvolvimento. O setor externo da economia brasileira foi um dos fatores mais importantes para determinar as oscilações econômicas locais. Apesar da importância da formação bruta de capital fixo para viabilizar um crescimento sólido ao longo dos anos, a indústria brasileira no período não logrou prosperar. Disso resultou que o crescimento da renda pode, apenas, ser momentâneo, se estendendo de 2003 a 2011.

Trata-se de mais um indício de que o modelo econômico que vigorou no Brasil, no período, foi um modelo de dependência. Se considerado quatro setores, o Brasil teve seu crescimento econômico determinado pelos investimentos feitos, ao ano. No entanto, o grau do crescimento econômico foi fortemente afetado negativamente pelo crescimento da importação e exportação do ano anterior. Um dos problemas que a dependência econômica coloca para os países é que para crescer, eles dependem do comércio exterior. Como os bens comercializados são bens de baixa complexidade industrial, há pouca agregação de valor internamente. Isso significa que os investimentos induzem pouco crescimento em outros ramos da economia. A expansão dos setores exportadores foi uma das consequências do período de prosperidade. No entanto, essa mesma expansão gerou gargalos para o crescimento econômico futuro. 


\section{CONCLUSÃO}

A hipótese que se pretendeu investigar ao longo dessa pesquisa é que a recuperação econômica o corrida entre 2001 e 2013 foi fruto das oscilações do mercado externo, sendo, portanto, mais um episódio do modelo "pare e siga". Buscou-se evidenciar o caráter dependente e subdesenvolvido do Brasil, entre 1999 e 2013. Na verdade, é provável que seria mais preciso caracterizar a economia brasileira como neocolonial. Isso porque o crescimento não só foi fruto do setor externo da economia brasileira, como foi acompanhado pelo aprofundamento da dependência. Essa situação é um elemento da crença na necessidade de um equilíbrio geral na economia.

A baixa capacidade de acumulação de capital, e a dependência do comércio exterior podem ser descritos através do modelo Vanek-Staley adaptado ${ }^{217}$. Para facilitar a análise do entrecho entre 1999 e 2013, pode-se produzir um esquema do equilíbrio momentâneo, e do deslocamento do mesmo, para cada subperíodo identificado. Isso permite colocar em evidência como se comportou a economia brasileira frente ao setor externo. Pretende-se, assim, sistematizar a tese aqui defendida.

Modelo 8.1 - Equilíbrio Vanek-Staley adaptado

Situação (a): 1999 a 2000

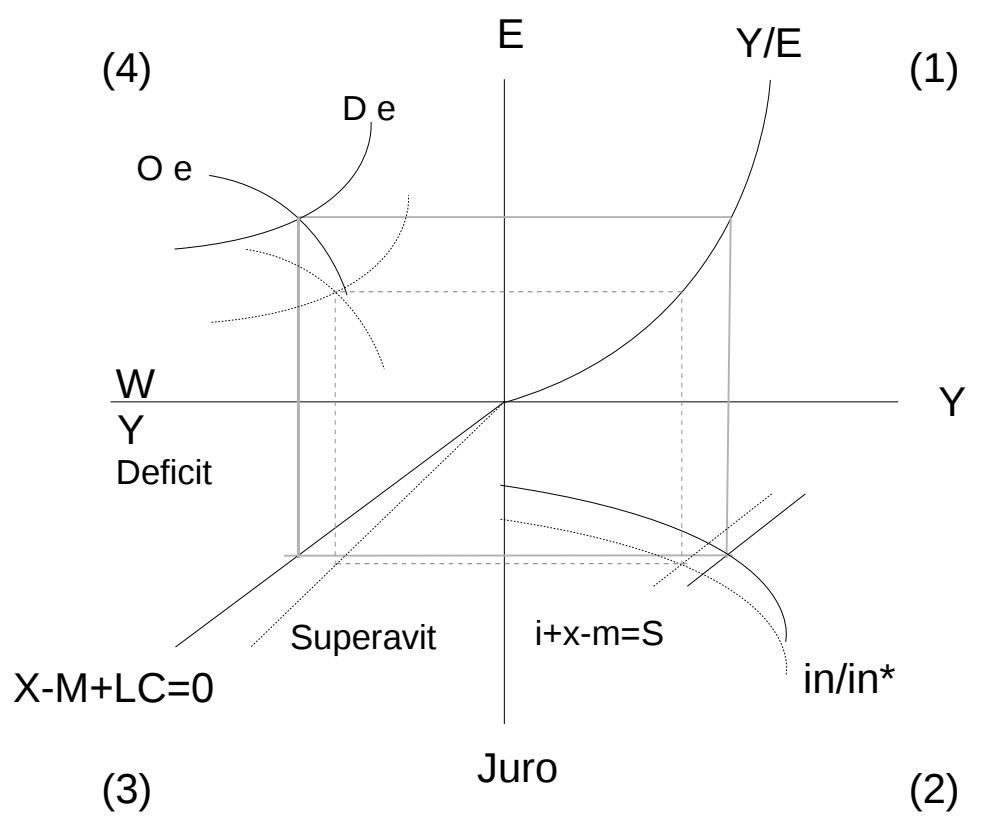

217 Variante do modelo Heckscher-Ohin, sob nome Heckscher-Ohlín-Vanek. Este modelo parte do pressuposto de que o equilíbrio é necessário. Ver, por exemplo, DAVIS, Donald R. \& WEINSTEIN, David E. The Factor Content of Trade, NBER, paper $\mathrm{n}^{\circ} 8637$ (2001). 
O modelo 8.1 traz a situação econômica do Brasil entre 1999 e 2000, comparando com uma situação de equilíbrio hipotética. Em traços sólidos, está a situação de equilíbrio expectada, e em tracejado está a posição que as variáveis se encontravam no período. Verificase que a único setor que manteve-se inalterado foi a produtividade. Isso porque, no modelo, considerou-se a produtividade brasileira estável em baixo nível de produtividade.

Entre 1999 e 2000, o país encontrava-se na zona do déficit do balanço de pagamentos, considerando apenas transações correntes e o capital de longo prazo. Como a exportação estava abaixo do necessário para financiar as importações, havia dependência da poupança externa. Esse era, em parte, resultado do câmbio valorizado em favor do real. O resultado foi que a curva "X-M+LC=0” se deslocou angularmente para direita, aumentando o papel do juro para atrair a poupança externa. Como resultado, houve ampliação da zona de déficit, verificado no terceiro quadrante do modelo. No período, a crise no setor externo também deslocou a linha de equilíbrio entre exportação, importação, investimento, e a poupança interna e externa (linha “ $\mathrm{i}+\mathrm{x}-\mathrm{m}=\mathrm{S}$ ”) para esquerda. Isso foi resultado do baixo volume do setor externo, para o nível de atividade econômica precedente.

Nesse cenário, a pressão inflacionária deslocou a curva da inflação interna pela externa (“in/in*”) para baixo. O resultado foi um novo ponto de equilíbrio com uma renda proporcionalmente menor, em relação ao ponto de equilíbrio expectado. Esse foi o resultado das crises entre 1999 e 2001. Esse processo está descrito no segundo quadrante do modelo.

Dada a produtividade do trabalho no Brasil, a renda mais baixa significava um ponto mais baixo na curva "Y/E", representando aumento do desemprego local, conforme verificável no primeiro quadrante. No quarto quadrante, observa-se que, como resultado do desemprego e do baixo PIB, houve redução no nível salarial local. Essa redução diminuiu o déficit no balanço de pagamentos, mas, em médio prazo, não o fez de forma suficiente.

O desempenho econômico descrito corresponde a um período de crise econômica. Entre 1994 e 1998, a moeda loca estava represada. Foi feita uma opção, até o ano eleitoral de 1998, de manter a paridade entre real e dólar. Isso favorecia (a) a venda de ativos brasileiros, e (b) a importação de bens de consumo. A política de liberalização e privatização (leia-se venda de ativos de empresas públicas brasileiras ao estrangeiro) levou à aceleração do desmonte do parque industrial local.

Sem investimentos em indústria de transformação, a curva de produtividade, ou 
mesmo entre a relação de investimento e o balanço comercial, não podia apresentar expansão. Em 1999, quando o câmbio foi liberado para oscilação, houve forte pressão inflacionária. Nos anos subsequentes, lojas e empresas diversas faliram, como resultado da queda na atividade econômica local.

Na época, dizia-se que o Brasil estava à beira de acabar. A única saída era voltar a adquirir divisas no comércio exterior. Como o mercado interno se tornou demasiadamente pequeno para sustentar a atividade econômica, era necessário buscar mercado estrangeiro. Mas o dólar ainda sobrevalorizado não permitia isso. Era antes necessário que o câmbio continuasse a desvalorizar.

Modelo 8.2 - Equilíbrio Vanek-Staley adaptado

Situação (b): 2001 - 2003

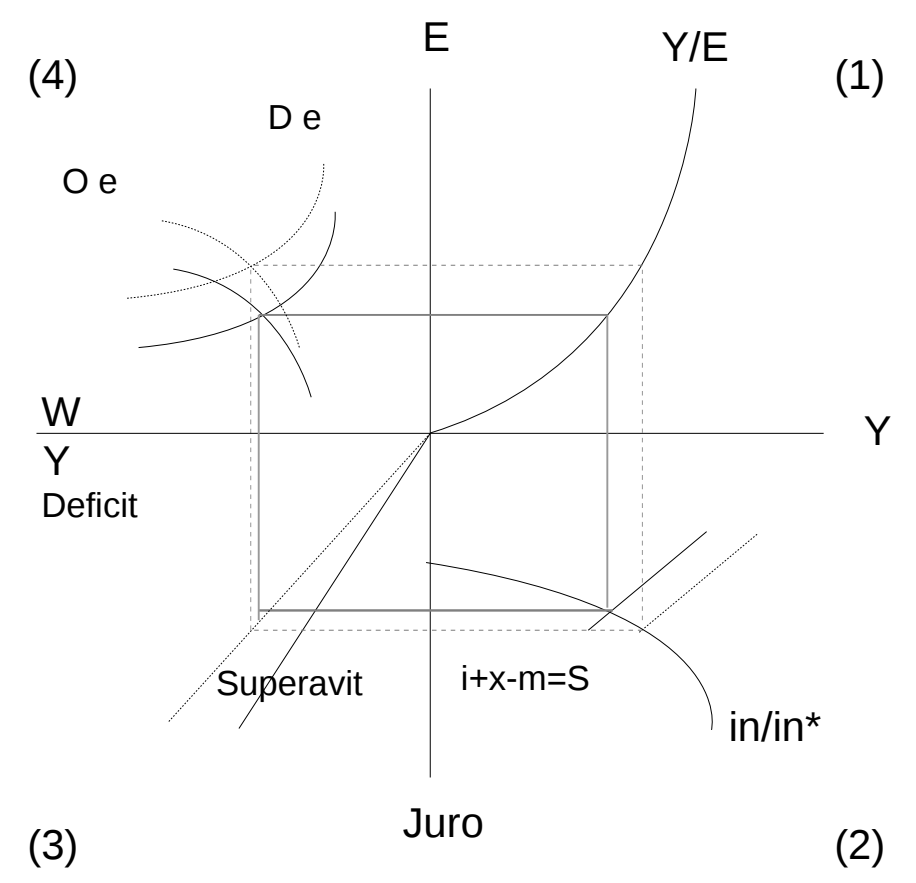

As crises econômicas foram acompanhadas da desvalorização cambial. O impacto dessa foram dois. O primeiro foi a redução das importações e gradual recuperação das exportações, a partir de 2001. Isso fez com que a curva “i+x-m=S” se deslocasse para direita. Houve pressão inflacionária, respondida parcialmente com o aumento dos juros local. Isso está descrito no segundo quadrante do modelo “b”.

Ainda, a nova composição do balanço de pagamentos causou deslocamento da linha “X-M+LC=0” em direção ao eixo da renda, diminuindo a importância imediata do juros na determinação do déficit no balanço de pagamentos. O resultado foi a transição para uma 
situação de balanço de pagamentos “equilibrado” (que na verdade significava, ainda, endividamento e venda de ativos). No período, ocorreu pequena melhoria salarial, e diminuise a pressão pelo desemprego.

Entre 2001 e 2003, foi o período do “exportar ou perecer”. Naquela época, o mercado interno já havia sido praticamente arrasado pelas crises econômicas. Mas, como o câmbio atingiu um patamar favorável às exportações, e como ocorreu, na época, ampliação da demanda chinesa por bens primários, o setor externo voltou a crescer. Ainda, as importações cresceram em ritmo mais lento do que as exportações.

Modelo 8.3 - Equilíbrio Vanek-Staley adaptado Situação (c): 2004 - 2007

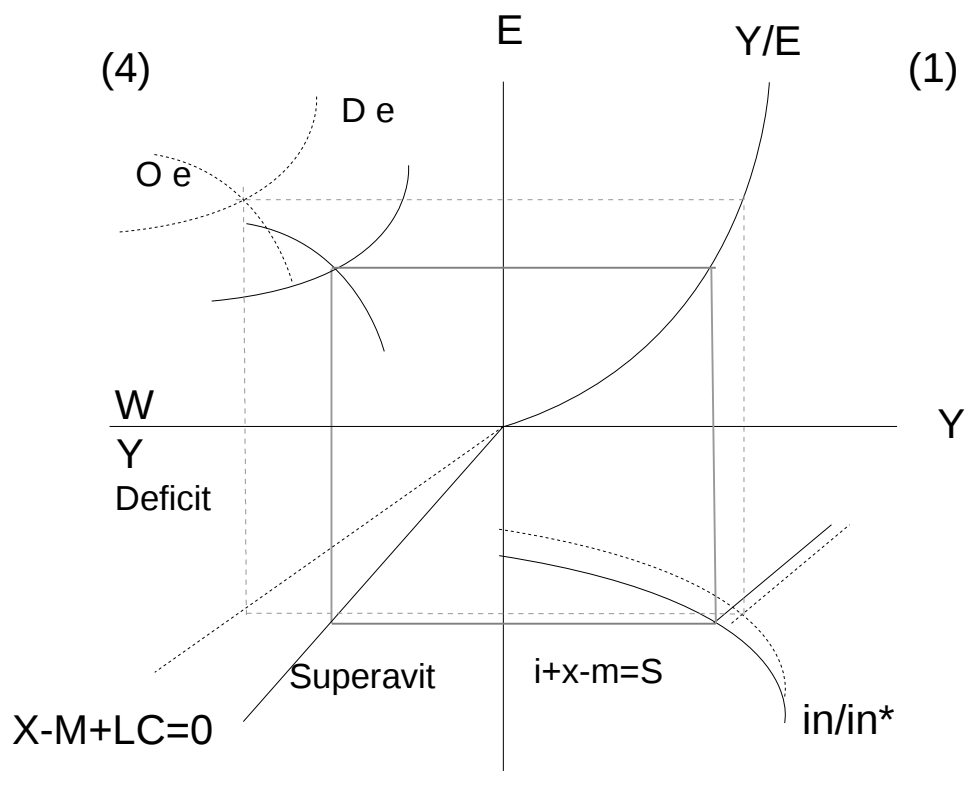

(3)

Juro

Como o mercado interno ainda estava limitado, dado os baixos salários e baixo nível de emprego, a instabilidade econômica ainda era uma realidade. O aumento da demanda, não correspondido por um aumento da produção para consumo, nem com aumento das importações, levou ao fortalecimento da pressão inflacionária. Ainda, em 2002, diante da insatisfação da população, e da possibilidade da vitória de um partido considerado, na época, simpático às camadas de menor renda da população, ocorreu inflação de especulação.

Entre 2004 e 2007, o saldo do balanço comercial permitiu nova inclinação do ponto de equilíbrio do balanço de pagamentos, reduzindo o papel da dívida externa como fonte de financiamento para as importações. Isso está descrito na alteração na curva "X-M+LC=0" 
para esquerda, ampliando a área do superavit, no modelo 8.3.

Ao mesmo tempo, a maior oferta de divisas permitiu o uso do câmbio como forma de controle da inflação, gerando menor inflação interna, sinalizado pelo deslocamento da curva “in/in*” para cima. A curva do balanço comercial (" $i+x-m=S$ ”) deslocou-se para direita, pela ampliação do setor externo. Nessas condições, ocorreu a redução de juros e ampliação da renda do país (conforme proposto no quadrante 2 do modelo “c”).

A renda ampliada foi direcionada para o setor exportador e para os setores de serviço, onde havia baixa produtividade. Ampliou-se bastante a capacidade de geração de emprego. Ao mesmo tempo, como havia novo saldo comercial no setor externo, foi possível a ampliação do salário no país, sem que surgisse déficit no balanço de pagamentos (deslocamento das curvas “De” e “Oe”).

Esse período, entre 2004 e 2007, foi a “era de ouro” da recuperação econômica recente do Brasil. O comércio exterior estava expandindo, os juros caindo, a inflação estava controlada, havia crescimento da renda e do emprego. O Estado acumulava divisas consideráveis em suas mãos. Foi possível realizar pagamento de grande parte da dívida externa, e mesmo voltar a usar o câmbio como ferramenta de controle de inflação.

O “milagre” da recuperação econômica levou a forte debates de qual era a origem do novo impulso de crescimento. O que era mais um episódio da estrutura de "Pare e Siga" foi interpretado como sendo resultado do sucesso das políticas de redistribuição de renda. $\mathrm{Na}$ verdade, no período, o Estado fez pouco (o que já era mais do que o governo anterior) para garantir essa redistribuição. Foi a expansão das exportações que permitiu esse crescimento da renda da população, caracterizado pelo: (a) aumento do salário mínimo (e do salário médio); e (b) aumento do nível de emprego. Não ocorreu investimentos suficientes no setor da industria manufatureira. Ao contrário, ocorreu (i) retomada do crescimento das importações (incluindo a importação de consumo); e (ii) aumento dos investimentos nos setores exportadores, de baixa produtividade.

Note que, no modelo, o aumento da renda levou a alocação de mão de obra para setores de baixa produtividade. Trata-se do crescimento dos setores exportadores, mas também o setor de serviços. A nova renda disponível permitiu que parte da mão de obra se dedicasse a funções secundárias em serviços. Multiplicaram-se as lojas de comércio (em especial as importadoras e exportadoras), os cabeleireiros, os pet-shops, etc. 
Modelo 8.4 - Equilíbrio Vanek-Staley adaptado

Situação (d): 2008 - 2011

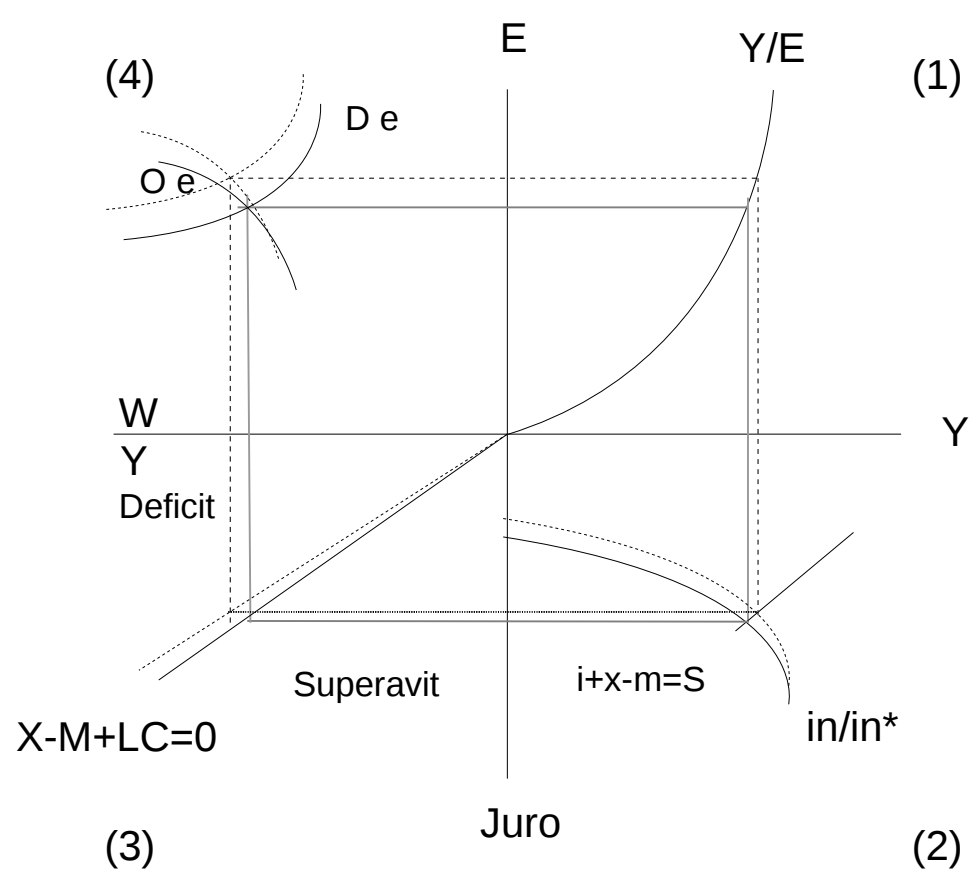

Entre 2008 e 2011, a expansão das exportações diminuiu de velocidade. Apesar dos chamados "superpreços" das commodities, as oscilações resultantes da crise econômica mundial (2008), afetaram a capacidade do Brasil de exportar. Ao mesmo tempo, as importações continuaram a crescer.

Graças ao aumento do investimento estrangeiro direto, a entrada de capital de longo prazo ampliou. O investimento estrangeiro direto é um tipo de capital de longo prazo que é pouco afetado pela taxa de juros, e mais afetado pela taxa de lucro expectada no país. O resultado foi um deslocamento angular da curva " $\mathrm{X}-\mathrm{M}+\mathrm{LC}=0$ ” para esquerda, ampliando a zona de superavit.

Esse movimento permitiu a ampliação de reservas de divisas, e mesmo a continuidade do uso do câmbio como ferramenta de controle da inflação. Isso deslocou a curva "in/in*” para cima. Não houve melhoria da curva “ $\mathrm{i}+\mathrm{x}-\mathrm{m}=\mathrm{S}$ ”, devido a ampliação da importação acima da exportação e da maior dependência de capital externo (transações correntes muito negativas, e conta de capital bastante positiva). Mesmo assim, o novo ponto de equilíbrio entre as transações correntes e a inflação interna relativa expressou ampliação da renda nacional, e diminuição dos juros.

A baixa produtividade dos setores beneficiados pelo novo incremento de renda foi, em 
parte, resultado do baixo aumento de investimento significativo nos setores dinâmicos da economia. Ao contrário, os novos investimentos, incluindo o investimento estrangeiro, se deu, mais uma vez, nos setores exportadores e no setor de serviços, onde havia baixa produtividade. O resultado foi maior ampliação da demanda de força de trabalho, e consequente alta salarial para compensar. Nesse ponto, a recuperação econômica começava a se esgotar, e o aumento do nível do salário não manteve o fôlego do período anterior. Em 2011, os salários começaram a crescer cada vez mais vagarosamente.

A baixa produtividade fazia com que cada novo crescimento demandasse maior emprego de força de trabalho. Ao mesmo tempo, a baixa expectativa de novos aumentos nos preços dos produtos exportados apontavam para queda futura na taxa de lucro. Como o real continuava sobrevalorizado, não havia incentivo para ampliação da produção de bens manufaturados, de maior produtividade. Também significava dificuldade de causar crescimento endógeno. Ainda assim, a política econômica adotada foi a de ampliar o consumo local. Isso fez aumentar a taxa de lucro dos setores de serviço, que atraíram investimentos, mas não alterou a taxa de lucro do setor manufatureiro.

Na época, parte dos especialistas já apontavam que a fonte de crescimento econômico anterior havia sido a alta das demandas chinesas. No entanto, a entrada de investimento estrangeiro passava a impressão, para outros, que a nova etapa de crescimento se daria por conta de uma política anticíclica que o governo aplicava. Na realidade, a alta da demanda, e consequente alta da taxa de lucro nos empreendimentos locais, levou à expansão do setor terciário.

Assim, parte das novas vagas de trabalho foi aberta no comércio e nos serviços urbanos (não exportáveis). Enquanto isso, o Brasil continuava sendo um grande consumidor de serviço estrangeiro, em especial os serviços de tecnologia, e de turismo. Isso pressionava o balanço de pagamentos para baixo, e consumia parte das divisas adquiridas com o investimento estrangeiro. As companhias que investiam no Brasil contratavam serviços de suas filiais, além de enviar remessas de lucros ao seus acionistas. O pagamento de royalties também consumia o rendimento. Os novos postos de trabalho eram em setores de baixa produtividade. Disso resultou que o crescimento econômico não ocorreu em conjunto a uma expansão de investimento na produção. 
Modelo 8.5 - Equilíbrio Vanek-Staley adaptado

Situação (e): 2012 em diante

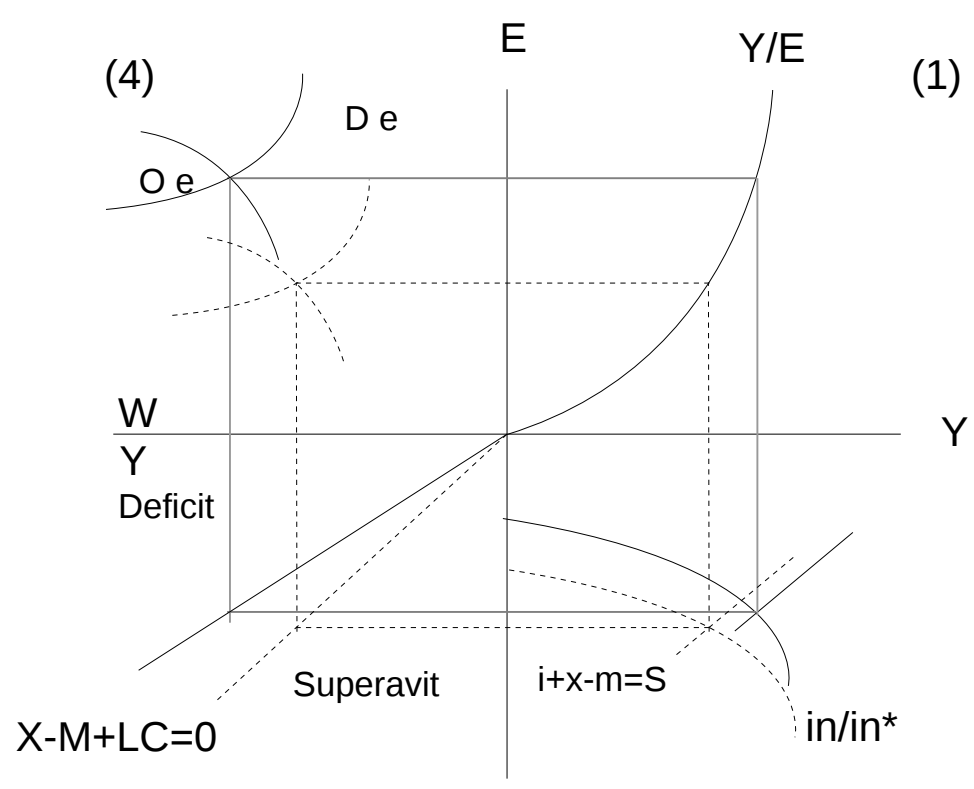

(3)

Juro

A partir de 2012, as importações continuaram a crescer. Mas houve ainda maior dificuldade de ampliar as exportações. Diante do déficit comercial que o Brasil adquiriu, e da dificuldade em ampliar os salários e o nível de emprego, sem que houvesse investimentos em setores de alta produtividade, ocorreu esgotamento da ampliação dos investimentos estrangeiros diretos. Como resultado, a curva " $\mathrm{X}-\mathrm{M}+\mathrm{LC}=0$ ” deslocou-se angularmente para direita, ampliando a zona de déficit. Ainda, a curva “i+x-m=S”, com a ampliação do déficit comercial (x-m), e com a redução da poupança externa, passou a se deslocar para esquerda e para baixo. Como a inflação vinha sendo controlada através do câmbio, o que não era mais uma opção, dado o aumento da zona de déficit do balanço de pagamentos, a linha "in/in*” deslocou-se para baixo.

O novo ponto de equilíbrio do setor externo da economia brasileira significava pressão para juros mais altos (na então política econômica brasileira), e menores crescimentos da renda nacional, ou mesmo crescimento negativo. Dada a baixa produtividade do Brasil, isso significou forte pressão para o desemprego e para o rebaixamento relativo dos salários, o que se expressa no deslocamento das curvas de oferta e demanda de força de trabalho (“Oe” e “De”) para baixo e para direita.

A trajetória da economia brasileira, descrita nos cinco modelos (de “a” a “e”), foi 
resultado da predominância do setor externo sobre o setor interno da economia brasileira. Isso aconteceu por conta do baixo nível de investimento em setores de maior produtividade. Por sua vez, os investimentos era desincentivados por conta da política de controle da inflação através do câmbio, e do câmbio sobrevalorizado. O resultado foi baixa competitividade da indústria de transformação local, que via seus preços aumentarem (devido a inflação) e os preços externos diminuírem (devido ao câmbio). Isso levou estagnação da curva "Y/E”, de produtividade. Ainda, limitou a determinação angular da curva de equilíbrio do balanço de pagamentos, que se expressa pela relação entre o déficit das transações correntes e a oferta de capital de longo prazo.

Em outras palavras, a trajetória resultou da importância do setor exportador e do consumo de luxo no país, e da pequena dimensão do consumo de massa e do setor de investimento (bens de capital). Trata-se de um esquema de dependência, altamente exposto aos movimentos de preço e de oferta de capital no mercado internacional. Isso levou ao comportamento cíclico, decorrente das oscilações nos termos de troca do país, que, por sua vez, caracterizou um crescimento da renda em modelo "Pare e Siga”.

O problema econômico brasileiro já está bem diagnosticado, na literatura. No entanto, a cada nova parada ou arrancada da economia, volta a aparecer diagnósticos débeis que apontam suposto aparecimento de novos problemas, ou superação de problemas anteriores. Aponta-se crise no orçamento, excesso de inflação, baixa demanda, etc., como as causas da crises. Ou encontra-se o "sucesso” da liberalização, ou da distribuição de renda, ou dos incentivos fiscais, como causa do crescimento.

Enquanto isso, os problemas estruturais continuavam inalterados. A propriedade continuava concentrada, a baixa produtividade ainda era crônica, a política cambial e fiscal continuavam a favorecer aqueles que já possuíam renda alta. Entre 1980 e 2013, os governos não fizeram muito para superar os gargalos sociais e econômicos do país. Atuaram sem qualquer plano de desenvolvimento. A perspectiva de que um governo futuro viesse a fazer diferente era baixa.

A baixa acumulação de capital, e a desigualdade de renda debilitaram a capacidade de crescimento autônomo da economia brasileira. Novos ciclos de crescimento só podiam resultar, nessas condições, ou de (a) um novo programa que solucionasse os gargalos; ou (b) de incentivos externos, em momentos de alta da demanda por bens exportáveis brasileiros. 
A economia brasileira continuava, ao final do entrecho de 1999 a 2013, a depender do desempenho nos países desenvolvidos (metrópoles). Essas, por sua vez, não se interessavam, nem necessitavam de qualquer desenvolvimento econômico no Brasil. Não é útil esperar que venha de fora uma solução para os problemas brasileiros. Tão pouco é frutífero apresentar novas soluções para o problema já conhecido. A solução já conhecida passa pela adoção de um outro tipo de governo. O caminho para o desenvolvimento já foi traçado, e resumido por Ragnar Nurkse: o capital se faz em casa.

Em parte, o problema reside na insistência em não aceitar o fato que o Brasil é subdesenvolvido. O governo, a mídia, e a maior parte dos estudiosos, hoje, preferem chamar o Brasil e país em desenvolvimento, país emergente, periférico (ou pior, semi-periférico). Nomenclaturas que escondem a real dimensão do problema: o Brasil possui baixa produtividade, baixa complexidade econômica, e consequente mercado pequeno. Mas, se os problemas estruturais continuam os mesmos, o ciclo econômico analisado (de 1999 a 2013) apresentou especificidades que precisam ser destacadas. A primeira (i) é oriunda de uma certa reorganização da divisão internacional do trabalho: a China se tornou a indústria do mundo. Isso significa que o fluxo de mercadorias se reorganizaram, tendo como centro relevante a China. Embora o capital chinês seja vultoso, parte significativa dessa indústria é resultante da aliança de facto entre China e o capital ocidental. Para o Brasil, essa reorganização significou o deslocamento da principal parceria comercial com os EUA para a China. No entanto, o Brasil continua dependente do capital estrangeiro oriundo, principalmente, da Europa e dos EUA.

A segunda (ii) especificidade do ciclo foi oriunda das políticas econômicas adotadas no período precedente, e continuadas no período em análise. Até a década de (19)80, cada ciclo de Pare e Siga (ocasionado pelos ciclos dos preços internacionais e pelas restrições externas) levou o Brasil a situação levemente superior em relação ao ciclo anterior. Isso ocorria pois, em cada ciclo, havia ali curtos impulsos industrializantes (em especial nos períodos de baixa). Dessa forma, a economia local atingia maior complexidade relativa (ao período anterior), e o mercado local crescia. Embora não haja se superado o subdesenvolvimento, parte da literatura acreditava que a cada novo ciclo abria-se oportunidades para superação futura. Desde a década de (19)90, isso mudou. A partir de então, cada novo ciclo tem deixado o Brasil em situação pior. A complexidade da economia 
local diminuiu, e o mercado minguou. Por isso, se verificada a capacidade de abastecimento da indústria de transformação brasileira, vemos que em 1993, ela havia subido para 72,6 ${ }^{218}$, após um período de queda. A nova “alta” atingiu ponto inferior ao período da alta anterior. Em 1998, período de baixa, atingiu o valor de 43,2. Em 2012, enquanto a nova baixa estava apenas sendo sinalizada, atingiu o valor de 47,42. A indústria de transformação sofreu forte contração no período seguinte.

Essa perda de complexidade econômica a cada novo ciclo é fruto da adoção das teses neoliberais, em especial (a) do uso do câmbio para controlar a inflação. Efetivamente, as teses adotadas a partir de (19)90 levaram a políticas econômicas que abriam mão da hipótese de industrialização local. Acreditou-se no conto da sociedade pós-industrial. O Brasil deveria se especializar em suas aptidões naturais (produtos agropecuários), e investir no setor de serviços. Deveria abandonar todo sistema de proteção à indústria local, e deixar que a competição moldasse as novas empresas. A inflação deveria ser controlada a todo custo (inclusive ao custo do crescimento do PIB), e o câmbio deveria ser mantido estável para atrair investidores. O capital estrangeiro iria adentrar no país e o desenvolver. Evidentemente, nada disso fez bem à economia brasileira. Ao invés de haver ganho de produtividade, houve fragilização da economia local. Ainda, (b) as firmas multinacionais que se instalaram no Brasil continuaram a aprimorar suas gestões. Inventaram novas formas (e fortaleceram velhas formas) de extrair o máximo de lucro de suas filiais. Afinal, nenhuma multinacional se instala em um país para ter prejuízo no médio prazo. O Brasil, ao abrir mão da autonomia de suas indústrias, passou a ter que pagar mais direitos de propriedade intelectual, e mesmo o leasing de equipamentos. As novas formas de drenagem de recursos permitiram a ampliação do déficit das contas correntes do balanço de pagamento. Somado a isso, o crescimento da renda de certas camadas, e o dólar sobreapreciado, criava a impressão de riqueza em determinadas camadas, que não tardaram em ir gastar no exterior os poucos recursos nacionais no país.

O crescimento econômico por si só não foi capaz de gerar desenvolvimento. Em parte, isso se explica pelo fato da taxa de crescimento média do PIB não superar em muito a taxa de crescimento média da população residente. Sem aumento da produtividade local, os $50 \%$ da população que detém menor rendimento apenas ingressaram como consumidores na economia de forma episódica, durante o período de alta da economia. Enquanto isso, as camadas de maior rendimento (os $10 \%$ do topo) realizavam gastos de consumo como se fizessem parte da 218 Ver tabela 6.2. 
elite das metrópoles. O consumo agregado da economia local foi praticamente determinado pelas camadas médias, aquelas que possuem renda entre os $10 \%$ do topo e os $50 \%$ da base.

O ciclo reforçou o caráter neocolonial do Brasil. Isto significa dizer que o país se tornou mais dependente da poupança externa. Ainda, a pauta de exportação, concentrada em produtos primários, aumentou a exposição da economia brasileira aos efeitos da deterioração dos termos de troca (em médio e longo prazo). A política econômica adotada, voltada ao exterior, também fortaleceu o efeito demonstração. As medidas tomadas pelo governo local visaram (a) atrair investimentos estrangeiros; (b) saciar a demanda interna com importações; (c) facilitar a exportação (de bens primários ou de baixo valor agregado) para o exterior. Tudo isso enquanto se maximizava as taxas de lucro do empresariado, privilegiando aqueles ligados ao setor externo, ou a construção civil. A administração do país pareceu mais adequada a um cais do porto do que a de uma nação. É disso que se trata quando se fala de neocolonialismo.

O subdesenvolvimento e o neocolonialismo são estruturas econômicas, mas também estão na mentalidade do subdesenvolvido. Tanto as elites locais como as camadas de menor rendimento não foram portadoras de um projeto nacional, no Brasil, entre 1999 e 2013. Ao contrário, mesmo um governo que se declarava representante do povo (e que foi eleito com apoio popular) aplicou uma política econômica voltada para fora. O subdesenvolvimento, portanto, foi fruto do passado colonial, mas também do presente neocolonial que se reproduz na ausência de projetos de desenvolvimento competentes.

Se a reprodução do subdesenvolvimento é um imperativo econômico, dada a estrutura social dos países neocoloniais, o estilo de vida da população local também facilitou aquela reprodução. O consumo de ostentação e a mimetização dos padrões culturais (e portanto de consumo) das elites das metrópoles são parte do problema. A forma de gerir a economia e a política local também incentivam a reprodução do subdesenvolvimento. Ao se deixar todas as decisões importantes delegadas ao setor privado, aceitou-se que a taxa de lucro determinaria os rumos da economia local. O rumo tomado foi nenhum. Os investimentos se concentraram nos setores menos produtivos, e no setor exportador. Enquanto isso, a saúde, a segurança, e os investimentos produtivos, não receberam a devida atenção.

O fato de haver se abandonado os termos "subdesenvolvimento" e "neocolonialismo" para explicar a economia brasileira também é significativo. A escolha de utilizar termos mais obscuros, e menos diretos, ou mesmo sem significado algum (termos como semi-periferia, 
emergente, sul global, etc.) demonstra a opção por não se enxergar o problema. Essa negação é fruto ou de interesses na manutenção do subdesenvolvimento, que favorece as parcelas de maior rendimento da população; ou da escolha pelo conforto. Ver o problema como ele é seria ter que enfrentá-lo. Admitir que o crescimento econômico, no Brasil, é mero fruto de oscilações dos mercados externos, e que a cada novo ciclo o país se encontrará em situação pior, é entender que, se nada for feito, o subdesenvolvimento se aprofundará. O neocolonialismo se fortalecerá. É entender que se deixado livre, o comércio exterior atuará contra o desenvolvimento local. O investimento estrangeiro irá fortalecer o domínio dos oligopólios sobre a atividade econômica local. As drenagens de recursos comprometerão, cada vez mais, aquilo que for ganho com a venda de produtos primários, ou de ativos locais. Uma economia deixada a deriva nunca chegará a qualquer lugar, e se tornará mais frágil a cada obstáculo com o qual trombar. Recorde-se da alegoria de Marx sobre o navio da Prússia. 


\section{BIBLIOGRAFIA}

ABREU, Marcelo de Paiva. Comércio exterior: interesses do Brasil. Rio de Janeiro: Elsevier, 2007.

ACKLEY, Gardner. Teoria Macroeconômica. Vol 1 e 2. São Paulo: Livraria Pioneira Editora,1969.

ALDRIGHI, Dante Mendes ; CARDOSO, André Daud . Crises cambiais e financeiras: uma comparação entre América Latina e Leste Asiático. Economia e Sociedade (UNICAMP. Impresso), v. 18, p. 61-117, 2009.

ALVES PINTO, Marcio Percival \& BIASOTO JR, Geraldo. (org) Politica Fiscal e Desenvolvimento no Brasil. Campinas: Editora Unicamp, 2006.

AMADO, Adriana Moreira \& CARUSO, Paulo Rodrigo de Santana. Liberalização, vulnerabilidade financeira e estabilidade, algumas considerações sobre a economia brasileira. Campinas: Economia e Sociedade, v 20 n3. 2011.

AMANN, Edmund \& BAER, Werner. "The Macroeconomic Record of the Lula Administration, the Roots of Brazil's Inequality, and Attempts to Overcome Them”. In: LOVE, Joseph \& BAER, Werner (orgs). Brazil under Lula Economy, Politics, and Society under the Worker-President. Nova Iorque: Palgrave Macmillan, 2009.

AMIN, Samir. Capitalismo periferico y comercio internacional. Buenos Aires, Ed. Periferia, 1974.

AMIN, Samir. The Reawakening of the Arab World. Challenge and Change in the Aftermath of the Arab Spring. Nova Iorque: Monthly Review Press, 2016.

AMIN, Samir. Imperialism and Unequal Development. Londres, Nova Iorque: Monthly Review Press, 1977.

AMONICA, M. T. ; OREIRO, J. L. C. ; FEIJO, C. A. . Acumulação de Capital, Restrição Externa, Hiato Tecnológico e Mudança Estrutural: teoria e experiência Brasileira. Estudos Econômicos (USP. Impresso), v. 42, p. 45-65, 2012.

ANDRADE, Rogério ; PRATES, D. M. . Exchange Rate Dynamics in a Peripheral Monetary 
Economy. Journal of Post Keynesian Economics, v. 35, p. 399-416, 2013.

ANTUNES, Ricardo. A desertificação neoliberal no Brasil (Collor, FHC e Lula). Campinas: Autores Associados, 2004.

ASIEDU , Elizabeth \& ESFAHANI, Hadi Salehi. “Ownership Structure in Foreign Direct Investment” in The Review of Economics and Statistics, Vol. 83, No. 4. 2001.

AZEVEDO, Fernando Simões. Aspectos teóricos sobre o comércio internacional e dois estudos empíricos para a balança comercial brasileira de bens e serviços não-fatores (SBCA). Belo Horizonte: Faculdade de Ciências Econômicas - UFMG, 2007.

BALDWIN, Robert. Desarrollo económico. Un análisis introductorio. Buenos Aires: Amorrortu editores,1970.

BARBOSA, Wilson do Nascimento. A Acumulação de Capital no Brasil. São Paulo: 2003.

BARBOSA, Wilson do Nascimento. A Corrente Estruturalista-Keynesiana de História Econômica. Revista de Economia Política e História Econômica (REPHE). ISSN: 1807 2674. No 16, Janeiro de 2009. Pg 75-99

BARBOSA, Wilson do Nascimento. Balanço da Economia Brasileira, 1940-1980. São Paulo: LCTE Editora, 2006.

BARBOSA, Wilson do Nascimento. Crescimento no Brasil e Flutuações no Comércio Exterior: 1947-1975. Lund: Universidade de Lund, 1976.

BARBOSA, Wilson do Nascimento. Políticas Econômicas do Governo e Estagnação: Duas Décadas Perdidas (1981-2000). DH - FFLCH - USP, 2004.

BARBOSA, Wilson do Nascimento. "O lugar da História Econômica entre as Ciências Sociais”. In Revista de Economia Política e História Econômica (REPHE). ISSN: 1807 2674. No 18, Agosto de 2009. Pg.125-172

BARBOSA, Wilson do Nascimento. Rendimentos Crescentes e Financiamento - Expectativas da Política Governamental Brasileira: 1947-1975. Lund: 1976.

BIANCARELI, A. M. . Perspectivas da economia brasileira: notas sobre o setor externo. Revista de Economia da PUCSP, v. 2, p. 91-118, 2011.

BELLUZZO, Luiz Gonzaga de Mello; TAVARES, Maria da Conceição. Desenvolvimento no 
Brasil: relembrando um velho tema. En: Políticas para a retomada do crescimento: reflexões de economistas brasileiros-Brasília: IPEA/CEPAL, 2002-p. 149-184, 2002.

BELLUZZO, L. G. M. ; CARNEIRO, R. M. . Globalização e integração perversa. Política Econômica em Foco, v. 1, p. 1-11, 2003.

BELLUZZO, L. G. M. . Os antecedentes da tormenta: origens da crise global. 1. ed. São Paulo; Campinas: Unesp; Edições Facamp, 2009.

BELluzZO, L. G. M. . O mito da conversibilidade. Revista de Economia Política (Impresso), v. 24, p. 218-222, 2004.

BELLUZZO, L. G. M. . Política Industrial: Os anos do povo. In: Emir Sader. (Org.). 10 anos de governos pós-neoliberais no Brasil. São Paulo: Boitempo, 2013, v. , p. 22-37.

BETTELHEIM, Charles. Planificação e Crescimento acelerado. Rio de Janeiro: Zahar Editores, 1976.

BHALLA, A. S. Uneven Development in the Third World. Londres: Macmillan Press LTD, 1995.

BIASOTO JR., Geraldo. “A Polêmica sobre o Déficit Público e a Sustentabilidade da Política Fiscal”. In: ALVES PINTO, Marcio Percival \& BIASOTO JR, Geraldo. (orgs) Politica Fiscal e Desenvolvimento no Brasil. Campinas: Editora Unicamp, 2006.

BORATAV, Korkut. “Net Resource Transfers And Dependency: Some Recent Changes In The World Economy” in: KÖSE, A. H. \& SENSES, F. et al. Neoliberal Globalization as New Imperialism. Nova Iorque: Nova Science Publishers, Inc., 2007

BRANDÃO, Antônio Salazar P. ; ALVES, Eliseu . Commodities agrícolas e preço do petróleo. Revista de Politica Agricola, v. XXII, p. 43-54, 2013.

BRESSER-PEREIRA, Luiz Carlos. A quase-estagnação brasileira e sua explicação novodesenvolvimentista. Escola de Economia de São Paulo, Getulio Vargas Foundation (Brazil), 2014.

BRESSER PEREIRA, Luiz Carlos. Desenvolvimento e crise no Brasil. São Paulo: Editora brasiliense, 1973.

BRESSER-PEREIRA, Luiz Carlos. Reflexões sobre o Novo Desenvolvimentismo $e \quad o$ Desenvolvimentismo Clássico. Revista de Economia Política, v. 36, n. 2, p. 143, 2016. 
BROWN, Michael B. The Economics of Imperialism. Harmondsworth: Penguin Books, 1974.

BUCKLEY, P. J.; GUARI, P. N. International investment and international trade in the product cycle. The Internationalization of the firm: a reader, p. 14-26, 1999;

CABRAL, Guilherme. Comércio exterior, análise e dados. Brasília: Centro Gráfico do Senado Federal, 1982.

CARKOVIC, Maria \& LEVINE, Ross. "Does Foreign Direct Investment Accelerate Economic Growth?” In: MORAN, Theodore H. \& GRAHAM, Edward M. \& BLOMSTRÖM, Magnus (Ed). Does Foreign Direct Investment Promote Development? Washington: Institute for International Economics, 2005.

CASAGRANDE, Elton Eustaquio \& GARCIA, Renato Vaz. Fiscal policy contradiction: $a$ perspective on Brazil and Mexico. Investigación Económica, Vol. 70, No. 277 (julioseptiembre de 2011), pg. 127-152

CASANOVA, Lourdes; KASSUM, Julian. The political economy of an emerging global power: in search of the Brazil dream. Nova Iorque: Palgrave Macmillan, 2014.

CASTRO, Marcus Faro de \& CARVALHO, Maria Izabel Valladão de . "Globalization and Recent Political Transitions in Brazil” in International Political Science Review, Vol.24, No. 4. 2003.

CHENA, Pablo Ignacio. Crecimiento restringido por la balanza de pagos en países exportadores de alimentos. Problemas del Desarrollo, Vol. 39, No. 155 (octubre-diciembre 2008), pg. 29-51

CHESNAIS, François. A Mundialização do Capital. São Paulo: Editora Xamã, 1996.

CHESNAIS, François. Finance Capital Today: Corporations and Banks in the Lasting Global Slump. Boston: Brill, 2016.

CINQUETTI, C. A. . Empresas multinacionais e desempenho comercial no Brasil: uma revisão da literatura. Economia e Sociedade (UNICAMP), v. 17, p. 525-538, 2008.

COES, Donald. "Exchange Rate Policy, Perceptions of Risk, and External Constraints under Lula”. In: LOVE, Joseph \& BAER, Werner (orgs). Brazil under Lula Economy, Politics, and Society under the Worker-President. Nova Iorque: Palgrave Macmillan, 2009.

COSTA, Fernando Nogueira da . Brasil dos Bancos. São Paulo: Edusp, 212. 
COUTINHO, Luciano. A terceira revolução industrial e tecnológica: as grandes tendências de mudança. Economia e sociedade, v. 1, n. 8, p. 69-87, 1992.

COUTINHO, Luciano. A fragilidade do Brasil em face da globalização. O Brasil e a economia global. Rio de Janeiro: Campus, p. 219-237, 1996.

COUTINHO, Luciano. Volta a Crescer. Política Democrática (Brasília), São Paulo, v. 1, p. 1$1,2003$.

CUNHA, André Moreira. A China e o Brasil na Nova Ordem Internacional. Curitiba: Revista de Sociologia Política, v 19, n suplementar, 2011.

DAVIS, Donald R. \& WEINSTEIN, David E. The Factor Content of Trade, NBER, paper ${ }^{\circ}$ 8637 (2001).

DE LA BARRA, Ximena."The dual debt of Neoliberalism.", in: BUENO, Richard \& LARA, José (orgs). Imperialism, Neoliberalism and Social Struggles in Latin America. Bostom: Brill, 2007.

DILLARD, Dudley. La Teoria Economica de John Maynard Keynes. Teoria de una Economia Monetaria. Madrid: Aguilar, 1971

DOBB, Maurice. Political Economy and Capitalism. Londres: Routledge, 1937.

DOBB, Maurice. Theories Of Value And Distribution Since Adam Smith. Cambridge: Cambridge University Press, 1973.

DEARDORFF, Alan V. Terms Of Trade Glossary Of International Economics. Singapura: World Scientific, 2006.

EMMANUEL, Arghiri. El Intercambio desigual. Ensayo sobre los antagonismos em las relaciones económicas internacionales. Madrid: Ed Siglo ventiuno, 1973.

EMMANUEL, Arghiri. Unequal Exchange. A Study of the Imperialism of Trade. Nova Iorque e Londres: Monthly Review Press, 1972.

EVANGELISTA, Priscila Honório. O impacto da liberalização do comércio de serviços na economia brasileira. Brasília: DE-UnB, 2008.

FARHI, Maryse ; FREITAS, Maria Cristina Penido de ; PRATES, Daniela Magalhães ; CINTRA, Marcos Antonio Macedo . A crise e os desafios para a nova arquitetura financeira internacional. Revista de Economia Política, v. 29, p. 1-2, 2009. 
FERREIRA, Adriana Nunes . O consumo das famílias e a retomada do crescimento. Política Econômica em Foco, v. 3, p. 65-72, 2004.

FILGUEIRAS, Luiz \& GONÇALVES, Reinaldo. A Economia Política do Governo Lula. Rio de Janeiro: Contraponto, 2007.

FLYNN, Matthew. "Between Subimperialism and Globalization: A Case Study in the Internationalization of Brazilian Capital” in Latin American Perspectives, vol 34, $N^{\circ} 6$. 2007.

FRIEDMAN, Milton \& ROOSA, Robert. Balança de Pagamentos: taxas de câmbio livres versus taxas de câmbio fixas. Rio de Janeiro: Victor Publicações, N/A.

FRITZ, Barbara. Tentativas de estabilização e crescimento por via da dívida externa: a economia brasileira de quatro décadas. Iberoamericana (2001-), Nueva época, Año 4, No. 14 (Junio de 2004), pg. 127-142

FRÖBEL, Folker; HEINRICHS, Jürgen; KREYE, Otto. The New International Division of Labour. Cambridge University Press, Cambridge: 2009

FURTADO, Celso. Cultura e desenvolvimento em época de crise. Paz e Terra, 1984.

FURTADO, Celso. El Desequilibrio Externo En Las Economías Subdesarrolladas. El Trimestre Económico, Vol. 25, No. 98(2) (Abril—Junio de 1958), pg. 232-239

FURTADO, Celso. Introdução ao desenvolvimento: enfoque histórico-estrutural. Paz e Terra, 2000.

FURTADO, Celso; IGLÉSIAS, Francisco. Formação econômica do Brasil. 1959.

GADELHA, Sérgio Ricardo de Brito. Política fiscal anticíclica, crise financeira internacional e crescimento econômico no brasil. Revista de Economia Política, vol 31, $\mathrm{n}^{\circ}$ 5 (125), pp 794-812, Edição especial/2011

GÉLÉDAN, Alain \& BRÉMOND, Janine. Dicionário Económico e Social. Lisboa: Livros Horizonte LTDA, 1988.

GÉLÉDAN, Alain \& BRÉMOND, Janine. Dicionário das Teorias e Mecanismos Económicos. Lisboa: Livros Horizonte LTDA, 1988.

GLASS, Amy Jocelyn \& SAGGI, Kamal. Multinational Firms and Technology Transfer. The 
Scandinavian Journal of Economics, Vol. 104, No. 4 (Dec., 2002), pg. 495-513

GÖRG, Holger \& STROBL, Eric. "Foreign Direct Investment and Local Economic Development: Beyond Productivity Spillovers” In: MORAN, Theodore H. \& GRAHAM, Edward M. \& BLOMSTRÖM, Magnus (Ed). Does Foreign Direct Investment Promote Development? Washington: Institute for International Economics, 2005.

GRATH, Anders. International Trade and Finance. Londres e Filadélfia: Kogan Page, 2008.

GUIMARAES, E. P. . "Política de Comércio Exterior Brasileira no Contexto da Abertura Comercial”. In: Marco A.S. Vasconcellos, M. Lima \& Simão Silber. (Org.). Gestão de Negócios Internacionais. 1ed.São Paulo: Saraiva, 2006, v. , p. 131-164.

GUSTAFSSON, Peter \& SEGERSTROM, Paul S. North-South Trade With Multinational Firms And Increasing Product Variety. International Economic Review, Vol. 52, No. 4 (November 2011), pg. 1123-1155

HARVEY, David. The New Imperialism. Oxford: Oxford University Press, 2003.

HELLER, Claudia . Oligopólio e Progresso Técnico no Pensamento de Joan Robinson. SAO PAULO: HUCITEC/FAPESP, 2000.

HELLER, H. Robert. Comércio Internacional, teoria e evidência empírica. São Paulo: Atlas, 1978.

HILFERDING, Rudolf. O Capital Financeiro. São Paulo: Nova Cultura, 1985.

HORIE, Leandro. Politica Econômica, Dinâmica setorial e a Questão Ocupacional no Brasil. Campinas: Unicamp, 2012.

IVANOVIĆ, Igor. Impact Of Foreign Direct Investment (FDI) On Domestic Investment In Republic Of Croatia. Review Of Innovation And Competitiveness, vol 1, issue 1, 2015. (USEI)

JAGUARIBE, Helio. Brasil, Mundo e Homem na Atualidade. Brasília: Fundação Alexandre de Gusmão, 2008.

KEYNES, John Maynard. The General Theory Of Employment, Interest And Money. Nova Iorque: Cambridge University Press, 2013 (primeira publicação : 1936)

KINDLEBERGER, Charles P. Economia Internacional. São Paulo: Editora Mestre Jou, 1974. 
KÖSE, A. H. \& ÖNCÜ, Ahmet. "Imbalances In The World Economy And Congestion In The Periphery”. in: KÖSE, A. H. \& SENSES, F. et al. Neoliberal Globalization as New Imperialism. Nova Iorque: Nova Science Publishers, Inc., 2007

KRAEMER, Armando. Taxa de câmbio e balanço de pagamentos. Porto Alegre: Sulina, 1973.

KUME, H. ; PIANI, Guida ; MIRANDA, Pedro . Tarifas de importação e evasão fiscal no Brasil. Economia Aplicada, v. 15, p. 65-82, 2011.

KUPFER, David. A indústria brasileira após 10 anos de liberalização econômica. Rio de Janeiro: Seminário Brasil em Desenvolvimento, IE/UFRJ, 2003.

LIPSEY , Robert E, \& SJÖHOLM, Fredrik. “The Impact of Inward FDI on Host Countries: Why Such Different Answers?”. In: MORAN, Theodore H. \& GRAHAM, Edward M. \& BLOMSTRÖM, Magnus (Ed). Does Foreign Direct Investment Promote Development? Washington: Institute for International Economics, 2005.

MACHADO, João Bosco Mesquita \& FERRAZ, Geleno Tinoco. Comércio Externo da China: efeitos sobre as exportações brasileiras. Brasília: IPEA, maio de 2006.

MAGDOFF, Harry. Imperialism: from the colonial age to the present. Nova Iorque e Londres: Monthly Review Press, 1978.

MAGDOFF, Harry. The Age of Imperialism. The Economics of U.S. Foreign Policy. Nova Iorque e Londres: Monthly Review Press, 1969.

MARTONE, C. L. . Os Ciclos no Brasil e Na Economia Mundial. Boletim FIPE, São Paulo, p. 11-12, 2001.

MENDONÇA, Ana Rosa Ribeiro de ; DEOS, Simone . Crises in the financial regulation of finance-led capitalism: a Minskyan analysis. Revue de la régulation, v. 6, p. 6, 2009.

MIGLIOLI, Jorge (org). Kalecki. São Paulo: Ática S.A. 1980.

MIKESELL, Raymond F. Financing World Trade. Nova York: Thomas Y Crowell company, 1969.

MIKESELL, Raymond F. Mecanismo de Ayuda Económica externa. México: Centro de Estudios Monetários Latinoamericanos, 1964.

MILANI, Ana Maria Rita. The Reduction of Inequality in Latin America during 2000-2010: 
A Path to Development?. World Review of Political Economy, Vol. 4, No. 4 (Winter 2013), pg. 437-454.

MORAN, Cristian. Imports under a Foreign Exchange Constraint. he World Bank Economic Review, Vol. 3, No. 2 (May, 1989), pg. 279-295

NETO, Martins; SOARES, Antonio. Income distribution and external constraint: Brazil in the commodities boom. Nova Economia, v. 27, n. 1, p. 7-35, 2017.

NONNENBERG, Marcelo José. China: Estabilidade e crescimento econômico. Revista de Economia Política, vol. 30, no 2 (118), pg. 201-218, abril-junho/2010

NOYOLA, Juan F. La Economía Cubana en los Primeiros Años de la revolución y otros ensayos. Mexico: Siglo Veitiuno. 1978.

NURKSE, Ragnar. Problema da Formação de Capital em Países Subdesenvolvidos. Rio de Janeiro: Civilização Brasileira, 1957.

OLIVEIRA, Fabricio Augusto de. “A Lógica das Reformas: A Evolução do Sistema Tributário (1966-2002)”. In: ALVES PINTO, Marcio Percival \& BIASOTO JR, Geraldo. (orgs) Politica Fiscal e Desenvolvimento no Brasil. Campinas: Editora Unicamp, 2006.

OLIVEIRA, Henrique Altermani de. Brasil-China: trinta anos de uma parceria estratégica. Revista Brasileira de Política Internacional. Vol 47. no.1 Brasília. Jan/Junho 2004.

OLIVEIRA, Henrique Altemani de. Brasil e China: Uma nova aliança não escrita?. Rev. Bras. Polít. Int. 53 (2): 88-106 [2010]

OCAMPO, José Antônio. “Developing Countries’ Anti-Cyclical Policies In A Globalized World”. In: XIII Seminario Regional De Politica Fiscal - Compendio De Documentos, CEPAL, 2001.

OCAMPO, José Antonio; VOS, Rob (Ed.). Uneven economic development. Nova Iorque: United Nations Publications, 2008.

OREIRO, José Luís \& PAULA, Luís Fernando de \& SOBREIRA, Rogério. Política Monetária, bancos centrais e metas de inflação. São Paulo: FGV, 2009.

OREIRO, J. L. C. ; PUNZO, L. ; Araújo, Eliane . Macroeconomic Constraints to Growth of Brazilian Economy: diagnosis and some policy proposals. Cambridge Journal of Economics, v. 36, p. 919-939, 2012. 
ORDÓÑEZ, Sergio. Capitalismo del conocimiento: ¿México en la integración?. Problemas del Desarrollo, Vol. 37, No. 146 (julio-septiembre 2006), pg. 51-77

PACHECO-LÓPEZ, Penélope. \& THIRLWALL, A. P. Trade Liberalization, the Income Elasticity of Demand for Imports, and Growth in Latin America. Journal of Post Keynesian Economics, Vol. 29, No. 1 (Autumn, 2006), pg. 41-66

PALAZZO, José Truda. Balanço de Pagamentos: fatores de pertubação do seu equilíbrio e procedimentos para superá-los. Porto Alegre: Tese para concurso de cátedra de "Comércio internacional e câmbios” da Faculdade de Ciências Econômica da Universidade do Rio Grande do Sul, 1954.

PALLOIX, Christian. As firmas multinacionais e o processo de internacionalização. Lisboa: Editorial estampa, 1974.

PATNAIK, Prabhat \& RAWAL, Vikas. "The Level Of A Ctivity In An Economywith Free Capital Mobility”. in: KÖSE, A. H. \& SENSES, F. et al. Neoliberal Globalization as New Imperialism. Nova Iorque: Nova Science Publishers, Inc., 2007

PAUlinO, Luís Antônio. “A Economia Política do Governo Lula da Silva”. Revista de Economia Política e História Econômica (REPHE). ISSN: 1807 - 2674. № 15, Dezembro de 2008. Pg. 17-50

PEREIRA, L. V. . O efeito China nas exportações brasileiras na América do Sul. Conjuntura Econômica (Rio de Janeiro), v. 66, p. 44-46, 2012.

PEREIRA, L. V. . Os principais parceiros do Brasil e a agenda de acordos. Conjuntura Econômica (Rio de Janeiro), v. 65, p. 58-59, 2011.

PEREIRA, Luiz (org). Subdesenvolvimento e desenvolvimento. Rio de Janeiro: Editora Zahar, 1973.

PERROUX, François. Économie et société. Contrainte - Échange - Don. Paris: Presses universitaires de France, 1960.

PIKETTY, Thomas. Capital in the twenty-first century. Harvard University Press, 2017.

PIRES, Marcos Cordeiro. As Relações Comerciais da República Popular da China e a América do Sul: Uma reflexão sobre a especialização produtiva. Julho de 2006.

PIRES, Marcos Cordeiro \& SANTILLÁN, Gostavo Enrique. Reflexões sobre a relação China 
e América Latina. Anuário de Integración, ano 2014.

PIRES, Marcos Cordeiro. "Reflexões Sobre Acumulação de Capitais, Desenvolvimento e Subdesenvolvimento”. In: SOUZA, Luiz Eduardo Simões de (org.). Ideologia e Ciência Econômica: Mais estudos de caso. São Paulo, LCTE, 2017.

PRATES, D. M. . A alta recente dos preços das commodities. Revista de Economia Política, v. 27, p. 323-344, 2007.

PREBISCH, Raúl. Dinâmica do Desenvolvimento Latino-Americano. Rio de Janeiro: Fundo de Cultura Brasil, 1969.

PIRES, Marcos Cordeiro. “A China e a Globalização: Aspectos de uma Estratégia Nacional”. In Revista de Economia Política e História Econômica (REPHE). ISSN: 1807 - 2674. Nº 25, Junho de 2011. Pg. 5-26

PIRES, Marcos Cordeiro. "Notas Sobre a Parceria Estratégica Brasil - China”. In SORIA, Adrián Bonilli \& GARCÍA, Paz Milet. FLACSO, 2015.

PIRES, Marcos Cordeiro. "O modelo de mercado aberto e a segunda década perdida na economia brasileira, 1991 - 2000”. In Revista de Economia Política e História Econômica (REPHE). ISSN: 1807 - 2674. No 02, Dezembro de 2004. Pg. 37-105.

POCHMANN, Marcio. Economia global e a nova Divisão Internacional do Trabalho. IE/Unicamp, Campinas, 2000.

POCHMAN, Marcio. O emprego na globalização. A nova divisão internacional do trabalho e os caminhos que o Brasil escolheu. Editora Boitempo, São Paulo:2007.

POCHMANN, Marcio . Políticas sociais e padrão de mudanças no Brasil durante o governo Lula. Ser Social (UnB), v. 13, p. 12-40, 2011.

POMERANZ, Lenina (org). Oskar Lange. São Paulo: Editora ática, 1981.

PREBISCH, Raúl. Dinâmica do desenvolvimento latino-americano. Rio de Janeiro: Editora Fundo de Cultura, 1969.

RAINELLI, Michel. Nova Teoria do Comércio Internacional. Bauru, EDUSC, 1998.

RANGEL, Ignacio. Economia: Milagre e Anti-Milagre. Rio de Janeiro: Jorge Zahar, 1985.

RAMSEY, Jase, \& ALMEIDA, Andre (org). The Rise of Brazilian Multinationals. Rio de 
Janeiro: Elsevier Editora, 2009.

REINERT, Kenneth A. An Introduction To International Economics. New Perspectives on the World Economy. Nova Iorque: Cambridge Press, 2012

ROMER, David. Advanced Macroeconomics. Barkeley: MC Graw Hill, 2001

RUGGLES, Richard \& RUGGLES, Nancy D. Contabilidade Nacional e Análise Macroeconômica. Lisboa: Livraria Sá da Costa editora, 1962.

SADER, Emir. “Brazil’s Workers Party in Power: A Lost Opportunity”. In: BUENO, Richard \& LARA, José (orgs). Imperialism, Neoliberalism and Social Struggles in Latin America. Bostom: Brill, 2007.

SANTOS, Milton. O Espaço Dividido: Os Dois Circuitos da Economia Urbana dos Países Subdesenvolvidos. São Paulo: Edusp, 2004.

SARQUIS, Sarquis José Buainain. Comércio Internacional e Crescimento Econômico no Brasil. Brasília: Fundação Alexandre de Gusmão, 2011.

SCREPANTI, Ernesto. Global Imperialism and the Great Crisis. Nova Ioeque: Monthly Review Press, 2014.

SCHINCARIOL, Vitor Eduardo. Crescimento Econômico no Brasil, 2003-2010. Um balanço da política econômica e do padrão acumulativo. São Paulo: LCTE Editora, 2012.

SCHINCARIOL, V. E. Economia e Política Econômica no Governo Dilma (2011-2014). São Paulo: Selo Tricontinental, 2017.

SCHUMPETER, Joseph A. The analysis of economic change. The Review of Economics and Statistics, v. 17, n. 4, p. 2-10, 1935.

SICSÚ, João. Rumos da Liberalização Financeira Brasileira. Revista de Economia Política, vol. 26, n 3. Setembro de 2006.

SHINOHARA, Miyohei. The Multiplier and the Marginal Propensity to Import. The American Economic Review, Vol. 47, No. 5 (Sep., 1957), pg. 608-624

SMITH, John. The Global South in the Global Crisis. Jornal of Labor and Society, 2017

SOARES, Fabio Veras. Brazil's Bolsa Família: A Review. Economic and Political Weekly, Vol. 46, No. 21 (MAY 21-27, 2011), pg. 55-60 
SOARES, Fábio Veras. EVALUATING THE IMPACT OF BRAZIL'S BOLSA FAMÍLIA: Cash Transfer Programs in Comparative Perspective. Latin American Research Review, Vol. 45, No. 2 (2010), pg. 173-190

SOARES DE LIMA, Maria Regina. “A Política Externa Brasileira e os Desafios da Cooperação sul-sul”. In Revista Brasileira de Política Internacional, vol 48, $\mathrm{n}^{0} 001$, Brasília, Brasil: 2005.

SÖDERSTEN, Bo. Economia Internacional. Rio de Janeiro: Interciência, 1979.

SOUZA, Luiz Eduardo Simões de \& PREVIDELLI, Maria de Fátima Silva do Carmo \& DA SILVA NETO, Julio Gomes. "A Economia Brasileira e a Crise Econômica Mundial”.Revista de Economia Política e História Econômica (REPHE). ISSN: 1807 2674. No 23, Dezembro de 2010. Pg. 5-25.

SOUZA, Luiz Eduardo Simões de \& SCHINCARIOL, Vitor Eduardo. “O Desenvolvimento Distante - um balanço das políticas do primeiro governo de Lula”. Revista de Economia Política e História Econômica (REPHE). ISSN: 1807 - 2674. Nº 08, Julho de 2007. Pg. 0532

SORIA, Adrián Bonilla \& GARCÍA, Paz Milet (orgs). China em América Latina y el Carive: Escenarios estratégicos subregionales. San José: Banco de Desarrollo de América Latina, 2015.

SUNDARARAJAN, V. \& THAKUR, Subhash. Input-Output Approach to Import Demand Functions: Experiments with Korean Data. Staff Papers (International Monetary Fund), Vol. 23, No. 3 (Nov., 1976), pg. 674-698

SWEEZY, Paul. The Theory Of Capitalist Development. Londres: Dobson Books, 1942

TAVARES, Maria da Conceição. Acumulação de capital e industrialização no Brasil. Editora da UNICAMP, 1985.

TAVARES, Maria da Conceição. Da substituição de importações ao capitalismo financeiro: ensaios sobre economia brasileira. Biblioteca de ciências sociais. Economia Biblioteca de ciências sociais (Zahar Editores), 1972.

VILARREAL, René. A contra-revolução monetarista, teoria, política econômica e ideologia do neoliberalismo. Rio de Janeiro: Editora Record,1984. 
WALBERG, Eric. Postmodern Imperialism Geopolitics And The Great Games. Atlanta: Clarity Press, 2011.

YEH, Yeong-Her. On the Consumption Pattern and Terms of Trade. The American Economist, Vol. 12, No. 2 (Fall, 1968), pg. 64-68

ZHANG, Wei-Bin. International Trade Theory. Capital, Knowledge, Economic Structure, Money, and Prices over Time. Japan: Springer, 2008.

\section{Obras institucionais:}

IBGE. Sistema de Contas Nacionais - Brasil. Ano de Referência 2010. 3a edição. Rio de Janeiro, IBGE, 2016.

International Credit Insurance \& Surety Association. A Guide to TradeCredit Insurance. Londer: Anthem Press, 2015.

VALE - Nossa História - 2012. Verso Brasil Editora, 2012.

\section{SÍTIOS DE INTERNET}

INSTITUCIONAIS:

http://www.ibge.gov.br/home/

http://www.ipeadata.gov.br/Default.aspx

http://www.bcb.gov.br/pt-br/\#!/home

http://www.mdic.gov.br/comercio-exterior

\section{NOTÍCIAS, REPORTAGENS E ENTREVISTAS}

http://aprosojabrasil.com.br/2014/a-batalha-da-producao-brasileira/

http://aprosojabrasil.com.br/2014/clima-e-falta-de-investimento-afetam-desempenho-no-pibaponta-aprosoja-brasil// 
http://economia.uol.com.br/ultimas-noticias/valor/2010/04/30/novo-presidente-da-anfaveabelini-pede-choque-de-competitividade.jhtm

http://exame.abril.com.br/negocios/noticias/vale-se-preparou-inverno-afirma-roger-agnelli$\underline{396709}$

http://www.abril.com.br/noticias/geral/anfavea-industria-automotiva-tenta-evitar-demissoes202105.shtml

http://www.biocana.com.br/index.php/conteudo/visualizar/2011-com-sustentabilidade http://www1.folha.uol.com.br/fsp/dinheiro/fi1811200717.htm

http://www.istoedinheiro.com.br/noticias/negocios/20150203/desafios-muriloferreira/228805.shtml

http://www.mecanicaonline.com.br/2005/04 abril/engenharia/rogelio golfarb.htm http://www.noticiasagricolas.com.br/noticias/agronegocio/136188-produtor-brasileiro-considere-se-culpado--por-glauber-silveira--da-aprosoja-brasil.html\#.WH-t42eIfQp http://www.petrobras.com.br/fatos-e-dados/graca-foster-fala-sobre-importancia-do-pre-salem-palestra-no-rio.htm

https://www.youtube.com/watch?v=i4mTx8mYbkQ : Agenda Econômica - Balança Comercial do Brasil - Bloco 2

https://www.youtube.com/watch?v=EcdNuzGA3dc - Agenda Econômica -Tatiana Prazeres https://www.youtube.com/watch?v=V9q8Vx9v-yk -Entrevista Glauber Silveira ao Canal Rural 08/06/2008

http://www.aepet.org.br/noticias/pagina/5948 - Desfazendo Mentiras Sobre A Vale Do Rio Doce, Data: 26/10/2007, Associação dos Engenheiros da Petrobrás.

https://www.youtube.com/watch?v=VRfeFWBhm8Q - Delfim Netto: Cenário Econômico Nacional e Internacional (Parte 1), erimônia de Posse do Conselho da Amcham 2016. Disponível em: 